\begin{abstract}
UNIVERSIDADE DE SÃO PAULO
FACULDADE DE FILOSOFIA, LETRAS E CIÊNCIAS HUMANAS

DEPARTAMENTO DE HISTÓRIA

PROGRAMA DE PÓS-GRADUAÇÃO EM HISTÓRIA SOCIAL
\end{abstract}

CAROLINA AMARAL DE AGUIAR

\title{
O Chile na obra de Chris Marker: um olhar para a Unidade Popular desde a França
}

VERSÃO CORRIGIDA

São Paulo 


\section{CAROLINA AMARAL DE AGUIAR}

\section{O Chile na obra de Chris Marker: um olhar para a Unidade Popular desde a França}

Tese apresentada ao Programa de Pós-Graduação em História Social da Faculdade de Filosofia, Letras e Ciências Humanas da Universidade de São Paulo para obtenção do título de Doutora em História

Orientador: Prof. Dr. Marcos Francisco Napolitano de Eugenio 
Aos meus pais e avós, pelo apoio em todos os momentos. 


\section{Agradecimentos}

Gostaria de agradecer inicialmente ao meu orientador, Marcos Napolitano, pelo olhar atento e pelas considerações sempre pertinentes. Agradeço também à sua ajuda proporcionando intercâmbios e contatos com outros pesquisadores.

Agradeço à FAPESP pela bolsa concedida, que possibilitou uma permanência estendida na França, sem a qual esta pesquisa não teria adquirido a mesma qualidade. Também sou grata ao auxílio recebido do convênio USP-Cofecub, que financiou a primeira estada francesa e incentivou a troca com os professores Olivier Compagnon, Anaiis Fléchet, Luiz Felipe de Alencastro, Eduardo Morettin, Gabriela Pellegrino Soares, Maurício Cardoso e o próprio Marcos, aos quais sou igualmente agradecida.

Faço um agradecimento especial aos professores Olivier Compagnon, pela orientação no estágio francês junto ao Institut des Hautes Études de l'Amérique latine (IHEAL), por sua acolhida e pelos seus conselhos fundamentais; e a Anaïs Fléchet, por ter me recebido na França e pelas inúmeras contribuições e conversas que colaboraram imensamente com esta tese.

Agradeço a outros professores que colaboraram com a pesquisa, especialmente Maria Helena Capelato, por seus conselhos na qualificação. Dedico especiais agradecimentos ao professor Eduardo Morettin, por suas indicações na qualificação, como também nas apresentações do grupo "História e audiovisual: circularidades e formas de comunicação”. Agradeço ainda a Mariana Villaça, Fabián Núñez, Mônica Almeida Kornis e Maria Ligia Prado.

É necessário agradecer aos inúmeros colegas da pós-graduação, cujo diálogo foi extremamente importante. Destaco os amigos do grupo Memória e Ditadura, que, nas reuniões da "sala 19", deram contribuições preciosas, bem como nas happy hours igualmente acadêmicas, em especial a Fernando Seliprandy, que assim como eu se aventura nos estudos de História e Cinema.

Agradeço também às contribuições dos amigos do grupo surgido na biblioteca da Cinemateca Brasileira em 2005, atualmente "espiralado", principalmente a Marina Takami pelo contato intenso nos meses na França.

Gostaria de mencionar outros colegas da História Social, especialmente aos do grupo temático de América Latina, com quem compartilhei reflexões, entre eles os “chilenistas" Alexsandro de Sousa e Silva e Carine Dalmás. Agradeço com carinho a Ângela Meirelles de Oliveira, amiga e parceira de doutorado, com quem dividi todas 
as etapas desta pesquisa, inclusive o estágio no IHEAL.

Destaco o convívio na França com colegas do IHEAL e da Association pour la recherche sur le Brésil en Europe (ARBRE), que, além da acolhida, proporcionaram debates fundamentais sobre a relação entre a França e a América Latina.

Sem dúvida, esta pesquisa não teria sido a mesma sem a colaboração do markeriano Nicolau Leonel, que generosamente partilhou seu material e suas impressões sobre a obra de Chris Marker. Pelo mesmo motivo, agradeço também a Emi Koide e ao "quase" markeriano Fernando Frias.

A pesquisa realizada nos arquivos foi de extrema importância para esta tese. Sou grata principalmente à acolhida de Mónica Villarroel na Cineteca Nacional de Chile e à Image, Son, Kinescope et Réalisations Audiovisuelles (ISKRA), que me cedeu filmes e documentos inéditos de inestimável valor.

A qualidade do texto aqui apresentado não seria a mesma sem a contribuição de Flávio Cintra do Amaral, tio e revisor (nesta função desde o mestrado), a quem sou agradecida. Meus agradecimentos também a Fernanda Machado pela ajuda com o francês.

Foi, com certeza, uma das minhas maiores satisfações a troca de $e$-mails com o "misterioso" Chris Marker, que me enviou em 2011 um emocionante relato. Agradeço-o, in memoriam. Sou grata a Silvio Tendler pela entrevista/conversa concedida.

Sou grata a minha família, especialmente aos meus pais (e seus respectivos companheiros), avós (destaco minha avó Terezinha, que partiu antes do fim desse longo processo) e irmãos. Agradeço especialmente à minha mãe, que contribuiu para uma estada mais prolongada na França.

Os amigos que gostaria de agradecer não caberiam nestas páginas. Mas certamente eles contribuíram muito para esta tese, mesmo que indiretamente. Destacaria Maíra e Antoine, que me receberam em algumas ocasiões em Paris apesar dos espaços reduzidos da cidade.

Por fim, agradeço com amor ao meu companheiro Ignacio Del Valle Dávila, que surgiu na minha vida por conta desta pesquisa e atravessou o Atlântico por razões que a superam. Além do apoio pessoal, suas contribuições, considerações e ajuda foram fundamentais para o resultado final. 


\author{
Resumo \\ O Chile na obra de Chris Marker: \\ um olhar para a Unidade Popular desde a França
}

Este trabalho analisa filmes do cineasta Chris Marker que indagaram sobre a Unidade Popular do Chile nos anos 1970. Entre as produções abordadas, estão duas que foram remontadas a partir de documentários chilenos feitos durante o governo de Salvador Allende: La première année (1973) e On vous parle du Chili: ce que disait Allende (1973). Além disso, mais três filmes desse realizador se dedicaram ao tema: $L a$ Spirale (1976), L'ambassade (1974) e O fundo do ar é vermelho (1977). Por meio do estudo dessa filmografia, identificaram-se quais foram as estratégias narrativas utilizadas e qual foi o discurso político sobre a chamada "experiência chilena" que essas estratégias elaboraram. A reflexão sobre o corpus permitiu verificar que o interesse por esse processo, visto desde a França, emergiu do espaço deixado pelas frequentes desilusões diante de uma referência política anterior, igualmente vinda da América Latina e que havia motivado os debates da esquerda francesa na década de 1960: a Revolução Cubana. Assim, optou-se por incluir também na pesquisa produções markerianas que nasceram do contato entre esse realizador e o Instituto Cubano del Arte e Industria Cinematográficos (ICAIC): Cuba si (1961), La bataille des dix millions (1970), On vous parle du Brésil: tortures (1969) e On vous parle du Brésil: Carlos Marighela (1970). A análise dos filmes elencados revela que, durante os anos da UP no poder, houve uma vontade de aproximação entre Chile e França que valorizava os caminhos empregados pela "via chilena ao socialismo", apontando-os como possibilidades para uma Nova Esquerda europeia. Porém, com o golpe de Estado de 1973, essa postura passou por uma revisão, e a experiência chilena serviu à elaboração de leituras que apontassem um "legado" e "lições" que poderiam ser retirados da queda da Unidade Popular. Nesse sentido, as produções de Marker fazem uma denúncia das ações da direita que derrubaram Allende, bem como constroem uma visão autocrítica que indica os "erros" cometidos pela própria esquerda que possibilitaram essa derrota. Essa tentativa de atribuir um "legado" e "lições" buscava responder sobretudo aos anseios de uma esquerda francesa que dispunha de um programa comum de governo fortemente inspirado naquele da UP chilena, mas que deveria ser submetido a uma revisão após o fracasso de sua referência latinoamericana. Sob essa visão, esta tese propõe um estudo voltado à circulação de ideias culturais e políticas entre América Latina e França, que delega ao continente um papel central nessa relação durante os anos 1960 e 1970 e a Chris Marker a função de um mediador cinematográfico.

\title{
Palavras-chave:
}

Chris Marker, Unidade Popular, cinema político, circulação de ideias políticas, Revolução Cubana, anos 1960 e 1970. 


\author{
Abstract \\ The Chile in the Chris Marker's work: \\ a look at the Popular Unity government from France
}

This work analyses the Chris Marker's films that inquired about the Popular Unity in the 1970's. Among the productions approached, two of them have been reassembled from other Chilean documentaries that had been made during the Salvador Allende's government: La première année (1973) and On vous parle du Chili: ce que disait Allende (1973). Furthermore, three other films by Chris Marker have analysed this subject: La Spirale (1976), The embassy (1974) and The grin without a cat (1977). By studying his filmography, this research could identify the narratives strategies that had been used by the director, as well as the political discourse elaborated by them. The reflections about the corpus allowed verify how the interest for this Chilean process, viewed from France, has emerged from an empty space left by the usual delusion given by an earlier reference that had motivated the French left during the 1960's, also gone from Latin-American: the Cuban Revolution. So, we chose to also include in the research the Marker's productions came from the relationship between this director and the Instituto Cubano del Arte e Industria Cinematográficos (ICAIC): Cuba si (1961), La bataille des dix millions (1970), On vous parle du Brésil: tortures (1969) and On vous parle du Brésil: Carlos Marighela (1970). The analysis of the films-selected shows that, during the UP's years in the power, there was a wish to approach Chile and France by valorising the "Chilean's way to the socialism" and pointing it as a possibility to the European "New Left". However, after the coup d'état in 1973, this attempt has been revised and the "Chilean experience" has been used to elaborate lectures that pointed a "legacy" and "lessons" from the follow of Popular Unity. In this sense, the Marker's productions denounce the right's actions to overthrow Allende, as well as built a self-criticism vision to indicate the left's "mistakes" that had collaborated to the defeat. This wish to show a "legacy" and "lessons" has dialogued with the expectations of a French's left that had have a common government programme tightly inspired in the Chilean's UP ones, but that has required a revision after the failure of its Latin-American reference. From this point of view, this thesis proposes a study based on the circulation of cultural and political ideas between Latin American and France that delegated to this continent a central role in this relationship during the 1960's and the 1970's, and assigned to Chris Marker the function of a cinematographic mediator.

\title{
Keywords:
}

Chris Marker, Popular Unity, political cinema, circulation of political ideas, Cuban Revolution, the 1960's and the 1970's. 


\author{
Resumen \\ Chile en la obra de Chris Marker: \\ una mirada a la Unidad Popular desde Francia
}

Este trabajo analiza filmes del cineasta Chris Marker que indagan sobre la Unidad Popular en los años 1970. Entre las producciones abordadas, se encuentran dos que fueron montadas a partir de documentales chilenos hechos durante el gobierno de Salvador Allende: La première année (1973) y On vous parle du Chili: ce que disait Allende (1973). Además de eso, otros tres filmes del realizador están dedicados a este tema: La Spirale (1976), L'ambassade (1974) y El fondo del aire es rojo (1977). Mediante el estudio de esa filmografía, se identificaron cuáles fueron las estrategias narrativas utilizadas y cuál fue el discurso político sobre la llamada "experiencia chilena" que esas estrategias elaboraron. La reflexión sobre el corpus permitió verificar que el interés por ese proceso, visto desde Francia, emergió del espacio dejado por las frecuentes desilusiones frente a una referencia política anterior, igualmente vinculada a América Latina y que había motivado los debates de la izquierda francesa en la década de 1960: la Revolución Cubana. Así, se optó por incluir también en la investigación producciones markerianas que nacieron del contacto entre ese realizador y el Instituto Cubano del Arte e Industria Cinematográficos (ICAIC), se trata de Cuba si (1961), La bataille des dix millions (1970), On vous parle du Brésil: tortures (1969) y On vous parle du Brésil: Carlos Marighela (1970). El análisis de los filmes señalados revela que, durante los años de la UP en el poder, hubo un deseo de aproximación entre Chile y Francia que valorizaba los caminos empleados por la "vía chilena al socialismo", apuntándolos como posibilidades para una Nueva Izquierda europea. Sin embargo, con el golpe de Estado de 1973, esa postura pasó por una revisión y la experiencia chilena sirvió para la elaboración de lecturas que apuntaban al "legado" y a "lecciones" que podían ser extraídas de la caída de la Unidad Popular. En ese sentido, las producciones de Marker hacen una denuncia de las acciones de la derecha que derribaron a Allende, y a la vez construyen una visión autocrítica que indica los "errores" cometidos por la propia izquierda que posibilitaron esa derrota. Esa tentativa de atribuir un "legado" y "lecciones" buscaba responder sobre todo a las ansias de una izquierda francesa que disponía de un programa común de gobierno fuertemente inspirado en aquel de la UP chilena, pero que debería ser sometido a una revisión después del fracaso de su referencia latinoamericana. Bajo esta visión, esta tesis propone un estudio enfocado en la circulación de ideas culturales y políticas entre América Latina y Francia que delega al continente un papel central en esa relación durante los años 1960 y 1970 y a Chris Marker la función de un mediador cinematográfico.

\title{
Palabras-clave:
}

Chris Marker, Unidad Popular, cine político, circulación de ideas políticas, Revolución Cubana, años 1960 y 1970. 


\author{
Résumé \\ Le Chili dans l'œuvre de Chris Marker: \\ Un regard vers l'Unité Populaire depuis la France
}

Ce travail analyse les films du cinéaste Chris Marker consacrés à l'Unité Populaire, dans les années 1970. Parmi les productions abordées, deux ont été remontées à partir de documentaires chiliens réalisés pendant le gouvernement de Salvador Allende : La première année (1973) et On vous parle du Chili : ce que disait Allende (1973). De plus, trois autres films du réalisateur traitent de ce thème : Spirale (1976), L'ambassade (1974) et Le fond de l'air est rouge (1977). À partir de l'étude de cette filmographie, nous avons cherché à identifier les stratégies narratives mises en place, et le discours politique élaboré par celles-ci sur ce que l'on nomme l' «expérience chilienne ». La réflexion sur le corpus a permis de vérifier que l'intérêt porté à ce processus, vu depuis la France, a émergé de l'espace laissé par les désenchantements fréquents face à une référence politique antérieure, issue également d'Amérique Latine, qui avait motivé les débats de la gauche française dans les années 1960 : la Révolution Cubaine. Ceci nous a conduit à inclure dans la recherche des productions de Marker, nées du contact entre ce réalisateur et l'Instituto Cubano del Arte e Industria Cinematográficos (ICAIC), à savoir : Cuba si (1961), La bataille des dix millions (1970), On vous parle du Brésil : tortures (1969) et On vous parle du Brésil : Carlos Marighela (1970). L'analyse des films cités révèle que, pendant les années où l'UP était au pouvoir, il y a eu une volonté de rapprochement entre le Chili et la France, qui, voyant d'un œil favorable les chemins empruntés par la «voie chilienne au socialisme », les considérait comme des possibilités pour une Nouvelle Gaucheeuropéenne. Cependant, avec le coup d'État de 1973, cette position a été revue et l'expérience chilienne a servi à l'élaboration de lectures orientées vers l' « héritage » et les « leçons » à être tirées de la chute de l'Unité Populaire. Dans ce sens, non seulement les œuvres de Marker dénoncent les actions de la droite qui a fait tomber Allende, mais elles construisent également une vision autocritique indiquant les « erreurs » commises par la gauche elle-même et qui ont rendu possible cet échec. Cette tentative d'attribuer un " héritage » et des « leçons » visait surtout à répondre aux aspirations de la gauche française, qui avait un programme commun de gouvernement, fortement inspiré de celui de l'UP chilienne, mais qui devait être soumis à une révision après l'échec de sa référence latino-américaine. Sous cette optique, la présente thèse propose une étude centrée sur la circulation d'idées culturelles et politiques entre la France et l'Amérique Latine, qui délègue au continent un rôle central dans cette relation pendant les années 1960 et 1970 et à Chris Marker la fonction de médiateur cinématographique.

\title{
Mots-clés :
}

Chris Marker, Unité Populaire, cinéma politique, circulation d'idées politiques, Révolution Cubaine, années 1960 et 1970. 


\section{Lista de abreviaturas:}

Ação Libertadora Nacional (ALN)

Acción Popular Independiente (API)

Agência Central de Inteligência (CIA)

Agir en Jeunes Socialistes (AJS)

Bibliothèque de documentation internationale contemporaine (BDIC)

Bibliothèque nationale de France (BNF)

Confederación Única de Profesionales de Chile (CUPROCH)

Confédération générale du travail (CGT)

Democracia Cristã (DC)

Escuela de Artes de la Comunicación de la Universidad Católica (EAC)

Fédération de la gauche démocrate et socialiste (FGDS)

Frente de Acción Popular (FRAP)

Image, Son, Kinescope et Réalisations Audiovisuelles (ISKRA)

Institut des hautes études de l'Amérique latine (IHEAL)

Institut national d'audiovisuel (INA)

Instituto del Arte e Industria Cinematográficos (ICAIC)

Juntas de Abastecimiento (JAP)

L'Office de Radiodiffusion-Télévision Française (ORTF)

Movimento Comunista Internacional (MCI)

Movimento Revolucionário 8 de Outubro (MR-8)

Movimiento de Acción Popular Unitaria (MAPU)

Movimiento de Izquierda Revolucionaria (MIR)

Organización de Solidaridad de los Pueblos de África, Asia y América Latina (OSPAAAL)

Organización Latinoamericana de Solidaridad (OLAS) 
Parti socialiste unifié (PSU)

Partido Comunista (PC)

Partido Comunista Brasileiro (PCB)

Partido Comunista Chileno (PCC)

Partido Comunista Francês (PCF)

Partido Nacional (PN)

Partido Radical (PR)

Partido Social Democracia (PSD)

Partido Socialista (PS)

Radio télévision belge (RTB)

Section française de l'internationale ouvrière (SFIO)

Service de Lancement des CEuvres Nouvelles (SLON)

Sociedad de Fomento Fabril (SOFOFA)

Sociedad Nacional de Agricultura (SNA)

Unidade Popular (UP)

Unión de Escritores y Artistas de Cuba (UNEAC)

Vanguarda Popular Revolucionária (VPR) 


\section{SUMÁRIO}

Introdução . .3

Capítulo 1 - De Cuba ao Chile: América Latina na obra de Chris Marker .........23

1. A Revolução Cubana no documentário de Chris Marker..............................................23

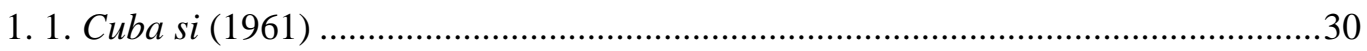

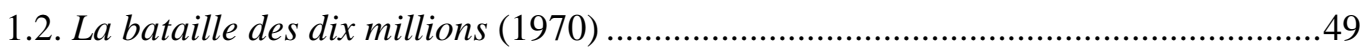

2. Cinema de contrainformação: comentários sobre o Brasil .........................................60

2.1. On vous parle du Brésil: tortures (1969) ..............................................................66

2.2. On vous parle du Brésil: Carlos Marighela (1970) ...............................................72

3. À Valparaiso (1963): o Chile de Joris Ivens comentado por Chris Marker ...............83

3.1. As imagens de Joris Ivens e o texto de Chris Marker...............................................86

3.2. Filme-escola: uma ponte entre dois continentes ...................................................93

Capítulo 2 - Chris Marker e o cinema chileno: versões francesas para produções sobre a Unidade Popular ............................................................................................96

1. Chris Marker no Chile: testemunha de um novo processo político e

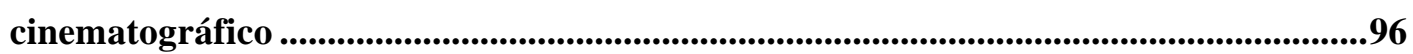

1.1. "Cineastas instrumentos do povo": documentário durante a Unidade Popular ......102

2. El primer año (1972) e La première année (1973) ...............................................................116

3. Chris Marker e a SLON em A batalha do Chile ............................................................133

4. Compañero presidente (1971) e On vous parle du Chili: ce que disait Allende (1973)

Capítulo 3 - La spirale (1976): imagens do Chile, denúncia e solidariedade......159

1. Muitas mãos e versões: a produção de um filme coletivo.............................................159

2. Temas e estratégias do documentário ..................................................................169

3. Uma denúncia feita em arquivos ....................................................................195

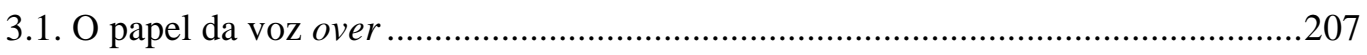

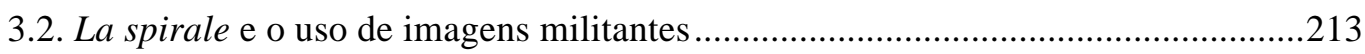

3.3. Outros ecos da revolução democrática: Chile de Allende na televisão francesa e seu

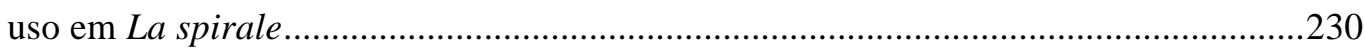

Capítulo 4 - L'ambassade (1974): do Chile à esquerda francesa (do documentário à ficção) ..................................................................................................................................243

1. "Isso não é um filme”": L'ambassade e os efeitos do real.................................................243

1.1. Filme-testemunhal e a desconstrução do "ciné-ma-véritê" 
2. O Chile fora de campo: a derrubada da Unidade Popular

3. A França em campo: emergência do Programa Comum ...............................................266

3.1. A Unidade Popular para o Programa Comum da esquerda francesa......................2.268

4. A esquerda teatralizada: solidariedade e conflitos .....................................................280

Capítulo 5 - O fundo do ar é vermelho (1977): “do Chile ao - que, de fato?”: apontamentos para uma "via europeia" ..........................................................297

1. Temas e estratégias do documentário ...................................................................................297

2. A trajetória de Fidel Castro e a revisão da Revolução Cubana.................................314

3. O programa comum da esquerda francesa em $O$ fundo do ar é vermelho ................322

4. A Unidade Popular chilena em $O$ fundo do ar é vermelho ........................................330

5. A Unidade Popular chilena para a "via europeia": outras leituras e legado após sua queda 340

Considerações finais................................................................................347

Referências bibliográficas ...................................................................................357

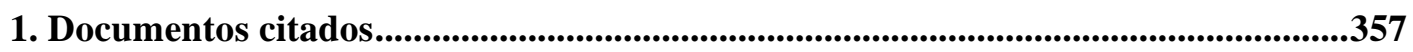

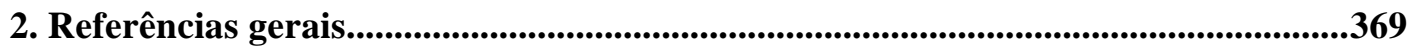

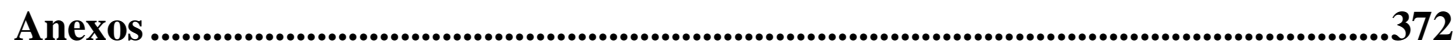

A) Chris Marker: filmografia completa.....................................................................................372

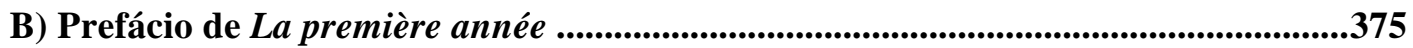

C) Esquema de produção e Plano de trabalho de A batalha do Chile .............................378

D) Texto da voz over de L'ambassade .......................................................................................381

Index de realizadores, produções e instituições cinematográficas citados ...........386 


\section{Introdução}

Os filmes de Chris Marker sobre a América Latina revelam como o continente alimentou os debates políticos da esquerda europeia, despertando paixões e posteriores revisões sobre as vias de acesso e os modelos de socialismo que se desejava implementar. Nessa perspectiva, a Revolução Cubana e o governo da Unidad Popular (Unidade Popular, UP) no Chile foram temas de grande relevância e mereceram um espaço significativo na filmografia do realizador francês. Esta pesquisa se propôs a analisar sua produção cinematográfica, verificando de que modo Marker constrói, por meio do cinema, visões sobre esses processos políticos, sobretudo no caso chileno, valorizado por suas equivalências com os projetos de união das esquerdas implementados no início dos anos 1970 na França.

Constantemente definido por termos que ressaltam o "mistério" em torno de sua figura (ORTEGA; WEINRICHTER, 2006) ou ainda como o mais "célebre dos cineastas desconhecidos" (DUBOIS, 2002), o volume de pesquisas sobre Chris Marker aumentou muito nos últimos anos, embora o acesso a seus filmes permaneça ainda muito limitado. No Brasil, sua obra passou a ser mais conhecida após uma retrospectiva organizada pelo Centro Cultural Banco do Brasil em 2009 (CHRIS, 2009), e por investigações recentes sobre sua obra, como a tese de Emi Koide (2011) e a dissertação de Nicolau Leonel (2010). Na França, além da coletânea de artigos organizada por Dubois (2002), destaca-se o trabalho pioneiro de Guy Gauthier (2001) e a publicação organizada por André Habib e Viva Paci (2008). Em língua inglesa, dois livros abordam sua filmografia com amplitude, porém com pouca profundidade: o de Nora M. Alter (2006) e o de Catherine Lupton (2008). Por fim, mais dois estudos merecem ser referenciados: $O$ bestiário de Chris Marker, catálogo organizado por Robert Grélier (1986), e a publicação espanhola dirigida por María Luisa Ortega e Antonio Weinrichter (2006).

Apesar dessa recente atenção que a obra de Marker recebeu na última década, ela ainda é insuficiente diante da vasta produção do realizador, que iniciou sua carreira ao lado de Alain Resnais nos anos 1950 e morreu em 2012, com 91 anos de intensa atividade. Em grande parte, a atenção insuficiente dada a sua obra se explica por seu frequente "silêncio", tendo em vista que ele constantemente se recusava a dar entrevistas ou declarações extrafílmicas sobre sua vida ou sua obra. Mas, por outro 
lado, essa insistência em caracterizar Marker como uma figura desconhecida é fruto também de uma valorização do potencial de intervenção política de seus filmes, que constantemente se preocupavam mais com o debate político da época em que foram feitos do que em se tornarem ícones de um discurso fechado sobre os movimentos históricos aos quais se dedicavam.

A filmografia de Marker apresenta uma ampla diversidade de estratégias e diálogos com outros movimentos cinematográficos de sua época. Assim, como será abordado, ele foi considerado um dos pioneiros do cinéma-vérité; inovou ao dar à fotografia um papel central em muitos de seus filmes; destacou-se por desenvolver um tom ensaístico; recorreu em muitas ocasiões ao filme de arquivo, atribuindo a esse gênero uma marca própria; incorporou frequentemente as novas tecnologias que despontavam; enfim, foi marcante pela variedade de estilos e técnicas, aliada a uma assinatura pessoal inconfundível. Apesar dessa pluralidade, alguns aspectos foram frequentes em sua obra: o papel ímpar da voz over, complementando ou questionando as imagens; o uso de um tom literário; a preocupação com a montagem, em detrimento de uma captação formalista dos planos; a predominância de um discurso político e internacionalista. Suas produções estiveram constantemente atreladas aos debates políticos do período em que foram feitas, recorrendo às inovações técnicas e estéticas para interferir nessas reflexões políticas.

Christian-François Bouche-Villeneuve, o Marker (o nome adotado é atribuído ao desejo de deixar uma "marca", um estilo próprio), começou sua carreira nos anos 1940 em Paris, como um ensaísta do jornal Esprit ${ }^{1}$. Nessa época, esteve envolvido em duas organizações voltadas para a difusão da cultura nos meios populares: Peuple et Culture e Travail et Culture ${ }^{2}$. Nesta última instituição, trabalhou na área teatral, aproximando-se posteriormente do crítico de cinema André Bazin ${ }^{3}$. Publicou um

\footnotetext{
${ }^{1}$ Catherine Lupton (2008) destaca que Marker publicava, sobretudo, poesias, contos, ensaios políticos e resenhas de livros e filmes. Vale ressaltar que Esprit era uma revista próxima aos intelectuais católicos progressistas, tendo sido fundada pelo filósofo Emmanuel Mounier. Entre os nomes de destaque que participavam dela nessa época, estavam Paul Ricœur, Jean Cayrol e André Bazin.

${ }^{2}$ Ortega e Weinrichter (2006) ressaltam que Peuple et Culture foi uma organização criada em $1944 \mathrm{em}$ Grenoble, com base na experiência adquirida no período da Resistência à ocupação nazista na França. Em 1946, foi transferida para Paris, onde passou a atuar ao lado de um organismo similar, o Travail et Culture, que se aproximou de forma progressiva do Partido Comunista Francês (PCF).

${ }^{3}$ Antoine de Baecque define o escritório de André Bazin no Travail et Culture como um espaço de formação de muitos cineastas: "Outra escola complementar: o escritório de André Bazin em Travail et Culture, rua des Beaux-Arts 5, onde são organizadas as sessões de sua rede de cineclubes, as Jeunesses Cinématographiques, e onde se encontraram alguns de seus primeiros discípulos. Chris Marker, Janine Kirsch, que trabalha na seção 'teatro' da associação, futura sra. Bazin, Alain Resnais, membro atuante do cineclube da Maison des Lettres, Rémo Forlani, outro membro de Travail et Culture, Alexandre
} 
romance, La cœur net, lançado em 1949. Na década seguinte, em 1954, criou os guias de viagens Petite Planète para a editora Seuil, estando à frente da coleção até 1958, revelando seu gosto por percorrer lugares variados e elaborar impressões sobre eles. Seu primeiro filme foi Olympia 52 (1952), sobre os jogos olímpicos de Helsinque. Dividiu a direção de Les statues meurent aussi (1953) com Alain Resnais e foi assistente de direção de Resnais em Noite e neblina (1955). Desde os anos 1950, Marker interessou-se em filmar nos mais diversos países e regiões, principalmente onde encontrava processos políticos inovadores, como demonstra Dimanche à Pékin (1956) e Lettre de Sibérie (1957) ${ }^{4}$.

Os filmes de Chris Marker sobre o Chile e a América Latina analisados nesta tese foram realizados entre os anos 1960 e 1970. Esse período costuma ser definido pelos pesquisadores como uma época "militante", quando sua obra esteve mais atrelada aos projetos de esquerda. No entanto, essa definição é reducionista. Em primeiro lugar, porque se pode dizer que essa abordagem "esquerdista" percorre toda a obra markeriana, e não apenas as produções dessa época. Também é necessário ressaltar que, apesar da alcunha de "cineasta militante" ser derivada de sua visão socialista, Marker realiza um cinema político, porém independente de organizações ou partidos (ele nunca foi filiado ao PCF, por exemplo, e discordou constantemente dessa instituição). Nesse sentido, ao longo deste trabalho, percebe-se que sua filmografia flertou em alguns momentos com um tom mais panfletário, mas que, de modo geral, se diferenciou no campo do cinema militante por analisar as próprias estratégias políticas e a de seus companheiros sob um prisma crítico e autocrítico um exercício raro entre os realizadores engajados.

Apesar dessas ressalvas, os anos 1960 e 1970 diferenciam-se na trajetória de Chris Marker pela predominância de um trabalho coletivo, numa referência à coletividade presente em organizações e movimentos políticos. Esse aspecto é importante, pois muitas das produções citadas nesta tese foram realizadas de forma que a atribuição de autorias - inclusive a do próprio Marker - torna-se uma tarefa delicada. Esse cuidado vale especialmente para o documentário La spirale, cujos

Astruc, cujo primeiro romance, Les vacances, chamou a atenção ao ser publicado pela Gallimard em 1945, cronista de Les Temps Modernes, a cabeça já tomada por projetos cinematográficos. E François Truffaut, adolescente que fora um dia protestar contra a concorrência do dono do lugar (as sessões dos respectivos cineclubes eram simultâneas), mas logo a partir de 1949 já havia sido conquistado e contratado como 'secretário particular' por Bazin." (BAECQUE, 2010, p. 60).

${ }^{4}$ Uma lista completa dos filmes de Chris Marker e das produções das quais ele participou pode ser encontrada nos anexos desta tese. 
créditos constantemente excluem o realizador francês da instância máxima de importância. Mesmo assim, optou-se por incluir essas produções, considerando que o objetivo deste trabalho não é fazer um panorama de sua filmografia, mas verificar como alguns filmes que contaram com a presença desse realizador discutem um determinado tema - o governo da Unidade Popular no Chile -, bem como mapear ações empreendidas por Marker que o revelam como um mediador ${ }^{5}$ entre a América Latina e a França nesses anos.

Muitas das produções citadas nesta tese contaram com o apoio do Service de Lancement des Euvres Nouvelles - SLON (cuja sigla significa "elefante", em russo) para serem viabilizadas. Essa produtora, criada em 1967 por intermédio de Chris Marker para a realização de Loin du Vietnam (1967) e À bientôt, j'espère (1968), ambas produções coletivas, teve como objetivo encontrar uma maneira de realizar filmes políticos dentro de um esquema de produção participativo, fora da organização hierárquica da indústria cinematográfica, e de dar chance a grupos sociais minoritários manifestarem seus próprios valores ${ }^{6}$. Primeiramente, a SLON foi registrada na Bélgica para escapar da censura francesa, mas, em 1974, foi ampliada e radicada em Paris com o nome de Image, Son, Kinescope, Réalisation Audiovisuelle ISKRA (que forma a palavra "faísca", em russo). Entre os filmes aqui analisados, $L a$ bataille des dix millions (1970), La première année (1973), La spirale (1976) e O fundo do ar é vermelho (1977) foram feitos por essa instituição. Além deles, destaca-

\footnotetext{
${ }^{5}$ Ao longo desta tese, utiliza-se constantemente a definição de Chris Marker como um mediador entre dois continentes. Assim, é necessário esclarecer que entende-se o conceito de mediador como um passeur, ou seja, alguém que estabelece conexões entre diversos grupos e sociedades em decorrência de sua circulação (GRUZINSKI, 2003). No livro Entre dos mundos: fronteras culturales y agentes mediadores (1997), Gruzinski e Queija expõem algumas questões que devem ser feitas para esses sujeitos: "De que maneira realiza-se a comunicação entre diferentes tradições em contato? Que elementos de determinada cultura busca-se difundir? Quais deles parecem mais suscetíveis a serem recebidos por outras ou quais elegem o receptor?" (QUEIJA; GRUZINSKI, 1997, p. 10, tradução nossa). Traduzido do original: “¿De qué manera se realiza la comunicación entre diferentes tradiciones en contacto? ¿Qué elementos de determinada cultura se busca difundir? ¿Cuáles parecen más susceptibles de ser recibidos por otra o cuáles elige el receptor?”. Essas questões estiveram no horizonte desta pesquisa sobretudo em relação ao discurso sobre a Unidade Popular chilena elaborado pelo realizador francês.

${ }^{6}$ Nesse sentido, destaca-se a atuação de Marker nos Grupos Medvedkine, que será referenciada em alguns momentos desta tese. Os Grupos Medvedkine foram criados entre 1968 e 1970 em meio a greves operárias realizadas nas cidades de Besançon e Sochaux. Eles retomam iniciativas levadas a cabo pelo Centro de Cultura Popular de Palentes-les Orchamps, coordenados por Pol Cèbe junto aos trabalhadores. Marker contribuiu para sua fundação, em abril de 1968, e atuou mais ativamente no Grupo Medvedkine de Besançon, ao lado de Bruno Muel e Jean-Luc Godard. Sobre a relação entre os Medvedike e a SLON, Anita Leandro escreve que: "Os Medvedkine ganham rapidamente autonomia, adquirindo uma câmera e uma mesa de montagem. A SLON - Société de Lancement des Euvres Nouvelles -, criada por Marker em 1967, fornecia película, transferência do som, revelação, cópia de trabalho e mixagem. Tudo isso era feito à noite, gratuitamente, pois a SLON não tinha nenhum financiamento." (LEANDRO, 2010, p. 104).
} 
se a série de "jornais contrainformativos" denominada On vous parle, cujo episódio dedicado ao Chile - On vous parle du Chili: ce que disait Allende (1973) - foi estudado nesta pesquisa, assim como os dois dedicados ao Brasil: On vous parle $d u$ Brésil: tortures (1969) e On vous parle du Brésil: Carlos Marighela ${ }^{7}(1970){ }^{8}$

Outro aspecto interessante da obra de Marker é sua preferência pelo cinema documental. Mesmo suas ficções - La jetée (1962) e L'ambassade (1974) podem ser situadas nesse gênero, enquanto Level 5 permanece em um limite bastante tênue dialogam diretamente com o documentário. No entanto, como já foi comentado, ele utiliza diferentes estratégias para compor seus discursos, que variam de um filme para outro, de um processo histórico documentado para outro. De toda forma, esse vínculo com o "real", embora normalmente apreendido por uma subjetividade marcante do realizador, fez com que vários pesquisadores identificassem o tema da memória como um dos mais presentes em sua filmografia. Esse aspecto será retomado, mas vale dizer que Marker se debruçou sobre os mais variados processos históricos, formulando reflexões sobre eles (em alguns casos sobre a forma de tese, porém predominantemente colocadas como questionamentos).

Essa forte presença da História em sua filmografia - seja em termos de proposições políticas para novos rumos, seja como balanços posteriores ao fim de um processo - levou Marker a se interessar por realidades políticas e sociais distantes da Europa, delimitando em muitas de suas produções um olhar estrangeiro. O conceito de espaço e de tempo são indissociáveis em muitos de seus filmes, que se situam na fronteira entre passado/presente/futuro, numa relação dialética entre o legado de uma experiência, suas consequências presentes e a continuação da luta política. Da mesma forma, em termos espaciais, o realizador buscou com frequência experiências fora de seu país que pudessem inspirar um élan revolucionário, demonstrando uma visão internacionalista desse processo de transformação social.

\footnotetext{
${ }^{7}$ Optou-se por manter a grafia original do documentário, que suprimiu um "l" do nome de Carlos Marighella. Assim, quando se trata do título dessa produção, utiliza-se a forma: On vous parle du Brésil: Carlos Marighela.

${ }^{8}$ A partir dos anos 1980, Chris Marker dialogou fortemente com as novas tecnologias, produzindo, por exemplo, o CD-ROM Immemory (1998) e organizando exposições e mostras no Second Life. De modo geral, seus filmes mantiveram algumas características anteriores, como a ênfase no cinema político, o comentário subjetivo marcante e o gosto por filmar em lugares distantes (aspectos que serão retomados ao longo desta tese). Nesse sentido, destacam-se as produções Sans soleil (1982), a série televisiva L'héritage de la chouette (1989), além dos filmes Le tombeau d'Alexandre (1993) e Level 5 (1996). Sua atuação nas últimas três décadas de vida não foi aprofundada por este trabalho, no entanto, aparece em outras obras sobre o realizador, como a tese de Emi Koide (2011) e os livros que se dedicam a balanços gerais sobre sua filmografia, como o de Catherine Lupton (2008).
} 
Diante desses aspectos da obra de Marker - sua visão política do outro (seja ele o estrangeiro ou os operários franceses, no caso de sua atuação nos Grupos Medvedkine) e sua apropriação das diversas experiências como motores da revolução -, este trabalho realizou um recorte temático em sua filmografia, dedicando-se ao estudo dos filmes markerianos sobre a chamada "experiência chilena"9 (1970-1973). Interessava, em um primeiro momento, analisar produções sobre esse tema, verificando tanto seus aspectos estéticos como o discurso elaborado por elas, tendo em vista que ambos os aspectos não podem ser dissociados. Assim, é necessário tecer breves considerações sobre a metodologia empregada, para posteriormente indicar alguns caminhos apontados por ela durante a pesquisa.

Tendo em vista o estatuto documental que deve ter o cinema em uma pesquisa historiográfica, os filmes aqui abordados foram considerados objetos de conhecimento sobre o tempo em que foram produzidos e suas implicações no presente. Para isso, foram submetidos a uma análise que considerou a linguagem técnico-estética própria das fontes audiovisuais, articulando-a às representações históricas e sociais propostas por essas produções, como sugere Marcos Napolitano (2006).

Portanto, pode-se dizer que, ao analisar um corpus fílmico determinado por um recorte temático - o olhar sobre a Unidade Popular chilena e sobre outras questões ligadas à América Latina que ajudam a elucidar esse olhar -, esta tese possibilita também a identificação de uma diversidade de estilos e de estratégias cinematográficas na obra de Chris Marker. Em diversas passagens, procurou-se articular seus discursos políticos às escolhas fílmicas. Em La spirale, por exemplo, um filme de arquivo se propõe a constituir uma denúncia, baseada em uma reunião de "provas documentais"; em L'ambassade, a ficção serve à reconstituição de um testemunho calcado em uma situação histórica real, mas silenciado em termos documentais pela repressão da ditadura; por fim, O fundo do ar é vermelho revisita as imagens militantes e televisivas rodadas em anos anteriores, permitindo uma revisão desse período por parte do realizador, que estabelece um novo discurso sobre o passado.

Para tecer esses e outros paralelos entre linguagem fílmica e discurso político, que serão abordados ao longo de toda tese, os filmes foram assistidos de forma

\footnotetext{
${ }^{9}$ Essa expressão da época referia-se ao desafio proposto pela Unidade Popular em realizar uma "transição ao socialismo em democracia".
} 
sistemática, o que constituiu uma etapa fundamental da pesquisa. Outra etapa metodológica contribuiu ainda para os resultados alcançados: o levantamento de documentos complementares que colaboraram para a compreensão das produções cinematográficas analisadas, situando-as nos debates de época e permitindo a verificação das escolhas do realizador ${ }^{10}$. Esse material extrafílmico ajudou a compreender, entre outras questões, o papel de Chris Marker como um mediador entre a Europa e a América Latina, contribuindo com a circulação de ideias e de produtos audiovisuais entre os dois continentes (como é possível perceber em sua relação com o Instituto Cubano del Arte e Industria Cinematográficos - Instituto Cubano de Arte e Indústria Cinematográficos, ICAIC - e com os cineastas chilenos).

Esses dois exercícios - análise dos filmes sobre a Unidade Popular e busca por documentos extrafílmicos que colaborassem com sua interpretação - revelaram algumas questões que, pouco a pouco, resultaram na estrutura aqui apresentada. Destacam-se três filmes realizados por Marker ${ }^{11}$ que abordaram a chamada "experiência chilena": L'ambassade (1974), La spirale (1976) e O fundo do ar é vermelho (1977). A cada uma dessas produções foi dedicado um capítulo, optando-se por esse método em detrimento de uma organização temática para que a análise das fontes audiovisuais fosse valorizada ${ }^{12}$. Cabe ressaltar que todos eles foram realizados após a queda de Salvador Allende, portanto, se apresentam como "balanços" dessa experiência tendo como horizonte a denúncia das ações da direita que derrubaram a UP, as autocríticas realizadas pela própria esquerda e uma mobilização em torno do exílio e da reversão do golpe articulada durante a ditadura. Esses aspectos, que

\footnotetext{
${ }^{10}$ Nesse sentido, foi necessário o esforço de focar nas fontes primárias e buscar outros materiais como colaborações historiográficas para o entendimento das questões levantadas pela análise dos filmes. No entanto, procurou-se evitar o risco de que "o cinema seja sufocado pela pesquisa histórica", como alertou Eduardo Morettin: "Para que possamos recuperar o significado de uma obra cinematográfica, as questões que presidem o seu exame devem emergir de sua própria análise. [...] Com esse movimento, evitamos o emprego da história como pano de fundo, na medida em que o filme não está a iluminar a bibliografia selecionada, ao mesmo tempo que não isolamos a obra de seu contexto, pois partimos das perguntas postas pela obra para interrogá-la." (MORETTIN, 2007, p. 63.)

${ }^{11}$ La spirale, como foi dito, é um filme coletivo. A questão da autoria será discutida no capítulo 3 , dedicado a esse documentário.

${ }^{12}$ É necessário enfatizar que optou-se por não dispor os filmes por capítulos em função de sua data de realização. Em primeiro lugar, apesar de finalizadas em anos distintos, as três produções foram feitas de maneira mais ou menos simultânea, logo após o golpe de Estado no Chile, entre 1973 e 1977. Em seguida, vale dizer que a escolha por analisar La spirale antes de L'ambassade decorre do fato de o primeiro filme optar por um tom de denúncia do inimigo, enquanto o segundo traz aspectos mais autocríticos. Dessa forma, a inversão da ordem cronológica facilita a compreensão dessa dimensão reflexiva diante do próprio campo político, que estará presente também em $O$ fundo do ar é vermelho.
} 
apareceram de formas distintas nos três filmes, emergiram na análise e foram tratados nesta tese.

Além desses filmes analisados nos três últimos capítulos, foram consideradas outras iniciativas empreendidas por Chris Marker sobre a Unidade Popular, parte delas realizadas quando a aliança esquerdista ainda estava no poder. Destacam-se duas versões francesas montadas a partir de produções de cineastas chilenos datadas do período do governo Allende e que foram modificadas pelo realizador para "adaptarem-se" ao contexto francês: La première année, de 1973, (feita a partir de El primer año, 1972, de Patricio Guzmán) e On vous parle du Chili: ce que disait Allende, de 1973 (curta-metragem adaptado de Compañero presidente, 1971, de Miguel Littin). Neste último caso, também foram feitas mudanças diante da perspectiva histórica após o 11 de setembro de 1973. Suas análises buscaram encontrar os novos sentidos adquiridos na montagem markeriana, revelados pela comparação com as montagens originais de Guzmán e Littin. Essas primeiras iniciativas, consequência de laços estabelecidos durante uma visita ao Chile em 1972, além de comprovarem um papel de mediador e de incentivador do cinema desse país latino-americano por parte de Marker, demonstram que havia interesse na França pela experiência chilena mesmo antes do golpe de Estado.

Esse interesse não foi exclusividade do realizador francês, mas de muitos intelectuais, artistas e políticos de diversas partes que desejavam vivenciar de perto essa aliança entre democracia e socialismo, considerada um novo caminho por grande parte das esquerdas internacionais. Alberto Aggio ressalta o lugar de destaque que a “experiência chilena", ou a "via chilena", ganhou nas esquerdas pelo mundo:

As atenções de boa parte do mundo voltaram-se para aquele país que, com a ascensão de Salvador Allende à presidência da República, passava a viver uma situação inédita. Pela primeira vez na História, um presidente declaradamente marxista chegava ao poder através de eleições gerais e livres e propunha implantar o socialismo como resultado da aplicação de seu programa eleitoral. (AGGIO, 2002, p. 15).

Nesse sentido, após assistir aos primeiros filmes, surgiu a hipótese de que o debate proposto pelo realizador sobre a Unidade Popular visava a dialogar com a 
estratégia da esquerda francesa ${ }^{13}$ em torno do estabelecimento de um programa comum entre comunistas, socialistas e radicais, propondo leituras sobre o caso chileno que, de alguma forma, colaboravam para a ação política na França e para o movimento revolucionário internacional. Essa ideia decorreu não apenas da presença desse debate nas produções mais "autocríticas" - caso de L'ambassade e O fundo do ar é vermelho -, mas também de sua ausência em La spirale (que evita tocar nos rachas desse campo político e sua responsabilidade para a queda da UP chilena). Percebeu-se, então, um papel exercido pelo Chile na filmografia desse realizador e no seio da esquerda francesa que delegava ao país latino-americano ora a função de modelo, ora a de contramodelo, como será analisado.

Para compreender o Chile na obra de Chris Marker - e nas discussões políticas europeias da época -, é necessário entender outro processo político que se tornou referência nos anos 1960, perdendo gradativamente esse status ao longo da década: a Revolução Cubana. O realizador foi um dos muitos intelectuais e artistas franceses que se aproximaram de Cuba após 1959, estabelecendo fortes vínculos com o ICAIC e disseminando uma visão positiva da ilha na França (como revela a análise de $C u b a$ $s i^{14}$ e de La bataille des dix millions). Essa espécie de "modelo" anterior - que assim como a Unidade Popular invertia o fluxo tradicional de circulação das referências, tornando a América Latina o palco de ações exemplares bem-sucedidas - alcançou grande sucesso como estratégia de chegada ao socialismo (via guerrilha) e de implementação de uma "democracia direta” em que seu líder, Fidel Castro, alcançava uma popularidade impressionante entre os cubanos.

Porém, foi a derrocada desse modelo (que é analisada especialmente em $O$ fundo do ar é vermelho), fruto, entre outros aspectos, da aproximação de Cuba com a União Soviética, que abriu espaço para a busca de um caminho democrático e eleitoral. Apesar dessa opção da esquerda ser, na Europa, anterior ao sucesso de Salvador Allende no Chile (encontrando raízes nos estudos de Antonio Gramsci ${ }^{15}$, por

\footnotetext{
${ }^{13}$ Vale dizer que essa estratégia defensora da via democrática esteve no horizonte dos partidos comunistas italiano e espanhol naquela época, contribuindo para a perspectiva da formação de uma "via europeia" ou de um "eurocomunismo" (como será explicitado no capítulo 5).

${ }^{14}$ Optou-se por utilizar a grafia "Cuba si”, tal como aparece nos intertítulos da produção de Marker, em detrimento do termo “¡Cuba sí!”, como seria o correto em espanhol.

${ }^{15}$ Greyfus e Groppo (2000) ressaltam que, principalmente no caso do Partido Comunista Italiano, as elaborações teóricas de Gramsci foram fundamentais para as tentativas aliancistas dos anos 1970. Os autores destacam aspectos estratégicos e de ação política presentes no pensamento gramsciano que estiveram presentes em vários momentos nos partidos comunistas europeus desde o pós-Segunda
} 
exemplo, e nas experiências das frentes populares dos anos 1930), esse episódio do início dos anos 1970 pareceu confirmar os esforços empreendidos por partidos esquerdistas na França, Itália e Espanha. No entanto, com o golpe de Estado de 11 de setembro no Chile, tornou-se necessária uma nova revisão, abrindo espaço para um debate que se debruçou especialmente nas causas dessa nova derrota e nas "lições" que poderiam ser tiradas.

Pode-se dizer que esta pesquisa nasceu de um recorte temático da filmografia do realizador - o Chile na obra de Chris Marker -, mas que o estudo desses filmes demonstrou a necessidade de abrir para novos caminhos, investigando a visão que ele havia estabelecido da Revolução Cubana em momentos anteriores. A análise dos documentários feitos sobre Cuba (ou sob a influência das políticas cinematográficas desse país, caso dos audiovisuais informativos sobre o Brasil) demonstram um engajamento em torno do projeto insurrecional, uma aposta na guerrilha como método válido, se não internacionalmente, ao menos em países onde a violência do imperialismo exigia o uso de uma outra violência, de caráter libertador - posição evidenciada, por exemplo, em Cuba si, como será analisado. Portanto, trata-se de uma postura metodologicamente oposta àquela adotada pela Unidade Popular chilena no início dos anos 1970. O que levou Marker a se interessar e defender "vias" tão distintas ao socialismo em um intervalo de tempo relativamente pequeno?

Quando contrapostas, produções como Cuba si e $O$ fundo do ar é vermelho revelam algumas pistas para responder a essa pergunta. A defesa da guerrilha, presente na obra de Marker nos anos 1960, depara-se com as inúmeras derrotas sofridas por essa estratégia ao longo da década. O crescente alinhamento da Revolução Cubana com as políticas da União Soviética, simbolizado pelo apoio de Fidel Castro à invasão da Tchecoslováquia em 1968, é outro fator que reforça uma “desilusão" do realizador com esse projeto. Esse vazio ideológico é, portanto, ocupado por uma nova estratégia vitoriosa em 1970 com Salvador Allende. Assim, apesar de focar nos filmes sobre a Unidade Popular, esta pesquisa ocupou-se também das múltiplas visões markerianas sobre Cuba, que ajudam a entender novas preferências políticas reveladas em sua obra sobre o Chile.

Os mesmos argumentos podem ser utilizados para justificar a presença de dois curtas-metragens sobre o Brasil nesta tese, que mereceram uma análise mais conciliação entre socialismo e democracia. 
aprofundada: On vous parle du Brésil: tortures e On vous parle du Brésil: Carlos Marighela. Realizados em parceria com o ICAIC, a pedido do instituto cubano, esses documentários fazem parte do intenso intercâmbio de Marker com Cuba e devem ser lidos nessa chave. Além disso, eles introduzem questões que dialogam tanto com o olhar sobre a Revolução Cubana, gradativamente revisto na filmografia markeriana, como sobre a Unidade Popular.

Nessas produções, há uma defesa aberta da luta armada como estratégia válida para a esquerda, especialmente em países submetidos ao imperialismo e às ditaduras militares que representavam seus interesses. Se esse aspecto, assim como o contexto de realização, as aproxima de Cuba, uma contingência comum as coloca sob uma óptica presente também em produções posteriores ao golpe chileno. Esses "contrainformes" audiovisuais sobre o Brasil foram montados após derrotas significativas na América Latina, sob a repressão de governos ditatoriais. Assim, On vous parle du Brésil: tortures é um filme-denúncia, como é também La spirale. Já On vous parle du Brésil: Carlos Marighela enfrenta o desafio de defender a estratégia guerrilheira de um líder morto, Marighella, como fazem as produções sobre a Unidade Popular montadas sob o impacto da trágica da morte de Salvador Allende. Interessa, portanto, verificar nesses documentários certos discursos e recursos fílmicos que permitem um diálogo com os filmes sobre o Chile.

É necessário ressaltar que muitos dos filmes analisados por esta tese foram feitos em contextos de grandes derrotas para a esquerda, campo político ao qual pertence o seu realizador. Essa característica colocou um problema pertinente desde o início desta pesquisa: de que forma essas experiências "fracassadas", caso da Unidade Popular após 1973 (ou ainda da Revolução Cubana após seu alinhamento com a União Soviética), poderiam servir a um discurso engajado na luta socialista? Essa visão sobre as próprias derrocadas, que algumas vezes assumem tom de denúncia, outras, de autocrítica, é um exercício presente na filmografia de Marker e nem sempre caro aos cineastas considerados "militantes". Portanto, apesar de cada produção responder a essa inquietude de uma maneira, pode-se afirmar que essa foi uma pergunta que percorreu as diversas análises desta tese.

De modo geral, nos filmes abordados neste trabalho, os processos revolucionários latino-americanos geram distintos sentimentos e resultam em perspectivas ideológicas e políticas também diversas. No início dos anos 1960, há um enorme otimismo em torno da Revolução Cubana, que dá a tônica de Cuba si. Esse 
otimismo é abandonado em La bataille des dix millions, quando a defesa do governo de Fidel Castro passa por assumir seus problemas e fragilidades. Em relação à Unidade Popular, o processo é mais complexo. O interesse em conhecer de perto esse fenômeno e mostrá-lo à França, por meio de La première année, é transformado em 1973 na necessidade de denunciar as manobras e a repressão da direita, que abortou uma experiência promissora (perspectiva presente em On vous parle du Chili: ce que disait Allende, La spirale e, de certo modo, em L'ambassade). Assim, ao contrário de Cuba, o Chile tinha sua via revolucionária impossibilitada, à primeira vista, pela vitória de seus inimigos. No entanto, um olhar mais apurado sobre a experiência chilena revelava também suas fragilidades, analisadas em L'ambassade e $O$ fundo do ar é vermelho.

Essa trajetória, do otimismo revolucionário à melancolia autocrítica, que será percorrida nesta tese, estimulou a pesquisa por informações extrafílmicas, presentes em algumas passagens, e que visaram a inserir os discursos de Marker em um debate político mais amplo, verificando suas abordagens e contribuições. Buscou-se ainda estabelecer um diálogo entre as produções aqui analisadas e a própria filmografia do realizador. Desse modo, outros filmes que não fazem parte do corpus deste trabalho, finalizados em outros períodos e contextos e dedicados a temáticas diversas, vêm à tona em alguns momentos, colaborando com a identificação de padrões estéticos e de estratégias narrativas que são constantes em sua obra, bem como de rupturas com certas práticas cinematográficas em casos determinados. Esse exercício contribuiu com esta tese na medida em que inseriu os documentos audiovisuais em um conjunto maior de reflexões cinematográficas do próprio diretor.

A relação entre os filmes analisados e outros cineastas e movimentos influentes da história do cinema (contemporâneos ou não ao realizador) foi outra preocupação que emergiu em várias passagens do texto. Dessa forma, procurou-se estabelecer o diálogo com estilos e estratégias consagradas, além das aproximações interpessoais e políticas estabelecidas por Marker nos anos 1960 e 1970. Isso colaborou para filiar certas características da obra cinematográfica markeriana como herdeiras de outras tradições (como do cinema soviético ou do cinema francês ligado à Frente Popular nos anos 1930). São escolhas estéticas e metodológicas que influem no debate sobre o cinema em sua época, e que repensam esse suporte do ponto de vista artístico e político. Em virtude dessas múltiplas relações, foi criado (nos anexos) 
um índice remissivo de realizadores, produções e instituições cinematográficas citados nesta tese.

Todas essas esferas extrafílmicas aparecem em momentos pontuais do texto, mas sempre em meio à análise fílmica, constituindo-se em alguns momentos como uma espécie de parênteses. A escolha pela integração entre as produções e os diálogos surgidos a partir delas foi fruto da preocupação em não retirar o foco dos filmes, fontes primárias deste trabalho. São eles que estruturam as divisões e subdivisões desta tese, tratados sempre em destaque. Em algumas passagens, há digressões que fogem às imagens, porém isso ocorre sempre em situações onde as informações “contextuais" trazem novos aportes que contribuam para a compreensão estética e/ou discursiva das produções audiovisuais.

No campo da História, o presente trabalho se insere em uma tendência crescente nos últimos anos, que valoriza abordagens transnacionais por meio da História Comparada ou de Histórias conectadas (linha na qual este trabalho se insere $)^{16}$. A análise dos filmes - a relação proposta por eles entre a Unidade Popular e o programa comum das esquerdas francesas - revela uma característica do cinema como veículo de circulação de ideias, no caso desta pesquisa, de ideias políticas. Assim, foi realizada uma vasta investigação historiográfica sobre a experiência chilena e as articulações políticas da França no início da década de 1970, que contribuíram para a compreensão das produções. Outros documentos históricos, além dos de natureza audiovisual, foram consultados, possibilitando a identificação de correntes e argumentos políticos dessa época que estão representados na obra de Chris Marker.

Dessa forma, vale dedicar algumas palavras aos procedimentos desta pesquisa, sobretudo aqueles empregados para consultar os filmes e os documentos citados. Empreendeu-se um grande esforço para conseguir as produções de Marker e de outros realizadores, sendo que o acesso a grande parte delas só foi possível por meio de contatos com outros pesquisadores da área de cinema, que generosamente compartilharam suas cópias. Em relação às fontes audiovisuais encontradas em arquivos, foram de grande utilidade as visitas realizadas especialmente à Cineteca Nacional de Chile (em Santiago), à ISKRA, ao Institut national de l'audiovisuel

\footnotetext{
${ }^{16}$ Uma excelente reflexão sobre os aportes e os possíveis limites concernentes aos estudos da História Comparada e das Histórias conectadas pode ser encontrado no texto Repensando a história comparada da América Latina (PRADO, 2005).
} 
(INA), à Cinémathèque française e à Bibliothèque François Truffaut (os quatro últimos em Paris). Documentos de outras naturezas que também contribuíram para o resultado final foram localizados na Bibliothèque nationale de France (BNF) e na Bibliothèque de documentation internationale contemporaine (BDIC) ${ }^{17}$.

Essa vasta documentação permitiu mapear conexões estabelecidas por Chris Marker com instituições e realizadores latino-americanos que foram importantes para o desenvolvimento do cinema no continente. Além de sua estada no ICAIC, onde realizou atividades de formação junto a cineastas cubanos, é exemplar o caso de sua atuação na montagem de A batalha do Chile, considerado atualmente um documentário icônico do cinema político da América Latina. Apesar da opção por não realizar uma análise fílmica dessa produção, já que a participação de Marker esteve ligada mais à sua produção do que à sua realização, o texto incorpora documentos inéditos encontrados no arquivo da ISKRA que ampliam a importância do realizador francês para a viabilidade do filme de Guzmán, montado no exílio.

Nesse sentido, vale reiterar a figura de Chris Marker como um mediador de "mão dupla" entre a França e a América Latina, colaborando com cineastas cubanos e chilenos, mas também recorrendo aos processos políticos do continente para repensar as próprias estratégias políticas da esquerda de seu país. No caso do Chile, essa dupla dimensão torna-se ainda mais importante devido ao fato de a aproximação entre o projeto político da Unidade Popular e o programa comum das esquerdas europeias ter sido intensa, bem como pela necessidade de fortalecer redes de solidariedade frente aos exilados que chegavam à Europa após o 11 de setembro de 1973. Portanto, o realizador colaborou ativamente com a circulação de ideias estéticas (no campo cinematográfico) e políticas nesse espaço transatlântico, contribuindo para que as experiências revolucionárias latino-americanas dos anos 1960 e 1970 adquirissem um espaço significativo nos debates sobre as vias de acesso e o tipo de socialismo que a esquerda europeia buscava implementar.

Assim, mais do que compreender como Chris Marker via a América Latina, esta pesquisa dedicou-se a analisar as abordagens propostas pelos filmes, situando o continente latino-americano - e, mais especificamente, o Chile - em debates que englobavam também os próprios projetos políticos europeus. Ou seja, propõe-se uma

\footnotetext{
${ }^{17}$ Além desses arquivos, outras bibliotecas também colaboraram para a pesquisa, como a da Cinemateca Brasileira e a do Institut des Hautes Études de l'Amérique latine (IHEAL), onde a pesquisadora realizou um estágio doutoral.
} 
visão que entende essa circulação atlântica como um processo complexo, que vai além da ideia de "influência" e que quebra a tradicional hegemonia atribuída à Europa nesse fluxo. O caso markeriano, do ponto de vista da História, constitui um exemplo de que esses mediadores colaboraram em muitos aspectos para o desenvolvimento de instituições no "Novo Mundo", ao mesmo tempo que trouxeram em sua bagagem reflexões determinantes para os rumos de alguns processos políticos e culturais que tomaram forma no "Velho Mundo". 18

Após essas considerações, é necessário apresentar de que maneira todas essas reflexões tomaram a forma de cinco capítulos, assim como identificar brevemente os objetivos e o conteúdos de cada um deles. Em "De Cuba ao Chile: América Latina na obra de Chris Marker", propõe-se a abordagem de três temáticas presentes na obra do cineasta. A primeira delas é a Revolução Cubana. Marker chegou a Cuba no final de 1960, permanecendo alguns meses no país. Em sua estada, estabeleceu laços com o ICAIC que resultaram em duas produções que exaltaram - cada uma a sua maneira o governo de Fidel Castro: Cuba si (1961) e La bataille des dix millions (1970), ambas analisadas neste primeiro capítulo. Além disso, o contato de Marker com Cuba desdobrou-se em uma cooperação que envolvia a produção e a difusão de filmes, que originou dois curtas-metragens de "contrainformação" realizados em solidariedade aos perseguidos pela ditadura militar no Brasil: On vous parle du Brésil: tortures (1969) e On vous parle du Brésil: Carlos Marighela (1970). Por fim, o capítulo dedica-se à primeira aproximação cinematográfica com o Chile, por meio da participação do realizador em À Valparaiso (1963), de Joris Ivens. Esses documentários sobre esses três países sugerem uma cooperação com as causas revolucionárias, mas também com a formação de instituições cinematográficas ainda incipientes na América Latina.

Assim como o primeiro capítulo, o segundo, "Chris Marker e o cinema chileno: versões francesas para produções sobre a Unidade Popular”, mescla a análise

\footnotetext{
${ }^{18}$ Em relação a atuação desses mediadores nos fluxos de circulação transatlânticos entre Chile e França - caso de Marker -, pode-se recorrer também ao conceito de transferts culturels, tal como elaborado por Michel Espagne (1999). Em seu estudo Les transferts culturels franco-allemands, o autor identifica transferências culturais entre espaços nacionais (França e Alemanha), afirmando que: "O termo transferência cultural marca uma preocupação de falar simultaneamente de múltiplos espaços nacionais, de seus elementos em comum, sem, contudo, justapor as considerações sobre um e outro para confrontá-las, compará-las ou simplesmente acumulá-las.” (ESPAGNE, 1999, p. 1, tradução nossa). Traduzido do original: "Le terme de transfert culturel marque un souci de parler simultanément de plusieurs espaces nationaux, de leurs éléments communs, sans pour autant juxtaposer les considérations sur l'un et autre pour les confronter, les comparer ou simplement les cumuler".
} 
de algumas produções com a identificação de laços de cooperação estabelecidos entre Marker e cineastas latino-americanos. Na época da Unidade Popular, o cinema no Chile ainda era uma prática incipiente, realizada com grandes dificuldades. No entanto, a vitória da aliança de esquerda e a perspectiva de testemunhar uma revolução social incentivaram o engajamento de realizadores nas causas do governo, resultando, sobretudo, em documentários que visavam a acompanhar as transformações e os conflitos desse período. Marker tomou contato em sua visita ao país, em 1972, com El primer año (1972), de Patricio Guzmán, empenhando-se para produzir uma versão que difundisse a UP na França, La première année (1973). Neste capítulo, é feita uma comparação entre as duas versões que permite encontrar mudanças que "adaptaram" o filme ao contexto francês, indicando alguns aspectos valorizados dessa "experiência chilena". O contato entre os dois após o golpe de Estado foi fundamental para a montagem de um filme-denúncia de grande visibilidade, A batalha do Chile - A insurreição da burguesia (1975). Sobre esse tema, vale destacar a vasta quantidade de documentos sobre a atuação da SLON nesse documentário, que revela fatos inéditos que valorizam a etapa francesa de produção, constantemente deixada de lado nos estudos sobre esse cineasta chileno. Por fim, este capítulo analisa uma remontagem de Compañero presidente (1971), de Miguel Littin, feita por Marker no momento da queda de Salvador Allende: On vous parle du Chili: ce que disait Allende (1973). Os novos cortes e a disposição das sequências ante essa entrevista de Régis Debray com o então presidente chileno demonstram novas preocupações sobre essa experiência que emergem com sua derrocada.

Os últimos capítulos se propõem a análises aprofundadas de três produções: La spirale (1976), L'ambassade (1974) e O fundo do ar é vermelho (1977). Em "La spirale (1976): imagens do Chile, denúncia e solidariedade", algumas características desse documentário são ressaltadas, como seu caráter coletivo, o fato de se tratar de um "filme de arquivo", ou "filme-montagem", e o papel da voz over. Durante a pesquisa, foi feito um longo e minucioso trabalho de identificar as origens de grande parte dos extratos e documentos que compõem esse "filme-denúncia" (já que a produção visa a expor as estratégias da direita que desestabilizaram o governo Allende, levando ao golpe de Estado). Essa identificação de uma filiação do material de arquivo serviu para verificar sentidos anteriores atribuídos às imagens e o estabelecimento de novos significados determinados especialmente pelo procedimento da montagem no período posterior ao 11 de setembro de 1973. Esse 
exercício de reelaborar uma herança imagética da Unidade Popular permite também entender a reelaboração política dessa experiência, realizada desde a França. O filme insere-se ainda em um contexto mais amplo de mobilização e apoio aos "derrotados" chilenos, procurando delatar os procedimentos escusos dos vencedores.

O capítulo 4, "L'ambassade (1974): do Chile à esquerda francesa (do documentário à ficção)", analisa essa complexa produção de Chris Marker, definida como uma ficção repleta de "efeitos do real". O texto procura desvendar as "pistas falsas" deixadas pelo realizador, que produzem um signo duplo de lugar: o enredo pode ser situado no Chile ou na França. Estabelece-se a tese de que o país latinoamericano permanece sempre "fora de campo", o que permite que o discurso proposto sobre a queda da Unidade Popular e suas causas seja válido também para outros contextos, como o cenário político francês. Nesse sentido, trata-se de uma produção que propõe um diálogo direto entre a experiência chilena e as tentativas de união em torno de um programa comum na nação do cineasta. L'ambassade incorpora ainda uma crítica direta ao mundo da esquerda - ao qual pertence Marker e seus companheiros -, ganhando ares de uma autorreflexão que ajuda a explicar o golpe de Estado. Por outro lado, a esfera da denúncia de uma repressão esmagadora por parte da direita segue presente, bem como um apontamento para as redes de solidariedade necessárias ao exílio subsequente ao 11 de setembro.

O último capítulo, "O fundo do ar é vermelho (1977): 'do Chile ao - que, de fato?': apontamentos para uma 'via europeia'”, opta por fazer um recorte temático nesse documentário, um dos mais emblemáticos da filmografia markeriana. Apesar da análise não ignorar outros trechos, evitando o risco de uma fragmentação que prejudicasse a visão do conjunto, os blocos temáticos dedicados ao governo da Unidade Popular e ao programa comum da esquerda francesa - e também as passagens que se remetem à Revolução Cubana - mereceram uma atenção especial. Essa escolha metodológica se justifica pelo fato da produção propor um balanço da esquerda em um período de dez anos (1967-1977), enfocando inúmeros eventos ocorridos em várias partes do mundo. $\mathrm{O}$ recorte permite, assim, verificar mudanças e permanências na abordagem em relação aos filmes analisados nos capítulos anteriores desta tese. Nessa comparação, percebe-se, por exemplo, uma revisão da figura de Fidel Castro e de Cuba, por meio de uma ressignificação de imagens presentes nos próprios filmes anteriores de Marker (assim como La spirale, O fundo do ar é vermelho também é constituído com material de arquivo). Em relação à Unidade 
Popular, repete-se um certo tom autocrítico que já estava presente em L'ambassade, porém incorporando novos aspectos. Esse tema é abordado intrinsicamente ligado às estratégias de união em curso na França (entre os partidos Comunista, Socialista e os radicais) e à emergência de uma esquerda nova (adepta dos preceitos democráticos), processos que recebem o apoio do realizador, mesmo que com ressalvas.

Como é possível perceber, a discussão sobre a Unidade Popular chilena esteve bastante presente na filmografia de Marker nos anos 1970. No entanto, conforme será demonstrado, seus filmes propõem abordagens distintas sobre esse assunto, tanto do ponto de vista da discussão política como das escolhas estéticas. Ao longo dos cinco capítulos, essa diversidade será enfatizada, mostrando que não há uma visão determinante sobre esse processo proposta pelo cineasta, mas múltiplas reflexões que enriqueceram o debate sobre a união entre socialismo e democracia na América Latina e na Europa.

Para entender essas diferentes abordagens sobre a Unidade Popular na filmografia de Chris Marker, vale ter em conta que entre as escolhas fílmicas de um documentário ou de uma ficção, estão eventos e enfoques historiográficos que se pretende lembrar ou esquecer, preferindo-se determinados temas ou períodos em detrimento de outros (ou alguns aspectos específicos de certos processos históricos). Assim, o cinema pode ser visto como um dos "lugares de memória" definidos por Pierre Nora (1997). Em um filme, como nesses espaços definidos pelo historiador francês, a consciência de ruptura com o passado se confunde ao desejo por uma memória valorizada e de outra desprezada. Nessa perspectiva, procurou-se verificar não apenas qual é o discurso feito por essas produções audiovisuais analisadas, como também quais são as ausências desse discurso.

Portanto, os filmes presentes nesta tese demonstram uma vontade de falar sobre a experiência chilena, mesmo após a sua queda, funcionando como espécies de testemunhos que reavivam a Unidade Popular, enfatizando a necessidade de não deixá-la cair no esquecimento. Assim, eles formulam uma memória (múltipla) sobre essa experiência, que responde a determinados anseios de seus realizadores e de interesses políticos em jogo na época em que foram feitas essas produções.

Para concluir essas considerações iniciais, vale retomar e aprofundar algumas hipóteses já esboçadas até aqui. A filmografia de Marker dedicada à Unidade Popular sugere uma revisão da defesa da via insurrecional, que esteve presente em sua obra entre 1960 e 1970, como mostra Cuba si e On vous parle du Brésil: Carlos 
Marighela. As constantes derrotas das guerrilhas latino-americanas e os novos rumos tomados pelo governo de Fidel Castro foram "desilusões" que estimularam o otimismo diante de uma nova estratégia que se fortalecia com a vitória de Salvador Allende: a "via democrática". Diante dessa hipótese, esta tese propõe uma visão sobre o realizador francês que o define como um importante mediador entre a América Latina e a Europa, função desempenhada com uma dupla dimensão: incentivador de novas práticas cinematográficas para os cineastas latino-americanos, ao mesmo tempo em que se torna um porta-voz das estratégias revolucionárias desse continente, estimulando sua incorporação nos debates da esquerda europeia.

Após o golpe de Estado do general Augusto Pinochet, essa incorporação de "referências" vindas da América Latina se enfraquece, caracterizando um baque não apenas para as esquerdas desse continente, mas igualmente para a europeia. Em um contexto de formulação de um programa comum entre PCF, PS e radicais, emerge uma nova hipótese: a de que o 11 de setembro chileno exigiu uma profunda revisão de suas próprias estratégias por parte da gauche francesa, que está presente nos filmes de Chris Marker. Essas duas primeiras hipóteses - o fato de a "derrota" do modelo insurrecional cubano ter ampliado a importância da "experiência chilena" e a de que a queda da UP levou à necessidade de revisão das próprias políticas da esquerda na Europa - apontam para uma terceira hipótese: a de que o dito "Terceiro Mundo" desempenhou, nos anos 1960 e 1970, o papel de formular novas maneiras para se chegar ao socialismo, ocupando um papel central nos debates internacionais sobre o assunto.

Uma última hipótese indica que as produções de Chis Marker aprofundam, sobretudo, dois aspectos que foram frequentes também em outros balanços sobre a UP realizados na França: a denúncia das ações da direita e do imperialismo que levaram à queda de Allende e uma autocrítica sobre os "erros" dessa aliança esquerdista que não permitiram sua sustentação no poder. Assim, a visão da América Latina como palco de importantes processos revolucionários e de derrotas que ultrapassaram suas fronteiras demandava, após 1973, a formação de redes internacionais de solidariedade aos seus "revolucionários", nas quais se destaca a causa dos exilados chilenos. Por outro lado, o papel central exercido pelo continente nos debates da esquerda europeia nos anos 1960 e 1970 fazia com que as derrotas além-mar se transformassem em impasses políticos na Europa. 
Portanto, a queda da Unidade Popular desencadeou um exercício autocrítico, presente nos filmes de Marker, que tinha também uma dupla dimensão: dedicava-se a entender os motivos da derrota chilena, mas com o objetivo de repensar os próprios caminhos da esquerda francesa. Esta última hipótese se fortalece pela análise de L'ambassade e de $O$ fundo do ar é vermelho. Nesse sentido, o Chile passou de "modelo" a um "contramodelo". Os "erros" de sua esquerda adquiriram o status de um legado, que, mais do que uma bandeira a ser erguida, indicava "lições" a serem tiradas. 


\section{Capítulo 1 - De Cuba ao Chile: América Latina na obra de Chris Marker}

\section{A Revolução Cubana no documentário de Chris Marker}

A presença de Cuba nas discussões políticas entre artistas e intelectuais na França durante os anos 1960 e 1970 pode ser exemplificada por um episódio narrado pelo escritor Jorge Semprún em Montand: la vie continue (1983). Nesse livro memorialístico, cujo fio condutor são as lembranças sobre Yves Montand, o escritor espanhol demonstra abertamente suas divergências com Régis Debray. Semprún descreve uma situação embaraçosa ocorrida em 1974 na casa de campo do ator e da atriz e escritora Simone Signoret ${ }^{19}$, em Autheuil. Jantavam os dois antagonistas, uma jovem atriz brasileira (identificada apenas como exilada política e companheira de Debray), Montand, Chris Marker, Dominique Landman (montadora e filha de Semprún), além dos atores Catherine Allégret, Jean-Pierre Castaldi e Jean-Claude Dauphin. Semprún alega que durante muitos anos evitara falar sobre Cuba com Debray, que havia se tornado uma das grandes referências para a esquerda francesa após o sucesso do ensaio Révolution dans la révolution? (1967), obra castrista. Porém, foi justamente um livro que repensava a estratégia armada que desencadeou a briga em Autheuil. Debray indagou a opinião de Semprún sobre o lançamento de $L a$ critique des armes (1974), dando-lhe a oportunidade de dizer, não em bom tom, o quanto abominava a defesa dos intelectuais franceses aos métodos e à "ditadura" de Fidel Castro.

A breve descrição desse episódio, que parece ter tido um final muito mais constrangedor do que sugere o parágrafo acima, exemplifica como o modelo de socialismo cubano esteve na pauta das discussões artísticas e intelectuais desde o sucesso da Revolução (1959) - e a posterior declaração de seu caráter socialista (abril de 1961) - até os anos 1970. A presença de Chris Marker como um participanteobservador orgânico desse grupo da intelectualidade francesa também é um dado

\footnotetext{
${ }^{19}$ Simone Signoret é uma figura central do círculo de Chris Marker. Além de sua amiga de infância, a atriz e escritora está presente em alguns de seus filmes, sendo, por exemplo, uma das pessoas que dá vida à voz over em $O$ fundo do ar é vermelho (1977), assim como seu marido, Yves Montand. O realizador também dedicou um documentário a ela: Mémoires pour Simone (1986).
} 
importante desse relato, já que, apesar da crítica feroz a Régis Debray e ao seu "estrelismo", Semprún não cita, em suas memórias, os filmes realizados por Marker (a quem elogia) para defender as ações de Fidel Castro.

Além dos desentendimentos no seio da intelectualidade europeia, esse episódio colabora com a reflexão sobre a maneira pela qual os processos revolucionários ocorridos na América Latina, especialmente a Revolução Cubana ${ }^{20} \mathrm{e}$ a vitória da Unidade Popular no Chile, ocuparam um papel central nos debates da esquerda na Europa. Nesse sentido, as duas obras de Debray que motivaram a discussão com Semprún - Révolution dans la révolution? e La critique des armes -, que serão retomadas em outros momentos desta tese, abordaram respectivamente esses dois processos de implementação do socialismo em território latino-americano, ao mesmo tempo que serviram para repensar as próprias estratégias esquerdistas em curso no continente europeu. Como será demonstrado, a defesa da luta armada e de uma "democracia direta" atribuídas a Cuba vão gradativamente se converter em uma "crítica às armas", que ganhou espaço após o êxito da UP chilena (embora também tenha sido revista com sua posterior derrota, via um golpe militar).

Para compreender o discurso elaborado por Chris Marker em seus filmes dedicados ao Chile, bem como as estratégias fílmicas utilizadas por ele para compor esse discurso, é necessário primeiro entender o vazio deixado pelas desilusões com os rumos da Revolução Cubana, subsequente ao período de sua exaltação. Marker foi um dos muitos entusiastas franceses diante do governo de Fidel Castro, como demonstrará a análise dos filmes Cuba si (1961) e La bataille des dix millions (1970). Além disso, o realizador estabeleceu intercâmbios estreitos com o ICAIC ${ }^{21}$ ao longo dos anos 1960, que devem ser mapeados. Pode-se dizer que essas ações se constituíram como uma primeira aproximação do cineasta com a América Latina,

\footnotetext{
${ }^{20}$ Claudia Gilman (2012) verifica essa centralidade da Revolução Cubana também na esquerda intelectual latino-americana, apontando sua reverberação na intelectualidade europeia. Considerado um fato original por ser uma revolução socialista vitoriosa sem a participação do Partido Comunista, o processo revolucionário cubano aparecia como uma alternativa ante ao abalo na confiança na União Soviética após a divulgação dos crimes do stalinismo, em 1956. Assim, Gilman identifica que a Revolução rompeu com uma perspectiva eurocêntrica, ocidentalista e do Atlântico Norte para dar lugar a uma perspectiva policêntrica.

${ }^{21}$ O ICAIC foi a primeira de uma série de organizações voltadas para a produção cultural do Estado após a Revolução Cubana, assim como a Casa de las Américas e o Instituto Cubano de Radiodifusión. Criado em 1959, menos de três meses após a tomada do poder pela guerrilha, aproveitou as instalações dos Estúdios Biltmore, construídas nos anos 1950, tornando-se uma das maiores estruturas de produção fílmica da América Latina. Além disso, ele dedicava-se à formação de cineastas alinhados ao discurso dos revolucionários, à exibição para um amplo público com salas de projeção e ao arquivamento em uma cinemateca com acervo significativo.
} 
formulando uma defesa da figura de Castro que seria repensada após a chegada de Salvador Allende à presidência chilena, em 1970.

O interesse por Cuba nos anos 1960 não foi exclusividade de Marker. Nas cartas escritas pelo então dirigente do ICAIC, Alfredo Guevara ${ }^{22}$, reunidas em ¿Y si fuera una huella? (2009), ele atribui o contato do governo revolucionário com o grupo de intelectuais e artistas de Paris à aproximação do ator Gérard Philipe ${ }^{23}$ e de sua mulher, Anne Philipe, com a Revolução Cubana. Em correspondência endereçada a Fidel Castro, escrita em 3 de janeiro de 1963, ele recorda a primeira visita do casal à ilha, em 1959, concluindo sobre Gérard:

\begin{abstract}
Atrevo-me a dizer que foi o primeiro intelectual francês de verdadeiro renome e real influência que valorizou nosso processo revolucionário em sua justa dimensão. Até sua visita, as revistas, repórteres e escritores, mais ou menos cegos, haviam se encarregado de nos apresentar como a revolução latino-americana característica de opereta, plena de romantismo e exotismo e, claro, sem a profundidade e a seriedade que a nossa tem. Ele nos apresentou a Jean-Paul Sartre e Simone de Beauvoir, a [Henri] Lefebvre e María Casares, a Gisèle Halimi e Claude Faux, a Yves Montand e Simone Signoret, a Chris Marker e Armand Gatti, enfim, para as pessoas mais ativas, complexas e polêmicas dos círculos artísticos, as quais desde então desempenham, de uma maneira ou de outra, um papel militante em defesa da nossa Revolução (GUEVARA, 2009, p. 117, tradução nossa) ${ }^{24}$.
\end{abstract}

Jean-Paul Sartre e Simone de Beauvoir se destacaram entre os intelectuais franceses pioneiros em visitar Cuba após a Revolução, permanecendo no país entre fevereiro e março de 1960. Em meio a outros compromissos políticos, estiveram nas dependências do ICAIC e foram alvo de um texto publicado na edição $\mathrm{n}^{\circ} 1$ da revista

\footnotetext{
${ }^{22}$ Alfredo Guevara tornou-se dirigente do ICAIC logo após sua criação em decorrência de sua atuação política nos anos 1950 contra o governo de Fulgencio Batista. Na época, ele era um militante do Partido Socialista Popular que, após o processo de centralização partidário, passou a integrar o Partido Comunista de Cuba (1965). Esteve à frente do Instituto até 1982, voltando ao cargo posteriormente, em 1991.

${ }^{23}$ Mariana Villaça (2011) destaca que Gérard Philipe chegou à Cuba em julho de 1959 com um projeto de montar um documentário sobre a guerrilha na Sierra Maestra. Porém, esse projeto não chegou a ser realizado.

${ }^{24}$ Traduzido do original: "Me atrevo a decir que fue el primer intelectual francés de verdadero renombre y real influencia que valoró nuestro proceso revolucionario en su justa dimensión. Hasta su visita, las revistas, reporteros y escritores, menores o demasiado ciegos, se habían encargado de presentarnos como la característica revolución latinoamericana de opereta, plena de romanticismo y exotismo, y claro sin la profundidad y seriedad que la nuestra tiene. El nos presentó a Jean-Paul Sartre y Simone de Beauvoir, a [Henri] Lefebvre y María Casares, a Gisèle Halimi y Claude Faux, a Yves Montand y Simone Signoret, a Chris Marker y Armand Gatti, en fin, a la gente más activa, complicada y polémica de los círculos artísticos, a quienes desde entonces juegan de un modo u otro un papel militante en la defensa de nuestra Revolución."
} 
Cine Cubano 25 "Simone de Beauvoir y Sartre hablan de cine" (1960) ${ }^{26}$. De acordo com o livro Les Amériques Latines en France, Sartre considerou a ilha essencialmente camponesa e um exemplo de democracia direta, declarando que havia encontrado em Fidel Castro e Ernesto Che Guevara “dois filhos” (LEENHARDT; KALFON, 1992). Em artigos publicados nos periódicos France-observateur e France-soir, descreveu a nação latino-americana de maneira idílica, recomendando às novas gerações uma viagem para vê-la de perto ${ }^{27}$.

Entre os cineastas estrangeiros não pertencentes ao bloco socialista ${ }^{28}$, destacase a colaboração de Joris Ivens com o Instituto, ensinando técnicas de seus documentários de cunho social aos realizadores cubanos e rodando os filmes Carnet de viaje e Cuba, Pueblo armado (ambos de 1961). Enquanto o primeiro tratava da Revolução, o segundo se dedicava a registrar as milícias operárias e camponesas. $\mathrm{O}$ holandês esteve em Cuba em setembro de 1960 na condição de contratado pelo

\footnotetext{
${ }^{25}$ Mariana Villaça afirma que a revista Cine Cubano, publicada pela primeira vez em junho de 1960 , tinha uma periodicidade trimestral, por vezes irregular. A autora descreve o periódico da seguinte maneira: "O perfil da revista Cine Cubano era a de um periódico voltado para a difusão das cinematografias nacional e internacional e à crítica especializada. Os primeiros números não apresentam muitas ilustrações, têm muitos ensaios e críticas assinadas, redigidos em linguagem pouco preocupada com o público leigo, com amplo uso de termos estrangeiros. Nesse sentido, chama atenção a qualidade literária e a erudição presentes em artigos e ensaios voltados para o cinema europeu e abertos a explorar o cinema socialista, que então se descortinava como novidade cultural para o público cubano." (VILLAÇA, 2010, p. 82-3).

${ }^{26} \mathrm{O}$ texto em questão é apresentado como uma curta entrevista realizada por Eduardo Manet e Edith Depestre e com os dois intelectuais franceses. Enquanto Simone de Beauvoir declara sua opinião sobre a Nouvelle Vague, classificando os cineastas desse movimento de "anarquistas de direita"; Sartre comenta sobre um roteiro cinematográfico que havia acabado de elaborar, La vie de Freud.

${ }^{27}$ Desde a publicação de $O$ existencialismo é um humanismo (1946), o filósofo francês era uma referência de engajamento político existencialista, que atribuía ao sujeito a responsabilidade por si e por todos os outros seres humanos. Defendendo-se da crítica de "aprisionar o homem em sua subjetividade individual" - postura característica de sua "condição burguesa" -, proferida por marxistas (especialmente os ligados ao Partido Comunista), Sartre admite, nesse texto referencial, que o ponto de partida de sua teoria é a subjetividade do indivíduo, mas considera o reconhecimento da universalidade do ser humano um fator necessário ao engajamento em causas coletivas. Esse modelo influenciou gerações da intelectualidade francesa, sobretudo após o enfraquecimento do stalinismo em 1956, sendo inclusive uma referência para figuras mais "independentes" da esquerda (de não alinhamento partidário), como Chris Marker. Esse cineasta teria sido aluno de Sartre no Lycée Pasteur, em Neuilly-sur-Seine (banlieue de classe alta onde Marker nasceu e morou com sua família), entre 1937 e 1939. O pesquisador Thomas Tode, no artigo "Fantasma Marker: inventario antes del filme" (TODE, 2008), afirma que ambos participaram nessa época da revista Trait d'union, fundada pelos alunos do Instituto, sendo o realizador francês o redator-chefe. Nessa época, ele foi colega de Simone Signoret, amizade que seguiria ao longo de sua vida. O contato com Sartre incentivou que Marker cursasse, após o liceu, o curso de Filosofia da Sorbonne.

${ }^{28}$ Entre os pioneiros do bloco socialista a visitar o ICAIC, destaca-se o soviético Roman Karmen, que rodou em Cuba, em 1961, os filmes Cuba hoy, Alba de Cuba e La lámpara azul. Sobre a importante colaboração com os países do leste, Mariana Villaça destaca que: "No início dos anos 1960 ocorreram várias interlocuções com o bloco socialista, das quais as mais produtivas foram aquelas com o Leste Europeu, como já observamos em relação à cartazística. Junto com uma grande quantidade de técnicos soviéticos que chegaram para 'fazer funcionar' o ICAIC, vieram profissionais tarimbados como Kurt Maetzig, Vladimir Cech e Roman Karmen.” (VILLAÇA, 2006, p. 66-7)
} 
ICAIC para organizar uma escola para documentaristas, concretizada apenas de modo informal. Nesse período, percorreu a ilha acompanhado de cineastas cubanos, cobrindo os enfrentamentos entre o Exército Rebelde e contrarrevolucionários (JORIS [...], 1960). Cabe ressaltar que entre as atribuições dos realizadores convidados pelo Estado estava a de propagandear os feitos da Revolução na Europa, função desempenhada pelos filmes de europeus citados nesta tese, inclusive os de Marker, Cuba si e La bataille des dix millions.

No livro Cinema cubano, Mariana Villaça (2010) destaca que, durante os chamados "anos dourados" da cinematografia em Cuba, a década de 1960, inúmeros cineastas passaram pelo Instituto, que priorizou, no entanto, colaboradores que tivessem comprovada experiência no cinema documental, gênero eleito como o prioritário para abordar as mudanças provocadas pelo processo revolucionário (VILLAÇA, 2010). Foi o caso de Ivens e também de Chris Marker, que começou o projeto Cuba si em janeiro de $1961^{29}$. Essa tendência levou ainda outros documentaristas ao país, como o ítalo-argentino Mario Gallo, que rodou em sua estadia Arriba el campesino e Al compás de Cuba (ambos de 1960) e a francesa Agnès Varda ${ }^{30}$.

O caso de Varda deve ser destacado, já que a cineasta e Chris Marker têm um longo histórico de amizade e colaboração ${ }^{31}$. A realizadora participou do projeto Loin $d u$ Vietnam (1967), a partir do qual se criou a SLON. Em Cuba, ela esteve a convite do ICAIC em 1962, sendo entrevistada pela revista Cine Cubano, $\mathrm{n}^{\circ}$ 6, publicada nesse mesmo ano. Na ocasião, rodou Salut les cubains! (1963), que teve como

\footnotetext{
${ }^{29}$ É importante destacar que alguns cineastas cubanos tinham contato com os europeus em viagens que realizavam à Europa, e não apenas em solo latino-americano. Em carta de 3 de agosto de 1960, Alfredo Guevara escreve ao poeta cubano Roberto Fernández Retamar sua tentativa (frustrada) de encontrar a escritora Anne Philipe, Chris Marker, Henri Langlois e Georges Sadoul durante temporada europeia.

${ }^{30}$ Sobre a contribuição de cineastas estrangeiros ao ICAIC, ver também PARANAGUÁ, 2003.

${ }^{31}$ A colaboração entre Marker e Varda remete, ao menos, à criação do Groupe des Trente (Grupo dos Trinta), em 20 de dezembro de 1953, em reação à revogação da lei que garantia a exibição de um curtametragem antes de cada sessão de cinema na França. Apesar de visto como reativo, tendo em vista a importância cada vez maior desse formato como um espaço de experimentação de novas práticas cinematográficas, Catherine Lupton destaca o caráter propositivo do grupo: "A Declaração do Grupo dos Trinta pode ter sido concebida como um movimento defensivo, mas, ao ser posta no papel, revelou a força dos realizadores de curtas-metragens franceses, seu 'estilo, qualidade e a ambição nos assuntos tratados'; seus autores efetivamente criaram o manifesto para o que se tornaria uma década próspera para a produção de curta-metragem na França, significativamente impulsionada pela introdução, em 1955, de um novo sistema de concessão de ajuda para os curtas." (LUPTON, 2008, p. 47, tradução nossa). Traduzido do original: "The Declaration of the Group of Thirty may have been conceived as a defensive move, but by setting down on paper the perceived strengths of French short filmmaking, its 'style, quality and ambitions subject matter', its authors effectively created the manifesto for what would turn out to be a flourishing decade for short film production in France, significantly assisted by the introduction from 1955 of a new system of grant aid for short films.".
} 
assistente Sara Gómez (uma das mulheres mais ativas no cinema desse país, com produções próprias e assistência recorrente a Tomás Gutiérrez Alea). O documentário de Varda apresenta semelhanças ao de Marker, como será abordado a seguir.

É necessário enfatizar entre as presenças europeias marcantes na Cuba pósrevolucionária outro personagem-chave nessa pesquisa: Régis Debray. De acordo com Leenhardt e Kalfon (1992), ele se ofereceu frente à embaixada de Cuba em Paris para lutar nas forças internacionalistas durante a invasão norte-americana à Baía dos Porcos (junto ao seu amigo Bernard Kouchner, que se tornaria posteriormente um dos fundadores do programa humanitário Médicos sem Fronteira). Os autores afirmam (com bastante ironia), que mesmo sem conhecer uma palavra em espanhol, Debray alfabetizou camponeses da Sierra Maestra. Anos depois, em 1965, voltou à ilha a convite do próprio Castro, transformando sua nova experiência em Révolution dans la révolution?, publicado em 1967. Defensora da estratégia foquista e dos métodos empregados na Revolução Cubana, a obra tornou-se uma "coqueluche" na esquerda francesa, sendo um dos principais veículos de defesa do caminho armado ao socialismo. Afinal, seu autor havia deixado Cuba para acompanhar Ernesto Che Guevara na Bolívia e, como consequência, foi preso e condenado a 30 anos de prisão (em um episódio de difíceis articulações diplomáticas, que levou Debray ao centro dos noticiários internacionais). Marker certamente foi um dos intelectuais e artistas que se seduziram pelas palavras do jovem, referindo-se ao livro em alguns de seus filmes ${ }^{32}$.

Vale destacar que a colaboração entre as esquerdas cubana e europeia (especialmente francesa) envolveu ainda a circulação de técnicos como agrônomos e economistas, que não se encaixam nas categorias anteriormente citadas de intelectuais e artistas. Esse panorama mostra que a troca entre Cuba e a Europa costumava ser de mão dupla, sendo que os europeus buscavam na ilha possíveis alternativas bemsucedidas para sua própria militância enquanto que, para os cubanos, interessava sobretudo difundir os ideais revolucionários, assim como capacitar tecnicamente as novas instituições de Estado que se formavam ou se renovavam. Nesse sentido, a contribuição no campo cinematográfico, em torno das atividades do ICAIC, é exemplar. O documentário Cuba si pode ser analisado como uma defesa da

\footnotetext{
${ }^{32}$ Isso ocorre, por exemplo, em La spirale (1976) e em O fundo do ar é vermelho, onde Révolution dans la révolution? é citada como obra que marcou época. Além disso, Debray aparece em On vous parle du Chili: ce que disait Allende (1973) e no próprio O fundo do ar é vermelho.
} 
Revolução para espectadores franceses, mas também como um laboratório de experimentação e trocas no dia a dia do set de filmagem.

Diante dessas considerações, pode-se afirmar que a relação política da esquerda estabelecida entre Cuba e a França nos anos 1960 teve traços em comum àquela desenvolvida entre o país europeu e o Chile na década posterior, como será demonstrado. Entre as semelhanças, está o fato de a ilha ter se constituído como uma referência a ser analisada, da qual se poderia tirar estratégias válidas para o contexto francês, especialmente no tocante à proximidade de Fidel Castro com o povo. Esse fenômeno, que invertia o fluxo mais tradicional na circulação de ideias entre os dois continentes (que historicamente reproduziu hegemonias políticas e econômicas, delegando à Europa um lugar central e à América Latina um papel secundário), foi repetido frente ao otimismo da esquerda francesa com a chegada da Unidade Popular chilena ao poder.

No entanto, há uma grande diferença nesse fluxo circulatório entre a França e Cuba e entre a França e o Chile. No primeiro caso, que intensificou-se após a Revolução Cubana, o processo revolucionário latino-americano era considerado uma alternativa especialmente para os países com um passado de colônia. No final dos anos 1950 e início dos anos 1960, os textos de Frantz Fanon emergiam em um contexto de decadência do projeto colonial francês (materializada pela independência da Argélia, em 1962) e colaboravam para que os acontecimentos em Cuba fossem vistos também como fruto de uma violência libertadora contra o imperialismo. Assim, inserida na "metrópole", a esquerda francesa tinha muito a apreender com os cubanos, mas os métodos insurrecionais, em particular, não encontravam um espaço significativo nos projetos voltados à política interna. Por outro lado, o caso chileno seria ainda mais instigante para os esquerdistas, como será demonstrado nesta tese, por se apresentar como uma via ao socialismo adequada às especificidades europeias.

Cabe, nesse momento, analisar as produções de Marker que resultaram de um intenso intercâmbio com o ICAIC, verificando também as propostas estéticas e políticas apresentadas por esses filmes sobre Cuba. 


\section{1. Cuba si (1961) $)^{33}$}

Marker chegou a Cuba em dezembro de 1960, e logo iniciou a gravação das cenas usadas em Cuba si. A sequência inicial do filme mostra uma parada militar, e é seguida por imagens de crianças pedindo presentes de Natal, que, na ilha, são ofertados no Dia de Reis. O documentário une a tradição festiva da data com as comemorações do segundo aniversário da Revolução, em $1^{\circ}$ de janeiro de 1961. Durante seus 52 minutos, dois aspectos são bastante explorados: a autenticidade cultural do povo cubano e a liberdade de exercê-la em sua plenitude após a libertação promovida pelos revolucionários. O realizador exibe o nascimento de uma nova nação, simbolizada pelos pedidos de meninos e meninas aos reis magos alegoricamente barbudos como os revolucionários da guerrilha. A voz over anuncia:

Era o ano passado, em Havana. Preparávamo-nos para celebrar, nessa ordem: o $1^{\circ}$ de janeiro, que é o $1^{\circ}$ de janeiro, o 2 de janeiro, que é o aniversário da Revolução, e o Dia de Reis, que é o Natal - o verdadeiro Natal, o dia dos presentes, quando ofertamos às crianças os bebês-cachorros, que crescerão, os bebês-coelhos, que crescerão, os periquitos batizados de peixes, os ursos e as bonecas, e também os bebês metralhadoras, que crescerão! (Cuba si, 1961, tradução nossa $)^{34}$

Nessa sequência inicial, a militarização aparece como uma característica da sociedade cubana amplamente exaltada em Cuba si. O documentário é repleto de cortejos militares, sempre mesclados à multidão nas ruas, filmada por câmeras em travelling e alguns close-ups, o que permite caracterizá-la como uma soma de pessoas multiétnicas. Soldados caminham com metralhadoras, mas também com tambores. A celebração é garantida, na visão de Chris Marker, pela unidade do povo e sua disposição em se defender dos inimigos internos e externos. Esse país recém-liberto, “ex-quintal” dos Estados Unidos, está agora nacionalizado, porém, não sem tensões e ameaças.

\footnotetext{
${ }^{33}$ A análise de Cuba si foi realizada com base em uma cópia obtida por meio de outros pesquisadores da obra de Chris Marker. O documentário encontra-se disponível também no youtube: <http://www.youtube.com/watch?v=7TI5Avxoojo\&playnext=1\&list=PLC492C57B6C27A9FC\&featur e=results_video> (acesso em 25 fev. 2013). O texto da voz over de Cuba si está publicado integralmente em Commentaires I (MARKER, 1961).

${ }^{34}$ Trecho da voz over de Cuba si (1961), traduzido do original: "C'était l'année dernière, à La Havane. On se préparait à célébrer dans l'ordre: le $1^{\mathrm{er}}$ janvier, qui est le $1^{\mathrm{er}}$ janvier, le 2 janvier, qui est l'anniversaire de la Révolution, et le jour des Rois, qui est Noël - le vrais Noël, le jour des cadeaux, où l'on offre aux enfants des bébés-chiens, qui grandiront, des bébés-lapins, qui grandiront, des perruches baptisées poissons, des ours et des poupées, et aussi des bébés mitraillettes, qui grandiront!"
} 

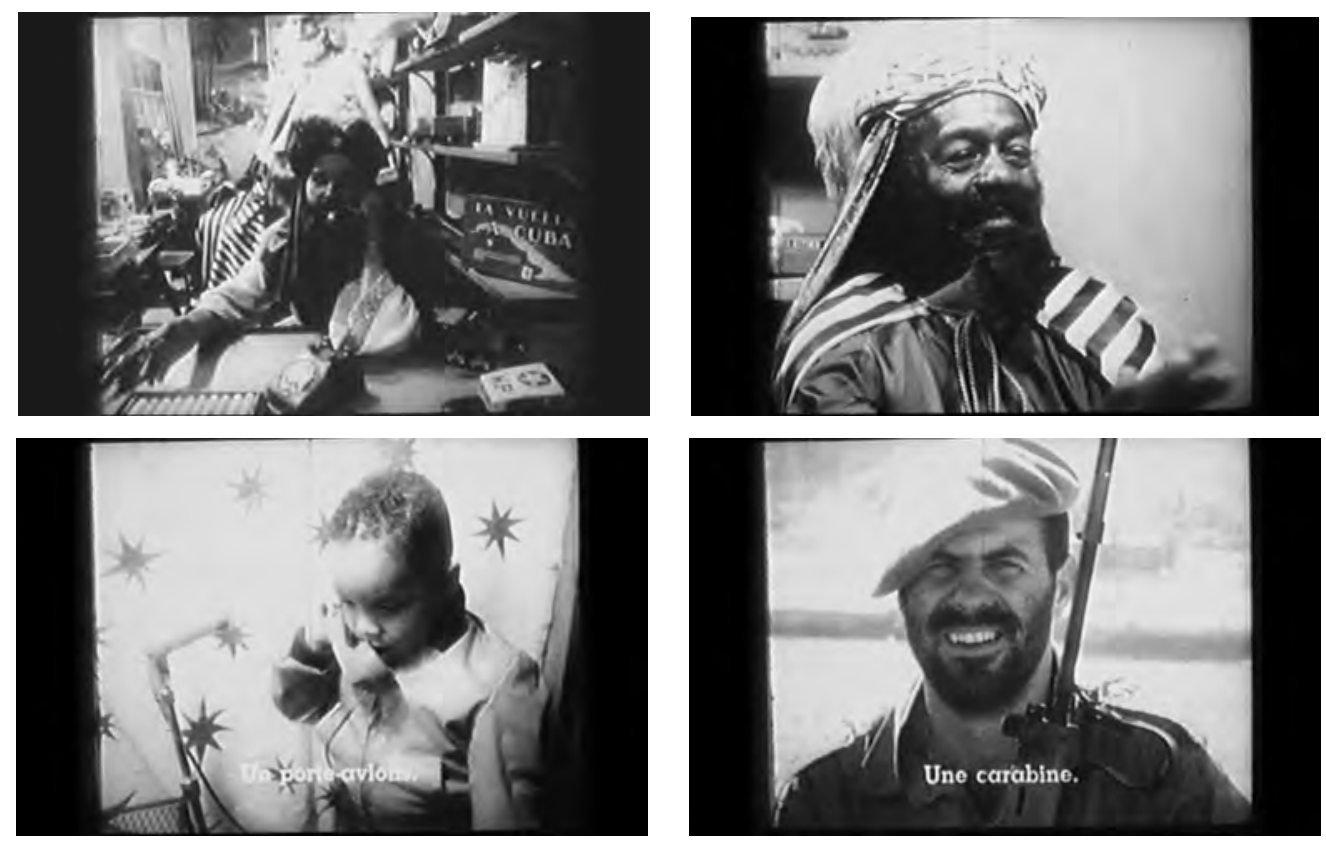

Sequência de Cuba si.

O clima de festa, mas também de conspiração, mostrado por Marker em Cuba si, condiz com os desafios enfrentados pelo Estado cubano no princípio de 1961. Em carta escrita ao embaixador de Cuba na França, Harold Gramatges, datada de 4 de janeiro de 1961, Alfredo Guevara (2009) anuncia a presença de Marker no país e sua intenção de rodar um documentário com roteiro do realizador cubano Eduardo Manet, declarando ciência de que o diplomata foi responsável pela vinda do cineasta francês ${ }^{35}$. Na mesma correspondência, no entanto, o diretor do ICAIC compartilha a preocupação com as constantes ameaças dos Estados Unidos, que haviam rompido relações diplomáticas e tinham planos de agressão. De fato, os meses dedicados à montagem de Cuba si possibilitaram a incorporação de cenas do ataque norteamericano à Baía dos Porcos, ocorrido em 17 de abril de 1961, em suas sequências finais ${ }^{36}$.

\footnotetext{
${ }^{35}$ No artigo "Marker, si!", publicado na Cine Cubano, $\mathrm{n}^{\circ}$ 6, Eduardo Manet (1962) declara que Chris Marker terminava a montagem de Description d'un combat (1960), filme rodado em Israel, quando recebeu o convite do ICAIC para acompanhar as festas do segundo aniversário da Revolução Cubana, ao qual respondeu positivamente.

${ }^{36}$ Enfatizando a militância de Marker em favor de Cuba, Eduardo Manet relata a reação do cineasta francês, já em seu país, ao receber a notícia da ofensiva norte-americana: "Armand Gatti me contava que quando chegou à França a notícia do ataque da Playa Girón, Marker o tirou literalmente da cama (eram sete da manhã) para iniciar imediatamente visitas e reuniões que levariam ao mundo o protesto dos cineastas franceses contra esse ato de vandalismo. E, conta Gatti, a partir desse momento, Chris Marker dividiu as pessoas em três categorias: seus amigos (os que disseram sim a Cuba de imediato); seus conhecidos (os que titubearam) e os que não conhecia mais dali em diante (os que disseram não)." (MANET, 1962, p. 53, tradução nossa). Traduzido do original: "Armand Gatti me contaba que cuando llegó a Francia la noticia de ataque del Playa Girón, Marker lo tiró literalmente de la cama (eran las
} 
Marker também insere na montagem fotos de jornais franceses sobre o episódio, bem como narrações da rádio local. A voz over anuncia que os relatos da imprensa europeia relembraram ao realizador seus passeios meses antes em Havana, fazendo dos fragmentos de imagem presentes em sua memória espécies de oráculos de uma situação de conflito iminente entre um mundo em transformação e as forças conservadoras que pretendiam barrar esse processo. A voz over relaciona a insatisfação dos Estados Unidos à consolidação de um Estado social justo e não submetido às suas vontades. Por meio desse recurso narrativo, o cineasta declara que, apesar da distância, são suas lembranças que o fazem confiar na resistência do povo cubano.

Ao caracterizar a França como o lugar da montagem de Cuba si, portanto, um espaço-tempo distinto ao da captação das imagens (aquele de uma Cuba que passa a existir em sua memória e nas imagens registradas), Marker repete uma estratégia já usada em Dimanche à Pékin (1956), filme que exalta a cultura chinesa e as ações do Estado comunista. Nessa outra produção, em que a câmera percorre em travelling objetos chineses repousados em uma sacada de Paris (o que fica claro pela trajetória rumo à vista da Torre Eiffel), a voz over explicita uma característica inerente ao cinema documental, que transforma extratos apreendidos em meros fragmentos do passado. Essas tomadas feitas em países distantes se tornam, na capital francesa, lembranças de uma viagem: "Nada é mais belo que Paris, a não ser um souvenir de Paris. E nada é mais belo que Pequim, a não ser um souvenir de Pequim. E eu, em Paris, me lembro de Pequim e conto os meus tesouros." (Dimanche à Pékin, 1956, tradução nossa). ${ }^{37}$

Da mesma forma, os planos gravados em Cuba se convertem em lembranças vistas de Paris. A questão do local de onde fala o realizador é fundamental em toda a obra de Marker que, quando se remete a lugares distantes, assume seu ponto de vista como estrangeiro. É possível perceber, na abordagem dos filmes sobre processos latino-americanos que serão abordados nesta tese, o diálogo direto com a sociedade francesa, uma marca de muitas produções desse realizador, bem como a tendência de

siete de la mañana) para iniciar de inmediato visitas y reuniones que llevarían al mundo la protesta de los cineastas franceses contra el hecho vandálico. Y, cuenta Gatti, a partir de ese momento Chris Marker dividió a la gente en tres compartimientos: sus amigos (los que dijeron sí a Cuba de inmediato); sus conocidos (los que titubearon) y los que no reconocerá en adelante (los que dijeron no)."

${ }^{37}$ Traduzido do original: "Rien n'est plus beau que Paris, sinon le souvenir de Paris. Et rien n'est plus beau que Pékin, sinon le souvenir de Pékin. Et moi, à Paris, je me souviens de Pékin et je compte mes trésors.". 
internacionalizar o discurso político, uma característica presente em Cuba si, assim como nas produções sobre a Unidade Popular chilena, com destaque para L'ambassade.

Pode-se dizer que a obra de Chris Marker aponta para uma visão internacionalista dos processos políticos que aborda. Um exemplo desse esforço em conectar as realidades locais a um único conflito mundial - entre revolucionários e conservadores, entre capitalismo e socialismo - está presente em uma sequência de Cuba si composta por uma sucessão de planos curtos rodados em lugares diversos: corridas de automóvel, desfile de moda na Europa, competição de beleza de animais... Após esse pot-pourri de imagens da elite, veem-se chefes de Estado, astronautas, guerras e touradas. A voz over guia o percurso pelas diversas regiões: França, Argélia, América, Congo, Laos, África. Nessa passagem, Cuba é contraposta ao luxo e à violência disseminados em outros espaços, constituindo-se como uma exceção, uma ilha livre dos males do imperialismo.
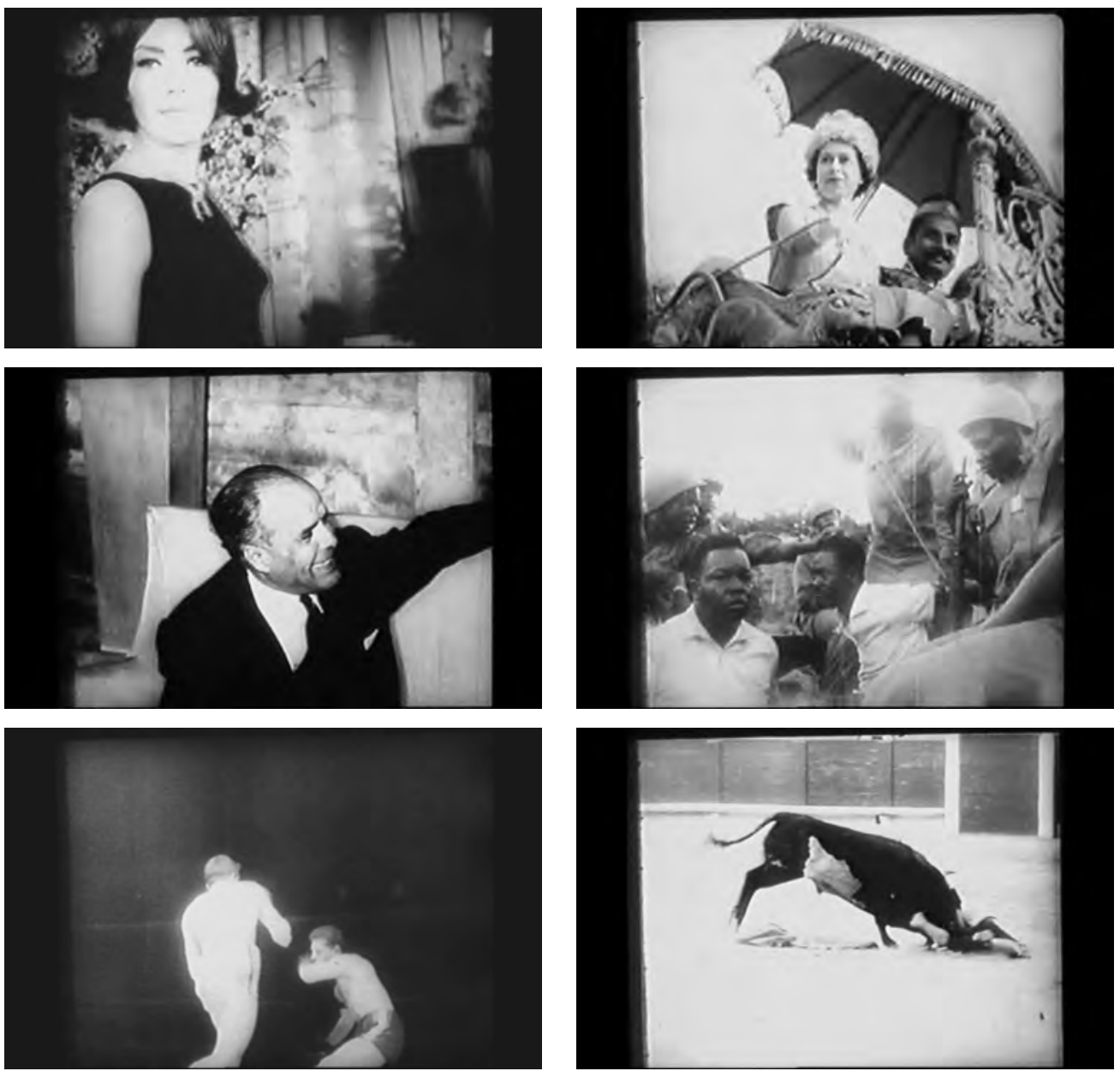

Pot-pourri de imagens de Cuba si. 
É interessante notar como Marker atribui um status diferente à violência promovida pelo imperialismo e àquela exercida pelos revolucionários cubanos, caracterizada como libertadora. Em Cuba, as armas e os tambores, o exército e o povo, compartilham as ruas em enormes manifestações de apoio ao governo. As metralhadoras, as mesmas pedidas pelas crianças aos reis magos no início do filme, são os artefatos de defesa, enquanto que as utilizadas pelas potências imperialistas, são as de ataque. Nesse sentido, vale destacar que há um julgamento ético da violência, pelo qual ela pode ser considerada "boa" ou "má", de acordo com o fim ao qual se destina.

Entre as estratégias fílmicas usadas por Marker para transmitir o clima de conspiração relacionado ao enfrentamento entre essas duas forças - luta armada libertadora e poderio militar imperialista (revolução e contrarrevolução) -, está o uso de imagens associativas de natureza metafórica, como já havia ocorrido na sequência inicial das crianças e de seus presentes do Dia de Reis. Ao caracterizar a tensão anterior ao ataque à Baía dos Porcos (evento posterior à estada de Marker em Cuba, mas já previsto por ele em suas "imagens-oráculos"), o realizador traz cenas de crocodilos submersos em Playa Girón. Aparentemente quietos, eles se preparam para dar o bote, assim como os vizinhos yankees e os anticastristas cubanos ${ }^{38}$. As tomadas desses traiçoeiros animais são acompanhadas pela notícia do ataque transmitida em uma rádio francesa, na qual o locutor questiona em off o resultado e a postura que a população teria frente ao ataque à "ditadura de Fidel Castro". Um corte introduz cenas da invasão norte-americana e do poderio militar defensivo de Cuba. A voz over declara que, em 20 de abril de 1961, o mundo não apenas viu a vitória do governo revolucionário, como apreendeu que o povo cubano estava pronto a defender sua Revolução.

Essa sequência final de Cuba si, assim como muitas outras, deixa claro que se trata de um filme militante no sentido mais estrito do termo, feito para atuar em prol de uma causa - no caso, a Revolução Cubana. A produção exalta o processo em curso no país em tom celebrativo (cabe dizer que a proposta inicial de título da produção era Celebración). Mesmo a afirmação em favor da ilha, "Cuba si”, tirada de um dos lemas do governo revolucionário, reforça o caráter propagandístico do documentário.

\footnotetext{
${ }^{38}$ Essa oposição entre revolução e contrarrevolução por meio de associações metafóricas está presente também em uma das sequências iniciais do filme, com a presença de um jogo de beisebol, paixão nacional cubana e norte-americana.
} 
Sua intenção é evidentemente rebater a visão hegemônica negativa de Fidel Castro na imprensa da Europa, sobretudo da França. Esse artifício está presente na passagem descrita anteriormente, em que os planos dos crocodilos fazem oposição à análise do comentarista de rádio francês. Da mesma forma, as manchetes dos periódicos europeus são negadas por artifícios da montagem.

Em artigo publicado na revista Cine Cubano, em 1961, Eduardo Manet, integrante da equipe de Cuba si, descreve episódios da estada de Marker no ICAIC e comenta sobre os objetivos e estratégias do filme. Manet cita uma declaração do diretor francês que diz que a produção rodada em Cuba deveria ser extremamente parcial, já que Dimanche à Pékin e Lettre de Sibérie (1957) teriam sido acusadas de demonstrar certo distanciamento ou ambiguidade em seu posicionamento político. De fato, esse documentário não deixa dúvidas do alinhamento de Marker ao lado da Revolução, o que é visível principalmente na caracterização de Fidel Castro.

Em Cuba si, a voz over declara que, para o resto do mundo, especialmente para os norte-americanos, é mais fácil ressuscitar o mito e associar Fidel Castro à figura de Robin Hood do que entender sua verdadeira origem. Uma sequência de justaposição de gravuras e cenas audiovisuais de ficção representando o "príncipe dos ladrões" ${ }^{39}$ é intercalada a imagens documentais da guerrilha na Sierra Maestra, ligando Castro e Hood por meio da seleção de cenas que lembram o estereótipo do homem "bárbaro" (um barbudo vivendo nas matas e comendo com as mãos) ${ }^{40}$. O comentário proferido pela voz over, no entanto, torna a situação mais complexa:

Trata-se, talvez, de Robin Hood... Somente tomar dos ricos e dar aos pobres, no século em que estamos, não consiste necessariamente em atacar as diligências. E quando Robin Hood leu Marx, quando nas suas montanhas ele prepara as leis e as reformas da futura

\footnotetext{
${ }^{39}$ As cenas de ficção usadas nessa sequência foram retiradas do filme Robin Hood (1922), de Allan Dwan.

${ }^{40}$ De acordo com Guy Gauthier, essa sequência contou com a participação de William Guéry, que havia colaborado com Dimanche à Pékin criando uma cena de animação. Esse procedimento de montagem por meio da associação de elementos diversos (animação, ilustrações, trechos ficcionais e documentais etc.), teria se transformado em uma referência para o cinema militante. De fato, há características comuns entre essa passagem e as colagens desenvolvidas por Santiago Álvarez. Gauthier descreve os procedimentos empregados nesse trecho: "Tudo estava previsto, fotos de diferentes formatos, desenhos, manchetes de jornal, fotogramas extraídos do filme americano Robin Hood, mas também enquadramentos e movimentos de câmera. Tudo se agrega e adquire sentido e ritmo na montagem, segundo uma complexa mecânica supervisionada pelo autor: do mercado de pulgas à mecânica de precisão." (GAUTHIER, 2001, p. 45, tradução nossa). Traduzido do original: "Tout était prévu, photos de différents formats, dessins, titres de journaux, photogrammes extraits du film américain Robin des Bois, mais aussi les cadrages et les mouvements d'appareil. Tout s'assemble et prend sens et rythme au montage, selon un mécano complexe supervisé par l'auteur: du marché aux puces à la mécanique de précision.”
} 
república, uma parte do mundo começa a se dar conta com pesar que está atrasada também, mais que um Robin Hood. Assim, morrem as lendas. O mito de Robin Hood se desfaz em pedaços. Em seu lugar, uma Revolução. (Cuba si, 1961, tradução nossa) $)^{41^{\circ}}$

Buscando ir além do mito, Marker insere, na sequência posterior às representações de Castro como um "bárbaro", planos dele estudando. A representação da Revolução "barbárie" (aquela espalhada pelos Estados Unidos) dá lugar à da “civilização", por meio do retrato de um líder instruído. Nessa etapa, Cuba si se assume claramente como um contraponto aos estereótipos negativos em torno do cubano, dedicando-se a entender inclusive suas contradições. Grandes manifestações em apoio à causa revolucionária "desmentiriam", na estratégia do realizador, a visão de que se tratava de um ditador. A narrativa do documentário caminha para a sugestão de que, ao invés de um fenômeno totalitário - como defendia a imprensa francesa -, a Revolução era um exemplo de democracia direta.
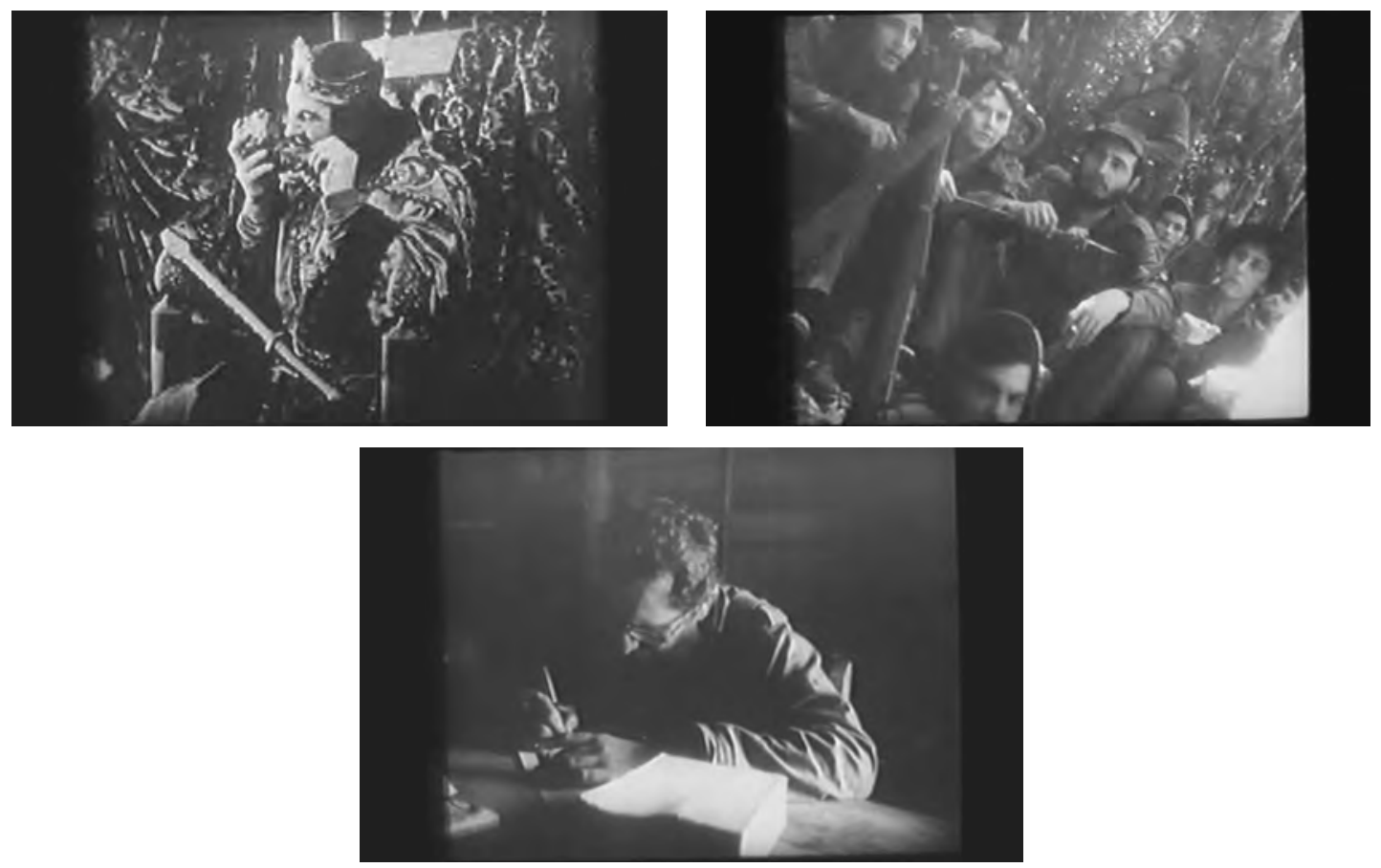

Sequência de Cuba si que intercala imagens da Sierra Maestra e de Robin Hood (Allan Dwan, 1922).

\footnotetext{
${ }^{41}$ Traduzido do original: "C'est peut-être Robin des Bois... Seulement, prendre aux riches et donner aux pauvres, au siècle où nous sommes, ne consiste pas forcément, à attaquer les diligences. Et lorsque Robin des Bois a lu Marx, lorsque dans ses montagnes il prépare les lois et les réformes de la future république, une partie du monde commence à s'apercevoir avec douleur quelle est en retard, aussi, d'un Robin des Bois. Ainsi, meurent les légendes. Le mythe de Robin des Bois vole en éclats. A sa place : une Révolution.”.
} 
Para perceber esse fato, faltava, como indica a voz over, que o exterior compreendesse os aspectos culturais da Revolução Cubana. Ela também comenta que, enquanto as cenas de fuzilamento de um ex-comandante de Batista rodaram o mundo, as dos prisioneiros políticos disputando competições de xadrez com seus guardas permaneciam desconhecidas (até serem mostradas em Cuba si). Enquanto as manchetes da imprensa francesa publicavam que Castro era acusado de trair seus companheiros pelo Departamento de Estado, as faces dos engravatados "almofadinhas" que formavam esse órgão eram inéditas na Europa. Se o presidente aparecia como um anticristão perante os europeus, ninguém havia ainda entrevistado os padres cubanos a respeito (especialmente o que defende no filme as políticas do novo governo como aquelas mais próximas das bases do cristianismo). Assim, o realizador francês se dedica a trazer contra-argumentos ao discurso da mídia francesa, gerando um panorama extremamente favorável a Cuba.

Marker lança ainda a seguinte pergunta: quem é Fidel Castro? Filho de proprietário de terras, aluno jesuíta e fundador da primeira república socialista das Américas. Como se deu a metamorfose entre sua formação e sua condição atual? A resposta é inserida na montagem por meio de um fragmento de entrevista com o próprio chefe de Estado, sequência originalmente registrada por Étienne Lalou e Igor Berrère para o programa Faire face, da televisão francesa L'Office de RadiodiffusionTélévision Française (ORTF) e cedida a Marker. Nessa entrevista, Castro atribui seu sucesso principalmente a uma vocação política, a uma tendência natural à justiça e a um ambiente favorável à revolução - como o que estava dado em Cuba devido à desigualdade social. Ele declara que nem os revolucionários, nem as revoluções, dependem deles mesmos, explicando-se diretamente ao público francês:

Não pode haver revolução fora de tempo. Quantos Marats, e quantos Dantons e quantos Robespierres haverão nascido na França desde que a França existe. E, no entanto, somente um Marat, somente um Danton e somente um Robespierre se transformaram em revolucionários. Quando? Quando a monarquia feudal já estava em decadência. (Cuba si, 1961, tradução nossa) ${ }^{42}$

Em outro trecho dessa mesma entrevista, inserido mais à frente na montagem, Castro cita novamente a França para explicar porque, após dois anos, ainda não havia

\footnotetext{
${ }^{42}$ Traduzido do original: "No puede haber revolución fuera de tiempo. Cuantos Marats, y cuantos Dantones y cuantos Robespierres habrán nacido en Francia desde que Francia existe! Y sin embargo solo un Marat, solo un Danton y solo un Robespierre devienen en revolucionarios. Cuando? Cuando la monarquía feudal estaba ya en decadencia."
} 
ocorrido eleições em seu país. A escolha dessa sequência por Marker visava a rebater a constante acusação de que se tratava de uma ditadura, portanto, de um governo não desejado pelas democracias ocidentais. Lembrando os anos durante os quais a ilha esteve submetida ao governo do ditador Batista, o líder cubano considera a hipótese de se instaurar um processo eleitoral posterior à institucionalização da Revolução e à criação de novos arranjos políticos. Porém, ele compara a nação latino-americana à europeia, estranhando o fato dos franceses não entenderem que o "eleitorismo" não resolveria os problemas de uma nação - nas palavras de Castro. Segundo ele, enquanto na Europa a população estava descontente, em Cuba havia eleições todos os meses em praça pública, visível no apoio expresso por aclamação popular. Claramente, esse trecho indica a posição do realizador ao lado das análises esquerdistas que consideravam a ilha um exemplo de democracia direta (como já havia defendido Sartre, por exemplo, em sua estada $)^{43}$.

Essa oposição entre uma falsa democracia, não representativa da vontade do povo, e o governo revolucionário aparece como um forte argumento no discurso de Marker. Do ponto de vista da seleção de planos, são as cenas de multidão, sobretudo aquelas nas quais os cubanos civis aparecem mesclados ao exército nas paradas militares (confirmando que, no caso de Cuba, as armas são libertadoras, e não opressoras $^{44}$, as que mais confirmam essa tese da democracia direta. Em relação às temáticas abordadas, o alinhamento militante do realizador com o Estado valoriza

\footnotetext{
43 Claudia Gilman (2012) aponta que essa ênfase em uma nova forma de democracia, que rebatia as críticas sobre o caráter ditatorial da Revolução Cubana, respondia ao diagnóstico de que a Europa vivia uma "idade de ferro" em oposição ao "fermento revolucionário" de outras regiões. A autora destaca que o terceiro-mundismo vinha ao encontro da urgência de um novo esquerdismo revolucionário, diante das fórmulas insuficientes em voga na esquerda europeia (como a "socialdemocracia" e o que a autora chama de "economicismo do proletariado").

${ }^{44}$ Em relação à exaltação da violência como forma de conquista da liberdade, é necessário enfatizar a presença das ideias de Frantz Fanon e seu eco frente aos processos de descolonização. Assim como Marker, Fanon começou sua carreira de ensaísta na revista Esprit nos anos 1950. Grande parte de suas obras foram publicadas pelas edições Maspero, outra evidência que o aproxima do circuito de produção e convívio do realizador francês. A defesa das guerras de libertação nacional contra o imperialismo, nas quais a Argélia colocava em questão a postura dos intelectuais de esquerda da França frente a esses processos, esteve presente no chamado Nuevo Cine Latinoamericano (principalmente no Grupo Cine Liberación e no Cinema Novo, com destaque para a obra de Glauber Rocha), mas também nas produções markerianas que pensaram a América Latina. Ao fazer seu primeiro documentário ao lado de Alain Resnais, Les statues meurent aussi (1953), Marker atacava as políticas neocoloniais francesas ao mostrar os objetos de arte africana destituídos de seu significado no Musée de l'homme. Se é possível relacionar essa produção ao pensamento de Fanon, o mesmo pode ser feito com Cuba si, montado coincidentemente no ano de lançamento de Les damnés de la terre, uma defesa aberta do uso da violência para a libertação neocolonial. O prefácio dessa edição de 1961, escrito por Sartre, se tornou, bem como a obra, referência fundamental para se abordar a condição de "colônia", delimitando parâmetros de análise na esquerda francesa anti-imperialista desde então.
} 
aquelas que mostram as transformações da realidade social do país. Sendo assim, além de celebrar, o documentário busca também difundir essas mudanças.

A voz over é, sem dúvida, um dos elementos-chave nesse processo. Porém, a música cubana também está presente como um recurso sonoro de exaltação da Revolução. São muitas as cenas onde ela acompanha a multidão e as marchas militares. A principal delas - e a mais criticada também ${ }^{45}$ - é a sequência já citada, em que um cortejo militar se transforma inesperadamente em uma conga, dançada pelo povo que acompanhava a fanfarra. Outra canção presente no documentário, sobreposta a imagens de grandes manifestações populares, é Después de un año, de Carlos Puebla, que celebra o primeiro aniversário do governo. O refrão "Y el pueblo después de un año repite, Gracias Fidel" exalta o apoio popular ao líder revolucionário e é usada pelo realizador com essa finalidade.

Além do clima festivo, a defesa de Marker a Cuba passa pela oposição entre o novo governo e o período em que Batista esteve no poder - essa sim, uma verdadeira ditadura. Em suas sequências iniciais, Cuba si indica que industrialização, reforma agrária e alfabetização eram os três pilares da Revolução. 1961 é caracterizado como o "ano da educação", já que cada cubano alfabetizado deveria cuidar de um não letrado para, dessa forma, mudar as péssimas estatísticas do setor (1,5 milhão de analfabetos). Em outra cena, é possível ver uma praia repleta de populares, enquanto a voz over indica que antes ela era ocupada apenas pela elite. Ao final da primeira parte do documentário ${ }^{46}$, são alternadas tomadas gravadas durante o período de Batista com

\footnotetext{
${ }^{45}$ Michel Mardone, no artigo "Conga no!", publicado em fevereiro de 1964 em Cahiers du Cinéma, critica Cuba si, citando especificamente essa cena. Ele acusa o filme de não acrescentar nada ao debate, trazendo uma análise rasa e tendenciosa do lado de Fidel Castro. Sobre a cena da conga, ele afirma que se trata de uma mise en scène travestida de tomada documental: "Por que saudar como uma feliz coincidência tomada pela câmera a mudança de ritmo da fanfarra militar que se põe a tocar uma conga, se essa cena foi preparada com a colaboração do melhor tocador de conga de Havana? Trata-se de comprovar se os cubanos desgostam de passo de ganso? Nós duvidaríamos disso, inútil montar uma cena para isso. Na realidade, Marker e seus cúmplices filmam a felicidade e a despreocupação para esconder a verdade, de que uma situação revolucionária exige uma política, pois eles serviram de vitrine para todas as demagogias. Da mesma forma, nós cantávamos e dançávamos na rua sob o governo de Batista: o que isso prova?" (MARDONE, 1964, p. 72-3, tradução nossa). Traduzido do original: "Pourquoi saluer comme un bienheureux hasard saisi par la caméra le changement de rythme de la fanfare militaire qui se met à jouer une conga, si cette scène a été préparée, avec la collaboration du meilleur joueur de conga de La Havane? D’agit-il de vérifier que les Cubains manquent de goût pour pas de l'oie? On s'en douterait, inutile de monter une mise en scène pour cela. En fait, Marker et ses compères ne filment le bonheur et l'insouciance que pour se cacher la vérité, à savoir qu'une situation révolutionnaire exige un politique, car elles ont servi de paravent à toutes les démagogies. Sous Batista également, on chantait et on dansait dans les rues: qu'est-ce que cela prouvait?".

${ }^{46} \mathrm{O}$ documentário é dividido em duas partes. Cada uma delas tem cerca de 26 minutos. Apesar delas não apresentarem uma grande coerência interna de temas, pode-se dizer que a primeira prioriza as
} 
outras realizadas após a mudança de poder. Se antes havia palácios e pobreza extrema, se o povo era massacrado pela repressão militar - bem como os guerrilheiros que o defendiam -, sobrava apenas uma estátua de um "bebê Napoleão" do luxo palaciano anterior a $19599^{47}$ (em mais uma sequência onde Marker faz referência à história de seu próprio país).
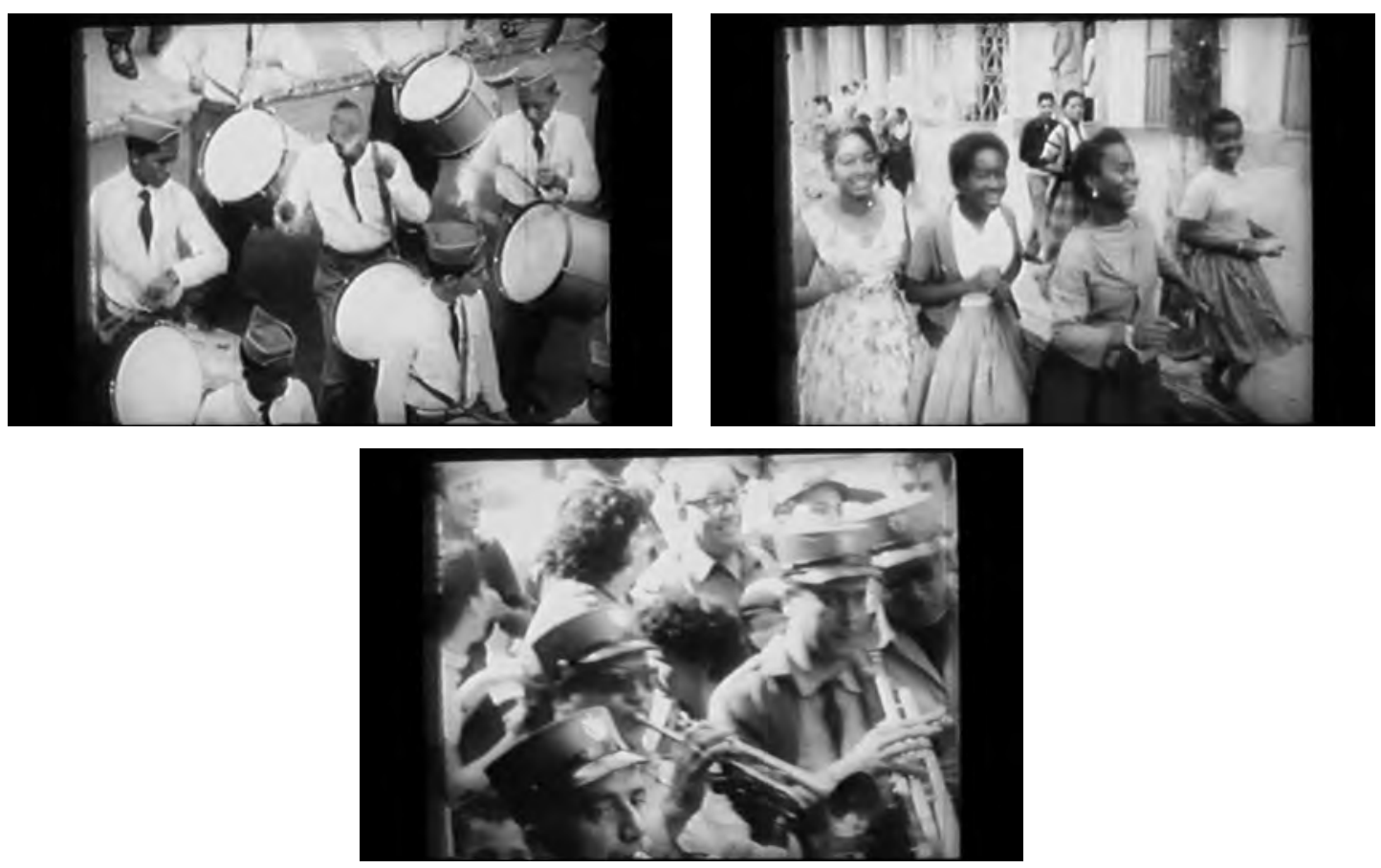

Sequência de Cuba si.

A representação cênica de um mundo decadente e de outro emergente está em várias passagens do filme. Esse procedimento é evidente quando o realizador insere na montagem imagens do arquivo do ICAIC rodadas na Sierra Maestra. Concomitante aos registros de Ernesto Che Guevara, Raul e Fidel Castro e Camilo Cienfuegos, a voz over indica que o objetivo da guerrilha era destruir uma ditadura e construir uma sociedade nova. As cenas de vida compartilhada entre os guerrilheiros na mata anunciam aspectos de uma coletividade que iria, na visão do realizador, estar presente após a vitória. Além de armas, eles manuseiam a massa do pão, tijolos, máquinas de escrever e aparelhos eletrônicos. É por meio de uma televisão fabricada manualmente

mudanças causadas pela Revolução, enquanto a segunda dedica-se a compreender Cuba perante o cenário internacional e ao ataque dos Estados Unidos à Baía dos Porcos.

${ }^{47}$ Vale destacar que, se a primeira metade do filme começa com imagens dos "novos bebês" adquiridos pelas crianças no Dia de Reis, como os "bebês metralhadoras", esse "bebê Napoleão" decadente, abandonado em um jardim de um palácio em ruínas, simboliza a troca de uma sociedade por outra. A passagem de um bebê a outro representa o fim de uma situação colonial e a emergência da emancipação política. 
que eles assistem ao governo de Batista, "o mais corrompido da história cubana", que prioriza as atualidades esportivas como forma de alienação política. A voz over ressalta que a população camponesa colabora com os revolucionários (embora esses atores sociais não estejam representados nas imagens). Porém, ela completa que, se havia em comum o desejo em romper, como construir essa nova sociedade ainda era um problema para o futuro, durante o ano de 1958.

Embora estejam presentes com mais frequência na segunda produção de Marker sobre Cuba, La bataille des dix millions, em Cuba si há algumas sequências em que o trabalho manual aparece como um valor desejável para essa nova sociedade. Se essa atribuição é evidente nas cenas da Sierra Maestra, ela é retomada na segunda parte do documentário, quando os ministros de Castro são filmados cortando cana-deaçúcar e dando o exemplo para a produção. Essa sequência é importante, no discurso do realizador francês, pois se contrapõe à riqueza do império dos usineiros de Batista, época de exploradores e explorados. Na Revolução, essa distinção estaria ausente, e todos trabalhariam em conjunto para o bem comum, como ocorria nas matas entre os revolucionários ${ }^{48}$.

A ideia é a de uma passagem entre dois mundos, entre a Cuba antiga e a nova, entre Cuba e o resto do mundo, entre Cuba e a França. Na sequência em que a voz over diz que a rádio francesa anunciara o ataque norte-americano em 17 de abril, e que trouxe à memória a estada no país latino-americano, um carro atravessa um túnel em Havana enquanto são proferidos comentários sobre as transformações revolucionárias. A expropriação de empresas pelo Estado, diz o comentário, é também a transição de um mundo para outro, um processo irreversível. A oito mil quilômetros de distância, resta ao realizador a confiança no povo cubano, declara, e as falsas notícias dos periódicos europeus. Nesse trecho, o caminho entre o túnel e a

\footnotetext{
${ }^{48}$ Essa valorização do trabalho manual e a representação dos revolucionários como trabalhadores se relacionam à ideia de um "homem novo", tal como entendida por Ernesto Che Guevara. Pericás (1998) ressalta que, embora esse conceito fosse anterior (está presente em Karl Marx, Friedrich Engels e Mao Tsé-Tung), ele foi atrelado ao plano de desenvolvimento econômico instaurado após a Revolução Cubana, convertendo-se em um sistema de incentivos que entendia o máximo aproveitamento da mão de obra como meio de construir o socialismo. Esse sistema foi aplicado inicialmente na produção de cana-de-açúcar e, posteriormente, estendeu-se à agricultura em geral e à indústria. Vale destacar que o filme La bataille des dix millions é uma representação máxima dessa política, assim como de sua derrocada (como será abordado). Em Cuba si aparece a filosofia de um "homem novo" surgido em uma nova sociedade socialista, confirmando a tese de que esse conceito presente nas reflexões de Guevara ecoou em outros imaginários extra Cuba: "De qualquer maneira, as ideias do revolucionário argentino tiveram de fato uma influência grande, não só nas concepções gerais do governo da ilha como também no imaginário dos movimentos de esquerda em toda a América Latina, assim como apresentaram consequências reais na economia e política de Cuba na época em que ele era um dos principais dirigentes daquele país." (PERICÁS, 1998, p. 107).
} 
claridade da estrada (repleta de outdoors propagandeando a Revolução) é um recurso metafórico que materializa cenicamente esse trânsito em universos opostos, em que os métodos de Fidel Castro são os motores para deixar um dos universos para trás.

Em Cuba si, encontram-se alguns recursos estilísticos amplamente presentes na filmografia de Chris Marker. Um deles, sem dúvida, é o comentário marcante. Em suas produções, pode-se dizer que texto e imagem estão interligados, sendo que, muitas vezes, um questiona ou afirma com veemência o outro. A voz over, como será analisado ao longo desta tese, tem o papel fundamental de trazer texto às imagens. Vale ressaltar que Marker começou sua carreira como ensaísta e escritor, atribuindo à palavra um peso tão grande quanto ao universo visual. Nesse documentário, a voz over apresenta algumas particularidades comuns a outras produções, como a ironia, o lirismo, o papel informativo e a função questionadora (que muitas vezes desconstrói possíveis conclusões às quais as sequências podem levar). É ela que faz, por exemplo, com que alguns materiais de arquivo incorporados, como as capas de jornais franceses com críticas negativas a Castro, sirvam de prova contra a imprensa francesa, e não como um ataque ao líder cubano - como poderia ocorrer apenas com a visualização, sem a voz over. Em artigo publicado no periódico Les lettres françaises, em 1963, Georges Sadoul ${ }^{49}$ elogia Cuba si, ressaltando o surgimento de um novo estilo documental:

Eu não defendo que o cinema verdade suponha a supressão de todo comentário. É certo que ele deve evitar o rom-rom explicativo e abusivo dos documentários da "vieille vague". Eu conheço excelentes curtas-metragens em que não podemos ver mais as imagens, de tanto que temos as orelhas afetadas pela declamação de grandiloquências imperativas ou de finas alusões "poéticas". O grande mérito de Marker, nos seus primeiros filmes, é ter criado um novo estilo de documentário, em que as imagens adquirem um novo

\footnotetext{
${ }^{49}$ Em Cinefilia, Antoine de Baecque (2010) escreve que a contribuição de Georges Sadoul como crítico de cinema de Les lettres françaises começou em novembro de 1944. Desempenhou, frente ao periódico, um papel de crítico stalinista, caracterizado por Baecque como alguém que "se pretendia a encarnação da consciência comunista nos círculos do cinema francês", o que lhe rendeu o papel de antagonista da geração da Nouvelle Vague. O autor declara ainda que, apesar de dolorosa para o crítico, Sadoul jamais se manifestou a respeito da divulgação do relatório de Khrutchev, em 1956. Assim como Marker, demonstrava um gosto por viagens, percorrendo a Europa do Leste, a China, o Japão e Cuba. O crítico francês visitou o ICAIC em abril de 1960 e passou a ser, desde então, um dos principais colaboradores da revista Cine Cubano. Nesse sentido, a exaltação da Revolução em Cuba si agradou Sadoul, conforme se nota na análise publicada em 1963.
} 
sentido graças aos seus comentários. (SADOUL, 1963, p. 1, tradução nossa) ${ }^{50}$

Para os cineastas do ICAIC, a estada de Chris Marker teve outra função além de divulgar na Europa os feitos da Revolução. No artigo "Tres semanas de trabajo junto a Chris Marker", de Eduardo Manet, percebe-se que o relato do cubano sobre os métodos markerianos, descritos detalhadamente nesse exemplar da revista Cine Cubano, visava a contribuir com a formação de documentaristas latino-americanos. Fartamente ilustrado com fotos do realizador francês, o artigo identifica uma linha comum entre o processo do documentário rodado em Cuba e suas produções anteriores - Dimanche à Pékin, Lettres de Sibérie e Description d'un combat (1960):

Um homem chega com uma câmera na mão a um país determinado depois de ter lido muito sobre esse país e conversado com um bom número de nativos do mesmo. O homem desembarca sem preconceitos, disposto a empregar o sistema mais lógico para as pessoas honestas captarem uma realidade: misturar-se à vida cotidiana. (MANET, 1961, p. 30)

Em seguida, ele indica detalhadamente os métodos de Marker, dividindo-os em duas categorias: gerais (tomar o fato no instante em que é produzido, eleger fatos representativos e integrar figuras humanas à paisagem sempre que possível) e específicos (captação de rostos em movimento, utilização de animais como metáforas e captar uma tendência da "alma nacional"). Dessa maneira didática, Manet determina preceitos que poderiam ser seguidos por cineastas cubanos. Ele destaca ainda procedimentos de Marker como editor, por meio dos quais ele transforma em "arte" os planos captados. Unir um cinema testemunhal e documental com a arte, além dos compromissos com o mundo "real" a ser retratado, são os preceitos básicos que o realizador cubano valoriza no trabalho do francês.

O processo de um documentário necessita de métodos definidos, sensibilidade artística e engajamento político. São esses três aspectos que Manet "aprende" durante

\footnotetext{
${ }^{50}$ Traduzido do original: "Je ne suis pas pour que le cinéma vérité suppose la suppression de tout commentaire. Bien sûr qu'il doit éviter le ronron explicatif et abusif des documentaires 'vieille vague'. Je connais d'excellents courts métrages dont on ne pouvait plus voir les images, tant on avait les oreilles causées par la déclamation de grandiloquences impératives ou de fines allusions 'poétiques'. Le grand mérite de Marker, dans ses premiers films, est d'avoir créé un nouveau style de documentaire, où les images prenaient un sens nouveau grâce à ses commentaires."

${ }^{51}$ Traduzido do original: "Un hombre llega cámara en mano a un país determinado después de haber leído mucho sobre ese país y conversado con buen número de naturales del mismo. El hombre desembarca sin prejuicios, dispuesto a emplear el sistema más lógico que tiene todo ser honesto para captar una realidad: el de mezclarse a la vida diaria."
} 
a estada de Marker e que aparecem em Cine Cubano expostos de forma pedagógica. $\mathrm{O}$ artigo é interessante também por narrar a vontade do realizador francês em registrar as mais diversas imagens, que poderiam eventualmente ser aproveitadas na montagem. No trecho a seguir, ele descreve, por exemplo, como foram gravadas as tomadas da comemoração do segundo aniversário da Revolução, que estão na sequência inicial de Cuba si:

Concentração do 2 de janeiro na Praça Cívica. Marker, Arri na mão, se mistura à multidão. Vendedores de bilhetes de loteria, sorveteiros, milicianos, crianças, velhos... a câmera capta rostos, mãos, expressões, atos. Com tal rapidez que algum dos componentes da equipe me pergunta assombrado: "Você crê que isso sairá?". Ele sequer mede a luz. Três "tomadas" realizadas com a rapidez de um tiro de metralhadora. Marker se volta para nós: "Bom, a sequência está terminada. Podemos ir." (MANET, 1961, p. 28 , tradução nossa) ${ }^{52}$

De fato, Cuba si é repleto de cenas de multidão, nas quais se nota, porém, detalhes de cada indivíduo retratado. Em Cuba, eles têm muitas caras, cores e gestos, que marcam a diversidade cultural e a alegria do povo, aspectos evidenciados no documentário.

Identificar as estratégias fílmicas de Marker na obra dos cineastas do ICAIC é uma tarefa difícil, pois há métodos distintos presentes nesse grande conjunto de filmes e de realizadores cubanos. Porém, algumas características que se tornaram hegemônicas, sobretudo nos documentários, estão, de alguma forma, em Cuba si. No trecho citado acima, Eduardo Manet descreve, por exemplo, a preferência pela rapidez do registro, pela captura da espontaneidade do povo, mesmo que isso implicasse em uma menor qualidade da imagem. Esse procedimento de gravação condiz com alguns dos preceitos defendidos pelo cinéma vérité, para o qual a experiência vivida é o mais relevante na tomada fílmica ${ }^{53}$. Fruto de uma tentativa de

\footnotetext{
${ }^{52}$ Traduzido do original: "Concentración del 2 de enero en la Plaza Cívica. Marker, Arri en mano, se mezcla a la muchedumbre. Vendedores de 'bonos del INAV', heladeros, milicianos, niños, ancianos... la cámara recoge rostros, manos, expresiones, actos. Con tal rapidez que uno de los componentes del equipo me pregunta asombrado: ¿Tú crees que esto saldrá?'. El no mide ni siquiera la luz. Tres 'tomas' realizadas con la rapidez de un tiro de ametralladora. Marker se vuelve hacia nosotros. 'Bueno, la secuencia ya está terminada. Podemos irnos."

${ }^{53}$ A aproximação de Marker com o cinéma vérité é complexa. Apesar de muitos pesquisadores o considerarem um expoente dessa vertente na França dos anos 1960, pode-se dizer que há aproximações e distanciamentos de sua obra com esse modo de fazer cinema. Guy Gauthier restringe essa aproximação aos seus dois filmes cubanos: Cuba si e La bataille des dix millions (GAUTHIER, 2001). No entanto, várias práticas usuais do cinéma vérité não estão presentes nessas produções. É o caso, por exemplo, do som direto, que só é usado nos discursos. A cena mais comentada de Cuba si, a marcha
} 
unir vanguarda estética e vanguarda política - assim como havia feito Dziga Vertov na União Soviética nos anos 1920 -, esse cinema foi desenvolvido na Europa principalmente pelo Grupo Dziga Vertov (cujo membro mais célebre era Jean-Luc Godard) e largamente seguido na América Latina (SÁNCHES-BIOSCA, 2004).

Mariana Villaça defende, no entanto, que o melhor termo para descrever o tipo de cinema que se desenvolveu a partir desses preceitos, no caso de Cuba, é cine urgente, no lugar de "cinema verdade" ou ainda de "cinema direto" (tal como relacionado ao cinema de Robert Drew nos Estados Unidos), já que a ideia de tomadas oportunas que fossem ao encontro da realidade estava presente, mas nem todas as técnicas dos gêneros europeu e norte-americano eram seguidas. Esse outro termo, cunhado por Santiago Álvarez, descrevia a necessidade de um registro rápido aliado a uma narração ágil, método que empregava no Noticiero ICAIC Latinoamericano (dos quais Chris Marker utiliza material fílmico para La bataille des dix millions). Em Cuba si, essa parece ter sido a estratégia utilizada principalmente para gravar as manifestações de rua, a partir das quais Marker demonstra um sentimento de ver a História acontecer, ou seja, uma certa urgência em registrar e divulgar os momentos que vivenciava em Cuba.

Cabe ressaltar, porém, que esse provável ensinamento de Chris Marker aos cineastas do ICAIC - priorizar o que se filma ao invés de como se filma - já havia sido trazido por Joris Ivens; diga-se de passagem, uma das referências também para o cineasta francês. Em artigo publicado na Cine Cubano em 1960, um trecho transcrito de uma entrevista com Ivens dá conselhos semelhantes aos "markerianos":

Se eu me permitisse dar um conselho aos jovens cineastas cubanos, diria que isso representa a melhor lição fílmica para eles. Que se esqueçam dos problemas de técnica e estilo. Tais coisas se adquirem com o tempo. O importante é deixar agora que a vida entre os "estúdios" não os convertam em burocratas da câmera. Filmar rápido e o mais diretamente possível tudo o que acontece. Acumular material direto, candente, pode ser considerado a melhor maneira para lograr uma cinematografia com características nacionais. ("JORIS", 1960, p. 22, tradução nossa)

militar que toca conga, foi provavelmente encenada - tal como muitas das usadas em Nanook, o esquimó (1922), de Robert Flaherty -, recolocando a questão do real (a encenação da realidade pode ser "mais real" que as imagens autenticamente documentais?). Essa discussão será aprofundada do capítulo 4, dedicado à analise do filme L'ambassade (1973).

${ }^{54}$ Traduzido do original: "Si yo me permitiera dar un consejo a los jóvenes cineastas cubanos, diría que eso representa la mejor lección fílmica para ellos. Que se olviden de los problemas de técnica o estilo. Tales cosas se adquieren con el tiempo. Lo importante es dejar ahora que la vida entre los 'Estudios', 
Essas estratégias de registro do cine urgente pareciam, tanto para Ivens e Marker como para os cineastas do ICAIC, o melhor método para acompanhar o processo de construção de uma nova realidade, em outras palavras, a maneira mais compatível de se fazer cinema em meio a uma revolução. Assim, elas se relacionam também às técnicas desejadas para um cine armado ${ }^{55}$, aquele que serviria tanto para a defesa (caso explícito de Cuba si) como para o ataque. Nesse ponto de vista, a utilidade de um filme estaria na sua eficácia revolucionária, da mesma forma que seu realizador deveria ser igualmente um revolucionário em suas concepções e ações políticas.

Vale destacar que se Cuba si se aproxima dos métodos usados por grande parte dos documentaristas do ICAIC (especialmente Santiago Álvarez) em suas técnicas de registro das imagens, ele difere substancialmente desse corpus fílmico na utilização do texto, bem como na montagem. É necessário ressaltar ainda que o filme demorou para ser exibido em Cuba, fato que até 1962 não havia ocorrido ${ }^{56}$. Para Álvarez, por exemplo, há uma preferência por utilizar palavras em forma de intertítulos e uma importância pequena da voz over. Essa estratégia valorizaria as tomadas "em direto", atribuindo uma veracidade maior ainda aos fatos registrados.

Em Marker, ocorre justamente o contrário. A voz over corrobora ou contradiz as imagens; estabelece uma ligação entre os diversos planos por meio de um texto discursivo autoral; e também imprime uma individualidade - a do diretor - que está escamoteada na maioria dos documentários cubanos. Quando ela assume a posição espacial do realizador no momento da montagem, um francês relembrando sua estada de volta à sua terra natal, revela uma subjetividade que concede às imagens anteriores o papel de fragmentos memorialísticos. Essa subjetividade assumida é um recurso raro no cinema político cubano, com exceção do cinema ficcional de Tomás Gutiérrez Alea, onde ela é frequente, e de obras esporádicas de personalidades mais à margem, como Sara Gómez e Nicolás Guillén Landrián - discípulos de Alea (PARANAGUÁ, 2003).

que no se conviertan en los burócratas de la cámara. Filmar rápido y lo más directamente posible todo lo que suceda. Acumular material directo, candente, puede considerarse como el mejor medio para lograr una cinematografía con características nacionales."

${ }^{55}$ Sobre esse tema, ver ÁLVAREZ, 1975.

${ }^{56}$ Em seu artigo para a Cine Cubano, em 1962, Eduardo Manet deseja que as condições permitissem que o filme pudesse finalmente ser exibido em Havana, o que indica que não havia sido visto em sua montagem final até aquele momento (MANET, 1962). 
Nesse sentido, apesar de semelhanças entre o documentário de Marker e o de cubanos, o que remeteria a uma certa "escola" europeia, são muitas as diferenças que permitem afirmar que o ICAIC desenvolveu um caminho autônomo, com a criação de estratégias narrativas próprias e o diálogo com outros atores (como os latinoamericanos de países como Argentina, Venezuela, Chile e Brasil, no contexto do Nuevo Cine Latinoamericano). Dessa maneira, há, por exemplo, mais proximidade entre produções como Cuba si e Salut les cubains! (1963) ${ }^{57}$, de Agnès Varda, do que entre Cuba si e o Noticiero ICAIC Latinoamericano de Álvarez.

De forma parecida ao filme de Marker, o de Varda opta por celebrar a Revolução e a cultura do povo cubano, além de se colocar como um olhar estrangeiro sobre a questão ${ }^{58}$. Assim como Marker afirma sua posição desde Paris, Varda inicia sua produção com cenas de um grupo de música cubana tocando em Saint-Germaindes-Prés. O conjunto é registrado por muitas câmeras, amadoras e profissionais, reafirmando o "modismo" do tema na cena artística francesa. Realizado dois anos após Cuba si, ele faz referências explícitas ao documentário anterior, especialmente em suas sequências iniciais (inseridas logo após as rodadas na França), nas quais aparecem símbolos clichês da ilha, como os crocodilos, as barbas e a conga no lugar da marcha militar. A diretora interroga em que medida essa visão de fora ${ }^{59}$, esses primeiros estereótipos adquiridos em sua terra natal, se confirmam ou não ao longo de sua estada.

Apesar de algumas diferenças estilísticas e temáticas (o papel da mulher, por exemplo, é uma questão para Varda, bem como a religião afro), a cultura cubana, a mestiçagem e as mudanças positivas geradas pelo novo governo são aspectos celebrados em Salut les cubains! que já estavam em Cuba si. Se no documentário de Marker a canção exercia um papel importante, no de Varda ela é o elemento fundamental, desempenhando uma função narrativa e exemplificando a riqueza cultural do povo. Outro ponto em comum entre as duas produções é a exaltação das cenas de multidão e sua afirmação como "verdadeiros" momentos democráticos, corroborando a tese de que haveria nesse país uma nova forma de democracia direta ${ }^{60}$.

\footnotetext{
${ }^{57}$ Uma análise da retórica presente tanto em Cuba si como em Salut les cubains! foi publicada no artigo de DREYER, 2006.

${ }^{58}$ Chris Marker aparece nos agradecimentos de Salut les cubains!.

${ }^{59}$ Cabe ressaltar que, ao citar por uma das duas vozes over a cena da marcha militar tocando conga, Varda considera o filme de Marker como uma dessas referências.

${ }^{60}$ Apesar das semelhanças, há muitas diferenças entre os dois filmes. A questão da cultura cubana é bem mais explorada em Salut les cubains!, que investiga, além da cultura popular, o seu aspecto
} 
Essa breve comparação entre os dois documentários permite afirmar que, além de contribuir para o desenvolvimento de novas estratégicas fílmicas para os cineastas do recém-criado ICAIC, Cuba si se tornou uma referência nos meios intelectuais e artísticos franceses para pensar a Revolução Cubana. Vale ressaltar que o filme foi censurado em 1961, época de sua produção, por defender o governo de Fidel Castro (no lugar de combatê-lo) ${ }^{61}$, tornando-se público apenas em setembro de 1963 . Nessa ocasião, apareceram muitos textos na imprensa de esquerda exaltando-o, entre eles o já citado artigo de Sadoul ${ }^{62}$. Outro artigo publicado em L'Humanité, em 14 de setembro de 1963, reproduziu um trecho de carta datada de 31 de julho de 1961, do então Ministro da Informação, Louis Terrenoire, sobre os motivos que levaram à interdição:

Esses filmes não podem ser classificados como documentários, pois eles constituem uma apologia do regime castrista. Certamente, o que é recordado ou reportado sobre o regime anterior em conformidade com a verdade histórica, mas... Todo filme de propaganda ideológica não pode receber autorização, em razão dos riscos que esse gênero de produção traz à ordem pública... (TERRENOIRE, 1961 Apud "SYMPHONIE", 1963, p. 1, tradução nossa) $)^{63}$

A carta do censor indica que o motivo da interdição foi justamente o caráter militante do documentário, ou melhor, sua clara intenção de propagandear a Revolução. Em alguns desses artigos daquela época, está presente a ideia de que $C u b a$ si só foi liberado quando a vitória dos revolucionários passou a ser mais um fato histórico do que um acontecimento político recente, ou seja, quando o filme já perdera parte de seu poder de persuasão. Apesar de muito celebrada pela esquerda e ainda uma referência de engajamento (sobretudo para os artistas, como mostra o filme de

erudito. Estão "saudadas" figuras como os poetas Nicolás Guillén Landrián e Roberto Retamar; o escritor Alejo Carpentier; os pintores Wilfredo Lam e René Portocarrero; Alfredo Guevara e a cineasta Sara Gómez (do campo cinematográfico). As práticas da santeria, religião afrocubana, destacam-se entre os temas abordados.

${ }^{61}$ De acordo com o artigo de Georges Sadoul (1963), o então Ministro da Informação de Charles de Gaulle, Louis Terrenoire, afirmou que poderia liberar o documentário caso o texto da voz over fosse modificado para uma versão "nada ideológica".

${ }^{62} \mathrm{Na}$ Cinémathèque française estão disponíveis inúmeros artigos publicados na época de lançamento de Cuba si, em 1963. Foram citados, nesta tese, apenas alguns desses textos, já que a intenção é analisar o filme, e não sua recepção crítica.

${ }^{63}$ Traduzido do original: "Ces films ne peuvent être qualifiés de documentaires, puisqu'ils constituent une apologie du régime castriste. Certes, ce qui y est rappelé ou rapporté du régime antérieur est conforme à la vérité historique, mais... Tout film de propagande idéologique ne peut recevoir une autorisation, ne serait-ce qu'en raison des risques que ce genre de production comportent pour l'ordre public..." 
Varda), em 1963 a "coqueluche" Cuba deixava de ser uma epidemia. Leenhardt e Kalfon (1992) apontam alguns episódios que contribuíram para o enfraquecimento dessa visão lírica e romântica: a crise dos mísseis (em outubro de 1962), quando os soviéticos instalaram mísseis em solo cubano supostamente sem consultar Fidel Castro; e o acordo de venda de açúcar para o bloco socialista em 1963. Os autores defendem que esses acontecimentos evidenciaram a dependência que o país latinoamericano tinha da União Soviética, abalando a visão idílica frequente em intelectuais e artistas da gauche française. Nesse contexto, a tese da democracia direta, presente nos documentários de Marker e de Varda, perdia seu poder de persuasão.

Após a partida de Che Guevara da ilha para seguir a guerrilha em outras partes do mundo, em 1965, e sua morte na Bolívia, em 1967, abordar a Revolução Cubana passou a ser uma questão ainda mais delicada, como é possível perceber no discurso e nas estratégias narrativas de outro documentário de Chris Marker sobre o tema: $L a$ bataille de dix millions. Nessa produção, a celebração presente em Cuba si dá lugar a uma reflexão mais complexa sobre o processo cubano, embora sem abrir mão da militância em favor do governo de Castro. Porém, os argumentos presentes nessa militância serão outros.

\subsection{La bataille des dix millions $(1970)^{64}$}

Após a experiência de Cuba si, Chris Marker se manteve à distância como um colaborador do ICAIC. Em 18 de agosto de 1968, por exemplo, ele enviou a Alfredo Guevara (2009) um roteiro do cineasta Peter Kassovitz (húngaro radicado em Paris e pai do ator e diretor Mathieu Kassovitz) sobre Salvatore Giuliano, legendário camponês e contraventor que lutou pela separação da Sicília. Marker propunha que o Instituto cubano aceitasse a coprodução desse projeto. $\mathrm{Na}$ correspondência, ele indicava como referência o documentário Les chemins de la fortune (1964), no qual Kassovitz havia entrevistado Douglas Bravo ao seguir a guerrilha venezuelana na companhia de Régis Debray. Consultava a opinião de Guevara sobre projetos

\footnotetext{
${ }^{64}$ A análise de La bataille des dix millions foi feita a partir da cópia em VHS disponível na Cinémathèque française, em Paris. Para a transcrição das falas e da voz over, foi utilizado o texto publicado na revista Jeune cinéma (MARKER, 1970). Como o acesso a uma cópia em DVD ou o empréstimo do VHS eram proibidos, não foi possível a inclusão de fotos desse documentário.
} 
cinematográficos do jornalista Jean Lartéguy a serem produzidos pela televisão francesa, que retratavam a luta armada na América Latina. E manifestava a vontade de exibir o recém-concluído Loin du Vietnam (1967) em Cuba.

Nessa carta, fica evidenciado, portanto, que a colaboração entre Marker e o ICAIC não era apenas estilística - ou seja, não visava somente à discussão de novas estratégias fílmicas e modelos estéticos no campo do cinema militante de esquerda -, mas também abordava o processo de produção e difusão de filmes. A criação da SLON, em 1967, mostra que o cineasta francês buscava caminhos para realizar seus próprios projetos e de seus companheiros sem depender das estruturas em voga de finalização e distribuição das grandes produtoras. Nesse sentido, ele procurava parcerias com instituições que pudessem fortalecer o coletivo, como era o caso do ICAIC e da emissora pública francesa ORTF (tema que será retomado no capítulo 3 desta tese).

Um dos frutos da cooperação entre a SLON e o ICAIC foi justamente La bataille des dix millions (1970) ${ }^{65}$. O filme também repetiu a parceria de Loin du Vietnam entre Marker e a montadora Valérie Mayoux, que esteve posteriormente presente em outros projetos desse realizador, como na versão francesa de El primer año (1971), em La spirale (1976) e em O fundo do ar é vermelho (1977). Produzido em um momento extremamente desfavorável a Cuba, a minuciosa análise presente no filme se reivindica como autocrítica. O lirismo trazido pelas imagens e pela voz over na produção anterior é substituído pelo uso de longas sequências - muitas delas discursos extensos e com poucos cortes de Fidel Castro - que trazem explicações de ordem econômica para a crise da produção de cana-de-açúcar.

Em 1969, Marker voltou a abordar Cuba e intensificou a parceria com o ICAIC. Foi nessa ocasião que montou La bataille des dix millions, no qual utilizou sobretudo imagens do Noticiero ICAIC Latinoamericano e da produção Despegue a las 18.00 (1969), de Santiago Álvarez ${ }^{66}$. Nesse período, ele pôde acompanhar de perto o desafio empreendido por Castro como solução para os problemas econômicos enfrentados pela ilha. E esse desafio é apresentado pela voz over logo nas sequências iniciais,

\footnotetext{
${ }^{65}$ Além da SLON e do ICAIC, participaram da produção de La bataille des dix millions a Radio Télévision Belge (RTB) e a produtora K.G., de Costa-Gavras.

${ }^{66}$ Nessa mesma época, ele produziu ainda dois documentários sobre o Brasil, que serão abordados no próximo subcapítulo, On vous parle du Brésil: tortures (1969) e On vous parle du Brésil: Carlos Marighela (1970).
} 
sobrepostas às imagens do chefe de Estado falando à televisão cubana em meio aos esforços para superá-lo:

Trata-se ainda de alcançar uma cifra excepcional: 10 milhões de toneladas, nem uma libra a menos. Fidel fixou essa norma como um atleta que fixa a barra do salto em altura ao nível do recorde mundial. Nada de meio sucesso: é o recorde ou o fracasso. ( $\mathrm{La}$ bataille des dix millions, 1970, tradução nossa) ${ }^{67}$

Em seguida, o texto explica o porquê da escolha da cana-de-açúcar, o único recurso renovável exportável em larga escala de Cuba, e o porquê dos 10 milhões, a cifra máxima equivalente ao potencial de compra dos países socialistas consumidores do açúcar cubano e à capacidade técnica. A voz over - que nesse documentário deixa muitas vezes a poética de lado em detrimento de explicações técnicas - informa que a União Soviética havia exigido uma planificação para 1970, e por isso a meta havia sido firmada para esse ano. Mas ela afirma que Castro admitia, no referido programa, haver uma grande distância entre os números reais e os ideais. Esse primeiro trecho, composto pelas imagens do líder e o discurso acima proferido pela locução em over, compõe uma espécie de prólogo, inserido antes dos créditos. Nele se conhece o plano, e também sua incapacidade de realização.

A derrota está anunciada desde o início. Cabe, portanto, entendê-la, explicá-la. As cenas seguintes são extraídas do documentário Despegue a las 18.00, de Santiago Álvarez, que retrata os esforços dos trabalhadores da parte oriental de Cuba (especialmente de Girón) para produzir o açúcar. Se havia na montagem original do realizador cubano o objetivo de verificar as falhas e incentivar o trabalhador, no documentário de Marker, as mesmas imagens são usadas para sensibilizar o espectador europeu sobre quem são esses "perdedores": homens simples, mulheres e crianças. Enquanto a câmera foca o rosto de alguns deles, a voz over se defende de possíveis queixas vindas da esquerda que seu filme poderia receber:

Então, se nós mostrarmos essas imagens cotidianas de Cuba, essas filas intermináveis, essas dificuldades de provisão, esses "No hay", "não há", que se repetem como um refrão, se nós dissermos que em Cuba há irritação, estaremos dando armas ao adversário? Um início de resposta talvez seja: essas imagens são de um filme cubano, Despegue a las 18:00, de Santiago Álvarez, e essas palavras foram

\footnotetext{
${ }^{67}$ Texto da voz over de La bataille des dix millions, traduzido do original: "Or il s'agit d'atteindre un chiffre exceptionnel: 10 millions de tonnes, pas une livre de moins. Fidel a fixé cette norme comme un athlète fixe la barre du saut en hauteur au niveau du record du monde. Pas de demi-succès: c'est le record, ou l'échec.".
} 
pronunciadas - entenda você mesmo - por Fidel Castro. (La bataille des dix millions, 1970, tradução nossa) ${ }^{68}$

Na parte final, a voz over finalmente quantifica a derrota: ao invés das 10 milhões de toneladas, foram produzidas 8,5 milhões, um recorde, mas distante do desejado. Além disso, os demais setores produtivos da ilha haviam ficado paralisados, agravando a crise econômica. Diante da catástrofe, Castro fala para uma multidão no dia 26 de julho de 1970, em um discurso largamente aproveitado pela montagem de La bataille des dix millions. Cabe dizer que Fidel Castro é o grande protagonista do filme e seu maior mérito destacado é a capacidade de fazer uma autocrítica. Ele está presente em inúmeros longos planos-sequências (dispositivo pouco habitual na filmografia de Marker), como nesse em que faz um mea-culpa:

\begin{abstract}
Nossos inimigos dizem que nós temos dificuldades, e nisso nossos inimigos têm razão. Eles dizem que nós temos problemas, e, na verdade, eles têm razão, nossos inimigos. Eles dizem que há descontentamento, e, na verdade, eles têm razão, nossos inimigos. Eles dizem que há irritação, e eles, na verdade, têm razão, nossos inimigos. Como vocês veem, nós não temos medo de admitir quando nossos inimigos têm razão. Nós vamos começar assinalando, em primeiro lugar, em todos esses problemas, nossa responsabilidade a todos - a minha, em particular. (CASTRO Apud La bataille des dix millions, 1970, tradução nossa) ${ }^{69}$
\end{abstract}

Tanto nesse trecho do final como nas sequências iniciais que utilizam planos de Despegue a las 18.00, Marker claramente se dirige aos setores da esquerda que não suportavam as críticas. Nesse sentido, pode-se dizer que La bataille des dix millions inaugura uma fase no cinema militante desse realizador que repensa as próprias estratégias dessa orientação política, sem, no entanto, abrir mão da defesa do socialismo. Ele será seguido, por exemplo, por On vous parle de Prague: le deuxième

\footnotetext{
${ }^{68}$ Trecho da voz over de La bataille des dix millions, traduzido do original: "Alors si nous montrons ces images quotidiennes de Cuba, ces queues interminables, ces difficultés d'approvisionnement, ces 'No hay', 'Il n'y en a pas' qui revient comme un refrain, si nous disons qu'à Cuba il y a de l'irritation, sommes-nous en train de donner des armes à l'adversaire? Un commencement de réponse peut-être: ces images sont celles d'un film cubain, Despegue a las 18:00, de Santiago Álvarez, et ces paroles ont été prononcées - vous l'entendrez vous-même - par Fidel Castro."

${ }^{69}$ Discurso de Fidel Castro em La bataille des dix millions, traduzido do original: "Nos ennemis disent que nous avons des difficultés, et là-dessus nos ennemis ont raison. Ils disent que nous avons des problèmes, et en réalité ils ont raison, nos ennemis. Ils disent qu'il y a du mécontentement, et en réalité ils ont raison, nos ennemis. Ils disent qu'il y a de l'irritation, et en réalité ils ont raison, nos ennemis. Comme vous voyez, nous n'avons pas peur d'admettre lorsque nos ennemis ont raison. Nous allons commencer par signaler en premier lieu, dans tous ces problèmes, notre responsabilité à tous - et la mienne en particulier."
} 
procès d'Arthur London $(1971)^{70}$, documentário que registra os bastidores de $A$ confissão (1970), filme dirigido por Costa-Gavras e estrelado por Yves Montand, ambos parceiros de Marker, e que é baseado no polêmico livro de Arthur London que combatia o stalinismo relatando a perseguição sofrida no ano de 1951, em Praga. Em On vous parle de Prague, aparecem questões como: "O que é ser um verdadeiro comunista?". Em uma entrevista usada na montagem, Jorge Semprún questiona: é preciso fazer a autocrítica mesmo dando "água ao moinho adversário"? Para ele, assim como para Marker, a revisão das ações erradas teria o poder de evitar novos rumos mal escolhidos.

Dessa maneira, La bataille des dix millions, produzido quase concomitantemente a On vous parle de Prague, analisa as razões da derrota não para “dar água ao moinho adversário”, mas para evitá-la em uma próxima vez. É esse objetivo que dá ao filme o estatuto de um balanço político e econômico, mais do que uma elaboração poética, como a presente em Cuba si. Além dos idealismos, é necessário fazer uma análise minuciosa. Marker insere outro discurso de Castro, proferido na comemoração do centenário de Lenin, em 22 de abril de 1970, no qual o líder afirma que, independente das diferenças, o Estado soviético era um privilégio de qualquer movimento revolucionário. A voz over confirma essa fala ao constatar que, se os Estados Unidos eram a grande ameaça à Revolução, é evidente que seu principal aliado seria o governo de Moscou. A questão cubana não é vista como um episódio local, ela está ligada a um cenário que envolve interesses e lutas políticas em escala mundial. Nesse sentido, ela é, para o diretor, um interesse de todos.

Porém, além desse cenário internacional, estão homens e mulheres cubanos. Após o discurso de Castro, a montagem traz planos curtos de entrevistas com pessoas respondendo à mesma pergunta: o que você falaria para Lenin se ele estivesse vivo? "Quem?”; “o fundador do socialismo, o russo?”, são algumas das respostas. A situação imagética e impossível é proposta a um pescador, a agricultores, à bailarina... A simplicidade das frases, incompletas ou pouco articuladas, evidencia uma distância entre as discussões teóricas e os problemas reais. A voz over traz um importante fator que une a análise política ao cotidiano do povo, e que é o grande argumento presente no documentário para justificar a derrota na produção das 10 milhões de toneladas: o subdesenvolvimento:

\footnotetext{
${ }^{70}$ Além desses dois documentários, outros filmes de Chris Marker enveredam pelo viés autocrítico. É o caso de produções abordadas nesta pesquisa, como L'ambassade (1973) e O fundo do ar é vermelho.
} 
É com muitos desses homens que se trava essa batalha dos Dez Milhões. No início dessa empreitada, ninguém sabia ao certo se Fidel pensou que ela poderia ser perdida. Se bem que ganhar ou perder, diante do subdesenvolvimento, toda batalha já é uma vitória. (La bataille des dix millions, 1970, tradução nossa) ${ }^{71}$

Após essa fala, o documentário traz cenas da propaganda oficial pela produção dos 10 milhões. Em seguida, Castro, em discurso de inauguração do programa em 14 de julho de 1969, se dirige a 30 mil macheteros (como são chamados esse tipo de lavrador em Cuba). No próximo plano, panorâmico em plongée, é possível ver um campo de cana-de-açúcar onde trabalham milhares de pessoas. Alguns planos mais próximos destacam pilhas de cana, máquinas a todo vapor e sacas sendo acumuladas. A montagem estabelece, nessa sequência, uma clara relação de causa e consequência entre as medidas oficiais do Estado e a resposta dos cubanos. Portanto, os motivos que explicam a derrota não passam pela falta de mobilização social. Ao contrário, mais uma vez, o governo revolucionário e o povo estão colados, na visão do realizador.

Os argumentos técnicos que Marker cita para justificar a derrota passam por fatores de ordem econômica. O problema, anuncia a voz over, não está na produção, mas em outras etapas necessárias para se chegar ao açúcar. Inicialmente, tratava-se de uma questão de rendimento, ou seja, muita cana era cortada para pouco produto final. Isso porque a produtividade depende do tempo entre o corte e a queima. A qualidade técnica dessa queima também influi. Fora a difícil logística de distribuição, já que, após resolvida a dificuldade de transportar de maneira mais ágil a matéria-prima, ocorria de algumas usinas estarem sobrecarregadas. No documentário, essas são as principais razões técnicas que explicam o fracasso dos 10 milhões. Como se vê, são argumentos que evidenciam as dificuldades de se produzir em um país subdesenvolvido, com recursos limitados e pouco investimento em tecnologia e infraestrutura.

A questão do terceiro mundo não era central em $C u b a s i^{72}$, cujos esforços exaltavam a cultura cubana sem aprofundar os problemas relativos à sua condição de

\footnotetext{
${ }^{71}$ Trecho da voz over de La bataille des dix millions, traduzido do original: "C'est avec beaucoup de ces hommes-là que s'est livrée la bataille des Dix Millions. A la veille de la déclencher, personne sans doute ne saura si Fidel a pensé quélle pouvait être perdue. A ceci près que gagnée ou perdue, en face du sous-développement, toute bataille est déjà une victoire."

${ }^{72}$ Cabe ressaltar que o debate sobre a questão do subdesenvolvimento ganhou força ao longo dos anos 1960, especialmente em Cuba. Em 1966, o país sediou a Primera Conferencia Tricontinental de La Habana, que fundou a Organización de Solidaridad de los Pueblos de África, Asia y América Latina
} 
nação subdesenvolvida. Em La bataille des dix millions, ela é fundamental para explicar as dificuldades enfrentadas pelo governo castrista. Outro elemento novo em comparação ao documentário anterior é a exaltação de uma solidariedade terceiromundista. No começo do filme, há cenas de filas de cubanos querendo doar sangue para vítimas de um terremoto no Peru. "Fraternidade americana, mas também fraternidade do subdesenvolvimento" ${ }^{, 73}$, diz a voz over. Ela alerta ainda que o governo peruano se opôs ao imperialismo norte-americano, o que transforma a solidariedade do povo cubano em um movimento de mão dupla. Os Estados Unidos são um inimigo comum, pois bloqueia, na visão do realizador, o progresso real da América Latina.

Junto ao subdesenvolvimento, esse boicote norte-americano a Cuba é apontado como um dos principais fatores para que a safra de 10 milhões não fosse alcançada. Em uma cena de animação, um submarino se aproxima da ilha e um personagem desembarca de dentro dele. Quando tira seu disfarce, revela ser o superhomem. Essa vinheta introduz o episódio no qual a organização anticastrista Alpha-66 apreendeu equipamentos de dois barcos de pesca de uma cooperativa estatal cubana e deteve 11 pescadores em uma ilha das Bahamas. $\mathrm{O}$ evento causou protestos na frente da embaixada norte-americana em Havana, porém, o fato teria sido difundido internacionalmente pela Reuters como uma manifestação em razão dos problemas empreendidos na safra de cana-de-açúcar. Como resposta, o governo cubano colaborou para que 100 mil manifestantes tomassem as ruas exigindo a libertação dos detidos.

Dessa forma, em La bataille des dix millions, é correto afirmar que o subdesenvolvimento e o imperialismo são apontados como os dois fatores fundamentais para explicar a derrota na produção da safra. Embora proponha um discurso autocrítico, na análise dos acontecimentos Marker acaba por atribuir a elementos externos às ações da esquerda as razões dessa derrota. Nas estratégias fílmicas, são usados inúmeros recursos para atrelar a imagem de Castro à do povo, demonstrando uma união entre ambos. Isso está claro na multidão que acompanha os discursos do líder, e mais ainda nas sequências dos trabalhadores nas lavouras. A voz over descreve o duro cotidiano dos macheteros para servir ao país. O trabalho, quando

(OSPAAAL). No ano seguinte, foi realizada, também em solo cubano, a conferência da Organización Latinoamericana de Solidaridad (OLAS), que é citada por Chris Marker no filme On vous parle du Brésil: Carlos Marighela.

${ }^{73}$ Trecho da voz over de La bataille des dix millions traduzido do original: "Fraternité américaine, mais aussi fraternité du sous-développment." 
empregado pelo bem comum, caso do episódio representado no documentário, adquire um caráter dignificante ${ }^{74}$.

Diante dessa argumentação, pode-se dizer que, mesmo reivindicando o papel de repensar a Cuba festiva da Revolução para avaliar possíveis erros, La bataille des dix millions não rompe com um dos principais argumentos pró-Fidel Castro presente em Cuba si: a ideia da existência de uma democracia direta. Além das cenas da multidão apoiando o líder, recurso imagético explorado nos dois documentários, no filme de 1970, essa discussão é aprofundada nas sequências finais, que avaliam um provável legado da experiência dos 10 milhões: o desenvolvimento de núcleos autogestores, particularmente nas fábricas cubanas.

A retórica autocrítica de Castro é intercalada na montagem com cenas de entrevistas com trabalhadores. Eles respondem à questão: "O que mais te tocou no discurso de Castro?" A primeira resposta inserida na montagem é também a mais direta: "É o que ele diz sobre a participação dos operários nas decisões". Com os esforços concentrados nas lavouras de cana, as fábricas estiveram entregues aos seus próprios funcionários. Isso ocorreu principalmente em Santiago de Cuba, onde, conforme informa uma das falas do chefe de Estado, eles demonstraram uma preocupação com a produção com "amor e entusiasmo incríveis". Ele conclui que:

Com falta de tudo, eles se preocuparam mais com a fábrica e com a produção do que se lhes faltassem pessoalmente... E isso é a confirmação viva, real, de que o proletariado, o proletariado industrial, é a classe verdadeiramente revolucionária, a classe potencialmente mais revolucionária. (CASTRO Apud La bataille des dix millions, 1970 , tradução nossa) ${ }^{75}$

Portanto, uma das consequências "positivas" da derrota, aquela válida para a elaboração de novas estratégias, foi o surgimento de formas organizativas na indústria e a emergência, em Cuba, de um novo sujeito revolucionário: o proletariado. Essa postura valorizada no final de La bataille des dix millions condiz com as ações do

\footnotetext{
${ }^{74}$ Vale destacar que, mais do que Cuba si, La bataille des dix millions retoma a ideia de "homem novo" desenvolvida por Che Guevara como meio de viabilizar economicamente o socialismo aproveitando ao máximo a mão de obra. No caso desse documentário, aparece um certo voluntarismo ligado à cooperação com os companheiros e com a nação que é responsável pelo aumento da safra.

${ }^{75}$ Discurso de Fidel Castro em La bataille des dix millions, traduzido do original: "Manquant de tout, ils se souciaient davantage de l'usine et de la production que de ce qui leur manquait personnellement... Et ça, c'est la confirmation vivante, réelle, de ce qu'est le prolétariat, le prolétariat industriel: la classe véritablement révolutionnaire, la classe potentiellement la plus révolutionnaire!."
} 
realizador empreendidas na França junto ao Grupo Medvedkine de Besançon ${ }^{76}$. Ele foi criado em abril de 1968, a partir da projeção de À bientôt, j'espère (1967), de Marker e Mario Marret, durante a grande greve e a ocupação na usina Rhodiaceta. Esse documentário, montado com base em entrevistas com os trabalhadores grevistas, foi mal recebido pelos mesmos, que declararam incompreensão frente às escolhas dos realizadores em não enfatizar a opressão sofrida e suas reivindicações trabalhistas do modo como se deveria. Marker teria concordado com as críticas e, constatando que não poderia fazer o filme que eles fariam, propôs a criação de um coletivo operário que montasse produções próprias e organizasse mostras e debates na fábrica ocupada. Com a participação de nomes como Godard, Varda e Bruno Muel, produziu, entre outros títulos, Classe de lutte (1969), situado em torno das discussões da Confédération générale du travail (CGT).

Após os créditos iniciais de La bataille des dix millions, Chris Marker problematiza o que é pensar o tema Cuba em 1970. Se, na época de Cuba si, a esquerda europeia festejava a chegada de Fidel Castro ao poder e havia um interesse em conhecer de perto a ilha e seu povo, ao longo dos anos 1960 diversos setores dessa esquerda romperam com esse paradigma, questionando a ausência de um processo eleitoral condizente com os padrões da democracia representativa ocidental. Para muitos intelectuais e artistas (como manifesta Semprún no episódio que abre este capítulo), era incompatível com as estratégias dos partidos esquerdistas europeus defender uma ditadura. Marker, porém, não havia rompido com sua visão positiva do país latino-americano e de seu líder, questionando o porquê de se abandonar os modelos quando eles demonstravam estar em crise. No início do documentário, a voz over coloca de maneira ácida:

Este ano, Cuba não está exatamente na moda. Nós, europeus, nós amamos muito os povos em luta, desde que eles sejam completamente mártires ou completamente vitoriosos. Quando eles não se prestam mais a manifestos inflamados ou a um teatro militante, quando sua luta está no campo sem prestígio da realidade cotidiana, das dificuldades cotidianas, com tudo aquilo que ela tem de desagradável, nós nos afastamos deles, e como essas velhas atrizes que casam com homens cada vez mais jovens, nós nos casamos com causas cada vez mais jovens e procuramos, em algum

\footnotetext{
${ }^{76}$ Marker sugeriu o nome do cineasta Alexandre Medvedkin para o grupo em referência ao projeto Cinetrem, desenvolvido pelo cineasta russo em 1932. A iniciativa consistia em viajar pela União Soviética equipado de um "cinetrem", usando o cinema como um meio para analisar os problemas práticos enfrentados por camponeses e operários, propondo a eles que encontrassem soluções.
} 
outro lugar, um novo rosto para sonharmos. (La bataille des dix millions, 1970 , tradução nossa) ${ }^{77}$

Nesse sentido, comparando os dois filmes, pode-se dizer que Cuba si procurou rebater as críticas à Revolução Cubana feitas pela imprensa europeia e outros setores sociais que se manifestavam contrários a esse acontecimento, sobretudo ao seu principal sujeito, Fidel Castro. Por outro lado, La bataille des dix millions reafirmou a defesa do governo cubano, mas sugeria analisar a derrota do episódio dos "10 milhões" como parte de uma luta mais ampla, contra o imperialismo e contra o subdesenvolvimento. Assim, este filme dialoga muito mais com a própria esquerda europeia (ao contrário do que ocorria na produção de 1961, que rebatia críticas "direitistas"), especialmente com os que encaravam Cuba como um modelo ultrapassado (para Marker, tratava-se dos adeptos dos modismos) e os "órfãos" stalinistas que não permitiam abordar esse campo político em situações de derrota.

Dessa forma, a partir da comparação entre os dois filmes markerianos sobre esse país latino-americano, pode-se afirmar que surgiu, ao decorrer da década de 1960, a necessidade de revisões políticas internas (autocríticas), procedimento presente em várias produções desse diretor, bem como um incipiente desejo por menos divergências para se encontrar um caminho adequado à revolução. Essas características estão presentes em outras obras, principalmente nas dedicadas ao balanço da Unidade Popular que, assim como La bataille des dix millions, foram feitas em contextos de derrotas da esquerda. Marker elaborou constantemente uma delicada operação de apontar as falhas dessas derrotas e compreender suas razões, sem abrir mão, no entanto, de um discurso engajado com as causas revolucionárias pelas quais militava. A articulação desses dois movimentos aparentemente opostos (auto)crítica e engajamento - será analisada ao longo de toda esta tese.

Essa postura crítica diante dos próprios projetos revolucionários levou Chris Marker a escrever uma carta a Alfredo Guevara, em 8 de maio de 1971, se posicionando sobre o chamado "Caso Padilla", quando o escritor Heberto Padilla foi preso em Cuba, acusado de "atividades subversivas" (GUEVARA, 2009). Solto 38

\footnotetext{
${ }^{77}$ Trecho da voz over de La bataille des dix millions, traduzido do original: "Cette année, Cuba n'est plus tellement à la mode. Nous, Européens, nous aimons bien les peuples en lutte, à condition qu'ils soient ou tout à fait martyrs, ou tout à fait victorieux. Quand ils ne prêtent plus à manifestes enflammés ou à théâtre militant, quand leur lutte se porte sur le terrain sans prestige de la réalité quotidienne, des difficultés quotidiennes, avec tout ce qu'elles ont de déplaisant, nous nous détournons d'eux, et comme ces vieilles actrices qui épousent sans cesse de plus jeunes hommes, nous épousons de plus jeunes causes et nous cherchons, ailleurs, un nouveau visage à nos rêves."
} 
dias depois, se apresentou junto à Unión de Escritores y Artistas de Cuba (UNEAC) para se desculpar publicamente, assinando uma "confissão" também em nome de outros escritores. O realizador francês se dirige a Guevara de maneira afetuosa, mas caracterizando a autocrítica do escritor cubano de "grotesca" e "inverossímil", comparando o fato com os processos de Moscou. No entanto, declara que mais importante do que o "Caso Padilla" seria o "Caso Fuentes", elogiando a postura do escritor Norberto Fuentes de não assumir a "autocrítica" forçada pelo governo de Cuba.

Para Claudia Gilman (2012), o "Caso Padilla" foi um dos aspectos que colaborou com o enfraquecimento do papel central que a Revolução Cubana havia ocupado nos debates intelectuais durante os anos 1960. O episódio representou uma fratura, colocando em discussão temas como a liberdade de criação e o lugar dos escritores no processo revolucionário. Dessa forma, embora não tenha rompido definitivamente com a Revolução Cubana, Marker acompanhou o movimento de outros intelectuais europeus após esse episódio, como os próprios Jean-Paul Sartre e Simone de Beauvoir. Em O fundo do ar é vermelho (que será analisado no capítulo 5), o realizador revisita esse país e seu principal líder, optando, no entanto, por um viés muito menos complacente do que aquele presente em Cuba si e La bataille des dix millions. 


\section{Cinema de contrainformação: comentários sobre o Brasil}

O intenso contato de Chris Marker com os cineastas cubanos ao longo dos anos 1960 permitiu que ele tivesse acesso ao Noticiero ICAIC Latinoamericano, recebendo material fílmico diretamente desse Instituto. Muitos dos informes produzidos sob a direção de Santiago Álvarez foram incorporados em produções markerianas, sendo que La bataille des dix millions se realizou basicamente com cenas desses cinejornais. Foi de Cuba também que Marker recebeu as entrevistas gravadas com um grupo de brasileiros exilados durante a ditadura militar, especificamente os ex-presos políticos libertados em troca do embaixador norteamericano Charles Burke Elbrick, sequestrado em 1969. Esse material bruto ganhou na edição o formato de dois curtas de "contrainformação", episódios da série On vous parle: On vous parle du Brésil: tortures (1969) e On vous parle du Brésil: Carlos Marighela (1970).

A ideia de montar curtos episódios de contrainformação surgiu logo após a criação da SLON e correspondia aos anseios desse coletivo em dar voz a pessoas que não teriam espaço na grande mídia. Catherine Lupton associa esse fenômeno aos efeitos "pós-Maio de 68”, quando o descrédito com o cinema comercial e a televisão impulsionou a proliferação de produções coletivas com a intenção de valorizar a perspectiva dos estudantes, dos trabalhadores em greve e de outros setores sociais que se declaravam "em luta". Chris Marker e a SLON estiveram à frente de algumas iniciativas com essas características, com destaque para as séries Ciné-tracts, Nouvelle société (produzida junto aos trabalhadores no Grupo Medvedkine de Besançon) e On vous parle.

Os chamados Ciné-tracts eram curtas em $16 \mathrm{~mm}$, de dois ou três minutos, realizados ao longo das agitações de Maio de 68 para incentivá-las. Alguns foram editados por anônimos, mas outros contaram com a participação de Godard, Resnais, Jean-Pierre Gorin (integrante do Grupo Dziga Vertov), Philippe Garrel, Jackie Raynal, além do próprio Marker ${ }^{78}$. Eles se consagraram como espaços de experimentação técnica, montados com a predominância de fotogramas fixos, articulados a colagens e textos. Viva Paci identifica nessa experiência inúmeras

\footnotetext{
${ }^{78}$ Apesar do caráter coletivo e da valorização da não autoria, Viva Paci atribui a ideia e a iniciativa de montar os Ciné-tracts a Chris Marker (PACI, 2008).
} 
características que se repetiram ao longo da produção markeriana, como a complexa articulação entre texto e imagem e o entrelace de imagens de diferentes naturezas (práticas presentes de maneira similar nos guias de viagem publicados pela Petite Planète, nos livros de fotografia e no CD-ROM Immemory). Essas características estiveram presentes nas diversas iniciativas de contrainformação utilizadas pelo realizador no final dos anos 1960, ao lado dos trabalhos realizados pelos Grupos Medvedkine e pelos periódicos On vous parle. Essas produções audiovisuais têm pontos em comum, como destaca Paci:

No âmbito dos modos de produção, o trabalho coletivo e a função de agit-prop dos ciné-tracts se inscrevem no rastro de projetos coletivos apoiados por Marker, que se apresentam como os herdeiros da tradição de agitação e de propaganda, no sentido revolucionário do termo, aquele que praticava Alexandre Medvedkine por meio de seu ciné-train, por exemplo. (PACI, 2008, p. 170 , tradução nossa) ${ }^{79}$

A inspiração de Marker no cineasta russo Alexandre Medvedkine ${ }^{80}$ é explicita, sobretudo nos boletins de notícia realizados junto aos operários na ocupação de fábrica em Besançon, intitulados Nouvelle société. Constituído por oito episódios, tinha como objetivo examinar as condições de trabalho opressivas das indústrias francesas, caracterizando-se como um espaço de discussão, denúncia e utilização do cinema para a causa revolucionária. Sua grande referência era o projeto empreendido por Medvedkine na União Soviética em 1932 - de transformar um trem em "estúdio móvel" equipado para rodar, editar, transportar e exibir filmes -, que interessou ao cineasta francês especialmente por seu uso na formação política popular, permitindo que os trabalhadores avaliassem sua própria ação ao se verem projetados na tela.

Durante a implementação do cinetrem, muitos "filmes-informes" de cerca de 8 a 10 minutos foram montados. De acordo com o próprio Medvedkine, os métodos do cinema, tal como pensado por Dziga Vertov, tiveram muita utilidade para o projeto, que via o documentário não como uma "informação passiva, mas como uma

\footnotetext{
${ }^{79}$ Traduzido do original: "Au niveau des modes de production, le travail collectif et la fonction d'agitprop des ciné-tracts s'inscrivent dans la foulée des projets collectifs soutenus par Marker, qui s'affichent comme les héritiers de la tradition de l'agitation et de la propagande, au sens révolutionnaire du terme, celle que pratiquait Alexandre Medvedkine via son ciné-train par exemple."

${ }^{80} \mathrm{Em}$ 1993, poucos anos após a morte de Alexandre Medvedkine (em 1989), Chris Marker homenageou o diretor russo com Le tombeau d'Alexandre. Nesse filme, ele volta a abordar o projeto que inspirou suas iniciativas de contrainformação, os cinetrens. É preciso destacar também que Marker teria, de acordo com o próprio Medvedkine, organizado uma publicação de seu livro em Buenos Aires, intitulado em espanhol 294 dias sobre ruedas. Medvedkine declara que o livro teria circulado bastante na América Latina a partir dessa edição.
} 
intervenção ativa e crítica" (MEDVEDKINE, 2007, p. 128, tradução nossa) ${ }^{81}$. Dessa maneira, é possível verificar tanto na obra de Medvedkine como nos periódicos de contrainformação montados por Marker uma referência à tradição documental do kino-nedelya (cinesemana) e do kinopravda ("cinema-verdade") desenvolvidos por Vertov na União Soviética nos anos $1920^{82}$. Esses informativos foram criados com a intenção de "proteger" o proletariado da influência maléfica do "cinema artístico" (encenado), bem como de propor outro conteúdo para o formato "atualidades" tal como elaborado pelas francesas Pathé e Gaumont ${ }^{83}$.

A partir dessas experiências de noticiários, Vertov desenvolveu o conceito de kinoki (ou "cinema-olho"), atribuindo ao cinema o potencial de "ver os processos da vida em uma ordem temporal inacessível ao olho humano" (VERTOV, 2007, p. 33, tradução nossa) ${ }^{84}$. Dessa forma, a montagem teria o potencial de fazer ligações imperceptíveis ao olhar, ou seja, compor um discurso vinculado de maneira mais "verdadeira" à realidade do que sua percepção acessível ao ser humano. Essa concepção evidencia um ponto em comum entre Vertov, Medvedkine e Marker. Apesar de formatos e estratégias cinematográficas distintas, o discurso desses três diretores aproxima a cobertura das atualidades de uma função de conscientização popular frente ao processo revolucionário. Portanto, reivindica para si a elaboração de uma "verdade".

Metodologicamente, aos olhos desses três diretores, os "filmes-informes" deveriam ter agilidade. Essa motivação fez Medvedkine unir, por exemplo, diferentes etapas envolvidas na prática cinematográfica em um trem multifuncional: a produção, a divulgação e a exibição. Nesse sentido, vale destacar outro importante projeto de levar às telas informações recentes como forma de impulsionar a revolução: o Noticiero ICAIC Latinoamericano, comandado por Santiago Álvarez. Sem dúvida, essa foi outra importante referência para Chris Marker ao planejar seus periódicos de contrainformação no final dos anos 1960. De acordo com o cineasta cubano, entre 1960 e 1990, o ICAIC produziu um total de 1493 episódios do Noticiero ICAIC Latinoamericano sobre temas variados, que percorreram mais de 90 países (ÁLVAREZ, 2010).

\footnotetext{
${ }^{81}$ Traduzido do original "información pasiva, sino como una intervención activa y critica".

${ }^{82}$ O projeto kino-nedelya foi desenvolvido por Vertov em 1918.

${ }^{83}$ Os termos que se encontram entre aspas nesta frase foram tirados de manifestos de Dziga Vertov publicados no livro Articles, journaux, projets (VERTOV, 1972).

${ }^{84}$ Traduzido do original: "ver los procesos de la vida en un orden temporal inaccesible al ojo humano".
} 
Em discurso proferido no XI Festival Mundial de la Juventud y los Estudiantes, em julho de 1978, Álvarez (2010) discorre sobre o "jornalismo cinematográfico", resumindo algumas orientações do gênero que estão presentes também nos trabalhos de Marker. Reivindicando Vertov e o cineolho como os antecedentes "mais legítimos" do Noticiero ICAIC Latinoamericano, o realizador declara que a principal diferença entre o cinema documental e o jornalismo cinematográfico é o dinamismo deste último gênero. Além disso, ele se distanciaria de outros tipos de reportagens em outros suportes por acoplar uma reflexão mais apurada durante a edição. De acordo com Álvarez, “o emprego das estruturas de montagem permite que a notícia originalmente filmada se reelabore, se analise e se localize no contexto que a produz, outorgando-lhe maior alcance e uma permanência quase ilimitada." (ÁLVAREZ, 2010, p. 35, tradução nossa). ${ }^{85}$

O diálogo constante de Marker com os cineastas do ICAIC certamente o aproximou da prática dos cinejornais, impulsionando, por exemplo, a série On vous parle, que contou com material vindo de Cuba para a edição dos dois episódios sobre o Brasil. Esse projeto desenvolvido pela SLON pretendia valorizar a voz de homens e mulheres envolvidos em processos de lutas revolucionárias, em diversas regiões. Chris Marker esteve ligado diretamente a vários números desses boletins informativos. Como diretor, montou as edições On vous parle du Brésil: tortures (1969), On vous parle du Brésil: Carlos Marighela (1970), On vous parle de Paris: Maspero, les mots ont un sens $(1970)^{86}$, On vous parle de Prague: le deuxième procès d'Arthur London (1971) e On vous parle du Chili: ce que disait Allende ${ }^{87}$ (1973, em parceria com Miguel Littin). Além desses títulos, ele colaborou com os demais filmes do projeto: On vous parle d'Amérique latine: le message du Che (Paul Bourron, 1968) e On vous parle de Flins (Guy Devart, 1970) ${ }^{88}$.

\footnotetext{
${ }^{85}$ Traduzido do original: "El empleo de las estructuras de montaje permite que la noticia originalmente filmada se reelabore, se analice y se ubique en el contexto que la produce, otorgándole mayor alcance y una permanencia casi ilimitada."

${ }^{86}$ On vous parle de Paris: Maspero, les mots on un sens é um retrato do editor francês, montado principalmente a partir de uma entrevista com o mesmo. Fundador da Éditions Maspero, ele foi responsável pela publicação de muitos títulos engajados à esquerda, entre eles, o comentário do filme O fundo do ar é vermelho.

${ }^{87}$ Esse episódio será analisado no capítulo 2 desta tese.

${ }^{88}$ É provável que outros episódios montados dessa série tenham sido perdidos. On vous parle du Chili, por exemplo, é indicado como o de número 10, o que significa que deve haver ao menos dois que não aparecem listados neste parágrafo. Os títulos elencados são os indicados no site da Image, Son, Kinescope et Réalisations Audiovisuelles (ISKRA). Disponível em: 〈http://www.iskra.fr/>. Acesso em: 25 fev. 2013.
} 
Ao contrário do comentário marcante presente nas demais produções de Chris Marker, geralmente proferidos pela voz over e que lhe concede o papel de completar as imagens, alguns dos títulos montados para essa série utilizam pouco esse recurso, e de forma secundária. Caracterizados como "boletins de notícias", preferem a adoção de outras técnicas do gênero documental, como o uso de entrevistas, materiais de arquivos, fotografias, recortes de jornal impresso, colagens etc. Essa pouca importância do texto pessoal do realizador procura valorizar a palavra do "outro", no caso, os sujeitos revolucionários em questão. Traz ainda um certo tom de objetividade desejável no discurso jornalístico. Nesse sentido, a presença da voz over é rara e aparece apenas com um caráter informativo, sempre corroborando ou contextualizando os documentos trazidos pela montagem. Algumas dessas estratégias serão aprofundadas na análise nos episódios dedicados ao Brasil e no dedicado ao Chile, On vous parle du Chili: ce que disait Allende, analisado no capítulo $2 .{ }^{89}$

Santiago Álvarez destacou outro significativo papel desempenhado pelos noticiários cinematográficos: a criação de uma memória visual nos espectadores (ÁLVAREZ, 2010). Esse recurso está presente na série On vous parle, que diferentemente de Nouvelle Société (cuja formação revolucionária se dava sobretudo no "fazer" cinema) visava à conscientização por meio da exibição, da tomada de consciência a partir da nova informação aportada pelos boletins. Os episódios sugeriam novos heróis, novos líderes. Abordavam processos pouco conhecidos na França ou apenas tratados pelos meios de comunicação conservadores ${ }^{90}$, que atribuíam uma imagem negativa aos revolucionários em questão. Dessa forma, se afirmava como um mecanismo de contrainformação.

Em relação à difusão dos episódios de On vous parle destinados ao Brasil On vous parle du Brésil: tortures e On vous parle du Brésil: Carlos Marighela -, uma carta de Alfredo Guevara endereçada em 1970 a um brasileiro conhecido como

\footnotetext{
${ }^{89}$ Vale destacar que nem todos os episódios da série adotam esse tom informativo e impessoal. Dois deles se destacam especialmente por uma presença autoral de Marker no comentário: On vous parle de Paris: Maspero, les mots on un sens e On vous parle de Prague: le deuxième procès d'Arthur London. Em ambos, está em jogo a questão do lugar do intelectual de esquerda na revolução, o que os torna filmes mais reflexivos sobre esse campo político do que noticiários de contrainformação.

${ }^{90}$ É necessário lembrar que a SLON se instalou primeiramente na Bélgica, mudando-se para a França somente em 1974 com o nome de ISKRA. Essa estratégia visava a escapar da censura, o que mostra que os meios de comunicação e o cinema francês passavam por um processo de controle e eventualmente de controle de divulgação, como ocorreu no início dos anos 1960 com Cuba si.
} 
Dirceu $^{91}$ leva à conclusão que ela seria feita em circuitos alternativos, assim como os demais exemplares da série. Nessa correspondência, o então diretor do ICAIC se refere sobretudo a sua insatisfação com recentes publicações na França que denegriam a imagem da Revolução Cubana na mídia (lembrando que, mesmo entre os intelectuais de esquerda, o início dos anos 1970 resultou em uma perda massiva de apoio após o "Caso Padilla" e o alinhamento de Cuba com a URSS durante a Primavera de Praga). Após divulgar as "más notícias", Guevara anuncia a finalização do filme de Marker montado com base no material gravado no Instituto de cinema cubano:

Já está terminado o documentário denunciando a tortura no Brasil, e o regime em geral, e parece que terá chance de ser transmitido pela TV francesa e de circular, ao menos, pelos circuitos paralelos (universidades, cineclubes, grupos de pressão etc.). Os cineastas revolucionários funcionam, são coerentes e eficazes. Essa é outra categoria de gente, que nada se parece a dos fraudulentos que se simulam intelectuais e carecem da condição primeira de quem se inclina às possibilidades da arte, ou da ciência: o rigor. (GUEVARA, 2009, p. 214) ${ }^{92}$

É esse caráter de contrainformação, reforçado na correspondência de Guevara, que permitia seu uso como um cinema-denúncia. Nesse sentido, os filmes sobre o Brasil, especialmente On vous parle du Brésil: tortures, anteciparam um tom que esteve presente também nas produções sobre o Chile. Entre as atribuições de Marker como um mediador entre a América Latina e a França, estava a difusão, na Europa, da repressão e das perseguições instauradas pelas ditaduras latino-americanas. Sob essa perspectiva, esses filmes se autoatribuem uma verdade histórica, procurando consolidar uma nova versão historiográfica para os fatos, favorável ao ponto de vista da esquerda.

O tom de denúncia empregado nessas produções sobre o Brasil, assim como a estratégia do realizador em difundi-las em televisões europeias, se repetiram, por

\footnotetext{
${ }^{91}$ Apesar de não haver indicação de sobrenome na correspondência nem indícios que permitam uma confirmação, é provável que o brasileiro em questão seja o ex-líder do movimento estudantil José Dirceu, já que ele esteve no grupo de exilados brasileiros que foram a Cuba libertados na ocasião do sequestro do embaixador norte-americano Charles Burke Elbrick.

92 Traduzido do original: "Ya está terminado el documental denunciando la tortura en Brasil, y en general el régimen, y aparece que tendrá "chance" de ser transmitido por la TV francesa y de circular, cuando menos, por los circuitos paralelos (universidades, cine-clubes, grupos de presión, etc.). Los cineastas revolucionarios funcionan, son coherentes y eficaces. Ésta es otra categoría de gente, que nada se parecen a los tramposos que si simulan intelectuales y carecen de la condición primera de quién se asoma a las posibilidades de arte, o de la ciencia: el rigor."
} 
exemplo, em On vous parle du Chili: ce que disait Allende. Nesse documentário, que será analisado no capítulo 2, há a tentativa de dar voz às vítimas dos governos ditatoriais, por meio da rememoração das falas de Allende, de forma semelhante ao espaço concedido pelo realizador aos exilados brasileiros em On vous parle du Brésil: tortures. Na passagem entre os anos 1960 e 1970, reforça-se em sua obra, como verifica-se nos filmes citados, a estratégia de exaltar líderes da esquerda latinoamericana (aos moldes da defesa incondicional de Fidel Castro em Cuba si). Esse esforço é claro em On vous parle du Brésil: Carlos Marighela.

Por fim, mais dois aspectos justificam a inserção dessas produções sobre o Brasil nesta tese. O primeiro é o fato de que estabelecem um discurso engajado à esquerda mesmo após derrotas trágicas e então recentes desse campo político. Assim, os dois episódios de On vous parle du Brésil foram montados em momentos bastante desfavoráveis aos personagens que abordam, já que tratam de líderes de organizações de esquerda presos e torturados, além do próprio Marighella, assassinado um ano antes do filme a ele dedicado. No caso do Chile, On vous parle du Chili, L'ambassade e La spirale lidaram com esse desafio de defender os preceitos da Unidade Popular em um contexto próximo à sua derrocada por meio de um violento golpe militar.

Outro aspecto que deve ser reiterado, e que igualmente justifica a presença desses filmes nesta tese, é o fato de essas produções terem sido montadas em cooperação com o ICAIC. Dessa forma, elas respondem aos anseios do Instituto, que determinam a predominância de certos enfoques. Marker realizou esses documentários tendo em vista os interesses cubanos e suas conexões com a guerrilha brasileira. Portanto, pode-se dizer que os dois On vous parle du Brésil integram a "fase Cuba" do cineasta, demonstrando, de certo modo, o otimismo frente à Revolução e seus métodos.

\subsection{On vous parle du Brésil: tortures $(1969)^{93}$}

On vous parle du Brésil: tortures foi montado com material recebido de Cuba, mais especificamente, com entrevistas realizadas com ex-prisioneiros do governo

\footnotetext{
${ }^{93}$ A análise de On vous parle du Brésil: tortures foi realizada a partir de uma cópia cedida pelo arquivo da ISKRA, em Paris.
} 
militar brasileiro, cuja liberdade foi negociada em troca do embaixador norteamericano Charles Burke Elbrick, sequestrado pela Ação Libertadora Nacional (ALN) e pelo Movimento Revolucionário 8 de Outubro (MR-8). O documentário em $16 \mathrm{~mm}$ e com cerca de 20 minutos - apresenta duas partes com estratégias de montagem distintas. A primeira faz uma introdução sobre o caso, composta de documentos visuais e uma locução em over de caráter informativo, claramente baseada no manifesto redigido pela ALN e pelo MR-8; enquanto a segunda traz depoimentos de seis brasileiros entrevistados.

A coincidência entre a comemoração do 7 de setembro de 1969 pelos militares e o episódio do sequestro, entre 4 e 6 desse mesmo mês, é ressaltada pela voz over na introdução e na conclusão do documentário, dando um sentido metafórico à independência do Brasil. Embora comemorasse a data, a ditadura se mostrava exatamente o oposto da liberdade evocada pelo evento, ideia que é reiterada na sequência final, em que o fotograma de um jornal francês informa o discurso de Emílio Garrastazu Médici nesse dia: “A repressão será dura e implacável”. Essa aproximação entre a celebração histórica e os fatos atuais permite a interpretação de que os entrevistados seriam novos libertadores, atribuindo aos protagonistas um peso nas lutas políticas do presente que poderiam ser imortalizadas pela História.

A associação do sequestro à festa da independência é proferida por uma voz over na introdução, que se restringe a dar informações que atualizem o público europeu com dados sobre o episódio. Os militares que aparecem ao redor do general Médici em fotos tiradas em 7 de setembro de 1969, diz a locução, estão no poder há cinco anos. Porém, na proximidade da data comemorativa, receberam uma notícia chocante: o embaixador dos Estados Unidos havia sido sequestrado por um grupo de revolucionários. Charles Burke Elbrick é descrito como o legítimo representante do imperialismo norte-americano no Brasil, portanto, como um braço importante de apoio ao governo ditatorial. A situação é ilustrada por meio de recortes de jornais brasileiros e franceses, inseridos na montagem.

Em seguida, a voz over segue completando o desfecho dessa ação, citando textualmente o documento que pedia a libertação de quinze prisioneiros políticos em troca do embaixador, assinado pela ALN e pelo MR-8:

Saibam todos que esta é uma luta sem tréguas, uma luta longa e dura, que não termina com a troca de um ou outro general no poder, mas que só acaba com o fim do regime dos grandes exploradores e 
com a constituição de um governo que liberte os trabalhadores de todo o país da situação em que se encontram. (On vous parle du Brésil: tortures, 1969) ${ }^{94}$

É evidente que o manifesto endereçado ao governo com as condições do sequestro é a principal fonte na qual Marker se apoia para construir sua $\operatorname{argumentação~}^{95}$. A dualidade da data da independência, por exemplo, tão enfatizada pela voz over na introdução e na conclusão, já integrava o texto em questão, que opunha a comemoração do governo e da classe a qual ele representaria à celebração do povo: "Na Semana da Independência, há duas comemorações: a da elite e a do povo, a dos que promovem paradas e a dos que raptam o embaixador, símbolo da exploração." (MANIFESTO, 1969).

Outros documentos simbólicos desse episódio estão presentes na montagem. A famosa foto dos treze prisioneiros em frente ao Hércules 56, avião que os levaria ao México, bem como as sequências audiovisuais dos mesmos desembarcando no exílio mexicano e, posteriormente, reunidos com Fidel Castro em Cuba (para onde seguiram), são alguns dos materiais de arquivo que Marker utiliza para informar o espectador. Os demais são trechos exibidos geralmente em planos longos, em que seis dos quinze ex-prisioneiros declaram o que sofreram em suas detenções no Brasil: José Ibrahim (líder operário paulista), João Leonardo da Silva Rocha (advogado baiano), Ivens Marchetti (arquiteto), Mario Roberto Zanconato (estudante de medicina em Minas Gerais), Onofre Pinto (ex-sargento) e Maria Augusta Carneiro Ribeiro (líder estudantil mineira, militante no Rio de Janeiro).
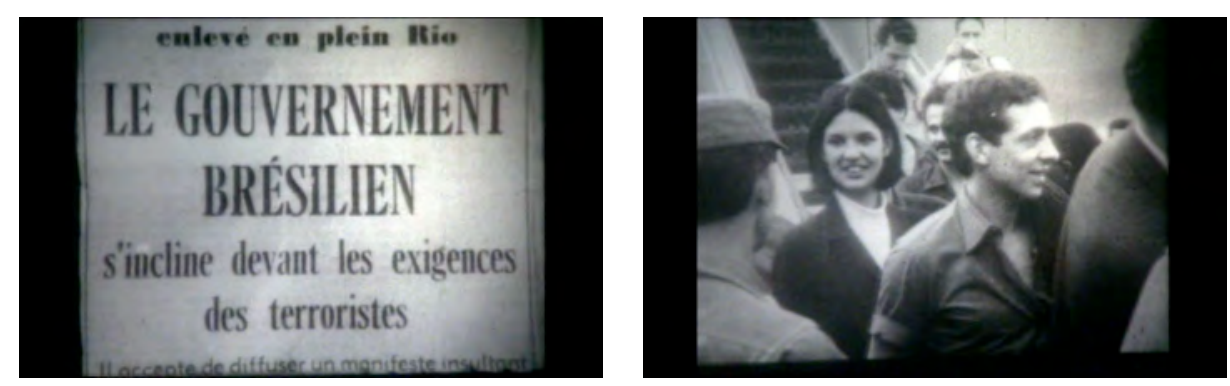

Imagens que compõe On vous parle du Brésil: tortures.

\footnotetext{
${ }^{94}$ Em On vous parle du Brésil: tortures, o trecho é proferido pela voz over em francês. Porém, como o original está em português, ele aparece citado na seguinte fonte: Manifesto do sequestro do embaixador $\begin{array}{lcc}\text { americano. Rio } & \text { (1969). } & \text { Disponível }\end{array}$ <http://www.franklinmartins.com.br/estacao_historia_artigo.php?titulo=manifesto-do-sequestro-do-
embaixador-americano-rio-1969>. Acesso em: 25 fev. 2013 . ${ }^{9} \mathrm{O}$ manifesto é evocado visualmente também como forma de apresentar os depoentes. Antes de cada testemunho, a câmera focaliza o nome do entrevistado na lista de pessoas que deveriam ser soltas, conforme a exigência da ALN e do MR-8.
} 
O tom predominante nos depoimentos é a descrição das torturas. Todos eles se declaram torturados e esmiúçam o uso de procedimentos como o pau-de-arara, os choques elétricos, as diferentes técnicas para golpear, as torturas psicológicas... Relatam seus próprios sofrimentos, mas também o de outros companheiros que viram ser violentados, tendo em vista que essas sessões costumavam ser assistidas por outros presos políticos, como uma forma de forçar as confissões. Cabe, porém, a esta análise, verificar, além dessas narrações traumáticas, que aspectos valorizados no processo de montagem permitem ao realizador elaborar um discurso sobre esse tema.

O primeiro testemunho trazido na montagem é o de José Ibrahim, que, em 1968, liderou a greve operária em Osasco e teve um importante papel na manifestação do $1^{\mathrm{o}}$ de maio na Praça da Sé. Ele recebe destaque, sendo a primeira voz a ser escutada, como forma de enfatizar um suposto aspecto popular na resistência à ditadura militar. Essa ideia, a de que a tortura atingia todas as classes sociais, aparece ainda no depoimento de Ivens Marchetti, então integrante do MR-8, que declara que se tratava de uma prática "generalizada", que afetava todo o povo brasileiro. Assim como Ibrahim, os demais entrevistados iniciam sua fala identificando-se pelo nome e profissão, o que permite ao documentário caracterizar uma gama de distintas ocupações, corroborando a tese de que a conduta do Estado brasileiro em torturar seus opositores estaria disseminada ${ }^{96}$. Onofre Pinto, um dos fundadores da Vanguarda Popular Revolucionária (VPR), é ainda mais enfático ao dizer que inclusive os religiosos não estavam imunes a essa violência.

Um tema comum nos depoimentos é descrever pessoas que foram torturadas mesmo sem participar de movimentos políticos de oposição. Leonardo Rocha, integrante da ALN, narra que sua esposa, que não estava envolvida em ações da luta armada, havia sido presa com ele. Ibrahim denuncia ainda ter presenciado na prisão a tortura de um advogado, sua mulher e seu filho, em busca de uma confissão do homem, que não tinha participação em qualquer ação contrária à ditadura. Os trechos dos relatos selecionados na montagem são principalmente os que reforçam a ideia de um exercício da violência por parte do Estado, que não se restringia aos seus opositores políticos, mas atingiriam todo o povo brasileiro.

\footnotetext{
${ }^{96}$ Todos os depoentes dizem primeiramente seu nome e profissão para a câmera. Essa forma de identificação remete-se à prática do testemunho, tal como realizado na esfera jurídica. Portanto, essa opção utilizada na gravação feita pelo ICAIC normatiza as falas dos exilados, agregando-lhe um valor legal.
} 
Da mesma forma que os testemunhos destacam a presença da tortura em diferentes classes sociais e profissões, algumas falas informam que essa prática estaria disseminada também por todo o território nacional. Essa ideia aparece no depoimento de Mário Roberto Zanconato, então integrante da Corrente Revolucionária de Minas Gerais, que apesar de descrever esse estado como o lugar onde a violência repressiva era mais intensa, declara que ela estava presente em todo o país. Ao trazer entrevistados de diferentes partes do Brasil à cena, a montagem corrobora essa declaração.

On vous parle du Brésil: tortures traz algumas das estratégias comuns à série que integra: documentos de arquivos como fotos e notícias de jornal; valorização da fala dos protagonistas revolucionários em detrimento da do diretor (a voz over exerce um papel apenas informativo, sem interrogar as imagens ou o depoimento dos entrevistados, e se posicionando em tom informativo); uso de entrevistas que visam a colocar em evidência novos sujeitos históricos. Assim, o documentário discorre sobre a ditadura militar em formato próximo ao jornalístico, dando voz a atores que em seu país não tinham oportunidade de falar e corroborando suas declarações. Nesse sentido, se constitui como um canal de contrainformação, ao buscar trazer uma "verdade" oposta àquela presente na mídia submetida aos limites da censura e ao discurso oficial do governo brasileiro.

Pode-se afirmar que se trata, sobretudo, de um filme de denúncia. On vous parle du Brésil: tortures é montado para mostrar que a violência não era apenas esporádica ou excessos dos "porões", mas sim disseminada e comandada pelas esferas máximas do poder político no Brasil. Isso fica claro ao final do documentário, quando Marker cita a frase de Médici no 7 de setembro de 1969, de que a repressão será "dura e implacável". Inserida após as falas dos torturados, ela associa os eventos narrados a um comando superior, dando-lhe oficialidade e institucionalidade. Essa informação, impedida de circular pela censura e pela repressão, passa a ser divulgada na série $O n$ vous parle, que retrata a tortura e o terror não como recursos eventuais, e sim como práticas institucionalizadas.

Tendo em vista que os episódios de On vous parle eram exibidos em mostras de curtas, ocupações de fábricas e movimentos sociais - além de circularem em um grupo considerável de artistas e intelectuais franceses de esquerda -, os boletins dessa série contribuíram para que esses grupos sociais conhecessem a gravidade do que se passava nessa ditadura latino-americana. Vale ressaltar ainda que muitos exilados 
políticos brasileiros passavam pela França, sendo recebidos justamente por setores das esquerdas europeias que se mobilizavam para abrigar e dar apoio a refugiados políticos latino-americanos. Portanto, mesmo que de maneira indireta, um cinejornal de contrainformação que denunciasse a tortura no Brasil poderia colaborar para a resistência ao governo ditatorial, bem como para o estabelecimento de laços de solidariedade no exílio.

É necessário ressaltar o peso dado ao testemunho nesse episódio de On vous parle. Ele é um elemento fundamental para a denúncia, principalmente frente a uma ditadura repressora e que não permitia a circulação de outras provas, como laudos ou provas materiais. Portanto, nessas circunstâncias, ele seria a única forma de revelar a verdadeira situação a qual estaria submetido o "povo brasileiro", para usar um termo amplo como o repetido no documentário. Esses testemunhos adquirem um caráter coletivo na montagem, ao integrarem diferentes relatos pessoais para a confirmação de uma tese comum, a de que a tortura era algo disseminado e institucionalizado. Em termos de estratégias fílmicas, Marker optou por utilizar na montagem trechos em que a câmera enquadra em close-up o rosto de um colega, enquanto o outro narra os procedimentos aos quais foi submetido. Vê-se, no rosto do companheiro ao lado, uma dor que transpassa a esfera do indivíduo, e que reverbera em uma sociedade como um todo.
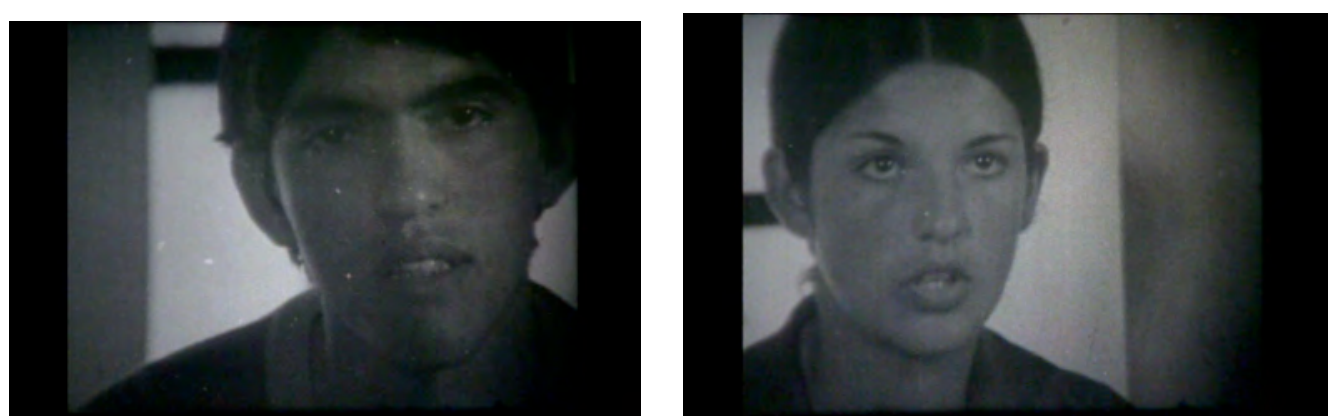

José Ibrahim e Maria Augusta Carneiro Ribeiro em On vous parle du Brésil: tortures.

A constituição de uma denúncia internacional era, certamente, a motivação do ICAIC ao enviar o material a Chris Marker, imaginando seu potencial de difusão na Europa. Com isso, o combate à ditadura brasileira tornava-se uma causa revolucionária internacional (assim como a dor visível nos close-ups dos companheiros brasileiros que era compartilhada por seus colegas). Foi provavelmente a circulação desse filme que fez com que os mesmos depoimentos fossem usados em 
uma produção italiana editada no ano seguinte, em 1970: Brasile tortura $^{97}$. Mais recentemente, trechos dessas entrevistas apareceram em Hércules 56 (2006), de Silvio Da-Rin. Essa apropriação quase quarenta anos depois para a elaboração de uma produção documental que justifica a luta armada do passado, caso do filme de DaRin, vai ao encontro das intenções que teria Santiago Álvarez, produtor do Noticiero ICAIC Latinoamericano, de que os cinejornais de contrainformação criassem uma memória visual que servisse para "reconstruir" a "verdade histórica" em tempos posteriores (ÁLVAREZ, 2010, p. 36). ${ }^{98}$

\subsection{On vous parle du Brésil: Carlos Marighela $(1970)^{99}$}

"Sem homens armados, nada podemos contra a ditadura" (On vous parle du Brésil: Carlos Marighela, 1970) ${ }^{100}$. Essa frase da voz over em On vous parle $d u$ Brésil: Carlos Marighela resume a mensagem do documentário, uma clara defesa da luta armada no Brasil. O curta, feito em $16 \mathrm{~mm}$ e com 17 minutos de duração, traz como fonte principal uma entrevista com um exilado político do governo militar brasileiro $^{101}$. Além disso, inúmeros documentos, como fotografias, trechos de

\footnotetext{
${ }^{97}$ Há poucas informações disponíveis sobre este documentário, datado de 1970 (um ano após o filme de Marker) e produzido pela UTF, de acordo com o catálogo da Cineteca Sarda (disponível em: <http://www.lacinetecasarda.it/catalogo/vedischede.php?ID=11765\&sezione=Scheda>; acesso em: 25 fev. 2013). É mais provável, porém, que ele tenha sido montado a partir de On vous parle du Brésil: tortures, que circulava em meios militantes da Europa.

${ }^{98}$ Assim como On vous parle du Brésil: tortures, outros documentários utilizaram a entrevista com expresos pela ditadura militar brasileira para denunciar a tortura praticada nesse país. No es hora de llorar (1971), de Pedro Chaskel e Luis Alberto Sanz, traz entrevistas gravadas no Chile com torturados que se encontravam exilados após as negociações em função do sequestro do embaixador suíço, Giovanni Bucher, em 1970. Esse mesmo grupo de exilados aparece no filme estadunidense Brazil, a report on torture (1971), de Haskell Wexler e Saul Landau. A referência a essas outras produções, de conteúdo e objetivos semelhantes aos presentes nos documentários de Marker, revela a existência de uma rede internacional de denúncia das ações empreendidas pelo regime militar brasileiro e de solidariedade às suas vítimas.

${ }^{99} \mathrm{~A}$ análise deste filme foi realizada com base em uma cópia cedida por colegas pesquisadores. Por conta de sua exibição na Cinemateca Brasileira em 2009, trabalhou-se com uma versão legendada em português. Dessa forma, os trechos correspondentes serão citados de acordo com a legenda.

${ }^{100}$ Trecho da voz over, traduzido do original: "Sans hommes armés, on peut rien contre la dictature."

${ }^{101}$ Ao contrário dos testemunhos que estão presentes em On vous parle du Brésil: tortures, que estão gravados originalmente em português, esse está registrado diretamente em francês. De acordo com a voz over, tratava-se de um companheiro de Marighella, e o depoimento teria sido gravado em Cuba. No entanto, o próprio Marker deu uma outra versão à pesquisadora Emi Koide em uma entrevista enviada à ela por e-mail: "As entrevistas com os depoentes de On vous parle foram filmadas em sua chegada à Havana. Eu ainda tinha boas relações de trabalho com os cubanos nessa época, embora eu não dividisse seu otimismo revolucionário a qualquer preço (meu companheiro Santiago Álvarez começava um de seus notáveis Noticiero por 'Como Cuba nos anos 50, o Brasil está na antessala da
} 
películas e recortes de jornal, compõem a montagem, alinhavada por uma locução em tom informativo ${ }^{102}$. Todos esses elementos são articulados para compor um retrato de Marighella, morto um ano antes de Chris Marker finalizar esse filme, assim como para mostrar que ele fazia parte de um amplo movimento de resistência em seu país.

Se On vous parle du Brésil: tortures se constitui sobretudo como um filmedenúncia sobre a violência institucionalizada pelo Estado no Brasil, o episódio da série dedicado a Carlos Marighella usa a estratégia da contrainformação para passar uma visão positiva do líder assassinado e divulgar a organização de uma ampla resistência, na qual a guerrilha urbana teria um papel de destaque. Realizado em um momento de derrota para a esquerda armada brasileira, o documentário de Marker adota um discurso militante no sentido mais estrito do termo, incentivando a continuidade das ações empreendidas pelo líder da ALN, ao afirmar que o caminho que ele seguia, apesar de sua morte, era o único possível no contexto repressivo.

Logo em suas primeiras sequências, o documentário faz uma referência direta ao seu propósito de contrainformação. A câmera focaliza um aparelho televisor no qual se vê apresentadores de telejornais. Em seguida, a voz over comenta: “Assim que a televisão der às coisas e às pessoas seu verdadeiro lugar, nós escutaremos, por exemplo, isso" (On vous parle du Brésil: Carlos Marighela, 1970). Essa frase é a deixa para a exibição do rosto de um exilado político, que não pode ser reconhecido, pois aparece de perfil e na sombra. A voz over declara que a entrevista foi gravada em Cuba, onde vivem muitos exilados brasileiros, e que como ele pensava em voltar clandestinamente ao seu país, preferia manter o anonimato ${ }^{103}$. Sua imagem refilmada

Revolução'. Eu o via mais no sótão). Para Marighella, eu entrevistei clandestinamente em Paris (não se vê mais que sua sombra) um dos membros de seu grupo, um dos que eu tinha os contatos. Eles estão todos mortos." (MARKER, 2004). Traduzido do original: "Les entretiens avec les témoins d'On vous parle, ont été filmés à leur arrivée à La Havane. J'avais encore de bons rapports de travail avec les Cubains en ce temps-là, même si je ne partageais pas leur optimisme révolutionnaire à tous crins (mon camarade Santiago Álvarez commençait un de ses remarquables Noticiero par 'Igual que Cuba en los '50s, Brasil es en la antesala de la Revolucion...' Moi je le voyais plutôt au grenier). Pour Marighella, j'ai interviewé à Paris clandestinement (on ne voit que son ombre) un des membres de son groupe, un de ceux avec qui j'avais des contacts. Ils sont tous morts."

${ }^{102}$ Não foram encontradas maiores informações sobre quem dá vida à voz over de On vous parle du Brésil: Carlos Marighela. Porém, essa locução foi feita por um homem com um sotaque perceptível, aparentando ser o de um brasileiro.

${ }^{103}$ Vale lembrar que, em depoimento posterior, Marker declarou que a entrevista foi gravada em Paris. Apesar das possíveis modificações impostas ao fato pela memória, é possível que essa versão seja verdadeira, pois o depoimento é gravado em francês. Além disso, como se tratava de um militante em situação clandestina - fosse em Cuba ou na França -, possivelmente a voz over imprimiu "pistas falsas" que dificultassem o conhecimento de sua identidade. 
por Marker diretamente da tela aparece em outros momentos de On vous parle $d u$ Brésil: Carlos Marighela, intercalada ao material de arquivo que integra a montagem.

$\mathrm{O}$ documentário informa, em suas sequências iniciais, a data em que foi realizado: 4 de novembro de 1970, um ano após o assassinato de Carlos Marighella pelo regime "mais abominável deste planeta", de acordo com a voz over: a ditadura dos generais do Brasil. Ao som de um samba marcado por uma cuíca, uma série de fotografias das manifestações estudantis de 1968 é exibida. Destaca-se uma delas, em que um estudante picha algo sobre um muro, que recebe um tratamento de animação que compõe letra a letra a palavra pichada: "Liberdade"104. A câmera percorre os registros fotográficos, focalizando algumas das pessoas retratadas. São utilizados close-ups e afastamentos; assim como cortes bruscos para passar de uma cena à outra, muitas vezes dentro de uma mesma fotografia. A edição imprime um ritmo de videoclipe que acompanha o fundo musical sincopado do samba, variando o tempo de exibição de cada imagem.
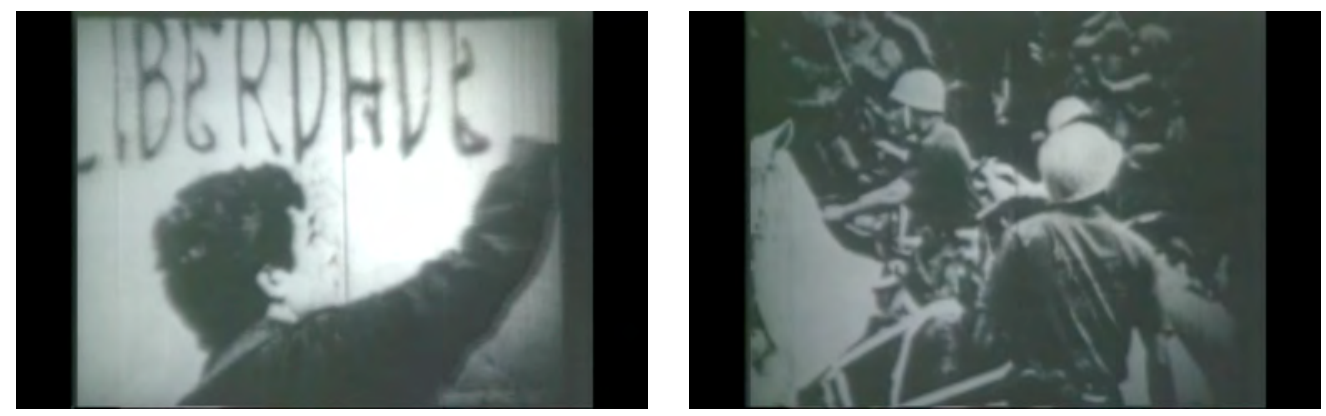

Fotogramas utilizados em On vous parle du Brésil: Carlos Marighela.

Ao lado das grandes mobilizações de operários e estudantes (como informa a locução em over), estão cenas da polícia reprimindo-as. No caso das fotografias, em que aparecem grupos de policiais, a câmera se aproxima para tentar focalizar o rosto de cada um, mas a perda de resolução não a permite. Nesses planos iniciais, Marker evidencia a existência de duas forças antagônicas: repressão e resistência. Elas são mostradas como consequência uma da outra. $\mathrm{O}$ documentário visa a exibir uma ampla

\footnotetext{
${ }^{104}$ A montagem de On vous parle du Brésil: Carlos Marighela utiliza imagens icônicas da resistência à ditadura no Brasil, como a que um jovem picha os dizeres "Abaixo a ditadura" durante a passeata dos 100 mil (em 26 de junho de 1968) e a que um rapaz escreve a palavra "liberdade" sobre um muro (também de 1968). No caso desta última imagem, citada nesta análise, é interessante notar que a mesma percorreu o mundo e integra diversos cartazes em solidariedade à oposição brasileira, divulgados na Hungria, em Cuba, na França, na Dinamarca, entre outros países. Alguns desses cartazes podem ser vistos na publicação de SACCHETTA, 2012, p. 44-5.
} 
organização popular como resposta às ações do Estado brasileiro, conforme indica a voz over nessas sequências iniciais:

Brasil, 1968. Após quatro anos de ditadura militar, de repressão às universidades e aos sindicatos, o povo se organiza para enfrentar o poder dos generais. As primeiras greves acontecem em São Paulo, em Minas Gerais e no Rio de Janeiro. Ao mesmo tempo, os estudantes saem às ruas e atacam a ditadura usando táticas de combate de rua e desmoralizando cada vez mais o inimigo. As manifestações de massa se sucedem. Seguindo o exemplo dos estudantes, outros setores da população começam a se organizar e rompem com o imobilismo e a legalidade impostos pela ditadura. Ocupação, manifestação, greves, luta contra a censura fazem a polícia mudar a ação contra os prisioneiros políticos. Essas são as formas de luta de massa. (On vous parle du Brésil: Carlos Marighela, 1970)

Em uma sequência posterior, o documentário volta a exibir uma série de fotografias da repressão policial e, por alguns segundos, congela na tela a imagem de um homem atrás das grades. A voz over afirma que a violência e o terror da ditadura no Brasil só encontraram precedentes no nazismo, fato corroborado na montagem por uma fotografia e extratos audiovisuais do enterro do estudante Edson Luís, morto em 28 de março de 1968, em ação policial que reprimiu protestos estudantis no Rio de Janeiro. O movimento de câmera que percorre detalhes da foto possibilita a leitura de um cartaz que cobre seu caixão: “Aqui está o corpo de um estudante morto pela ditadura”. Essa morte simboliza a ruptura com o tema da resistência pacífica. Se, no início do filme, estavam presentes, ao lado das cenas de repressão, registros visuais de grandes manifestações e protestos, o discurso proferido pela voz over em sua segunda metade defende cada vez mais a via armada, tendo em vista que, diante desse regime “mais abominável do planeta”, essa opção se mostrava como a única saída. Nesse sentido, a exaltação das ações de Carlos Marighella passa a ser o tom predominante.

As sequências posteriores ao enterro de Edson Luís continuam mostrando fotografias da repressão, que são acompanhadas pelo seguinte comentário da voz over:

Durante o ano de 1968, o inimigo havia atirado contra os estudantes e as massas, causando numerosas mortes entre os combatentes de rua, geralmente desarmados. A experiência mostrou que grupos de homens armados organizados para ataques a bancos e a quartéis, apesar de sua limitação, podiam ser utilizados para enfrentar o poder de fogo superior do inimigo. Para Marighella, as ações de pequenos grupos não excluem a ação das massas, ao contrário, elas 
são necessárias. Sem homens armados, não se pode enfrentar a ditadura. (On vous parle du Brésil: Carlos Marighela, 1970)

Essas palavras deixam clara a opção de Marker em defender a via armada como forma de resistência no enfrentamento da ditadura. No entanto, trata-se de um discurso aparentemente contraditório, tendo em vista sua elaboração diante de um episódio de derrota para a guerrilha brasileira: o assassinato de Carlos Marighella. Essa contradição é solucionada pela exaltação do líder da ALN, que busca transformá-lo em um mártir cuja morte não foi em vão, ao contrário, poderia torná-lo um símbolo que incentivasse ações como as que ele defendia.

A primeira cena do filme é justamente a de uma bandeira hasteada. On vous parle du Brésil: Carlos Marighela busca transformar o guerrilheiro brasileiro, assim como ocorreu com a imagem de Che Guevara após sua morte, em um incentivo - uma bandeira - aos movimentos revolucionários posteriores. Em uma passagem do documentário, o ex-companheiro de Marighella narra um episódio em que um homem do grupo havia sido morto pela repressão. Ao saber da morte dessa pessoa a quem tinha muita estima, apesar de ter ficado muito emocionado, o líder da ALN teria declarado apenas que o colega havia cometido um erro fatal. A inserção desse trecho do testemunho indica que a ação política deveria estar acima das afeições individuais. A luta armada, no caso brasileiro, era necessária para enfrentar uma ditadura caracterizada, nas palavras da voz over, como uma força repressiva cujo furor não poupava "nem os padres, nem as religiosas, nem as crianças".

Nesse sentido, pode-se afirmar que o documentário procura resolver a contradição de sua militância pela luta armada no Brasil mesmo após a morte de seu principal nome por meio do reforço da ideia de um legado político deixado por Carlos Marighella. A imagem do rosto do guerrilheiro em meio a faixas negras aparece algumas vezes ao longo do filme, permanecendo na tela por alguns segundos no plano final. Após informar que ele havia morrido em decorrência de uma emboscada com mais de oitenta policiais, a voz over afirma que, embora a ditadura acreditasse que a morte de seu "inimigo número 1" deteria a "luta revolucionária do povo brasileiro", a guerrilha urbana seguiria ainda mais ativa do que antes: "Mas a ideia da ação, sempre presente no pensamento de Marighella e pela qual ele deu sua vida, já tinha conquistado muitos militantes revolucionários." (On vous parle du Brésil: Carlos Marighela, 1970). Na mesma linha argumentativa, Marker insere na montagem um trecho do depoimento do exilado brasileiro, que caracteriza o líder da ALN como um 
símbolo que poderia tornar-se uma bandeira, assim como ocorreu com Che Guevara para a América Latina: "A figura de Marighella, o exemplo de Marighella, devia frutificar em todo o Brasil" (Exilado brasileiro Apud On vous parle du Brésil: Carlos Marighela, 1970).

O depoente segue afirmando que, "como ele disse: 'se eu morrer, outra pessoa pegará o meu fuzil'. Para ele, isso não era uma posição retórica, mas ele achava realmente que a ação tinha como umas das consequências possíveis a morte" (Exilado brasileiro Apud On vous parle du Brésil: Carlos Marighela, 1970). Essas palavras que encerram o documentário, enquanto o rosto de Marighella é focalizado na tela, comprovam a estratégia narrativa de atribuir um legado político ao guerrilheiro, mantendo assim um discurso militante mesmo após sua morte. Dessa maneira, é necessário verificar que qualidades políticas são atribuídas ao líder nesse filme, que ao serem exaltadas poderiam servir de exemplo para a luta revolucionária.

Um dos episódios da vida política de Marighella destacados no documentário é o de sua expulsão do Partido Comunista Brasileiro (PCB), em 1966. A voz over refaz sua trajetória política desde o golpe em 1964, dizendo que ele havia tentado em vão levar o partido a essa prática política, quando era membro do comitê-central do PCB. Marker insere na montagem um trecho da carta que ele escreveu aos seus companheiros de partido pedindo demissão do cargo que ocupava, poucos meses antes de ser expulso, que é lida pela voz over:

Após ter dito e repetido que a massa deve se opor contra a violência das classes dominantes, nada foi feito para que as palavras se transformassem em ação. Prega-se o pacifismo por falta de consciência revolucionária, que só nasce a partir da luta. Para o Brasil, só há uma saída: a luta armada. (MARIGHELLA Apud On vous parle du Brésil: Carlos Marighela, 1970)

O papel do entrevistado na montagem é, sobretudo, o de passar uma visão positiva de Carlos Marighella. Ele declara que o líder da ALN não era um homem violento, e sim amável e gentil, que agia nas organizações das quais participava usando sempre a persuasão. Ele o caracteriza ainda como alguém que não criticava as outras estratégias revolucionárias, estando aberto ao diálogo. Essa visão contrasta com a informação de que foi expulso do Partido Comunista Brasileiro (PCB), o que demonstra uma clara tomada de posição de Marker ao lado da luta armada no Brasil e crítica ao Partido. Vale lembrar que o realizador nunca se filiou ao Partido Comunista Francês (PCF), apesar de, como será analisado nesta tese, se aproximar de sua 
estratégia política em alguns momentos. Pode-se dizer que o cineasta flertou com distintos modelos das esquerdas nos anos 1960 e 1970, mas manteve sempre uma abertura ao diálogo entre eles e propenso à ideia da internacionalização das ações revolucionárias.

Esse apoio de Marker à luta armada, predominante na produção sobre Cuba e sobre o Brasil, parece, em um primeiro momento, contraditório frente aquele dado à Unidade Popular chilena nos anos 1970. Muitas vezes o realizador tentou apaziguar as diferenças entre as vias insurrecional e pacífica, enfoque presente, por exemplo, em On vous parle du Chili: ce que disait Allende e La spirale. No entanto, essa aparente contradição entre os dois períodos de sua filmografia pode ser contornada pela identificação de um esforço, na obra markeriana, de evitar os sectarismos. Essa hipótese será melhor delimitada sobretudo nos capítulos dedicados a L'ambassade e O fundo do ar é vermelho, filmes que criticam abertamente as divergências internas da esquerda.

Cabe aqui, portanto, identificar que a ideia de que todos os caminhos poderiam ser válidos aparece em On vous parle du Brésil: Carlos Marighela. $\mathrm{Na}$ passagem citada acima, Marker demonstra insatisfação diante da expulsão de Marighella pelo PCB, atribuindo à falta de flexibilidade ao Partido, e não ao líder da luta armada, à intolerância ao debate. O realizador voltará a ser crítico com os partidos em $O$ fundo do ar é vermelho. Nessas aproximações preliminares à sua obra, deve-se enfatizar uma certa abertura, verificada em seus filmes, aos diversos caminhos. Assim, por exemplo, em uma ditadura a via insurrecional poderia ser a única possível (como defende o discurso desse documentário sobre o Brasil), enquanto que outros contextos revolucionários poderiam facilitar a adoção da via democrática.

Como porta-voz de contrainformação, o brasileiro entrevistado em On vous parle du Brésil: Carlos Marighela segue elaborando uma imagem positiva de Marighella, dizendo que ele defendia o internacionalismo revolucionário ao acreditar que a Revolução Brasileira, o combate à burguesia e a expulsão do imperialismo norte-americano pelas organizações armadas do país colaborariam para que a luta revolucionária se espalhasse. A ligação do líder da ALN com outros movimentos internacionais é valorizada no filme, principalmente quando a voz over atribui à sua participação na OLAS, realizada em Cuba em agosto de 1967, sua aderência à guerrilha urbana. A montagem insere uma fotografia do evento em que se vê, ao 
fundo do palco, uma enorme imagem de Che Guevara, que seria morto três meses após a conferência. Inúmeras referências buscam colocar Marighella próximo ao revolucionário latino-americano, em uma clara tentativa de lhe atribuir um legado pós-morte semelhante ao que Guevara teria para as gerações que lhe sucederam.

Cabe ressaltar que a referência à OLAS (que visava a criar "ondas" revolucionárias de dimensão continental) e a evocação da figura de Che são alguns dos aspectos presentes em On vous parle du Brésil: Carlos Marighela que indicam o alinhamento dessa produção de Marker com a reafirmação internacionalista da Revolução Cubana, que previa sobretudo o espraiamento da luta armada no continente latino-americano. No entanto, o documentário é montado em um momento em que essa opção vinha sofrendo importantes derrotas. Em O apoio de Cuba à luta armada no Brasil, Denise Rollemberg (2001) indica alguns episódios que, a partir do final da década de 1960, minaram esse projeto e aproximaram Cuba da União Soviética:

Ao longo dos anos 1964, 1965 e 1966, as derrotas das tentativas de implantação de focos guerrilheiros foram inúmeras, levando à morte diversos guerrilheiros. Em 1968, diante de uma grave crise econômica, o isolamento internacional de Cuba e da derrota das guerrilhas na América Latina, sobretudo na Venezuela, na Colômbia, na Guatemala e na Bolívia, Fidel buscou a reaproximação com a URSS, simbolizada no apoio à invasão à Tchecoslováquia. Nos primeiros meses de 1969, as negociações comerciais entre os dois países já apontavam para a distensão da crise. O compromisso de pôr fim à exportação da revolução acabou se concretizando em 4 de agosto de 1970: Cuba não atacaria os países vizinhos e os EUA não invadiriam a Ilha. A partir de 1972, Cuba integrou-se formalmente no Bloco Socialista, incluindo-se no Conselho para a Ajuda Econômica Mútua, o COMECOM. (ROLLEMBERG, 2001, p. 17)

Paradoxalmente, a autora indica que a maior parte dos brasileiros que foram a Cuba realizar treinamentos para atuar na luta armada esteve nesse país após 1968. Rollemberg identifica três momentos de apoio da Revolução Cubana aos movimentos revolucionários brasileiros: pré-1964, especificamente em torno das Ligas Camponesas; logo após o golpe militar, quando o Estado cubano apoiou o grupo resistente de Leonel Brizola, cuja base eram ex-sargentos expulsos da marinha; e finalmente a partir de 1967, quando endossou as tentativas de implementação de grupos guerrilheiros no Brasil. Nesse terceiro período, a proximidade com 
Marighela ${ }^{105}$ passou a ser cada vez mais intensa, especialmente após sua presença na OLAS, e a ALN se destacou como a organização que enviou o maior número de integrantes para se aperfeiçoarem junto ao governo de Fidel Castro. Destacam-se também o contato cubano com militantes do MR-8 e da VPR.
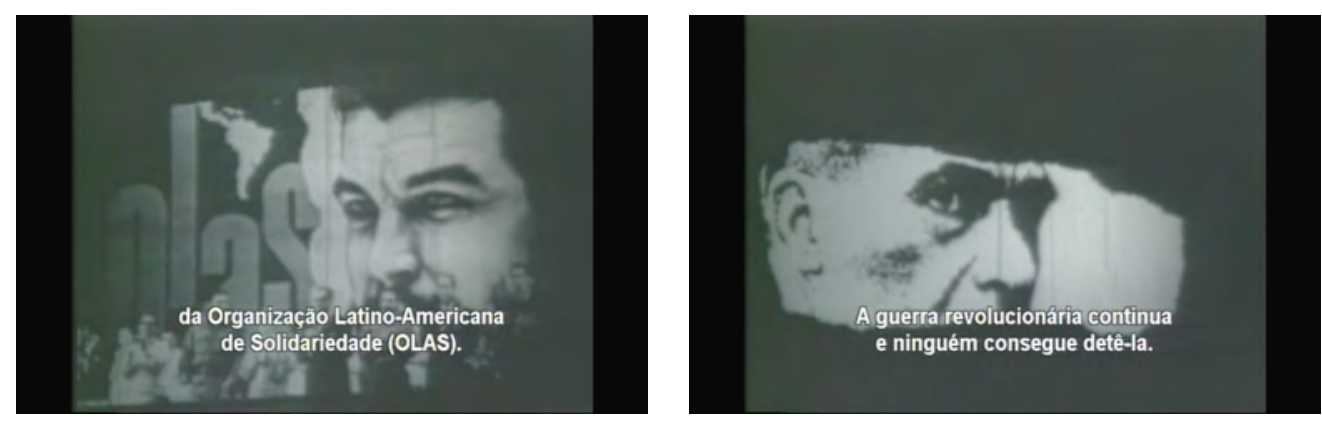

Fotogramas de On vous parle du Brésil: Carlos Marighela.

Diante dessas considerações, pode-se dizer que o envio de material audiovisual do ICAIC para Marker após a morte de Marighella, bem como os depoimentos sobre a tortura mandados um ano antes, condizia com a política de apoio do Estado cubano à luta armada no Brasil. Nesse sentido, a montagem de On vous parle du Brésil: Carlos Marighela corroborava as expectativas cubanas e a dos revolucionários brasileiros de compor um discurso militante, defendendo a guerrilha no país sul-americano e exaltando o líder da ALN. Assim, o realizador francês desempenhou, por meio dos dois curtas analisados neste subcapítulo, um papel de mediador entre essas expectativas de espraiamento das ações armadas na América Latina e as esquerdas europeias, seguindo uma concepção internacionalista do processo revolucionário que se repetirá em sua filmografia sobre a Unidade Popular.

On vous parle du Brésil: Carlos Marighela é uma espécie de atualização de On vous parle du Brésil: tortures. Se um ano antes Marker havia montado um filmedenúncia para informar sobre a repressão no Brasil, o documentário de 1970 foca nos movimentos de resistência (inicialmente retratada como "pacífica", mas levada à adoção das armas com o endurecimento da ditadura militar, de acordo com o discurso da produção markeriana), caracterizando-se como um incentivo à luta armada. A imagem de Fidel Castro recebendo os prisioneiros trocados pelo embaixador norte-

\footnotetext{
${ }^{105}$ Apesar do intenso contato entre o governo cubano e Carlos Marighella, Denise Rollemberg destaca que a subordinação do guerrilheiro brasileiro aos comandos de Cuba foi mais um mito criado pela repressão do que uma realidade. Ela afirma que Marighella defendia a autonomia da ALN, mesmo considerando o treinamento cubano um passo importante para a luta armada no Brasil.
} 
americano é reprisada nessa produção posterior, já que foi a ALN de Marighella e o MR-8 que possibilitaram que esses torturados seguissem ao exílio. Ao relembrar essa ação bem-sucedida da guerrilha urbana brasileira, o realizador busca comprovar sua eficácia como tática revolucionária.

Assim como Cuba si, On vous parle du Brésil: Carlos Marighela considerava a luta armada como um caminho viável para a América Latina, buscando desfazer imagens negativas de seus respectivos líderes - Fidel Castro e Marighella difundidas na imprensa europeia. A comparação entre outros filmes de Marker sobre o continente latino-americano permite encontrar relações entre muitos deles. La spirale (1976), por exemplo, denuncia as ações da direita chilena para derrubar Salvador Allende, da mesma forma que On vous parle du Brésil: tortures se constitui como uma denúncia sobre a repressão aos resistentes brasileiros. Esse documentário, que denunciou o golpe no Chile, e será analisado no capítulo 3 desta tese, traz um desafio metodológico presente tanto em La bataille des dix millions como em On vous parle du Brésil: Carlos Marighela: construir um discurso militante de esquerda em momentos em que esse campo político sofreu graves derrotas.

Diante dessas possíveis ligações entre as produções markerianas que focam na América Latina, que serão retomadas ao longo deste trabalho, é possível verificar algumas questões que se repetem na obra de Chris Marker, como o engajamento em diferentes causas revolucionárias; a utilização do cinema como contrainformação face ao domínio dos meios de comunicação hegemônicos pelos setores politicamente conservadores; a internacionalização da causa revolucionária, que ultrapassa as fronteiras nacionais; a elaboração de um discurso autocrítico que permita avançar à revolução após a compreensão de suas próprias fragilidades.

Assim, ao trazer Cuba, Brasil e Chile para a cena política europeia, Marker procura ampliar as discussões internas da esquerda francesa, mobilizando-as para outras causas e utilizando essas causas exógenas para repensar as estratégias internas. Sem dúvida, embora esse processo seja mais evidente no caso chileno devido à sua proximidade com o modelo adotado pelos partidos de esquerda franceses, como será analisado ao longo desta tese, isso ocorre também com os outros dois países. A Revolução Cubana, por exemplo, servirá para repensar o modelo de democracia europeu, ao ser caracterizada como uma prática de democracia direta, com amplo apoio popular. Já os filmes sobre o contexto brasileiro cumprem um papel de mobilizar apoio internacional à resistência nesse país latino-americano, inserindo-se 
no movimento de solidariedade internacional a um povo que resiste à repressão (esse aspecto se repetirá igualmente nas produções dedicadas ao Chile). ${ }^{106}$

${ }^{106}$ Além das produções sobre a América Latina feitas sob a realização ou com a cooperação de Chris Marker analisadas nesta tese, o realizador escreveu comentários para o projeto Soy Mexico (1965), publicado em seu livro Commentaires II (1967). A ideia era fazer um filme episódico - aos moldes de Soy Cuba (1964), de Mikhail Kalatozov -, abordando a cultura e a Revolução mexicanas e sua relação com o estrangeiro. 


\section{3. $\grave{A}$ Valparaiso $(1963)^{107}$ : o Chile de Joris Ivens comentado por Chris Marker}

A obra de Chris Marker se aproxima em muitos aspectos da realizada por outro europeu que também se interessou em filmar a América Latina: Joris Ivens. De uma geração anterior aquela do cineasta francês, o holandês se tornou referência para um cinema que se propunha militante e internacionalista, sem abrir mão do lirismo. Assim como faria Marker, Ivens se interessou por diferentes processos revolucionários pelo mundo, registrando da Guerra Civil espanhola (em Terre d'Espagne, 1937) à Revolução Cubana (nos documentários já citados Carnet de viaje e Cuba, Pueblo armado, de 1961). Os dois têm em comum um interesse pelos países orientais, já que dedicaram inúmeras produções à China, ao Japão, ao Vietnã, entre outras nações ${ }^{108}$. Aproximam-se por um tom poético na relação entre texto e imagem, como nos documentários La Seine a rencontré Paris (que Ivens finalizou em 1957) e Le joli mai (feito por Marker em 1963), ambos sinfonias urbanas de Paris.

Além dessas similitudes estilísticas e temáticas, fruto da tentativa de união de lirismo e revolução, esses realizadores trabalharam juntos em dois projetos. Um deles foi a elaboração de Loin du Vietnam (1967) - responsável pela criação da SLON -, coprodução de Marker e Ivens que reuniu ainda Claude Lelouch, Alain Resnais, Agnès Varda, Jean-Luc Godard e William Klein com o objetivo de mobilizar um amplo apoio à resistência vietnamita na guerra contra os Estados Unidos. O documentário retomava, porém, uma colaboração entre esses dois nomes do cinema militante já ocorrida em 1962, ano em que foi produzido À Valparaiso. Esse primeiro projeto significou para o holandês o início de uma longa parceria com o Chile, que o levou quatro vezes ao país. Já Marker, que participou escrevendo o comentário durante a finalização em Paris, estabeleceu um contato inicial com essa nação latinoamericana que ganharia grande visibilidade em seus projetos dos anos 1970.

\footnotetext{
${ }^{107}$ Para a análise de À Valparaiso foi utilizada uma cópia do filme encontrada na Cineteca Virtual de Chile. Disponível em: <http://www.cinetecavirtual.cl/fichapelicula.php?cod=2>. Acesso em: 25 fev. 2013. A versão foi confrontada com o comentário integral e a decupagem publicados na revista Cinéma l'Avant Scène (1967).

${ }^{108}$ No caso de Marker, destacam-se os seguintes títulos dedicados à reflexão aos países orientais: Dimanche à Pékin (1958), Le Mystère Koumiko (1965), Sans soleil (1982), A.K. (1985) e Level 5 (1996). Já Ivens realizou: The Four Hundred Million (1939), Indonesia Calling (1946), Viêt Nam (1965), Le Peuple et ses fusils (1968), Rencontre avec le président Hô Chi Minh (1969), Chine (1973), Comment Yukong déplaça les montagnes (1976) e Une histoire de ballon, lycée $n^{\circ} 31$ Pékin (1977).
} 
A pesquisadora Tziana Panizza Montanari (2011), no livro Joris Ivens en Chile, atribui a um contato direto entre o realizador holandês e o então senador Salvador Allende o convite para conhecer e colaborar com o Centro de Cine Experimental de la Universidad de Chile (Centro de Cinema Experimental da Universidade do Chile). Ela afirma que esse contato teria sido estabelecido em Cuba, no ano de 1961, e o político havia se oferecido para ser o intermediário dessa relação diplomática. Porém, esse fato é de difícil comprovação, pois os registros documentais encontrados indicam a presença de Ivens no ICAIC em novembro de 1960, enquanto que o futuro presidente chileno esteve na ilha alguns dias após a Revolução Cubana, em janeiro de $1959^{109}$ - o que não descarta, mesmo que indiretamente, uma possível comunicação entre os dois. De qualquer modo, a autora anexa em seu trabalho um telegrama enviado pela universidade chilena em 31 de outubro de 1961 ratificando oficialmente o desejo pela ida do cineasta ao país.

Surgido da institucionalização de um cineclube estudantil fundado anos antes por Pedro Chaskel, ocorrida em 1959, o Centro de Cine Experimental teve como primeiro diretor Sergio Bravo, que ficaria no cargo até a conclusão de À Valparaiso (sendo substituído posteriormente por Chaskel). Ao longo dos anos 1960, esse centro cinematográfico foi responsável por grande parte da produção chilena, em que se destacava o caráter documental, apesar de importantes ficções (como El chacal de Nahueltoro, 1969, de Miguel Littin). Essas produções tinham em comum a preferência por temáticas sociais, que valorizavam grupos minoritários, como mineiros, mapuches, camponeses, operários etc. Esse assunto será retomado ao longo desta tese, já que muitas das características encontradas nesses filmes pioneiros seguiriam em destaque no cinema da Unidade Popular, bem como no produzido posteriormente no exílio. Porém, vale destacar a relevância do Centro para a consolidação de uma produção nacional vinculada à necessidade de uma transformação da sociedade, marca corroborada após a experiência ao lado de Joris Ivens.

Na década de 1960, Ivens esteve quatro vezes no Chile, sendo a última delas em outubro de 1969 como convidado do Encuentro de Cineastas Latinoamericanos no Festival de Cine de Viña del Mar. Além do filme que traz o comentário de Marker, o holandês montou mais duas produções. O curta El pequeño circo (1963) consistia

\footnotetext{
${ }^{109}$ Ele voltou a Cuba ainda para o encontro da OLAS, em 1967, e já empossado presidente da república, em 1972.
} 
de tomadas feitas para À Valparaiso (algumas de suas cenas estão no documentário sobre a cidade portuária) reeditadas e acompanhadas por um texto do poeta Jacques Prévert. Já El tren de la victoria foi realizado em 1964, quando Ivens voltou ao país com recursos da televisão francesa para registrar a campanha presidencial de Salvador Allende, que utilizou um trem para percorrer o território chileno. Nessa ocasião, o projeto foi abortado pelos financiadores, o que não impediu o diretor de concluí-lo com apoio da Frente de Acción Popular (FRAP), a coalizão de esquerda responsável pela candidatura derrotada. De acordo com Panizza, nenhum desses títulos chegou a ser exibido na América Latina na época, e atualmente podem ser encontrados nos acervos do Filmmuseum de Amsterdã.

O projeto para a elaboração de À Valparaiso se concentrou nas duas primeiras viagens de Ivens ao Chile. Em abril de 1962, em sua primeira visita, participou de seminários e debates sobre seus próprios filmes, a maioria exibida pela primeira vez no país. Esteve em contato principalmente com os jovens cineastas ligados ao Centro de Cine Experimental, como Sergio Bravo, Pedro Chaskel, Joaquín Olalla, Miguel Littin, Héctor Ríos, Fernando Bellet, Patricio Guzmán Campos (que não é o mesmo que realizaria A batalha do Chile, mas sim um fotógrafo), entre outros. Muitos desses jovens trabalharam na produção do documentário sobre a cidade portuária. Além desses contatos, Ivens ministrou uma conferência no Salão de Honra da Universidade do Chile, e expôs a Pablo Neruda sua vontade de usar o processo de produção de uma película como escola para a nova geração. A ideia de registrar Valparaíso teria nascido também do contato com o poeta chileno, durante uma visita à sua casa $L a$ Sebastiana. Dessa forma, o holandês retornou à Europa por cinco meses com o objetivo de buscar recursos para essa empreitada.

A segunda viagem de Ivens ao Chile ocorreu em setembro de 1962. Junto ao Centro de Cine Experimental, atuaria na produção de À Valparaiso a Argos Films, então dirigida por Anatole Dauman - e que estaria presente em muitas produções de Chris Marker (como La spirale). Esteve a cargo da produtora francesa o envio de película virgem e os gastos com o próprio diretor e com Georges Strouvé (diretor de fotografia e único estrangeiro, ao lado de Ivens, na etapa chilena $)^{110}$. Nessa ocasião, o

\footnotetext{
${ }^{110} \mathrm{Na}$ equipe chilena de À Valparaiso se destacam: Sergio Bravo (assistente de direção); Luis Conejo (gerente de produção); Rebeca Yañez (fotógrafa e tradutora para o francês); Joaquín Olalla e Carlos Böker (assistentes de direção); Patricio Guzmán Campos (câmera); e Leonardo Martínez (assistente de câmera). Pedro Chaskel declara não ter participado por conta de uma hepatite que o abateu nesse período.
} 
holandês seguiu ministrando conferências e reuniu os jovens realizadores para analisar os filmes deles, imprimindo seu olhar diretamente sobre as montagens em andamento. A rodagem do documentário foi feita entre outubro e novembro de 1962. Já a edição, realizada em Paris entre abril e maio de 1963, contou com a participação de nomes de peso do cinema francês: Jean Ravel (montador), Jean Rouch, Edgar Morin e Chris Marker. Gustavo Becerra-Schmidt, músico chileno, ficou responsável pela trilha sonora, que se baseava na canção francesa Hardi les gars vire au guindeau (Nous irons à Valparaiso), a inspiradora do projeto cinematográfico. Ele e Bravo, de acordo com Panizza, foram à França para a finalização.

A circulação do filme foi muito maior na Europa do que no Chile, como era de se esperar tendo em vista que o cinema chileno encontrava-se ainda em um momento incipiente. Em junho de 1963, estreou na École Normale Supérieure, em Paris. María Luisa Ortega e Antonio Weinrichter, no artigo "Itinerarios y bifurcaciones", registram uma exibição no cinema La Pagode, em 1964, na mesma sessão que La jetée (1962), ficção de Chris Marker montada com base em imagens fotográficas fixas (ORTEGA; WEINRICHTER, 2008, p. 26). À Valparaiso esteve presente em festivais internacionais, sendo premiado em Bérgamo (Itália) e Oberhausen (Alemanha). No Chile, a autora narra o lançamento do documentário em setembro de 1964, ocasião em que Ivens estava no país para filmar El tren de la victoria. Ela informa ainda que as cópias que ficaram na cinemateca da Universidade do Chile desapareceram no período da ditadura, colaborando com que a produção seguisse pouco conhecida no país em que foi realizada.

\subsection{As imagens de Joris Ivens e o texto de Chris Marker}

Um breve plano de À Valparaiso, de cerca de dez segundos, mostra Pablo Neruda - não identificado como tal - descendo uma escada em formato de caracol em sua casa La Sebastiana, acompanhado de dois cachorros. Sua obsessão colecionista de mapas da região contribuiu como material de arquivo presente na montagem. Eva Fiszer, esposa de Joris Ivens, aparece por alguns segundos vestida de branco e com uma sombrinha, como uma legítima aristocrata chilena exibindo seus trajes na última moda europeia. Ao lado dos figurantes famosos, estão outros atores locais, recrutados 
pelo diretor na Agrupación Teatral Valparaíso (ATEVA), bem como prostitutas do porto representando a si próprias como personagens dessa cidade. Ao melhor estilo Nanook, o esquimó (1922), de Robert Flaherty, o realizador holandês encena a realidade, recorre aos acasos bem-ensaiados para dar veracidade às notas tomadas para sua representação documental de Valparaíso.

O filme é montado como um apanhado de impressões, amarradas por um texto lírico escrito por Chris Marker especialmente para ele. Em entrevista à autora, concedida por e-mail em 2011, o cineasta francês declarou - com a humildade recorrente de não lhe autoatribuir uma autoria alheia - que “"meu comentário foi largamente apoiado nas notas de Joris” (MARKER, 2011, tradução nossa). ${ }^{111}$ De fato, a perfeita combinação entre texto e imagem, a capacidade de narrar a cidade tal como vista por Ivens, impressionam, tendo em vista que Marker o escreveu à distância (sobre uma Valparaíso imaginada, tal como lhe foi descrita por seu companheiro viajante). De acordo com os pesquisadores de sua obra, o francês teria o redigido em apenas dois dias, respondendo a um anseio do amigo:

O comentário para À Valparaiso foi escrito por Chris Marker, baseado nas anotações de Ivens e aparentemente no espaço de dois dias, depois de Marker ter encontrado Ivens extremamente desencorajado porque ele se programara para mixar o filme, mas não tinha ainda um texto adequado. Quando Ivens expressou sua admiração pela velocidade com que o comentário foi entregue, Marker laconicamente comentou que ele tinha apenas ficado sem dormir e tinha bebido um pouco de rum cubano. (LUPTON, 2008, p. 197, tradução nossa) $)^{112}$

A referência ao "rum cubano", embora anedótica, remete a uma inspiração que pode ter vindo da experiência de Cuba si, já que assim como o filme realizado um ano antes, À Valparaiso é uma espécie de ode a um povo que resiste às intempéries ${ }^{113}$. Marker encontrou nas imagens de Ivens a poesia cotidiana na luta diária pela sobrevivência, mas também um potencial violento para a libertação. O imperialismo e a miséria (fruto de uma exacerbada desigualdade social na cidade chilena) são

\footnotetext{
${ }^{111}$ Traduzido do original: "Mon commentaire s'était largement appuyé sur les notes de Joris."

112 Traduzido do original: "The commentary for $\grave{A}$ Valparaiso was written by Chris Marker, based on Ivens's notes and apparently in the space of two days, after Marker had found Ivens extremely discouraged because he was scheduled to mix the film but did not yet have a suitable text. When Ivens expressed his amazement at the speed with witch the commentary had been delivered, Marker laconically remarked that he had just gone without sleep and drunk a little Cuban rum."

${ }^{113}$ Apesar de À Valparaiso ter sido lançado em 1963, vale lembrar que foi produzido ao longo de 1962.
} 
elementos explosivos que, ao longo do documentário, se desdobram em um potencial para a transformação.

Apesar de não ter participado da montagem, Marker imprimiu uma de suas principais características ao filme, que é questionar e complementar as imagens por meio do texto. Seu comentário é proferido pela voz over - interpretada pelo ator Roger Pigaut -, que guia o espectador pela paisagem urbana. A cidade é uma metáfora para a sociedade: assim como as classes sociais, ela se desdobra em camadas. No entanto, se trata de uma "metáfora às avessas", já que a disposição das moradias em Valparaíso concentra os ricos próximos ao porto, abaixo, e os pobres em uma espiral ascendente cujo traçado relaciona a miséria aos níveis mais altos das colinas. Ivens valoriza as tomadas feitas nos muitos ascensores que ligam a parte baixa à parte alta, bem como o esforço em subir contraposto à facilidade em descer as escadas. Esses elementos ligam os dois mundos, e são também os espaços de encontro entre a elite e o povo. Acompanhando um plano em que a câmera se movimenta como se estivesse dentro de um desses elevadores, mas provavelmente gravado em um voo panorâmico devido a sua amplitude, Marker escreve para essa cena que mostra uma infinidade cada vez maior de telhados: "Sobre as colinas, existe uma outra cidade. Não uma cidade: uma federação de vilas, uma por colina. 42 colinas, 42 vilas. Não uma outra cidade: um outro mundo. Dois mundos que se comunicam pelas rampas, pelas escadas, pelos elevadores." (À Valparaiso, 1962, tradução nossa) ${ }^{114}$
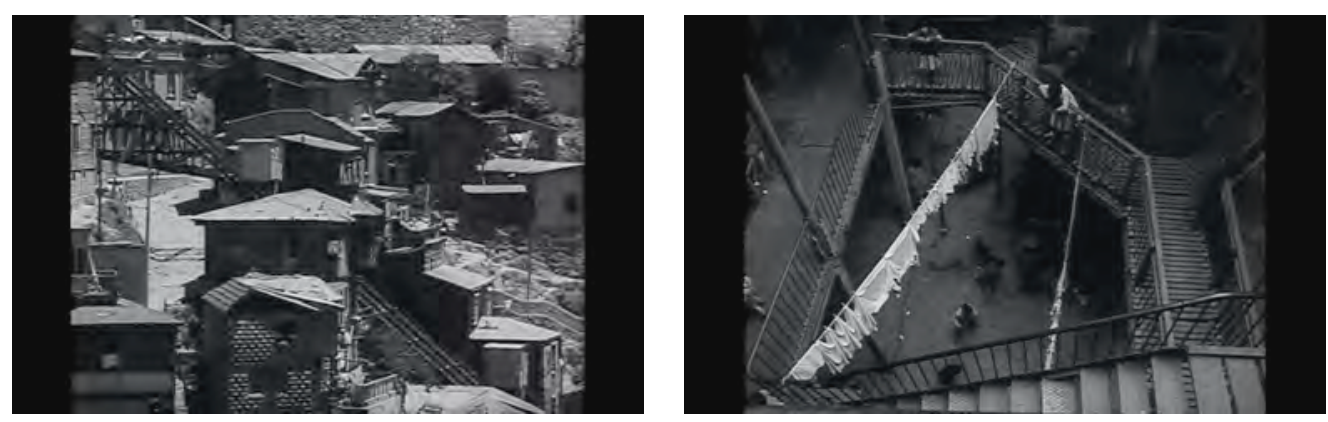

Fotogramas de À Valparaiso.

Em sua sinfonia-urbana de Valparaíso, Ivens ressalta os elementos naturais. A fotografia joga com a intensa luz do sol, contrapondo planos fechados mais escuros com a claridade de tomadas panorâmicas. O vento se torna visível, nas diversas

\footnotetext{
${ }^{114}$ Texto da voz over de À Valparaiso, traduzido do original: "Sur les collines, une autre ville existe. Pas une ville: une fédération de villages, une par colline. 42 collines, 42 villages. Pas une autre ville: un autre monde. Deux mondes qui communiquent par les rampes, par les escaliers, par les ascenseurs.".
} 
sequências em que meninos soltam pipas - nelas também o céu está em destaque. Em cima das colinas, as roupas secam, os cabelos das jovens se tornam esvoaçantes. No mar, transitam navios, mas também pássaros e um leão-marinho. No comentário de Marker, todos esses elementos se relacionam diretamente com a vida dos habitantes locais. E se são eles os responsáveis pela beleza dessa cidade, são também obstáculos na luta pela sobrevivência cotidiana. Com a ventania, o fogo se espalha de uma casa para a outra, são constantes os incêndios no alto das colinas. O vento sopra forte com a altitude: "É bom para secar a roupa lavada, é pior para os pulmões das crianças" (À Valparaiso, 1962, tradução nossa) ${ }^{115}$, problematiza a voz over. A intensa iluminação natural torna a miséria menos evidente, de acordo com o comentário do realizador francês: "Com o sol, a miséria não parece mais ser a miséria, os elevadores não parecem mais ser os elevadores. Essa é a mentira de Valparaíso. Sua mentira é o sol. Sua verdade é o mar" (À Valparaiso, 1962, tradução nossa $)^{116}$.

Um senhor sem uma perna sobe uma escada, enquanto a voz over complementa seu esforço: “121 degraus, ele sabe, ele os conta. É necessário ter o coração forte e também uma boa memória" (À Valparaiso, 1962, tradução nossa) ${ }^{117}$. A altitude imprime uma dificuldade a mais na sobrevivência em Valparaíso. Ela dificulta, por exemplo, a chegada de água, e também de comida. Ivens gravou planos impressionantes dentro de um cortiço no alto das colinas. Neles, novamente estão as escadas. Nessa cidade, elas parecem não acabar. Para essa sequência, Marker escreveu: "Quanto mais subimos sobre as colinas, mais as pessoas são pobres. No topo, os pobres dos pobres. Na cintura de cada colina, grandes casas em ferro negro e ferrugem, os castelos dos pobres. Como viver?" (À Valparaiso, 1962, tradução nossa) ${ }^{118}$

Valparaíso ("le valle du Paradis", como traduz o comentário de Marker) é uma espécie de cidade às avessas. Sua topografia concentra os pobres no cume da pirâmide, deixando a base para os mais abastados. Essa particularidade do cenário

\footnotetext{
${ }^{115}$ Texto da voz over de À Valparaiso, traduzido do original: "C'est bon pour sécher le linge, c'est moins bon pour les poumons des enfants".

${ }^{116}$ Texto da voz over de À Valparaiso, traduzido do original: "Avec le soleil, la misère n'a plus l'air d'être la misère, les ascenseurs n'ont plus l'air d'être des ascenseurs. Tel est le mensonge de Valparaiso. Son mensonge, c'est le soleil. Sa vérité, c'est le mer".

${ }^{117}$ Texto da voz over de À Valparaiso, traduzido do original: "121 marches, il le sait, il les compte. Il faut avoir le cœur solide et aussi une bonne mémoire".

${ }^{118}$ Texto da voz over de $\grave{A}$ Valparaiso, traduzido do original: "Plus on monte sur les collines, plus les gents sont pauvres. Au sommet, les pauvre des pauvres. À la ceinture de chaque colline, de grandes maison en fer noir et rouillé, les châteaux des pauvres. Comment vivre?".
} 
urbano é enfatizada no filme, tanto por tomadas inusitadas quanto pela narrativa da voz over. Panizza (2011) destaca que, em 1964, quando o documentário foi exibido no Chile, uma das cenas que mais desagradou foi um plano curto, em que uma mulher da aristocracia descia as escadas levando um pinguim preso a uma coleira, como um animal de estimação. A autora narra que o caráter "documental" da obra foi colocado em dúvida, diante de uma imagem tão improvável. No entanto, em seu comentário, foi justamente esse aspecto inusitado, idílico, que Chris Marker quis ressaltar. Se $\grave{A}$ Valparaiso está no limite entre o real e o encenado, entre fato e imaginação, o realizador francês dá ao extraordinário uma esfera cotidiana, como fica claro no trecho escrito para esse polêmico plano: "Nessa cidade, todos os dias, ao meio-dia, o sol realiza seus milagres. Todas as mulheres de Valparaíso, portadoras de sombrinhas, levam para passear todos os pinguins de Valparaíso.” (À Valparaiso, 1962, tradução nossa) ${ }^{119}$.
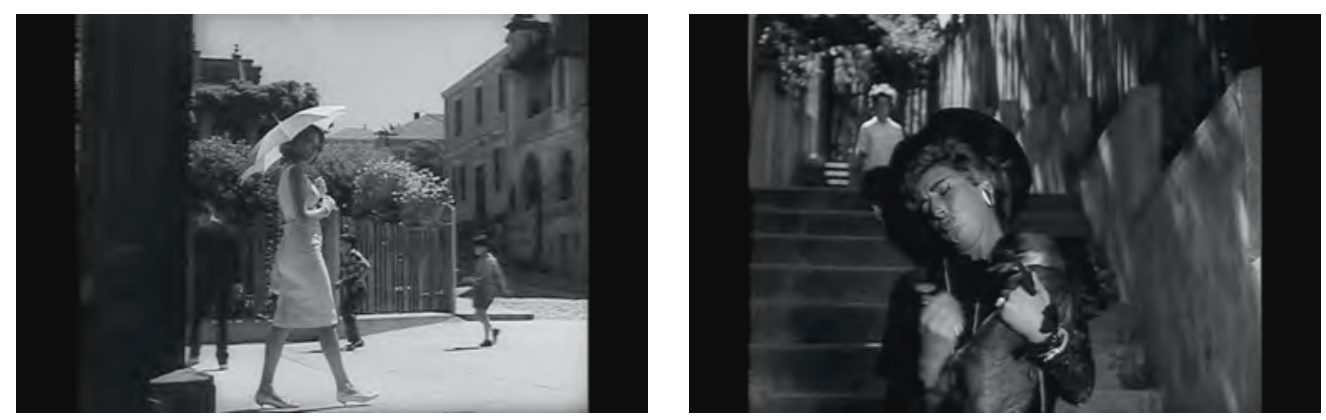

Fotogramas de À Valparaíso: à esquerda, Eva Fiszer como figurante;

à direita, a polêmica cena do pinguim.

Se essa polêmica cena pode ter sido encenada, a única sequência em que há falas além da voz over é um registro documental de uma assembleia de moradores, gravada no alto de uma das colinas - uma espécie de "conselho de cidadãos", como define Marker. A falta de acesso à água para quem vive no alto, na miséria, leva o povo a discutir soluções. Apesar de breve, a inserção dessa passagem aponta para uma ruptura da ordem cotidiana. Se o plano do passeio nas escadas parecia normalizar o inaceitável (um pinguim com uma madame saindo para tomar sol), essa sequência mostra que há um movimento de transformação vindo do alto, das esferas mais pobres da cidade. A parte final do filme aponta para a revolta, e visa a responder uma questão

\footnotetext{
${ }^{119}$ Texto da voz over de À Valparaiso, traduzido do original: "Dans cette ville, tous les jours à midi, le soleil accomplit ses prodiges. Toutes les femmes de Valparaiso porteuses d'ombrelles sortent pour promener tous les pingouins de Valparaiso."
} 
do comentário colocada anteriormente, quando a voz over constata que a comida e a bebida não subiam o morro sozinhas: "A que preço a vontade de viver? A que preço a felicidade?" (À Valparaiso, 1962, tradução nossa) ${ }^{120}$.

À Valparaiso é filmado em preto e branco, com uma fotografia que explora as luzes e as sombras dessa cidade. Porém, seus cinco minutos finais são gravados em cores, constituindo uma quebra com as sequências anteriores. Se a água, o vento e o fogo (que queima os casebres) foram abordados na primeira parte do filme, o comentário de Marker anuncia que o quarto elemento de Valparaíso, tema da última parte, é o sangue. A passagem para as cenas coloridas ocorrem em um bordel, em meio aos marujos estrangeiros que se divertem entre as prostitutas e as cartas de baralho. De repente, uma briga, uma ruptura da ordem que introduz o vermelho na tela. Trata-se de uma alegoria propícia para abordar uma das temáticas que perpassa o filme desde o início, mas que finalmente ganha centralidade: o imperialismo.

As cenas feitas no bordel, em À Valparaiso, certamente são encenadas, porém, contam com a presença de prostitutas reais. Elas lembram algumas sequências que compõem Soy Cuba, de Mikhail Kalatozov, concluído pouco depois da produção de Ivens, em 1964. O fato é que a metáfora da América Latina como um "bordel”, um lugar de diversão e exploração dos estrangeiros dos países desenvolvidos, havia ganhado força após a Revolução Cubana, que justamente buscou romper com essa dinâmica. Nas tomadas feitas pelo holandês da parte baixa da cidade, Marker identifica símbolos dessa dominação econômica e cultural ao que o Chile também estava submetido: o Banco de Londres, um Arco do Triunfo, referências europeias nos monumentos e nos produtos consumidos. O comentário lembra, ironicamente, que as contribuições da França ao Novo Mundo seriam os corsários e a "última das sociedades secretas": a Aliança Francesa.

Apesar de serem temas que perpassam o documentário, é na parte colorida que colonização e imperialismo são abordados de maneira direta. Mapas do Novo Mundo emprestados por Neruda expõem serpentes marítimas, monstros e piratas, obstáculos na época das navegações para a desejada conquista do Eldorado (ou do paraíso, para citar a origem do nome da cidade). A colonização espanhola é lembrada por Marker em seu comentário diante das imagens dessas cartografias e gravuras, que remetem aos tempos da conquista:

\footnotetext{
${ }^{120}$ Texto da voz over de À Valparaiso, traduzido do original: "A quel prix la volonté de vivre? A quel prix le bonheur?"
} 
Memórias de corsários: Hawkins, Drake, Joris van Spielberg ${ }^{121}$. Torturas e pilhagens. Memórias dos espanhóis. Torturas e pilhagens, e opressão colonial por séculos. Memórias dos incêndios. Os elementos engrandecem os homens. Depois do fogo, o mar. Memórias das tempestades. Os barcos de Júlio Verne jogam na costa os náufragos de Gavarni ${ }^{122}$. E a volta continua. A Inglaterra apoia a Independência do Chile. Isabel II da Espanha bombardeou a cidade. Último esforço do colonizador frustrado, inundações, incêndios, ciclones e pilhagens, foi o que coube a esse povo pacífico. E não havia terminado. (À Valparaiso, 1962, tradução nossa) $)^{123}$

Junto a essa última frase, o filme mostra uma gravura do Tio Sam abrindo o canal do Panamá no mapa da América com um prego, fechando assim um ciclo de invasores entre Espanha, piratas, Inglaterra e Estados Unidos.
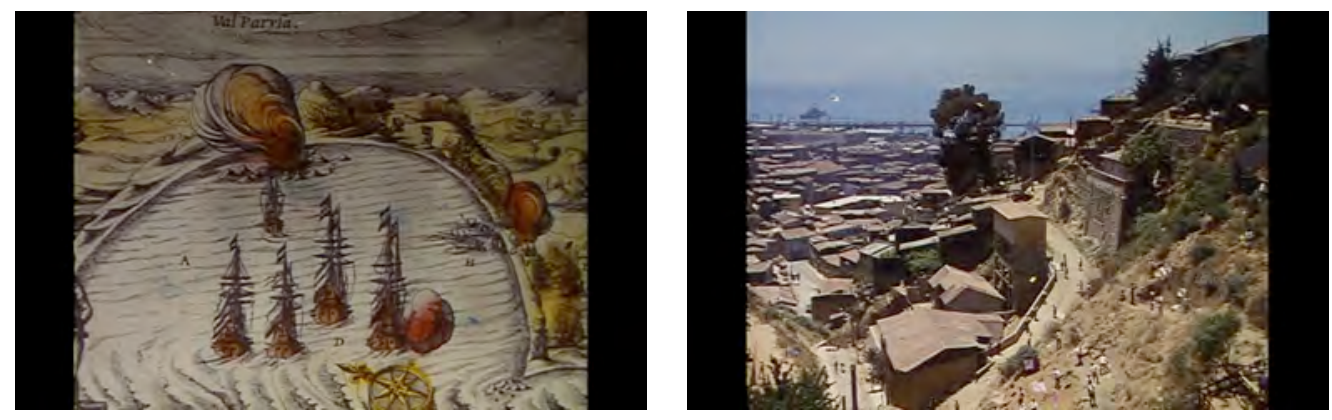

Fotogramas de À Valparaiso.

Após descrever as "aventuras" pelas quais Valparaíso passou, Marker identifica em seu comentário os desafios que a população enfrenta no presente: conquistar uma casa habitável, jardins cultiváveis e justiça - além de um duelo de pipas no céu da cidade portenha. O texto produzido para o filme de Ivens traz à tona o problema do Terceiro Mundo, as mazelas do subdesenvolvimento fruto de séculos de exploração. Nesse sentido, a evocação da violência, como um elemento transformador - que traz cor ao documentário, a começar pelo vermelho-sangue - pode ser relacionada às ideias de Frantz Fanon, que dois anos antes do lançamento de $\grave{A}$

\footnotetext{
${ }^{121}$ Piratas ingleses e holandês que estiveram na região de Valparaíso (comuna de El Quisco) entre os séculos XVI e XVII.

${ }^{122}$ Referência ao ilustrador e aquarelista francês Paul Gavarni, autor de uma gravura usada na montagem dessa sequência final.

${ }^{123}$ Texto da voz over de À Valparaiso, traduzido do original: "Mémoire des corsaires: Hawkins, Drake, Joris de Spielberg. Tortures et pillages. Mémoires des espagnols. Tortures et pillages, et oppression coloniale pour des siècles. Mémoires des incendies. Les éléments relèvent les hommes. Après le feu, la mer. Mémoire des tempêtes. Des bateaux de Jules Verne jettent au rivage des naufragés de Gavarni. Et la ronde continue. L'Angleterre soutient l'Independence du Chili. Isabelle II d'Espagne fait bombarder la ville. Dernier sursaut du colonisateur frustré de terre, déluges, incendies, cyclones et pillages, tel devait être de ce peuple pacifique. Et ce n'était pas fini."
} 
Valparaiso publicara Les damnés de terre. O cineasta francês imprime em seu comentário os ares das guerras de libertação evocados pelo autor caribenho que tanto influenciou a esquerda francesa na época.

Durante os anos 1960 e 1970, Fanon se tornou também uma referência importante para o Nuevo Cine Latinoamericano, sendo citado textualmente em filmes como La hora de los hornos (1968), realizado por Fernando Pino Solanas e Octavio Getino, integrantes do Grupo Cine Liberación. Nesse sentido, pode-se dizer que seus livros alimentaram o discurso da dependência como fruto dos processos coloniais e neocoloniais, bem como de uma ampla defesa por parte de setores da esquerda adeptos do uso das armas e da violência como instrumentos de libertação. No entanto, é necessário estudar a circulação de ideias entre a Europa (ou mais especificamente a França, onde Fanon produziu seus escritos) e a América Latina como trocas de mão dupla. Esse mesmo olhar deve ser empregado ao elaborar afirmações sobre os resultados dessa aproximação de Ivens e Marker com o continente latino-americano. A presença de teorias de Fanon no cinema dos dois lados do Atlântico permite concluir que, assim como as pessoas, os discursos se deslocam.

\subsection{Filme-escola: uma ponte entre dois continentes}

À Valparaiso é, antes de mais nada, um filme-escola. Sua rodagem foi um estágio para os jovens realizadores chilenos que teve desdobramentos na forma e nas temáticas que caracterizaram o cinema desse país nos anos 1960 e, posteriormente, durante o governo da Unidade Popular. Sua montagem fez com que essa experiência ecoasse no meio cinematográfico de esquerda francês, incorporando a esse processo de produção coletiva nomes como o de Chris Marker. De forma parecida, Ivens e Marker haviam atuado dois anos antes em Cuba, quando ministraram seminários e produziram documentários em conjunto com realizadores cubanos.

O convite do Centro de Cine Experimental de la Universidad de Chile para a ida de Joris Ivens foi consequência justamente de sua experiência anterior com jovens cineastas em Cuba (na ocasião em que fez Carnet de viaje e Cuba, Pueblo armado), mas também de uma viagem à China. No Central Newsreel and Documentary Film Studio, em Pequim, o cineasta holandês produziu com o auxílio de aprendizes Before 
spring (1958), na ocasião em que foi professor nessa instituição. Essa concepção do cinema militante como um espaço de aprendizado técnico e político foi seguida por Marker, que poucos meses após Ivens, ainda em 1960, esteve no ICAIC rodando com companheiros cubanos o documentário Cuba si.

Vale ressaltar que essa ida dos cineastas europeus militantes a outros países, dentro de uma concepção de filme-escola, não deve ser encarada como uma mera aparelhagem das instituições estrangeiras pelos realizadores mais experientes. $\mathrm{O}$ processo de rodagem e de edição dessas produções deve ser analisado como espaço de circulação de ideias, tanto das técnicas cinematográficas como dos projetos políticos que esses documentários se propunham a discutir. O mesmo ocorre em relação à divulgação dessas produções, que embora tenham tido pouca circulação, de maneira geral, foram exibidas em ambientes e grupos nos quais os preceitos marxistas ecoavam. Ivens e Marker, que se destacam pelo caráter internacionalista de suas obras, estiveram em muitas nações e testemunharam importantes momentos da história das esquerdas ${ }^{124}$. Nesse sentido, desempenharam o papel de mediadores entre a Europa e o além-mar.

No caso específico da América Latina, ambos foram referências constantes para o que passou a ser chamado de Nuevo Cine Latinoamericano, rótulo que identifica, entre outras características comuns, a predominância de um discurso latinoamericanista sobre a condição de subdesenvolvimento do continente, bem como as estratégias para a superação dessa condição. Se em termos técnicos eles contribuíram para o fortalecimento de instituições incipientes - como o ICAIC e o Centro de Cine Experimental -, pode-se dizer que se serviram dos debates políticos e das transformações em curso nos países latino-americanos para elaborar um discurso reflexivo sobre os próprios caminhos das esquerdas europeias.

Em relação a Chris Marker, a experiência no ICAIC o aproximou desse cinema que se propunha inovador na América Latina. Também o levou a repensar o próprio conceito de democracia na França diante de um modelo cubano representado em seus filmes como o de uma democracia direta, em que o líder era um representante legítimo da vontade popular. Já o primeiro contato com o Chile, via Joris Ivens, foi igualmente uma oportunidade de testemunhar nas imagens do holandês outras formas

\footnotetext{
${ }^{124}$ É necessário lembrar que, além de À Valparaiso, Ivens fez ainda o filme El tren de la victoria, em 1964, quando registrou a campanha eleitoral de Salvador Allende à presidência do Chile, em 1964, pela FRAP, ocasião em que o democrata-cristão Eduardo Frei se consagrou vencedor.
} 
de se organizar politicamente, de tirar da precariedade material as ideias para uma real transformação da sociedade. Dessa forma, os temas abordados nessas produções dos anos 1960 serão retomados na década posterior. No entanto, o contexto chileno passou a atrair ainda mais seu interesse, tendo em vista que esse país consagrou vitorioso pela via eleitoral um presidente socialista: Salvador Allende. E foi a vontade de conhecer de perto esse fato que o levou, em 1972, a viajar para as terras que havia imaginado quando escreveu o comentário de À Valparaiso. 


\section{Capítulo 2 - Chris Marker e o cinema chileno: versões francesas para produções sobre a Unidade Popular}

\section{Chris Marker no Chile: testemunha de um novo processo político e cinematográfico}

As visitas de Joris Ivens ao Chile no início dos anos 1960, acompanhadas a distância por Chris Marker, produziram um testemunho das tentativas dos partidos comunista e socialista chilenos de chegar ao poder por meio da vitória eleitoral: o documentário El tren de la victoria (1964). Apesar das distintas linhas políticas seguidas pelos dois partidos - o Partido Comunista (PC) valorizava a via pacífica baseada em alianças, enquanto o Partido Socialista (PS) pautava seu caminho ao socialismo nas lições armadas da Revolução Cubana -, o filme de Ivens registrou a união de ambos na campanha de Salvador Allende à presidência em 1964 em torno da FRAP, repetindo uma parceria que havia sido derrotada em 1958. Embora frustrada com a vitória de Eduardo Frei, da Democracia Cristiana (Democracia Cristã, DC), a estratégia de uma frente ampla cresceu no Chile ao longo da década, consolidando, em 1970, o relançamento de Allende como candidato dos dois principais partidos de esquerda - PC e PS -, mas também do Partido Radical (PR), do Partido Social Democracia (PSD), da Acción Popular Independiente (API) e do Movimiento de Acción Popular Unitaria (MAPU) ${ }^{125}$.

A formação dessa nova frente ampla, intitulada de Unidade Popular, era acompanhada por setores da esquerda europeia, sobretudo intelectuais, artistas, jornalistas e cineastas. Além do filme de Ivens, outras produções audiovisuais na França trataram do contexto político chileno, como as reportagens televisivas produzidas pela $\mathrm{ORTF}^{126}$, que foram incorporadas em produções posteriores de Marker na condição de material de arquivo, como ocorreu em La spirale (1976) e $O$ fundo do ar é vermelho (1977). Televisões de outros países, como Suécia, Dinamarca e Alemanha Oriental, também se interessaram por registrar e divulgar os acontecimentos políticos do Chile.

\footnotetext{
${ }^{125}$ Em 1973, entrariam ainda na aliança da UP a Izquierda Cristiana e o MAPU obrero y campesino.

${ }^{126}$ Essas reportagens televisivas produzidas pela ORTF serão analisadas no capítulo 3 , que aborda o documentário La spirale.
} 
Esse interesse, que já existia nos anos 1960, tornou-se ainda maior com a vitória de Salvador Allende e os conflitos que antecederam sua posse. Com 36,63\% dos votos (contra 35,29\% para a DC e $28,09 \%$ para o Partido Nacional, PN), obtidos em 4 de setembro de 1970, o candidato filiado ao PS precisou ser ratificado como vencedor pelo Congresso Nacional em um novo pleito ocorrido em 24 de outubro desse mesmo ano. No entanto, dois dias antes, esse episódio foi tumultuado pelo atentado contra o general legalista René Schneider, atingido em uma frustrada tentativa de sequestro comandada pelo grupo de extrema direita Patria y Libertad e pelo general Roberto Viaux - apoiados por armas fornecidas por Henry Kissinger e a Central Intelligence Agency (a Agência Central de Inteligência norte-americana, CIA $)^{127}$. A ideia dos opositores era acusar a extrema-esquerda e, assim, desestabilizar o país e forçar uma rejeição ao novo presidente por parte dos parlamentares. Porém, com a farsa revelada e a opção da Democracia Cristã em apoiar o resultado das urnas, Allende foi confirmado na presidência chilena. Um dia depois, Schneider morreu em decorrência dos ferimentos. Esse período de tensão anterior à posse, ocorrida em 4 de novembro, foi um dos mais abordados pela televisão francesa e por alguns dos documentários que serão analisados nesta tese.

Esse breve histórico sobre a situação no Chile, que vivia uma inédita vitória eleitoral da esquerda seguida de um clima de conflito, justifica o papel de destaque que o país alcançou no cenário político internacional no início dos anos 1970. Se Cuba havia sido um modelo de chegada e de consolidação do socialismo no início da década de 1960, em âmbito internacional, o processo chileno tornava-se uma nova referência e atraía holofotes ao valorizar a democracia como via de acesso ao poder. Alberto Aggio (2002) analisa de que forma essa nação passou a ser sinônimo de uma nova estratégia, um novo caminho que podia ser seguido pelas esquerdas em outras partes do mundo:

Nascia aí a chamada experiência chilena, expressão cunhada na época por intelectuais e políticos de esquerda, não apenas no Chile, com o claro sentido de indicar a opção e o desafio que se abria diante da esquerda daquele país, cujo presidente eleito e empossado

\footnotetext{
${ }^{127}$ O general René Schneider era visto como um empecilho a uma possível tentativa de golpe de Estado com o apoio dos Estados Unidos. Seu sequestro fez parte do chamado Projeto Fubelt, levado a cabo pela CIA. Dessa forma, o assassinato de Schneider abriria caminho para que um opositor do novo governo assumisse o posto, o que não ocorreu devido à descoberta da farsa. O documentarista cubano Santiago Álvarez tratou do episódio no filme De América soy hijo... y a ella me debo... (1972). Para saber mais sobre o episódio, ver KORNBLUH, 2003.
} 
anunciava a intenção de realizar a "transição ao socialismo em democracia". (AGGIO, 2002, p. 16)

Se, nos tempos do governo reformista de Eduardo Frei, essa nação latinoamericana já havia sido visitada por Joris Ivens, dez anos depois, Chris Marker (que participou à distância de À Valparaiso, escrevendo o comentário) foi ao país com a intenção de filmar o processo único de transição social iniciado pela eleição de Allende. Membro da comitiva de Costa-Gavras, que esteve em 1972 no Chile para rodar Estado de sítio (1973), Marker logo abandonou seu projeto autoral para apoiar a incipiente consolidação do cinema chileno, que caminhava atrelada a um desejável apoio - por parte dos cineastas - ao governo da Unidade Popular.

Sua estada chilena, em 1972, resultou em importantes contatos e, mais concretamente, na elaboração de uma versão francesa para o filme El primer año (1972), de Patricio Guzmán, que será analisada neste capítulo. Os laços de amizade e os intercâmbios estabelecidos por Chris Marker em sua viagem seriam mantidos após o golpe de Estado em 1973, servindo para mobilizar esforços em prol do massivo exílio chileno na Europa, como demonstra sua colaboração para a rodagem e a montagem de A batalha do Chile - A insurreição da burguesia (1975), também de Guzmán. O realizador francês atuou ainda articulando e realizando documentários no qual denunciou ações da direita e dos Estados Unidos para a derrubada de Allende, assim como retomou as ideias do presidente morto em 11 de setembro de 1973 nos círculos do cinema militante francês, especialmente com o filme On vous parle $d u$ Chili: ce que disait Allende. Em entrevista enviada à autora por e-mail em 27 de outubro de 2011, Marker resume sua ida ao Chile, embora com algumas imprecisões ${ }^{128}$ :

Eu vim a Santiago em 73 com a equipe de Costa-Gavras, que rodava Desaparecido. Evidentemente, aproveitei para explorar ao máximo os aspectos acessíveis da UP. Ganhei uma amiga para toda a vida: Carmen Castillo. Reencontrei Mattelart, cujas análises

\footnotetext{
${ }^{128}$ Nesse trecho do depoimento, Marker forneceu duas informações incorretas. Sua ida ao Chile se deu em 1972, ano de lançamento de El primer año (mais precisamente em maio, de acordo com Patricio Guzmán), embora ele indique no e-mail o ano de 1973. Além disso, Costa-Gavras rodava em Santiago o filme Estado de sítio, e não Desaparecido (apesar da confusão se justificar porque o enredo dessa outra produção, de 1982, se passe em torno do golpe de Estado chileno de 1973), como declarou o realizador francês. Embora todo historiador deva ser cauteloso diante dos depoimentos, já que refletem uma memória porosa e mutante, no caso do testemunho de Marker esse cuidado precisa ser ainda maior. Ele forneceu constantemente - e de modo proposital - "pistas falsas" sobre sua vida e obra, colaborando para o caráter misterioso que criou em torno de si mesmo. É possível que alguns desses atalhos "enganosos" estejam presentes na entrevista fornecida à autora. Vale, portanto, apontá-los.
} 
heterodoxas me seduziram, e Patricio Guzmán, que acabara de terminar El primer año. Após outros encontros com outros cineastas, concordamos que esse era o melhor filme para informar o público francês, e no meu retorno eu realizei a vf [versão francesa]. (MARKER, 2011, tradução nossa) ${ }^{129}$

O contato de Marker com o ambiente político e cultural chileno não se deu apenas por sua presença na comitiva de Costa-Gavras, mas também por intermédio de outras figuras importantes do métier intelectual parisiense que estavam no país. Foi o caso de Armand Mattelart, com quem realizaria o documentário La spirale, após o golpe de Estado. Outro mediador, o jornalista Régis Debray, foi um dos que tiveram maior destaque nos contatos entre Chile e França no início dos anos 1970, assim como já havia ocorrido em relação a Cuba na década anterior. Antes de ir à América Latina, em 1972, Marker teve contato com o livro Entretiens avec Allende sur la situation au Chili, de Debray, publicado um ano antes pela editora de François Maspero $^{130}$. O embate entre o jornalista francês e Allende, documentado também em Compañero presidente (Miguel Littin, 1970) e em On vous parle du Chili: ce que disait Allende (Littin e Marker, 1973) certamente foi uma referência para as reflexões markerianas sobre os acontecimentos dessa época.

No prefácio que antecede a entrevista transcrita com Allende, Régis Debray narra sua passagem pelo Chile. A polêmica internacional em torno de sua prisão na Bolívia, quando acompanhava Che Guevara na guerrilha em que foi morto, transformou o jornalista em um nome conhecido das esquerdas. A grande mobilização que o episódio gerou, pedindo sua soltura, despertou o interesse do novo presidente chileno por sua figura, dando-lhe a oportunidade de acompanhar de perto mais uma vitória do socialismo na América Latina. De acordo com o relato de Debray, sua ida ao Chile se deu "por acaso", quando o avião que o deportava após a libertação dos quatro anos de cárcere pousou em Iquique, em dezembro de 1970. Sabendo de sua estada no país, Allende teria pedido a seu Ministro do Interior, José Tohá, que

\footnotetext{
${ }^{129}$ Traduzido do original: "Je suis venu à Santiago en 73 avec l'équipe de Costa-Gavras, qui tournait Missing. J'en ai évidemment profité pour explorer au maximum les aspects accessibles de l'UP. J'y ai gagné une amie pour la vie : Carmen Castillo. J'ai rencontré Mattelart, dont les analyses hétérodoxes m'ont séduit, et Patricio Guzmán qui venait de terminer El primer año. Après d'autres rencontres avec d'autres cinéastes, nous sommes tombés d'accord que ce film était le mieux à même d'informer le public français, et à mon retour j'ai entrepris d'en faire la vf [version française]."

${ }^{130}$ Vale lembrar que Marker dedicou a esse editor o filme On vous parle de Paris: Maspero, les mots ont un sens (1970).
} 
conduzisse o francês a Santiago. Recebido por Eduardo Paredes ${ }^{131}$, também responsável por outros exilados políticos, foi pessoalmente convidado para passar o Natal e o ano novo com o chefe de Estado, iniciando diálogos que o permitiram intimidade para propor a conversa posteriormente registrada por Miguel Littin, em janeiro de 1971.

Em seu prefácio, Debray indica alguns laços estabelecidos no Chile: Beatriz Allende (a "Tati"), Augusto Olivares e Claudio Jimeno. Provavelmente, o jornalista francês foi o intermediário da amizade que surgiu entre Marker e Carmen Castillo, tendo em vista que a ex-mulher de Miguel Enríquez (secretário do Movimiento de Izquierda Revolucionaria - MIR), e também cineasta, foi uma das encarregadas de receber Debray, assim como fazia com guerrilheiros vindos de outros países, na categoria de funcionária do Palácio de La Moneda ${ }^{132}$. Em suas idas e vindas entre Santiago e Paris, é certo que ele se constituiu como um importante mediador entre os intelectuais e artistas dos dois países. Em suas memórias pessoais, Castillo (2002) descreve detalhes de sua relação com o escritor:

Régis alugou minha pequena casa de tijolos de La Quinta, aquela onde eu havia morado com Andrés [Pascal] até o começo do ano de 1971. Ele viveu então entre Paris e Santiago e, em cada uma de suas estadas chilenas, nós nos encontrávamos para longos passeios na rua Simon Bolívar, pacífica e fresca sob os plátanos. Ele queria conhecer tudo, cada detalhe, a política do MIR o inquietava. [...] Sua missiva era preciosa, e sua amizade nos reconfortou (CASTILLO, 2002, p. 152-3, tradução nossa) ${ }^{133}$

Dos contatos citados por Marker na entrevista de 27 de outubro de 2011, certamente o estabelecido com Patricio Guzmán foi um dos mais significativos para o cinema chileno. Conforme declarou o realizador francês, ao se deparar com o filme $E l$ primer año em sua visita ao Chile, recém-finalizado em 1972, ele julgou ser mais importante divulgá-lo na Europa do que realizar um documentário autoral sobre o

\footnotetext{
${ }^{131}$ Eduardo Paredes foi diretor da Chile Films, substituindo Leonardo Navarro em março de 1973. Paredes, que era médico, militante do Partido Socialista e havia sido diretor da Polícia de Investigação, assumiu esse posto na condição de homem de confiança de Salvador Allende. Em 11 de setembro de 1973, foi preso e, dias depois, assassinado pela ditadura miltar chilena.

${ }^{132}$ Embora não tenha sido possível confirmar a informação, é provável que Debray e Marker tenham estado juntos em Santiago em 1972, já que o primeiro realizou inúmeras viagens entre Chile e França nessa época, chegando a alugar uma casa na capital chilena.

${ }^{133}$ Traduzido do original: "Régis loua ma petite Maison en briques de La Quinta, celle où j'avais habité avec Andrés [Pascal] jusqu'au début de l'année 1971. Il vécut ensuite entre Paris et Santiago et, lors de chacun de ses séjours chiliens, nous nous retrouvions pour de longues promenades dans la rue Simon Bolivar, paisible et fraîche sous les platanes. Il voulait tout connaître, chaque détail, la politique du MIR l'inquiétait. [...] Sa missive était précieuse et son amitié nous réconforta."
} 
governo da Unidade Popular. Essa decisão condiz com o espírito militante e coletivo que perpassava sua produção no início dos anos 1970, diante do qual o cinema era antes de mais nada um veículo para criar e circular novas ideias em prol de uma transformação social. Assim, ele considerou o documentário de Guzmán um retrato bem elaborado dos conflitos e mudanças decorrentes do governo de Allende, caracterizando-se como uma fonte de informação para os círculos europeus.

Patricio Guzmán descreve seu encontro com Marker em Santiago, em maio de 1972 (GUZMÁN, 2012). Segundo seu relato, o francês bateu na porta de sua casa, surpreendentemente, apresentando-se e pedindo autorização para levar seu filme à Europa. O cineasta chileno - que ressalta a emoção de conhecer o autor de La jetée $e^{134}$ (1962), filme que admirava - reconhece também a importância que essa abertura para o cenário internacional representou em sua trajetória, bem como o papel de destaque que Marker exerceria posteriormente com o envio de película virgem e o auxílio à montagem do que veio a ser A batalha do Chile.

Percebe-se nas ações de Marker após sua ida ao Chile uma preocupação em incentivar a produção de chilenos, em um período em que o país vivia um processo político que era referência mundial, mas que ainda carecia de estrutura técnica para consolidar uma cinematografia de relevância. De forma semelhante à relação que havia estabelecido em Cuba com Alfredo Guevara, o realizador francês manteve contato com Guzmán após a volta a Paris, desempenhando um papel de articulador entre os cenários cinematográficos francês e chileno.

Marker contribuiu para divulgar o cinema do Chile e buscou responder a suas demandas. Esse intercâmbio intenso ocorreu sobretudo por meio de cartas trocadas com Guzmán (sendo que algumas delas serão referenciadas nesta tese) e da elaboração de versões francesas para filmes realizados no país latino-americano. Cabe, porém, antes de analisar de que maneira essa troca se refletiu em discursos fílmicos elaborados e reelaborados, compreender o momento vivido pelo cinema na época da chegada de Allende à presidência, assim como o contexto em que esses documentários chilenos foram feitos. Vale destacar que parte dessas produções militantes rodadas na nação latino-americana ganharam novos significados após o golpe de Estado de 1973, se transformando, por exemplo, em material de arquivo para o documentário La spirale.

\footnotetext{
${ }^{134}$ O segundo filme realizado por Patricio Guzmán, ElectroShow (1966), foi montado com fotos fixas, método que pode ter sido utilizado a partir da observação da montagem de La jetée.
} 


\section{1. "Cineastas instrumentos do povo": documentário durante a Unidade Popular}

Desde os anos 1960, havia no Chile uma tendência à "politização" das produções cinematográficas, presente tanto nos documentários como nas ficções. Embora ainda muito incipiente, o cinema nacional nesse período se apoiava principalmente no Centro de Cine Experimental de la Universidad de Chile. Articulado à formação universitária, embora de caráter autônomo, o Centro valorizava experimentações estéticas documentais, em formato curta-metragem, que abordassem principalmente temáticas da história e da tradição do país. Entre os filmes iniciais que contaram com sua colaboração, destaca-se À Valparaiso, abordado no primeiro capítulo desta tese.

A predominância da temática social, que incorporava a escassez de recursos técnicos como elemento que agregava valor ao cinema de luta, acompanhava o movimento do Nuevo Cine Latinoamericano, que deu o tom do Primer Festival de Cine Nuevo Latinoamericano (1967), realizado em Viña del Mar. Na edição seguinte $^{135}$, em 1969, o foco das atenções estava em La hora de los hornos (1968), de Fernando Pino Solanas e Octavio Getino. O Chile apresentou, entre outras produções, a obra considerada um marco do Nuevo Cine Chileno ${ }^{136}$ : El chacal de Nahueltoro (1969), de Miguel Littin. Realizado no Centro de Cine Experimental, com colaboração de Pedro Chaskel, questionava os conceitos de justiça (social e jurídica) em torno do assassinato de uma família pobre por um homem igualmente sem perspectivas.

Mais do que uma vitrine para as produções do Chile, os festivais de Viña del Mar tornaram-se importantes espaços de troca e circulação para os realizadores chilenos, colocando-os em contato com ideias e projetos empreendidos por outras cinematografias, especialmente de países como Cuba, Argentina e Brasil. Nesse período, por exemplo, foram estabelecidos vínculos com o ICAIC, que se fortaleceriam durante o governo da Unidade Popular, tomando a forma de parcerias e coproduções. De acordo com Ignacio Del Valle Dávila (2012b), é provável também que, na edição de 1969, Miguel Littin tenha entrado em contato com as discussões -

\footnotetext{
${ }^{135}$ Vale destacar que o Festival de 1969 foi o último realizado antes do golpe de Estado de 1973. As atividades permaneceram suspensas durante a ditadura, sendo retomadas apenas em 1990.

${ }^{136}$ De acordo com a pesquisadora Jacqueline Mouesca, em Plano secuencia de la memoria de Chile: veinticinco años de cine chileno (1960-1985), o termo foi cunhado posteriormente por um jornalista.
} 
senão com o texto em si - em torno do manifesto Hacia un tercer cine (redigido em 1969 por Pino Solanas, Getino e o Grupo Cine Liberación), que, ao lado de Eztetyka da fome (1965), de Glauber Rocha, e Por un cine imperfecto (1969), de Julio García Espinosa, foi um dos elementos mais influentes do Nuevo Cine Latinoamericano.

Dessa forma, pode-se dizer que esses festivais serviram para estreitar vínculos com cineastas estrangeiros - latino-americanos e europeus -, sendo espaços de circulação de realizadores, produções fílmicas e reflexões em torno delas. Eles resultaram ainda em subprodutos, como artigos e críticas cinematográficas sobre os filmes exibidos, que foram divulgados na América Latina e na Europa. A presença física de figuras importantes para a cinematografia francesa garantiu sua repercussão entre os cineastas e críticos franceses. Foi o caso de Joris Ivens, que voltou ao Chile pela quarta vez para participar da edição de 1969, em Viña del Mar. É necessário destacar ainda, nessa mesma edição, a participação do crítico francês Louis Marcorelles, então colaborador assíduo dos Cahiers du Cinéma.

Na década seguinte, o acirramento das disputas eleitorais chilenas de 1970 e a possibilidade real de uma vitória da Unidade Popular geraram entusiasmo entre os cineastas. Esse clima de euforia e de expectativa por uma verdadeira mudança social estava presente, por exemplo, no documentário Venceremos (1970), de Pedro Chaskel e Héctor Ríos, produzido pelo Centro de Cine Experimental ${ }^{137}$. Os contatos ocorridos nos anos anteriores, sobretudo em torno desse Centro, foram intensificados com a criação de um comitê de produtores ligado à campanha de Salvador Allende, tal como ocorreu com artistas e intelectuais de outras áreas ${ }^{138}$. Essa iniciativa produziu o Manifesto de los cineastas de la Unidad Popular (1970), uma espécie de guia programático para o trabalho cinematográfico nos novos tempos que se anunciavam. Constituído por um prólogo e treze declarações, o Manifesto constatava que era necessário compartilhar a luta do povo: "CINEASTAS CHILENOS: é o momento de empreender junto ao nosso povo a grande tarefa de libertação nacional e de

\footnotetext{
${ }^{137}$ Esse filme será retomado no capítulo 3, pois suas imagens foram utilizadas em La spirale.

${ }^{138}$ Dois documentários chilenos realizados no início dos anos 1970 registraram o trabalho de artistas plásticos que usaram o muralismo como propaganda política: Brigada Ramona Parra (1970), de Álvaro Ramírez, e Pintando con el pueblo (1971), de Leonardo Céspedes (ambos produzidos com apoio do Centro de Cine Experimental). São registros documentais da ação dos jovens ligados à UP que pintavam coletivamente cenas do povo em luta.
} 
construção do socialismo" (MANIFESTO, 1970, Apud MOUESCA, 1988, p. 70, tradução nossa) ${ }^{139}$.

Postulando-se como texto coletivo, o Manifesto não traz assinatura e termina com a frase de efeito: "Cineastas chilenos, venceremos". No entanto, de acordo com Del Valle Dávila (2012b), Miguel Littin, posteriormente, reivindicou a autoria em diversas entrevistas, corroborando com a instauração de uma polêmica em torno de sua filiação e da aderência por parte dos realizadores aos preceitos defendidos nesse texto. O pesquisador destaca que:

O texto foi aprovado pelo Departamento de Cinema Experimental da Universidade do Chile e pela Escuela de Artes de la Comunicación de la Universidad Católica, ou seja, pelas duas principais instituições do país dedicadas à realização, e pela maioria dos cineastas chilenos. No entanto, curiosamente, uma grande parte dos realizadores não tardaria a tomar uma certa distância em relação aos seus postulados. (DEL VALLE DÁVILA, 2012b, p. 437, tradução nossa) ${ }^{140}$

Apesar da provável autoria de Littin em detrimento de uma redação coletiva, o aval das principais instituições do cinema chileno ao Manifesto (1970) tornou-o um porta-voz dos debates cinematográficos da época. Mesmo sem determinar preceitos estéticos, defendia que o cinema deveria contribuir para que o "instinto de classe" do povo se transformasse em "sentido de classe". Um caminho possível para esse objetivo - que era também uma etapa para se chegar ao socialismo - seria retratar as grandes lutas populares sufocadas pela "história oficial". Tomando conhecimento delas pelo cinema, a população se identificaria como sua herdeira no presente e projetaria perspectivas para o futuro. Assim, esse Manifesto cita "heróis" apropriados pela esquerda, como Luis Emilio Recabarren, Manuel Rodrigues ou ainda trabalhadores anônimos caídos por lutar pela emancipação política, econômica e cultural do Chile. Havia no documento um clima de euforia, proveniente da sensação de que uma nova etapa histórica se iniciava. Por meio dele e dos filmes feitos no período, os cineastas se proclamavam protagonistas na implementação da nova era, ao lado de operários, mineiros e camponeses.

\footnotetext{
${ }^{139}$ Traduzido do original: "CINEASTAS CHILENOS: es el momento de emprender juntos con nuestro pueblo, la gran tarea de la liberación nacional y de la construcción del socialismo".

${ }^{140}$ Traduzido do original: "Le texte a été approuvé par le Département de Cinéma Expérimental de l'Université du Chili et l'École des Arts de la Communication de l'Université Catholique, c'est-à-dire par les deux principales institutions du pays dédiées à la réalisation, et par la majorité des cinéastes chiliens. Cependant, curieusement, une grande partie des réalisateurs ne tarderont pas à prendre une certaine distance par rapport à ses postulats."
} 
O cinema seria, portanto, um mecanismo de incentivo e de comunicação das transformações sociais. Enquanto as lutas populares teriam o papel de motivar a produção cinematográfica, os cineastas deveriam instrumentalizá-las. Dessa maneira, noções clássicas do cinema militante estão presentes no Manifesto: o filme como arma, e seu realizador como sujeito político comprometido com as modificações sociais. Sua quarta declaração evidencia essa orientação: "Entendemos por arte revolucionária aquela que nasce da relação conjunta do artista com o povo, unidos por um objetivo comum: a libertação. O povo, como motivador da ação e efetivamente o criador; o cineasta, como seu instrumento de comunicação.” (MANIFESTO, 1970, Apud MOUESCA, 1988, p. 71, tradução nossa) ${ }^{141}$. Nessa concepção, o engajamento político precederia o desempenho da profissão; portanto, como todos os outros trabalhadores, eles deveriam se colocar a serviço do socialismo.

Esses preceitos verificados no Manifesto consolidam uma predominância das questões sociais que já estava presente nos anos 1960, mas que se tornou ainda mais forte na cinematografia chilena com a chegada da Unidade Popular ao poder. São muitos os documentários que abordam os conflitos sociais ocorridos no país, como é o caso de No nos trancarán el paso (1971), de Guillermo Cahn, que trata dos embates entre camponeses e grandes proprietários pela terra, retratando um homem do campo politizado, consciente de sua exploração e se organizando para combatê-la. Outras produções enveredam por um caminho semelhante ao sugerirem uma nova perspectiva política para os grupos sociais desfavorecidos. A questão dos mapuches e de sua luta pela terra, por exemplo, foi tema dos documentários Nutuayin Mapu (ou Recuperemos nuestra tierra), de Carlos Flores, Guillermo Cahn, Samuel Carvajal, Luis Araneda e Antonio Campi; e Amuhuelai-mi (Ya no te irás), de María Luisa Mallet, ambos produzidos em 1971.

A exemplo do que faziam muitas das músicas da Nueva Canción Chilena que levaram ao sucesso Inti-Illimani, Víctor Jara, Ángel Parra, Patricio Manns, o grupo Quilapayún, entre outros - o cinema ligado à Unidade Popular abordou diversas lutas sociais, algumas recentes e outras históricas. Essas canções serviram de trilha sonora para as produções audiovisuais, como o hino Santa María de Iquique, de Luis Advis, que fez grande sucesso três semanas antes das eleições. Em 1969, já havia

\footnotetext{
${ }^{141}$ Traduzido do original: "Que entendemos por arte revolucionario aquel que nace de la relación conjunta del artista y del pueblo unidos por un objetivo común: la liberación. Uno, el pueblo, como motivador de la acción y en definitiva el creador, y el otro, el cineasta, como su instrumento de comunicación."
} 
embalado o documentário de Claudio Sapiaín, Escuela Santa María de Iquique 1907, sobre o massacre ocorrido no início do século XX que matou mais de uma centena de trabalhadores do salitre em greve que se alojavam na Escuela Domingo Santa María, do porto de Iquique ${ }^{142}$.

Escuela Santa María de Iquique 1907 foi um documentário produzido pelo Centro de Cine Experimental em parceria com a Chile Films, instituição estatal que existia desde 1942 e que ganhou importância após a vitória de Salvador Allende. A política cinematográfica da Unidade Popular optou por não criar um órgão dedicado ao cinema, mas sim aparelhar a Chile Films, transformando-a na principal produtora dos cineastas chilenos, embora na prática ela tenha enfrentado muitas dificuldades para exercer esse papel. Del Valle Dávila aponta que a elaboração do Manifesto de los cineastas de la Unidad Popular possivelmente colaborou para que Miguel Littin fosse escolhido o primeiro presidente dessa instituição no novo governo, bem como sua experiência prévia no Centro de Cine Experimental e no Canal 9 (também pertencente à Universidade do Chile). No entanto, sua gestão foi marcada por problemas e discussões. A pesquisadora Jacqueline Mouesca (1988) realiza, em Plano secuencia de la memoria de Chile, uma avaliação sobre esse período:

Grandes foram os erros e as insuficiências que mostraram os três anos de gestão de Chile-Films durante a Unidade Popular. Improvisação, voluntarismo, desperdícios, sectarismo. Como em muitas outras frentes da vida nacional, esses mil dias foram apenas um tempo de ensaios, de titubeio, de lutas para superar as querelas internas e as contradições; os erros eram virtualmente inevitáveis. Contudo, nesses três anos, há também um saldo importante de coisas positivas. $\mathrm{Na}$ Chile-Films, graças ao trabalho desenvolvido em seu primeiro período, se lançaram em boa medida as bases do cinema chileno do futuro, no qual, há de convir, que Miguel Littin tem razão: em suas oficinas, fizeram suas primeiras armas a maioria dos que depois integrariam o extenso panteão dos cineastas do exílio. (MOUESCA, 1988, p. 63-64, tradução nossa) ${ }^{143}$

\footnotetext{
${ }^{142}$ Algumas cenas desse documentário foram utilizadas na montagem de La spirale.

${ }^{143}$ Traduzido do original: "Grandes fueron errores e insuficiencias que muestran los tres años de gestión de Chile-Films durante la Unidad Popular. Improvisación, voluntarismo, despilfarros, sectarismo. Como en muchos otros frentes de la vida nacional, esos mil días fueron apenas un tiempo de ensayos, de titubeos, de luchas por superar las querellas internas y las contradicciones; los errores eran virtualmente inevitables. Con todo, en esos tres años hay también un saldo importante de cosas positivas. En Chile-Films, gracias al trabajo desarrollado en su primer período, se echaron en buena medida las bases del cine chileno del futuro, en lo cual hay que convenir que Miguel Littin tiene razón: en sus talleres hicieron sus primeras armas la mayoría de los que después integrarían el extenso plantel de los cineastas del exilio."
} 
Em relação às produções da Chile Films, muitas seguiram um padrão relativamente semelhante às de curta duração que eram feitas já antes da posse de Salvador Allende, mas se autoatribuíram a função de conscientizar a população ante a necessidade de apoiar as mudanças implementadas no país. Nessa categoria, se destaca Descomedidos y Chascones (1972), de Carlos Flores, documentário de cunho pedagógico que visa a incentivar o engajamento político dos jovens. $\mathrm{O}$ filme critica os "descomedidos y chascones", os "rebeldes sem causa", com seus cabelos e visuais importados dos hippies norte-americanos, cobrando da juventude burguesa postura política. Para isso, usa animações e outros elementos do mundo pop e uma linguagem irônica. Um exemplo desse tom provocativo ocorre na sequência em que uma figura semelhante à de um professor se posiciona ao meio de um painel que traz à sua direita a sigla USA (ao lado de outras como CIA e PN) e à sua esquerda a sigla UP (bem como MIR, MAPU, PS, PC etc.). A mensagem mostra apenas dois posicionamentos possíveis. Mas, se por um lado escamoteia subdivisões desses dois campos políticos esquerda e direita -, por outro reflete a polarização real da sociedade chilena em 1972, quando uma batalha pelo prosseguimento ou não das reformas implementadas por Salvador Allende marcava o país.

Se o filme de Flores buscava a conscientização de setores da burguesia, outros se dirigiam diretamente aos trabalhadores, colocando-se como porta-vozes de demandas da Unidade Popular - caso de Entre ponerle y no ponerle (1971), de Héctor Ríos, e Mijita (1970), de Sergio Castilla. O documentário de Ríos aborda as consequências nefastas do alcoolismo. Sequências audiovisuais de homens caindo de bêbados e de hospitais abrigando vítimas da bebida são mostradas como exemplos dos prejuízos do consumo do álcool para a sociedade, o que é comprovado por depoimentos que endossam o mal que tal hábito ocasionava às famílias. Porém, as cenas finais são esperançosas, com união e fartura na mesa, repetindo a estratégia comum em muitas dessas produções de serem finalizadas com ares dos novos tempos. Proletários nas fábricas e nas minas são filmados produzindo, em uma tentativa de confirmar que a luta pelas transformações sociais era feita com trabalho, que enriqueceria o novo país. Mijita, de maneira semelhante, volta-se a um setor da sociedade: as mulheres. Desempenhando o papel de mães e trabalhadoras, elas depõem sobre as dificuldades da jornada dupla e da necessidade de se organizar para conseguir mudar suas condições de vida. 
Enquanto estratégia de divulgação, havia a tentativa de transmitir essas produções em centros não comerciais, como federações de estudantes, sindicatos, ocupações de terras e de moradias. Patricio Guzmán declara, em entrevista para Pedro Sempere no livro Chile, el cine contra el fascismo (1977), que seu documentário El primer año foi divulgado no formato $16 \mathrm{~mm}$ em circuitos populares, sendo camponeses e operários seu maior público. Enquanto isso, cópias em $35 \mathrm{~mm}$ eram veiculadas nos cinemas das grandes cidades. No entanto, de acordo com Jacqueline Mouesca, em El documental chileno, essa estratégia fez com que grande parte da população chilena ficasse à parte dessa produção audiovisual ligada à Unidade Popular:

\begin{abstract}
Ainda que a produção de documentários tenha vivido, em geral, um auge nos anos da Unidade Popular, sua difusão pública foi precária, porque não eram exibidos nas salas de cinema comercial e eram desconhecidos, portanto, para uma boa parte da população. Eram mostrados em locais sociais: sindicatos, escolas universitárias, assentamentos camponeses, associações de vizinhos, o que não era garantia de que a difusão podia alcançar níveis verdadeiramente de massa. (MOUESCA, 2005, p. 78, tradução nossa) ${ }^{144}$
\end{abstract}

Conforme os conflitos políticos se agravavam na sociedade chilena, as produções da Chile Films passaram a abordar as grandes discussões em torno da dificuldade em implementar o socialismo no país por meio da via democrática. Nesse sentido, o que ficou conhecido como "experiência chilena", a revolução social sem abrir mão da democracia, foi constantemente comparada no cinema a outros modelos revolucionários latino-americanos, especialmente à Revolução Cubana. Esse tipo de produção se tornou mais frequente após a visita de Fidel Castro ao Chile, em 1971, e muitas vezes serviu de porta-voz para a Unidade Popular e seu presidente. Foi o caso, por exemplo, de El diálogo de América $(1971)^{145}$, de Álvaro Covacevich, uma conversa entre os chefes de Estado chileno e cubano mediada por Augusto Olivares.

Outra produção da Chile Films que dá voz a Allende é Compañero Presidente (1971), de Miguel Littin. Como já foi ressaltado, trata-se da gravação de um diálogo realizado no ambiente familiar do presidente, que recebeu o francês Régis Debray em

\footnotetext{
${ }^{144}$ Traduzido do original: “Aunque la producción de documentales vivió, en general, un auge en los años de la Unidad Popular, su difusión pública fue precaria, porque no se exhibían en las salas de cine comerciales y eran desconocidos, por lo tanto, para una buena parte de la población. Se mostraban en locales sociales: sindicatos, escuelas universitarias, asentamientos campesinos, organismos vecinales, lo que no era garantía de que la difusión pudiera alcanzar niveles de verdad masivos."

${ }^{145}$ Esse documentário será retomado mais adiante devido à sua utilização em La spirale.
} 
suas residências em Santiago e Valparaíso entre 4 a 6 de janeiro de 1971. Ignacio Del Valle Dávila ressalta que a iniciativa do documentário surgiu de um acordo entre os dois protagonistas, de forma que Littin o realizou a pedido do chefe de Estado. Esse filme serviu de material de arquivo para On vous parle du Chili: ce que disait Allende, montado por Chris Marker logo após o golpe de Estado que pôs fim à experiência da Unidade Popular, e que será analisado neste capítulo.

O filme de Littin busca aproximar o público do líder por meio de seu registro no cenário privado. Intercaladas à entrevista, são inseridas cenas do entrevistador chegando à casa de Allende, dos dois sobrevoando a capital chilena e do contato do presidente com o povo em comícios públicos. O próprio título, ao utilizar uma acunha do governante socialista, o coloca como um "igual": a hierarquia é quebrada para que fique claro que ele, como companheiro, coordena uma grande batalha que deve ser seguida por todos.

A questão da via democrática ou da luta armada é importante nesse filme, já que o entrevistador francês é um conhecido defensor da luta armada como estratégia revolucionária. Sua posição era mundialmente difundida por Révolution dans la révolution?, que endossa o caminho adotado pela Revolução Cubana, e pelo fato de ele ter acompanhado a guerrilha de Che Guevara. Após ganhar a liberdade, vivendo no Chile, Debray teve a oportunidade de fazer perguntas capciosas para Allende sobre o caráter de seu governo ("Estamos mesmo diante de um regime socialista ou não?") e sobre sua possibilidade de sustentação ante as pressões da burguesia.

A serenidade do "compañero presidente" ao responder que sua eleição era apenas uma etapa da transformação que estava em curso, assim como em expor as mudanças já concretizadas pelo seu governo, fazem com que uma crescente admiração vá surgindo em Debray e no público ao longo do documentário. As referências na fala de Allende aos seus ídolos Che e Zhou Enlai e o retrato de Ho Chi Minh focalizado na parede da casa do presidente inserem o caso chileno no contexto internacional revolucionário. Porém, por outro lado, a presença de um defensor da luta armada em cena atribui à discussão sobre a via chilena uma importância necessária, sobretudo diante do fato de que, apesar da chegada ao poder, a Unidade Popular enfrentava graves conflitos. Até que ponto rever essa questão poderia incentivar outras estratégias de sustentação de Allende? O filme oscila entre essa pergunta e a defesa do líder. 
Diante desse panorama do que se convencionou chamar de uma cinematografia da Unidade Popular, pode-se dizer que os anos em torno da Chile Films e das políticas cinematográficas da UP são dispersos, marcados por similitudes, mas também por certa organização (ou a falta dela) espontânea. No Manifesto redigido durante a campanha, apesar da presença de doutrinas teóricas, a falta de preceitos estéticos não permite caracterizá-lo como um manual de como fazer cinema. Ao contrário: em suas declarações os autores preveem: "Que o cinema revolucionário não se impõe por decreto. Portanto, não postulamos uma forma de fazer cinema, mas tantas quantas forem necessárias no transcorrer da luta" (MANIFESTO, 1970, Apud MOUESCA, 1988, p 71, tradução nossa ${ }^{146}$. Dessa forma, Del Valle Dávila aponta que mais correto do que afirmar a existência de um cinema da UP, seria referir-se a uma filmografia realizada durante seu governo, tendo em vista que foram poucas as políticas cinematográficas realmente implementadas na vigência dessa aliança de esquerda:

Não nos parece pertinente falar de um cinema da UP porque nenhuma política cinematográfica minimamente definida emanou do governo Allende ou dos partidos que o sustentavam. Mas isso não torna menos interessante o estudo do cinema feito durante a UP - entende-se, do período que vai das eleições de 1970 ao golpe de Estado de 1973 -, porque os realizadores chilenos, mediante uma ampla diversidade de opções estéticas, tentaram desenvolver um cinema que acompanhava o processo revolucionário que vivia o país e que revolucionava, ao mesmo tempo, o campo cinematográfico e as formas autônomas dessa arte. (DEL VALLE DÁVILA, 2012b, p. 435, tradução nossa) ${ }^{147}$

Mesmo assim, existem características comuns a muitas das produções realizadas nesse período, como a predominância de uma montagem que permite a associação lógica das imagens sem a necessidade (ou com pouca presença) de uma voz over que sugestionasse a leitura. A escolha por temas de relevância social, afinados com os discursos da Unidade Popular, também foi outra marca desse cinema. Muitos desses documentários utilizam como estratégia o close-up nos rostos e marcas

\footnotetext{
${ }^{146}$ Traduzido do original: "Que el cine revolucionario no se impone por decreto. Por lo tanto, no postulamos una forma de hacer cine sino tantas como sean necesarias en el transcurrir de la lucha.".

${ }^{147}$ Traduzido do original: "Il ne nous semble pas pertinent de parler d'un cinéma de l'UP parce qu'aucune politique cinématographique un tant soit peu définie n'émanait du gouvernement d'Allende ou des partis qui le soutenaient. Il n'en reste pas moins intéressant d'étudier le cinéma produit pendant l'UP, c'est-à-dire de la période allant des élections de 1970 au coup d'État de 1973, parce que les réalisateurs chiliens, grâce à une large diversité d'options esthétiques, ont tenté de développer un cinéma qui accompagnerait le processus révolutionnaire que le pays vivait et qui, en même temps, révolutionnerait le secteur cinématographique et les formes autonomes de cet art.".
} 
corporais (mãos, rugas ou assessórios, por exemplo) que identificam as classes sociais em jogo na cena política. A busca pela clareza e pelo fácil entendimento, que permitiria a difusão em meios não intelectualizados e de formação, é outro aspecto predominante. Por fim, vale destacar a trilha sonora, especificamente a presença da Nueva Canción Chilena como uma manifestação da integração a uma política de arte popular mais ampla, visível também na pintura das brigadas muralistas ${ }^{148}$.

Em um período de conflitos sociais cada vez mais acirrados, a perspectiva de um "cinema educativo", simplista e bipolarizado, como os filmes do Centro de Cine Experimental e os curtas com apoio da Chile Films, deram lugar a produções em que a discussão política aparecia de maneira mais elaborada, e nas quais a situação chilena começou a ser abordada de outro ponto de vista. Foi o caso do filme Compañero presidente, em que as questões postas por Debray a Allende colocaram na berlinda o próprio status quo do governo da UP e a possibilidade da via democrática se sustentar no poder. As contradições e possíveis fragilidades da Unidade Popular foram avaliadas também em El diálogo de América, embora o documentário reafirme o apoio a essa frente de esquerda. Essas duas produções, a de Littin e a de Covacevich, afastaram-se, tanto esteticamente quanto em termos de debate político, da maioria dos curtas realizados nesse período devido à complexidade presente em sua análise da situação política do país.

Durante a Unidade Popular, surgiu ainda uma perspectiva que não estava explicitada no Manifesto: a ideia de um cinema-testemunho. Essa perspectiva estava presente sobretudo na filmografia de Patricio Guzmán e seduziu Chris Marker por retratar a complexa situação do Chile sob múltiplos aspectos. Além de mobilizar apoio e explicar didaticamente as transformações causadas pela UP, o engajamento político adquiriu, em seus filmes, o papel de denunciar os acirrados conflitos sociais e os boicotes comandados pela burguesia. Essas produções abrigaram ainda anseios dos trabalhadores e de setores das classes populares que manifestaram em seus depoimentos algumas contradições presentes no processo de implementação do socialismo no país. Mesmo assim, Guzmán não abriu mão de um apoio incondicional ao governo Allende nos discursos fílmicos produzidos. É necessário afirmar que, com a exceção do canal estatal, quase todos os grandes veículos de comunicação estavam nas mãos dos opositores do presidente. Nesse sentido, o cinema se colocou como um

${ }^{148}$ Sobre as brigadas muralistas durante o governo da Unidade Popular, ver DALMÁS, 2006. 
meio de contrainformação, apesar de estar em acordo com o discurso do Estado. Essas duas funções, denúncia e alternativa à imprensa oficial, seriam mantidas e intensificadas no cinema do exílio, após 1973.

Patricio Guzmán havia estado relativamente ausente da cena de crescimento do cinema de cunho popular no final dos anos 1960 por ter estudado na Espanha ${ }^{149}$. Após a posse de Allende, porém, ele voltou ao Chile, em 1971, disposto a registrar as mudanças implementadas em seu país natal. De acordo com seu relato no livro Chile: el cine contra el fascismo (1977), produzido em sua volta forçada ao território espanhol após 1973, ele declara ter tido a impressão de estar diante de um corpo documental do processo de transformação chileno ao se deparar com os documentários feitos no Centro de Cine Experimental. Resolveu, assim, elaborar um método de filmagem mais adequado a esse papel.

Com o auxílio da Escuela de Artes de la Comunicación de la Universidad Católica (Escola de Artes da Comunicação da Universidade Católica, EAC) ${ }^{150}$, Guzmán montou uma equipe ${ }^{151}$ - na qual ele era o mais velho, com apenas 30 anos para filmar o primeiro ano do governo de Salvador Allende ${ }^{152}$. O roteiro apenas sugeria algumas hipóteses, já que a estratégia principal era a formação de um grupo de pesquisa que estudaria, por meio dos informes da imprensa de direita e de esquerda, os principais conflitos cotidianos ocorridos no país e as implementações do novo governo. De acordo com o realizador, a principal característica desse método é que ele não utilizava materiais de arquivo, mas sim tomadas em primeira mão (GUZMÁN; SEMPERE, 1977). Em 15 de abril de 1971, Guzmán redigiu um texto de

\footnotetext{
${ }^{149}$ Patricio Guzmán estudou originalmente no Instituto Fílmico da Universidade Católica do Chile, ocasião em que realizou ElectroShow (1966). Porém, no ano seguinte, obteve uma bolsa para ir à Espanha se aperfeiçoar na Escuela Oficial de Cinematografía de Madrid, permanecendo quatro anos no país.

${ }^{150}$ A EAC foi outra importante produtora durante os anos da Unidade Popular, ao lado do Centro de Cine Experimental de la Universidad de Chile e da Chile Films. Alfredo Barría Troncoso, no livro El espejo quebrado: memorias del cine de Allende y la Unidad Popular, descreve que essa escola priorizava o formato curta-metragem e destaca os documentários Gabriela Mistral (1971), de Rafael Sánchez, Casas viejas (1972), de David Veras Meiggs, e Campamento Sol Nasciente (1972), de Ignacio Aliaga, como outras produções feitas com auxílio dessa instituição.

${ }^{151}$ No livro Chile: el cine contra el fascismo (1977), Patricio Guzmán destaca que, além dele, faziam parte da equipe Antonio Ríos (filho de Héctor Ríos), como camera man, e Felipe Orrego, como operador de som e chefe de produção.

${ }^{152}$ A relação entre Patricio Guzmán e a EAC parece ter sido complexa. Em carta escrita a Chris Marker, em 15 de agosto de 1972 (GUZMÁN, 1972), na ocasião das negociações para a versão francesa de El primer año, ele declara que a instituição "não entendia nada de cinema" e que cometia inúmeros erros técnicos, dizendo que tivera muitos problemas durante as filmagens.
} 
introdução para divulgar com o documentário, no qual expressa a concepção aplicada à produção de El primer año:

Creio, por outro lado, que a forma cinematográfica mais eficaz para capturar tudo isso é um Noticiário feito com profundidade. Um noticiário tratado como se fosse um grande argumento dramático, em que os protagonistas se confundam com os atores, em que o plano dramático seja determinado pela lógica magistral dos mesmos fatos que essa situação histórica que estamos vivendo. Tenho a impressão que essa é a forma mais coerente, mais funcional, para deixar testemunho desses dias. (GUZMÁN, 1971, p. 142 tradução nossa) ${ }^{153}$

O pesquisador Jorge Ruffinelli (2008) alerta que El primer año foi realizado no decorrer de uma situação complexa, quando o cinema estava nas mãos da Unidade Popular - portanto, não havia a presença de um tom de denúncia contra o poder político hegemônico -, mas essa aliança esquerdista não possuía o poder econômico e o domínio dos "aparatos ideológicos" (como a imprensa escrita, televisiva e radiofônica). Esse paradoxo contribuiu para que o documentário adquirisse um estatuto complexo, caracterizando-se como um filme militante que não se inseria nas tradicionais categorias de combate, oposição ou mesmo propaganda política. Tampouco pode ser taxado como portador de uma visão "neutra", colocando-se deliberadamente ao lado do discurso governamental. Para o pesquisador, "El primer año, ainda que o autor o tenha chamado de filme 'celebratório', só tinha triunfos conjunturais e não definitivos para celebrar; e a luta pelo poder verdadeiro estava apenas começando". (RUFFINELLI, 2008, p. 62, tradução nossa) ${ }^{154}$

Nesse sentido, a definição empreendida pelo próprio Patricio Guzmán para sua obra, “cinema-testemunhal” (GUZMÁN; SEMPERE, 1977), apresenta-se como o termo mais adequado para definir essa produção. Vale ressaltar que o foco da equipe, conforme salienta Ruffinelli (2008), era sobretudo registrar um processo de formação de organismos autônomos de "poder popular", que se constituíam como consequência das lutas políticas durante a Unidade Popular. Algumas das imagens de El primer año

\footnotetext{
${ }^{153}$ Traduzido do original: "Creo, por otra parte, que la forma cinematográfica más eficaz para atrapar todo esto es un Noticiario hecho en profundidad. Un noticiario tratado como si fuera un gran argumento dramático, en que los protagonistas se confundan con los actores, en que el plan dramático sea determinado por la lógica magistral de los mismos hechos de esta situación histórica que estamos viviendo. Tengo la impresión de que ésta es la forma más coherente, más funcional, para dejar testimonio de estos días."

${ }^{154}$ Traduzido do original: "El primer año, aunque el autor la llamó alguna vez de una película 'celebratoria', tenía sólo triunfos coyunturales y no definitivos que celebrar y la lucha por el poder verdadero apenas estaba comenzando."
} 
viriam a integrar a terceira parte de A batalha do Chile III - O poder popular, lançada apenas em 1979. Nessa etapa da trilogia, aparece um viés mais crítico em relação à incapacidade da UP em formar organizações eficientes desse poder "espontâneo" e "autônomo", o que teria contribuído para a derrocada do governo Allende e a dificuldade de reversão do golpe de Estado. Há, nesse ponto, um exemplo de como as tomadas que objetivavam registrar as transformações do primeiro ano passaram a adquirir um novo sentido após o golpe, portando um tom melancólico, o que diferencia a parte final das outras duas da famosa trilogia de Guzmán:

A terceira parte de A batalha do Chile foi dedicada por inteiro ao poder popular, mas pareceu inoportuna, quando este já havia desaparecido sobre a repressão da ditadura. Talvez por esse motivo, essa terceira parte não tinha o impacto dramático das duas primeiras de A batalha do Chile. Nas duas primeiras partes, o motivo da luta política, desde as frentes de resistência e do exílio, ainda que transformados, seguiam vivos. (RUFFINELLI, 2008, p. 63, tradução nossa) ${ }^{155}$

Em maio de 1972, El primer año estreou, sendo exibido, como já foi salientado, especialmente em núcleos camponeses e operários. Após a finalização dessa primeira experiência, Guzmán iniciou o projeto de registrar o segundo ano do governo Allende, dessa vez em parceria com a Chile Films. Diante da intensificação dos conflitos no país, agravados pela greve de caminhoneiros, em outubro de 1972 , que interrompeu o abastecimento de produtos fundamentais, gerando uma grave crise, o cineasta abandonou um projeto sobre o herói da independência Manuel Rodríguez para filmar La respuesta de octubre ${ }^{156}$ (1972). Esse documentário tratava dos cordões industriais ${ }^{157}$, iniciativas de organização nas comunidades para suprir a escassez da produção.

\footnotetext{
${ }^{155}$ Traduzido do original: "La tercera parte de La batalla de Chile [A batalha do Chile] estuvo dedicada por entero al poder popular, pero apareció a destiempo, cuando éste ya había desaparecido bajo la represión de la dictadura. Tal vez por ese motivo, esa tercera parte no tendría el impacto dramático de las dos primeras de La batalla de Chile. En esas dos primeras partes, el motivo de la lucha política, desde los frentes de la resistencia y del exilio, aunque transformados, seguían vivos."

${ }^{156}$ Ao que parece, esse filme foi desmontado durante a edição de $A$ batalha do Chile e não restou uma cópia da versão original. No período em que foi realizada essa pesquisa, em arquivos chilenos, franceses e acervos particulares, ele não foi localizado e, extraoficialmente, a pesquisadora obteve informações de que teria sido desmantelado. Porém, no arquivo da ISKRA, foi encontrada a transcrição do texto original. Sua comparação com as imagens de A batalha do Chile III - O poder popular confirma que muitas das cenas originalmente pertencentes a essa produção foram incorporadas na trilogia montada no exílio.

${ }^{157}$ Sobre os cordões industriais formados no governo da Unidade Popular, ver BORGES, 2011.
} 
Nessa segunda produção da equipe de Guzmán, a ideia de um filme para documentar as mudanças do governo UP já estava enfraquecida diante da evidência revelada na experiência de El primer año de que a equipe fazia, de fato, um testemunho histórico de uma situação de conflito civil. Nesse sentido, La respuesta de octubre, enquanto "arma" de combate, foi transmitido da mesma forma que o filme anterior: em núcleos operários. Em depoimento, o diretor ressalta que era um documentário que interessava principalmente a esse setor:

Não é um filme para todo o público em seu conjunto. $\mathrm{O}$ campesinato, por exemplo, não o entende e não se interessa por ele. É um período de luta de classes intensa, em que as obras especializadas cobram um valor muito específico, ou seja, setores de operários, setores da população em geral exigem filmes de seus próprios problemas. (GUZMÁN; SEMPERE, 1977, p. 73, tradução nossa) ${ }^{158}$

As estratégias usadas pela equipe de Guzmán aproximavam seus filmes de um cinema de guerrilha em tom de reportagem, contraposto ao tom dominante na grande imprensa chilena da época. $\mathrm{O}$ cineasta e sua equipe partiam para as ruas com seus aparatos, como os revolucionários com armas em punho. Em seu testemunho, o cineasta relata o medo que passou com seus companheiros ao filmar, disfarçados de repórteres de um canal da oposição, o comício dos grevistas, correndo o risco de terem suas identidades pró-UP descobertas (GUZMÁN; SEMPERE, 1977). Outra dificuldade enfrentada pela equipe foi o fato da Chile Films ter passado a privilegiar os noticiários televisivos após a saída de Miguel Littin.

A instituição estatal chilena enfrentava ainda a falta de recursos básicos, como rolos de película, devido ao bloqueio das importações vindas dos Estados Unidos. Em 1972, para seguir com o projeto de registrar o governo de Salvador Allende (dessa vez, o seu terceiro ano), Guzmán solicitou e obteve ajuda de Chris Marker, que havia se mostrado um colaborador importante desde a divulgação de El primer año ${ }^{159}$ na França. Essa parceria será analisada ainda neste capítulo.

\footnotetext{
${ }^{158}$ Traduzido do original: "No es una película para todo el público en su conjunto. El campesinato, por ejemplo, no la entiende ni le interesa. Este es un período de lucha de clases intensa, en que las obras especializadas cobran un valor muy específico, es decir, sectores de obreros, sectores de población en general exigen películas de sus propios problemas."

${ }^{159}$ A ajuda de Marker a Guzmán será detalhada no subitem "Chris Marker e a SLON em A batalha do Chile", pertencente a este capítulo.
} 


\section{El primer año (1972) e La première année $(1973)^{160}$}

Os métodos de filmagem e de divulgação de Guzmán estavam de acordo com muitos dos projetos empreendidos por Marker na França nessa mesma época, especialmente em torno dos Grupos Medvedkine, que faziam das fábricas o espaço de produção e de debate cinematográfico. Essa semelhança ajuda a explicar o interesse do cineasta francês pelo filme El primer año e seu empenho por divulgá-lo no continente europeu. Em 6 de dezembro de 1972, a Universidade Católica do Chile assinou um contrato delegando à SLON os direitos de distribuição do documentário na Europa (Ocidental e Oriental) e na África francofônica. Esse contrato autorizava possíveis ajustes que o adaptassem para a melhor compreensão desse público, que deveriam ser realizados pelo coletivo criado por Marker e pela Argos Films (parceira da SLON em muitas produções, inclusive em La spirale).

El primer año, gravado originalmente como "cinetestemunhal", seguia alguns preceitos do cinema-direto: valorização de entrevistas, editadas em longas tomadas e com poucos cortes; o uso do zoom acentuado, que aproxima o espectador dos protagonistas; o menosprezo da inserção de material de arquivo, preferindo a presença de tomadas inéditas. Nesse documentário, a associação de planos, especialmente os de naturezas opostas entre si (por exemplo, festas populares contrapostas a vernissages burguesas), é mais importante para o encadeamento de ideias do que a presença de um texto exterior que guie a interpretação, proferido por uma voz over. Essas características decorriam do método de Guzmán de realizar um registro em tom de reportagem, no "calor da hora". Na versão montada por Marker, La première année, parte dessas características são mantidas, porém o diretor francês imprime mais agilidade e insere novos elementos de caráter elucidativo, que modificam o caráter original.

Em termos gerais, Marker manteve a ordem das sequências como editadas por Guzmán. No entanto, realizou cortes pontuais com a finalidade de imprimir dinamismo ao documentário. Nos minutos iniciais de El primer año, por exemplo, há

\footnotetext{
${ }^{160} \mathrm{O}$ filme El primer año não está disponível em arquivos institucionalizados, nem no Chile, nem na França. Sua análise foi feita com base em duas cópias conseguidas por meio de outros pesquisadores da área, que configuravam a versão chilena do documentário e a versão francesa (sendo que esta estava sem som). Colaboraram para a comparação entre elas os documentos escritos encontrados nos arquivos da ISKRA, que traziam os textos integrais (em espanhol e em francês), a transcrição dos diálogos e as marcas de corte entre uma versão e outra.
} 
um longo trecho dedicado a um grupo de mapuches que havia ocupado uma propriedade, montado com depoimentos em off sobre sua relação com a terra e planos próximos intercalados a planos detalhes. Essa sequência é mantida na versão francesa, porém com a supressão de uma longa fala sobre a situação das crianças na comunidade. Marker preservou os testemunhos que reivindicavam a ligação histórica desse povo com o território, argumento que justificava a ocupação - vista no filme como uma espécie de reparação de um dano causado aos indígenas.

A mesma redução na quantidade de depoimentos ocorre em outras passagens. Ao abordar a nacionalização dos minérios, Guzmán havia entrevistado inúmeros mineiros e muitos deles se repetiam. Nesse trecho, Marker "enxugou" o filme, retirando da sequência entrevistas que ressaltavam aspectos já mencionados. Na segunda metade de El primer año, Guzmán retomava o assunto, e outros trabalhadores davam sua opinião sobre a ação do governo em nacionalizar o cobre. Nessa parte, La première année suprimiu cerca de 2 minutos e meio, reduzindo os planos dessa sequência de oito para três depoimentos de trabalhadores. O realizador francês descartou a entrevista de um músico sobre o assunto, preferindo manter o foco nos protagonistas das classes populares. Esse procedimento, de retirar repetições pontuais, tornando a produção mais dinâmica, foi realizado de forma semelhante na ocasião em que o documentário se dedica à estatização das fábricas.
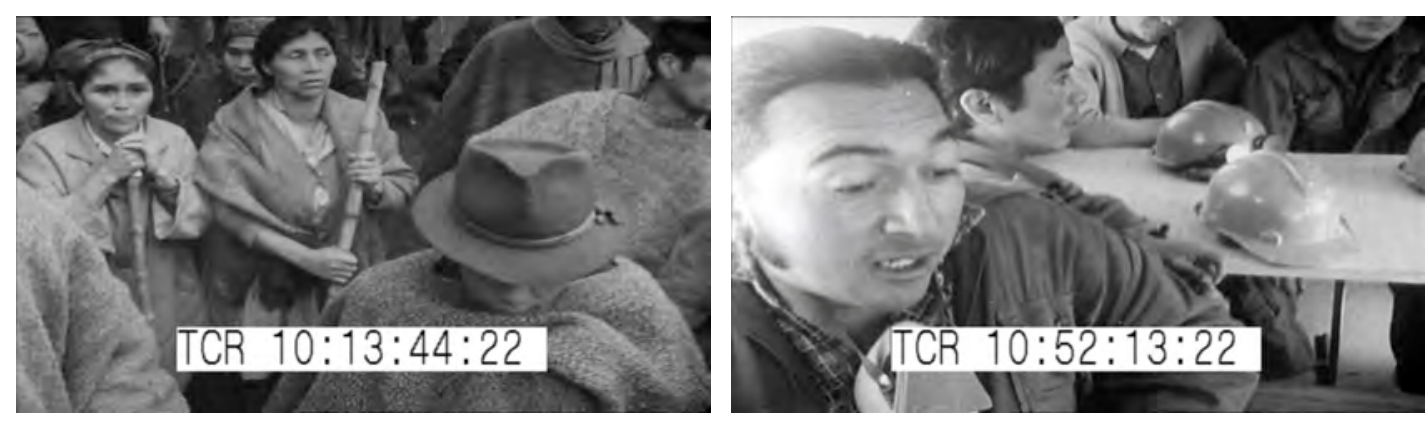

Imagens de mapuches e mineiros de El primer año mantidas em La première année.

Ainda em relação aos cortes feitos para a versão francesa, destaca-se uma longa passagem suprimida em que pessoas anônimas davam sua opinião sobre a visita de Fidel Castro ao Chile, no final de 1971. A presença de Castro e seu encontro com Allende é o tema que encerra El primer año, com destaque para a avaliação feita pelo presidente cubano da importância desse encontro entre "a Revolução Cubana e a Revolução Chilena" (em suas palavras). Nessa passagem, Guzmán abandona 
momentaneamente o povo como protagonista para dar voz ao chefe de Estado cubano, mas logo volta a suas investigações nas ruas para saber como foi a recepção a esse convidado ilustre. As declarações escolhidas para a montagem original eram extremamente favoráveis e entusiásticas diante do evento. Porém, Marker optou por excluir essa sequência de sua versão, assim como a de um mineiro que agradecia a doação de açúcar realizada por Castro diretamente à mina em que ele trabalhava.

Nenhum desses cortes, porém, modificou significativamente o discurso fílmico elaborado por Guzmán na versão original. Ao que tudo indica, eles foram feitos com o intuito de deixar o documentário mais ágil e suprimir repetições. Em um artigo divulgado na ocasião da morte de Marker, Guzmán (2012) confirma que essa seria a intenção do cineasta francês, declarando satisfação com as mudanças:

Chris Marker não apenas escreveu uma boa resenha da obra, mas também dirigiu uma dublagem excepcional para ela. Primeiro me pediu autorização para abreviar o filme (tinha 110 minutos). Claro que eu disse sim. A verdade é que era um filme reiterativo. Nunca fiquei feliz com a montagem. Tem sequências emocionantes. Mas, sem dúvida, sobraram dez minutos ou até mais. (GUZMÁN, 2012, tradução nossa) ${ }^{161}$

Nesse trecho, Guzmán se refere à "dublagem” inserida por Marker, ou seja, a locução em over acrescentada na versão francesa. Em algumas passagens da montagem original, o realizador francês julgou que faltavam maiores informações. Assim, a voz over, quase ausente em El primer año, ganhou importância em La première année. No documentário chileno, ela interferia em momentos muito pontuais, contribuindo apenas com dados objetivos e relevantes (como informação de datas e lugares). A ênfase no "testemunhal", a preocupação em valorizar o aspecto "real" do registro, levaram o diretor chileno a rechaçar esse recurso. Porém, Marker o valoriza e redige novos parágrafos. Esses novos fragmentos seguiam, em geral, a tendência de informar com certo distanciamento, prática que se afasta de uma das mais constantes características markerianas, que é a importância equivalente entre texto e imagem - sendo que, muitas vezes, as palavras servem para questionar e desconstruir os planos. Mesmo assim, a ironia e o refinamento de Marker estão presentes nesses acréscimos textuais.

\footnotetext{
${ }^{161}$ Traduzido do original: "Chris Marker no sólo escribió una buena reseña de la obra, sino que dirigió un doblaje excepcional para ella. Primero me pidió autorización para aligerar el filme (tenía 110 minutos). Por supuesto le dije que sí. La verdad es que era un filme reiterativo. Nunca estuve feliz con el montaje. Tiene secuencias emocionantes. Pero sin duda le sobraban diez minutos o incluso más."
} 
Um exemplo desse novo tom da voz over, que imprime a assinatura do realizador francês, aparece em uma das sequências de La première année, supostamente gravada em 5 de setembro de $1970^{162}$, poucas horas após o triunfo da Unidade Popular. Na versão de Guzmán, as cenas de mansões fechadas no Bairro Alto - símbolo da burguesia recolhida após a derrota -, interrompidas por um entregador de jornal que traz as "boas-novas", eram suficientes para mostrar o poder mudando de mãos. No entanto, na versão francesa, Marker explica esse fato por meio da voz over, sempre recorrendo a uma refinada ironia:

Leilões, liquidações, compras de divisas, retiradas massivas nos bancos, exílio por avião: é o começo da sabotagem econômica. A esquerda nem estava ainda no poder, e a direita já aplicava sua estratégia digna de Maquiavel e Gribouille: provocar a catástrofe para se vangloriar de tê-la anunciado. (La première année, 1973, tradução nossa) $)^{163}$

Em algumas passagens, a versão francesa acrescentou texto à fala da voz over com o objetivo de inteirar o espectador europeu de quem eram os protagonistas mostrados no documentário. Isso ocorreu, por exemplo, no trecho dedicado aos povos mapuches, que necessitavam, na visão de Marker, de algumas palavras extras para que se compreendesse sua presença nos conflitos políticos durante a Unidade Popular (no caso, como ocupantes de fundos de grandes proprietários) ${ }^{164}$ :

Os mapuches vivem nas "reduções" - que são, por definição, as piores terras. Eles foram espremidos, e os que vão à procura de trabalho nas cidades tornam-se subproletários comparáveis aos trabalhadores imigrantes. Não faz muito tempo, eles eram massacrados por diversão, como no Brasil. Sua ideia é agora retomar as terras que lhes foram roubadas. Sua técnica é plantar os pés no local de suas novas cercas, e defendê-las. (La première année, 1973, tradução nossa) ${ }^{165}$

\footnotetext{
${ }^{162}$ Apesar de o intertítulo indicar essa data para a captação das imagens do Bairro Alto, é possível que elas tenham sido registradas depois do dia 5 de setembro de 1970, já que, nessa época, Guzmán ainda vivia na Espanha.

${ }^{163}$ Texto da voz over de La première année, traduzido do original: "Ventes aux enchères, liquidations, achats de devises, retraits massifs dans les banques, exils par avion: c'est le début du sabotage économique. La gauche n'est pas encore au pouvoir, que la droite applique déjà cette stratégie digne de Machiavel et de Gribouille: provoquer la catastrophe pour se justifier de l'avoir annoncée."

${ }^{164}$ Aparece ainda uma explicação sobre os povos mapuches do prólogo montado por Chris Marker para a versão francesa. A voz over caracteriza-os como uma ilha de resistência de três séculos, localizada ao sul do Chile, já resistente durante o domínio espanhol. Acompanhando esse texto, o realizador insere imagens de múmias mapuches e fotografias dos indígenas do final do século XIX/começo do século XX, em uma clara alusão à sobrevivência desse povo apesar das adversidades.

${ }^{165}$ Texto da voz over de La première année, traduzido do original: "Les mapuches vivent dans les 'réductions' - qui sont par définition les plus mauvaises terres. Ils y sont à l'étroit, et ceux qui vont
} 
Nos dois trechos citados acima, retirados do texto escrito para a voz over da versão francesa, pode ser verificada a estratégia de inserir elementos e aproximações ao universo europeu. Em relação aos mapuches, a comparação com os imigrantes, que eram obrigados a trabalhar em péssimas condições (como subproletários) ao se deslocar de seu local de origem para os centros econômicos da Europa, torna a compreensão de sua situação mais acessível. Essa ligação, sobretudo com o contexto francês, aparece em outras sequências em que Marker cria falas para uma locução over, como em um dos momentos finais de La première année, em que relaciona o movimento estudantil chileno com o Maio de 68 na França:

A politização da juventude toma muitas formas. Um certo "poder jovem", por meio de slogans semelhantes aos de Maio de 68, do gênero "Papai, eu não quero ser como você", se organiza em misteriosas comunidades de combate, de essência mais fascinante que "esquerdista". (La première année, 1973, tradução nossa) ${ }^{166}$

Além dessas duas estratégias - cortes de cenas pontuais e inserção de novos textos por meio da voz over -, a principal modificação realizada por Marker em $E l$ primer año foi a inserção de um prólogo de pouco mais de seis minutos. Esse trecho, ausente na versão chilena, foi montado com fotos do próprio Marker, de Raymond Depardon e das agências Gamma e Snack International, que foram dispostas na tela como slides. O comentário desse prólogo introduz o Chile ao público francês, com informações geográficas e históricas ${ }^{167}$. Primeiramente, localiza o país no mapa e profere observações sobre sua curiosa constituição territorial, citando a definição de Régis Debray, em Entretiens avec Allende sur la situation au Chili, que o classificou como uma "faixa de terra geograficamente louca, mas historicamente sensata" $" 168$.

\footnotetext{
chercher du travail en ville deviennent un sous-prolétariat comparable aux travailleurs immigrés. Il n'y a pas si longtemps, on les massacrait par jeu, comme au Brésil. Leur idée est saintement de reprendre les terres qu'on leur a volées. Leur technique est de planter des pieux sur l'emplacement de leur nouvelles clôtures, et de les défendre."

${ }^{166}$ Texto da voz over de La première année, traduzido do original: "La politisation de la jeunesse prend beaucoup de formes. Un certain 'pouvoir jeune', à travers des slogans apparemment très Mai 68, du genre 'Papa, je ne veux pas devenir comme toi', s'organise en mystérieuse communautés de combat, d'essence plus fascinante que gauchiste."

${ }^{167}$ De acordo com o próprio Marker, no texto de introdução à versão francesa, o objetivo do prólogo era estabelecer um vínculo entre o momento atual e a história do Chile: "Assim, um pedaço de informação foi criado para estabelecer a continuidade - e, esperamos, a clareza - entre o Chile histórico e o Chile atual.” (MARKER, 1977, p. 133, tradução nossa). Traduzido do original: “Así, un trozo de información se ha creído que establece la continuidad - y esperamos la claridad - entre el Chile histórico y el Chile actual."

${ }^{168}$ Texto da voz over de La première année, traduzido do original: "Frange de terre géographiquement folle, mais historiquement raisonnable".
} 
Em seguida, por meio de imagens de arquivo, constrói uma breve narração sobre o passado colonial e uma ambígua independência (que havia sido apoiada por potências europeias - Inglaterra, Alemanha - e pelos Estados Unidos para disputarem com a Espanha o domínio sobre a exploração do salitre e do cobre). O prólogo informa ainda sobre o estabelecimento de uma aliança desses novos dominadores estrangeiros com a burguesia local, em um exercício que mostra o esforço de identificar as origens por trás dos inimigos da Unidade Popular nos anos 1970. Nesse sentido, fica evidente a intenção de Marker em relacionar os conflitos entre classes, tal como exposto no documentário de Guzmán, à história do país, por meio da articulação de fotografias e de um texto explicativo.

O prólogo de La première année constitui um retrato da esquerda chilena, refazendo seu percurso histórico até a chegada ao poder com as eleições de 1970. Um slide das primeiras décadas do século $\mathrm{XX}$ mostra um grupo de homens com punhos erguidos, na clássica saudação esquerdista, que será repetida em outra foto dos tempos da UP. Outro slide, mais ou menos da mesma época, exibe uma grande manifestação com faixas do Partido Comunista. A sequência seguinte traz cenas de repressão a trabalhadores e populares, que são interrompidas por um cartaz da Frente Popular iniciada em 1938, onde se vê o rosto do ex-presidente Pedro Aguirre Cerda $^{169}$. O tema seguinte desse prólogo é a República Socialista de 1932, que, apesar de ter durado apenas treze dias, foi um importante episódio para a história da esquerda nacional. Entre as fotografias inseridas na montagem, há uma que se destaca: um grupo de homens carrega uma representação gigantesca do símbolo máximo do socialismo, a foice e o martelo. É essa imagem que marca uma ruptura com o passado e introduz uma nova sequência visual, dessa vez com retratos em close-up de trabalhadores ligados à Unidade Popular.

Nesse trecho, que refaz em fotografias a história da esquerda chilena, existe uma clara tentativa de estabelecer uma coerência nessa trajetória, na qual a busca por uma união é o mote comum entre os períodos ressaltados. Esse nexo é coroado quando, após a sequência de fotos recentes de trabalhadores, Marker insere em seu prólogo uma fotografia de Salvador Allende sendo beijado por uma mulher indígena. Essa imagem sintetiza todos os temas apresentados na abertura de La première année

\footnotetext{
${ }^{169}$ Vale ressaltar que a Frente Popular chilena, uma aliança entre os partidos Radical, Comunista e Socialista baseada na defesa de uma "democracia política como fundamento de uma coalisão" (AGGIO, 1999), foi rompida em 1941, mas Pedro Aguirre Cerda seguiu governando até sua morte, nesse mesmo ano.
} 
até então, especialmente a resistência ao colonialismo e ao imperialismo apoiada por uma organização popular em torno dos partidos de esquerda. A voz over é a responsável por relacionar todos esses slides, narrando o caminho desse campo político até a coroação da vitória eleitoral da Unidade Popular, em que sempre confluíram os interesses de comunistas e socialistas:

O partido comunista foi fundado em 1922 por [Luis Emilio] Recabarren. Ele conheceu a repressão e a clandestinidade e não seria por muito tempo o partido mais poderoso da oposição. Em 1933, é constituído um partido socialista de um tipo incomum: decididamente marxista, decididamente alheio à social-democracia europeia e recusando um certo modelo de obediência internacional. Entre seus fundadores, um médico que se tornaria deputado e senador: Salvador Allende Gossens. (La première année, 1973, tradução nossa) $)^{170}$

Vale destacar que nessa passagem está presente um artifício marcante do prólogo de La première année: por um lado, Marker busca exemplos e comparações entre a história chilena e a francesa, visando a oferecer referências ao seu público; por outro, ressalta certas especificidades encontradas no Chile. É claro, no texto da voz over citado acima, como o realizador opta por caracterizar o socialismo nesse país latino-americano como "incomum” (não submetido à Internacional). Além disso, apesar de em outros trechos comparar as Frentes Populares ocorridas nessas duas nações nos anos 1930, ele afirma que não havia uma influência direta desse fenômeno europeu na constituição política chilena.

O prólogo de Marker apresenta também uma visão polarizada entre esquerda e direita na história chilena, embora identifique outros atores políticos fora dos limites desses dois campos, como a Democracia Cristã ("reformista") e o MIR (na "vanguarda"). Buscando uma linha comum entre os partidos comunista e socialista, despreza contradições importantes no interior da esquerda chilena, entre elas as dificuldades de entendimento no período anterior à formação da Frente Popular ${ }^{171}$.

\footnotetext{
${ }^{170}$ Texto da voz over de La première année, traduzido do original: "Le parti communiste est fondé en 1922 par Recabarren. Il connâitra la repression et la clandestinité, et n'en deviendra pas moins le parti le plus puissant de l'opposition. En 1933 se constitue un parti socialiste d'un type peu courant: résolument marxiste, résolument étranger à la social-démocratie européenne, mais refusant un certain modèle d'obédience internationale. Parmi ses fondateur, un médecin devenu député, mais sénateur: Salvador Allende Gossens."

${ }^{171}$ Essas orientações diversas entre os partidos comunistas e socialistas nos anos 1930, que se atenuaram nos momentos antecedentes à formação da Frente Popular, são destacadas por Alberto Aggio em Frente popular, radicalismo e revolução passiva no Chile: "[...] a despeito das péssimas relações existentes entre o Partido Comunista (PC) e o Partido Socialista (PS) - o primeiro seguindo as linhas da III Internacional e rechaçando as tendências parlamentares do PS, e o segundo rejeitando a
} 

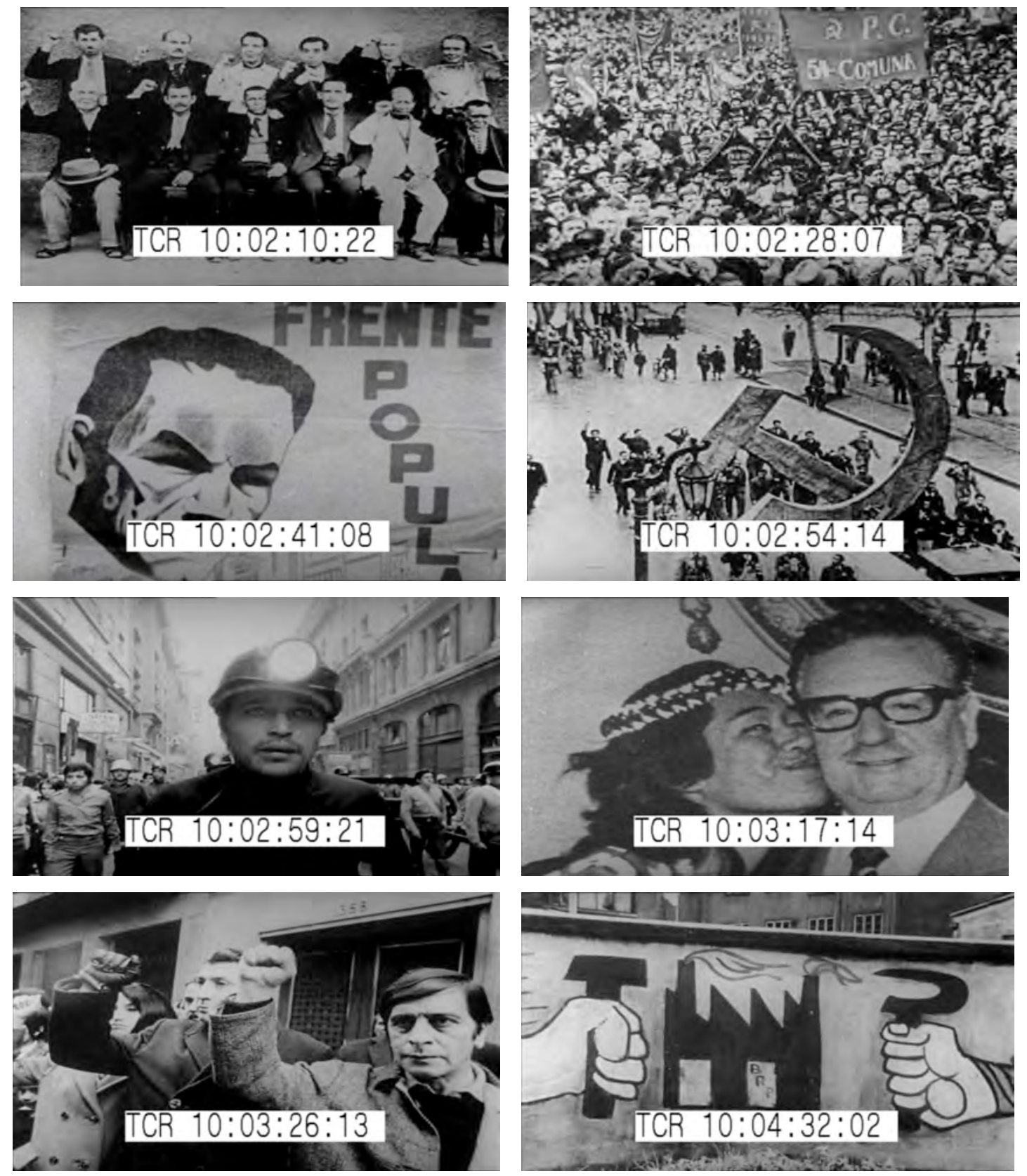

Fotogramas do prólogo montado por Chris Marker para La première année.

A exemplo do que ocorre em outras produções audiovisuais sobre o Chile que serão analisadas nesta tese, como em On vous parle du Chili: ce que disait Allende e La spirale, o prólogo criado para La première année estabelece uma relação entre a Frente Popular dos anos 1930 e a Unidade Popular dos anos 1970. O símbolo da foice e do martelo aparece constantemente nas fotos dessas duas décadas, bem como a imagem de trabalhadores organizados em torno de movimentos sociais e partidos. Se

orientação ultraesquerdista do PC anterior a 1935 -, seus interesses começaram a convergir quando o governo de [Arturo] Alessandri lançou uma repressão indiscriminada contra os sindicatos, atingindo seguidores de ambos partidos”. (AGGIO, 1999, p. 103). 
Marker já havia citado textualmente o prefácio de Entretiens avec Allende sur la situation au Chili, de Régis Debray, essa aproximação entre os dois fenômenos é mais um indício de que a introdução à versão francesa de El primer año se apoia em informações trazidas por esse livro (cuja primeira edição havia sido publicada um ano antes pelas edições Maspero).

No entanto, é preciso destacar que, na obra de Debray, há uma tensão concernente à escolha por uma aliança frentista nos anos 1930 que se perde no prólogo de La première année, apesar da opção comum em aproximar os dois períodos ${ }^{172}$. O jornalista francês destaca que essa escolha é feita em detrimento da "luta de classes" e do armamento dos operários, já explicitando em sua análise sobre a Frente Popular argumentos presentes em seu debate com Allende sobre a questão da via de chegada ao socialismo - armada ou democrática. Dessa forma, mesmo utilizando Debray como fonte, Marker ameniza a discussão sobre os limites de uma coalizão entre os partidos de esquerda. O mesmo procedimento de escamotear divergências, elegendo um discurso aglutinador, será adotado em On vous parle $d u$ Chili: ce que disait Allende, como será abordado a seguir.

É necessário enfatizar que essa linearidade entre o governo Allende e os movimentos frentistas anteriores, sobretudo o de 1938, tem a função, no prólogo de Marker, de trazer ao público francês uma referência histórica de alianças esquerdistas que lhe fosse próxima, tendo em vista que seu país também viveu, nos anos 1930, uma Frente Popular. Assim, há em seu discurso a priorização de experiências comuns às nações latino-americana e europeia, o que ajuda a explicar seu interesse na década de 1970 pela Unidade Popular e seu sucesso eleitoral. Esse tema será constantemente retomado ao longo desta tese, porém é válido citar aqui a interpretação de Alberto Aggio sobre essa similaridade do fenômeno frentista:

\footnotetext{
${ }^{172}$ A tensão na análise de Debray sobre a Frente Popular de 1938 pode ser verificada no trecho seguinte: "As lutas eleitorais, os debates parlamentares, as competições de partidos constituem assim o ponto de encontro entre dois polos antagônicos. O centro de gravidade da luta de classes é transposto e deslocado em relação à ação presidencial e parlamentar no quadro político-jurídico existente desarmando e sublimando a ação direta das forças operárias. Independente se as divergências e os conflitos se resolvam ou não, há um acordo em relação ao lugar do enfrentamento: o terreno legal, delimitado pela Constituição e seus usos, da luta política ao poder." (DEBRAY, 1971, p. 39, tradução nossa). Traduzido do original: "Les luttes électorales, les débats parlementaires, les compétitions de partis constituent ainsi le point de rencontre des deux pôles antagonistes. Le centre de gravité de la lutte de classe est transposé et déplacé au niveau de l'action présidentielle et parlementaire, dans le cadre juridico-politique existant - désamorçant et sublimant l'action directe des forces ouvrières. Que les divergences et les conflits se résolvent ou non, il y a un accord de fait sur le lieu de l'affrontement: le terrain légal, délimité par la Constitution et les usages, de la lutte politique au sommet."
} 
O êxito político da Frente Popular no Chile assume, de fato, uma significação histórica universal. O Chile foi, ao lado da França e da Espanha, o único país latino-americano a conhecer a vitória eleitoral e o estabelecimento de um governo baseado na política de Frente Popular adotada pelo Movimento Comunista Internacional (MCI), a partir de agosto de 1935. Essa estratégia foi definida pela Internacional Comunista em função do entendimento de que haveria a necessidade de se impulsionar a unidade de ação entre os comunistas e outras forças políticas com o intuito de se fazer frente, política e ideologicamente, ao fascismo e ao nazismo, então em ascensão na Europa ocidental. (AGGIO, 1999, p. 17)

O período entre a Frente Popular de 1938 e a vitória da Unidade Popular é brevemente descrito no prólogo de La première année pelas referências aos governos Jorge Alessandri, classificado como sendo de uma direita tradicional e autoritária, e Eduardo Frei, descrito como representante de um reformismo limitador e não suficiente para sanar os problemas do país. É com essa introdução que Marker apresenta, por meio da voz over, o cenário eleitoral de 1970. Nesse sentido, enquanto exibe fotografias em que se destacam pichações nos muros chilenos de referências ao MIR (contraditoriamente, já que não fazia parte da aliança eleitoral) e aos partidos que disputavam o pleito, a locução em over informa que:

A direita conservadora se reúne em torno de Alessandri, partidário de um retorno aos métodos autoritários. A democracia cristã, consciente de uma pressão popular mais exigente, se afasta do reformismo. A esquerda se reagrupa na Unidade Popular, que inclui socialistas, comunistas, radicais, sociais-democratas, assim como uma fração da esquerda descolada da democracia cristã. Fora da Unidade Popular, mas a apoiando: o MIR, movimento de vanguarda, partidário da ação direta na perspectiva de uma "guerra revolucionária prolongada e irregular”. (La première année, 1973, tradução nossa) ${ }^{173}$

É interessante ressaltar, nesse parágrafo, que as posições do MIR, apesar de ocuparem um papel de destaque em parte das produções francesas analisadas nesta tese, têm sua crítica à Unidade Popular amenizada. Ao contrário, elas costumam citar seu apoio à UP, sem, no entanto, aprofundar as controvérsias que esse partido tinha

\footnotetext{
${ }^{173}$ Texto da voz over de La première année, traduzido do original: "La droite conservatrice se rassemble autour d'Alessandri, partisan d'un retour aux méthodes autoritaires. La démocratie chrétienne, consciente d'une poussée populaire plus exigeante, s'engage plus loin dans le réformisme. La gauche se regroupe dans l'Unité populaire qui comprend socialistes, communistes, radicaux, sociaux-démocrates, ainsi qu'une fraction de gauche détachée de la démocratie chrétienne. A l'extérieur de l'Unité populaire, mais la soutenant: le MIR, mouvement d'avant-garde, partisan de l'action directe dans la perspective d'une 'guerre révolutionnaire prolongée et irrégulière."
} 
com os membros do governo. A atenuação desse debate político já se encontrava nos filmes realizados pelos cineastas chilenos no início dos anos 1970, que constantemente mostram cenas de ocupações de terra ou de fábricas coordenadas por esse movimento - muitas vezes sem apoio das instâncias governamentais, cujo ritmo de desapropriações era frequentemente mais lento - como indícios de transformações geradas por Allende.

No documentário El primer año, de Patricio Guzmán, mesmo com o filme trazendo opiniões diversas entre os grupos de trabalhadores entrevistados, são irrelevantes às referências ao discurso do MIR nesses embates internos. Nesse sentido, o movimento ganhou espaço na versão francesa, porém continuou restrito a poucas citações. Além do prólogo, ele é mencionado na parte de La première année dedicada aos mapuches, na qual a voz over informa que suas ações junto a esse povo pressionaram o governo a acelerar a reforma agrária. Embora possa parecer uma crítica à UP, o MIR aparece nesse discurso mais como um incentivador do que como uma oposição, já que os depoimentos dos indígenas que seguem na montagem comprovam a melhoria gerada pela vitória de Allende.

O prólogo de La première année se encerra referindo-se ao fato do presidente chileno guardar em seu escritório um exemplar do livro Guerra de Guerrilhas, de Che Guevara, com a seguinte dedicatória: "A Salvador Allende, que busca obter a mesma coisa com outros meios, Che" (La première année, 1973, tradução nossa) ${ }^{174}$. Essa informação está também no livro de Debray e indica uma de suas principais tensões: a discussão sobre a via chilena rumo ao socialismo. Em El primer año, esse debate é evocado pela figura de Fidel Castro em visita ao Chile, porém seu apoio incondicional ao que ele chama de "Revolução Chilena" minimiza as discordâncias - ao contrário do que ocorre em Compañero presidente, de Miguel Littin, em que a presença de Debray e sua defesa das armas exigem de Allende o desenvolvimento de uma argumentação favorável ao socialismo democrático.

Vale ressaltar que a voz over - incluindo a do prólogo - foi proferida pelo ator François Perier, o mesmo que voltaria a desempenhar esse papel em La spirale e em O fundo do ar é vermelho. A escolha dos dubladores é mais um indício do esforço empreendido por Marker em atualizar o documentário não apenas para o público, mas para a realidade francesa. Nesse sentido, ele mobilizou uma grande equipe de

\footnotetext{
${ }^{174}$ Fala de Salvador Allende presente em La première année, traduzida do original: "À Salvador Allende, qui essaie d'obtenir la même chose avec d'autres moyens, Che".
} 
colaboradores, mantendo o caráter de produção coletiva que já estava presente no método original de Guzmán. É possível, inclusive, que trabalhadores dos Grupos Medvedkine tenham participado do projeto, emprestando voz aos operários, camponeses e mineiros chilenos. O cineasta francês escreveu um texto de introdução a La première année, usado na divulgação do filme em 1972, no qual expõe a preocupação de encontrar atores sociais equivalentes aos que participam de El primer año:

Para transmitir essas vozes ao público francês - guardando ao máximo a cor, a música das vozes de origem -, grandes atores, cineastas e trabalhadores contribuíram: são, de fato, os trabalhadores franceses que emprestam suas vozes em eco para os trabalhadores chilenos, mas é François Perier quem desempenha o papel do narrador e é Delphine Seyrig quem modula as reflexões da burguesia de encanto menos discreto que a de Buñuel. É François Armoul, Bernard Paul, Georges Rouquier, Edouard Luntz e muitos outros para quem se reparte os textos das mulheres, dos pescadores, dos camponeses, dos militantes, enquanto que os grandes advogados parisienses, Georges Kiejman e Leo Matarazzo, aceitaram representar a arte oratória quando se tratava justamente de um advogado e de um médico convertidos em tribunos: Fidel Castro e Salvador Allende. (MARKER, 1972, p. 133-4, tradução nossa) ${ }^{175}$

Essa preocupação com a dublagem representa mais do que um mero preciosismo da parte de Marker: ela reflete a tentativa de ser fiel, na versão francesa, ao espírito da produção original - descrito nesse trecho como "cor" e "música das vozes de origem". Ela indica também que o grande diferencial do documentário de Guzmán, na opinião do realizador europeu, era a presença dos trabalhadores como protagonistas, característica que deveria ser mantida. As novas vozes precisariam manter entonações e vocabulários típicos dos sujeitos sociais envolvidos nos conflitos que circundavam a Unidade Popular. Nesse sentido, ele revela sua intenção em aportar uma contribuição inovadora ao debate sobre o Chile realizado na França, conforme revela esse texto introdutório: "Falou-se muito do Chile na França nos

\footnotetext{
${ }^{175}$ Traduzido do original: "Para transmitir estas voces al público francés - guardando al máximo el color, la música de las voces de origen -, grandes actores, cineastas y trabajadores han aportado su concurso: son en efecto los trabajadores franceses quienes prestan sus voces en eco a las de los trabajadores chilenos, pero es François Perier el que desempeña el papel de narrador y es Delphine Seyrig quien modula las reflexiones de una burguesía de encanto menos discreto que la de Buñuel. Es Françoise Armoul, Bernard Paul, Georges Rouquier, Edouard Luntz y muchos otros quienes se reparen los textos de las mujeres, de los pescadores, de los campesinos, de los militantes, mientras que los grandes abogados parisienses, Georges Kiejman y Leo Matarazzo, han aceptado representar el arte oratorio cuando se trataba justamente de un abogado y de un médico convertidos en tribunos: Fidel Castro y Salvador Allende."
} 
últimos dois anos, mas, quando pudemos escutar diretamente as vozes chilenas, as vozes dos camponeses, dos operários e dos militantes que vivem a realidade - e as contradições - da Unidade Popular?” (MARKER, 1972, p. 133, tradução nossa) ${ }^{176}$.

Além do texto redigido para o prólogo e daquele destinado à divulgação, mais uma redação foi pensada como forma de complementar El primer año em sua versão francesa. Trata-se de um posfácio escrito pelo próprio Patricio Guzmán, que deveria tomar forma audiovisual, encerrando La première année. Esse projeto original foi abortado, conforme informa uma correspondência trocada entre a Universidade Católica do Chile e a SLON. Em carta de 11 de agosto de 1972, a equipe chilena se declarava de acordo com a inclusão de mais essa parte, porém anunciava sua impossibilidade diante da falta de negativo virgem para rodá-la. Apesar de não ter sido filmado, algumas ideias desse posfácio podem ser conhecidas por meio de um documento presente nos arquivos da ISKRA (desdobramento atual da SLON), que traz o que seria o discurso previsto para a voz over.

O texto escrito por Guzmán para a versão francesa buscava uma espécie de atualização entre a data de gravação das imagens, 1971, e o ano de sua remontagem na Europa, 1972. Ele evidencia tensões presentes na montagem original, declarando que a burguesia chilena demonstrou mais "consciência de classe" que os setores populares, conseguindo aliar a extrema-direita e a Democracia Cristã para bloquear as transformações de estrutura, abalar a base popular governamental e encontrar um meio de destituir Allende (nas palavras do autor). Mas, além de acusar os opositores, o documento expõe falhas de "direção econômica" e de "direção política" da Unidade Popular, atribuindo-lhe uma parcela de culpa pela situação conflituosa do país. Mesmo assim, Guzmán reafirmava que a UP ainda era a concretização das "aspirações revolucionárias do povo chileno", reiterando seu apoio ao governo: "E é a partir desse apoio de classe que a Unidade Popular continua a ser o único caminho aberto ao povo chileno" (GUZMÁN, 1972c, tradução nossa) ${ }^{177}$.

A versão original de Guzmán, como já foi dito, trazia opiniões diversas entre os trabalhadores entrevistados; servia a um debate controverso sobre os temas relativos à UP, como as ocupações de terra e as nacionalizações. Dessa forma, na

\footnotetext{
${ }^{176}$ Traduzido do original: "Se ha hablado enormemente de Chile en Francia desde hace dos años, pero, ¿cuándo hemos podido escuchar directamente las voces chilenas, las voces de los campesinos, de los obreros y de los militantes que viven la realidad - y las contradicciones - de la Unidad popular?"

${ }^{177}$ Traduzido do original: "Et c'est à partir de ce soutien de classe que l'Unité Populaire continue d'être le seul chemin ouvert au peuple chilien".
} 
tentativa de um cinema-direto que concedesse voz aos setores populares, mantinha os pontos de vista distintos na montagem final. Isso evidenciava contradições do processo político chileno, tais como as destacadas no texto do posfácio não realizado. Essas características foram posteriormente apontadas como as responsáveis pelo fracasso da distribuição do filme na Europa, conforme indicam correspondências encontradas no arquivo da ISKRA. Em carta enviada por Inger Servolin (1973b), uma das fundadoras e responsável pela SLON, à produtora Sonia Jordan, da EAC, datada de 5 de abril de 1973, a equipe francesa usa a palavra "fiasco" para descrever o público de La première année, em cartaz nas salas de Paris ${ }^{178}$. O texto ainda aponta que a difusão da produção para as televisões italianas, alemãs e canadenses era prejudicada pelo fato desses veículos terem filmado bastante por conta própria no Chile. Se, por um lado, essa afirmação reforça o interesse que o governo Allende provocava na Europa nessa época, por outro, contribuiu para dificultar a circulação desse documentário. Essa dificuldade de divulgação parece ter sido revertida após 1973, quando o golpe militar reacendeu o interesse pelos episódios chilenos. Nessa ocasião, a documentação revela que emissoras da Alemanha, Suécia, Finlândia, Noruega, Holanda, entre outros países, estariam interessadas em adquirir os direitos de exibição do filme.

Muitas correspondências entre a SLON e a Universidade Católica discorrem sobre as razões do fracasso de distribuição do documentário na Europa, especialmente na França. Nessa mesma carta de abril de 1973, Servolin expõe um argumento que se repete em outros documentos: o de que as eleições para o legislativo francês, realizadas em março de 1973, haviam influenciado para que os partidos de esquerda não se interessassem em divulgar o filme. Conforme a produtora francesa:

Nós contávamos com o apoio dos partidos esquerdistas daqui para falar sobre o filme, mas nossa campanha foi muito calma e cuidadosa, e o ponto principal era não assustar as pessoas e particularmente não provocar debates! Assim, o filme foi retirado antes das eleições, em 28 de fevereiro. (SERVOLIN, 1973b, tradução nossa) $)^{179}$

\footnotetext{
${ }^{178}$ La première année esteve em cartaz durante duas semanas, no Studio de la Harpe, em Paris, quando era exibido em quatro sessões por dia. No total, a produção obteve 2322 espectadores, conforme informa correspondência de Servolin datada de 5 de abril de 1973.

${ }^{179}$ Traduzido do original: "We had accounted on the support of the leftish parties here to talk about the film, but our campaign was very calm and careful, and the main point was not to scare people, and particularly not provoke questions! So the film was withdrawn before the elections on the $28^{\text {th }}$ of February."
} 
Em correspondência anterior, escrita em $1^{\circ}$ de março de 1973, Servolin havia alertado a equipe chilena sobre a má recepção da imprensa de esquerda, usando a mesma linha argumentativa sobre o desinteresse em mostrar conflitos internos em época de eleições ${ }^{180}$. Vale destacar que a esquerda francesa, envolta na consolidação de um programa comum entre os partidos Socialista e Comunista, obteve mais votos em 1973 do que no pleito legislativo anterior (1968) e no presidencial $(1969)^{181}$, portanto, encontrava-se em meio a tentativas de consolidação de alianças para ampliar sua base de sustentação, diante da qual as fragilidades da Unidade Popular chilena poderiam gerar desconfiança no eleitorado. A representante da SLON escreve a Sonia Jordan dizendo-se mais preocupada com a disputa eleitoral chilena do que com a francesa, mas alertando-a sobre o boicote dos jornais esquerdistas ao documentário:

Nós realmente pensamos no interesse das pessoas antes das eleições aqui e no Chile, mas, na verdade, os jornalistas políticos não perceberam a ocasião. E nós temos a impressão que os jornais que apoiam a união das esquerdas não quiseram, então, levantar questionamentos, na verdade, numa atitude "de não assustar de forma alguma as pessoas e não apresentar qualquer problema ou dificuldade" - uma atitude um tanto hipócrita! (SERVOLIN, $1973 a)^{182}$

O possível interesse - ou desinteresse - das esquerdas europeias por $L a$ première année foi tema de correspondência entre Guzmán e Marker, conforme revelam cartas trocadas entre eles em 1972. O chileno faz menção, em 24 de julho desse ano (GUZMÁN, 1972a), à dificuldade exposta pelo francês em fazer a esquerda francesa se interessar por um "filme de um país de esquerdas que têm problemas". Diante da rejeição do documentário pela seleção do festival de Pesaro, Guzmán lhe escreve novamente, em 15 de agosto, voltando à questão: "Contudo, creio que

\footnotetext{
${ }^{180}$ Poucas foram as matérias dedicadas ao filme na imprensa francesa. Entre elas, está a de Jean-Luc Douin, publicada em Télérame, em 17 de fevereiro de 1973. O crítico termina seu artigo destacando a coincidência de datas entre as eleições legislativas chilenas e francesas, ambas realizadas em março de 1973: "No próximo dia 4 de março, as eleições legislativas no Chile decidirão se a União Popular se manterá no poder ou se a oposição obterá a destituição do presidente Allende. É também em março que os franceses irão votar. Como os eleitores franceses não fariam alguma comparação?" (DOUIN, 1973, tradução nossa). Texto original: "Le 4 de mars prochain, les élections législatives au Chili décideront si l'Union Populaire garde le pouvoir ou si l'opposition obtient la destitution du président Allende. C'est aussi en mars que les Français iront voter. Comment les électeurs français ne feraient-ils pas quelques rapprochements?".

${ }^{181}$ O histórico em torno da elaboração de um programa comum será abordado no capítulo 4.

${ }^{182}$ Traduzido do original: "We really headed on the interest of people before the elections here and in Chili, but as a matter of fact the political journalists did not catch the occasion. And we have the impression that the newspapers supporting the left union did not want so take up the questions, as the attitude actually is 'do not by any means frighten the people and do not present any problems or difficulties' - a rather hypocrite attitude!"
} 
estamos frente ao problema que você mesmo assinalava: uma esquerda com problemas, já não é uma esquerda tão interessante.” (GUZMÁN, 1972b, tradução nossa). ${ }^{183}$

Por outro lado, a má divulgação de La première année foi um argumento apropriado pela própria Universidade Católica, após 11 de setembro de 1973, para romper o contrato com a SLON e tentar impedir sua difusão na Europa. Em abril de 1974, o coletivo francês recebeu uma carta com esse propósito, fato que gerou uma nova resposta de Guzmán (GUZMÁN, 1974), que nessa ocasião já se encontrava exilado em Cuba. O realizador chileno orientou a equipe responsável pela versão francesa a ignorar as correspondências enviadas desde o Chile, assim como a não enviar rendimentos contratuais. Ele classifica a nova direção da Universidade como "claramente ligada ao fascismo".

Nesse sentido, a correspondência em torno de La première année, bem como a análise das modificações realizadas por Marker em sua versão original, revela a tentativa de trazer o filme de Guzmán ao cenário cinematográfico e político francês, dando grande visibilidade à Unidade Popular chilena na França (apesar da falha em atingir este último objetivo ante a pouca divulgação). Esse esforço de Marker pode ser visto como forma de instrumentalizar o debate em torno dos limites enfrentados pela aliança dos partidos de esquerda, já que o realizador francês optou por adaptar uma produção que mostrava os trabalhadores no centro de embates sobre os caminhos a serem seguidos pelo governo.

Por outro lado, a opção por El primer año deve ser encarada como forma de denunciar boicotes e dificuldades enfrentados por Salvador Allende frente as ofensivas contrarrevolucionárias da direita chilena e internacional. Em 1972, ano em que o documentário foi difundido na França, essa denúncia poderia servir de alerta a possíveis contraofensivas dos setores conservadores adiante da formação de uma "Unión populaire" ${ }^{184}$ que demonstrava um potencial de crescimento eleitoral. Ainda sob essa perspectiva, a exibição dos boicotes ocorridos no Chile em La première année antecipou um tom que seria predominante após o golpe militar de 1973, quando Marker se empenhou em divulgar uma "verdade" sobre os anos da UP distinta da

\footnotetext{
${ }^{183}$ Traduzido do original: "Sin embargo, creo que estamos frente al problema que tú mismo señalabas: una izquierda con problemas, ya no es una izquierda demasiado interesante."

${ }^{184}$ O termo "Unión Populaire" é usado aqui entre aspas, pois se refere a uma expressão comum na França nessa época para designar a aliança em prol de um programa comum das esquerdas.
} 
disseminada pelos militares e mobilizar apoio aos opositores da ditadura, muitos deles na condição de exilados na Europa.

Essas motivações ao dedicar-se à Unidade Popular serão retomadas ao longo desta tese, tendo em vista que a aproximação de Marker com esse tema foi intensificada pela adaptação de mais uma produção chilena - Compañero presidente, denominada em sua versão francesa como On vous parle du Chili: ce que disait Allende - e pela atuação do diretor em outros filmes (na condição de realizador ou colaborador) - L'ambassade (1974), La spirale (1976) e O fundo do ar é vermelho (1977). 


\section{Chris Marker e a SLON em A batalha do Chile}

Após o 11 de setembro de 1973, o contato de Patricio Guzmán com Chris Marker, estabelecido durante a elaboração da versão francesa de $E l$ primer año, permitiu que o material salvo da montagem do que seria um filme sobre o terceiro ano do governo Allende se transformasse em material bruto para A batalha do Chile. Mais do que nunca, a ideia de testemunhar um processo histórico desempenhou o seu papel, não da maneira como supunha Guzmán: ao invés de registrar uma revolução, ele havia filmado o percurso de um dos golpes militares mais violentos do século XX. Nesse sentido, vale destacar uma das cenas do primeiro capítulo dessa trilogia, $A$ insurreição da burguesia, que paradoxalmente é uma das únicas não registradas pela equipe do chileno. Trata-se da famosa sequência gravada pelo operador de câmera Leonardo Henrichsen para a TV sueca, quando ele filmava a tentativa de derrubada frustrada da Unidade Popular, o "el tancazo", ocorrida cerca de dois meses antes do golpe bem-sucedido: sem deixar o oficio perante a ameaça dos soldados insurgentes, ele focaliza o homem que, após puxar o gatilho, se torna o seu assassino. ${ }^{185}$

A batalha do Chile se transformou em um ícone do cinema de exílio, feito por cineastas chilenos que se encontravam fora de seu país de origem e para um público também ausente do território nacional (consequências da repressão e da censura impostas pela ditadura). Mais do que "instrumentos do povo", como previa o Manifesto de los cineastas de la Unidad Popular, Guzmán e outros realizadores se tornaram testemunhas das articulações que derrubaram o governo no qual acreditavam. O otimismo presente nos documentários realizados no Chile após a vitória eleitoral - como aqueles produzidos pelo Centro de Cine Experimental, pela EAC e pela Chile Films ${ }^{186}$ - cedeu lugar à tentativa desesperada de denunciar as

\footnotetext{
${ }^{185}$ Patricio Guzmán narra que esse material fílmico foi recuperado por operários de esquerda que encontraram a câmera de Henrichsen caída, entregando-a à Chile Films (GUSMÁN, SEMPERE, 1977). Essa impressionante sequência tornou-se um ícone da denúncia do fascismo pinochetista após o 11 de setembro de 1973, sendo constantemente reproduzida, inclusive pela televisão francesa.

${ }^{186}$ Após o golpe, as instituições cinematográficas atuantes no governo Allende sofreram várias sanções ou foram fechadas. De acordo com Villarroel e Mardones: "Após o golpe de Estado muitos dos professores da Universidade do Chile foram expulsos e a infraestrutura do departamento audiovisual foi levada à televisão ou arrematada pelo melhor lance. Foram fechados os departamentos de cinema das Universidades do Chile e Técnica do Estado, UTE. Além disso, em 1978, foi fechada a Escola de Artes da Comunicação da Universidade Católica.” (VILLARROEL; MARDONES, 2012, p. 21). Traduzido do original: "Tras el golpe de Estado muchos de los profesores de la Universidad de Chile fueron expulsados y la infraestructura del departamento audiovisual fue llevada a la televisión o rematada al mejor postor. Fueron clausurados los departamentos de cine de la Universidades de Chile y
} 
verdadeiras manobras por trás do golpe militar, rebatendo o discurso oficial de que o general Augusto Pinochet "normatizava" o país, "expurgando" o "excesso de política e marxismo" ${ }^{187}$ reinante no período de Allende. Essas obras, em linhas gerais, buscaram retratar os acontecimentos do 11 de setembro como resultado de conflitos acirrados nos anos da UP, mas sobretudo de ações contrarrevolucionárias empreendidas pela direita local com apoio dos Estados Unidos.

Nesse sentido, o material audiovisual registrado durante o período entre 1970 e 1973 esteve presente na disputa pela memória dos anos da Unidade Popular, que se iniciou no pós-golpe, sendo incorporado por outras produções como imagens de arquivo. Adquiriram, portanto, um status documental que serviu a uma rememoração dos feitos de Allende, com ênfase em sua busca pelo poder popular autônomo e por uma sociedade igualitária. Nessa disputa, ocorrida sobretudo fora do Chile, às margens da intensa repressão do general Pinochet, surgiu a necessidade de aproveitar as obras desses cineastas como oposição ao discurso ditatorial de "colocar ordem" em uma situação de caos - tal como era argumentado pelo governo golpista. Sendo assim, as imagens da UP se tornaram armas não mais para mudar a vida do povo, mas para denunciar à comunidade internacional torturas, assassinatos e perseguições, uma tarefa atribuída ao cinema do exílio.

Sem dúvida, A batalha do Chile foi uma das produções realizadas nesse contexto que mais se destacou, recebendo prêmios importantes, como o Grande Prêmio do Festival Internacional de Grenoble (1975, 1976), o Grande Prêmio do Júri no Festival Internacional de Leipzig (1976), o Grande Prêmio no Festival Internacional de Bruxelas (1977), o Grande Prêmio no Festival Internacional de Benalmádena (1977), Grande Prêmio do Festival Internacional de Havana (1979), entre outros. Esse sucesso pode ser atribuído, parcialmente, à densidade do material fílmico que Guzmán dispunha na montagem. Uma parte desses extratos pertencia originalmente aos documentários El primer año e La respuesta de octubre; a outra era constituída de imagens inéditas, gravadas para uma produção dedicada ao terceiro ano do governo Allende que nunca chegou a ser concluída devido ao golpe.

A contribuição de Chris Marker com a equipe de filmagem de Guzmán começou justamente no projeto desse último filme, que a princípio tinha o nome de $E l$

Técnica del Estado, UTE. Por otra parte, en 1978, fue cerrada la Escuela de Artes de la Comunicación de la Universidad Católica.

${ }^{187}$ Os termos colocados entre aspas nessa frase retomam aqueles que frequentemente eram usados por Pinochet nos discursos proferidos logo após o golpe de Estado. 
tercer año (ou Equipe el tercer año, já que mais do que um título, tratava-se de uma referência ao ato de cobrir o terceiro ano de mandato de Salvador Allende). Os problemas econômicos que se agravavam impediram a entrada de película virgem no Chile, em decorrência de um bloqueio às importações vindas dos Estados Unidos. Mesmo a Chile Films enfrentava carência desse material, estando impossibilitada de colaborar com o cineasta chileno e seu coletivo. A solução encontrada pela equipe foi pedir auxílio para a Produtora América (PROA), um grupo de esquerda que forneceu os equipamentos, e para Chris Marker.

A ajuda foi solicitada a Marker em carta redigida em 14 de novembro de 1972, publicada posteriormente em Chile: el cine contra el fascismo (GUZMÁN; SEMPERE, 1977, p. 76-77). Nessa correspondência, Guzmán descreve a tensa situação vivida por seu país no período anterior às eleições parlamentares de março de 1973, com greves nos transportes, comércio e outros setores. Como reflexo, informa, a Chile Films estava em "colapso", e tanto seu roteiro sobre Manuel Rodríguez como qualquer outro parecia despropositado se não retratasse os distúrbios que tomavam conta do Chile. Dessa maneira, o realizador discorria sobre os objetivos de sua equipe e das dificuldades em obter meios para realizá-los, finalizando o relato com um pedido de auxílio. Marker respondeu imediatamente com um telegrama afirmativo e, em fevereiro de 1973, enviou o material solicitado.

$\mathrm{O}$ arquivo da ISKRA em Paris dispõe de uma pasta sobre $A$ batalha do Chile em que estão documentos importantes para compreender a parceria envolvida na rodagem das imagens e na montagem desse filme. No caso do envio de película virgem, ele parece ter sido realizado via Estados Unidos ${ }^{188}$, como revela uma correspondência endereçada desde Nova Iorque a Guzmán, por Edmond Caprasse, em 7 de fevereiro de 1973. Nessa carta, ele anuncia, na condição de representante da SLON, a remessa de película em $16 \mathrm{~mm}$ e de fita magnética. Posteriormente, em agosto de 2012, o realizador chileno exaltou o feito na ocasião da morte de Marker:

Os cinco membros da equipe de $A$ batalha do Chile não acreditávamos ao contemplar essas latas reluzentes (que pareciam espelhos). Nunca havíamos visto latas novas, já que sempre havíamos usado bobinas velhas com a data de validade do material

\footnotetext{
${ }^{188}$ Guzmán, no depoimento por ocasião da morte de Marker, em agosto de 2012, declara que recebeu a película diretamente da Kodak, o que foi possível, à revelia do bloqueio das importações, pelo fato de todos os encargos já estarem pagos. No entanto, cabe ressaltar que não há nos arquivos um documento que confirme que essa empresa foi a emissora, mas apenas um papel timbrado da August Films, possivelmente parceira da SLON em Nova Iorque, com a lista de materiais enviados.
} 
vencida. Também era a primeira vez que víamos as caixas de cartolina novas das fitas magnéticas. Deveríamos começar a filmar de imediato, com a máxima prudência (a fim de não esgotar o estoque antes do tempo). (GUZMÁN, 2012, tradução nossa) $)^{189}$

Esse envio da produtora norte-americana respondia a um pedido direto de Marker, em correspondência de 17 de janeiro de 1973. Nessa carta, ele descreve Guzmán como um "correspondente" da SLON no Chile, valorizando a parceria entre as duas partes. Em troca do material solicitado, oferecia $10 \%$ da receita a ser arrecadada com a exploração do filme na França depois de sua finalização ${ }^{190}$. Além dos termos objetivos do acordo, ele anexa uma espécie de sinopse e se refere ao título do documentário em andamento como Le moment de vérité, declarando que seu tema eram as eleições legislativas de março de $1973^{191}$. Marker completa ainda que Guzmán teria todos os outros itens necessários para sua realização: pessoal, laboratório, montagem e mixagem. O mais interessante dessa correspondência, porém, é o fato dela caracterizar o papel da SLON como o de uma coprodutora, antes mesmo da necessidade de se montar o filme no exílio, o que mostra que a ideia inicial do acordo entre os realizadores era mais do que uma mera ajuda: “A SLON, em Paris, representa a cooperativa de Guzmán, e terá a responsabilidade de finalizar a versão francesa do filme, assim como sua distribuição" (MARKER, 1973, tradução nossa) ${ }^{192}$.

Mesmo com os poucos registros sobre La respuesta de octubre, alguns documentos encontrados no arquivo da ISKRA revelam que, assim como havia ocorrido com El primer año e como estava previsto para o novo documentário de Guzmán (nessa época sem nome definido, ora chamado de El tercer año, ora de Le moment de vérité), essa produção teria também uma versão de divulgação para a Europa realizada pela SLON. Os indícios encontrados nesta pesquisa levam a crer que não sobrou uma cópia integral de sua montagem original (nem da chilena, nem da francesa), apesar de suas cenas terem sido decupadas e usadas em A batalha do Chile,

\footnotetext{
${ }^{189}$ Traduzido do original: "Los cinco miembros del equipo de La Batalla Chile no dábamos crédito al contemplar estas latas relucientes (que parecían espejos). Nunca habíamos visto latas nuevas ya que siempre habíamos empleado bobinas viejas con la fecha del material vencido. También era la primera vez que veíamos las cajas de cartón nuevas de las cintas magnéticas. Había que ponerse a filmar de inmediato con la máxima prudencia (a fin de no agotar el stock antes de tiempo)."

${ }^{190}$ De fato, os contratos assinados posteriormente entre a equipe chilena e a produtora francesa previam direitos extras à parte europeia - como uma cópia $16 \mathrm{~mm}$ com comentário em francês - como contrapartida ao fornecimento de película e fita magnética durante a rodagem.

${ }^{191}$ Vale destacar que as cenas gravadas para esse filme sobre as eleições legislativas são justamente as que iniciam a primeira parte de A batalha do Chile - A insurreição da burguesia.

${ }^{192}$ Traduzido do original: "SLON, à Paris, représente la coopérative de Guzmán, et aura la responsabilité de la finition du film dans sa version française, ainsi que de la distribution."
} 
como já foi salientado. No entanto, foi encontrada a transcrição das falas pertencentes ao filme tanto em espanhol como em francês, o que demonstra que seu texto foi traduzido com a intenção de exibir a produção na França.

A hipótese que surge, baseada nos contratos e nas correspondências encontrados na ISKRA, é a de que havia um plano de divulgação semelhante ao que ocorreu em La première année a ser realizado com La respuesta de octubre, mas que possivelmente resultou apenas em uma tradução do filme. Alguns documentos corroboram essa hipótese. Uma carta da SLON à organização do Festival de Leipzig, de $1^{\circ}$ de novembro de 1973 (SERVOLIN, 1973c), indica Patricio Guzmán como participante desse evento, exibindo justamente a produção realizada entre outubro e novembro de 1972. Nessa ocasião, pode-se dizer que a SLON agiu como distribuidora do filme, atuando pela sua difusão. Alguns dias depois, em 5 de novembro, o realizador chileno assinou uma autorização permitindo que a SLON fizesse “operações necessárias”, especialmente novas cópias (GUZMÁN, 1973b). A referência a uma versão francesa é citada por Guzmán (1973c) em carta ao produtor chileno Federico Elton, em 16 de dezembro de 1973, na qual ele cobra a tal versão, que deveria ter, segundo ele: um texto em francês proferido por um narrador francês; a filmagem dos letreiros em francês; cortes com o intuito de "abreviar" o documentário; elaboração de um epílogo associando os episódios retratados à queda de Allende.

Dessa forma, pode-se afirmar que a colaboração entre a equipe de Guzmán e a SLON, iniciada com La première année, se intensificou antes mesmo do golpe, com negociações para coproduções e colaborações em torno de La respuesta de octubre e do projeto El tercer año (que se transformaria em A batalha do Chile). Nessa época, ela representava para os realizadores chilenos um meio de dar visibilidade ao seu trabalho, denunciar no contexto internacional o que ocorria no Chile e, principalmente, viabilizar o processo de produção em um contexto de crise econômica que afetava as instituições culturais nacionais. Além disso, agregava valor ao coletivo em seu próprio país, facilitando a captação de recursos internos, como revela uma correspondência de 27 de janeiro de 1973, na qual Guzmán pede a Marker o envio de folhetos da versão francesa de El primer año, evidenciando que "[...] há senhores que se impressionam muito com a estreia francesa, e assim poderíamos captar 
financiadores quem sabe com mais rapidez." (GUZMÁN, 1973a, tradução nossa) ${ }^{193}$. É certo, todavia, que esse contato se tornou ainda mais estreito após o 11 de setembro, quando o realizador chileno e parte de seus colegas se tornaram exilados na Europa e seguiram no intuito de editar a enorme quantidade - e qualidade - de material fílmico que detinham sobre os anos da Unidade Popular.

Patricio Guzmán foi preso alguns dias após o golpe de Estado e esteve no Estádio Nacional durante duas semanas, nas quais foi ameaçado de fuzilamento e presenciou muitas das atrocidades ordenadas pela ditadura de Pinochet ${ }^{194}$. Ao ser libertado, embarcou para o exílio, assim como outros membros da equipe, especialmente José Pino, Bernardo Menz e Federico Elton. Ele destaca o importante papel exercido por Elton na ocasião, que foi o responsável por reunir e retirar do país todo material filmado por eles durante o governo Allende, fazendo com que nada fosse apreendido pelos militares - até mesmo os documentos escritos foram salvos (GUZMÁN; SEMPERE, 1977). Ao desembarcar em Paris, seu primeiro ponto de chegada ao exílio (posteriormente iria à Espanha e a Cuba), Guzmán declara ter se encontrado com Marker ainda no aeroporto:

Depois do golpe de Estado e depois de estar preso duas semanas no Estádio Nacional, por fim pude voar até a França. Foi um momento emocionante. A passagem foi paga pelos meus velhos companheiros espanhóis (da Escola de Cine de Madri)... No aeroporto de Orly, estava Chris, em um salão, quase completamente só. Olhava-me com muita curiosidade, punha as mãos como uma viseira, mudava de lugar. Não podia reconhecer-me, já que eu havia cortado a barba.

Nós nos deslocamos até Paris em um automóvel novo. Chegamos a uma casa de muito luxo, onde almoçamos. $\mathrm{O}$ ambiente era elegante. Havia belas mulheres (talvez gente do cinema), Chris era um grande sedutor. Mas sem dúvida era o marciano mais importante da reunião. Meu francês era deplorável. Durante anos, quase nunca pude entender realmente o que escutava. Minha capacidade de simulação aumentou até chegar a uma espécie de perfeição. Depois do almoço, fomos devolver o automóvel (que era emprestado). Finalmente pegamos o metrô, com minhas malas nas costas. Chegamos finalmente até uma pensão barata. Nos despedimos, e

\footnotetext{
${ }^{193}$ Traduzido do original: "[...] hay señores que impresionan mucho con el estreno francés, y así podríamos captar financistas quizás con mayor rapidez."

${ }^{194}$ Os relatos dos acontecimentos em torno de sua prisão e seu testemunho sobre o que se passava no Estádio Nacional foram publicados em 1977, no livro Chile: el cine contra el fascismo (GUZMÁN; SEMPERE, 1977).
} 
Chris se afastou em uma motocicleta de segunda mão. (GUZMÁN, 2012, tradução nossa) ${ }^{195}$

Apesar de um certo tom anedótico, esse relato expõe a função que Marker exerceria em A batalha do Chile após a chegada de Guzmán no exílio: a de produtor. A presença do realizador chileno na Europa iniciou os esforços pela produção de um documentário monumental, que utilizasse o material "salvo" da ditadura como instrumento de denúncia das verdadeiras motivações por trás dos conflitos no Chile ${ }^{196}$. Assim, o projeto El tercer año, que também já havia recebido o nome de Le moment de vérité (em referência ao caráter decisivo atribuído às eleições parlamentares de 1973), se transformou no que seria o primeiro capítulo, $A$ insurreição da burguesia, de uma trilogia.

A SLON executou um plano de trabalho e iniciou inúmeras tentativas de arrecadar fundos para a viabilidade do filme, que só ganhou o título de A batalha do Chile em sua fase final de montagem, realizada em Cuba ${ }^{197}$. De acordo com o depoimento de Guzmán (2012), Marker se empenhou pessoalmente em pedir auxílio financeiro para o documentário, marcando reuniões e almoços com a alta burguesia parisiense e nomes importantes do meio artístico (como Frédéric Rossif e Florence Delay). Além disso, ajudou pessoalmente ao companheiro exilado, hospedando-o na casa de amigos no período em que esteve na França.

\footnotetext{
${ }^{195}$ Traduzido do trecho original: "Después del golpe de Estado y después de estar preso dos semanas en el Estadio Nacional, por fin pude volar hacia Francia. Fue un momento emocionante. El pasaje me lo pagaron mis antiguos compañeros españoles (de la Escuela de Cine de Madrid)... En el aeropuerto de Orly estaba Chris, en un salón, casi completamente solo. Me miraba con mucha curiosidad, se ponía las manos en forma de visera, se cambiaba de lugar. No podía reconocerme, ya que me había cortado la barba.

Nos desplazamos hasta París en un automóvil nuevo. Llegamos a una casa de gran lujo donde almorzamos. El ambiente era elegante. Había bellas mujeres (tal vez gente de cine), Chris era un gran seductor. Pero sin duda era el marciano más importante de la reunión. Mi francés era deplorable. Durante años casi nunca pude entender realmente lo que escuchaba. Mi capacidad de simulación aumentó hasta llegar a una especie de perfección. Después del almuerzo fuimos a devolver el automóvil (que era prestado). Finalmente tomamos el metro, con mis maletas a cuestas. Llegamos finalmente hasta una pensión barata. Nos despedimos y Chris se alejó en una motocicleta de segunda mano."

${ }^{196}$ O então embaixador da Suécia no Chile, Gustav Harald Edelstam, foi uma figura fundamental no resgate das películas de Guzmán após o 11 de setembro. Sua atuação no auxílio aos militantes perseguidos será abordada no capítulo 4 , mas cabe aqui algumas considerações sobre a operação montada por Edelstam para salvar as gravações feitas na época de Allende. Mónica Villarroel e Isabel Mardones (2012) reconstituíram essa fuga de materiais por meio de depoimentos, chegando à conclusão que as latas de filme saíram do Chile em um barco chamado Rio de Janeiro, que partiu de Valparaíso em direção à Suécia. A funcionária da embaixada Lilian Indseth teria estabelecido contato com a esposa do realizador chileno, que lhe entregou cerca de cem rolos de película. Vale destacar que a embaixada da Alemanha também colaborou com a saída de filmes no contexto do pós-golpe, especialmente em relação às gravações de Raúl Ruiz (VILLARROEL; MARDONES, 2012).

${ }^{197} \mathrm{Na}$ época em que o projeto esteve a cargo da produtora francesa, manteve-se com o nome genérico de El tercer año.
} 
Por outro lado, havia uma mobilização por parte da SLON para conseguir parcerias com outras instituições, como modo de financiar o documentário. No arquivo da ISKRA, existem algumas cartas enviadas por Inger Servolin (1973d, 1973e), entre as quais se destacam duas de mesmo teor, endereçadas à televisão sueca e à televisão da Alemanha Oriental, pedindo recursos em termos de coprodução ou oferecendo previamente os direitos de exibição após a finalização. $\mathrm{O}$ texto se repete em ambas, apresentando os dois responsáveis pelo projeto - Patricio Guzmán e Federico Elton - e narrando as dificuldades que ambos haviam passado no Estádio Nacional até finalmente alcançarem o exílio. Esse fator pesou no discurso pelo financiamento, sobretudo porque punha seus realizadores na condição de testemunhas de um processo que, devido à repressão interna, era pouco conhecido no exterior. Para completar, seu status de vítimas reforçava a necessidade de apoiar não apenas o filme, mas os próprios refugiados submetidos a essa condição em decorrência de seu engajamento em prol da UP. Vale destacar que as emissoras desses dois países já se interessavam em acompanhar os acontecimentos no Chile durante a Unidade Popular, veiculando produções sobre o tema e enviando seus próprios correspondentes à América Latina.

Nessas correspondências, destaca-se também a ênfase na presença de Chris Marker na equipe, embora fique claro que o discurso fílmico seria composto pelos realizadores chilenos. Essa espécie de "aval" do diretor francês era visto como fundamental para assegurar a continuidade do projeto e seu sucesso, tendo em vista que os latino-americanos eram meros desconhecidos no contexto europeu da época. Em carta enviada por Servolin à TV sueca, datada de 17 de novembro de 1973, ela usa esse argumento para atrair os investidores ${ }^{198}$ :

Talvez seja importante destacar também que Chris Marker vai participar do filme, mas, é claro, respeitando como sempre nosso princípio de ter filmes feitos do interior, nós achamos importante que o filme deva ser feito por chilenos que tragam sua experiência e seu conhecimento sobre seu povo. (SERVOLIN, 1973e, tradução nossa) $)^{199}$

\footnotetext{
${ }^{198}$ O mesmo parágrafo se encontra também na correspondência de 11 de dezembro de 1973 , enviada à televisão da Alemanha Oriental.

${ }^{199}$ Traduzido do original: "It's perhaps important to point out as well that Chris Marker will participate on the film, but of course, respecting as usual our principle of having films made from the interior, we find it important that the film should be made by Chileans bringing their experience and their knowledge about their people."
} 
Entre os documentos da ISKRA, está um planejamento detalhado de 29 etapas previstas desde o recebimento das latas até a elaboração da última versão de $A$ batalha do Chile - A insurreição da burguesia, incorporando etapas da produção e um plano de trabalho (SLON, s/d). Esses manuscritos, embora sejam apenas intenções de procedimentos, e não informes feitos a posteriori, permitem a compreensão da rede de articulações envolvida no processo de realização do documentário. Por meio deles, estima-se a participação de alguns atores e estabelece-se um percurso de circulação do material até sua chegada ao ICAIC, onde foi realizada a maior parte da montagem ${ }^{200}$. Com base nessas fontes da ISKRA, não é possível saber a resposta das televisões contatadas pela equipe francesa como coprodutoras, embora o fato de não estarem creditadas no filme indique uma participação nula ou remota. Porém, pode-se afirmar que a Suécia foi um dos países por onde o material bruto passou antes de chegar a Paris e, posteriormente, em Cuba. Esse fato é significativo, pois essa nação foi uma das que mais recebeu chilenos exilados, abrigando organizações de solidariedade voltadas para o tema, como Chilekommitté e Comitê Salvador Allende (fato que será retomado no capítulo 4).

$\mathrm{O}$ esquema de produção revela que o material bruto foi enviado do Chile à Suécia pela Produtora América (que colaborava com El tercer año desde o início do projeto) e pela Santos Dumont ${ }^{201}$. Federico Elton, que estava exilado em Paris, foi encarregado pela SLON de ir buscar o material. Sua ida ao país é citada na correspondência de Servolin à televisão sueca e também em carta enviada ao próprio Elton por Patricio Guzmán, que estava na Espanha (GUZMÁN, 1973c). Nesse último documento, de novembro de 1973 - escrito em tom bastante informal, já que se tratava de uma comunicação pessoal entre dois amigos -, o realizador chileno demonstra desconfiança ante a possibilidade da coprodução sueca e pede para que o companheiro averigue a chance desse acordo e garanta a integridade do material e seu envio à França:

Como já estamos no final do mês, vejo a coisa com certo ceticismo. Você tem de ir à Suécia no começo de janeiro, como combinamos, a fim de chegar lá no máximo dia 3 e se ambientar. Se, ao chegar, não tiver aparecido ainda o produtor, então tem de deixar em cofre, acorrentado, guardado, o material em sua integridade e voltar à

\footnotetext{
${ }^{200} \mathrm{O}$ trajeto do material bruto do Chile à Suécia foi mapeado em VILLARROEL; MARDONES, 2012.

${ }^{201}$ Não foram encontradas, ao longo da pesquisa, mais dados sobre essa instituição, Santos Dumont, que aparece citada em documentos relativos à produção de A batalha do Chile. É possível, pelo contexto das referências localizadas, que fosse uma produtora.
} 
Paris para reiniciar os esforços. (GUZMÁN, 1973c, tradução nossa $)^{202}$

Há distintas versões do esquema de trabalho nos arquivos da ISKRA, o que revela que o processo foi alterado inúmeras vezes até sua migração a Cuba. Mas, de modo geral, esses esquemas indicam que, reunido o material bruto na SLON, seria feita nessa produtora uma primeira montagem, prevista para março de $1972^{203}$. Em seguida, a equipe iria ao ICAIC, em abril e maio, para realizar a segunda e a terceira versões da edição. No país latino-americano, seriam filmados as fotografias e os intertítulos. Em junho, voltariam a Paris para usar os laboratórios aí disponíveis na finalização e na confecção de cópias de divulgação. Parte dos trabalhos relativos ao som de A batalha do Chile - A insurreição da burguesia teria começado na Espanha.

Dessa maneira, pode-se dizer que, embora a participação do instituto cubano estivesse programada desde o início, ela cresceu ao longo do processo de produção, já que inicialmente era restrita a apenas uma de suas etapas. Essa migração para Cuba se deu, sobretudo, por intermédio de Marker, que apresentou Saúl Yelin a Guzmán logo após a chegada do diretor no exílio (GUZMÁN, 2012). Diretor de relações internacionais do ICAIC, Yelin é descrito por Mariana Villaça como uma espécie de "embaixador do cinema cubano", já que possuía muitos contatos na Europa e domínio de vários idiomas (VILLAÇA, 2010). Como "braço direito" de Alfredo Guevara, serviu, no caso de $A$ batalha do Chile, como um intermediário entre sua instituição e a SLON.

É importante refletir sobre os motivos que levaram ao desaparecimento da SLON dos créditos de A batalha do Chile - A insurreição da burguesia -, tendo em vista o importante papel que essa instituição exerceu no documentário, conforme foi demonstrado neste capítulo. Sua participação está restrita aos agradecimentos pessoais a Chris Marker e à menção de sua autoria entre as fontes de material de arquivo utilizado. Além de aparecer na lista geral de colaboradores, o nome do

\footnotetext{
${ }^{202}$ Traduzido do original: "Como ya estamos en finales de mes, veo la cosa con cierto esceptismo. Tú tienes que marcharte a Suecia a primeros de Enero, tal como acordamos, a fin de que llegues allá a lo sumo el tres y te ambientes. Si al marcharte no ha aparecido todavía el productor, entonces tienes que dejar abovedado, encadenado, guardado, el material en su integridad, y volver a Paris para reiniciar gestiones." (GUZMÁN, 1973c).

${ }^{203}$ Apesar de guardar três versões diferentes para o esquema de produção, o arquivo da ISKRA tem apenas uma versão do Plano de trabalho, que coincide com o terceiro esquema. Dessa forma, as afirmações realizadas neste texto foram retiradas desse documento, que quando cotejado com o restante da documentação da produtora demonstrou-se o mais atualizado. No entanto, não significa que esse Plano tenha sido cumprido à risca, mas apenas que seu conteúdo correspondia ao planejamento em fase inicial do processo de produção de A batalha do Chile.
} 
realizador francês está ainda entre os responsáveis pelo roteiro (assim como Pedro Chaskel e outros que entrariam na etapa cubana do processo), o que é um indício de que até a ida a Cuba o esquema de produção depositado nos arquivos da ISKRA pode ter sido seguido. Nesse caso, é possível que o material bruto tenha chegado ao país caribenho já com uma primeira edição realizada na França, hipótese não confirmada, mas endossada pelos indícios encontrados.

As pesquisas no acervo da ISKRA revelaram aspectos nunca antes abordados nas diversas publicações que se dedicam ao estudo de A batalha do Chile. Nessas fontes, de modo geral, a participação do ICAIC na montagem é exaltada, sendo que a atuação da SLON é restrita à mera intermediação de Chris Marker no processo com o instituto cubano. No entanto, os documentos aqui analisados revelam que o diálogo entre a equipe chilena e a francesa começou antes mesmo do golpe de 11 de setembro, em acordos que previam o envio de película em troca de encargos obtidos com sua divulgação na Europa. Após o trágico evento que pôs fim à Unidade Popular, esse diálogo se transformou em um plano de realização dirigido pela SLON, que se materializou em ações concretas de produção, inclusive com a efetuação de inúmeros contratos e pagamentos aos envolvidos.

A carta enviada por Guzmán a Elton (GUZMÁN, 1973c) cita uma remuneração feita pela SLON ao realizador no valor de mil francos. No entanto, as altas despesas necessárias à sua instalação e de sua família geraram a necessidade de mais um montante, de 1500 francos, solicitados por Guzmán por meio dessa correspondência. No documento, está um retrato das muitas dificuldades enfrentadas pelos exilados na chegada à Europa: "Conclusão. estou vivendo dos móveis que vendi em Santiago. Necessito que a SLON me envie 1500 francos a mais. Não somente para 'descansar', mas para viver, pois ainda não tive trabalho." (GUZMÁN, 1973c, tradução nossa ${ }^{204}$. Essa carta é mais uma evidência de que a atuação da produtora francesa no processo de realização de A batalha do Chile foi intensa nos primeiros meses de exílio dos realizadores.

A correspondência enviada por Guzmán a Elton é escrita em um tom impaciente, como é possível perceber no trecho citado no parágrafo acima, e revela preocupação diante da lentidão na produção do documentário. O realizador usa da

\footnotetext{
${ }^{204}$ Traduzido do original: "Conclusión, estoy viviendo de los muebles que vendí en Santiago. Necesito que SLON me envié 1500 francos más. No solamente para 'descansar', sino para vivir, porque no he tenido trabajo todavía."
} 
ironia e até de um vocabulário pouco ortodoxo para responder às demandas feitas pela SLON (como o título definitivo e as músicas que seriam usadas), insinuando que havia uma preocupação maior com a difusão do filme do que com os esforços em concretizar sua montagem. Essa carta traz indícios importantes para entender a permanência de Guzmán em Cuba (conforme ele mesmo indica no depoimento de 2012, foi ao país para ficar seis meses e acabou ficando seis anos), assim como para compreender um posterior "silêncio" sobre a participação da SLON na primeira parte de A batalha do Chile. Nessa correspondência, ele ameaça um rompimento com as tentativas de arrecadar recursos na Europa, inclinando-se a estreitar as relações com o ICAIC: "Se não aparece um produtor, quer dizer simplesmente que não aparece, que teremos que ir a Cuba desde já, porque ninguém em Paris se interessa em nos dar cem mil francos. E ponto." (GUZMÁN, 1973c, tradução nossa) ${ }^{205}$

Dessa maneira, pode-se dizer que o pouco conhecimento desse material de arquivo disponível na ISKRA e o apoio dos estudos sobre A batalha do Chile prioritariamente em fontes testemunhais contribuíram para um apagamento da atuação da SLON na produção do filme. Apesar de não haver documentos que comprovem um rompimento de fato com a produtora francesa, é provável que, com a chegada ao ICAIC e a perspectiva de montar os outros dois episódios em Cuba, a equipe chilena tenha preferido esse caminho em detrimento de seguir com as negociações na Europa. Dessa forma, o discurso elaborado posteriormente pelos envolvidos preferiu manter a participação de Marker como uma peça importante - o que, sem dúvida, favoreceu que o filme circulasse nos meios cinematográficos europeus -, mas subvalorizar essas primeiras etapas iniciadas no exílio francês, que foram também fundamentais para que o filme fosse montado em um momento relativamente próximo ao golpe de 1973.

Por fim, vale ressaltar um papel importante da SLON, atribuído pelo próprio Guzmán na correspondência de novembro de 1973c: ao difundir os documentários dos realizadores chilenos na Europa, colaborava diretamente com os movimentos de solidariedade montados no exílio. Nessa correspondência, ele pede agilidade na tradução e na montagem de uma versão francesa para La respuesta de octubre, calculando os benefícios que isso poderia trazer. Ele comenta o crescimento da demanda por La première année após o golpe, concluindo que existia uma procura

\footnotetext{
${ }^{205}$ Traduzido do original: "Si no cae productor, quiere decir simplemente que no cae, que tendremos que marcharnos à Cuba desde ya, porque nadie se interesa en Paris por darnos los cien mil francos. Y punto."
} 
por materiais filmados no Chile de Allende, o que garantiria rentabilidade à produção sobre o segundo ano da Unidade Popular. A arrecadação poderia beneficiar, segundo ele, não apenas a SLON, mas os comitês pró-Chile.

O objetivo deste subcapítulo foi justamente analisar a atuação de Chris Marker e da SLON em A batalha do Chile - A insurreição da burguesia. Esse papel foi, principalmente, o de produtor e mediador entre os sujeitos que participaram do processo de produção. Nesse sentido, optou-se aqui em não realizar uma análise fílmica, já que o papel do cineasta francês no resultado final da montagem não parece ter sido tão relevante. Foi realizada ainda a escolha por não aprofundar a etapa cubana da realização do documentário, já que ela foi detalhadamente descrita pelo próprio Guzmán no livro Chile: el cine contra o fascismo (1977). Vale, porém, algumas breves considerações sobre essa fase.

Em seu relato sobre a parceria com o ICAIC, Guzmán declara que a decisão de ir ao instituto cubano foi tomada a partir da constatação de que não seria possível juntar os recursos necessários na Europa. É certo, todavia, que essa ida já estava prevista no início da montagem, embora com outra duração e importância. Dessa forma, ele descreve como se juntou a Federico Elton, José Pino, Pedro Chaskel (a quem valoriza enormemente pelo papel na montagem) e Marta Harnecker em Havana, recompondo parte da equipe original de El tercer año. O realizador chileno enfatiza ainda a importância de vivenciar a Revolução Cubana para a construção de um discurso fílmico que, certamente, ganhou ares de autocrítica nas duas últimas partes da trilogia - $O$ golpe de Estado e $O$ poder popular. Também em Cuba, os esforços em torno de A batalha do Chile mobilizaram outras instituições de apoio aos exilados chilenos, como o Comitê Chileno Antifascista, onde havia um centro de documentação que alimentou os cineastas com fontes bibliográficas diversas. Nesse sentido, Guzmán afirma que o resultado teria sido outro caso o filme tivesse sido montado em um país capitalista.

A batalha do Chile - especialmente seu primeiro episódio, A insurreição da burguesia - pode ser visto como desencadeador de uma experiência que pôs em contato distintos atores, sendo em si mesmo um objeto de resistência no contexto do exílio chileno. Como foi mostrado neste capítulo, seu projeto e suas ideias foram difundidos em distintos países mesmo antes de sua montagem, aglutinando esforços em torno de uma resistência à ditadura chilena desde o exterior. Nesse sentido, a atuação de Marker e da SLON colaborou com a difusão do documentário e com o 
engajamento de forças políticas para sua concretização - inclusive sendo o intermediário direto com o ICAIC.

Em reportagem publicada no periódico Rouge (de Montreuil), em 5 de janeiro de 1977, por ocasião da exibição da segunda parte, O golpe de Estado, Guzmán teceu alguns comentários sobre a circulação de $A$ insurreição da burguesia ${ }^{206}$. De acordo com o realizador, o público nos cinemas parisienses havia sido, como era de se esperar, "politizado", mas restrito. No entanto, ele declara que, em Cuba, a produção havia circulado bastante, em "cinemas-móveis" que percorriam o país. Porém, se a quantidade de espectadores seguiu baixa na França, a exemplo de La première année, a repercussão do documentário nos meios especializados foi muito maior, pelo que se pode estimar pela grande quantidade de notícias e artigos publicados na época. $\mathrm{O}$ golpe de Estado e as trágicas notícias que chegavam do Chile ajudam a explicar esse aumento do interesse pelo tema, bem como a mobilização em torno dos movimentos de solidariedade. Em 21 de maio de 1975, o crítico Louis Marcorelles (1975a) classificou a exibição do filme em Cannes com um dos maiores destaques do Festival $^{207}$. Ele avaliou ainda a importância dos três principais colaboradores, em uma clara tentativa de juntar nomes de peso do cinema militante chileno, cubano e francês em torno de A batalha do Chile: Pedro Chaskel, Julio García Espinosa e Chris Marker.

A ligação de Marker com o filme, embora tenha sido pouco esmiuçada nos artigos da época, foi citada constantemente na imprensa francesa como modo de chamar atenção para a produção. O mesmo Marcorelles (1975b) publicou um longo depoimento de Guzmán em 27 de junho de 1975, em que o realizador chileno narrava a importância do cineasta francês na elaboração de uma versão francesa para $E l$ primer año e no envio de película virgem ao Chile ainda nos anos da Unidade Popular. No entanto, ele não faz nenhuma menção a sua articulação na produção de $A$ batalha do Chile, dedicando todos os créditos da montagem ao ICAIC e a Pedro Chaskel.

\footnotetext{
${ }^{206}$ Guzmán declara nessa mesma reportagem que o comentário realizado para a versão francesa de $A$ batalha do Chile - A insurreição da burguesia era apenas uma tradução literal do original, mas constata que a locução em francês havia imprimido uma emoção ausente na versão em espanhol, que buscava certa "frieza" (em suas palavras).

${ }^{207}$ A batalha do Chile - A insurreição da burguesia participou da Quinzena dos Realizadores do Festival de Cannes, em maio de 1975. No entanto, sua estreia nos cinemas de Paris ocorreu apenas em novembro desse mesmo ano.
} 
Como foi demonstrado, a memória sobre esse documentário criou uma ênfase em torno da presença de Chris Marker no processo de A batalha do Chile, em que seu nome foi constantemente evocado como um elemento agregador de valor - uma espécie de "selo" do cinema militante -, mas que desprezou a participação efetiva da SLON na produção do documentário. Na ocasião da morte de Marker, Guzmán publicou um depoimento - bastante citado neste capítulo -, rememorando a importância do francês em sua principal obra, e declarando também sua estranheza com o fato de Marker nunca ter lhe procurado após o depósito de uma cópia do filme no escritório da produtora:

Nunca recebemos nenhuma nota, nenhuma carta, nenhuma mensagem telefônica a respeito do filme por parte dele. Durante meses nos perguntamos por que não o fez. Durante anos me perguntei isso.

É necessário dizer que vivíamos um tempo muito politizado e o grupo de Chris formava parte de artistas e intelectuais muito radicais de esquerda. Meu filme não o era. Ao contrário, A batalha do Chile é pluralista e não está dedicado a nenhuma outra militância que não seja a do sonho chileno (a luta de um povo sem armas), a utopia de um povo em sua perspectiva mais ampla, que eu pude ver com meus olhos e sentir com meu corpo dentro desse Chile vibrante com o qual muito me identifiquei e me identifico hoje. Na realidade, durante muito tempo senti que era difícil para mim ser reconhecido na França com minha obra de cinema-direto, a primeira do Chile e uma das poucas do mundo que mostra passo a passo a agonia de um povo revolucionário. (GUZMÁN, 2012, tradução nossa) ${ }^{208}$

Sua hipótese, a de que seu filme era muito pluralista para um grupo de "radicais de esquerda" franceses, parece não se sustentar. Em primeiro lugar, porque A batalha do Chile - A insurreição da burguesia não apresenta, como as duas últimas partes da trilogia, pontos de vista distintos no interior da própria esquerda, já que se dedica à urgência de denunciar as ações da direita. Essa "autocrítica" aparece com força apenas em $O$ golpe de estado e, sobretudo, em $O$ poder popular (produções

\footnotetext{
${ }^{208}$ Traduzido do original: "Nunca recibimos ninguna nota, ninguna carta, ningún mensaje ni llamada telefónica acerca del filme por parte de él. Durante meses nos preguntamos por qué no lo hizo. Durante años yo me he preguntado lo mismo.

Hay que decir que vivíamos un tiempo muy politizado y el grupo de Chris formaba parte de artistas e intelectuales muy radicales de la izquierda. Mi película no lo era. Por el contrario, La batalla de Chile es pluralista y no está dedicada a ninguna otra militancia que no sea la del sueño chileno (la lucha de un pueblo sin armas), la utopía de un pueblo en su perspectiva más amplia, que yo pude ver con mis ojos y sentir con mi cuerpo adentro de ese Chile vibrante con el que me identifiqué y me identifico hoy. En realidad, durante mucho tiempo sentí que era difícil para mi ser reconocido en Francia con mi obra de cine directo, la primera de Chile y una de las pocas en el mundo que muestra paso a paso la agonía de un pueblo revolucionario."
} 
posteriores à atuação da SLON). Além disso, a filmografia de Marker nos anos 1970 traz inúmeras produções dedicadas às contradições, aos fracassos e às derrotas desse campo político, caso especialmente de On vous parle de Prague: le deuxième procès d'Arthur London (1971), L'ambassade (1974) e O fundo do ar é vermelho (1977). Assim como a carta enviada a Federico Elton em 1973, esse depoimento de Guzmán corrobora a tese de que possíveis tensões surgidas durante o processo de produção em Paris contribuíram para a consolidação de uma memória que o apagou, exaltando a atuação do ICAIC - sem dúvida, de importância muito maior. 


\section{Compañero presidente (1971) e On vous parle du Chili: ce que disait Allende $(\mathbf{1 9 7 3})^{209}$}

Em correspondência de 27 de janeiro de 1973, Guzmán (1973a) perguntava a Marker sobre o recebimento de cabos e notas fiscais que havia enviado à França por intermédio de Régis Debray. Essa menção é apenas mais um dos muitos indícios que confirmam o papel de mediador exercido pelo jornalista francês entre o Chile e seu país de origem durante a Unidade Popular, considerando que o mesmo estabeleceu residência nas duas nações e, como já foi colocado, tinha proximidade com a presidência da república. Nesse sentido, foi justamente sua entrevista com Salvador Allende, publicada no livro Entretiens avec Allende sur la situation au Chili e editada no documentário Compañero presidente (1971), de Miguel Littin, a fonte escolhida por Marker para abordar a UP nos meses subsequentes à sua queda.

Com o golpe militar em setembro de 1973 e a morte do líder da Unidade Popular, Marker se interessou em remontar essa produção, transformando-a em um instrumento de denúncia e mobilização em torno da solidariedade ao Chile - causa pela qual se engajaria também, quase dois anos mais tarde, em A batalha do Chile. Assim, sua proximidade com Debray permitiu o acesso a uma cópia de Compañero presidente e, com a autorização de Littin, o realizador utilizou a SLON para montar mais um episódio da série de boletins informativos de caráter militante: On vous parle $d u$ Chili: ce que disait Allende (1973). Em entrevista à pesquisadora, enviada por $e$ mail em 27 de outubro de 2011, ele comentou a iniciativa de editar esse documentário, atribuindo todos os créditos ao diretor chileno:

On vous parle $d u$ Chili é, como você notou, uma versão reduzida do filme de Miguel Littin. Eu não tenho nada a ver com isso: simplesmente julguei urgente, logo após o golpe de Estado, apresentar uma imagem de Allende diferente das lágrimas de crocodilo derramadas pela mídia, e como, graças a Régis Debray, eu tinha uma cópia de Compañero presidente, me foi possível transmitir em um canal de televisão esses trechos de um retrato inteligente e justo. Em seguida, nosso coletivo ISKRA o fez circular

\footnotetext{
${ }^{209}$ Para este subcapítulo, foi analisado um DVD de Compañero presidente lançado no Chile pelo selo "100 años de Chile", assim como uma cópia de On vous parle du Chili: ce que disait Allende cedida à pesquisadora pela ISKRA. Também foi consultada a transcrição da entrevista de Debray com Allende, publicada em Entretiens avec Allende sur la situation au Chili (1971).
} 
na série On vous parle, com permissão de Miguel Littin. (MARKER, 2011, tradução nossa) $^{210}$

Nesse depoimento, aparecem alguns aspectos interessantes para pensar $O n$ vous parle $d u$ Chili. O primeiro é a declaração de que o filme foi realizado a princípio para ser exibido na televisão e que, em seguida, circulou em circuitos alternativos e militantes com auxílio da $\mathrm{SLON}^{211}$. Isso mostra que Marker editou sua versão tendo em vista uma divulgação garantida, em um momento em que o interesse pelo Chile era crescente, em virtude do golpe e da trágica morte de Salvador Allende no palácio de La Moneda. O segundo aspecto é que esse relato confirma a hipótese de que, apesar do crédito ser atribuído aos dois diretores, a remontagem de Compañero presidente foi realizada com a autorização, mas sem a presença de Littin, que se encontrava no exílio no México. Assim, embora Marker tenha se esforçado para atribuir todos os méritos ao realizador chileno, vale ressaltar que seus novos cortes geraram diferenças significativas entre as duas produções. É necessário ainda destacar que, além de uma simples redução do filme, o realizador francês alterou a ordem das sequências, imprimindo-lhe outras características.

Valérie Mayoux, que trabalhava como montadora na ISKRA, ao lado de Marker, comentou sobre a urgência em produzir uma versão a partir de On vous parle $d u$ Chili e do material que a produtora já tinha em mãos. Seu depoimento, publicado em um dossiê especial sobre o realizador francês organizado pela Positif em março de 1997, destaca também a intenção concretizada de vender o documentário para a televisão, em um momento em que o golpe de Estado no Chile atraía os holofotes da imprensa francesa. Ela declara que, quando começavam a planejar o que seria $O$ fundo do ar é vermelho, esse evento interrompeu os trabalhos devido a uma nova urgência:

Logo a seguir, ocorreu o golpe de Estado no Chile, e nós pegamos de imediato um dos extratos que nós tínhamos em mãos, a

\footnotetext{
${ }^{210}$ Traduzido do original: "On vous parle du Chili est, comme vous l'avez noté, une version raccourcie du film de Miguel Littin. Je n'ai donc rien à y voir: j'ai simplement jugé urgent, tout de suite après le putsch, de présenter une image d'Allende différente des larmes de crocodiles déversées par les media, et comme grâce à Régis Debray j'avais une copie de Compañero Presidente, il m'a été possible de refiler à une chaîne de télévision ces extraits d'un portrait intelligent et juste. Ensuite notre collectif ISKRA l'a fait circuler dans la série On vous parle, avec l'accord de Miguel."

${ }^{211}$ On vous parle du Chili foi uma das produções exibidas em 1974 na mostra Solidariedade com Chile, integrante do Festival de Oberhausen, na Alemanha. Essa mostra exibiu nove filmes, sendo a maior parte produzida por realizadores não chilenos, mas que se engajaram na causa solidária aos perseguidos pela ditadura instaurada naquele país. Ver (VILLARROEL; MARDONES, 2012).
} 
entrevista de Régis Debray com Allende filmada por Miguel Littin. Chris me enviou em missão: eu me lembro de ter ido encontrar Philippe Gildas na televisão para lhe vender isso, com sucesso. Então, nós fizemos uma montagem de urgência, que foi difundida logo em seguida. (MAYOUX, 1997, p. 94, tradução nossa) ${ }^{212}$

Nessa entrevista, o embate entre Salvador Allende - símbolo da "via pacífica" ao socialismo - e Régis Debray - visto na França como um dos maiores defensores da tática de guerrilhas - é bastante forte em algumas passagens, criando vários momentos de tensão. No filme de Littin, os dois protagonistas aparecem frente a frente em quase todos os planos, cada um de um lado da mesa, materializando essa polarização. Debray, que se define na conversa como um "provocador", incomoda o presidente chileno, questionando, por exemplo, se seu governo seria revolucionário ou reformista, bem como sobre os limites do caminho democrático diante de um parlamento e de um judiciário conservadores. A frágil posição de um país latinoamericano cujas nacionalizações desagradavam aos Estados Unidos e a postura das forças armadas chilenas são outros assuntos delicados na entrevista.

Ignacio Del Valle Dávila revela que a produção de Compañero presidente foi marcada por tensões, o que torna o debate sobre o filme acalorado até os dias de hoje (DEL VALLE DÁVILA, 2012b). O pesquisador entrevistou Miguel Littin em 2008, ocasião em que ele declarou que teria sido contra a realização do documentário, por considerar que o presidente não deveria se submeter às pressões do jornalista. Com a insistência de Allende, aceitou fazê-lo, apesar de afirmar ter entrado em conflito durante o processo, acusando Debray de colocar seu "ego de intelectual" à frente da causa da Unidade Popular. A própria Beatriz Allende, que havia recebido o francês no palácio presidencial, escreveu a Alfredo Guevara em 12 de abril de 1971, depois de assistir à montagem final, queixando-se do papel de "juiz" que o entrevistador teria assumido para si mesmo, decidindo sobre se a experiência chilena seria ou não uma revolução (GUEVARA, 2009, p. 233).

Apesar dessa tensão, na edição de Littin, os cenários das gravações - a casa do entrevistado e a residência presidencial de Valparaíso - contribuem para a imagem de um chefe de Estado acessível, um "companheiro", o que o faz se sobressair diante das

\footnotetext{
${ }^{212}$ Traduzido do original: "Là-dessus il y a eu le coup d'État au Chili, et nous avons tout de suite pris un des morceaux que nous avions sous la main, les entretiens de Régis Debray avec Allende filmés par Miguel Littin. Chris m'a envoyé en délégation: je me souviens être allée voir Philippe Gildas à la télévision pour lui vendre ça, avec succès. On a donc fait un montage d'urgence, qui a été diffusé tout de suite."
} 
provocações de Debray. A alcunha expressa no título, "companheiro presidente", é confirmada por algumas sequências de gravações externas, intercaladas em determinadas passagens na montagem com a entrevista propriamente dita, nas quais se vê multidões saudando o chefe de Estado. Os últimos três minutos do documentário, especialmente, exaltam um novo momento da História chilena, pela presença do hino da Unidade Popular, Venceremos, e também por cenas de grandes manifestações de rua. No entanto, mesmo nesse trecho, escuta-se ao fundo a voz de Debray em off reiterando que, se diante do lema pátrio chileno, "pela razão ou pela força", a razão havia vencido no pleito eleitoral, valeria perguntar-se "até quando" ela se sustentaria.

Quando cotejado com Entretien avec Allende sur la situation au Chili, a íntegra da conversa entre Allende e Debray, percebe-se que Littin se esforçou em amenizar essa tensão sobre a via de acesso ao socialismo (mesmo que ela continue presente), cortando algumas das questões delicadas postas pelo francês. A primeira evidência dessa tentativa de moderação é notada pela quantidade de supressões na discussão sobre a situação recente do Chile, que tinha muito mais espaço no texto escrito. Por outro lado, o tema das heranças políticas do chefe de Estado seguiu tendo importância na produção audiovisual. Há ainda em Compañero presidente outras estratégias para aliviar o embate. No livro, por exemplo, aparece a indagação de que o governo teria sofrido uma "desmobilização popular" quando comparado o período atual (janeiro de 1971) ao pré-eleitoral. Em alguns trechos da entrevista, Debray pressiona Allende a criticar instâncias políticas superiores, como a Corte Suprema e o parlamento, pressão diante da qual ele procura esquivar-se. Esses aspectos foram ignorados pelo realizador chileno.

A montagem de Chris Marker, feita logo após o golpe de Estado de 1973, reduziu ainda mais a tensão entre os dois protagonistas. De modo geral, sua edição segue uma lógica "de trás para frente"; ou seja, os últimos planos da versão chilena introduzem On vous parle du Chili. Essa opção denota um esforço em reconstituir esse passado recente e rememorá-lo, reforçando aspectos fundamentais do governo deposto. Se Compañero presidente havia sido um teste imposto pelo próprio Allende para que, ao responder as provocações de Debray, ganhasse repercussão internacional, o filme produzido para a SLON minimiza a presença do entrevistador francês e exalta o discurso bem elaborado do líder morto da Unidade Popular. A montagem original, de cerca de 70 minutos, foi reduzida a 15, nos quais estão ressaltadas falas proféticas 
do presidente (o documentário apresenta uma espécie de "tragédia anunciada") e discursos que o caracterizam como um homem sábio e sensato. Antes do início das sequências, Marker inseriu um intertítulo que deixa claro suas intenções:

Em 1971, o cineasta chileno Miguel Littin fez um filme em torno de uma conversa entre Régis Debray e o presidente Allende: Compañero presidente. Nós agrupamos aqui as passagens dessa conversa que podem ajudar a compreender o projeto político de Allende, assim como as forças pelas quais ele foi abatido. Apoio ao povo chileno. (On vous parle du Chili, 1973, tradução nossa) $)^{213}$

On vous parle du Chili começa com um texto ausente na versão anterior, proferido pela voz em off de Debray. A sequência dos dois protagonistas em um helicóptero, entre Santiago e Valparaíso, é aproveitada por Marker para inseri-los em cena, porém, o som da entrevista usado por Littin para acompanhar essa passagem é substituído pela nova gravação de áudio do jornalista francês, que, de provocador, se torna um "narrador", uma testemunha do processo chileno. Nesse sentido, ele declara que encontrou Allende em janeiro de 1971 no Chile, após sair da prisão na Bolívia, e que depois de ter se aproximado da vida e da morte de Che Guevara, deparava-se com alguém que encarnava o polo oposto, a via eleitoral. À revelia dessa oposição, narra que Che e Allende se encontraram e se estimavam, e que mais tarde viriam a ter mais alguma coisa em comum: o mesmo assassino. Percebe-se, já nessa abertura, que se recorre ao próprio Debray para minimizar as diferenças entre os caminhos da revolução.

Se a principal tensão da versão de Littin era o embate entre duas vias ao socialismo - a armada e a democrática -, em On vous parle du Chili prevalece a opinião de Allende de que cada povo teria seu próprio caminho, sobretudo na América Latina, como ele declara em uma das primeiras sequências da montagem. $\mathrm{O}$ símbolo da vitória socialista pelas urnas guardava um exemplar autografado de Guerra de guerrilhas, portanto, não havia um embate, mas sim uma opção que se demonstrava a mais adequada ao povo chileno.

Após a introdução de Debray, Marker insere na montagem uma das últimas cenas do filme de Littin, em que, em uma tomada externa, os dois protagonistas conversam lado a lado. A escolha por esse plano como o inicial da entrevista pode ser

\footnotetext{
${ }^{213}$ Intertítulo de On vous parle du Chili, traduzido do original: "En 1971, le cinéaste chilien Miguel Littin a fait un film autour d'une conversation entre Régis Debray et el président Allende: Compañero presidente. Nous avons groupé ici des passages de cette conversation qui peuvent aider à comprendre le projet politique d'Allende, ainsi que les forces auxquelles il s'est heurté. Soutien au peuple chilien".
} 
vista como mais uma tentativa de aproximá-los, já que a paisagem ao fundo e o tom mais informal quebra uma tensão acentuada nas tomadas internas, onde eles aparecem sempre frente a frente, em lados opostos de uma mesa. Além disso, o realizador francês reforça os inúmeros close-ups do rosto de Allende, estratégia já presente em Littin para gerar intimidade e endossar a alcunha de "companheiro".
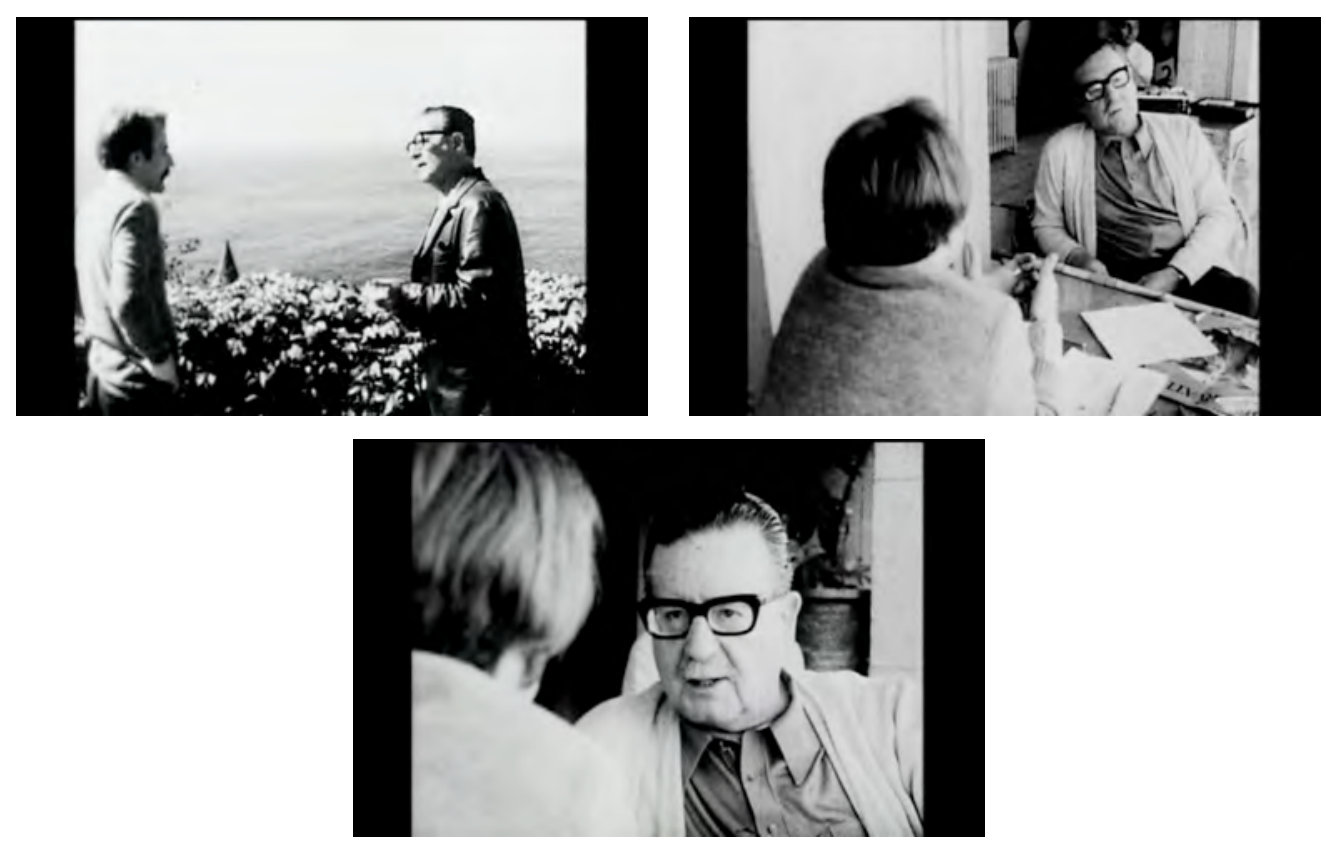

Fotogramas de On vous parle du Chili: ce que disait Allende.

Dos diversos temas presentes na montagem chilena, Marker valoriza alguns, em detrimento de outros. A questão da independência econômica ante os Estados Unidos é um dos problemas centrais em sua versão, demonstrando que o cenário internacional ganha importância em relação às questões internas. Nesse sentido, o apoio subentendido ao golpe de Estado pelo governo norte-americano é apontado como um dos grandes responsáveis pela derrota. O presidente responde ao entrevistador que conquistariam o poder de fato quando o cobre, o ferro e os outros recursos naturais fossem chilenos; quando o país fosse "economicamente independente". Assim, as nacionalizações são apontadas como um mérito da Unidade Popular, mas também como um argumento para explicar sua derrubada. Para valorizar essa tese, o realizador insere a seguinte fala de Compañero presidente, na qual Allende declara acreditar no respeito de Nixon ao seu cargo, profetizando, porém, que: “[...] se, mais uma vez, eles quiserem fazer tábula rasa da autodeterminação, da 
não intervenção, bem! Então, eles vão encontrar uma resposta digna de um povo e de um governo" (On vous parle du Chili, 1973, tradução nossa) ${ }^{214}$.

Mesmo com a amenização do tom do debate, o realizador francês inclui em sua versão uma das cenas mais tensas do filme, quando o jornalista pergunta quem vai se sobressair nos conflitos internos, a burguesia ou o proletariado. Essa passagem, porém, iniciava um assunto que Marker valorizou também em outros filmes sobre o Chile: a Frente Popular. Como já foi exposto, esse tema foi, de modo recorrente, uma chave para aproximar a Unidade Popular das referências políticas francesas, e é retomado em On vous parle du Chili. Allende caracteriza a aliança de esquerdas a qual pertence não como uma reedição do fenômeno dos anos 1930, mas como algo novo, cuja principal diferença estava na participação real das classes populares. Essa tese é corroborada pela opção de manter na montagem algumas das cenas da multidão saudando o chefe de Estado, atribuindo-lhe o apoio do povo.

Outra escolha de Marker, diante do material fílmico disponível, foi manter a discussão sobre a participação dos operários nas indústrias, tema que reverberava diretamente em sua militância junto às fábricas francesas. Allende declara que não se tratava de autogestão, mas que, em seu governo, esses operários tinham uma participação ativa na direção de empresas estatais. Diante dessa discussão, insere-se na montagem cenas de repressão policial que, no documentário de Littin, faziam o papel de contraponto entre o novo governo e o anterior. Novamente, um novo trecho proferido pela voz em off de Debray dá outro sentido às imagens reprisadas, que agora servem para indagar se os instrumentos de repressão que sempre serviram a esse fim poderiam atuar de outra forma - pergunta que, obviamente, seria respondida negativamente pelo desenrolar dos fatos que acarretaram no golpe de Estado ${ }^{215}$.

$\mathrm{Na}$ mesma linha "profética", Marker insere um depoimento de Allende reafirmando a legalidade das forças armadas chilenas, enquanto exibe imagens do mesmo desfilando ao lado dos generais. No contexto pós-11 de setembro de 1973, essas sequências transmitem um ar de complô presente nos anos da Unidade Popular, constituindo em On vous parle du Chili uma denúncia contra o novo governo. Debray pergunta sobre enfrentamento e traição, confirmando que essa possibilidade já estava

\footnotetext{
${ }^{214}$ Fala de Salvador Allende em On vous parle du Chili, traduzida do original: "[...] si, une fois de plus, ils veulent faire table rase de l'autodétermination, de la non intervention, eh bien! Alors, ils vont rencontrer une réponse digne d'un peuple et d'un gouvernement."

${ }^{215}$ A questão da repressão policial durante o governo de Salvador Allende é um tema retomado em $O$ fundo do ar é vermelho, como será abordado no capítulo 5.
} 
presente no governo Allende antes de sua queda. O presidente declara viver um clima permanente de conspiração e explica ao jornalista que adotou uma guarda pessoal de “amigos", por não confiar no chefe de polícia que havia pertencido ao governo Eduardo Frei.
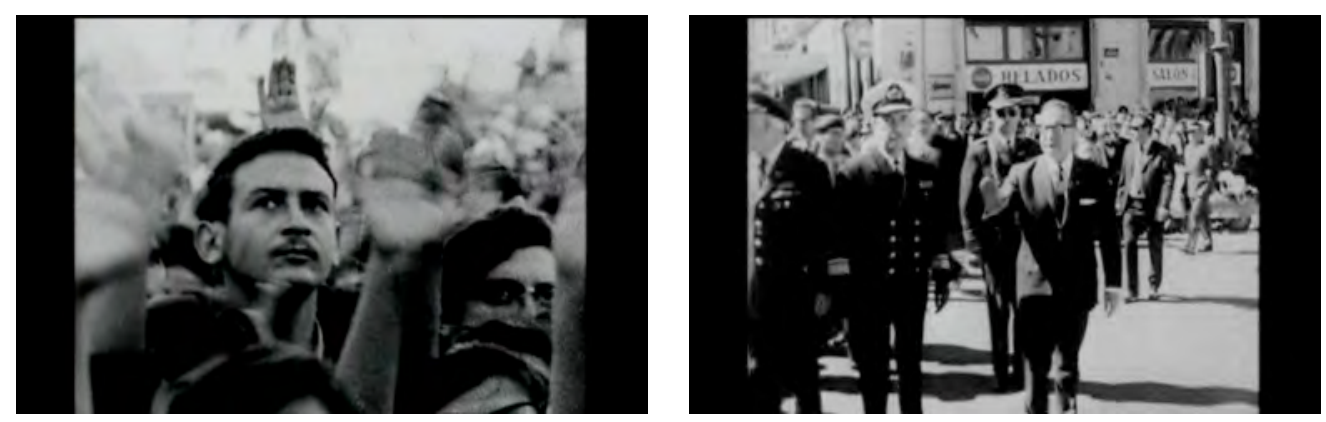

Apoio popular e presença do exército em fotogramas de On vous parle du Chili: ce que disait Allende.

Dessa forma, pode-se dizer que, editada logo após a instauração da ditadura militar, a versão de Marker se constitui como um cinema de denúncia, ao contrário da versão chilena, que se propunha a discutir o rumo de uma revolução em curso. On vous parle du Chili tem como objetivo relembrar algumas das ideias de Allende, mas sobretudo apresentá-lo positivamente ao público francês, mobilizando forças em torno da resistência chilena e dos movimentos de solidariedade internacional. Em uma das últimas sequências, o documentarista francês mostra uma declaração do presidente afirmando que um dos grandes erros da burguesia é pensar que a personalidade faz a história. O trecho se transforma, no contexto pós-1973, em uma incitação ao prosseguimento dos movimentos sociais. Profeticamente - ou prevendo um provável fim para os intensos conflitos no Chile -, Allende afirma:

O movimento social não desaparece porque um dirigente desaparece. Ele pode ser retardado, prolongado, mas, no final das contas, ele não pode ser parado. No caso do Chile, se me assassinarem, o povo seguirá sua rota, com a diferença que as coisas serão talvez mais difíceis, muito mais violentas, porque as massas aprenderão uma lição objetiva muito clara, a que essa gente não se detém diante de nada. (On vous parle du Chili, 1973) (16 $^{216}$

\footnotetext{
${ }^{216}$ Fala de Salvador Allende em On vous parle du Chili, traduzida do original: "Le mouvement social ne disparaît pas lui-même parce qu'un dirigeant disparaît. Il peut être retarde, il peut se prolonger, mais en fin de compte, il ne peut pas s'arrêter. Dans le cas du Chili, si on m'assassine, le peuple poursuivra sa route avec la différence que les choses seront peut-être beaucoup plus difficiles, beaucoup plus violentes parce que les masses apprendront une leçon objective très claire c'est que ces gens-là ne s'arrêtent devant rien."
} 
Assim como já havia feito em 1970 em On vous parle du Brésil: Carlos Marighela, Marker opta por um documentário que exalta um líder da esquerda latinoamericana (embora Marighela e Allende também representem símbolos de vias distintas da luta pelo socialismo). Essa produção anterior se aproxima em muitos aspectos de On vous parle $d u$ Chili, especialmente por terem sido ambas montadas logo após a morte desses líderes. Pode-se dizer que, no documentário sobre o Chile, o realizador encontrou uma solução muito parecida para resolver a contradição de elaborar um discurso militante em um contexto de derrota para o campo político no qual atuava. Nos dois filmes, ele reforça a ideia de um legado político, de uma "bandeira" que será adotada por outros homens e mulheres que participam da luta revolucionária.

Esse tom final presente em On vous parle du Chili atribui ao espectador uma tarefa: a de seguir uma luta que não foi terminada - no discurso fílmico -, apesar da perda de uma importante batalha. Dessa maneira, esse documentário se apresenta como uma denúncia, porém, igualmente, como um instrumento de mobilização em torno da causa sustentada por Allende. Isso explica, em grande parte, a atenuação das diferenças entre o "presidente companheiro" e Debray, que se encontra inclusive nos novos trechos de áudio gravados pelo jornalista francês. Faz parte dessa estratégia minimizar as diferenças entre os diversos caminhos encontrados pelas esquerdas e aproximá-los diante da proclamação de que, no fundo, todos eles militam por uma causa comum: o socialismo.

A escolha de Marker em reeditar El primer año e Compañero presidente, além de um evidente apoio ao processo chileno, decorria de sua preocupação, na época, em analisar os processos da própria esquerda, sem abrir mão nem da autocrítica, nem de um discurso militante. Tal esforço atingiu seu ponto máximo com o filme $O$ fundo do ar é vermelho (1977), que, não por acaso, dedica sua última parte à compreensão do governo e da queda de Salvador Allende, como será analisado no capítulo 5. Porém, os cortes feitos no filme de Littin mostram que, ao contrário de La première année, o documentário On vous parle du Chili minimiza os conflitos internos para incentivar a mobilização em torno da resistência ao golpe. A explicação pela mudança de tom decorre do contexto em que cada uma dessas produções foi montada: uma antes, outra depois do 11 de setembro de 1973.

Neste capítulo, mostrou-se um importante papel desempenhado por Chris Marker na divulgação e na produção (no caso de A batalha do Chile) de obras de 
cineastas chilenos - mais especificamente, Patricio Guzmán e Miguel Littin - na Europa. É interessante notar como o realizador atualizou o tema da Unidade Popular, valorizando, por exemplo, referências à Frente Popular e elegendo passagens que reverberassem nas discussões políticas das esquerdas francesas. Desse modo, pode-se dizer que além, de um mediador entre os próprios produtos envolvidos nesse intercâmbio - os documentários em questão -, ele atuou, de forma análoga, como um mediador das ideias políticas, fornecendo subsídios para o debate sobre os acontecimentos no Chile antes e depois do golpe de Estado.

Nos demais filmes analisados nesta tese, especialmente em L'ambassade e $O$ fundo do ar é vermelho, ficarão mais claras as motivações e de que forma o realizador elaborou diferentes discursos sobre a experiência chilena. 


\section{Capítulo 3 - La spirale $(1976)^{217}$ : imagens do Chile, denúncia e solidariedade}

\section{Muitas mãos e versões: a produção de um filme coletivo}

A iniciativa de montar La spirale (1976) surgiu do reencontro de Armand Mattelart e Chris Marker na França, logo após o golpe de Estado do general Augusto Pinochet, em 1973. O sociólogo, que havia trabalhado por 11 anos no Chile como professor na Escuela de Sociología de la Universidad Católica de Chile (Escola de Sociologia da Universidade Católica), dedicava-se ao estudo dos meios de comunicação e de seus usos políticos no país. De suas observações sobre esse setor durante a Unidade Popular, desenvolveu uma teoria de como ocorreu a construção de um complô que derrubou o governo de Salvador Allende, na qual defendia a tese de que a burguesia chilena articulou uma "frente de massa leninista de direita" (ou seja, se apropriou de uma estratégia esquerdista de mobilização popular para favorecer a queda do governo $)^{218}$, contando com a colaboração da imprensa e de seus agentes. Marker propôs a ele, então, expor suas ideias e sua experiência militante no contexto chileno por meio de um documentário.

Cabe, portanto, antes de tecer considerações sobre o filme, analisar a trajetória de um de seus realizadores, Mattelart, que, assim como Marker, foi um mediador na circulação de ideias entre a Europa e a América Latina nos anos 1960 e 1970. Nesse sentido, o artigo de Mariano Zarowsky (2012), “Armand Mattelart: un itinerario intelectual entre América Latina y Europa”, colabora para a compreensão do papel singular que o sociólogo desempenhou no estabelecimento de redes circulatórias. O autor ressalta que, na década de 1960, o belga foi fundamental para a consolidação do

\footnotetext{
${ }^{217}$ A análise presente neste capítulo foi feita com base em um DVD de La spirale lançado no Chile pelo Le monde diplomatique, em colaboração com a Coporación Parque por la Paz - Villa Grimaldi.

${ }^{218}$ A tese de que a burguesia chilena adquiriu um caráter "leninista" ao adotar um modelo de formação de uma "linha de massa" que jogasse a seu favor é desenvolvida por Armand Mattelart (1977) no livro Frente culturales y movilizacion de masas. Nesse texto, o sociólogo defende que, mesmo antes da vitória da Unidade Popular, a burguesia demonstrou flexibilidade para conciliar diversos setores sociais, permitindo-a preservar seus interesses dentro dos limites da democracia formal. Mattelart discorre, nesse raciocínio, sobre a presença das sociedades e das associações patronais desde o século XIX no Chile. Para ele, o poder gremial presente no país - que agrupava indivíduos por profissões e atividades, e não pela categoria de empregado ou patrão - permitiu que a direita mobilizasse apoio mesmo entre os trabalhadores. Tais argumentos estão presentes também em La spirale.
} 
ensino de ciências sociais no Chile - atendendo a um convite dos jesuítas ligados à Universidade Católica quando tinha apenas 26 anos -, levando ao país seus conhecimentos aprendidos nas universidades europeias, mais precisamente fruto de sua formação na Université catholique de Louvain (Universidade Católica da Lovaina) e no Institut national d'études démographiques (Instituto Nacional de Estudos Demográficos), em Paris. Na década seguinte, inverteu o fluxo de influência ao carregar consigo ao exílio aportes às teorias da comunicação desenvolvidos durante sua experiência latino-americana. Zarowsky utiliza o percurso singular de Mattelart para identificar redes internacionais bilaterais formadas por intelectuais "múltiplos e cosmopolitas", defendendo que:

[...] Armand Mattelart, como muitos outros de sua geração - mas, sem dúvida, alguém notável entre eles - pôs em contato a partir de sua atividade, mundos sociais e espaços de produção cultural heterogêneos (nos quais, evidentemente, a política tinha prioridade), assim como tradições intelectuais de diversos espaços nacionais (que também supõem, em rigor, atuações e modos de ler tradições de pensamentos "universais"), em especial em relação à sua concepção e prática do marxismo. (ZAROWSKY, 2012, p. 223, tradução nossa) ${ }^{219}$

Entre as contribuições de Mattelart para o meio universitário chileno, Zarowsky destaca a fundação, em 1968, do Centro de Estudios de la Realidad Nacional (Centro de Estudos da Realidade Nacional), ao lado de Jacques Chonchol (que seria, posteriormente, o ministro da Agricultura de Salvador Allende). Além disso, ele foi assessor e pesquisador da Editora Nacional Quimantú ${ }^{220}$ e um dos colaboradores da direção do MIR na Universidade Católica. Essa trajetória caracteriza Mattelart como um participante ativo nos debates da esquerda chilena, tanto no governo de Eduardo Frei como nos tempos da Unidade Popular. Zarowsky reforça ainda sua atuação como um mediador interno na América Latina, estabelecendo redes

\footnotetext{
${ }^{219}$ Traduzido do original: [...] Armand Mattelart, al igual que muchos otros de su generación - pero sin duda alguien notable entre ellos - puso en contacto a partir de su actividad mundos sociales y espacios de la producción cultural heterogéneos (donde evidentemente la política tenía el puesto de comando), así como tradiciones intelectuales de diversos espacios nacionales (que también suponen, en rigor, acentuaciones y modos de leer tradiciones de pensamiento "universales"), en especial en relación con su concepción y práctica del marxismo.

${ }^{220}$ A Editora Nacional Quimantú nasceu da estatização da editora Zig-Zag pelo governo de Salvador Allende, após uma greve organizada por seus trabalhadores com essa finalidade, em 12 de fevereiro de 1971. Dirigida por Joaquín Gutiérrez, tinha como principais objetivos a massificação da leitura no país, por meio de edições de baixo custo e fácil acesso, e priorizar livros que contribuíssem com a emancipação do povo para um processo revolucionário. Sobre esse projeto, ver o artigo "La cultura en la Unidad Popular: porque esta vez no se trata de cambiar un presidente", de César Albornoz (ALBORNOZ, 2005).
} 
e publicações plurinacionais, sobretudo com o semiólogo argentino Héctor Schmucler e com o brasileiro Hugo Assmann - importante teólogo da Teologia da Libertação -, com os quais fundou a revista gramsciana latino-americanista Comunicación y Cultura (publicada entre 1973 e 1985).

Após a volta forçada à Europa, a atuação política junto à esquerda chilena nos anos anteriores e seu contato próximo com os exilados renderam a Mattelart um status privilegiado nos meios intelectuais da França durante seu processo de reinserção, de acordo com Zarowsky ${ }^{221}$. Nesse sentido, o interesse acentuado dessa esquerda europeia pela Unidade Popular e sua derrocada - que vinha das tentativas comuns em estabelecer uma união "gauchista", mas também do temor de que a repressão ganhasse espaço no quadro político interno, como havia ocorrido no Chile ${ }^{222}-$ deu espaço para que o sociólogo publicasse em importantes periódicos, como Le monde diplomatique e Les Temps Modernes. O convite de Chris Marker para a direção do documentário La spirale pode ser visto como um dos exemplos da valorização da experiência chilena de Mattelart pela intelectualidade francesa. Nesse âmbito, sua contribuição ocorria principalmente por meio de análises sobre as "lições" que podiam ser extraídas posteriormente à queda da UP, como ficará claro nos comentários sobre esse filme.

O convite de Marker a Mattelart, no entanto, fez com que o processo de produção de La spirale tenha sido controverso, pelo que se pode concluir diante das diferentes versões de seus participantes, o que torna difícil atribuir responsabilidades ao seu resultado final. Parte dessa dificuldade decorre da própria figura "enigmática" de Marker, que foi avesso às entrevistas e aos depoimentos exteriores aos presentes em sua filmografia. Diante desse silêncio, as principais fontes que permitem traçar comentários sobre o processo de realização desse documentário são depoimentos de Armand Mattelart (THIRARD, 1976), Valérie Mayoux (MAYOUX, 1997) e Silvio Tendler (BROOKEY, 2010), que trazem algumas contradições, além de atribuições e peso diversos aos membros da equipe. Cabe ressaltar, porém, que são fontes testemunhais, cuja subjetividade deve ser levada em conta. Além disso, parte delas foi produzida com um grande distanciamento de tempo em relação à ocorrência dos fatos, devendo ser consideradas como registros de memória.

\footnotetext{
${ }^{221}$ Zarowsky ressalta que, embora tenha ocorrido essa valorização de Mattelart nos meios intelectuais devido a sua experiência chilena, ele só ocupou um posto importante na universidade francesa dez anos após sua chegada, em 1983, na Université de Rennes (Universidade de Rennes).

${ }^{222}$ Esses temas serão desenvolvidos nos capítulos 4 e 5.
} 
Independente das distintas versões sobre seu processo de produção, todas são unânimes ao afirmar que o projeto de La spirale partiu de Chris Marker. Nesse sentido, o realizador repetiu o papel de articulador que havia exercido anos antes, em 1966, quando reuniu uma grande equipe do meio cinematográfico francês em torno de uma causa política. Nessa ocasião, foi ele o responsável por juntar nomes como Alain Resnais, Jean-Luc Godard, William Klein, Claude Lelouch, Agnès Varda, Joris Ivens, Michèle Ray, entre muitos outros colaboradores, para montar um filme de episódios em apoio ao povo vietnamita na guerra contra os Estados Unidos ${ }^{223}$. Diante desse processo coletivo, Laurent Véray caracteriza Loin du Vietnam (1967), documentário que deu origem à SLON, da seguinte forma: "O filme se situa no impulso de entusiasmo, de solidariedade, de esperança que acompanha ou prolonga os combates de libertação nacional, em particular a Revolução Cubana". (VÉRAY, 2004, p. 6, tradução nossa) ${ }^{224}$.

A organização geral de Loin du Vietnam esteve a cargo de Jacqueline Meppiel, que também trabalharia como montadora em La spirale. Além de cineastas, o projeto reuniu músicos, jornalistas, escritores e fotógrafos, muitos dos quais participaram de encontros semanais para discutir a Guerra do Vietnã, durante um período de seis meses, nos quais debatiam textos, filmes e documentos diversos enviados por colaboradores $^{225}$. Essa iniciativa de 1966 antecipou procedimentos que seriam usados em outros coletivos de cinema militante que se espalharam após Maio de 1968, entre os quais se destacam a própria SLON e os grupos Dynadia, Medvedkine e Dziga Vertov.

Véray ressalta que a iniciativa de apoiar o Vietnã retomou uma tradição cinematográfica iniciada por colaboradores da Frente Popular nos anos 1930, reivindicando um certo "espírito mítico" militante daquele tempo. A organização da produção, tanto de Loin du Vietnam como de La spirale, que previa discussões e participação de autores diversos a serviço de uma causa coletiva, tem raízes, sobretudo, em La vie est à nous (1936), que foi um dos filmes mais importantes entre

\footnotetext{
${ }^{223}$ De acordo com Laurent Véray (2004), a iniciativa para a montagem de Loin du Vietnam surgiu quando uma organização não governamental francesa organizou a campanha "un milliard pour Le Vietnam" como forma de arrecadar recursos para o envio de medicamentos ao país asiático. Robert Bozzi, dono de uma galeria que havia reunido muitos artistas em torno dessa campanha, teria sugerido a Marker fazer o mesmo com os cineastas.

${ }^{224}$ Traduzido do original: "Le film se situe dans l'élan d'enthousiasme, de solidarité, d'espérance qui accompagne ou prolonge les combats de libération nationale, en particulier la révolution cubaine".

${ }^{225}$ Vale ressaltar que Loin du Vietnam reuniu extratos fílmicos e gravações feitas principalmente no Vietnã, em Cuba, nos Estados Unidos e na França.
} 
os que se engajaram na estratégia frentista vitoriosa de $1936^{226}$. Creditado a Jacques Becker, Jacques B. Brunius, Henri Cartier-Bresson, Jean-Paul Le Chanois, Maurice Lime, Pierre Unik, André Zwoboda e Jean Renoir ${ }^{227}$, esse misto de imagens ficcionais, compostas em formato de episódios, e extratos documentais foi produzido pelo Partido Comunista Francês (embora tenha incorporado em sua equipe "gauchistas" não filiados) com a ideia de engajar operários na transformação social e garantir o sucesso nas urnas. O pesquisador Guy Gauthier, cuja obra reúne muitos textos dedicados a Chris Marker, relaciona os coletivos da década de 1930 aos que se disseminaram a partir de Maio de 1968:

La vie est à nous ecoa por sua adesão genérica de artistas representativos, não somente do PCF, que exerceu, nesse caso, a função de unificador, mas das ideias da esquerda. Loin du Vietnam, no fim dos anos 1960, será igualmente coletivo, e não menos anônimo, mas característico das tendências mais terceiro-mundistas que nacionais. (GAUTHIER, 2004, p. 25, tradução nossa) ${ }^{228}$

Apesar da diferença identificada por Gauthier entre o enfoque nacionalista de La vie est à nous e o discurso anti-imperialista de Loin du Vietnam, ele aproxima essas duas produções pela desvalorização da autoria e pelo potencial de unificar diferentes setores da esquerda, mesmo os que não pertenciam ao PCF. No filme de 1936, esse caráter aglutinador é evidenciado pela forte presença da canção L'internationale, que o perpassa, desembocando em um grande plano final que mostra uma massa crescente de pessoas aderindo à música.

La spirale também pode ser visto como uma iniciativa similar a essas duas anteriores, especialmente pelo objetivo de reunir, em torno do próprio processo de produção, diferentes setores esquerdistas em prol de uma causa - no caso, o Chile. É importante reiterar que o tema da Frente Popular dos anos 1930, processo que unia a história chilena à francesa, foi um dos mais evocados nos documentários analisados nesta tese, que estabeleciam paralelos na configuração política desses dois países.

\footnotetext{
${ }^{226}$ Do ponto de vista do cinema documental, os filmes que colaboraram com a Frente Popular tiveram também um caráter coletivo. Dessa forma, destaca-se a cooperativa operária Ciné-Liberté, presidida por Jean Renoir, que se instaurou após a vitória eleitoral de 1936. Essas iniciativas de apoiar um cinema operário também foram resgatadas posteriormente por Marker, principalmente com os Grupos Medvedkine.

${ }^{227}$ Além desses diretores, o filme contou ainda com a participação de Jacques Prévert como roteirista.

${ }^{228}$ Traduzido do original em francês: “La vie est à nous reflète par son générique l'adhésion d'artistes représentatifs, non pas du PCF, qui faisait en l'occurrence fonction de rassembleur, mais des idées de gauche. Loin du Vietnam, à la fin des années 60, sera tout aussi collectif, et pas davantage anonyme, mais caractéristique des tendances plus tiers-mondistes que nationales.'
} 
Nesse sentido, retomar a tática dos cineastas dos anos 1930 ganhava uma relevância ainda maior na elaboração de uma memória sobre os anos da Unidade Popular chilena. Apesar das múltiplas particularidades dessas duas cinematografias - cujas figuras centrais podem ser identificadas como Renoir e Marker -, elas têm em comum a evidência do debate sobre o lugar do cinema e de seus realizadores no processo revolucionário.

É necessário ressaltar que a tendência de enfraquecimento da noção de autoria foi uma marca do cinema militante a partir dos anos 1960, tanto na França quanto na América Latina ${ }^{229}$ e uma ruptura com a tendência anterior do cinema de autor, que havia ganhado força após a publicação do texto "Naissance d'une nouvelle avantgarde: la camera stylo" (1948) em L'écran français, de Alexandre Astruc. Nos anos 1950, a ideia da câmera como uma caneta - e do realizador como um autor -, presente em Astruc, adquiriu novos contornos com os "Jovens Turcos" do Cahiers du cinéma, gerando embates com críticos e cineastas esquerdistas da "rive gauche", por estender sua "política dos autores" ao cinema comercial estadunidense ${ }^{230}$. Assim, a partir de Loin du Vietnam, La spirale e inúmeros outros filmes realizados em coletivos cinematográficos, essa noção foi afrontada na prática, dissolvendo a presença do estilo de determinado diretor a uma equipe ampla e diversa.

\footnotetext{
${ }^{229}$ Em relação ao cinema militante na América Latina, no contexto do Nuevo Cine Latinoamericano, a questão da autoria e de sua negação foi bem mais complexa do que na França, como exemplifica a discussão sobre Hacia un tercer cine (1969), de Octavio Getino e Fernando Pino Solanas. No artigo Hacia un tercer cine: del manifiesto al palimpsesto (DEL VALLE DÁVILA, 2012), Ignacio Del Valle Dávila analisa que, se o manifesto ficou famoso por estabelecer o conceito de tercer cine como o oposto ao cinema industrial estadunidense e ao cinema ligado à política dos autores, modificações realizadas por seus signatários nas diferentes versões do texto revelam uma dificuldade dos mesmos em definir o segundo cinema. Tal desafio é proveniente de filmografias que transitam entre esses dois conceitos - filmes de autor e cinema militante, segundo e terceiro cinemas -, entre as quais a de Glauber Rocha é a que melhor contradiz a existência de conceitos estanques. Del Valle Dávila descreve atenuações na redação desse manifesto: "Na primeira versão, afirma-se 'ainda no chamado 'cinema de autor', enquanto que, na segunda edição, a proposição se relativiza: 'ainda que em grande parte do chamado 'cinema de autor', No segundo texto, Getino e Solanas reconhecem que o cinema de autor pode, em algumas ocasiões, alcançar certa independência criativa a respeito do modelo hegemônico. Como veremos, essa atitude mais aberta ao 'cinema de autor', ou segundo cinema, será uma das características fundamentais da segunda versão do manifesto.” (DEL VALLE DÁVILA, 2012, tradução nossa). Traduzido do original: "En la primera versión se afirma 'aún en el llamado "cine de autor' ', mientras que en la segunda edición la proposición se relativiza: 'aún en gran parte del llamado 'cine de autor' '. En el segundo texto, Getino y Solanas reconocen que el cine de autor puede en ocasiones alcanzar cierta independencia creativa respecto del modelo hegemónico. Como veremos esta actitud más abierta hacia el "cine de autor" o segundo cine será una de las características fundamentales de la segunda versión del manifiesto.”.

${ }^{230}$ Sobre os debates estabelecidos no seio da crítica cinematográfica francesa nos anos 1950 e 1960 , sobretudo nos Cahiers du cinéma, ver os livros $O$ autor no cinema, de Jean-Claude Bernardet (BERNARDET, 1994), e Cinefilia, de Antoine de Baecque (BAECQUE, 2010).
} 
Diante dessas considerações, a atribuição de autorias em La spirale adquire uma importância menor em decorrência de um postulado prévio que procura afrontála. Ao reunir uma equipe híbrida, com diferentes olhares e características, o filme caracteriza-se como uma obra distinta na filmografia de Chris Marker, embora incorpore algumas estratégias presentes em suas demais produções. Além disso, o uso de extratos que não foram produzidos pelos seus realizadores, mas sim por múltiplos cineastas, faz dela ainda mais coletiva. Essas questões serão retomadas ao longo deste capítulo, porém devem ser salientadas nas considerações sobre o processo de produção.

Em seus créditos iniciais, La spirale divide seus realizadores em dois grupos, sem, no entanto, discriminar as funções desempenhadas ou o status de importância de cada um deles. Entre os primeiros destacados estão, além do próprio Mattelart, as montadoras Jacqueline Meppiel e Valérie Mayoux ${ }^{231}$. Marker encabeça a lista da segunda leva de relacionados, seguido por François Perier (ator que empresta seu tom à voz over, tal como havia feito para a versão francesa de La première année), JeanMichel Folon (renomado artista gráfico que desenhou as figuras alegóricas do jogo Política, importante elemento cênico do documentário, e que havia feito o convite para a exibição de La première année no Studios de la Harpe), Jean-Claude Éloy (música), Silvio Tendler (montagem), Pierre Flament (montagem), Luc Perini (música), Étienne Becker (montagem) e Antoine Bonfanti (música).

Em entrevista publicada em 1976 (THIRARD, 1976), Mattelart descreve à Positif as etapas e os critérios de pesquisa para o levantamento das imagens de arquivos usadas na montagem do filme. Esse depoimento, colhido no ano do lançamento do documentário, enfatiza seu caráter coletivo ao valorizar a presença das montadoras Meppiel e Mayoux, que começaram, em janeiro de 1974, uma intensa busca por gravações audiovisuais e documentos de outras naturezas produzidos durante a fase da Unidade Popular. Em outubro desse mesmo ano, de acordo com a publicação, o brasileiro Silvio Tendler foi incorporado à equipe de edição. Já o papel de Chris Marker é pouco ressaltado pelo sociólogo, que declara que, embora ele tenha sugerido a produção do filme e reunido os realizadores, permaneceu ausente da edição até novembro, quando retornou para finalizá-la.

\footnotetext{
${ }^{231}$ Jacqueline Meppiel trabalhou também com Chris Marker em La bataille des dix millions, enquanto Valérie Mayoux participou da montagem de O fundo do ar é vermelho.
} 
Uma versão bastante contraditória com a de Mattelart é apresentada por Marcia Brookey (2010), com base em entrevista com Silvio Tendler. A pesquisadora descreve que o cineasta brasileiro estava no Chile em 1973, portando uma câmera emprestada por Marker. Diante do trágico desfecho dos conflitos no país, que o levou a documentar o golpe de Estado e seus preâmbulos, foi convidado pelo documentarista francês para integrar a equipe de La spirale, que contaria ainda com a colaboração de Régis Debray (que também havia regressado à França com o cerceamento das liberdades pela ditadura chilena). De acordo com o depoimento de Tendler, a chegada de Mattelart à equipe teria forçado a saída de Debray e criado um grande desentendimento diplomático, contornado politicamente pela intervenção de Chris Marker, que convidou Folon e as montadoras para levar a produção até o fim. "Alfinetando" o sociólogo belga, o brasileiro dispara: "Aí, na hora dos créditos, o Mattelart assumiu. O filme é assinado pelo Armand Mattelart, Valérie Mayoux, Jacqueline Meppiel e Folon. E aí, na segunda cartela, aparece: E também, Chris Marker, Silvio Tendler e outros.” (TENDLER Apud BROOKEY, 2010, p. 63).

A despeito da discussão sobre a participação da autoria, outros aspectos sobre a produção podem ser apreendidos com base nesses depoimentos. A entrevista de Mattelart, apesar do aspecto subjetivo, colabora para o mapeamento e a catalogação do material audiovisual usado na montagem. De acordo com o diretor, foram utilizados principalmente três tipos de inserções audiovisuais: 1) Filmes de autor, especialmente de diretores militantes como Patricio Guzmán, outros chilenos e o cubano Santiago Álvarez; 2) Noticiários produzidos pela Chile Films; 3) Reportagens diversas de redes de televisões de várias partes do mundo, sobretudo francesas, muitas das quais trazendo originalmente enfoques de direita. Todas essas "categoriais originais" destacadas adquiriram novos significados na edição, muitas vezes opostos aos pretendidos pelas tomadas realizadas durante o governo de Salvador Allende.

Um exemplo dessa prática recorrente destacada por Mattelart em sua entrevista é o do panelaço realizado por mulheres, em dezembro de 1971, contra uma suposta escassez econômica vivida no país. Originalmente, as cenas haviam sido registradas por uma rede direitista norte-americana como "prova" do caos instalado pelo governo da UP. No documentário, porém, as imagens aparecem intercaladas com outras em preto e branco, da mesma manifestação, gravadas por realizadores militantes do coletivo organizado por Patricio Guzmán. Apesar dos objetivos opostos em filmar a marcha feminina, presentes a priori nas diferentes concepções das 
equipes de filmagem, elas puderam ser reunidas em uma única cena não apenas por serem do mesmo evento, mas, sobretudo, por mostrarem a mesma coisa: mulheres com feições brancas; com roupas, assessórios e cortes de cabelo "burgueses"; enfim, aspectos que indicam seu pertencimento à elite. Essa opção por reunir imagens produzidas com objetivos opostos em conjuntos de sequências temáticas únicas faz parte do método de trabalho dos realizadores, como será abordado em outros exemplos ao longo desta tese.

Para produzir La spirale, a equipe enfrentou ainda uma grande dificuldade na pesquisa de material de arquivo. Após o golpe militar, assim como seus realizadores, muitas das imagens dos documentários militantes chilenos e da Chile Films, gravadas durante a Unidade Popular, foram exiladas. Ou seja, saíram clandestinamente e de forma difusa do país ${ }^{232}$. Portanto, reunir as gravações, tanto as efetuadas por realizadores de esquerda como as feitas por redes de TV de direita, foi também uma forma de desafiar esse exílio, que com a proibição de exibição e a destruição de planos rodados durante os anos da UP realizadas pelo novo governo visava a impor um "esquecimento" dessa época.

Os realizadores empreenderam também uma busca por documentos de outros tipos, como recortes de jornal, fotografias, publicações etc. Nessa categoria, destacase ao longo desta pesquisa a localização de um livro financiado pelo governo de Salvador Allende que é mostrado no documentário e fornece substratos importantes para o comentário. Divulgado pela Secretaria General de Gobierno, em 1972, Documentos Secretos de la ITT reproduz provas documentais de que a empresa de telecomunicações havia articulado um plano com conhecimentos da CIA que visava a impedir a vitória e a posse do candidato da $\mathrm{UP}^{233}$. Nesse caso, ao contrário do que

\footnotetext{
${ }^{232}$ As produções chilenas usadas como material bruto foram encontradas graças a uma rede solidariedade articulada no exílio. Por exemplo, um telegrama enviado por Meppiel aos Amigos da Cinemateca Alemã, em 30 de agosto de 1974, solicitava uma cópia do documentário chileno Miguel Ángel Aguilera, presente, de Álvaro Ramírez (Apud VILLARROEL; MARDONES, 2012). No entanto, apesar desse "exílio" de imagens, vale destacar que muitas delas já estavam fora do país antes de 1973. Em primeiro lugar, porque foram em grande parte registradas por observadores estrangeiros, enviados principalmente por televisões de diferentes nações. Também, porque muitos dos realizadores vindos de fora compravam material audiovisual de arquivo para incorporarem em produções sobre o Chile, mesmo antes do golpe de Estado. Esse procedimento foi empregado, por exemplo, pelos alemães Gerhard Scheumann e Walter Heynowski, que realizaram filmes sobre a Unidade Popular.

${ }^{233}$ A ligação estreita entre a International Telephone and Telegraph (ITT) e a CIA foi descoberta em 1972 pelo jornalista Jack Anderson, que localizou correspondências e documentos secretos trocados entre esses dois órgãos. Essas fontes provavam a existência de um plano de golpe militar que impediria a eleição e a posse de Salvador Allende e foram publicadas pelo governo da Unidade Popular como prova de um complô à presidência por parte dos Estados Unidos.
} 
ocorreu com a sequência audiovisual do panelaço de mulheres, o sentido original do documento, feito pela esquerda, foi reforçado pela voz over.

O material levantado para a montagem foi dividido em dois grupos, conforme o depoimento de Mattelart: "Esse material foi classificado desde o começo seguindo dois grandes princípios: a ordem cronológica dos eventos e as classes ou grupos sociais que são os atores do evento" (THIRARD, 1976, p. 27, tradução nossa) ${ }^{234}$. Esses critérios de organização, especialmente o que define os atores sociais implicados nos documentos de arquivo, enfatizam o foco principal do documentário, que é a luta de classes durante o governo de Salvador Allende. Dessa forma, embora de modo geral o roteiro caminhe das eleições de 1970 até o golpe de 1973 (e uma breve indicação da situação do país posterior a ele), ao longo dos blocos temáticos, as sequências não estão organizadas de forma cronológica. Esse formato levou à escolha por identificar a organização dos planos na decupagem segundo os temas, e não de acordo com períodos históricos abordados.

${ }^{234}$ Traduzido do original: “Ce matériel a été classé dès le début suivant deux grand principes: ordre chronologique des événements et classes ou groupes sociaux que sont les acteurs de l'événement”. 


\section{Temas e estratégias do documentário}

O movimento em espiral pode ser definido como uma trajetória que não se fecha, que está sempre em ascensão. Para a matemática, caracteriza-se por uma função contínua e incessante, que possui infinitas revoluções orbitais que jamais retornam ao seu ponto de origem. Essa curva serviu à filosofia como metáfora para modelos de entendimento da realidade e do pensamento humano, tornando-se mais conhecida pela espiral hegeliana, constantemente simplificada como um processo de produção do conhecimento que envolve tese, antítese e síntese. Portanto, pode-se dizer que a espiral é, por excelência, o caminho pelo qual se estrutura o pensamento dialético.

Por meio da escolha do título, os realizadores de La spirale dão pistas de que pretendem desenvolver uma trajetória em aberto, constituída por inúmeras voltas e reviravoltas que sempre impedem o retorno ao ponto de partida. Essa opção se liga a dois aspectos complementares relacionados ao fato de o filme se constituir com um estatuto de "documentário" que pretende formular um conhecimento sobre um período histórico ou processo político (no caso, o governo da Unidade Popular no Chile e sua derrocada, em 1973, pelo golpe de Estado): o modo como é construída a narrativa fílmica, entendida aqui como a articulação de sons e imagens que produzem um sentido; e o próprio desencadear dos episódios situados no espaço e tempo abordados pelos diretores.

A espiral relaciona-se ao ritmo imposto ao filme, que caracteriza os conflitos durante os anos da Unidade Popular como uma sucessão de ações e reações, ataques e contra-ataques, revolução e contrarrevolução. O espectador se vê, assim, inserido em uma trajetória de curvas sem fim, que o leva à expectativa de aguardar qual será a próxima etapa adotada pela direita e a resposta contraposta pela esquerda. Forma e conteúdo se acompanham, assim, em "revoltas" que se aceleram conforme o desfecho aponta para o que todos esperam: o previamente conhecido golpe de Estado.

$\mathrm{Na}$ primeira cena de La spirale aparece a imagem em preto e branco de Salvador Allende, discursando para uma multidão no Estádio Nacional. Trata-se de uma tomada apropriada do filme De América soy hijo... y a ella me debo... (1972), do cubano Santiago Álvarez, gravada em Santiago no dia 2 de dezembro de 1971 (data 
indicada por um intertítulo). Muitos aplausos são ouvidos após a fala do então presidente, em som direto:

Eu lhes digo, companheiros, companheiros de tantos anos, mas digo com calma, com absoluta tranquilidade. Não tenho vocação para apóstolo, nem tenho vocação para Messias, não tenho índole de mártir, sou um lutador social que cumpre uma tarefa, a tarefa que o povo me deu. Sem ter carne de mártir, não darei um passo atrás [...]. Deixarei La Moneda quando tiver cumprido o mandato que o povo me deu. [...] Não tenho outra alternativa. Só me crivando de balas poderão impedir a vontade que é fazer cumprir o Programa do povo. (La spirale, 1976, tradução nossa) $^{235}$

Após o corte, a próxima cena começa com um intertítulo indicando o mesmo espaço, porém outro tempo: "Santiago - 11 de setembro de 1973". A ruptura vem acompanhada do som direto em off de bombas, aviões, tiros, introduzindo o que mostram as imagens seguintes. Pessoas correndo nas ruas, tanques de guerra, aviões e helicópteros sobrevoando a cidade, La Moneda em chamas... Essas cenas coloridas, provavelmente gravadas por emissoras de televisão, já eram conhecidas do espectador. Até esse momento, o áudio se restringe a acompanhar o registro visual, reproduzindo, além dos barulhos de guerra, informes por rádio dos soldados a um general que os comanda pela voz em off.
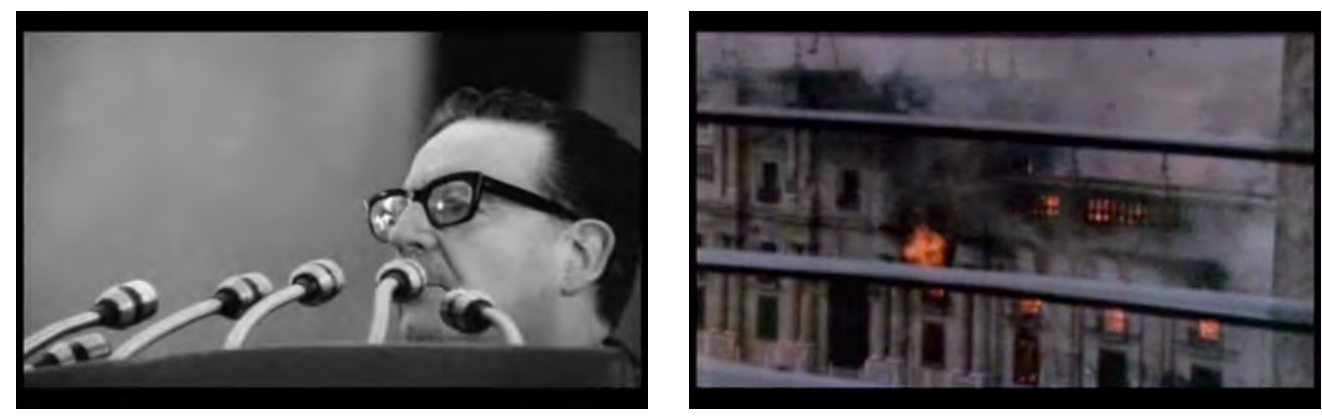

Fotogramas do prólogo de La spirale.

A descrição desse prólogo anuncia o desfecho da espiral, o momento final da narrativa documental. A fala de Allende traz um tom premonitório que indica que o conhecido fim já estava pressuposto muito antes, durante os anos da Unidade Popular. As imagens da cena do golpe militar, embora em um primeiro olhar pareçam

\footnotetext{
${ }^{235}$ Fala de Salvador Allende em La spirale, traduzida do original: "Yo les digo a ustedes compañeros, compañeros de tantos años, pero digo con calma, con absoluta tranquilidad. Yo no tengo pasta de apóstol ni tengo pasta de Mesías, no tengo condiciones de mártir, soy un luchador social que cumple una tarea, la tarea que el pueblo me ha dado. Sin tener carne de mártir, no daré un paso atrás [...]. Dejaré La Moneda cuando cumple el mandato que el pueblo me diera. [...] No tengo otra alternativa. Sólo acribillándome a balazos podrán impedir la voluntad que es hacer cumplir el Programa del pueblo."
} 
contrárias à sequência anterior do "presidente companheiro", são, na verdade, complementares. Unidas em um bloco temático de planos, as duas partes dessa apresentação confirmam - além do sentimento de que o projeto do governo popular sempre esteve em risco - a credibilidade e os princípios do líder da UP. O espectador, em 1976, conhece de antemão o suposto suicídio cometido no 11 de setembro no palácio de La Moneda; ou seja, sabe que a resistência do presidente em fazer valer a legalidade democrática, conforme o prometido em 1971, se transformou em uma tragédia histórica.

Após a entrada dos créditos, La spirale se volta do trágico ao festivo, com cenas comemorativas da vitória eleitoral de 1970 nas urnas. O mesmo presidente que sucumbiu com seu palácio aparece dançando, enquanto o povo participa dessa grande festa. O tom de otimismo é complementado pela trilha sonora de El pueblo unido, jamás será vencido, interpretada pelo grupo Quilapayún, um dos principais expoentes do movimento da Nueva Canción Chilena. A voz over, em função informativa, começa seu fervoroso trabalho, que será esmiuçado mais adiante, indicando tratar-se do dia 4 de setembro de 1970, quando Salvador Allende foi eleito presidente do Chile. Após um corte, o próximo plano mostra miniaturas dos candidatos que concorreram em 1970, acompanhados pela interrogação trazida pela mesma voz: Que forças participaram desse combate eleitoral?

Assim se inicia o primeiro bloco temático, com pouco mais de oito minutos, que apresenta as forças em jogo que serão abordadas durante o filme: a Unidade Popular, o Partido Nacional e a Democracia Cristã. Nessa parte, os trechos de filmes e outros documentos (no caso, matérias de jornal, fotos e as próprias "novas canções" dos anos 1960 e 1970) servem à recuperação de uma perspectiva histórica da atuação de cada parte envolvida nos conflitos que virão a seguir, com referências não cronológicas a outros momentos da História chilena. $\mathrm{O}$ espectador passa a saber que Jorge Alessandri é um ex-presidente, filho de ex-presidente, e um símbolo da direita. Seus eleitores, mostrados em imagens televisivas coloridas da campanha de 1970 portando fisionomia e trajes da burguesia nacional, pensam que ser patrão é um “direito divino" e que o comunismo é a causa da "desordem" (conclusão direcionada pela voz over). Descobre também que a DC, por meio de Eduardo Frei, governava o país desde 1964, com apoio dos Estados Unidos, que procuravam uma forma alternativa de controlar os "ímpetos esquerdistas" latino-americanos que não fossem as sangrentas ditaduras em curso em algumas nações. No entanto, por meio de 
imagens em preto e branco retiradas do documentário militante Miguel Ángel Aguilera, presente (1970), de Álvaro Ramírez, o público acompanha o enterro de um companheiro morto em confrontos com a polícia democrata-cristã, o que revela um lado cruel desse governo que se denominava de centro-esquerda. Por fim, o espectador é apresentado à UP por uma cena de seu comício em que o som direto saúda a entrada de um comunista bastante conhecido na Europa: "Neruda, Neruda, o povo te saúda". O ilustre Prêmio Nobel aparece acompanhado do socialista Salvador Allende, personagem cuja vida política é narrada a seguir por meio de fotos e pela voz over que o caracteriza como alguém que não terá outro objetivo a não ser consolidar uma ampla frente de esquerda.

A descrição desse bloco inicial introduz uma estratégia que estará presente também em outras passagens do filme, que é a utilização de trechos fílmicos e documentos de outras naturezas realizados em anos anteriores à formação da Unidade Popular. Essa escolha da montagem permite aos realizadores inserir as forças e os conflitos retratados durante o governo Allende em um processo histórico nacional e internacional em curso há pelo menos cem anos. O documentário não trata, portanto, de um episódio isolado. O golpe militar, explicado por esses recursos, deixa de ser uma exceção imposta por uma realidade anômala, como é inicialmente caracterizado por seus porta-vozes, para fazer parte de um jogo político muito anterior (de uma parte da espiral que precede o recorte do documentário).

Nesse sentido, sendo um de seus principais realizadores um reconhecido sociólogo (e idealizador da tese defendida no filme), é possível afirmar que La spirale se utiliza constantemente de categorias sociológicas de análise. Conceitos como imperialismo, estratégia política, estratégia militar, mobilização social, frente de massa, entre outros vastamente utilizados no vocabulário político constituem subblocos do documentário. A narrativa integral, que vai das eleições de 1970 até cenas de 1975, é interrompida constantemente por digressões históricas que buscam, com o uso de imagens de arquivo anteriores à Unidade Popular, inserir o tempo e o espaço tratados em temas da sociologia. Essa prática será mapeada em algumas passagens destacadas neste capítulo.

Após o prólogo e a apresentação dos principais partidos políticos chilenos, o documentário se divide em sete grandes blocos, indicados por intertítulos numerados: 1) $O$ plano, 2) $O$ jogo, 3) A frente, 4) A aproximação, 5) $O$ ataque, 6) $O$ exército e 7) O golpe. De modo geral, esse é o grande percurso narrativo que obedece a um 
critério cronológico, que vai dos primeiros boicotes planejados após a vitória de Allende nas urnas até o triunfo direitista com a intervenção militar. Essa opção dos diretores indica também o foco principal que perpassa todas as partes do filme: a análise das estratégias da direita (nacional e internacional) para impedir que a estratégia da esquerda de implementar o socialismo pela via democrática seja bemsucedida.

Cabe, diante dessa estrutura narrativa, avaliar uma situação paradoxal para um filme realizado por reconhecidos militantes da esquerda. Se a maior parte das produções engajadas no discurso pró-socialismo busca incentivar pessoas a aderir a uma causa, La spirale trata de uma situação histórica de caminho retrógrado do ponto de vista esquerdista, ou seja, na qual a vitória se tornou uma realidade, mas foi revertida por uma contrarrevolução. Diante dessa derrota, o documentário se propõe a abordar o inimigo, entender os passos que levaram ao seu sucesso.

Qual seria, porém, o ganho para um filme militante ao optar por tratar de seu inimigo, um grande vitorioso no período de sua realização? Não haveria um perigo em caracterizá-lo como um adversário invencível, que sempre consegue virar mais uma volta ascendente da espiral? Essas são algumas das perguntas que este capítulo procura responder, cabendo mencioná-las à medida que as estratégias narrativas forem identificadas. É importante ressaltar, porém, que a espiral é uma trajetória que não se fecha, permanece em aberto, assim como o curso da história, o que pode indicar que a saída está na proposta de futuros movimentos possíveis, fora do campo desse filme.

A metáfora da espiral é materializada cenicamente ao final do primeiro bloco, O plano. Em uma das poucas tomadas feitas especialmente para o documentário, considerando que a maior parte dos planos é retirada de produções anteriores, os realizadores fornecem uma espécie de bibliografia consultada, sendo que alguns títulos serviram de fonte audiovisual para a montagem enquanto outros apenas de inspiração (como é o caso das ficções citadas pelos autores, por exemplo, La tierra prometida, de Miguel Littin). Ao som de uma música de suspense, utilizada sempre que o clima de complô se intensifica, a câmera percorre rolos de película empilhados. O movimento circular e rápido da câmera colabora para que, uma sobre a outra, as 
latas redondas se aproximem de um formato espiralado ${ }^{236}$. Nesse momento, a voz over afirma que a presente produção pode ser mais uma a integrar essa "espiral" de filmes militantes:

Não contamos aqui a história da Unidade Popular. Outros filmes já o fizeram e muitos outros serão necessários para expressar a riqueza desses três anos. Queremos explicar como a direita chilena fez desses três anos uma máquina infernal, posta em funcionamento antes mesmo que Allende tivesse sido eleito. Uma escada para the desestabilizar. (La spirale, 1976, tradução nossa) ${ }^{237}$
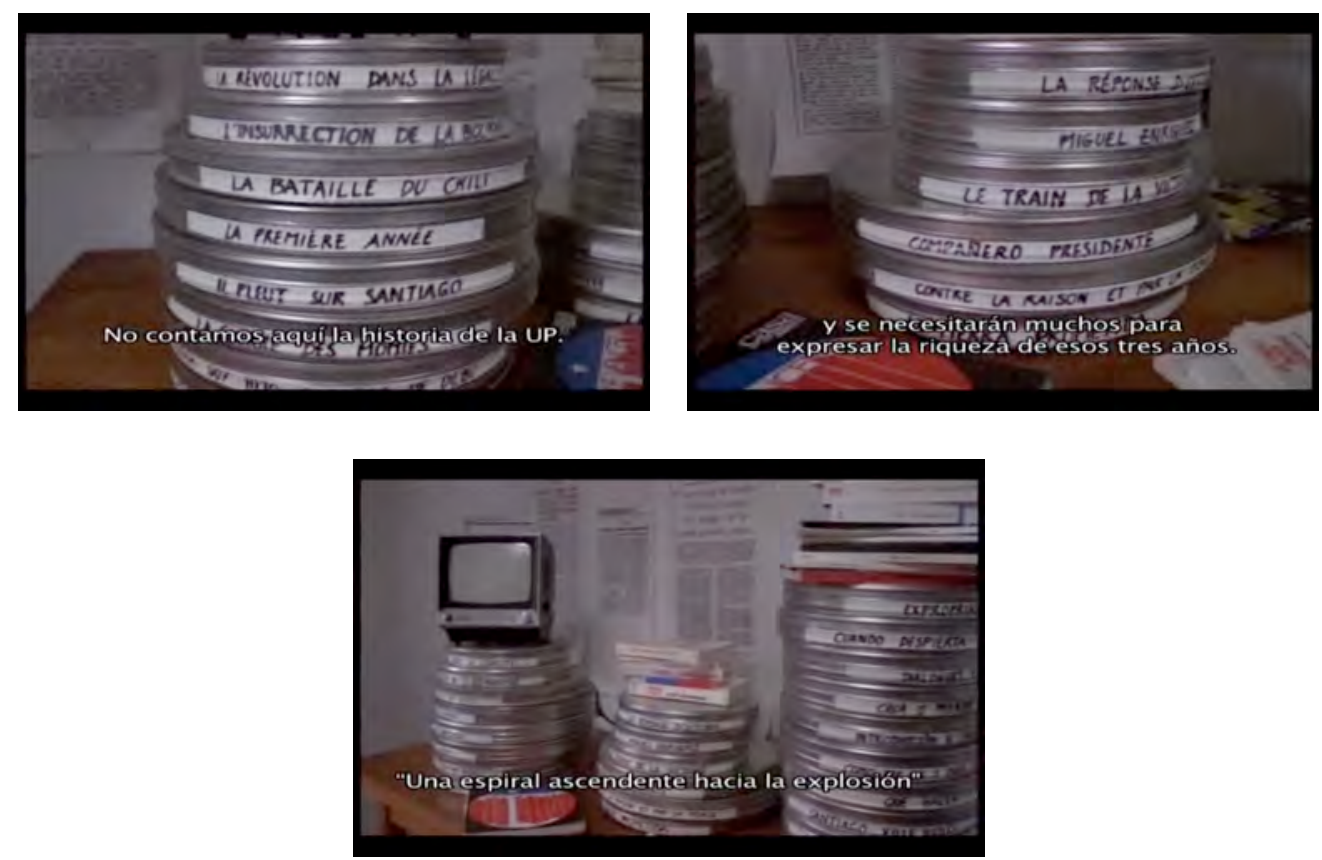

Fotogramas de La spirale que faz referência a filmes anteriores sobre a Unidade Popular e sua queda.

\footnotetext{
${ }^{236}$ Os títulos indicados nas etiquetas das latas de negativo correspondem a produções militantes realizadas até aquele momento sobre temas ligados à Unidade Popular e sua derrocada. São elas: $A$ batalha do Chile (Patricio Guzmán); Conversation with president Allende; De América soy hijo... y a Ella me debo... (Santiago Álvarez); La guerre des momies (Gerhard Scheumann e Walter Heynowski); Chove sobre Santiago (Helvio Soto); El primer año (Patricio Guzmán); A insurreição da burguesia (Patricio Guzmán); Révolution dans la légalité; La tierra prometida (Miguel Littin); Compañero presidente (Miguel Littin); Le train de la victoire (Joris Ivens); Miguel Enriquez; Contre la raison et par la force (Carlos Ortiz Tejeda); La respuesta de octubre (Patricio Guzmán); El diálogo de América (Álvaro Covacevich); Venceremos (Pedro Chaskel); Vote+fusil (Helvio Soto); Septembre chilien (Bruno Muel); Santiago, ville violée; Qué hacer? (Saúl Landau e Raúl Ruiz); ¿Cómo, por qué e para qué se asesina a un general? (Santiago Álvarez); Introducción a Chile (Miguel Torres); Casa o mierda; Diálogos de exilados (Raúl Ruiz); Cuando despierta el pueblo; e La expropiación (Raúl Ruiz).

${ }^{237}$ Texto da voz over de La spirale, traduzido do original: "Nous ne racontons pas ici l'histoire de l'Unité populaire, d'autres films le font et il faudra beaucoup pour exprimer toute la richesse de ces trois années. Nous voulons expliquer comment la droite chilienne a fait de ces trois ans une machine infernale, mise en route avant même que Allende soit élu. Un escalier pour le tonner."
} 
Tendo em vista os temas abordados ao longo desse primeiro bloco - o clima de caos econômico implantado após a eleição de Allende, o assassinato do general René Schneider e o escândalo envolvendo a multinacional ITT -, essa cena deixa claro que as próximas etapas seguirão o mesmo tom de denúncia. Ou seja, o objetivo dos realizadores, antes de tudo, é desvendar e tornar conhecidas as táticas da direita que a fizeram bem-sucedida em sua contrarrevolução.

Nessa lógica, o título que introduz a segunda parte adianta um novo elemento narrativo que será apresentado ao final da mesma: O jogo. Como já foi adiantado, o documentário utiliza constantemente categorias sociológicas que quebram uma cronologia presente na narrativa mais ampla, lembrando ao espectador que cada um dos assuntos tratados faz parte de uma disputa política que vai muito além do Chile e da derrocada de seu governo popular. Nesse sentido, é sintomático que a cena que inicia essa segunda parte se passe em outra Santiago, de $\mathrm{Cuba}^{238}$. O desembarque das tropas norte-americanas na cidade, em 1902, indica ao espectador que se trata de uma disputa antiga, cujas forças envolvidas continuam a atuar. Cabe à voz over, em tom irônico, efetuar a ligação dessa gravação remota com o contexto em que é produzido La spirale: "A ideia que os estadunidenses devem algumas vezes defender um povo de si próprio não é uma descoberta de Kissinger. É uma constante na história imperial. Os EUA protegiam Cuba desde 1902.” (La spirale, 1976, tradução nossa) ${ }^{239}$

O imperialismo, conforme as referências trazidas nas cenas a seguir, já esteve presente em Cuba, na Argélia, no Vietnã. É, portanto, um conceito sociológico recorrente, que desencadeia conflitos entre dominadores e povos que pretendem se libertar (ou resistir). Nesse raciocínio, o documentário abandona momentaneamente os campos de batalha para se voltar aos campi das universidades. Se já era comum entre os militares a confecção de jogos de simulação para o treinamento de guerra, na década de 1960, os Estados Unidos desenvolveram uma versão civil dessa prática: o jogo Política. A partir dessa descoberta, possivelmente fruto das investidas das montadoras nos arquivos norte-americanos, os realizadores encontraram uma maneira de explicar o ocorrido no Chile para o espectador (potencialmente europeu ou exilado,

\footnotetext{
${ }^{238}$ As cenas em preto e branco dessa sequência, gravadas em 1902 durante a ocupação de Santiago de Cuba pelas tropas norte-americanas, foram retiradas do filme De América soy hijo... y a ella me debo... (1972), de Santiago Álvarez.

${ }^{239}$ Texto da voz over de La spirale, traduzido do original: "L'idée que les américains doivent quelques fois défendre un peuple contre lui-même n'est pas une découverte de Kissinger. C'est une constante à l'histoire impériale. Les États-Unis protègent Cuba depuis 1902."
} 
já que a ditadura impedia a exibição da produção em território chileno) ${ }^{240}$. Mais do que isso, desenvolveram uma forma pela qual a abordagem de um episódio local adquire uma dimensão global.

Após tomadas de estudantes nos campi das universidades norte-americanas, o filme apresenta ao espectador documentos datilografados contendo as regras aplicadas à simulação. Trata-se de uma "prova" de que a ideia do jogo não partiu da cabeça dos diretores, mas das mentes formadas sob o imperialismo dos Estados Unidos, mais precisamente na Fletcher School of Law and Diplomacy (Escola de Direito e Diplomacia de Fletcher). Enquanto a voz over explica as regras do jogo, a câmera focaliza em close-up algumas palavras-chaves em inglês como "política", "desenvolvimento", "simulação", "intento nacional", "conflito revolucionário": “Trata-se de um país imaginário, batizado Pátria. Sua indústria principal é o cobre, extraído de uma região mineira chamada Cupria, controlada por uma companhia estadunidense real: a Anaconda Copper $^{241}$. Objetivo do jogo: determinar como reagirão, em caso de um enfrentamento de classes, as forças envolvidas." (La spirale, 1976, tradução nossa) $)^{242}$

Dos documentos "reais" encontrados pela equipe, o documentário passa para sua representação alegórica, materializada nos bonecos desenhados por Folon. Cada personagem corresponde a um sujeito social, ou seja, novamente se trata de um modelo sociológico genérico que identifica classes e atores presentes em diversas sociedades (não apenas no caso específico chileno), mas que pode ser aplicado a esse contexto local. Ao longo do filme, eles serão movidos como simulacros dos sujeitos

\footnotetext{
${ }^{240}$ Uma pesquisa realizada na revista Le film français ao longo da década de 1970 permite mapear alguns dados sobre a recepção de La spirale na França, mais especificamente o tempo em que o documentário ficou em cartaz e em que período. Nesse sentido, pode-se afirmar que estreou em Paris e em salas da periferia dessa cidade em abril de 1976, permanecendo em exibição até setembro desse mesmo ano. O periódico registra cerca de 29.638 entradas vendidas ao longo de dezoito semanas. Outro dado interessante é que integrou a seção "Perspectivas" do Festival de Cannes no ano em que foi lançado (1976), na categoria "filmes recentes", quando também estiveram no evento A batalha do Chile (primeira parte) e Actas de Marusia, de Miguel Littin. Enquanto o primeiro fazia parte da "Quinzena de realizadores", o segundo competiu como o filme oficial representante do México (país onde Littin encontrava-se no exílio).

${ }^{241}$ Anaconda Cooper é uma referência direta à companhia mineradora estadunidense de mesmo nome. Uma das maiores do mundo em sua época, adquiriu, em 1922, a companhia Chuquicamata, que administrava a maior mina de cobre do mundo, localizada no norte do Chile. Em 1971, foi nacionalizada pelo governo de Salvador Allende.

${ }^{242}$ Texto da voz over de La spirale, traduzido do original: "Il s'agit d'un pays tout à fait imaginaire, baptisé Patria, qui a avait pour principale industrie le cuivre, extrait d'une région mineure nommée Cupria, laquelle était contrôlée par une véritable compagnie américaine, l'Anaconda Copper. Objectif du jeu: déterminer comment, dans le cas d'un affrontement de classe, réagirait les forces en présence."
} 
atuantes nos conflitos durante a Unidade, atuando como espécies de "avatares" desses sujeitos e assumindo o formato de peças de tabuleiro estilizadas ${ }^{243}$.

Assim como o cinema, os jogos também são formas de representação do mundo real, que propõem modelos com base em uma leitura da realidade. Expressões como "distribuir as cartas", "analisar as jogadas", "blefar", "dar um xeque-mate", "neutralizar o adversário" são usadas constantemente nos diálogos relativos a disputas de naturezas diversas, como as bélicas e as que envolvem projetos políticos opostos. Enquanto simulacros, contribuem para a compreensão das dinâmicas da sociedade. Diante dessas considerações, pode-se dizer que a alegoria do tabuleiro e da movimentação de suas peças exerce, em La spirale, uma função narrativa didática, que colabora para que o espectador organize as informações fornecidas sobre o período da Unidade Popular, visualizando os sujeitos citados e suas ações.

No campo das ciências sociais, existe uma vasta bibliografia que recorre à metáfora do jogo para analisar os movimentos políticos e suas variáveis ${ }^{244}$. Um dos conceitos que melhor colabora para a compreensão da proposta de La spirale ao recorrer a essa alegoria é o de guerra de posições, de Antonio Gramsci, que propunha que a construção da hegemonia (entendida como direção intelectual e moral exercida sobre os demais grupos sociais, do ponto de vista político e cultural) era necessária antes da ruptura do Estado. Esse conceito serve à análise do uso do jogo como elemento narrativo pois, assim como os realizadores do documentário, o autor italiano recorria à terminologia militar ao definir estratégias políticas concernentes à sociedade civil, definindo como "trincheiras" alguns de seus setores, como os meios de comunicação social, as igrejas, os sindicatos etc.

\footnotetext{
${ }^{243}$ A metáfora do jogo e sua relação com a vida real foi retomada por Chris Marker no filme Level 5 (1996), em que a personagem Laura interage com um videogame que recria a batalha de Okinawa. Sua meta é encontrar testemunhas que a ajudem a relembrar um episódio do "esquecimento coletivo", e trazê-lo, assim, à tona. Assim como em La spirale, estão em pauta alguns elementos clássicos do universo dos jogos, como a estratégia (fator presente também nas disputas bélicas), a disputa entre dois ou mais sujeitos, o ato de remontar (caso dos quebra-cabeças) etc. Nas duas produções, há uma ligação entre o mundo real e sua simulação, na qual a prática "ficcional" de jogar permite a recomposição de uma realidade dissolvida. Uma análise apurada da questão do jogo em Level 5 pode ser encontrada na tese de Emi Koide, em que a autora faz uma relação da possibilidade de reviver o passado por meio dessa prática com a espiral do tempo proposta por Vertigo (no caso deste filme, de 1958, optou-se por utilizar o título original, em detrimento da tradução brasileira, Um corpo que cai): "Esta ideia da possibilidade de repetir, do duplo, encontra-se sempre presente na obra de Marker. A possibilidade (ou não) de jogar novamente, de reviver a história, o desejo de repetir para recuperar o que foi perdido que se revela impossível, ou de repetir para criar outra configuração das coisas são leitmotivs markerianos." (KOIDE, 2011, p. 68)

${ }^{244}$ Ver, como exemplo: Champagne (1996); Goffman (1985); e Murray (1991).
} 
De forma semelhante à teoria gramsciana, porém de orientação política inversa, La spirale expõe uma guerra de posições cujos protagonistas não são revolucionários, e sim os conservadores. Nesse sentido, se o documentário já havia proposto a tese que a burguesia chilena utilizou técnicas da esquerda na desestabilização do governo Allende - por meio da teoria de Mattelart em relação a uma "frente de massa leninista de direita" -, é possível afirmar que a presença de Política endossa a defesa de que a direita buscou conquistar a hegemonia em setores estratégicos da sociedade civil antes de consolidar sua "contrarrevolução" com o golpe de Estado. A alegoria do jogo serve, então, para analisar e narrar etapas prévias de um processo cuja deposição do presidente pelas forças armadas ocorre como o auge de um conflito que envolveu trincheiras anteriores.

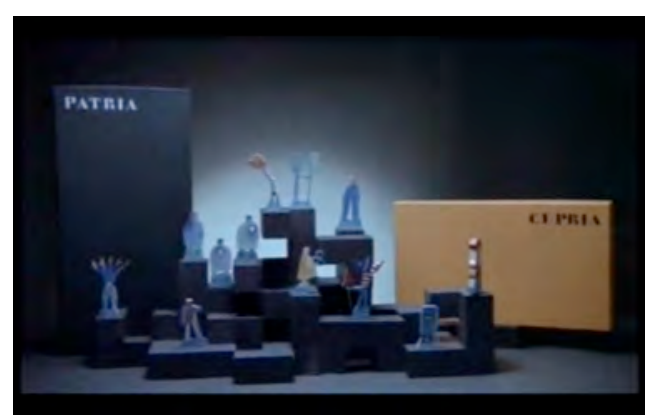

Fotograma de La spirale com tabuleiro do jogo Política.

Cada boneco de Folon focalizado em close-up nesse plano-sequência representa uma categoria social, totalizando doze atores principais, conforme anuncia a voz over:

[...] o governo; os partidos políticos de direita do tipo conservador; os partidos de centro tipo Democracia Cristã; os partidos de esquerda batizados, em homenagem ao vício e à virtude ${ }^{245}$, "forças de libertação nacional"; a oligarquia urbana, aristocracia do dinheiro; os proprietários de terra; as classes médias; o proletariado; os estudantes; os capitalistas estrangeiros; as embaixadas capitalistas estrangeiras; e os militares, dos quais o Pentágono tinha evidentemente o conhecimento de todas as opções possíveis. ( $L a$ spirale, 1976, tradução nossa) ${ }^{246}$

\footnotetext{
${ }^{245}$ Esse comentário é um exemplo de como muitas vezes a ironia marca o tom da voz over. Ao afirmar que os partidos de esquerda são chamados pelas universidades norte-americanas de "forças de libertação nacional", a locução salienta como um mesmo termo pode ser taxado de pejorativo ou elogioso, de acordo com o campo político que o emprega (no caso, usado pela direita, adquire um tom de "vício", embora, para a esquerda, "libertar" as nações do imperialismo seja uma característica positiva).

${ }^{246}$ Texto da voz over de La spirale, traduzido do original: “[...] le gouvernement; les partis politiques de droite type conservateur; les partis politiques du centre type Démocratie chrétienne; les partis
} 

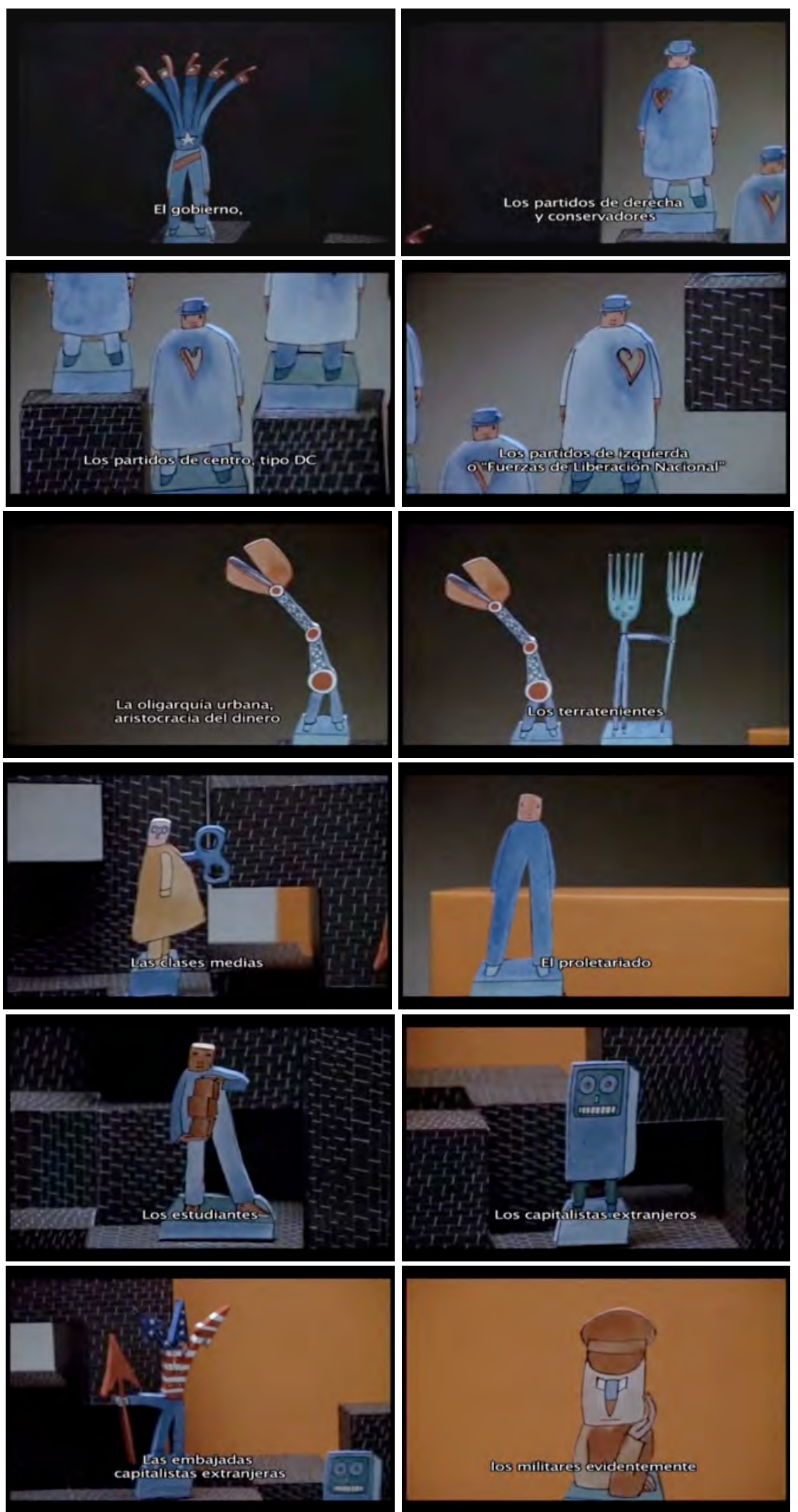

Alegorias do artista Folon para forças políticas no Chile.

politiques de gauche baptisés, hommage du vice à la vertu, 'forces de libération nationales'; l'oligarchie urbaine, l'aristocratie de l'argent; les propriétaires terriens; les classes moyennes; le prolétariat; les étudiants; les capitalistes étrangères; les ambassades capitalistes étrangères; et les militaires, dont le Pentagone tenait évidement à connaitre toutes les options possible." 
Ao longo do documentário, outros sujeitos serão apresentados, caracterizados alegoricamente pelo artista gráfico como "pássaros". Esses personagens secundários, mas não menos importantes para o processo político, são justamente aqueles que, ao final do bloco $\mathbf{O}$ jogo, começam a ser movidos para setas marcadas no tabuleiro. Em diversas passagens do filme, a câmera foca uma mão dispondo-os em uma espécie de comissão de frente. É a voz over, mais uma vez, que informa o espectador sobre sua identidade: grêmios e grupos corporativos, na forma de associações profissionais de trabalhadores.
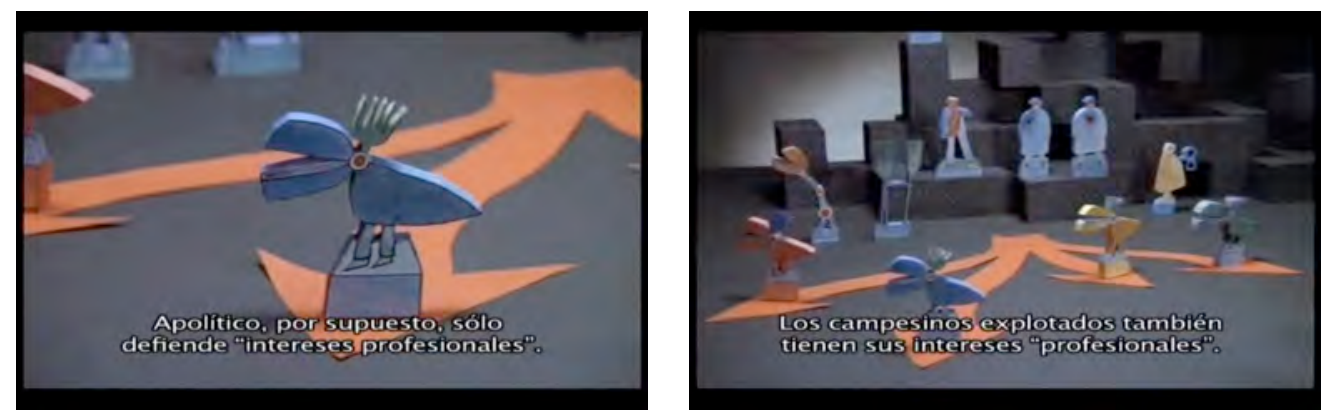

Alegorias do artista Folon para forças políticas no Chile.

A crítica a esses setores sociais e sua atuação para a derrubada do governo Allende é um discurso central em La spirale. O objetivo de denunciar como esses representantes da alta burguesia, disfarçados de instituições protetoras do proletariado, boicotaram as mudanças sociais em curso está claro em diversas sequências. As peças "pássaros" do jogo encontram equivalência em quatro associações do Chile dessa época: Sociedad de Fomento Fabril (Sociedade de Fomento Fabril, SOFOFA), Sociedad Nacional de Agricultura (Sociedade Nacional de Agricultura, SNA), Cámara de Comercio (Câmara de Comércio) e Cámara de Construcción (Câmara da Construção). Durante os anos da UP, esses grêmios foram responsáveis por greves, paralisações, fechamento de fábricas, quebra de tratores, interrupção no abastecimento, entre outras sabotagens. Conforme o documentário se desenvolve, outros sujeitos também são dispostos sobre flechas demarcadas no tabuleiro de Política: as mulheres e os estudantes.

A apresentação dos grêmios finaliza o bloco $\mathbf{O}$ jogo, cujo principal tema é o imperialismo (como categoria sociológica e como fenômeno presente no Chile desde a hegemonia britânica no final do século XIX). Ela anuncia, entretanto, um novo enfoque temático que será central até o momento do golpe de Estado: a teoria de que ocorreu a formação de uma "linha de massa leninista de direita" no país. 
Um intertítulo indica o bloco de número três, A frente, mais uma etapa da espiral. Essa parte recorre amplamente à trajetória espiralada para tratar da relação dialética entre revolução e contrarrevolução. A polarização entre dois universos pertencentes a classes sociais distintas é exposta logo na abertura, quando - ao som de A desalambrar, de Víctor Jara - duas cenas de uma sequência se chocam: na primeira, ocorre o close-up de mãos e rostos de camponeses; na segunda, um plano panorâmico em plongé sobrevoa uma mansão campestre com piscina. Essa escolha é significativa também da posição adotada pelos diretores, que claramente optam pela proximidade ao mostrar os pobres e pela distância ao exibir os ricos. Em combinações como essas, fica evidente o ponto de vista dos realizadores, mesmo que o material fílmico que utilizem na montagem tenha sido capitado por outras pessoas.

Assim, caracteriza-se um prelúdio das batalhas que virão a seguir, no bloco $\mathbf{A}$ frente: ocupações de terra $\mathrm{x}$ ofensiva dos proprietários; nacionalização do cobre $\mathrm{x}$ complô de seu preço no mercado internacional; nacionalização dos bancos x criação da imagem de caos econômico. Como é possível observar, para cada medida adotada pela Unidade Popular, ocorre, na visão dos diretores, uma contraofensiva da direita, prosseguindo com a espiral.

O quarto bloco, A aproximação, começa e termina com gravações realizadas durante a visita de Fidel Castro ao Chile. A figura do líder da Revolução Cubana é emblemática por representar, ao mesmo tempo, uma vitória e um abalo para a UP. Uma sequência gravada no Estádio Nacional, em novembro de 1971, documenta a popularidade do cubano. Porém, a voz over anuncia que há um risco por trás das imagens de festividade:

10 de novembro de 1971, Fidel Castro, respondendo a um convite de Allende, chega ao Chile em visita oficial. Ele percorrerá o país durante 22 dias, curioso de tudo, falando de tudo, fiel a si mesmo. Um presente para a esquerda chilena, que recebe em sua casa o mais prestigiado líder revolucionário vivo da América Latina; mas também para a direita, que encontra a ocasião de explorar a presença de um "bicho-papão" que ela já utilizava há um ano para amedrontar. (La spirale, 1976, tradução nossa) ${ }^{247}$

\footnotetext{
${ }^{247}$ Texto da voz over de La spirale, traduzido do original: "Le 10 novembre 1971, Fidel Castro, répondant à l'invitation d'Allende, arrive au Chili en visite officielle. Il parcourra le pays pendant 22 jours, curieux de tout, parlant de tout et égal à lui-même. Cadeaux pour la gauche chilienne, qui reçoit chez-elle le plus prestigieux leader révolutionnaire vivant de l'Amérique latine; mais également cadeaux pour la droite, qui trouve l'occasion de concrétisé sur une présence l'épouvantail qu'elle agit depuis un an."
} 
Na sequência seguinte, um dirigente gremialista alerta para o "perigo" ao qual o país se encaminhava: "O governo da Unidade Popular está nos conduzindo inexoravelmente a ter um modelo político que é idêntico ao da Cuba marxista de Fidel Castro." (La spirale, 1976, tradução nossa) ${ }^{248}$. O som direto de entrevistas, preferencialmente feitas com setores conservadores, é abundante em todo o bloco A aproximação, tanto quanto os discursos públicos. Os estudantes democrata-cristãos que ocuparam a Universidade Católica (alertando para o surgimento do "fascismo vermelho"), o ex-presidente Eduardo Frei (destacando o papel da mulher para a preservação dos valores morais e espirituais do Chile) e o presidente da Confederación Única de Profesionales de Chile (Confederação Única de Profissionais do Chile, CUPROCH, mais uma organização patronal) são algumas das vozes reproduzidas pelo documentário nessa parte.

Esse procedimento mostra uma escolha incomum em produções militantes, que costumam abusar dos depoimentos de grandes nomes da esquerda. Porém, não se trata de dar "voz" ao inimigo, mas sim de inserir seu discurso envolto em uma série de sons e imagens que o torna um "tiro pela culatra", uma tentativa de desmascaramento de sua ideologia. Um exemplo é o trecho em preto e branco de um Centro de Madres, no qual a câmera focaliza rostos simples, muitos de aparência indígena. A mesma sequência poderia estar em uma propaganda da Democracia Cristã sobre sua atenção às mães necessitadas, já que foi gravada durante o governo Frei. Mas a voz over outra vez atribui o ponto de vista dos diretores aos fragmentos audiovisuais, modificando seu conteúdo original: "Todo o trabalho social da DC consiste em criar Centros de Mães, Centros de Jovens, conselhos de bairros e numerosas pequenas comunidades separadas que, juntas, formam uma sociedade harmoniosa e sem reivindicações." (La spirale, 1976, tradução nossa). ${ }^{249}$ As mulheres tricotando parecem, dessa forma, entretidas por uma atividade que retira delas o potencial de participação política.

Os discursos de Castro e Allende fazem um contraponto à esquerda ao discurso dos inimigos, abrindo uma nova esfera na espiral. O apoio emocionado do

\footnotetext{
${ }^{248}$ Fala de líder gremialista em La spirale, traduzida do original: "El gobierno de la Unidad Popular nos está conduciendo inexorablemente hacia un modelo político que es idéntico à Cuba marxista de Fidel Castro".

${ }^{249}$ Texto da voz over de La spirale, traduzido do original: "Tout le travail social de la démocratie chrétienne, d'ailleurs réel, consiste en créer des Centres de Mères, des Centres de jeunes, des conseils de cartier et plusieurs des petites communautés séparées dont ensembles forment une société harmonieuse et sans revendications."
} 
"companheiro presidente" aos operários em greve em uma fábrica, falando como um líder sindical que comanda uma assembleia, clama para que se evitem mais prejuízos para o país: "Ou seja, aí se necessita a consciência dos trabalhadores. Para dizer que eles não podem, que são trabalhadores que podem pressionar fortemente. E não podem fazê-lo contra o governo, pois é o seu governo. Eles são governo." (La spirale, 1976, tradução nossa) ${ }^{250}$ Claramente, se trata de uma resposta ao discurso gremialista, sobretudo o da CUPROCH, cujos associados recebiam treinamento e bolsas das instituições de ensino dos Estados Unidos.

Com isso, o documentário volta a inserir uma tomada do tabuleiro, criado justamente nesses centros de formação de cérebros a serviço do imperialismo (na visão do documentário). A câmera enfoca a figura alegórica da pequena burguesia, caracterizada por Folon como um homem movido por uma manivela nas costas. "A pequena burguesia se compõe de vários atores", informa a voz over ao posicionar as alegorias "pássaros" (instituições patronais), mulheres, estudantes e embaixadas estrangeiras na linha de massa. Esse tipo de movimentação das peças remete novamente à ideia de uma guerra de posições às avessas (manobrada pelos conservadores), na qual pouco a pouco são conquistados importantes setores da sociedade civil que consolidam uma hegemonia da direita que precede a tomada do Estado - ou, o golpe.

Fidel Castro, em entrevista retirada de El diálogo de América (Álvaro Covacevich, 1972), é quem volta para finalizar o quarto bloco, com uma fala que não por acaso foi retirada de um filme onde ele conversa frente a frente com Salvador Allende:

Essa resistência entrega um procedimento clássico, mas mais desenvolvido. É um procedimento que nós classificamos de fascista. E que trata, portanto, de ganhar a massa. Massa com demagogia, se possível nos setores mais atrasados das camadas humildes. Ganhar massa nas camadas médias. Então agora falta uma questão para demonstrar. Se seus interesses se resignam passivelmente às mudanças que a Unidade Popular e o povo chileno querem levar adiante. E resta esperar se nós vamos analisar teoricamente essa

\footnotetext{
${ }^{250}$ Fala de Salvador Allende presente em La spirale, traduzida do original: "O sea, ahí se necesita la conciencia de los trabajadores. Para decir que ellos no poden, que son trabajadores que poden presionar fuertemente. Y no pueden hacerlo contra el gobierno, pues es tu gobierno. Ellos son gobierno.”
} 
questão, ganhar resistência, resistência forte, incluindo a resistência violenta. (La spirale, 1976, tradução nossa) $)^{251}$

Um vencedor da via insurrecional, portanto, prevê o processo contrarrevolucionário que barraria a vitória do socialismo pela democracia (a tal "linha de massa leninista de direita", na tese de Mattelart). Embora o documentário não apresente uma contradição entre os dois caminhos da esquerda - armado ou democrático -, já que as imagens dos presidentes cubano e chileno indicam uma aliança, essa é uma tensão implícita na fala descrita acima. Se, por um lado, entendese o aviso como um apoio, por outro ele adverte que a chegada ao socialismo não poderia ser feita apenas pelo voto. A resistência "forte" e "violenta" evocada por Fidel Castro não deveria ser descartada. Embora, como será abordado neste capítulo, a autocrítica dos partidos esquerdistas seja negligenciada nessa produção, cabe destacar que há alguns momentos de tensão em que ela emerge de maneira indireta, como nessa declaração do líder cubano.

Vale destacar ainda a atenção dada pelo documentário à visita de Castro ao Chile, evento que foi um dos momentos de maior fragilidade e de conflitos durante a Unidade Popular, sobretudo pela presença de uma espécie de "bicho-papão" em território nacional - para usar um termo empregado pela voz over. Em La spirale, passa-se a ideia de aliança entre os dois líderes socialistas, e o argumento de que cada povo deveria encontrar seu próprio caminho. Porém, o filme deixa de explorar algumas implicações ligadas à estada do cubano, como as que podem ser percebidas em sua fala citada acima, mas que não são aprofundadas pela narrativa: o acirramento das críticas aos opositores do governo Allende e a incitação ao caminho armado como forma de consolidar a revolução ${ }^{252}$.

\footnotetext{
${ }^{251}$ Fala de Fidel Castro presente em La spirale, traduzida do original: "Esa resistencia acusa un procedimiento clásico, pero más desarrollado. Es un procedimiento que nosotros clasificamos de fascista. Y que trata, por tanto, de ganar la masa. Masa con demagogia, si posible en los sectores más atrasados de las capas humildes. Ganar masa en las capas medias. Entonces ahora falta una cuestión por demonstrar. Si sus intereses se resignarán pasiblemente a los cambios de estructura que la Unidad Popular y el pueblo chileno quieren levar adelante. Y esperar si nosotros vamos analizar teóricamente esa quistión, ganar resistencia, resistencia fuerte, incluso la resistencia violenta."

${ }^{252}$ As tensões relacionadas à visita de Fidel Castro ao Chile, em novembro de 1971, aparecem em muitos filmes do período, inclusive naqueles que serviram de material de arquivo para La spirale. Se em Compañero presidente, de Miguel Littin, o debate sobre a via ao socialismo já havia sido tratado de maneira polêmica - vale lembrar que o próprio diretor se manifestou contrário a que Salvador Allende respondesse às provocações de Régis Debray em um documentário -, em El diálogo de América, de Álvaro Covacevich, a discussão sobre a opção armada e a pacífica se intensifica. Nessa produção, há a tentativa de colocar o Chile e Cuba como países "irmãos" (fruto em parte da mediação de Augusto Olivares entre os dois líderes), enfatizando que "cada povo teria seu próprio caminho". No entanto, as falas de Castro costumam desafiar os limites de uma revolução sem armas, denunciando que a
} 
No artigo "Uma insólita visita: Fidel Castro no Chile de Allende", Alberto Aggio (2003) aponta essas duas características - ênfase na existência de uma contrarrevolução em curso e na superação da via democrática para uma implementação real do socialismo pelas armas - como predominantes nos discursos castristas realizados em novembro de 1971, quando o então primeiro-ministro cubano permaneceu 24 dias no Chile. Para o autor, Castro atuou no sentido de incentivar uma radicalização do processo chileno, o que confirmaria sua tese da impossibilidade da opção pacífica e preservaria sua hegemonia revolucionária no continente, resultando em um afloramento das táticas da oposição e das divergências internas no seio da Unidade Popular. Como exemplo desse acirramento ideológico, ele cita a passeata das "panelas vazias", comandada por mulheres da burguesia e que eclodiu em $1^{\circ}$ de dezembro de 1971. Aggio escreve que:

A maior parte dos observadores reconhece que o Chile passou a ser um país bastante diferente depois da presença de Castro. Sua visita pode, de fato, ser considerada como um ponto de inflexão no desenvolvimento dos acontecimentos que iriam marcar e definir a sorte da experiência chilena. É claro que não corresponde a uma análise correta atribuir à visita em si a ruptura do equilíbrio que anteriormente havia caracterizado a vida institucional chilena. Contudo, há que se reconhecer que a série de intervenções feitas por Fidel ao longo da viagem acabou por produzir ou acentuar um ambiente de confrontação entre esquerda e direita que impediria ou impossibilitaria, a partir daquele momento, qualquer convivência democrática. Uma outra consequência direta da visita - de consequências gravíssimas - foi a explicitação das diferenças no seio da Unidade Popular. (AGGIO, 2003, p. 154)

Apesar de não atribuir à visita de Castro um prejuízo à Unidade Popular, como faz Alberto Aggio, La spirale passa a valorizar o tema dos boicotes da burguesia ao governo após as imagens do líder cubano no Chile. O ritmo se acelera do quinto bloco em diante, à medida que esses movimentos conservadores passam a dar o tom à narrativa. Permanece, no entanto, a tentativa dos realizadores de intercalar contrarrevolução e revolução nas diversas sequências temáticas.

Em O ataque, cenas tiradas de filmes militantes e de redes de televisão são entrepostas na montagem para mostrar o caos instalado pela greve dos transportes, em

burguesia não aceitaria facilmente as transformações sociais em curso e alertando para um conflito inevitável. Já em El primer año, de Patricio Guzmán, as cenas finais mostram o primeiro-ministro cubano como alguém querido pelo povo, retratando-o com mais proximidade do que o chefe de Estado chileno. Essa diferença de tratamento não deixa de evidenciar um tensionamento interno na esquerda durante a longa estadia de Fidel Castro, que está presente nos documentários da época, mesmo quando tentam equiparar os dois modelos latino-americanos. 
1972. Como é possível notar, apesar de não respeitar um critério cronológico na ordem das sequências, o documentário segue uma cronologia na abordagem dos episódios, rumo ao golpe. Eleições (1970), primeiras articulações da direita, visita de Castro ao Chile (1971) e greve dos transportes (1972) são alguns dos marcos dos anos de Unidade Popular que compõem a espiral da história. Assim, cria-se uma concepção historiográfica na narrativa na qual o tempo não se organiza de maneira linear, um acontecimento sucedendo o outro, mas espiralada, dando espaço para voltas inesperadas ao longo do processo.

Esse quinto bloco - O ataque - traz indícios de resposta à questão já colocada nesta tese: como um filme feito por realizadores adeptos de um projeto esquerdista revolucionário pode se dedicar à vitória do inimigo sem capitular? Por meio da descrição de duas cenas que o compõem, embora não apareçam seguidas na montagem, é possível visualizar uma saída encontrada a esse dilema. Caminhoneiros em greve, deitados ao lado de seus caminhões parados, fazem uma grande manifestação estática com a presença de bandeiras do Chile. Alguns minutos depois, são apresentadas cenas de bicicletas e tratores nas ruas, pessoas se organizando para distribuir produtos em falta, carroças levando alimentos aos bairros pobres. A escolha por esses dois grupos de registro - a tentativa de imobilizar a sociedade, vinda dos contrários à UP, e as ações coletivas encabeçadas pelos favoráveis a ela - passam a ideia de que o processo revolucionário segue de maneira espontânea e autônoma, com o fortalecimento do poder popular ${ }^{253}$.

Os temas presentes nesse bloco reforçam a presença de ações e reações: greve no transporte $\mathrm{x}$ meios alternativos de locomoção; paralisação de pequenos comerciantes x criação das Juntas de Abastecimiento (Juntas de Abastecimento, JAPs); greve geral nas fábricas x ocupações operárias; ocupação da Universidade Católica $\mathrm{x}$ engajamento de estudantes nos movimentos populares. $\mathbf{O}$ ataque se encaminha para o final, porém, com a indicação de uma crescente mobilização popular por parte da esquerda, com ocupações de terras e indústrias e grandes passeatas nas ruas. A voz over, mais uma vez, se posiciona sobre a situação, indicando a essência dessa nova etapa da espiral, posterior ao "paro" geral:

\footnotetext{
${ }^{253}$ Muitas das cenas presentes neste bloco fazem parte também do documentário A batalha do Chile III - O poder popular (1979). Originalmente, foram gravadas para a produção La respuesta de octubre (1972).
} 
O movimento pensava que o tempo trabalhava para ele. A paralisação do país ia sublevar o povo contra o governo, o governo encurralado capitularia diante da oposição. O caminho seria simples. Mas a realidade é mais sutil. A direita tentou colocar a Unidade Popular em uma situação impossível. Ela a colocou em uma situação difícil. E é dessa dificuldade que vai nascer o contraataque. (La spirale, 1976, tradução nossa) ${ }^{254}$

A vitória parcial da esquerda após o enfraquecimento da greve geral não permite, porém, que a espiral se feche. Apesar do bloco $\mathbf{O}$ ataque terminar com esse resultado positivo, ele insere novos atores em cena, ao mostrar gravações de televisão nas quais Allende entra no plenário acompanhado de militares. Trata-se do anúncio da integração dos generais Luis Sepúlveda, Carlos Prats e Ismael Huerta ao governo (este último, descrito pela voz over como futuro ministro de Pinochet). Para os realizadores, tratava-se de uma maneira de o poder executivo mostrar aos grevistas que existia uma aliança entre as forças armadas e a classe operária.

Dessa forma, a deixa para o sexto bloco está dada. O exército discorre sobre as forças armadas, visando a combater sua autoimagem de "legalista" e mostrando seu caráter dúbio durante a Unidade Popular. La spirale caracteriza sua "neutralidade" histórica no Chile como uma falácia, um mito autoconstruído, usando como argumento o fato de elas serem tradicionalmente tutoradas por nações estrangeiras e atuantes na repressão aos movimentos populares (portanto, não confiáveis). Uma cena retirada do especial Six mois d'Unité populaire (1971), produzido pela televisão francesa ORTF, confirma essas hipóteses por meio de uma entrevista com o general Canales:

[Entrevistador francês:] Os serviços secretos estadunidenses não estariam tentados a encorajar certos elementos das forças armadas chilenas a fomentar um golpe militar contra o governo do senhor Allende, que podemos considerar como, se você quiser, hostil aos interesses americanos?

[Canales:] Não senhor. Os serviços secretos de inteligência estadunidenses não têm acesso às forças armadas. Portanto, é impossível estimular um golpe de Estado por parte do exército.

\footnotetext{
${ }^{254}$ Texto da voz over de La spirale, traduzido do original: "Le mouvement pensait que le temps travaillait pour lui. La paralysie du pays dresserait le peuple contre le gouvernement, le gouvernement, impuissant, capturait devant la opposition. Le chemin était simple. La réalité est plus subtile. La droite cherche à mettre la Unité populaire dans une situation impossible. Elle l'a mis dans une situation difficile. Et de cette difficulté même va naître la contre-attaque."
} 
[Entrevistador francês:] Então, vocês têm o governo do senhor Allende e vocês continuam trabalhando da mesma maneira que antes.

[Canales:] Sim, da mesma maneira, naturalmente. [...] A atitude das forças armadas em relação ao governo da Unidade Popular é a mesma que tivemos durante toda a história do Chile. As forças armadas chilenas são essencialmente apolíticas, essa é nossa tradição histórica e nossa tradição militar. Nós somos apolíticos, constitucionalistas e legalistas, são forças armadas essencialmente profissionais. (La spirale, 1976, tradução nossa) $)^{255}$

O conhecimento prévio que o espectador tem do golpe, possível graças ao auxílio das tropas norte-americanas, transforma o que seria uma simples entrevista em prova da deslealdade dos militares chilenos. A voz over desempenha ainda o papel de reforçar essa impressão, ao interromper Canales para informar que o mesmo foi destituído do exército em 1972 em decorrência da suspeita de ter apoiado a greve geral. Essa informação, de certa maneira, insere um tom de crítica à decisão do governo em incorporar as forças armadas aos seus quadros. Afinal, o histórico de sua atuação deveria gerar desconfiança de suas boas intenções. Nesse caso, encontra-se um exemplo de que, apesar da autocrítica da esquerda não ser o objetivo do documentário, algumas vezes ela aparece nas escolhas dos realizadores introduzida na narrativa pelo desfecho desfavorável decorrente de algumas de suas decisões.

A riqueza de detalhes e elucubrações aos que o filme leva é indício de que ele foi pensado para o espectador que, mesmo sendo europeu, sabe o que se passou no Chile. Porém, adquiriu esse conhecimento principalmente em periódicos que não se preocupavam - ou se interessavam - em explicar as razões e os meandros usados pela direita chilena para derrubar o governo da UP. Sendo assim, La spirale se propõe a ser, sobretudo, uma fonte detalhada de informação, sob um ponto de vista da esquerda (conforme será mais explorado no subcapítulo relativo ao uso da voz over). No artigo

\footnotetext{
${ }^{255}$ Diálogo reproduzido de La spirale, traduzido do original: "[Entrevistador francês:] Est-ce que les services secrets américain ne seront pas tenté à encourager certains éléments de les forces armées chiliennes à fomenter un coup d'État contre le gouvernement de monsieur Allende, qu'on peut juger comme, si vous voulez, hostile aux intéresses américains?

[Canales:] Non, monsieur. Les services secrets d'intelligence des États-Unis n'ont pas accès aux forces armées. En conséquence, c'est impossible stimuler un coup d'État de part de l'armée.

[Entrevistador francês:] Donc, vous avez le gouvernement de monsieur Allende et vous continuez votre travail de la même manière qu' avant.

[Canales:] Oui, de la même manière, naturellement. [...] L'attitude des forces armées par rapport au gouvernement de l'Unité populaire c'est la même que nous avons eu pendent tout l'Histoire du Chili. Les forces armées chiliennes sont essentiellement apolitiques, c'est ça notre tradition historique et notre tradition militaire. Nous sommes apolitiques, constitutionnalistes et légalistes, sont forces armées essentiellement professionnelles."
} 
"Savoir posthume (La spirale)", publicado em 1976 - logo após o lançamento do documentário -, o crítico Serge Toubiana ressalta sua importância como veículo de contrainformação aos meios hegemônicos:

Uma das características para um filme como esse é que seu espectador em potencial já tenha um certo saber sobre o assunto em questão. Então, se sabemos o que se passou, resta saber como isso se passou, e por quê. É a essas questões que o filme tenta responder, é a esse espectador que o filme se dirige. (TOUBIANA, 1976, p. 57, tradução nossa) ${ }^{256}$

O conhecimento construído a partir dos documentos encontrados pelas montadoras é a versão de que o Chile viveu um intenso período de conflitos internos, em que forças de esquerda e de direita se enfrentaram arduamente, até que o último recurso que restou aos conservadores da ordem burguesa teve de ser empregado: o golpe de Estado. Dessa forma, o bloco final intensifica o ritmo dos ataques e contraataques, tornando mais curtas as voltas da espiral, reduzindo-as ao espaço temporal de dias e horas. O golpe enfatiza uma resistência frenética da Unidade Popular, que conseguiu reafirmar sua popularidade nas urnas (nas eleições parlamentares de março de 1973); respondeu à presença das mulheres, estudantes e outros setores que compunham a "linha de massa" direitista com a maior manifestação popular da história do Chile; combateu a tentativa frustrada de tomada do poder pelo exército, " $\mathrm{el}$ tancazo", com um ato em prol do fechamento do parlamento; minimizou a crise econômica por meio dos cordões industriais - ou seja, utilizou de todos os mecanismos legais e da participação popular para se manter "rumo ao socialismo".

Nesse bloco, como nos demais, os produtores utilizam largamente o mecanismo de alternar cenas de filmes militantes com imagens captadas para televisão, que servem, em igual medida, para endossar o discurso fílmico. Suas disposições na montagem, mesmo que originalmente tenham sido gravadas sob pontos de vista ideológicos opostos, são complementares. As sequências da manifestação realizada no dia do aniversário da eleição presidencial, em 4 de setembro de 1973 (tanto as coloridas como as em preto e branco), abrem espaço para os gritos em som direto de "Allende, Allende, o povo te defende". Close-ups em rostos de "populares" retomam o recurso de caracterizar as forças em jogo pela

\footnotetext{
${ }^{256}$ Traduzido do original: "Une des caractéristiques pour un film comme celui-ci, c'est que son spectateur possible possède déjà un certain savoir sur le référent en question. Donc, si on sait ce qui s'est passé, il reste à savoir comment ça s'est passé, pourquoi. C'est à ces questions que le film tente de répondre, c'est à ce spectateur que le film s'adresse.
} 
aparência de classe dos participantes de cada evento retratado. O corte após a representação desse acontecimento direciona o espectador para o local onde está sendo articulado o pedido de renúncia do presidente: a Universidade Católica, espaço por excelência dos filhos da burguesia nacional. Esses dois ambientes contrapostos, visivelmente habitados por setores diversos da sociedade, identificam as forças em jogo e os interesses defendidos pelos protagonistas.
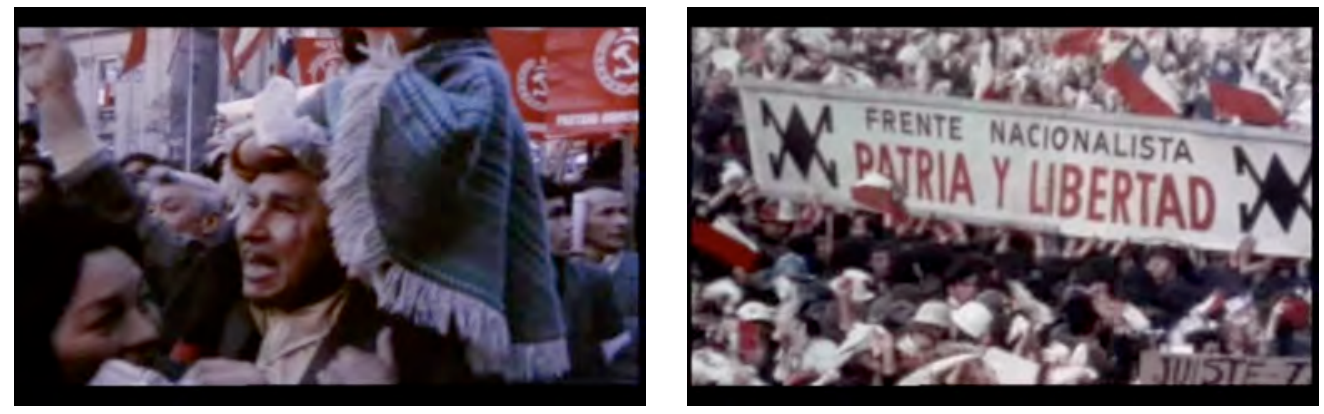

Manifestações favorável e contrária a Salvador Allende em La spirale.

Além dos enfrentamentos políticos e sociais, o bloco $\mathbf{O}$ golpe explora as tensões militares e paramilitares atuantes em 1973. Enquanto o espectador acompanha um fragmento que retrata caminhões carregados de soldados passando entre pessoas e carros nas ruas de Santiago, a voz over enfatiza o clima de conspiração:

A partir daí, o papel do exército torna-se determinante. Unido ou dividido? Aliado ou inimigo? Deve-se apaziguar, ao preço de concessões impopulares, ou contrariar, assumindo o risco de uma guerra civil? Para quem não teve a responsabilidade dessas decisões, o julgamento após o golpe é muito fácil. A hostilidade dos trabalhadores ao exército se baseia na experiência concreta. ( $\mathrm{La}$ spirale, 1976, tradução nossa) ${ }^{257}$

O trecho acima é um indício de que, por mais que em alguns momentos ocorra uma leve autocrítica da esquerda, o objetivo dos realizadores não é julgar seus aliados, mas sim conhecer melhor seu inimigo. Talvez, por agir no calor dos acontecimentos, como ressalta a voz over, as decisões tomadas não foram as mais adequadas. Enquanto a direita fabricava seus métodos em simulações criadas pelos cérebros universitários norte-americanos - e as aplicava internacionalmente -,

\footnotetext{
${ }^{257}$ Texto da voz over de La spirale, traduzido do original: "À partir de là, le rôle de l'armée devient déterminant. Uni ou divisée Allié ou ennemi? Il faut que la apaiser au prix des concessions impopulaires ou il la contre au risque d'une guerre civil? Pour qui n'a pas eu la responsabilité de cette décision le jugement après le coup est trop facile. L'hostilité des travailleurs à elle repousse sur l'expérience concrète."
} 
comunistas e socialistas têm como seus maiores parceiros organizações espontâneas de poder popular - como indica essa passagem do filme.

Imagens semelhantes às presentes no prólogo, que mostra o ataque ao La Moneda, integram o final desse último bloco. Elas são inseridas após uma sequência tomada em 11 de setembro de 1973, na qual Allende acena da sacada do palácio e se recolhe, o que faz com que a câmera focalize pessoas nas ruas o aplaudindo. Sua última aparição pública antes de sua morte é também uma metáfora de sua saída de cena. Os planos seguintes, apresentados com uma música de suspense ao fundo e cortes com intervalos que deixam a tela preta por alguns segundos, trazem fotografias do fatídico dia do golpe. A voz over dá lugar a uma voz em off de um general: "Para cada membro das forças armadas que seja vítima de atentados, em qualquer hora ou qualquer oportunidade, se fuzilará de imediato cinco prisioneiros marxistas pelas forças armadas." (La spirale, 1976, tradução nossa) $)^{258}$

"O mais tenaz defensor da via pacífica será o primeiro morto da luta armada." Essa frase, proferida pela voz over enquanto são exibidas cenas de prisões, retoma o prólogo inicial, quando Allende declarava que só deixaria o mandato concedido pelo povo no seu último dia. Do contrário, conforme ele mesmo previu, teriam que o tirar do cargo a balas. A contradição com a fala anterior do presidente, porém, era o fato de que, em oposição à sua declaração de setembro de 1971, ele tinha, sim, "carne de mártir".

Eis então que os realizadores deixam claro o que pressupunham que o espectador soubesse, como indica a voz over: "O resto da história vocês conhecem: os prisioneiros, o estádio, os fuzilamentos, os milhares de mortos, os corpos recuperados nos rios, as torturas, os campos de concentração, a vingança contra todos os focos de poder popular, as fábricas, os cordões, as populações." (La spirale, 1976, tradução nossa) ${ }^{259}$ As informações novas levadas ao espectador (ou contrainformações, já que há uma tentativa de modificar o ponto de vista dominante na grande imprensa) são, portanto, aquelas anteriores ao ataque a La Moneda, mais precisamente as responsáveis pelo fim da Unidade Popular. Nessa altura, o documentário volta a se

\footnotetext{
${ }^{258}$ Voz de um militar em La spirale, trecho traduzido do original: "Por cada miembro de las fuerzas armadas que sean victimas de atentados, a cualquiera hora y cualquiera oportunidad, se fusilará de inmediato a cinco de prisioneros marxistas a través de las fuerzas armadas"

${ }^{259}$ Texto da voz over de La spirale, traduzido do original: "Le reste vous connaissez: les prisonniers, le Stade, les fusillades, les milliers de morts, les corps repêchés dans le fleuve, les tortures, les champs de concentration, et la vengeance contre touts les feuillés de pouvoir populaire, les usines, les cordons, les 'poblaciones'."
} 
ocupar de seus inimigos, agora no poder. E é contra o seu discurso que todos os argumentos anteriores foram empreendidos.

O final do último bloco retrata uma espécie de aclamação do golpe por setores abastados da sociedade chilena, seu triunfo. Pinochet e outros generais entram em marcha no Congresso Nacional, em cenas coloridas extraídas de uma televisão. A sequência seguinte é a de uma entrevista com o presidente da CUPROCH, que contraditoriamente à intenção do entrevistado, corrobora o discurso dos realizadores de esquerda, já que ele afirma que o 11 de setembro coroou "toda uma obra". Outras falas da direita, como a de uma "madame" da alta burguesia comemorando o período de "liberdade" que se iniciava com a ditadura, causam repúdio - sentimento compatível à consciência adquirida pelo espectador dos métodos usados por essa classe para voltar ao poder.

A fala que encerra o bloco $\mathbf{O}$ golpe não podia ser outra senão a de Pinochet. Criticando o materialismo histórico marxista, o general defende uma "desintoxicação" e uma "libertação política" do Chile. Porém, o documentário não termina nessa etapa da espiral. Uma nova volta é aberta com um intertítulo que indica o ano de 1975, seguido por imagens de uma bucólica partida de futebol no Estádio Nacional. Nessa etapa, as sequências selecionadas pela montagem trazem a ideia de "normalidade": jovens burgueses nas universidades, pessoas conversando em cafés...

A sequência seguinte, porém, traz em off uma voz silenciada no 11 de setembro. Dois dias antes do golpe, um trabalhador do cordão Vicuña Mackenna diz que essa experiência de poder popular não pode ser facilmente apagada, pois nem os patrões, nem o fascismo, nem a burguesia poderiam impor ideias ao operariado. As cenas que acompanham sua fala são as dos cordões industriais pré-1973. Claramente, os realizadores apostam, com essa escolha de montagem, no legado político deixado pelo governo da Unidade Popular como uma possibilidade de reversão do golpe de Estado.

Ao confrontar novamente essas duas vozes, da direita vencedora e do poder popular que "hiberna" no país, o documentário se encaminha para o final retomando o jogo Política, para nele identificar o lugar atual de cada uma das peças. Nesse trecho, a crítica contundente é direcionada às classes médias que, segundo a voz over, voltaram ao fundo da caixa (ou seja, saíram de cena, apesar de terem sido fundamentais para a queda da UP). Em uma nova sequência da mão movendo os bonecos de Folon, há um close-up na alegoria relativa ao exército. A câmera se afasta 
e expõe ao seu lado as que representam as embaixadas e os capitalistas estrangeiros. Algumas das peças que estavam na linha de massa (os "pássaros") são colocadas ao lado do trio. Outras, são guardadas: aquelas com manivela, os estudantes, o partido de esquerda, as mulheres... A sequência termina focalizando a representação das forças armadas.

Nessa espécie de posfácio, inserido após o término dos sete blocos principais, La spirale dá ainda mais espaço à voz de seus realizadores, expondo claramente seu objetivo e se resguardando de possíveis críticas por não se debruçar sobre os erros da esquerda. A voz over declara:

Dizer que a estratégia da direita foi a única razão da queda de Allende é um argumento estranho. Seria dizer que o inimigo é invencível. Os que não toleram nenhuma crítica à Unidade Popular não se dão conta do lado obscuro de sua fidelidade. Mas há duas coisas. Primeiro, desde o começo, um plano inspirado pelos EUA e organizado pela direita, realizado pela mobilização da pequena burguesia, fixou como objetivo a destruição por todos os meios da tentativa socialista. Segundo, essa tentativa levou o povo a uma irradiação política que a monstruosa ditadura não apagará facilmente de sua consciência. (La spirale, 1976, tradução nossa) ${ }^{260}$

Nessa fala, aparece novamente a ideia do legado político deixado pelas experiências de poder popular durante a Unidade Popular. Ela fortalece a hipótese de uma saída para que o filme, que trata da vitória do inimigo, não "capitule" é a valorização das formas de organização extraestatais e espontâneas, que se criaram como resposta aos boicotes da direita contra o governo. Assim, mais do que um Estado socialista, a UP teria sido vitoriosa ao criar modos de produção e distribuição coordenados pelo povo, como será retomado a seguir.

A tese de que a direita chilena criou uma linha de massa leninista parte do pressuposto de que sua vitória decorreu do domínio e da apropriação de métodos do "inimigo", ou seja, foi bem-sucedida ao se utilizar das táticas da esquerda. Portanto, para combater o grupo que agora está no poder é útil percorrer o mesmo caminho: entender sua forma de agir, seus objetivos e sua maneira de movimentar as peças

\footnotetext{
${ }^{260}$ Texto da voz over de La spirale, traduzido do original: "Dire que la stratégie de la droite était la seule raison de la chute d'Allende est un argument étrange. Il reviendrait dire que l'ennemi est invincible. Et ceux qui ne tolèrent aucune critique d'Unité populaire ne seront peut-être pas toujours en compte de cette face obscure de sa fidélité. Mais, deux choses: une, dès l'origine, un plan inspiré par les États-Unis et organisé par la droite chilienne, réalisé par la mobilisation de la petite bourgeoisie, c'est à donner pour but la destruction de par touts les moyens de la tentative socialiste; l'autre, que cette tentative a exposé le peuple chilien à une irradiation politique que la monstrueuse dictature des généraux ne efface pas facilement de sa conscience."
} 
durante a partida - sua guerra de posições, para usar o termo gramsciano. Nesse sentido, o jogo da "Política" exige um conhecimento objetivo das regras, uma análise fiel da realidade e uma definição certeira dos passos a serem dados em cada etapa da “espiral”. Essa forma de pensar os conflitos sociais justifica as estratégias fílmicas descritas nos parágrafos anteriores para a construção de uma argumentação coesa e objetiva do governo UP, presente na voz over, na articulação dos planos na montagem e na narrativa predominantes no documentário. Esses aspectos serão trabalhados nos demais itens deste capítulo. 


\section{Uma denúncia feita em arquivos}

Os limites entre o documentário e a ficção foram arduamente discutidos pelos teóricos do cinema, bem como explorados por cineastas que muitas vezes se atrevem a produzir no limiar desses dois gêneros ${ }^{261}$. A definição de que o filme documental teria o mundo real como referência não é suficiente, tendo em vista que, muitas vezes, esse mundo pode ser ainda melhor representado em produções ditas ficcionais. Nesse sentido, entre as concepções que costumam se arriscar nessa fronteira maleável, as considerações de Roger Odin (1994) colaboram para um entendimento do campo onde se localiza La spirale. Para o pesquisador, o que diferencia o filme documental não é uma noção de realidade ou sua análise, já que uma ficção pode muito bem desempenhar esse papel. Ele cria o conceito de "leitura documentarizante", ou seja, a existência de um efeito - fruto de determinadas estratégias ${ }^{262}$ - que fazem com que o espectador classifique determinado cinema como "documento".

La spirale, como já foi abordado, tornou-se possível a partir de uma extensa pesquisa efetuada em diversos arquivos pelas montadoras Jacqueline Meppiel e Valérie Mayoux, além de Silvio Tendler e Armand Mattelart ${ }^{263}$. Em entrevista a PaulLouis Thirard, publicada na Positif, em 1976, Mattelart lista alguns locais onde foi feita a busca por documentos audiovisuais e de outras naturezas que compõem o documentário: “[...] cinematecas, arquivos de televisão dos Estados Unidos, da Europa do Norte, de países da América Latina, Cuba em particular, que nos ofereceram algo equivalente ao que daria na versão final do filme em $35 \mathrm{~mm}$ ”. (THIRARD, 1976, tradução nossa) ${ }^{264}$

\footnotetext{
${ }^{261}$ Um exemplo de produção que joga com esses dois gêneros na obra de Chris Marker é L'ambassade, que será analisada no capítulo 4.

${ }^{262}$ Cabe ressaltar que, para Roger Odin, a responsabilidade pela leitura documentarizante não é apenas do realizador, mas, muitas vezes, pode ocorrer na recepção, por uma postura do espectador.

${ }^{263}$ A pesquisa feita pelos realizadores nos anos 1970 foi refeita, de certa forma, em uma publicação de 2008, coordenada pela Cinemateca Chilena (VILLARROEL, 2008). A instituição busca, há alguns anos, reunir o material fílmico produzido sobre o Chile e/ou no país, percorrendo para isso arquivos na Europa e na América Latina. Grande parte desse acervo encontrado é fruto do interesse despertado na época da instalação da "via chilena ao socialismo", que atraiu a atenção de todo mundo para essa nação. Porém, a necessidade de vasculhá-lo nas cinematecas e instituições internacionais decorre do fato de que, bem como seus autores, muitos dos registros audiovisuais dos anos de Allende foram "exilados" após 1973.

${ }^{264}$ Traduzido do original: "[...] cinémathèques, archives de télévision des États-Unis, de 1’Europe du Nord, des pays d'Amérique Latine, Cuba en particulier, qui nous offrit l'équivalent de ce qui devait donner dans le film $35 \mathrm{~mm}$ de projection définitive."
} 
Em La spirale, foram reproduzidas muitas estratégias que dão a sensação de "documento", já presentes nos documentários e materiais televisivos anteriores utilizados pelos realizadores. Entre elas, destacam-se o uso de entrevistas, recortes de jornal, imagens de arquivo, gravações de vídeo e áudio realizadas de maneira direta (em algum evento "oficial", por exemplo), entre outras. Todas estas técnicas colaboram para que o espectador se veja diante dos acontecimentos. Dessa maneira, existe uma clara intenção de atribuir uma "verdade" histórica aos eventos abordados, especialmente às sabotagens e às ações da direita que levaram ao golpe militar no Chile.

A maneira pela qual o filme organiza os documentos encontrados nos arquivos opta pela presença de muitos cortes sequenciais, buscando integrá-los por meio do argumento que perpassa toda a produção. Assegurando a continuidade da narrativa, a voz over é a principal responsável por manter uma coerência e rememorar constantemente a tese de que ocorreu uma conspiração por parte da direita chilena, com ajuda dos Estados Unidos, para derrubar o governo de Allende. Transmite-se, assim, a sensação de que todos os trechos, apesar de registrados em momentos, lugares e situações distintos, fazem parte de um mesmo processo.

No entanto, embora em muitos momentos da produção exista o esforço em evidenciar uma continuidade e uma articulação entre as imagens e o texto da locução em over, uma abordagem tensionadora interroga diversas vezes as sequências, alertando o espectador para o fato de que o que se vê nem sempre corresponde a uma interpretação fechada da realidade. Nesse ponto, há uma relação com a prática de Chris Marker em seus filmes que, a todo tempo, interrompe a linearidade para trazer a dúvida quando, a princípio, haveria uma certeza. Um exemplo dessa estratégia da montagem, que será retomada em outros momentos deste trabalho, ocorre ao final do bloco A frente, quando a mesma entrevista de Augusto Olivares que havia sido exibida minutos antes é contraposta ao seguinte comentário da voz over, que repete a exibição inserindo uma nova informação que transforma a entrevista a priori informativa em uma imagem de denúncia da situação atual do país:

Augusto Olivares morreu no dia do golpe de Estado, junto a Salvador Allende, seu amigo. Desde o 11 de setembro de 1973, suas estações de rádio e gráficas foram destruídas. Seus jornais, fechados. Nenhum jornal de esquerda ou simplesmente de oposição à Junta chega ao Chile. Nenhum opositor se expressa no rádio ou na 
televisão. Em dezembro de 1974, 40 jornalistas ainda estavam nos campos de concentração. (La spirale, 1976, tradução nossa) ${ }^{265}$

Outra estratégia de La spirale referente ao uso de imagens de arquivo é encadear documentos relativos ao período abordado, anos 1970, a outros de décadas anteriores. Essa forma de montar permite, por exemplo, relacionar a Unidade Popular a momentos mais remotos da história do Chile, como a República Socialista de 1932. Ao apresentar o processo eleitoral e seu candidato único das esquerdas, uma fotografia de Allende na juventude introduz uma sequência de outras fotos relacionadas à primeira tentativa esquerdista chilena, provocando um efeito de associação do líder da UP a uma tradição revolucionária no país.

Já no penúltimo bloco, $\mathbf{O}$ exército, esse recurso de montagem serve para reforçar o discurso da voz over de que há duas práticas concomitantes em jogo há muitos anos: um histórico de repressão das forças armadas e uma tradição de resistência por parte do povo. Essa ideia é transmitida pela presença de imagens do massacre de operários na Escola de Santa Maria de Iquique, ocorrido em 1907, em meio a outras cenas que tratam das lutas políticas no período da Unidade Popular. As fotos do começo do século são acompanhadas pela entrevista em off de um dos sobreviventes, que classifica o período até o governo de Jorge Alessandri como um "regime de terror" para a classe trabalhadora. A sequência seguinte, o enterro de um jovem assassinado pela polícia nos anos 1970, com a presença do presidente Salvador Allende, corrobora a convicção desse novo governo em mudar a história.

$\mathrm{O}$ uso de materiais de arquivo de diferentes naturezas organizados como "provas" remete à tradição do gênero documental em buscar estratégias que passem ao espectador a sensação de autenticidade. A voz over, como será abordado no próximo subitem, é um dos elementos fundamentais para direcionar esse olhar. Porém, mesmo em cenas com som direto, sua inserção na linha argumentativa delimitada pela montagem reforça o ponto de vista dos realizadores. Um bom exemplo pode ser encontrado ainda na primeira parte do filme, $\mathbf{O}$ plano, que insere uma sequência da televisão francesa ORTF que comprovaria a tese de que a direita chilena propagou um clima de caos econômico, mesmo com declarações sonoras

\footnotetext{
${ }^{265}$ Texto da voz over de La spirale, traduzido do original: "Augusto Olivares est mort le jour du coup d'État au coté de Salvador Allende, son ami. Depuis le 11 septembre 1973, ses stations de radio de l'Unité populaire et ses imprimés ont été détruits. Ses journaux, fermés. Plus un seul journal de gauche ou simplement d'opposition à la Junte n'est pas arrête au Chile. Plus un seul opposant qui s'exprime dans la radio ou la télévision. En décembre 1974, 40 journalistes étaient encore dans les champs de concentration."
} 
contrárias à afirmação ${ }^{266}$. Na fronteira entre o Chile e a Argentina, o entrevistador questiona um homem que segue com a família, estabelecendo o seguinte diálogo reproduzido em La spirale:

[Entrevistador francês]: Você está deixando o Chile, senhor?

[Homem de carro]: Não, não. Vamos fazer um passeio.

[Entrevistador francês]: Nenhuma relação com os acontecimentos?

[Homem de carro]: Nenhuma relação com os acontecimentos. (La spirale, 1976, tradução nossa) ${ }^{267}$

Nesse caso, a imagem comprova o oposto do que declara o entrevistado: ao focalizar o veículo se afastando em seu caminho, após a citada negação da "fuga", a câmera revela uma bagagem volumosa que enfatiza a informação de que a burguesia deixava o país.
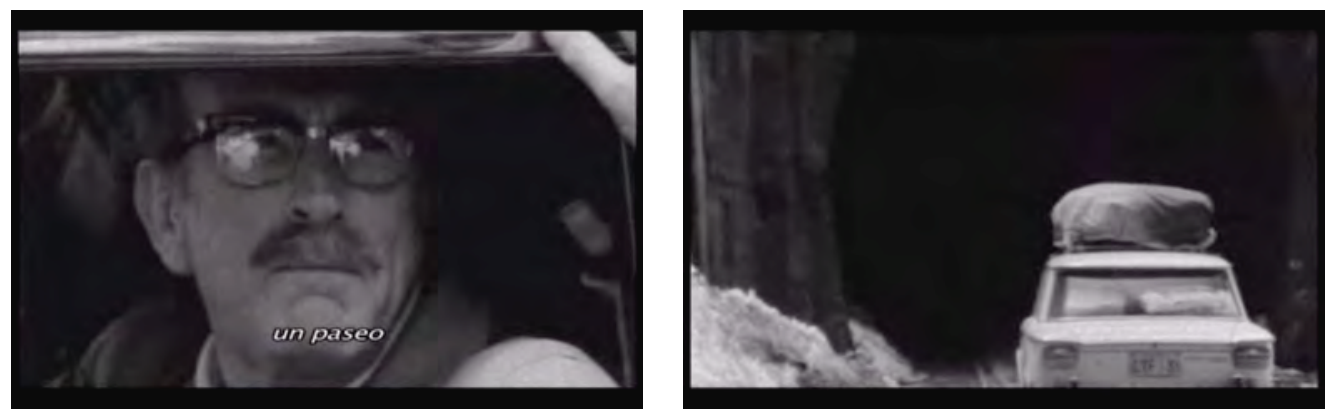

Fotogramas de La spirale.

Além do uso de materiais de natureza audiovisual, cuja mudança em relação ao seu uso original será desenvolvida mais adiante, os realizadores utilizam outros tipos de documentos para "provar" seu ponto de vista. Isso ocorre em cenas de closeups de capas de jornal e cartazes. Nesse caso, publicações da direita são as preferidas pela montagem. No entanto, ao invés de corroborar o discurso do "inimigo", a forma como são inseridas na montagem e a presença da voz over modificam sua significação original, transformando-as em porta-vozes da esquerda.

Ao tratar da campanha presidencial de Jorge Alessandri, do Partido Nacional, para citar um caso em que essa estratégia é usada, La spirale traz manchetes de época

\footnotetext{
${ }^{266}$ Essa cena faz parte, originalmente, do especial da ORTF intitulado Le Chili: un nouveau Cuba? (1971).

${ }^{267}$ Diálogo de La spirale, traduzido do original: "[Entrevistador francês]: Vous ne quittez pas le Chile, monsieur ? / [Homem de carro]: Non, non, nous allons à une promenade... / [Entrevistador francês]: Sans rapport avec les événements ? / [Homem de carro]: Sans rapport avec les événements."
} 
como: “Checoslovaquia, 1968. Chile 1970?”; "Un pueblo bajo el temor"; "Espionaje Soviético en Chile: o las andanzas de un agente comunista"; "Esto es el comunismo" (esta última, acompanhada de uma foto de um paredão). Se, quando foram produzidas, essas frases pretendiam alertar para o "perigo vermelho" no Chile, agora servem de evidência de que um complô foi armado no país, como é informado sobretudo pela voz over.

Vale destacar ainda outro tipo de documento utilizado, de natureza sonora, que adquire uma função narrativa importante: as músicas da Nueva Canción Chilena. El pueblo unido jamás será vencido, em gravação de Quilapayún, por exemplo, é responsável por transmitir o clima de euforia que acompanhou a vitória da Unidade Popular nas urnas. Já A desalambrar, de Víctor Jara, introduz o bloco A frente com uma reflexão: "Yo pregunto a los presentes / Si no se han puesto a pensar / Que esta tierra es de nosotros / Y no del que tenga mas" (La spirale, 1976, tradução nossa) ${ }^{268}$. Os versos acompanham fotos de camponeses, interrompidas pela sequência panorâmica de mansões no campo. São eles que anunciam, antes mesmo da voz over, que o próximo tema será reforma agrária. Canción de la propiedad social y privada, do conjunto Inti-Ilimani, indica, no bloco A frente, que o assunto tratado é a nacionalização das riquezas e, ao ser veiculada com cenas de pessoas de macacão pintando o muro com a frase "El cobre es chileno", enfatiza que essa iniciativa governamental teria o apoio popular.

Além disso, a música cria um clima de aproximação afetiva com as imagens e os personagens históricos retratados. Ela apela à emoção e atenua o discurso racional da narrativa. Antes mesmo do primeiro bloco, quando o documentário apresenta as forças em jogo na campanha eleitoral, entre elas a UP, a imagem de Víctor Jara em comício de 1964 emociona ao embalar as sequências seguintes com El poder popular. Da cena do músico e de seu violão, cujo chocante assassinato certamente comovia o espectador que o revia em 1975, a canção ganha status de voz over ao acompanhar as cenas de Le train de la victoire (1964), de Joris Ivens.

É importante lembrar que, compostas sob as mudanças sociais que levaram à vitória da Unidade Popular, essas "novas canções chilenas" também são documentos de época, tanto quanto os trechos audiovisuais, artigos de jornal ou fotografias. Nos exemplos de sua utilização descritos acima, novamente há uma mudança significativa

\footnotetext{
268 “Eu pergunto aos presentes / Se você não têm pensado / Que essa terra é nossa / E não dos que têm
} mais". 
no sentido original desses documentos que faz com que as músicas, originalmente pensadas como formas de incentivar o "engajamento" popular por seu potencial de compreensão, adquiram o estatuto de trilha sonora. Elas ilustram para o espectador de La spirale um clima de euforia dos anos da UP, de participação popular. Além disso, reforçam a voz over, inserindo novos comentários às imagens.

Ocorre ainda a presença de documentos escritos, como as próprias instruções do jogo Política, já destacadas neste capítulo. Elas mostram ao espectador que não se trata de uma ficção, ou seja, de que a simulação reproduzida pelos realizadores foi mesmo inventada pelas universidades dos Estados Unidos - um elemento que leva a uma "leitura documentarizante", conforme termo empregado por Odin. Para isso, estão sempre ao lado do tabuleiro cenográfico, como uma espécie de manual de instruções. Ao serem introduzidas em La spirale, as regras são submetidas a close-ups que ressaltam algumas palavras-chaves em inglês, novamente estratégia que objetiva "provar" seu conteúdo e sua procedência nacional.

Processo semelhante ocorre diante da publicação organizada pelo governo de Salvador Allende para denunciar o complô encabeçado pela multinacional ITT contra sua vitória (DOCUMENTOS, 1972). Nesse caso, o material foi publicado pela esquerda, porém, do mesmo modo que os documentos procedentes da direita citados no parágrafo anterior, torna-se prova para os realizadores, ao ter palavras-chaves percorridas e focalizadas pela câmera. Não há, no entanto, um questionamento sobre o status ético ou a parcialidade por parte dos autores desse dossiê, produzido pela Unidade Popular, enquanto que as indicações do jogo Política têm seu caráter ideológico evidenciado como prova de seu comprometimento com certos interesses políticos.

Nas sequências que se utilizam de fotografias, o filme traz novas mudanças de sentido. Em alguns casos, sua inserção na montagem faz com que se tornem espécies de fotogramas, como a série feita no dia 11 de setembro de 1973 na qual as fotos são intercaladas por uma tela preta, como em uma exibição de slides $^{269}$. Essa estratégia traz ainda um ganho em relação aos trechos audiovisuais: sua maior permanência na tela, além de uma pausa posterior à sua exibição, o que favorece o congelamento das

\footnotetext{
${ }^{269}$ Em relação ao uso de imagens fixas em uma produção audiovisual, vale destacar La Jeteé (1962), ficção que Marker montou apenas com fotografias. Nesse sentido, em seus filmes de arquivo, nos quais ele insere fotos na montagem em meio a extratos audiovisuais, existe uma retomada dessa prática, bem como o apelo à memorização proporcionado por esse suporte. A inserção de La jetée entre os limites da ficção e do documentário e de que maneira sua opção metodológica insere esse filme em um registro híbrido serão temas do próximo capítulo, que discutirá L’ambassade.
} 
imagens exibidas e sua melhor apreensão. O tempo histórico abordado retorna “congelado" por alguns instantes, para ser revisitado, e não esquecido. Trata-se, portanto, de um uso desses documentos na montagem que valoriza o exercício de memória sobre o terror vivido nesse dia.

No mesmo exemplo descrito no parágrafo anterior, a câmera também explora as fotos de modo a ressaltar detalhes que não estão em destaque nos documentos originais, como o rosto de Allende com um capacete em seu último registro em vida, exibido em um plano próximo. Dessa forma, esses arquivos de natureza não fílmica tornam-se enxertos de uma produção audiovisual, ganhando novos sentidos nesse suporte. Com o close-up, a fotografia, que congelava uma cena, de certa forma ganha movimento e outra leitura: o cenário desaparece e a expressão do presidente em seu último registro pode ser fixada na memória do espectador. Sua caracterização como um soldado da resistência, lutando por seu povo e pela legalidade até o fim, altera o caráter de um simples registro visual.
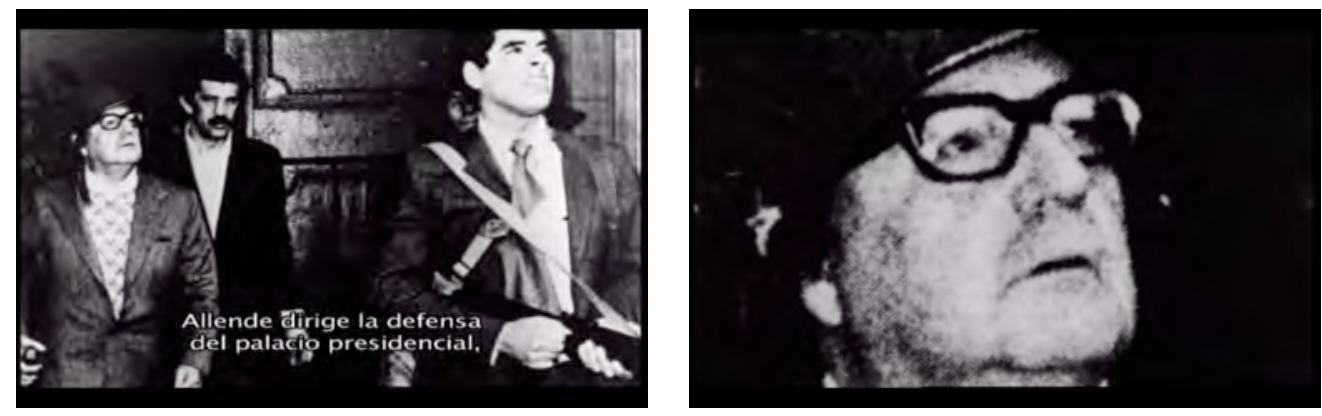

Fotograma de La spirale.

Devido ao seu processo de montagem e à forma de articulação dos documentos encontrados, Serge Toubiana caracteriza La spirale como uma tentativa de formar um "dossiê" de acusação contra os responsáveis pela derrocada da UP. Mas, mesmo destacando positivamente a riqueza da análise empreendida pelo documentário na articulação do material de arquivo, ele alerta para uma implicação do método escolhido pelos realizadores:

Nota-se aqui um problema inerente ao documentário político, ao menos ao documentário que faze feito com imagens provenientes de arquivos, de imagens que não são produzidas no mesmo tempo do filme. Em La spirale, esse problema se desdobra de um outro: entre o momento em as imagens foram tomadas e aquele em que o filme é montado, há a derrota de setembro de 1973, a morte. La spirale trabalha com imagens derrotadas, enlutadas, que já perderam seu 
sentido, mortas duas vezes. (TOUBIANA, 1976, p. 58, tradução nossa $)^{270}$

A questão colocada pelo crítico sobre a morte do sentido original das imagens (no caso de La spirale, uma morte dupla: a da remontagem e a do contexto em que foram tomadas) leva a considerações que devem ser destacadas na análise de um filme de arquivo. Nos exemplos elencados anteriormente, estão presentes sequências que trazem documentos inicialmente registrados em outros suportes: publicações escritas, fotografias e gravações sonoras. No caso dos registros escritos, por exemplo, o close-up se torna necessário para que o espectador consiga, no ritmo audiovisual empreendido no documentário, reter algumas palavras-chaves que serão vinculadas à argumentação conduzida pela voz over e de sua inserção na montagem. Ao invés de uma apreensão que leve em conta a argumentação do texto escrito, eles ganham o status de imagens, ao serem reduzidos a suas manchetes ou palavras ressaltadas a critério dos realizadores.

Além do conceito de "filme-dossiêe", proposto por Toubiana, outros termos são usados pelos pesquisadores para definir a filmografia de Marker que recorre a produções audiovisuais anteriores como material de arquivo. No artigo "O manual de história idealizado", de Ursula Langmann (1986), sobre O fundo do ar é vermelho (que será analisado no capítulo 5), a autora prefere a expressão "filme-montagem" para se referir a esse gênero, ressaltando que esse tipo de filme dificulta muitas vezes as afirmações sobre o "modo de ver" de seu autor. Langmann se refere ao fato de que o documentário ao qual se dedica usa uma quantidade tão grande de material gravado por outros que não é possível verificar preferências de ângulos, movimentos de câmera, tratamento da imagem, entre outros recursos previstos no momento da gravação.

Filme-dossiê, filme de arquivo, filme-montagem ou ainda found footage são alguns dos muitos termos possíveis para caracterizar uma prática cinematográfica em que o uso de materiais de autoria alheia ao realizador (ou ainda de tomadas feitas por ele a priori para outras produções e reutilizadas em um segundo momento) prevalece. A discussão sobre o significado de cada um desses termos distintos foi realizada de

\footnotetext{
${ }^{270}$ Traduzido do original: "On note ici un problème inhérent au documentaire politique, tout au moins au documentaire qui se fait avec des images issues d'archives, des images qui ne son pas produites dans le temps même du film. Avec La spirale, ce problème se double d'un autre: entre le moment où les images sont prises et celui où le film est monté, il y a la défaite de septembre 1973, la mort. $L a$ spirale travaille avec des images défaites, endeuillées, qui ont déjà donné leurs sens, mortes deux fois.".
} 
maneira pioneira em Film beget films, de Jay Leyda (1964), que optou pela expressão "filme-compilação" (compilation film), para evitar que a inserção da palavra "arquivo" confunda-os com filmes armazenados em arquivos ou ainda que o termo “montagem" reduza todo o processo de produção a uma única etapa ${ }^{271}$ :

O termo apropriado deveria indicar que os trabalhos começaram na mesa de corte, com tomadas de filmes já existentes. Ele também tem de indicar que o filme usado foi feito em algum tempo do passado. O termo também poderia indicar que é um filme fruto de uma ideia, para muitos dos filmes feitos nesse formato não é satisfatório ser meros registros ou documentos - e nesse fator reside meu principal interesse nesse formato, que será retomado nas próximas páginas por vários caminhos inconsistentes. Você pode sugerir um termo correto? (LEYDA, 1964, p. 9, tradução nossa). ${ }^{272}$

Carlos Adriano Jeronimo de Rosa, na tese $O$ mutoscópio explica a invenção do pensamento de Santos Dumont (ROSA, 2008), apesar de reconhecer a dificuldade de analisar produções cujas opções cinematográficas relativas às tomadas não são de autoria dos realizadores, como também o faz Langmann, ressalta que muitas vezes os materiais originais sofrem mudanças radicais, tendo sua materialidade alterada (cores, perfurações, alterações químicas etc.). No caso de $L a$ spirale, esse tipo de modificação de natureza material não ocorreu de forma significativa, porém como fica evidenciado em alguns dos usos de imagem de arquivo analisados nesta tese, a presença de close-ups, a alteração no tempo de exibição de uma cena e até mesmo a escolha por um determinado plano em detrimento de outro são aspectos que revelam alterações dos realizadores nos extratos originais e nas preferências estéticas. Dessa forma, é fundamental ter em conta que mesmo se o filme privilegia a montagem, essa etapa permite interferências nos documentos anteriores que devem ser esmiuçadas.

Um bom exemplo de como alterações no material fílmico original podem ser fundamentais para imprimir novos sentidos às imagens é o filme Le tombeau d'Alexandre (1993), do próprio Chris Marker. Nessa produção, ele insere entre as primeiras sequências um trecho retirado de A queda da dinastia Romanov (1927), de Esther Shub. Durante a exibição, porém, ele chama a atenção para um personagem

\footnotetext{
${ }^{271}$ Sobre a problematização em torno dos chamados "filmes de arquivo", além de Leyda, ver Recycled images, de William Charles Wees (1993).

${ }^{272}$ Traduzido do original: "The proper term would have indicated that the works begins on the cutting table, with already existing films shots. It also has to indicate that the film used originated at some time in the past. The term could also indicate that it is a film of idea, for most of the films made in this form are not content to be mere records or documents - and in this factor lies my chief interest in the form, which will have to be referred to in the following pages in various inconsistent ways. Can you suggest a right term?"
} 
que, na montagem de Shub, passava quase despercebido: um homem gordo que antecede a passagem da nobreza e que repreende alguém fora de campo. Na reprise do realizador francês, o plano original é exibido em câmera lenta e submetido ao seguinte comentário, que chama atenção para o gestual desse homem: "Esse gesto do homem gordo que bate a mão na testa, o que significa? Que o ajudante está um pouco louco? Não, significa uma ordem para tirar os chapéus" (Le tombeau d'Alexandre, 1993, tradução nossa) ${ }^{273}$. Mais adiante, Marker interpreta claramente os sinais desse personagem, afirmando que se trata de alguém que ordena aos pobres a saudar os ricos.

O uso dessa cena na filmografia de Marker é particularmente interessante por alguns aspectos. Primeiro, pela referência direta a Shub, que, assim como Vertov, se destacou como pioneiro nos filmes sem mise en scène, foi uma das primeiras a utilizar apenas materiais preexistentes em suas montagens, consagrando-se por uma técnica cinematográfica extremamente presente na obra do realizador francês. Em segundo lugar, pelo percurso dessas imagens de A queda da dinastia Romanov. Gravadas antes da Revolução de 1917, elas adquiriram distintos sentidos ao longo do tempo: de registros da família do czar, tornaram-se comemorativas de um novo tempo no aniversário de uma década da Revolução; na montagem de Marker, porém, servem de exemplo de um autoritarismo que seguiu com os líderes revolucionários (entre os quais Stálin é o símbolo máximo), colaborando com um balanço do que havia sido a URSS - tom predominante nesse documentário dedicado a Alexandre Medvedkine.

Essa mesma cena que serve para celebrar a queda de uma dinastia, mas também para refletir sobre o fim de uma das maiores potências do século XX quase sete décadas depois, é alisada por François Albera no artigo "La chute de la dynastie Romavov: de E. Choub à C. Marker” (2008). Ele ressalta o esforço em imprimir um olhar inédito a uma cena já muito reprisada; ver nela algo que ninguém havia visto. Esse tipo de procedimento, o da reprise (normalmente acompanhada de um forte comentário que constrói novos olhares e/ou destrói os anteriores) é uma marca dos filmes de arquivo de Marker, uma citação em déjà vu que retém planos anteriores para descobrir neles aspectos ainda não revelados.

\footnotetext{
${ }^{273}$ Trecho da voz over de Le tombeau d'Alexandre, traduzido do original: "Ce geste du gros homme qui se frappe le front, que dit-il ? Que l'assistance est fêlée ? Non, il leur signifie d'ôter leurs bonnets..."
} 
O mesmo procedimento ocorre em muitas passagens de La spirale, acarretando um problema metodológico à sua análise. O ponto de vista dos realizadores é visível pela montagem e pelas modificações que ela imprime no material anterior. É essa etapa do trabalho que altera significados originais e cria outros, permitindo inclusive que materiais que serviam ao discurso da direita passem a falar pela voz dos militantes da esquerda, seus realizadores. Alguns exemplos dessas mudanças já foram elencados, mas vale destacar a abundante presença de falas dos presidentes gremiais, dos generais e de outros setores conservadores da sociedade chilena que, ao invés de representarem seus autores, depõem contra eles e a favor da tese de que articulavam um boicote ao governo Allende.

Analisando o documentário Sociedade Anonyma Fábrica Votorantim, encomendado pela indústria Votorantim na São Paulo de 1922, Ismail Xavier debruça-se também sobre seu uso em outra produção: Os libertários (1976), de Lauro Escorel. Esse exercício, publicado no artigo "Progresso, disciplina fabril e descontração operária: retóricas do documentário brasileiro silencioso" (2009), o leva a refletir sobre a mudança no estatuto documental nesse tipo de filme de arquivo:

Completando esta discussão do estatuto das imagens, podemos ir além desta oposição entre documento espontâneo e encenação, lembrando que o documentário realizado num determinado momento, com seus critérios e seus objetivos particulares, produz imagens que são recicladas em outros filmes históricos que podem articular a matéria visível armazenada na película com outros textos ou falas de modo a projetar sobre ela novas significações e valores. (XAVIER, 2009. p 22)

Assim como o alerta de Toubiana, essa fala ressalta a importância de se debruçar atentamente sobre os "novos textos ou falas" que introduzem também "novas significações e valores" aos documentos selecionados pelos realizadores. No caso desta tese, esse exercício será realizado neste capítulo tendo em vista dois grandes grupos de imagens audiovisuais reaproveitadas: filmes militantes e trechos de televisão. Cabe ressaltar, porém, que ao atribuir esses novos sentidos, o documentário se propõe a ser um meio de construção de um novo conhecimento histórico baseado nos arquivos pesquisados. Portanto, um "novo lugar de memória", conforme define Pierre Nora (1997).

Os conflitos entre história e memória, o ponto de vista objetivo ou subjetivo, a abordagem "neutra" ou o posicionamento político. Esses universos dialogam e se 
enfrentam quando consideramos o filme como um "objeto de cultura", que desenvolve uma interpretação sobre o mundo histórico. Essa característica, presente também na ficção audiovisual, é ainda mais acentuada nas produções documentais históricas baseadas em arquivos, como é o caso de La spirale. Cabe, portanto, nessa concepção, a pergunta que dá título ao artigo de Laurent Véray, 'L'Histoire peut-elle se faire avec des archives filmiques?" (2008). Citando Chris Marker, entre outros cineastas, o autor ressalta que em seus filmes, compostos abundantemente de material de arquivo, o objetivo consiste em reconstruir uma "hipotética verdade histórica" que reflita sobre seus significados mais profundos. Portanto, mais do que uma encenação do passado, ele propõe sua interrogação:

A reconstrução do passado não é a única motivação, nem o único centro de interesse. Não mais do que os historiadores, esses cineastas não buscam reconstruir a realidade de ontem ao seu estado bruto. Eles interrogam, ao contrário, a evidência enganosa das imagens que eles utilizam, recolocando em questão sua pretensa objetividade, propondo outras leituras. (VÉRAY, 2003, p. 7, tradução nossa) ${ }^{274}$

Outro autor que faz referência à concepção historiográfica presente na filmografia de Marker é François Niney, no artigo "L'éloignement des voix répare en quelque sorte la trop grande proximité des plans" 2002). Para ele, a volta de imagens já vistas - ou seja, o uso de material de arquivo presente em outras produções fílmicas ou televisivas - são convites a recompor a história. Ela deixa de ser, assim, uma comemoração para ser uma retomada. As imagens do passado compõem uma cartografia formada por lembranças e esquecimentos. O papel do cineasta passa a ser, então, o de recompor as teias pelas quais é trançado o tecido do tempo. Portanto, a história pode sempre ser reinventada, ganhando novos sentidos.

Pode-se afirmar que esse processo está presente em La spirale ao pretender recontar o governo da Unidade Popular sobre um ponto de vista ainda inédito, usando para isso suas imagens e documentos. $\mathrm{O}$ objetivo de seus realizadores é remontar o tempo, criar uma nova versão para um passado recente. Nesse sentido, assim como fazem os historiadores, a ida aos arquivos é fundamental para que a nova

\footnotetext{
${ }^{274}$ Traduzido do original: "La reconstruction du passé n'est plus la seule motivation, ni le seul centre d'intérêt. Pas plus que les historiens, ces cinéastes ne cherchent à reconstruire la réalité d'hier à l'état brute. Ils interrogent au contraire la trompeuse évidence des images qu'ils utilisent, remettent en question leur prétendue objectivité, proposent d'autres lectures."
} 
argumentação tenha uma base sólida, tenha validade como um conhecimento possível de ser comprovado - ou questionado, exercício constantemente praticado por Marker.

\subsection{O papel da voz over}

Em seu artigo sobre La spirale, o crítico Serge Toubiana (1976) problematiza o fato de que as imagens utilizadas pela montagem de arquivo foram produzidas antes do golpe de 1973, ou seja, elas pertencem a um momento histórico que não existe mais. Nesse sentido, ele atribui à voz over o papel fundamental de reavivá-las, de conceder-lhes um novo sentido, o da representação fílmica de uma tragédia política. Diante dessa atribuição de importância à locução, ele se questiona: "Mas podemos imaginar o que seria desse desfile de imagens sem a voz do comentário, seria outra coisa que não um desfile mortuário, um enterro puro e simples de imagens de derrota?" (TOUBIANA, 1976, tradução nossa) ${ }^{275}$

No artigo "Les silences de la voix", Pascal Bonitzer (1975) identifica nos filmes de arquivo e nos de montagem uma tendência a utilizar uma voz over de caráter assertivo, quando não autoritário. Esse sistema "clássico", para ele, é aparentemente democrático, no entanto, pode impedir o espectador de pensar sobre os eventos tratados. Esse risco, presente em vários documentários, decorre do fato desse recurso narrativo representar uma forma de poder: externa ao que se encontra inscrito na bande-image, ela reflete e narra do lugar de um "outro". "Absolutamente outra e absolutamente indeterminada", de acordo com Bonitzer, ela supõe um saber.

As considerações desses dois autores atribuem à voz over um papel fundamental em filmes que utilizam imagens gravadas originalmente para outras produções, portanto, "costuradas" com um novo significado pela montagem. Em La spirale, de fato, ela é fundamental para dar um sentido aos documentos utilizados, agrupando-os sob uma argumentação central que defende que o golpe militar no Chile foi fruto de uma articulação conspiratória de direita. Essa característica informativa está presente na maior parte das passagens do documentário, em que a locução traz dados que complementam as cenas. No entanto, cabe pensar se, como defendeu

\footnotetext{
${ }^{275}$ Traduzido do original: "Mais peut-on imaginer ce que serait ce défilé d'images sans la voix du commentaire, serait-ce autre chose qu'un défilé mortuaire, un enterrement pur et simple d'images de défaite?"
} 
Toubiana, sem ela as imagens seriam um "desfile mortuário". E, retomando Bonitzer, se é possível inserir esse documentário coletivo na "categoria" clássica dos filmes de arquivo.

Vale destacar, para responder a essas perguntas, alguns traços marcantes da obra de Chris Marker, peça fundamental em La spirale. É o próprio Bonitzer quem caracteriza um estilo próprio do realizador, destacado também por outros pesquisadores "markerianos", com base em uma passagem de Lettre de Sibérie (1957): no filme, certa sequência é reproduzida três vezes com comentários diferentes. Esse procedimento indica uma maneira de utilizar a voz over como um fator que torna a imagem ambígua e desprovida de certezas.

Michel Revov (2005), no artigo "Investigando o sujeito: uma introdução", salienta que a voz over tem sido constantemente taxada de "ditatorial" nas últimas décadas, tendência que pode ser contestada pela filmografia de alguns diretores. Muitas vezes chamada de "voz de Deus", em referência ao tom de autoridade que impõe às imagens, foi questionada constantemente por afirmar uma espécie de conhecimento absoluto. Porém, para o autor:

Os conceitos atuais de conhecimento como sendo mais propriamente "parcial" parecem estar em desacordo com a voz over autoritária. Entretanto, nas mãos de Rouch e outros, como Marker, Michael Rubbo e Ross McElwee, a voz do diretor passou a implicar não tanto certeza quanto uma presença testemunhal tingida pela insegurança ou pela confusão. Em vez de repetir a imagem ou se certificar da sua autenticidade enquanto fato, este modo de voz over do documentário pode tanto questionar o que é mostrado quanto interpretá-lo de maneira autoritária. Emergindo primeiro com Rouch nos anos 50 (e mais obliquamente na obra de Marker em filmes como Lettre de Sibérie [1957] e Le mystère Koumiko [1965]), o potencial de significado da voz do autor passa a se desenvolver com uma sutileza e uma sofisticação jamais vistas. (RENOV, 2005, p. 252)

Apesar de La spirale ser fruto de um coletivo, e não um documentário "autoral" de Marker, traz algumas das características presentes em outros de seus filmes, especialmente no tocante ao uso da voz over. Um exemplo é o procedimento citado por Bonitzer em Lettre de Sibérie, ou seja, reprisar uma mesma cena atribuindo a ela outra locução. Isso ocorre ao final do bloco O plano, quando cenas da campanha de Salvador Allende, ao lado de Neruda e Víctor Jara, mostradas na apresentação como icônicas da formação da Unidade Popular, são reprisadas com o seguinte comentário over: 
Allende, nós sabemos, morreu com as armas nas mãos, crivado de balas como havia previsto. Neruda morreu de câncer alguns dias depois do golpe de Estado militar. Víctor Jara, que cantava nas imagens do "trem da vitória" também morreu, depois que os soldados the quebraram os punhos. Os assassinos vão bem, obrigado! (La spirale, 1976, tradução nossa) ${ }^{276}$
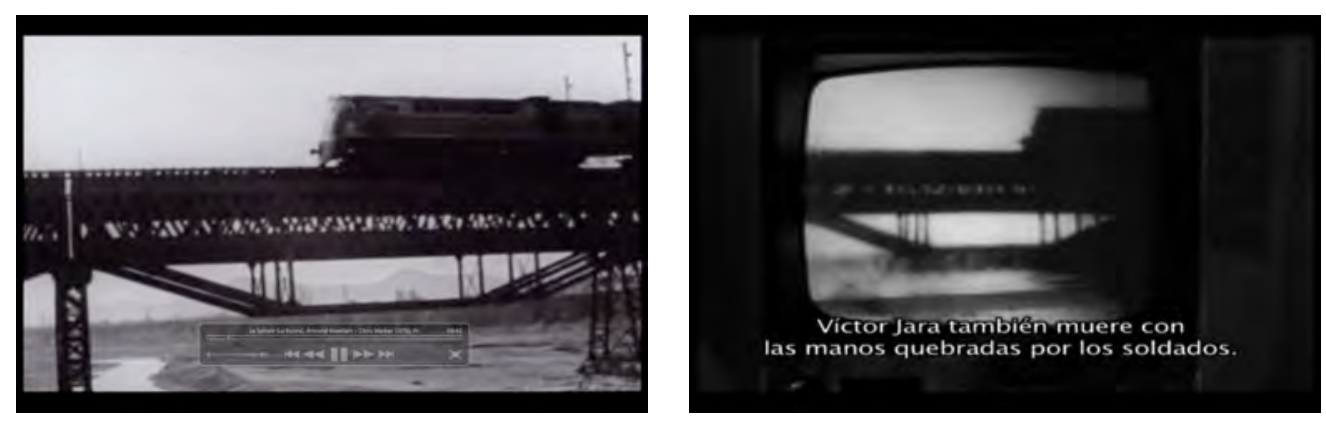

Fotograma de La spirale.

Como é possível perceber, a mesma sequência adquire dois sentidos: um que apresenta a Unidade Popular ao espectador, no início do documentário; outro que denuncia sua desarticulação forçada, ao final do primeiro bloco. Dessa forma, a constatação de Toubiana sobre a atribuição de um peso de "tragédia política" a cenas que perderam seu significado original é corroborada. Porém, vale ressaltar que essa voz múltipla não impõe um único saber: se os documentos dependem dela para seguirem existindo (desprovidos pelo curso da história de seu valor original), eles não estão submetidos, por sua vez, a um discurso autoritário à revelia das imagens - ou seja, os realizadores recorrem a um uso crítico da voz over.

No exemplo citado, é visível como a mesma cena pode adquirir mais de um sentido, dependendo do comentário ao qual é submetida. Essa prática aparece constantemente na obra de Marker, como ressalta Ursula Langmann em seu estudo sobre $O$ fundo do ar é vermelho:

Nos filmes de Chris Marker, há que prestar muita atenção aos comentários que dificilmente podem ser desligados da imagem porque ora a comentam, ora a completam, ora a contradizem, ao passo que, por sua vez, a imagem tem influência sobre os comentários. Produz-se, deste modo, uma correlação constante entre a imagem e o comentário, o qual, no filme Le fond de l'air est rouge [O fundo do ar é vermelho], é essencialmente "representado" pelas vozes off. (LANGMANN, 1986, p. 35)

\footnotetext{
${ }^{276}$ Texto da voz over de La spirale, traduzido do original: "Allende, on sait, est mort les armes à la main, criblé de bales comme il avait prévu. Neruda est mort du cancer quelques jours après le coup d'État militaire. Victor Jara, qui chantait sur les images du 'train de la victoire', mourut aussi, après que les soldats ont lui brisé ses poings. Les assassins vont bien, merci!"
} 
Vale destacar que, em $O$ fundo do ar é vermelho, existem múltiplas vozes over, o que reforça sua importância na articulação das imagens de arquivo. Uma passagem, em particular, questiona esses significados múltiplos de uma mesma tomada por meio da voz do próprio Chris Marker. Recuperando fragmentos de seu primeiro filme como realizador, Olympia 52 (1952), sobre os Jogos Olímpicos desse ano, ele encontra personagens que se inserem em outros contextos no documentário de 1977: o atleta Emil Zátopek seria um dos perseguidos do Partido Socialista em Praga; o campeão de salto chileno, ao invés de um cavaleiro, se transformaria no general Mendoza da Junta Militar de Pinochet. No sentido temporal regresso, ele relembra que "seu" cozinheiro, da equipe da Coreia do Sul em Helsinque, já havia sido um "astro" como o vencedor da maratona registrado por Leni Riefenstahl em 1938.

"Nunca se sabe o que se filma". Essa máxima proferida por Marker nessas sequências de $O$ fundo do ar é vermelho cabe em alguns momentos de La spirale. A passagem já citada em que uma entrevista com Augusto Olivares é repetida duas vezes, uma veiculada com áudio direto e outra com o comentário sobre seu suicídio no dia 11 de setembro, provoca uma nova reflexão inserida na reprise. Esse exemplo revela uma concepção de que as imagens têm uma história que prossegue após a rodagem, assim, devem ser constantemente revisitadas. O papel da voz over é ampliado por ser um instrumento que agrega novos valores, atualiza, desconstrói e reconstrói sentidos que foram perdidos pelo próprio decorrer dos acontecimentos.

A voz over tem, portanto, uma função decisiva na articulação dos documentos de arquivo, e também nas suas interpretações, que podem ser múltiplas. Assim, apesar de ocupar um lugar central para o desenvolvimento da argumentação dos realizadores, ela gera efeitos diversos ao longo do documentário. Informa, desinforma; afirma, questiona. Em todos esses casos, está visceralmente colada nas imagens que comenta.

Diante das cenas que registram pessoas fugindo de soldados nas ruas de Santiago, no bloco $\mathbf{O}$ golpe, a locução evita que o espectador tire conclusões óbvias, porém apressadas: não se trata do golpe, senão de "um ensaio". Nesse exemplo, que mostra registros da frustrada tentativa de golpe conhecida como "el tancazo", pode-se perceber como, apesar de ter um caráter meramente informativo em muitas passagens do documentário, a voz over vem, por vezes, barrar as evidências. Portanto, aprofunda o conhecimento que apenas pela observação dos documentos poderia ser incompleto. 
Outro aspecto evidente nessa fala é o tom irônico que acompanha o comentário proferido pela voz over durante todo documentário. Essa estratégia tem múltiplos efeitos, como o de impedir que um filme longo e tão carregado de informações adquira um tom "pesado", tornando-o inviável para o espectador. A ironia serve também para desmerecer e ridicularizar o discurso do adversário, função significativa diante do fato da produção, feita por militantes de esquerda, abordar a vitória da direita. Para introduzir o jogo Política na narrativa, os realizadores ironizam:

O duque de Wellington afirmava que a batalha de Waterloo tinha sido ganha no âmbito do jogo de Eaton. O império americano estima ganhar a sua a partir dos agradáveis campi das universidades. Ele pratica uma incessante pesca de cérebros e algumas vezes as próprias instituições se prestam a introduzir um novo tipo de estratégia. (La spirale, 1976, tradução nossa) ${ }^{277}$

$\mathrm{Na}$ parte em que trata das ações nacionalistas de Allende, articula uma fala com enfoque semelhante: "Se o que desagrada o inimigo é algo bom, e não uma coisa má, é necessário julgar, pela reação do senador estadunidense Javits, que a nacionalização do cobre pelo governo popular deveria ser uma boa coisa." ( $\mathrm{La}$ spirale, 1976, tradução nossa) ${ }^{278}$

Nesses dois exemplos, é possível verificar como o uso desse recurso de linguagem busca escancarar a ideologia adversária desconstruindo, por meio da ironia, a seriedade de seu discurso. O mesmo tom de crítica cômica recebe a burguesia chilena em várias passagens: "A memória da burguesia chilena é como um carnê de baile. Ela passa de braço em braço e é reconhecida.” (La spirale, 1976, tradução nossa) $)^{279}$; ou ainda "Em Santiago, os estudantes de direita reocupam os prédios universitários. Próximos à greve que é apoiada, por efeito, pelo patrões, não

\footnotetext{
${ }^{277}$ Texto da voz over de La spirale, traduzido do original: "Le Duque de Wellington disait que la Bataille de Waterloo avait été gagné sur le terrain du jeu de Eaton. L'empire américain compte gagner la sienne à partir des agréables campus des universités. Il pratique une incessante pèche au cerveau et quelques fois les institutions elles-mêmes se prête à la mise en point un nouveau type de stratégie."

${ }^{278}$ Texto da voz over de La spirale, traduzido do original: "Si ce qui déplait le ennemi c'est une bonne et pas une mauvaise chose, il faut juger pour la réaction du sénateur américain Javits que la nationalisation du cuivre par le gouvernement populaire devait être une bonne chose.".

${ }^{279}$ Texto da voz over de La spirale, traduzido do original: "La mémoire de la bourgeoisie chilienne est un carnet de bal. Elle est passée de bras en bras et avec reconnaissance."
} 
pelos operários, a ilusão está quase completa e a jovem burguesia chilena vivencia o luxo de um Maio de 68 com conteúdo inverso." (La spirale, 1976, tradução nossa) $)^{280}$

Em algumas sequências, a voz over é responsável por inserir um sentido às imagens totalmente alheio ao original. Próximo ao momento do golpe militar, a montagem se encaminha para esse desfecho por meio de cenas de Valparaíso, onde tropas norte-americanas estariam posicionadas. Com a ausência de "provas" desse fato, os realizadores utilizam enxertos do filme À Valparaiso, de Joris Ivens. Porém, as gravações noturnas de um navio no porto, complementadas por uma trilha sonora de suspense, enfatizam a ideia de complô que percorre o filme. Embora não haja créditos "falsos" atribuídos a elas, a locução refere-se deliberadamente à véspera do dia em que La Moneda foi atacada: "Na noite de 10 de setembro, a frota sai ostensivamente de Valparaíso para incorporar-se às manobras da marinha estadunidense. É a época da operação UNITAS." (La spirale, 1976, tradução nossa) ${ }^{281}$. Nesse caso, portanto, a imagem exerceu uma função narrativa importante, mesmo que seu sentido original tenha sido desconstruído pela voz over, que a utiliza para abordar um contexto mais de dez anos posterior à tomada.

François Niney (2002) ressalta que em documentários de montagem, como é o caso de La spirale, estabelecem-se diálogos entre as imagens, entre as imagens e a voz over (que na obra de Marker exerce constantemente o papel de "reflexão") e entre a voz over e o discurso que o espectador articula por meio da observação das imagens. Diante dessas instâncias, pode-se dizer que o exemplo referente ao filme $\grave{A}$ Valparaiso, citado no parágrafo anterior, é significativo da estratégia de causar no público determinado efeito desejado pelos produtores, mesmo que, em certa medida, ocorra a manipulação do sentido original da gravação.

Todos esses usos da voz over em La spirale colocam a questão das relações que são construídas no documentário entre passado, presente e futuro. Essa voz, assim como as imagens que ela comenta, é fundamental para a elaboração de uma nova memória. Ela insere outros significados e desfaz os anteriores, diante do objetivo colocado pelo filme: desvendar as estratégias do inimigo. Dessa maneira, deixam de

\footnotetext{
${ }^{280}$ Texto da voz over de La spirale, traduzido do original: "À Santiago, les étudiantes de droite réoccupent les bâtiments universitaires. À ce détaille près de la grève qui soutien par effet que des patrons, et pas des ouvrières, l'illusion est presque complète et le jeune bourgeoisie chilienne souffre le luxe d'un Mai 68 à front inversé."

${ }^{281}$ Texto da voz over de La spirale, traduzido do original: "Le 10 septembre au soir la flotte quitte ostensiblement Valparaíso pour rejoindre une manœuvre de la marine américaine. C'est l'époque de l'opération UNITAS."
} 
ser "mortuárias", derrotadas pelos novos e indesejáveis tempos da ditadura, para se fortalecerem por meio de uma utilização inédita. Criam novos conhecimentos, novos espaços e novos tempos. Vale citar novamente Ursula Langmann sobre as complexas relações que se estabelecem em filmes que utilizam essa estratégia:

Um espaço em que o espectador, durante a projeção do filme, vive o passado, o presente e o futuro; vê as imagens do passado (pelo fato de serem imagens, pertencem ao passado), acerca das quais fala o comentário (presente), e, a cada novo pensamento, aquele que lhe é imediatamente anterior passa, por sua vez, a pertencer também ao passado. (LANGMANN, 1986, p. 60)

\subsection{La spirale e o uso de imagens militantes}

La spirale, como foi abordado, é um filme de arquivo montado a partir da reunião de um corpo documental de natureza diversa. No tocante às imagens audiovisuais, o documentário recorre especialmente a gravações televisivas (que serão tratadas mais adiante) e a produções militantes realizadas durante os anos em que a Unidade Popular governava o Chile e nos meses que se sucederam ao golpe de Estado.

Além da assistência repetida e da decupagem do documentário, que permitiram a identificação da autoria de muitos dos trechos utilizados na montagem, a principal forma de reconhecer os filmes aos quais recorreram os diretores é a sequência, ao final do primeiro bloco $\mathbf{O}$ plano, na qual rolos de películas são percorridos pela câmera, permitindo que o espectador tome conhecimento de alguns títulos $^{282}$. A voz over, como já foi enfatizado, é a responsável por caracterizar esse corpo documental como porta-voz da "rica história" dos três anos da UP. Portanto, caberia a La spirale acrescentar algo a mais nessa narrativa: "Queremos explicar como a direita chilena fez desses três anos uma máquina infernal, posta em funcionamento antes mesmo que Allende tivesse sido eleito. Uma escada para the desestabilizar." (La spirale, 1976, tradução nossa) ${ }^{283}$

\footnotetext{
${ }^{282}$ Vale lembrar que esses títulos foram citados no item 2 deste capítulo.

${ }^{283}$ Texto da voz over de La spirale, traduzido do original: "Nous voulons expliquer comment la droite chilienne a fait de ces trois ans une machine infernale, mise en route avant même que Allende soit élu. Un escalier pour le tonner."
} 
É possível dividir esses documentos audiovisuais utilizados em quatro grupos, tendo em vista suas características originais. O primeiro é formado por curtasmetragens documentais realizados durante a Unidade Popular, principalmente os feitos nas escolas de cinema do Chile (da Universidade Católica e da Universidade de Chile), cujo papel para o incipiente cinema que surgia no país foi principalmente o de contribuir para o estabelecimento de instituições de apoio e de formar técnicos capazes de fazer cinema (não apenas operar os equipamentos, mas desenvolver um olhar de filmagem e montagem que constituíssem narrativas focadas nas questões sociais, como foi abordado no capítulo 2). Nesse recorte, é possível destacar dessa lista Venceremos (1970, Pedro Chaskel) e La expropiación (1972, Raúl Ruiz).

Um segundo recorte destaca produções igualmente realizadas no Chile da Unidade Popular, mas que se propuseram a discutir questões diretamente ligadas aos conflitos enfrentados pelo governo, bem como se debruçar sobre as dificuldades enfrentadas na tarefa de implementar o socialismo por meio da democracia. Nessas produções, são discutidas questões como a escolha da "via chilena", os impasses governamentais e as batalhas políticas que tomaram as ruas do país. Dois filmes se caracterizam como documentários que se dedicaram a "dar voz" ao presidente, propondo-lhes questões de debate, porém, reafirmando-lhe apoio. São eles: Compañero presidente (Miguel Littin) e El diálogo de América (Álvaro Covacevich), já citados anteriormente. Nesse grande bloco de produções, estão também os filmes de Patricio Guzmán, que se propuseram a ser um cinema testemunhal - com técnicas do cinema direto - sobre as mudanças em curso, mas que acabaram se tornando registros dos enfrentamentos que assolaram a nação: El primer año, La respuesta de octubre e A batalha do Chile. Esse material, analisado no capítulo anterior, foi amplamente utilizado na montagem de La spirale.

Cabe ainda ressaltar os filmes realizados por Santiago Álvarez, cujas cenas foram aproveitadas em La spirale: ¿Cómo, por qué y para qué se asesina a un general? (1971) e De América soy hijo... y a ella me debo (1972). Esses e outros documentários usados em La spirale foram feitos pelo ICAIC, instituição que teve contato intenso com Patricio Guzmán e Chris Marker, o que resultou, entre outras parcerias, na montagem do épico A batalha do Chile. Vale, portanto, enfatizar essa ligação entre o Marker, o ICAIC e cineastas chilenos perpassa a montagem de $L a$ 
spirale $^{284}$, e que foi de extrema importância para que os materiais fílmicos exilados após o golpe de Estado de 1973 pudessem ser preservados. A inserção dessa filmografia na produção francesa merecerá um subcapítulo à parte, já que retoma, de alguma forma, o tema da colaboração de Marker com o ICAIC, desenvolvido no Capítulo 1.

Por fim, é importante abordar produções contemporâneas à montagem de $L a$ spirale que, assim como este documentário, foram realizadas em um contexto de denúncia da situação chilena à comunidade internacional. Nesse grupo, estão filmes de diretores chilenos que se encontravam exilados na Europa e também de militantes europeus que se debruçaram sobre a tragédia chilena. Alguns títulos citados na sequência dos rolos em espiral que podem ser destacados são: Chove sobre Santiago (1975, Helvio Soto), Contre la raison et par la force (1974, Carlos Ortiz Tejeda), Septembre chilien (1973, Bruno Muel), Diálogos de exilados (1974, Raúl Ruiz), entre outros. No entanto, apesar dos realizadores citarem essas produções em La spirale, elas não foram incorporadas como material de arquivo. Possivelmente, isso se explica por serem filmes que, assim como o documentário em questão, foram finalizados após o 11 de setembro de 1973, ou seja, não trazem tomadas originais realizadas durante os anos da Unidade Popular. Por esse motivo, esse quarto grupo não será esmiuçado.

Vale destacar que toda essa filmografia de caráter militante que foi consultada ou incorporada como arquivo durante a montagem de La spirale adquiriu um sentido inédito, tendo seus significados anteriores alterados. Por sua extensão, não cabe aqui fazer o exercício de verificar cada um desses novos sentidos plano a plano, porém, pretende-se, nesta análise, verificar de que maneira algumas das cenas pertencentes a esses filmes foram modificadas, bem como verificar como suas características gerais dão espaço a novas preocupações após o golpe do Chile. Por meio desse olhar, pretende-se mapear tendências gerais à prática de incorporação de materiais prévios e de autorias diversas.

Em La spirale, na parte em que são apresentadas as forças políticas em jogo, logo após os créditos inicias, a tela escura dá lugar a cenas de pessoas nas ruas empunhando fotos de Salvador Allende. Em áudio direto, é possível ouvir "el pueblo unido, jamás será vencido", frase proferida em uma manifestação festiva. Essas sequências encerravam originalmente o documentário Venceremos, de Pedro Chaskel,

\footnotetext{
${ }^{284}$ Cabe lembrar ainda que as montadoras Valérie Mayoux e Jacqueline Meppiel localizaram muitos dos documentos usados em La spirale nos arquivos do ICAIC.
} 
finalizado ainda em 1970, mesmo ano em que a Unidade Popular chegou ao poder. Nesse filme, vinham anunciar e celebrar a chegada de novos tempos.

Venceremos é uma das produções realizadas pelo Centro de Cinema Experimental da Universidade do Chile pelo diretor da instituição, Pedro Chaskel. Finalizado antes da posse do presidente, traz muitas características presentes em outras produções realizadas durante o governo da Unidade Popular, tanto em sua técnica como em seu conteúdo ideológico. Sem a presença de uma locução over, constrói a narrativa exclusivamente pela sequência de imagens embaladas pela trilha sonora. Suas cenas iniciais opõem ícones da vida dos operários e dos ricos (imagens de bairros pobres com trabalhadores seguindo de ônibus são contrapostas a de mansões vazias e carros dirigidos por "burgueses", por exemplo). Para representar o lado do povo, insere canções da Nueva Canción Chilena; para acompanhar os planos de fachadas luxuosas, uma ópera italiana ou rock and roll, para denunciar a alienação dos jovens de elite.

O documentário identifica a presença de dois mundos, ou de duas classes antagônicas, que se materializam no cotidiano de Santiago. Os extremos são expostos de maneira cada vez mais impactante ao longo do filme: as fotografias de favelas e de pessoas doentes (vítimas da falta de saneamento e de alimentação adequados) chocam tanto quanto os cabelos rigorosamente aprumados dos jovens do ultradireitista Patria y Libertad. Cenas de crianças desnutridas e cheias de vermes, ou ainda trabalhando em lixões, são entrecortadas pelo modo de vida burguês: vitrines com produtos sem utilidade e concurso de beleza de cachorros.

O enfrentamento entre os dois universos retratados chega ao ápice quando o magro rosto de um bebê desnutrido, cujo close-up nos permite encarar seus olhos esbugalhados, marca uma ruptura no procedimento adotado até então. Inicia-se, com um corte, o conflito: manifestações nas ruas duramente reprimidas pela polícia introduzem movimento e enfrentamento. O povo luta com pedras contra o arsenal bélico das forças repressoras. Trata-se de cenas registradas no final dos anos 1960, durante o governo de Eduardo Frei, que terminava seu mandato justamente em 1970, quando Venceremos foi produzido.

A associação dos planos, definida muitas vezes pelo critério da oposição, leva ao entendimento de uma clara mensagem, que pode ser percebida em três diferentes momentos do filme: tomada de consciência, conflito de classes e, finalmente, o povo no poder. A linearidade em direção ao desfecho endossado pelo diretor faz com que 
essa clareza carregue um potencial didático: o discurso se funde nas evidências documentais, ante as quais o intolerável leva impreterivelmente à ação, e a ação abre o caminho à vitória. Ao adotar como título o lema da campanha de Allende, Venceremos, Chaskel afirma sua posição partidária, como fizeram outros cineastas da UP.

Em La spirale, essa linearidade é desfeita. Exibidas logo após o prólogo, finalizado com cenas do ataque ao La Moneda, as imagens da comemoração da vitória de Allende, retiradas de Venceremos, adquirem um tom nostálgico, em detrimento de seu sentido comemorativo original. O espectador já sabe que elas não se tornaram ícones de tempos promissores no qual o povo estaria no poder, mas sim de uma grande tragédia que, em 1975 (quando o filme era montado), parecia difícil de ser revertida.

A escolha por essas cenas para começar a contar uma história (já que entram logo após os créditos iniciais) denota também uma espécie de marco a partir do qual La spirale dedicará sua análise. Diferentemente de Venceremos, cujo foco estava no processo de conscientização das desigualdades que levou a Unidade Popular ao poder, o documentário de 1976 trata de uma etapa posterior: a luta de classes no governo Allende. Assim, as sequências veiculadas perdem seu lugar de ponto de chegada para se transformarem em ponto de partida. Não por acaso são essas cenas que introduzem a primeira frase proferida pela voz over: "4 de setembro de 1970. Salvador Allende é eleito presidente do Chile."

Outras sequências de Venceremos, retomadas em La spirale, são aquelas em que a população enfrenta soldados em Santiago. No caso, são imagens que já eram material de arquivo na montagem do filme de Chaskel, mas que adquirem, no pós-11 de setembro, outro papel. Se, no ano da eleição de Allende, ilustravam revoltas populares que demonstravam uma conscientização de classe, aparecem no bloco $\mathbf{O}$ exército como prova de que a classe operária sempre havia sido reprimida militarmente no Chile, inclusive no governo da Democracia Cristã. Assim, de exemplo positivo de mobilização social, se torna uma denúncia de uma tradição que explica a tomada do poder pelo exército.

Outra produção que teve trechos apropriados por La spirale é El diálogo de América, de Álvaro Covacevich. Vale lembrar que o documentário foi produzido na ocasião da visita de Fidel Castro ao Chile, no final de 1971, quando o diretor gravou uma longa conversa mediada por Augusto Olivares com os dois principais líderes 
esquerdistas latino-americanos daquele momento. Um ano depois, aprofundava a discussão em torno da via chilena para o socialismo com exibições no Chile e em Paris $^{285}$.

Com um prólogo que mostra uma reunião de trabalhadores, camponeses e estudantes, seguida pela cena de uma multidão de pessoas saudando Salvador Allende, o filme se passa quase todo nas dependências presidenciais, onde a entrevista foi gravada. Em alguns momentos, porém, cenas externas da visita do líder cubano ao Chile e imagens históricas dos dois países interrompem as sequências captadas (inclusive, com a exibição de alguns trechos de produções do ICAIC, incorporadas para exemplificar as conquistas da Revolução Cubana).

A discussão principal, conduzida por Olivares, é a questão do caminho adotado para a efetivação de um governo socialista. Interrogado sobre o assunto, Allende declara achar um "exagero" a afirmação de que o Chile havia inaugurado uma nova via para a revolução social, pois, para ele, cada povo deveria encontrar sua própria forma de "libertação". As dificuldades de levar seu projeto adiante, com o embargo econômico e as batalhas com a oposição, também são citadas. Caracterizados como dois fenômenos do socialismo na América Latina, Castro e o presidente chileno travam uma conversa que aproxima os dois processos como respostas à opressão e como herdeiras das lutas revolucionárias do povo latinoamericano, desprezando tensões que evidenciem as diferenças entre os projetos. $\mathrm{O}$ clima de integração e apoio prevalece durante a montagem do filme, apesar das diferenças evidentes que estavam em jogo.

O papel de Olivares é direcionar um diálogo (e não uma entrevista) entre os presidentes. O ambiente "caseiro" afasta a produção do cenário dos discursos oficiais. Da mesma forma, os processos chileno e cubano são a todo tempo retratados como complementares, indicando, por meio das falas de Allende e Castro, um destino revolucionário amplo para toda a América Latina. Existe um desejo de que outros países também possam se "libertar do imperialismo norte-americano", presente na evocação da figura de Che Guevara realizada por ambos. A exibição fora das fronteiras nacionais comprova o que o título do filme já indica: trata-se de uma conversa integradora, na qual as lutas populares de outras nações deveriam se incluir.

\footnotetext{
${ }^{285}$ Essa entrevista foi posteriormente publicada em Buenos Aires, no ano de 2003, na forma de livro, após sua transcrição (CASTRO; ALLENDE, 2003).
} 
Nessa produção, por outro lado, há um foco em revelar ao mundo o clima de pré-guerra civil que se instalava no Chile. Allende afirma claramente que só terminará seu mandato ao final do mesmo (fala, por sinal, semelhante à que abre La spirale, embora repetida em outra ocasião). A declaração é complementada pelo comentário de Castro que enfatiza que, quando um dirigente está disposto a morrer por uma causa coletiva, o povo também está. Nesse sentido, ao mesmo tempo em que a produção divulga à comunidade internacional uma versão "oficial" dos conflitos chilenos, ela enfatiza um suposto caráter de massa da revolução social no Chile. Isso fica claro ao final da produção, nas cenas sobrepostas de grandes manifestações populares, que encerram o diálogo, passando a mensagem de que a batalha popular é a mesma em todo o mundo.

Essa dimensão "panfletária" de incentivo a uma luta que é vista como latinoamericana se perde no uso das mesmas imagens na montagem de La spirale. Os trechos utilizados nesse documentário desmembram e isolam as declarações de Salvador Allende e Fidel Castro, recorrendo a elas para tratar de temas específicos relativos aos anos da Unidade Popular. No bloco A frente, por exemplo, que se inicia com a discussão em torno da questão da reforma agrária, uma sequência na qual o presidente chileno discorre sobre o assunto é incorporada na edição. O mesmo ocorre com outra fala sobre a nacionalização do cobre, que descolada do contexto original se torna um mero registro do que pensava Allende sobre o assunto.

Nesses exemplos, é possível verificar que o que se propunha como um "diálogo" sobre os caminhos para o socialismo no continente se torna uma relíquia de um projeto abortado. A figura de Olivares, um espectro em 1975, é sublimada. A imagem de Salvador Allende, também um "fantasma", relembra ao espectador projetos interrompidos pelo golpe de Estado, como a reforma agrária e as nacionalizações. Desse modo, se já havia em Covacevich certa tendência em denunciar um clima de conflito (ao reproduzir falas de Allende e Castro evocando a obrigação do líder em seguir com a luta de seu povo até a morte), em La spirale esse tom é retomado como forma de lembrar um projeto de sociedade tragicamente assassinado (novamente um espectro).

A recuperação de falas anteriores ao golpe que, de alguma forma, previam o trágico desfecho da Unidade Popular percorrem La spirale. Há na montagem uma declaração de Fidel Castro (já citada neste capítulo), em um tom semelhante ao presente no prólogo, que afirma uma espécie de "tragédia anunciada". Nesse sentido, 
a sequência retirada do filme de Covacevich é um dos poucos momentos em que a decisão de não questionar a via democrática ao socialismo é tensionada. Castro defende - justamente após uma cena em que há a manipulação de peças no tabuleiro do jogo Política equivalentes a setores das classes médias mobilizados na "frente de massas" da direita - a necessidade de mobilizar as massas, considerando prepará-la para o uso da violência: "E resta esperar se nós vamos analisar teoricamente essa questão, ganhar resistência, resistência forte, incluindo a resistência violenta."

Nessa fala, selecionada por La spirale, Castro endossa a tese central defendida pelos realizadores, a de que a burguesia chilena manipulou as massas e os setores médios para desarticular seus adversários, no caso, o governo popular que estava no poder. O líder cubano, porém, enfatiza a importância de se articular uma resistência, inclusive violenta, contra essa estratégia. Quando o documentário francês foi realizado, o espectador já sabia que isso não tinha sido feito, ou não de maneira efetiva, e que a direita havia ganhado o jogo. Nesse trecho, se no filme de Covacevich a declaração poderia servir de alerta, no novo documentário ganha um tom de autocrítica diante do fato de a esquerda não ter se preparado para uma situação evidente - em um dos raros momentos em que os possíveis erros da Unidade Popular aparecem em La spirale.

Outro material audiovisual de caráter militante largamente usado pelos realizadores de La spirale - talvez o que mais está presente entre as sequências do filme, ao lado das gravações televisivas - é o conjunto de cenas gravadas pela equipe de Patricio Guzmán. Nesse caso, o caráter testemunhal dessas obras (analisadas no capítulo 2) dá lugar à denúncia de uma situação ocorrida. As mesmas sequências registradas pela equipe do realizador chileno com estratégias de cinema direto, sem saber exatamente o que iriam eternizar, servem à construção de um objeto de memória que visa a materializar um conhecimento novo sobre a história da Unidade Popular.

Nesse sentido, pode-se afirmar que dois grupos de sequências retiradas dos filmes de Guzmán se destacam no documentário francês. Um diz respeito aos núcleos de consolidação do "poder popular", como imagens de ocupação de fábricas e juntas de abastecimento. $\mathrm{O}$ outro se refere às entrevistas e às cenas tomadas nas ruas, nas 
quais os protagonistas são membros da direita e outros atores que constituem a tal "linha de massa" de direita identificada pelos realizadores de La spirale ${ }^{286}$.

A opção de Guzmán em registrar também as oligarquias e as classes médias favoreceu a estratégia largamente utilizada em La spirale de intercalar cenas militantes com outras de veículos fora do campo da esquerda, submetendo-as ao mesmo comentário. No bloco A aproximação, por exemplo, ao mostrar as manifestações de mulheres, que corroboram a tese de que se formou uma "linha de massa" da qual os setores médios participaram ativamente, o documentário francês intercala imagens coloridas de TV com sequências em preto e branco retiradas de $\mathrm{La}$ respuesta de octubre. Nesse caso, a distância de objetivos entre o que pretendia Guzmán e os realizadores do novo documentário não é tão grande: ambos denunciavam a articulação de forças da direita. Porém, as duas produções diferem pelo conhecimento do trágico desfecho, que permite ao filme de 1976 construir uma hipótese aprofundada sobre a conspiração da burguesia.
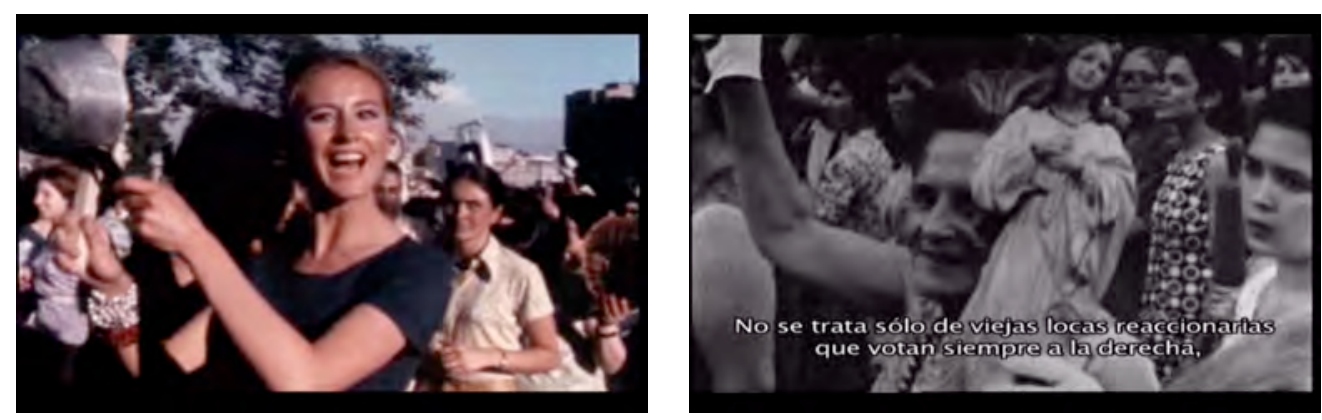

Fotogramas de La spirale.

A presença desse tipo de material só foi possível devido ao método da equipe de Guzmán de adentrar em territórios inimigos para investigar suas ações e conhecer seu discurso. Novamente, há uma semelhança com a montagem final de La spirale, que também utiliza essas sequências como forma de explorar o modo de agir do adversário. No entanto, enquanto no filme francês as manifestações da direita corroboram uma tese desenvolvida após a certeza de que realmente se tratava de um complô (dada pelo golpe de Estado de 1973), nos documentários do diretor chileno eram captadas com um objetivo investigativo que envolvia disfarces e estratégias para passar despercebido pelo inimigo.

\footnotetext{
${ }^{286}$ Cabe ressaltar que uma parte importante dos depoimentos de membros da direita estava originalmente no filme La guerra de los momios (1974), dos alemães Heynowski y Scheumann. As entrevistas com os líderes patronais, por exemplo, recorrentes em La spirale, aparecem utilizadas como material de arquivo também nos episódios de A batalha do Chile, de Guzmán.
} 
Em relação aos registros das mobilizações de esquerda, as imagens aproveitadas dos filmes de Patricio Guzmán contribuíram para que La spirale encontrasse uma saída diante do dilema de não capitular adiante da vitória do inimigo. Algumas delas são exibidas no bloco $\mathbf{O}$ ataque, quando a frente de massas da direita está consolidada, mas não consegue vencer o jogo devido às respostas dadas pelos movimentos populares autônomos. Nesse sentido, os montadores franceses usaram, por exemplo, sequências em que os alimentos são distribuídos por voluntários (como os estudantes e membros de organizações de esquerda), possibilitando à população o acesso a eles apesar da interrupção na sua distribuição, fruto da greve nos transportes. Jovens de aparência humilde transportando sacolas, bem como bicicletas transitando pelas ruas das comunidades carregadas de mantimentos, tornam-se símbolos de uma resistência que cria, ao mesmo tempo, uma consciência entre os setores mais humildes de que é possível organizar-se em detrimento das esferas superiores de poder (político ou econômico).

As mesmas sequências aparecem também em A batalha do Chile III - O poder popular. No entanto, se, em La spirale, elas são uma espécie de saída, de afirmação de que seria possível reverter o rumo da espiral e criar uma nova reviravolta em seu percurso, no final da trilogia de Guzmán, adquirem um viés nostálgico, o de um projeto que não se realizou. A diferença de momentos em que os dois documentários foram montados (1975 e 1979) pode ajudar a explicar que essas produções tenham adquirido tons distintos com base nas mesmas imagens, já que enquanto o filme francês deposita esperança em um legado político do governo de Salvador Allende como forma de resistir ao inimigo, o de Guzmán percebe que esse projeto ficou em um tempo passado que não se concretizou.

Uma das diferenças mais significativas entre os métodos usados nos documentários de Patricio Guzmán e em La spirale se refere à tentativa do diretor chileno em utilizar predominantemente imagens gravadas por sua equipe, recorrendo o mínimo possível aos filmes de arquivo. Essa máxima reforça sua vontade de realizar um cinema direto, cujo momento do registro é tão - ou mais - importante do que a montagem. Isso implica em preocupações diversas, como enquadramento, posicionamento da câmera, forma e presença da equipe nos cenários visitados. $\mathrm{O}$ ato de filmar traz em si um potencial revolucionário e combativo, pois permite que os processos políticos em conflitos sejam registrados e divulgados. Por isso, existia a 
preocupação em mostrar as produções em circuitos alternativos, especialmente os que incluíam o operariado.

Bem diversa é a utilização dessas imagens em La spirale. Nesse caso, a montagem se sobressai, e não é possível verificar um estilo único presente nas gravações, que são de naturezas bastante distintas. Assim, aspectos ligados ao ato de filmar se perdem. Por outro lado, a distância dos realizadores da tomada das cenas (espacial e temporal) acarreta em um saber privilegiado, que facilita a construção de uma argumentação histórica rica em detalhes e "provas". O conhecimento do trágico desfecho dessa batalha possibilita ainda que o uso das sequências responda a uma explicação coerente de causas que levam a um fim conhecido, e não apenas mostre uma situação de caos que ganhava corpo, mas que tinha um futuro ainda em disputa.

Em La spirale, a partida já está ganha. Porém, vale entender os motivos, as estratégias adversárias, rever as imagens do passado para tirar delas um novo saber. Mais importante é, portanto, o que se interpreta dos registros daquele período, como é possível adquirir uma consciência e um legado que ajudem na elaboração de novas jogadas. O documentário é montado em tom de denúncia, e também de uma análise política e sociológica apurada, que, por sua vez, não deixa de servir de "arma". Uma guerrilha que não utiliza trincheiras, mas o lugar privilegiado do saber. Mesmo que seja um saber póstumo.

\subsubsection{O ICAIC e a presença de extratos de Santiago Álvarez em La spirale}

O contato entre Chris Marker e o Instituto Cubano del Arte e Industria Cinematográficos, como já foi exposto no Capítulo 1, começou dois anos após sua criação, em março de 1959, e se estendeu até o princípio da década de 1970. Mariana Villaça (2010) identifica que a nova conjuntura europeia que se seguiu às agitações de 1968 enfraqueceu o debate do ICAIC com cineastas europeus (situação em que o caso de Marker parece ser um episódio na contracorrente, tendo em vista La bataille des dix millions), fazendo com que as atenções do instituto se voltassem para o próprio continente. Dessa maneira, dois festivais locais ganharam importância: o de Mérida ( $I$ Muestra del Cine Latinoamericano de Mérida, Venezuela), em setembro de 1968, e 
as duas edições do Festival del Nuevo Cine Latinoamericano de Viña del Mar (1967 e 1969).

Esses marcos do Nuevo Cine Latinoamericano já indicavam um ímpeto para o cinema político, que seria intensificado em diversos países do continente pela oposição aos regimes militares que se espalharam pela América Latina nos anos 1970. No caso de países como Chile e Nicarágua, nos quais governos de esquerda chegaram ao poder nesse período, o diálogo com o ICAIC se fez de maneira mais direta, seguindo a linha de estreitar relações políticas e fortalecer vínculos culturais. Nesse sentido, Mariana Villaça reforça que:

As promessas de mudança na direção do socialismo que ocorreram nessa década, primeiro no Chile e, mais tarde, na Nicarágua, atraíram o governo cubano para um estreitamento de relações com esses países, com vistas à construção de possíveis alianças. Assim, temas como o governo da Unidade Popular, no Chile, e a Revolução Nicaraguense tiveram um apelo especial em Cuba, a despeito de diferenças políticas e ideológicas existentes entre o governo cubano, o nicaraguense e o chileno. (VILLAÇA, 2010, p. 183)

Cartas trocadas por diversos atores com o diretor do ICAIC revelam que os contatos entre o instituto cubano e as instituições cinematográficas chilenas (sobretudo a Chile Films) foram constantes durante os anos da Unidade Popular, embora se caracterizem por uma certa tensão. O realizador Miguel Torres foi enviado de Cuba para cooperar com a estatal chilena - período no qual rodou Introducción a Chile (1972) - e escreveu a Alfredo Guevara em abril de 1971 com bastante pessimismo, recebendo como resposta um pedido de paciência diante do lento processo de mudança nas estruturas preexistentes enfrentado pelos cineastas chilenos (GUEVARA, 2009). A presença de Torres no país era uma das ações resultantes do Convenio Chile Films ICAIC, assinado por Guevara e Miguel Littin ${ }^{287} \mathrm{em}$ abril de 1971, que se estendeu até o fim do governo de Salvador Allende. Por meio desse convênio, as duas nações se prontificavam a colaborar não apenas para a realização de ficções e documentários, mas também para a difusão de produções e sua promoção em meios de comunicação ${ }^{288}$.

\footnotetext{
${ }^{287}$ Miguel Littin, nessa época, era o diretor da Chile Films, como foi colocado no capítulo 2.

${ }^{288}$ A grande presença de artigos dedicados a assuntos chilenos nas revistas Cine Cubano do início da década de 1970 ratificam as trocas intensas provenientes desse acordo, como defende Mariana Villaça: "A revista Cine Cubano, nessa época, trouxe várias entrevistas e reportagens sobre a história do cinema chileno, com o claro propósito de fomentar a simpatia dos cubanos pelos novos parceiros, ao mesmo tempo em que procurava orientar ideologicamente os cineastas chilenos, como percebemos nos
} 
Apesar dos problemas enfrentados na implementação efetiva do Convenio ICAIC Chile Films, destacam-se dois filmes de Santiago Álvarez produzidos nesse período, que foram largamente utilizados na montagem de La spirale. O primeiro deles é ¿Cómo, por qué y para qué se asesina a un general? (1971), uma investigação e denúncia sobre o assassinato do general René Schneider, morto em outubro de 1970. Baseado sobretudo em entrevistas, apesar do uso de material de arquivo (como cenas de Venceremos), esse documentário procurou desvendar o complô que tentou impedir a posse de Salvador Allende, retirando de cena uma peça "legalista" do exército e atribuindo a culpa à extrema-esquerda ${ }^{289}$.

A visita de Castro ao Chile, ocorrida entre novembro e dezembro de 1971, estabeleceu ainda outras parcerias significativas para a produção audiovisual desses países. Uma segunda produção de Álvarez realizada sob termos do Convenio foi De América soy hijo... y a ella me debo... (1972) ${ }^{290}$, uma extensa reportagem sobre a estada do líder cubano no Chile. Apesar da maior parte das tomadas feitas pelo documentarista enfatizar a presença do líder cubano no país, sua aproximação com Allende - aos moldes do que é feito em El diálogo de América, de Covacevich exerce a função de não opor as duas vias ao socialismo (a democrática e a insurrecional), valorizando a condição de ser latino-americano (como diz o título, todos são filhos da mesma terra).

Após o golpe de Estado de 11 de setembro de 1973, esse contato prévio entre cineastas chilenos e a intermediação de Chris Marker via ICAIC foram fundamentais para a montagem de gravações inéditas e a preservação de filmes realizados durante os anos de 1970, em detrimento da repressão ditatorial no Chile. O maior exemplo dessa parceria e de sua importância foi a montagem de A batalha do Chile, possível graças ao apoio do instituto cubano e abordada no capítulo 2. Vale relembrar que

questionários feitos a estes, cujo encadeamento de perguntas convergia para certas conclusões favoráveis às opções políticas cubanas." (VILLAÇA, 2010, p. 184-5) Sobre o convênio entre o ICAIC e a Chile Films, ver a tese de Ignacio Del Valle Dávila (2012), onde está presente também o texto integral firmado em 1971 entre os dois países.

${ }^{289}$ Uma carta enviada por Beatriz Allende a Alfredo Guevara em abril de 1972 mostra que esse filme foi censurado no Chile, apesar do governo esforçar-se por sua divulgação (GUEVARA, 2009). Na correspondência, ela revela detalhes sobre os censores, dizendo que haviam considerado o documentário um filme cubano que se intrometia nos assuntos nacionais. Esse episódio exemplifica algumas das dificuldades da Chile Films após a posse de Allende, órgão responsável pela difusão de ¿Cómo, por qué y para qué se asesina a un general?, que ainda estava submetida a uma estrutura herdada dos governos anteriores que impedia que a realização de seus projetos. No entanto, essa carta da filha do presidente ao ICAIC se refere a exibições clandestinas e à tentativa de veiculá-la na televisão da Universidade do Chile.

${ }^{290}$ Vale destacar que esse documentário tem três horas e quinze minutos e acompanha todo o percurso de Castro ao sul e ao norte do país, bem como seus comícios e falas ao povo chileno. 
estavam no exílio cubano nomes como Marta Harnecker e, posteriormente, Pedro Chaskel, peças fundamentais para a montagem da trilogia de Patricio Guzmán, ao lado de Julio García Espinosa ${ }^{291}$.

Essa contribuição de Marker com a edição dos materiais fílmicos de Patricio Guzmán permite afirmar que o contato próximo entre ambos e a intermediação do ICAIC ajudam a explicar a vasta presença de imagens em comum entre La spirale e $A$ batalha do Chile, como já foi salientado. Vale ressaltar que a primeira parte da trilogia aborda, assim como o documentário francês, a "contrarrevolução" - do ponto de vista das esquerdas - encampada pela direita chilena. Com soluções diversas de montagem, mesmo quando ocorre o uso das mesmas sequências, Guzmán defendeu que o golpe, antes de mais nada, foi fruto de uma "insurreição da burguesia" - assim como a tese dos realizadores franceses ${ }^{292}$.

Em depoimento de 1976 (THIRARD, 1976), Armand Mattelart ressalta a importância da pesquisa realizada pelas montadoras Jacqueline Meppiel e Valérie Mayoux em Cuba para o resultado final de La spirale ${ }^{293}$. Essa ação, mais do que uma simples etapa de pesquisa, indica que a presença de documentos de natureza audiovisual sobre o Chile em território cubano era significativa. Assim como seus realizadores, os rolos de película saíram do país "exilados" após o golpe de Estado, encontrando abrigo em arquivos europeus e de outros países latino-americanos para onde seguiram também seus autores. É significativo citar, nesse contexto, um trecho do depoimento de Patricio Guzmán que explica como conseguiu salvar da repressão

\footnotetext{
${ }^{291}$ Foi García Espinosa o responsável, em 12 de setembro de 1973 - um dia após o golpe de Estado por selecionar imagens relativas aos anos da Unidade Popular no poder para montar um Noticiero ICAIC Latinoamericano sobre os trágicos acontecimentos no Chile, conforme revela uma carta do mesmo direcionada a Alfredo Guevara (GUEVARA, 2009). A ideia era denunciar que "o fascismo" já vinha se articulando e boicotando o governo Allende nos anos anteriores, tese que podia ser defendida com base em produções realizadas entre 1970 e 1973. Ele cita na correspondência alguns dos filmes que serviram à elaboração dos cinejornais, como Introducción a Chile (Miguel Torres), El primer año (Patricio Guzmán), além de inúmeros curtas-metragens (Deuda externa, UNCTAD III, La merluza, Nuestro acero, Apuntes para una geografía, La pincoya, El crimen tan comentado, Oye cabrito e Libertad de prensa). García Espinosa alerta para a possível existência de outras produções no acervo do instituto, tendo em vista que se tratava de um levantamento prévio.

${ }^{292}$ Um exemplo de sequências comuns aos dois documentários está nas cenas relativas à tentativa frustrada de golpe militar, conhecida como "el tancazo". Pessoas correndo acompanhadas de barulhos de tiros aparecem em La spirale e também na primeira parte de A batalha do Chile.

${ }^{293}$ Entre as cartas trocadas com Alfredo Guevara, há uma assinada por Armand e Michèle Mattelart, datada de $1^{\circ}$ de novembro de 1971, quando o realizador ainda estava no Chile (GUEVARA, 2009). Nesse documento, ele revela o interesse de ir a Cuba após um convite do diretor do instituto para conhecer a ilha e para conversar sobre os conflitos chilenos. Essa correspondência mostra que o próprio Mattelart, assim como Marker, tinha um contato próximo com o ICAIC, o que facilitou a entrada das montadoras em seus arquivos.
} 
policial todo seu material gravado, revelando que a iminência do golpe gerou uma estratégia prevista de antemão:

Uma das chaves para que o material tenha sido resgatado de um modo tão ordenado era precisamente a organização que nós tínhamos desse material no momento de filmá-lo. Cada vez que se filmava uma lata de 400 pés, se anotava o título da sequência, se anotava em um registro e eu levava essa lata a um lugar seguro e secreto que somente eu conhecia. Por sua vez, a fita magnética era levada por Bernardo Menz a sua casa, à espera de ser levada a um lugar seguro. (GUZMÁN, SEMPERE, 1977, p. 91-2, tradução nossa) $)^{294}$

A "diáspora" de materiais fílmicos após o golpe do general Pinochet causa ainda hoje uma ausência desse tipo de documento nos arquivos chilenos, especialmente em sua cinemateca, como mostra a recente pesquisa da Cineteca Nacional de Chile frente a essa demanda (VILLARROEL, 2008). Entre os documentos localizados, destacam-se os pertencentes à Cinemateca Chilena en el Exilio, organizada em Cuba, que abrigou grande parte do material fílmico exilado após o golpe de Estado. Em relação ao acervo do ICAIC, os levantamentos preliminares indicaram a presença de cerca de setenta produções, além de aproximadamente trinta noticiários cubanos com referência ao Chile ${ }^{295}$. Foi o próprio Pedro Chaskel, em dezembro de 2006, quem reconheceu esse corpo documental, pedindo sua transferência ao patrimônio da Cineteca Nacional de seu país.

É importante identificar alguns dos trechos utilizados em La spirale que foram produzidos pelo ICAIC e verificar os novos significados que eles adquirem após o 11 de setembro de 1973. Seu primeiro plano é um trecho extraído de De América soy hijo... y a ella me debo..., de Santiago Álvarez. Trata-se de um discurso de Salvador Allende proferido em 2 de dezembro de 1971, na ocasião da visita de Fidel Castro ao Chile. A mesma cena, porém, no filme cubano, encerra o longa-metragem. A diferença entre as duas montagens, além da posição em que o comício é exibido, é que a produção francesa realiza um corte que suprime a sequência da multidão que

\footnotetext{
${ }^{294}$ Traduzido do original: "Y una de las claves para que el material se rescatara de un modo tan ordenado era precisamente el orden que nosotros teníamos del material en el mismo momento de filmarlo. Cada vez que se filmaba la lata de 400 pies, se anotaba el título de la secuencia, se anotaba en un catastro y esa lata me la llevaba yo a un lugar seguro y secreto que solamente yo conocía. Y a su vez, la cifra magnética se la llevaba Bernardo Menz a su casa, a la espera de llevarla a lugar seguro."

${ }^{295}$ De acordo com os dados oficiais da Cineteca Nacional de Chile, apesar desse levantamento preliminar indicar essa quantidade, apenas cinco longas-metragens, 94 latas com "materiais diversos" e 15 fitas de U.Matic foram entregues em estado de "sobreviventes" ao governo chileno. Porém, durante o período de realização desta pesquisa, esse material ainda não estava catalogado.
} 
ovaciona Castro e grita, em som direto, "a esquerda unida, jamais será vencida". No lugar, um fundo preto interrompe a fala do "futuro mártir" para indicar a data e o local do evento mostrado.

Em La spirale, não há o que comemorar. Tampouco se pode afirmar que a esquerda unida é imbatível, pois o mesmo Estádio Nacional que abrigava a festa em homenagem à presença de Castro havia se tornado um campo de prisões e fuzilamentos da ditadura. A fala de Allende (já citada neste capítulo), no entanto, é preservada e valorizada como parte do prólogo do documentário de 1976, seguida, como foi destacado anteriormente, pelas imagens do ataque ao La Moneda em 11 de setembro.

De América soy hijo... y a ella me debo..., que gravou originalmente esse discurso premonitório, consiste basicamente em um registro jornalístico das atividades de Castro no Chile. Ao inserir essa fala de Allende, reiterando sua tarefa frente ao povo, o faz celebrando a presença de mais um líder socialista à frente de um governo latino-americano. Álvarez não imaginava, no entanto, que registrava uma promessa que de fato seria cumprida - aquela de permanecer no cargo até a morte, caso fosse necessário. Dessa forma, vale relembrar a frase de Chris Marker, proferida em $O$ fundo do ar é vermelho, de que nunca é possível saber o que se filma. Essa máxima revela que as imagens têm uma história que ultrapassa o tempo e o espaço em que foram captadas. Dessa forma, devem constantemente ser revistas e reutilizadas com novos sentidos que as atualizem, como ocorre em La spirale.

Ao final do bloco A aproximação, que aborda a visita de Fidel Castro ao Chile, outra imagem desse mesmo discurso presente em De América soy hijo... y a ella me debo... é usada pelo documentário francês, intercalada com cenas de televisão que cobriam o evento no Estádio Nacional. Ao contrário do enfoque festivo e jornalístico dado por Álvarez a essa visita de Castro ao país andino, La spirale verifica - diante de seu saber póstumo privilegiado - uma dupla dimensão exposta pela voz over: trata-se de "um presente para a esquerda chilena", mas também para a direita, que faz do cubano uma espécie de "bicho-papão". Sob esse ponto de vista, os realizadores franceses complementam os trechos do filme cubano trazendo uma nova tomada registrada no mesmo momento, possivelmente por uma rede de TV, em que Allende critica as ofensivas da direita, alertando que um "germe fascista" percorre a sociedade por meio da mobilização de jovens e mulheres contra o governo. 
Outro filme de Santiago Álvarez que é bastante usado como material de arquivo para La spirale é ¿Cómo, por qué y para qué se asesina a un general? (1971). Em relação a esse título, não há uma mudança brusca de sentido entre as duas utilizações, pois assim como pretendia o diretor cubano, os realizadores franceses desejam denunciar a farsa em torno do sequestro e assassinato do general René Schneider. Nesse caso, a imagem da prisão dos lideres de Patria y Libertad e entrevistas com o general Roberto Viaux são reprisadas pelo documentário francês, e complementadas por novas informações encontradas pela equipe (notícias de jornal, trechos televisivos etc.). A principal diferença fica por conta da força adquirida pelo episódio na abordagem de Álvarez (feita logo após sua ocorrência, com tom de “jornalismo investigativo") e o sentido de rememoração com que aparece na produção francesa (nesse caso, mais um esforço de não esquecer as dificuldades enfrentadas antes mesmo da posse de Allende).

Outros trechos esparsos coletados pela equipe de La spirale nos arquivos cubanos aparecem distribuídos ao longo do filme, especialmente quando o assunto recai sobre o imperialismo norte-americano no continente. Vale destacar, por exemplo, uma fala de Che Guevara sobre o tema retirada de outra produção de Santiago Álvarez, Hasta la victoria siempre (1967), no qual o guerrilheiro acusa de "bestas" os imperialistas (incluindo entre eles os franceses na Argélia, o que torna essa seleção mais significativa tendo em vista a origem europeia do documentário).

Uma questão importante sobre o uso de imagens do ICAIC por La spirale diz respeito ao tratamento das duas "vias" tidas, na época, como os principais caminhos para a chegada ao socialismo: a insurreição armada (da qual Cuba se tornou o exemplo mais bem-sucedido) e a utilização dos meios democráticos (da qual o Chile era a maior referência). Como foi abordado em alguns momentos deste capítulo, tanto as produções cubanas como as chilenas não opõem claramente essas duas estratégias da esquerda para obtenção do poder político. Essa escolha dos diretores pode ser explicada pela tentativa de "preservar" de críticas a ideia de uma Unidade Popular formada pelo Partido Comunista e pelo Partido Socialista, já que essa discussão permanecia viva no cenário político francês, como será discutido nos dois próximos capítulos desta tese. 


\subsection{Outros ecos da revolução democrática: Chile de Allende na televisão francesa e seu uso em La spirale}

Entre os materiais de arquivo incorporados extensivamente em La spirale destacam-se reportagens produzidas durante o governo de Salvador Allende pela televisão francesa, mais especificamente pela ORTF. Essa vasta produção anterior ao golpe decorria do interesse internacional por uma aliança eleitoral vitoriosa entre os partidos comunista e socialista e atraiu os holofotes da imprensa francesa, que passou a seguir de perto os acontecimentos no Chile. Nos periódicos escritos, por exemplo, houve um estrondoso aumento de artigos sobre o país, como indicam os números mapeados por Pierre Vayssière (2005): de uma média inferior a 15 por ano durante a década de 1960, entre 1970 e 1973, a cifra anual ultrapassou os 150 textos publicados - sendo mais de 200 em 1973, quando ocorreu o golpe militar que destituiu o governo da Unidade Popular. A mesma tendência ocorreu nos noticiários televisivos: a ORTF, estatal que detinha o monopólio televisivo na França, veiculou inúmeras reportagens e alguns especiais sobre a experiência chilena de implementação do socialismo - entre eles, Le Chili: un nouveau Cuba? (1970) e Six mois d'Unité populaire (1971). Esses dois programas cederam inúmeras imagens ao documentário de 1976, tendo seus sentidos originais negados ou reafirmados, de acordo com a inserção nessa nova montagem.

De modo geral, os programas veiculados pela estatal francesa apresentavam uma visão positiva de Salvador Allende, embora alguns deles revelem tensões entre a Unidade Popular e seus opositores de direita, bem como os debates internos da esquerda chilena. Em um primeiro momento, esse fato pode parecer contraditório, tendo em vista que, no mesmo período em que o Chile era governado pela Unidade Popular (entre 1970 e 1973), Georges Pompidou - que havia derrotado os partidos de esquerda nas eleições de 1969 - presidia a França. Nesse sentido, é necessário tecer breves considerações sobre a ORTF para compreender as razões pelas quais os jornalistas simpatizantes da experiência chilena tiveram tanto espaço nesse canal do Estado francês.

Os estudos sobre a ORTF se dividem entre o mito de uma "idade de ouro" da televisão francesa no período (época de modernização e engajamento com o interesse público) e as críticas de que ela estava a serviço do Estado e submetida à censura. Essa ambivalência é caracterizada pela historiadora Patricia Legris (2008) como 
consequência de disputas internas que marcaram sua existência, sobretudo entre os realizadores e o controle estatal ao qual a instituição estava submetida. Em meio às agitações de Maio de 1968, o canal foi ocupado pelos sindicatos de técnicos, realizadores e produtores, que o paralisaram, deixando a França sem transmissões por seis dias. Essa greve evidenciou enfrentamentos que se estenderiam entre 1969 e 1972, quando havia uma divergência aberta entre o primeiro-ministro, Jacques Chaban-Delmas, que defendia uma maior liberdade na política audiovisual, e o presidente da república, Pompidou. Esse caso ficou conhecido como "experiência Chaban-Desgraupes" (em referência também a Pierre Desgraupes, então diretor da emissora), que favoreceu a existência de pontos de vista plurais em suas transmissões. A maioria dos informes realizados sobre o governo Allende data desse período de abertura, que permitiu inclusive a veiculação de materiais de realizadores e produtoras independentes. Mesmo no caso das produções da emissora, os jornalistas tiveram grande autonomia para imprimir sua opinião.

Grande parte das reportagens veiculadas na França sobre o período da Unidade Popular foi digitalizada e está disponível no arquivo do INA, em Paris. Por meio da consulta desse acervo, é possível estabelecer os períodos da UP que receberam mais atenção da imprensa televisiva francesa, assim como os debates sobre ela que estiveram em pauta na ORTF. Esse material audiovisual revela que, mais do que a vitória de Salvador Allende, em 4 de setembro de 1970, foi o atentado René Schneider, em 22 de outubro desse mesmo ano, o estopim para que o Chile se tornasse um tema frequente nos noticiários. No período de internação que antecedeu sua morte, o general foi tema de três informes: Situation au Chili, Les évènements au Chili e État d'urgence Chili: veille élections présidentielles.

Esses três noticiários dedicados ao atentado contra o general Schneider denunciam a ação da extrema-direita chilena. Em Situation au Chili, o apresentador faz uma introdução histórica descrevendo a Unidade Popular, e a compara com a Frente Popular francesa de 1936. Ele declara que, apesar da presença de rebeliões armadas em vários países da América Latina, a esquerda havia chegado à presidência do Chile por meio das urnas, mas que o problema seria saber se a direita permitiria sua posse. Da mesma forma, em Les évènements au Chili, o repórter enviado a Santiago afirma que o extremismo de direita, que não havia sido desarmado com a vitória eleitoral, punha em risco os procedimentos constitucionais. Essa reportagem traz ainda uma entrevista com Augusto Olivares, associando o terrorismo de direita 
aos fascismos europeus, e alerta para uma nova ameaça no continente latinoamericano. Todas elas caracterizam um clima de tensão, em que o complô dos ultraconservadores ameaçava um exemplo raro de democracia entre as esquerdas.

Dois desses informes veiculam entrevistas com Salvador Allende. Em Situation au Chili, uma breve frase do presidente recém-eleito afirma que os reacionários não abandonam o poder facilmente, mas que o povo estaria a seu lado. Em État d'urgence Chili, o entrevistador indaga o presidente sobre o que responderia aos que o definiam como um novo Fidel Castro, ao que Allende responde que o Chile iria exportar a democracia com um novo modelo de revolução, sem o uso da violência. Percebe-se, assim, nesses noticiários, exibidos em outubro de 1970 véspera da ratificação da vitória presidencial pelo congresso -, a valorização de um novo modelo histórico na América Latina. Se a Revolução Cubana havia se difundido como uma referência a ser seguida ou evitada, a televisão francesa mostra a pacífica "experiência chilena", na qual o perigo armado estava nas ações da extrema-direita, que não respeitava os ideais democráticos.

A comparação com Cuba é um referencial constante nas análises francesas sobre a Unidade Popular, tendência seguida nas reportagens veiculadas pela ORTF. Além desses três curtos informes, o canal exibiu um longo especial sobre o Chile em 23 de outubro de 1970, mostrando que acompanhava de perto o processo de transformação pelo qual passava o país - antes mesmo que o novo presidente assumisse seu cargo. O título desse especial, de cerca de 23 minutos, reproduzia a grande dúvida gerada por Salvador Allende no continente europeu: Le Chili: un nouveau Cuba?. Neste capítulo será analisada uma sequência específica do programa que se tornou uma das cenas mais emblemáticas de La spirale, justamente por corroborar a tese e o tom irônico empregado pelo documentário.

O especial da TV francesa responde a essa questão logo na primeira parte, onde Hasta siempre, comandante, de Carlos Puebla, é a canção escolhida para acompanhar os planos rodados em Santiago, que passa a ser cenário dos murais brigadistas da campanha da UP - primeiro indício visível na paisagem da grande mudança para a qual o país se preparava. A figura de Ernesto Che Guevara, porém, está distante, como se a música que marcou sua despedida de Cuba tivesse caracterizado também o fim de uma era na América Latina. Em seu lugar, um processo que consagrou esforços já conhecidos na Europa, conforme destaca a voz over. Após descrever os painéis da Unidade Popular como imitações "não tão 
inocentes" de Fernand Léger, ela classifica a união das esquerdas chilenas como uma espécie de Frente Popular, porém, com vitórias que as esquerdas europeias não alcançaram:

Essa vitória que os comunistas e socialistas franceses não encontraram desde 1936; que os homólogos italianos, mais fortes, nunca conseguiram desde a liberação; e eis que no fim do mundo, entre os Andes e o Pacífico, na América Latina, comunistas e socialistas chilenos a obtêm, assim, sem nenhuma metralhadora, mas por meio dos votos. (Le Chili, un nouveau Cuba?, 1970, tradução nossa) ${ }^{296}$

Nessa passagem, fica claro que o "ambiente revolucionário" é representado de maneira próxima às referências políticas europeias. Assim, interessa ao canal garantir que o Chile estava longe de Cuba, que seu projeto político preservava os preceitos democráticos ancorados nas tradições da Europa. O próprio "doutor Salvador Allende", como é denominado, é entrevistado para o especial e responde sobre essa questão ao entrevistador francês, que o provoca perguntando se é possível conciliar socialismo e liberdade. Registrado em close-up, o que o aproxima do espectador, o futuro presidente declara não ver oposição entre os dois conceitos e devolve a provocação ao jornalista, indagando-o se é possível ter liberdade em um país subdesenvolvido, em que muitos vivem em situação de miséria. O debate entre eles evolui para a garantia dada pelo novo governo de que as instituições constitucionais seriam preservadas. Allende lembra que o Chile viveu uma Frente Popular em 1938, formada por uma pluralidade de vertentes políticas, assim como a Unidade Popular que representava.

Essa opção por retratar o Chile como um novo modelo, distante da Cuba socialista e próximo às democracias europeias, aparece em algumas passagens de $L a$ spirale. O documentário de 1976 também recorre à Frente Popular para explicar as origens históricas da Unidade Popular, o que não deixa de ser um esforço para encontrar laços comuns à história francesa. Ao refazer a trajetória política de Salvador Allende antes mesmo do primeiro bloco, O plano, o filme insere um cartaz de propaganda da Frente chilena de 1938, enquanto ressalta a participação do futuro presidente socialista como ministro da Saúde de Pedro Aguirre Cerda. A UP é

\footnotetext{
${ }^{296}$ Texto da voz over de Le Chili, en nouveau Cuba?, traduzido do original: "Cette victoire que les communistes et les socialistes français n'ont plus retrouvés depuis 1936; que les homologues italiens, portant plus forts, ont jamais remporté depuis la libération; voilà qu'en le bout du monde, entre les Andes et le Pacific, en Amérique latine, communistes et socialistes chiliens l'obtient, comme ça, aucune pas de mitraillette, mais pour les votes."
} 
apresentada como fruto de um processo histórico que valorizou constantemente o diálogo entre as forças políticas e o caminho das urnas, características ausentes no caso cubano.

Em Le Chili: un nouveau Cuba?, há exemplos de que a ameaça democrática estava nos opositores desse novo governo. O clima de um boicote que se articulava percorre todo o especial, começando por uma de suas primeiras sequências, em que famílias burguesas são filmadas deixando o país. Se o povo é mostrado em grandes comícios saudando o novo presidente, a classe alta, vestida com casacos de pele, "busca a liberdade", como diz a voz over, no lado argentino da fronteira. O diálogo do entrevistador com um senhor e sua família, que negam estar de mudança e depois, quando o carro se afasta da câmera, vê-se que ela está carregado de malas, revela um caráter investigativo, em que as imagens registradas e as entrevistas são articuladas, às vezes de maneiras opostas, para montar um panorama da situação no Chile.

Essa mesma sequência, como já foi destacado, está presente em La spirale. É ela quem abre o primeiro bloco, $\mathbf{O}$ plano, logo após a exposição das forças políticas das eleições chilenas. Nesse sentido, o material televisivo é incorporado, em $L a$ spirale, como uma introdução ao tema do boicote da direita à Unidade Popular, que será desenvolvido ao longo de toda a produção, culminando no golpe de Estado. A teoria de que a fuga da burguesia iniciou o caos econômico é reforçada pela inserção de uma fala de Allende subsequente, que denuncia o "clima de caos" causado por esse setor. Não existe, portanto, uma mudança significativa de sentido entre o discurso elaborado por La spirale e a cena de Le Chili: un nouveau Cuba?. Essa permanência mostra que a tese defendida pelos realizadores do filme de 1976 encontrava raízes em um debate sobre a conspiração à UP que já circulava na França no pré-1973 e reproduzia teorias da própria esquerda do Chile.

A reportagem da ORTF busca diferentes atores sociais para identificar as forças em conflito no país latino-americano e, mais além, as forças que se articulavam contra o presidente. A equipe encontra grandes proprietários e industriais, e registra, por meio de entrevistas, sua insatisfação - o retrato de "um Chile de direita". Por outro lado, o entrevistador visita uma población onde membros do MIR militavam, revelando que essa organização pressionava Allende para fazer uma revolução, e não apenas reformas. Pode-se dizer, portanto, que Le Chili: un nouveau Cuba? apresentava um país com risco iminente de um golpe de Estado, e possivelmente de guerra civil, caso houvesse uma reação da extrema-esquerda. Essa atmosfera é 
confirmada pela fala presidencial que encerra o noticiário, caracterizando a UP como um baluarte da democracia, enquanto que os setores derrotados nas urnas são descritos como conspiradores e mercenários. Esse ponto de vista confirma os demais informes veiculados em outubro de 1970, que anunciavam um estado de alarme após o atentado a Schneider.

A narrativa de La spirale desenvolve ainda mais a investigação sobre as forças de direita que se articularam contra Salvador Allende, mas não incorpora trechos gravados na población visitada pelo jornalista da ORTF, onde a voz do MIR e as críticas que o Movimento fazia à Unidade Popular ganhavam força. Essa ausência comprova a hipótese de que o documentário de 1976, montado após o golpe de Estado, buscou apaziguar os conflitos internos da esquerda chilena, deixando de lado um rico material de arquivo que registrava a ação mirista nas comunidades pobres e um suposto apoio popular ao seu aporte crítico à UP. Não interessava aos realizadores de La spirale, que pretendiam estabelecer uma denúncia das estratégias golpistas, aprofundar o debate proposto pela televisão francesa sobre o status revolucionário ou reformista do Estado chileno.

Se Le Chili: un nouveau Cuba?, realizado antes mesmo da posse do novo presidente, já expunha graves fissuras e conflitos no Chile, o primeiro ano do mandato de Allende seria acompanhado desde a Europa com grande interesse. Na televisão, o país latino-americano seguiu em destaque. Em 4 de abril de 1971, a ORTF veiculava trechos de uma entrevista com o chefe de Estado latino-americano. Quatorze dias depois, divulgava outra entrevista, dessa vez com Pablo Neruda, então embaixador na França. No entanto, a principal produção dedicada à UP nesse ano foi Six mois d'Unité Populaire (1971), um programa em tom documental, de 37 minutos, realizado pelo jornalista Jean Bertolino, que procurou mostrar as transformações implementadas pela Unidade Popular.

Veiculado pela ORTF em 14 de maio de 1971, o programa seguia a linha de Le Chili: un nouveau Cuba? ao introduzir referências da esquerda francesa para analisar a UP. As primeiras imagens dessa produção são as de um comício que celebrava o $38^{\circ}$ aniversário do Partido Socialista chileno. A voz over verifica uma situação insólita: a canção composta por Claude Joseph Rouget de Lisle, La marseillaise, recebe uma letra adaptada ao contexto chileno, resultando em uma espécie de "transição entre o hino francês e A Internacional". Após exibir a aclamação do presidente por cerca de 2 mil pessoas, a locução over volta à cena para 
informar o grande objetivo da aliança pluripartidária vencedora: aliar socialismo e liberdade. Esse início não diferencia muito Six mois d'Unité Populaire da reportagem realizada antes da posse de Allende, já que ambas identificam méritos do novo governo. Ambas se dedicam também a verificar as mudanças na paisagem acarretas pela vitória eleitoral, destacando a presença dos murais como símbolos de uma era que se anunciava.

Apesar dessas semelhanças - uma evidente simpatia por Allende e o interesse por acompanhar de perto a situação chilena -, os seis meses que se passaram desde a posse do novo presidente fazem com que a preocupação sobre o caráter da revolução no país - seria esse um processo semelhante à Revolução Cubana? - seja deixada de lado em detrimento de um balanço sobre as verdadeiras transformações proporcionadas por essa revolução. Em Six mois d'Unité Populaire, se as tomadas dos carros norte-americanos trafegando nas avenidas induzem à ideia de que nada mudou, os murais brigadistas espalhados pelas paisagens revelam uma "atmosfera de luta" nas palavras da voz over -, ou ainda "a luta por um Chile novo". As sequências mais significativas, que marcam uma ruptura com os períodos históricos anteriores são aquelas gravadas em uma población, onde um caminhão lança-água, que era usado para dispersar manifestações, perde sua função original e passa a servir às necessidades do povo, levando água às comunidades mais carentes.

A voz over alerta que "tomará muito tempo para que o governo do senhor Allende possa solucionar as sequelas do passado". Essa constatação é fruto da escolha de Jean Bertolino, que, na reportagem, entrevista muitos atores sociais, em enfatizar os espaços de conflito na sociedade chilena. Além das poblaciones urbanas, ele dedica grande parte do documentário ao tema da reforma agrária (vale destacar que o ministro da agricultura, Jacques Chonchol, é uma figura bastante presente) e à questão dos fundos de terra mapuches, bem como à denuncia das dificuldades que esses pobres camponeses e indígenas enfrentavam em um país desigual.

A imagem de uma nação com fortes disputas é materializada em uma sequência em que a entrevista de um grande latifundiário - representante da família Wagner - é intercalada à de uma liderança camponesa. Alguns planos gerais mostram a enorme casa onde vive o proprietário. Ele é entrevistado na sala, e a câmera se afasta algumas vezes para evidenciar os objetos de valor. Suas declarações sofrem cortes para dar lugar às falas do camponês, já que ambos respondem à mesma questão: tendo sido declarada a desapropriação da fazenda, o que farão caso a decisão 
do governo seja mantida? Enquanto o primeiro ameaça deixar o país, o líder comunitário declara que a mansão será transformada em uma escola agrícola popular. Esse exemplo deixa claro que a montagem valoriza os pontos positivos das medidas implementadas pela Unidade Popular.

Muitas sequências de Six mois d'Unité Populaire foram incorporadas por La spirale, entre elas falas de Jacques Chonchol - dirigindo-se diretamente aos camponeses e, em seguida, à câmera da ORTF. Inseridos no bloco A frente, os trechos reutilizados respondem à organização da Sociedade Nacional de Agricultura, apresentada previamente pela voz over. Nesse sentido, as palavras do ministro de Allende se transformam em uma resposta à consolidação de mais uma organização patronal, que tutelava os camponeses sob interesses de seus próprios patrões. $L a$ spirale recupera também uma cena do material televisivo em que os trabalhadores rurais do acampamento Camilo Torres clamavam por terra com gritos de guerra. Portanto, no tocante à Reforma Agrária, existe nas duas produções audiovisuais um esforço em aproximar os interesses do povo às ações governamentais. Esse esforço não deixa de ser contraditório tendo em vista que ocupações de terras - ou nos fundos -, como as que aparecem nas gravações, eram feitas à revelia do Estado chileno, muitas vezes com incentivo de líderes do MIR, e representavam um desafio para a Unidade Popular na medida em que pressionavam por uma aceleração das expropriações.

Por um lado, existe uma certa valorização da fala institucional de Chonchol e uma amenização do embate entre o governo e as ocupações presentes nas duas produções; por outro, La spirale incorpora um longo trecho em que Bertolino visita um acampamento mapuche acompanhado de uma militante do MIR, porém, claramente amenizando os embates entre esse movimento e a Unidade Popular. Em Six mois d'Unité Populaire, a voz over informa que esses indígenas, que viviam em uma situação de miséria extrema, foram politizados pelo Movimiento de Izquierda Revolucionaria. Reprimidos no passado, durante a Unidade Popular, teriam conseguido espaço para ocupar fundos e pressionar por uma reforma agrária efetiva. O "apoio crítico" mirista à UP é remarcado e fica evidente também por uma certa tensão entre ação popular e respaldo estatal que permeia a cena.

Na sequência em questão, Ana Pizarro (professora e militante) age como tradutora, papel que lhe agrega igualmente a função de porta-voz dos mapuches. No especial da televisão francesa, ela explica longamente de que maneira o Movimiento 
agia nos acampamentos, mostrando o jornal El Miliciano, editado pelos indígenas e pelos militantes políticos. Extratos dessa passagem de Six mois d'Unité Populaire aparecem em La spirale, porém com cortes em trechos significativos, sobretudo naqueles que expõem a atuação mirista. Assim, o documentário de 1976 opta por manter apenas uma explicação sobre a pobreza em que viviam os camponeses, proferida pela tradutora, reduzindo o espaço destinado ao MIR. O periódico que aparecia originalmente, cujo nome expõe uma contraposição à via pacífica ao socialismo, é retirado de campo. Resta apenas uma breve indicação da voz over de que a esquerda revolucionária atuava na questão agrária, proferida em um tom informativo que não abre espaço para maiores elucubrações.

Em Six mois d'Unité Populaire, o Movimiento de Izquierda Revolucionaria recebe atenção especial, sendo sua militante Ana Pizarro a tradutora e a mediadora entre o jornalista francês e os grupos populares. A visão que o programa televisivo apresenta do MIR é bastante favorável. Em uma longa sequência registrada na Universidad de Concepción, berço do Movimento, ela é entrevistada por Bertolino, e explica a ele como, após a vitória da Unidade Popular, um novo conceito de universidade, aberta ao povo, estava sendo implementado. $\mathrm{O}$ exemplo desses novos tempos fica por conta de um estudante-operário, que é filmado tanto no espaço da sala de aula como na fábrica ocupada pelos cordões industriais onde trabalhava.

A ausência dessa longa sequência em La spirale novamente exemplifica de que modo o MIR perdeu espaço em comparação à produção veiculada pela ORTF. Se não é possível afirmar que ele está ausente no documentário de 1976, pode-se dizer que aparece em algumas situações pontuais, sempre em uma tentativa de colocá-lo em acordo com a Unidade Popular e nunca escancarando suas críticas. No entanto, sua inevitável presença em algumas passagens - como é o caso das tomadas no acampamento Camilo Torres - acaba gerando em alguns momentos um tensionamento que escapa ao desejo dos realizadores. Assim como ocorreu com a fala de Fidel Castro retirada de El diálogo de América - que mesmo inserida como exemplo de estratégias políticas "irmãs" (possíveis caminhos para a América Latina) desafiava a viabilidade da opção pacífica ao socialismo -, a cena que em o Movimiento de Izquierda Revolucionaria atua nos fundos mapuches ou aquela em que Miguel Enriquez clama por ocupações populares fora da via institucional (presentes no último bloco, O golpe) são exemplos de que o escamoteamento das diferenças internas da esquerda chilena era inevitável. 

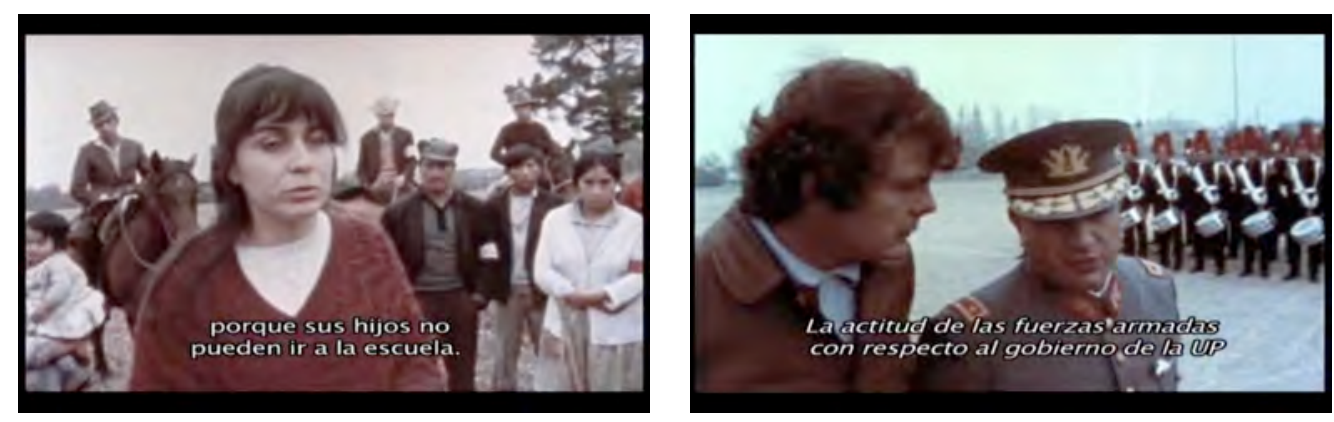

Fotogramas de Six mois d'Unité Populaire, presentes também em La spirale.

Cabe enfatizar que ocorre uma continuidade entre esses dois momentos da produção audiovisual francesa sobre o Chile - antes e depois do golpe - no que se refere ao esforço em denunciar a direita e sua ameaça à ordem democrática. Essa preocupação é notável nas reportagens de outubro de 1970 e aparece de forma profética em Six mois d'Unité Populaire. As sequências finais desse especial da ORTF se dedicam a compreender o papel do Partido Nacional na oposição, o posicionamento da Democracia Cristã após a derrota eleitoral e a atuação do exército. O objetivo de retratar a conspiração inimiga, que será o grande mote de La spirale, motivou seus realizadores a incorporarem uma entrevista feita por Bertolino com o general Canales, também já descrita neste capítulo, que é apresentada no filme de 1976 como uma grande prova da infidelidade do exército chileno, descontruindo seu autodiscurso de instituição legalista e desideologizada.

A preocupação com a possibilidade de um golpe de Estado no Chile já estava presente nos informes da ORTF, como pode ser demonstrado pela veiculação da reportagem sobre o assassinato do jornalista argentino Leonardo Henrichsen, em julho de 1973. Nesse período de tensão, a emissora tinha um correspondente especial no Chile, Jacques Ségui, que foi o encarregado de informar a situação do país após o golpe de Estado. Em 14 de setembro de 1973, a equipe francesa falou por telefone com esse jornalista, que informou que as fronteiras estavam fechadas e que a esposa de Allende, Hortensia Bussi, encontrava-se refugiada na embaixada do México. Ele ressaltou ainda que a maioria dos enviados estrangeiros encontrava-se em Mendoza, sem autorização para entrar no país, e que os que já estavam em Santiago não obtinham informações claras. Após a reportagem, o canal exibiu uma entrevista gravada quatro dias antes do ataque ao La Moneda com Eduardo Frei, que declarava acreditar somente na via democrática para mudar de presidente. 
O mesmo Jacques Ségui foi responsável por uma reportagem transmitida em 11 de setembro de 1974, quando denunciava a situação no Chile um ano depois do golpe de Estado. O jornalista utilizou a palavra "conspiração" para caracterizar as ações da direita que resultaram na morte de Allende e indicava o apoio dos Estados Unidos a essas ações. Entrevistado pela equipe, Augusto Pinochet declarou na ocasião que a situação no país estava normal, informação contestada pela voz over, anunciando que as pessoas precisavam saber que, na verdade, havia um estado de guerra ameaçando os chilenos.

Nesse sentido, o discurso elaborado por La spirale também responde às declarações do novo Estado chileno, que eram veiculadas pela televisão francesa, mesmo que esta apresentasse uma abordagem crítica à fala dos generais. O documentário, como já foi afirmado, rebate a ideia de que havia uma "normalização" do país após um período de caos gerado pela Unidade Popular, como defendiam as palavras dos militares, atribuindo à direita a responsabilidade pelos conflitos e pela crise que assolou o Chile durante o governo de Salvador Allende.

Sobre o espaço de destaque que o Chile ocupou na televisão francesa durante os anos 1970, é necessário ainda ressaltar que, muitas vezes, as notícias sobre o país latino-americano eram exibidas nas mesmas edições que veiculavam informes sobre a articulação para uma união esquerdista na França. Isso ocorreu, por exemplo, em outubro de 1970, quando as reportagens sobre o assassinato de Schneider dividiam os holofotes com uma matéria sobre um debate interno do PCF, no qual seu secretáriogeral, Georges Marchais, defendia que as alianças, sobretudo com o PS, deveriam ser o centro da estratégia. Nesse vídeo, ele discursava em nome de um "avanço na democracia francesa", que ampliasse a participação de trabalhadores e de democratas, e de uma grande aliança que mobilizasse toda a nação pela transformação da França.

A relação entre o projeto da esquerda francesa e a Unidade Popular tornava-se mais explícita nas reportagens que se seguiram à morte de Allende. A ORTF entrevistou François Mitterrand sobre o assunto, em 12 de setembro de 1973, que declarou sua admiração pelo homem que "desejou que seu povo dispusesse dele na liberdade democrática de construção de um socialismo", o que inspirava "o melhor entre nós". No entanto, apesar de admitir a inspiração na Unidade Popular, ele terminava sua declaração ressaltando a diferença entre um "socialismo da penúria" e um "socialismo da abundância" (entre um país subdesenvolvido e a França industrial). 
Em 7 de julho de 1974, o mesmo Mitterrand voltava a evocar Salvador Allende, morto no ano anterior, durante um comício de organizações de esquerda europeias. Uma faixa em solidariedade ao povo chileno ressaltava que esse tema esteve presente na conferência, enquanto a câmera da ORTF gravava o secretário do Partido Socialista francês dirigindo-se aos refugiados do país latino-americano sentados ao seu lado em um palco, afirmando que, desde o golpe militar, o Chile democrático da Unidade Popular havia se tornado um "símbolo de luz".

Esses exemplos confirmam que a atenção dedicada pela televisão francesa ao governo da UP e ao seu trágico desfecho vinham ao encontro de um papel ativo do caso chileno nas discussões sobre uma união das esquerdas francesas. O país latinoamericano foi visto na França como um paralelo possível, apesar da grande distância econômica e social entre ambos. Essa aproximação aparece, por exemplo, nos dois especiais analisados neste artigo - Le Chili: un nouveau Cuba? e Six mois d'Unité populaire -, em que são feitas inúmeras comparações entre os dois países, baseadas principalmente na presença do fenômeno comum de formação de frentes populares nos anos $1930^{297}$.

Essa estratégia de aproximação, como foi analisado, ocorreu também em $L a$ spirale. No entanto, se as produções audiovisuais francesas anteriores ao 11 de setembro de 1973 tinham espaço para abordar as múltiplas facetas da Unidade Popular, como suas contradições e sua complexa relação com o MIR, após o golpe, falar sobre as fissuras que colaboraram com sua queda poderia alimentar o exército inimigo - para usar a metáfora do jogo e da guerra adotada pelos realizadores do documentário. Mais uma vez, cabe enfatizar que, concebida como uma prova contra a direita chilena e seus aliados internacionais - os Estados Unidos -, essa produção não se ocupa do próprio campo político que a produz, a esquerda, concebendo-se como um objeto de denúncia que poderia colaborar com as redes de solidariedade ao Chile que se formavam no exílio europeu. No entanto, essa ausência do discurso autocrítico

\footnotetext{
${ }^{297}$ As discussões internas no seio da ORTF levaram ao encerramento de suas atividades no final de 1974. O fim do monopólio gerou a criação de sete novas sociedades, que se tornaram responsáveis pelos meios de comunicação na França. Algumas delas continuaram atentas aos acontecimentos no Chile durante a ditadura militar. Foi o caso do Institut national de l'audiovisuel, que veiculou uma série de quatro documentários de José María Berzosa intitulada Chili impressions (1978), que causou problemas diplomáticos entre os dois países, já que a empresa francesa havia se comprometido a mostrar a edição final ao governo chileno antes de veiculá-la, mas o fez com uma versão incompleta, que não permitia identificar as críticas que se veria posteriormente. A polêmica levou à suspensão dessa transmissão, episódio que demonstra que o presidente-ditador não recebeu da televisão francesa a simpatia dedicada ao seu antecessor, Salvador Allende.
} 
não seria uma constante de Chris Marker, que elaborou outras interpretações possíveis para a experiência chilena em L'ambassade e em $O$ fundo do ar é vermelho, que serão temas dos próximos capítulos. 


\section{Capítulo 4 - L'ambassade $(1974)^{298}$ : do Chile à esquerda francesa (do documentário à ficção)}

\section{1. “Isso não é um filme”: L'ambassade e os efeitos do real}

"Isto não é um filme. São anotações feitas no dia a dia. Na verdade, comentários, outras anotações, feitas quando eu não filmava mais." (L'ambassade, 1974, tradução nossa) ${ }^{299}$ As primeiras frases proferidas pela voz over $^{300}$ no início de L'ambassade (1974) indicam ao espectador que ele está diante de uma espécie de diário audiovisual, baseado em anotações que garantiriam um forte vínculo com o momento real em que as cenas foram rodadas. A negação de que a produção seja um filme reforça ainda mais essa ideia, já que remete à ausência de certos processos fílmicos que "editariam" a realidade, como a mise-en-scène, a presença de atores e, sobretudo, a montagem. As sequências que acompanham essa fala reforçam uma tentativa de aproximação com a realidade na medida em que, registradas em super-8, evocam a estética do filme amador e familiar, cuja falta de tratamento profissional das imagens facilitaria a desinibição dos indivíduos frente à câmera e seria acrescentada por um desconhecimento técnico para manipular posteriormente o "material bruto", alterando seus sentidos originais. No entanto, essas primeiras impressões serão desconstruídas ao longo dessa ficção.

L'ambassade é um filme - um curta-metragem - que "engana" o espectador por meio de muitas estratégias que serão analisadas ao longo deste capítulo. Seu principal mecanismo de ilusão é misturar uma série de indícios documentais (vinculados à tradição do filme familiar-amador, tão caro ao suporte super-8) à inclusão posterior da banda sonora, o que deixa suas imagens sujeitas à leitura guiada

\footnotetext{
${ }^{298}$ Para a análise realizada neste capítulo, foi utilizada uma cópia de L'ambassade presente no DVD Chris Marker: sixties, que acompanha a versão lançada em 2008 do filme $O$ fundo do ar é vermelho pela ISKRA e pela ARTE. Cabe ressaltar que a produção não sofreu modificações em relação à versão de 1974.

${ }^{299}$ Texto da voz over de L'ambassade, traduzido do original: "Ceci n'est pas un film. Ce sont des notes prises au jour le jour. En fait des commentaires, d'autres notes, prises quand je ne filmais pas."

${ }^{300}$ A opção pelo uso da expressão "voz over" para o caso de L'ambassade deve ser justificada pela complexidade do papel do narrador. Essa voz, nesse filme, é proferida por um dos personagens. Porém, a escolha de não usar o termo voz em off é justificada pelo fato do texto proferido por ela ter sido elaborado e inserido fora do tempo diegético - ou seja, em um momento cronológico posterior ao desenvolvimento das ações.
} 
pela voz over, principal artifício de Chris Marker para levar a certas interpretações. Dessa forma, é a mescla de um tipo de registro típico do cinema-verdade com a ausência do som direto, o que permite um desfecho inesperado para o público. Portanto, pode-se afirmar que o realizador utilizou configurações não usuais de determinados códigos dos gêneros cinematográficos, constituindo, assim, uma produção marcada pelo caráter experimental $^{301}$.

Essa ficção travestida de documentário foi realizada para participar de um festival de super- $8^{302}$. Nesse sentido, há uma nítida escolha do realizador em reiterar o experimentalismo que marcou o uso desse suporte por artistas e cineastas nos anos 1970, que era destinado originalmente pela indústria cinematográfica aos filmes caseiros e familiares (tanto por ser fácil o manuseio e o transporte da câmera quanto por seu custo acessível). Presença constante nas manifestações da contracultura, a difusão dessas câmeras leves serviu a um tipo de produção não industrial e feita em contextos alheios aos sets de filmagem, sendo frequentemente associada a outras práticas artísticas, como a performance. Nesse sentido, a escolha por um gênero híbrido entre o documentário e a ficção e de outras estratégias experimentais por Marker para esse filme dialogam com um movimento mais amplo nos anos 1970, que recorria principalmente ao super- 8 e ao $16 \mathrm{~mm}$ para repensar o próprio cinema ${ }^{303}$.

Guy Gauthier destaca o pioneirismo do realizador, ao ser um dos primeiros cineastas profissionais a utilizar esse suporte (GAUTHIER, 2001). Inserido no mercado pela Kodak, em 1965, o super-8 havia sido relançado em 1973, tendo sua

\footnotetext{
${ }^{301}$ Pode-se afirmar que L'ambassade é um filme experimental por apresentar características relativas à produção e à distribuição que rompem com aquelas dos gêneros cinematográficos mais tradicionais. É possível identificar algumas delas, como a realização fora do sistema industrial, a não distribuição nos circuitos dedicados a esse sistema e o questionamento de certos padrões narrativos. Uma definição adequada do termo "experimental" no cinema está presente em AUMONT; MARIE, 2010.

${ }^{302}$ Essa informação foi dada pelo próprio Marker para a autora (MARKER, 2011). No entanto, ele não informou para que festival L'ambassade foi produzido.

${ }^{303}$ Esse "movimento mais amplo" do experimentalismo dos anos 1970 ganhou força sobretudo nos Estados Unidos, com o que se convencionou chamar de "cinema experimental". Nesse sentido, algumas das características desse movimento, que teve como um dos expoentes Jonas Mekas, aparecem em L'ambassade, como as destacadas por Barbara Turquier: "Se a experimentação envolve primeiramente o exercício regulado e prazeroso de uma prática - filmar, dirigir, montar - e a exploração das possibilidades de um meio - o filme e sua banda sonora -, aquele que experimenta faz uso também uma situação econômica e política - à margem do sistema, o regime contemporâneo de consumação das imagens - e estabelece sua prática em referência ou em oposição a uma história - a tradição do cinema e das artes plásticas." (TURQUIER, 2005, tradução nossa) Traduzido do original: "Si l'expérimentation implique d'abord l'exercice réglé et jouissif d'une pratique - filmer, mettre en scène, monter - et l'exploration des possibilités d'un médium - le film et sa bande-son, - celui qui expérimente fait aussi usage d'une situation économique et politique - la marge contre le système, le régime contemporain de consommation des images, - et établit sa pratique en référence ou en opposition à une histoire - la tradition du cinéma et des arts plastiques.”.
} 
qualidade técnica aprimorada, inclusive com a possibilidade do registro sonoro simultâneo (embora seja necessário lembrar que esse recurso não é usado nessa produção). Isso permitiu que ele se tornasse uma ferramenta artística mais potente, sendo valorizado sobretudo por sua portabilidade. Gauthier considera que Marker encarou o aparato como um novo ponto de partida, justificando sua afirmação pelo título provisório do filme, Marker 001, modificado em um segundo momento para L'ambassade. O pesquisador relembra ainda outras produções markerianas que utilizaram câmeras leves, como Olympia 52 (1952) e Le mystère Koumiko (1967), caracterizando a valorização da praticidade em detrimento do resultado técnico como algo já presente na obra do diretor francês.

Vale analisar ao longo deste capítulo de que maneira essas escolhas pelo suporte e pela hibridização do gênero implicaram em um determinado discurso sobre a Unidade Popular e o golpe chileno em L'ambassade. É importante ressaltar, de início, que a produção não se assume como uma obra sobre o Chile, mas permite como será analisado - uma leitura de que remete a esse país. Se La spirale se propõe a estabelecer uma memória de esquerda sobre os conflitos responsáveis pela queda da UP, esse filme opta pela utilização do super-8 - que nos anos 1970 estava atrelado à ideia de desmonumentalização da arte e do cinema - para lançar hipóteses no lugar de provas. Portanto, ao contrário do documentário analisado no capítulo anterior, essa ficção se presta a fazer uma experiência que recorre ao tema da derrubada de Salvador Allende, em vez de sustentar uma tese fechada a respeito desse fato histórico. Isso não implica em abdicar da busca por uma explicação para o fim da experiência chilena, embora as conclusões sobre esse fato sirvam mais como um alerta futuro do que como uma interpretação unívoca do passado, como será demonstrado.

As primeiras imagens de L'ambassade exibem uma cena externa registrada de uma janela. O mesmo procedimento estará presente na sequência final, mas nesse momento serve para introduzir ao espectador uma estética amadora, com a câmera tremida e sem profundidade de campo. Essa pouca qualidade técnica contribui para que o campo externo ao operador de câmera - que é também o narrador - permaneça quase invisível, vindo à tona em alguns raros momentos. Nessa cena inicial, um avião cruza o céu, deixando um rastro de fumaça que marca sua trajetória. A mesma ação se 
repete no plano final da produção, em que o caminho de uma aeronave também encerra o filme $\mathrm{e}^{304}$, dando a ideia de fechamento de um ciclo.

$\mathrm{Na}$ segunda sequência, o público é apresentado ao ambiente onde todas as cenas foram rodadas: um apartamento repleto de obras de arte, no qual os personagens entram em blocos. O autor dessas notas audiovisuais feitas no "dia a dia" é um deles, que permanece sempre por trás da câmera, tendo seu rosto ocultado. Pode-se afirmar que as ações serão mostradas unicamente sob o seu ponto de vista, em tomadas subjetivas. É ele também quem narra os acontecimentos, embora o faça em um momento posterior ao tempo diegético, declarando sobre a escolha do suporte, no início do filme: "Mesmo fazendo uma demonstração das possibilidades do super-8, eu teria gostado de fazê-la longe dessa embaixada, e com outros personagens que não refugiados políticos" (L'ambassade, 1974, tradução nossa $)^{305}$.

Essa frase revela uma escolha do próprio Chris Marker em elaborar, antes de tudo, uma demonstração do suporte, embora motivações políticas contingenciais o tenham levado à temática abordada. Porém, ela mistura personagem e realizador, já que o personagem é também um realizador colocado pelo "acaso" em um determinado espaço - embaixada - e com determinados protagonistas - refugiados políticos. O narrador assume uma insatisfação diante de sua situação, dizendo que gostaria de filmar em outro contexto. Existe, nessa afirmação, duas justificativas que se sobrepõem: a vontade de experimentação estética e os acontecimentos históricopolíticos indesejados. Esses dois pilares estão articulados durante todo o filme.

Os limites tênues entre documentário e ficção estabelecidos por Marker são a marca desse experimentalismo e aparecem não apenas no material fílmico, mas destacados na entrevista à autora, concedida pelo realizador em outubro de 2011 . Na ocasião, ele relatou como gravou as sequências de L'ambassade, recorrendo a certos métodos pré-elaborados de mise-en-scène (que visam, por outro lado, à desconstrução desse recurso) que colaboraram com esse hibridismo de gêneros:

A rodagem foi realizada sobre o princípio da experiência Kulechov ${ }^{306}$, ou seja, eu reuni um certo número de amigos no único lugar que conhecia que poderia passar por uma embaixada (o

\footnotetext{
${ }^{304} \mathrm{O}$ sentido dessas imagens de aviões cruzando o céu será trabalhado em outras passagens deste capítulo.

${ }^{305}$ Texto da voz over de L'ambassade, traduzido do original: "Quitte à faire une démonstration des possibilités du super-8, j' aurais autant aimé la faire ailleurs que dans cette Ambassade, et avec d'autres personnages que des réfugies politiques."

${ }^{306}$ Referência de Marker ao cineasta Lev Vladimirovitch Kulechov.
} 
apartamento de Lou, a mulher de Wilfredo Lam, que representou o papel da recepcionista da casa) e que eu os deixei falar de coisas e dos outros, sem nenhuma relação entre os eventos, sabendo que qualquer expressão apoiada sobre um texto orientado, torna-se a expressão correspondente a esse texto. (MARKER, 2011, tradução nossa $)^{307}$

De forma mais clara, Marker reuniu um grupo de amigos no apartamento da esposa do pintor cubano Wilfredo Lam (autor de parte das obras que decora a "embaixada"), propondo-lhes experiências que não obrigatoriamente remetessem ao golpe no Chile (os tais "eventos" que perpassam a narrativa). Sua proposição baseada, como ele declara, no "efeito Kulechov" - partia do fato de que todos os planos, após a montagem e a inserção do texto final, independente do contexto original, levariam o espectador a uma interpretação determinada pelo realizador. No caso do cineasta russo, essa máxima se referia sobretudo à filmagem dos rostos dos atores, ou seja, uma mesma expressão poderia passar tristeza, angústia ou alegria, dependendo das demais imagens que a circundassem. No caso de Marker, pode-se dizer que esse "efeito Kulechov" é válido para o filme como um todo, o que faz dos procedimentos pós-rodagem etapas mais importantes do que a gravação ou a prática de direção de atores.

Essa premissa é um dos aspectos que situa L'ambassade nesse limite híbrido do gênero documental e da ficção: não havia um roteiro ficcional previamente dirigido aos protagonistas, apenas motivações colocadas em cena - como a transmissão do informe da Junta Militar do general Pinochet em um televisor, presente em uma das cenas principais - e o registro de reações inesperadas ante os incentivos dados pelo realizador. Ganham importância, como é uma característica de outras obras de Chris Marker, a etapa da montagem e o papel de uma narração em over que conduz a interpretações sobre as imagens. O uso de atores amadores (ou de "amigos" do realizador, entre os quais se encontram figuras importantes do cenário militante francês, como será analisado adiante) reforça um certo "naturalismo" na dramaturgia, na medida em que, ao invés de uma "atuação" no sentido clássico do

\footnotetext{
${ }^{307}$ Traduzido do original: "Le tournage s'est déroulé sur le principe de l'expérience de Kulechov, c'est à-dire que j'ai réuni un certain nombre d'amis dans le seul lieu connu de moi qui pouvait passer pour une ambassade (l'appartement de Lou, la femme de Wilfredo Lam, qu'on voit jouer la maîtresse de maison) et que je les ai laissé parler de choses et d'autres, sans aucun rapport avec les événements, sachant que n'importe quelle expression appuyée sur un texte orienté devient l'expression correspondant à ce texte."
} 
termo, há a elaboração de ações diversas, que só adquirem um senso unívoco nas etapas cinematográficas posteriores à gravação.

Porém, além da proposta inicial, outros aspectos do filme o situam entre o documentário e a ficção e permitem que o espectador o assista pensando em um registro, descobrindo apenas na cena final que estava equivocado. Seguindo a ideia de uma "leitura documentarizante" pressuposta pelo enunciador, formulada por Roger Odin (1994), cabe encontrar alguns indícios que permitam que a produção seja lida nessa chave, pelo menos até seu momento final. Um deles é o próprio discurso da voz over, que busca convencer o espectador do vínculo entre as imagens e o real. O outro advém da estética superoitista, que, como já foi dito, a relaciona ao registro amadorfamiliar, que, apesar do não profissionalismo, se insere como um subgênero do documentário. L'ambassade é propositadamente repleta de ruídos, enquadramentos pouco elaborados, uso inadequada da luz e movimentos inesperados da câmera (que quase sempre treme durante as filmagens). Nesse sentido, traz características do que Rubens Machado Jr. chamou de "efeito super-8"308.

Pois bem, o que eu estou chamando então de um efeito Super-8 se insinua e grassa como uma facilitação técnica, a redundar em faturas rústicas mas desenvoltas, explorando e elaborando o que o profissional chamaria de erro, barbeiragem ou incompetência. Apertar o botão e sair filmando, eis o gesto libertário! (MACHADO JR., 2006)

Essas características de L'ambassade e de outras produções de Marker, que situam seus filmes entre dois registros, fazem com que suas ficções dialoguem fortemente com o documental. Em 1962, o realizador lançou La jetée, uma ficção científica montada exclusivamente com fotografias e autodenominada como um "fotorromance". No entanto, essas duas produções têm mais em comum do que a possibilidade de uma leitura híbrida: ambas trabalham a relação entre memória e trauma $^{309}$. La jetée se desenvolve depois da Terceira Guerra Mundial, que destrói Paris, quando os sobreviventes passam a viver nos subterrâneos. Os sobreviventes do

\footnotetext{
${ }^{308}$ Há ainda mais um significativo indício documental, que é a coincidência dos acontecimentos da produção com episódios históricos ocorridos no Chile após o golpe de Estado, um ano antes de seu lançamento. Nesse sentido, o conhecimento prévio por parte do espectador de que fatos como os retratados no filme realmente ocorreram no país latino-americano reforçam uma possível leitura da obra na chave documental. Esse tema será abordado no item 2 deste capítulo.

${ }^{309}$ Vale ressaltar outra produção de Marker também situada em um gênero híbrido entre a ficção e o documentário - pendendo mais ao documentário - e que igualmente reflete sobre a memória e o trauma: Level 5 (1997). Nesse videojogo, a protagonista Laura (interpretada por Catherine Belkhodja) busca reconstruir a Batalha de Okinawa com auxílio de uma máquina.
} 
lado dos vencedores realizam uma experiência de volta ao passado usando como cobaia um homem marcado por uma imagem fixa, uma "imagem de infância" do terraço do aeroporto de Orly em que se destaca o rosto de uma mulher. Ao final, após viajar ao passado e ao futuro, ele compreende que essa imagem que o acompanha é uma "lembrança" de sua própria morte. O filme usa algumas fotos "documentais" de arquivo (como as que registraram as demolições realizadas em Paris por GeorgesEugène Haussmann), intercalando-as a fotos feitas a partir das encenações dos atores. O enredo de La jetée é uma clara alusão a Vertigo (1958) ${ }^{310}$, de Alfred Hitchcock, referenciado em especial na cena em que o viajante do tempo aponta em um tronco de árvore, em formato espiralado, de que tempo histórico ele vem - assim como indica Madeleine para Scottie.

A referência à espiral do tempo, já evocada em Vertigo (quando Scottie se vê diante de uma "Madeleine" que é também a "Carlotta" do passado e a "Judy" do futuro), uma constante na obra de Marker, aparece em La jetée para caracterizar um tempo não linear, em que os acontecimentos podem ser revisitados por meio da memória. Nesse sentido, os traumas são revividos, podendo, porém, resultar em desfechos distintos. Como na produção de Hitchcock, há em grande parte da obra markeriana uma relativização da ideia de verdade ao rememorar o passado, o que ganha ainda mais destaque nas produções ficcionais. Em L'ambassade, estão reunidas cenas rememoradas, em forma de um diário pessoal, que colocam em dúvida o que é narrativa real e inventada, bem como as próprias noções de tempo e espaço.

Diante dessas considerações, pode-se afirmar que a produção de 1974 faz jus à seguinte frase da voz over presente em La jetée: "Nada distingue as lembranças dos outros momentos: é somente mais tarde que eles são reconhecidos, em suas cicatrizes." (La jetée, 1962, tradução nossa) ${ }^{311}$. O trecho citado, que indaga sobre a imagem fixa que o protagonista tinha do passado, conclui: “[...] ele se perguntava há muito tempo se havia realmente visto, ou se ele havia criado esse momento de doçura para suportar o momento de loucura que viria [...]" (La jetée, 1962, tradução nossa) $)^{312}$. Essa mesma sensação de incerteza sobre o real e o imaginado é sentida pelo

\footnotetext{
${ }^{310}$ Como já foi dito, no caso de Vertigo optou-se em não utilizar o título brasileiro, Um corpo que cai por modificar o sentido original do filme.

${ }^{311}$ Texto da voz over de La jetée, traduzido do original: "Rien ne distingue les souvenirs des autres moments: ce n'est que plus tard qu'ils se font reconnaître, à leurs cicatrices."

${ }^{312}$ Texto da voz over de La jetée, traduzido do original: “[...] il se demanda longtemps s'il l'avait vraiment vu, ou s'il avait créé ce moment de douceur pour étayer le moment de folie qui allait venir $[\ldots] "$
} 
espectador de L'ambassade em sua última cena. Após a leitura de que se trata de um filme sobre o golpe do Chile - embora esse dado estivesse apenas sugerido -, é somente no último plano que as cicatrizes se formam: uma nova tomada feita da janela da "embaixada" mostra o rio Sena e a torre Eiffel. Surge, então, uma Paris encarcerada, como aquela de La jetée, que deixava de ser livre. Essa revelação retira das sequências anteriores qualquer status documental.

\subsection{Filme-testemunhal e a desconstrução do "ciné-ma-vérité"}

Chris Marker é constantemente apontado pelos especialistas como um representante do cinéma-vérité (cinema-verdade) - ou até mesmo do cinema direto ${ }^{313}$. Esse rótulo, por um lado, caberia a poucos de seus filmes, que preferem a predominância da voz over e das imagens de arquivo do que longas entrevistas em som direto e tomadas próprias com seus entrevistados (algumas das marcas presentes nesse gênero, inaugurado por Crônica de um verão, 1961, de Edgar Morin e Jean Rouch). Por outro lado, Marker foi um dos pioneiros desse tipo de cinema com Le joli mai (1963), uma clara referência ao documentário de Morin e Rouch, já que ambos percorrem Paris questionando alguns de seus habitantes sobre temáticas diversas ${ }^{314}$. Ambos utilizam ainda largas tomadas sem cortes realizadas com pessoas comuns emitindo opiniões e destacam a voz dos seus realizadores, inserindo-os também como personagens. Nesse sentido, esses dois documentários foram rotulados de "ciné-ma-

\footnotetext{
${ }^{313}$ Apesar de alguns realizadores e historiadores do cinema optarem por utilizar os termos "cinemaverdade" e "cinema-direto" como sinônimos (baseados em semelhanças entre os dois gêneros, como o uso de aparatos portáteis e do registro rápido), nesta tese preferiu-se associar Chris Marker ao "cinemaverdade", considerando que existem diferenças significativas entre essas duas práticas. A maior delas é, sem dúvida, o lugar do realizador. Enquanto o cinema-direto, filiado à figura de Robert Drew, defendia a ideia de um cinema "testemunhal" com características de "cinereportagem", o "cinema-verdade", atrelado a cineastas franceses como Rouch e Morin, optava por desvelar a presença e a intervenção do cineasta. Silvio Da-Rin mapeia as diferenças entre esses gêneros, mostrando que em alguns aspectos eles chegam a ser opostos: "Tentando resumir suas diferenças para com Rouch, Drew disse que 'a coisa mais importante que parece ter acontecido com as pessoas que ele [Rouch] escolheu filmar é o fato de tê-las filmado'. A afirmação tinha um tom de escândalo, porque seu método era, neste sentido, diametralmente oposto - o fosso existente entre um lado e outro da câmera negava o contato e impedia qualquer transformação." (DA-RIN, 2004, p. 156)

${ }^{314}$ As referência de Le joli mai a Crônica de um verão são muitas. A começar pelo título: enquanto o filme de Edgar Morin e Jean Rouch se refere ao período mais festivo de Paris - o verão -, Marker nomeia sua produção com o mês considerado o mais alegre e bonito da cidade - maio. Os próprios Morin e Rouch aparecem em uma tomada curta desse documentário, bem como outros cineastas importantes para Marker, como Jean-Luc Godard, Alain Resnais e Jacques Rivette, desempenhando o papel de figurantes anônimos dessa cidade pulsante.
} 
véritê", ou "cinema-minha-verdade", com destaque para a subjetividade sugerida pelo pronome possessivo $^{315}$.

Diante dessa opção por uma prática direta de cinema (o que permitiu a alcunha de "cinema-direto" por parte de alguns pesquisadores, embora aqui se prefira o termo “cinema-verdade"), com planos mais longos e a valorização do registro em função da montagem, a utilização do pronome possessivo estabelece que, apesar de haver um desejo de amenizar as interferências entre o cinema e a realidade (entre câmera e entrevistado), a presença do realizador implica sempre em um determinado ponto de vista. Portanto, essas duas produções pioneiras reconhecem um desejo pela verdade, como também uma impossibilidade em alcançá-la, fato que deve ser revelado ao espectador.

Nessas breves considerações sobre um gênero com o qual Marker dialoga de forma ambígua - pioneiro, mas pouco adepto -, é possível verificar que L'ambassade incorpora algumas características do ciné-ma-vérité, mas com o objetivo oposto ao que esse cinema se propunha a fazer: ao invés de recorrer a elas para aproximar-se do real, mesmo que o reconhecendo inatingível, esse filme as utiliza para mascarar uma ficção. Dessa maneira, é simultaneamente a ausência e a presença dessas características que revela o porquê dessa produção se constituir como um "falso" documentário.

Do ponto de vista metodológico, as câmeras leves foram extremamente úteis ao cinema-verdade, pois permitiam o fácil manuseio e transporte, facilitando o trabalho do realizador no momento dos fatos ou ainda em ambientes fora dos estúdios (como as ruas, as fábricas etc.). O super-8 seria um suporte ideal para essas aspirações, mesmo que sua qualidade técnica fosse reduzida. Portanto, a própria

\footnotetext{
${ }^{315}$ Mesmo com essas semelhanças, Catherine Lupton ressalta diferenças significativas entre as duas produções: "Crônica de um verão une avidamente as pessoas em um espírito de investigação sociológica, persuadindo-as a desvelar seus verdadeiros 'eus' por intermédio da câmera e limitando-se, em grande parte, a um núcleo central que já era de amigos e associados de Rouch e Morin. Le joli mai lança uma rede mais ampla e permite que seus sujeitos mantenham suas próprias palavras e sistemas de valor, desafiando-os somente com questões ou observações incisivas pontuais, ao invés de contar com a montagem para estabelecer comparações críticas e contrastes que identifiquem as mais amplas fissuras sociais, políticas e raciais da França contemporânea por meio da vida e da opinião de indivíduos." (LUPTON, 2008, p. 83, tradução nossa). Traduzido do original: "Chronicle of a summer avidly brings people together in the spirit of sociological enquiry, cajoling them into unveiling their true selves through the intermediary of the camera, and largely confining itself to a core group who were already friends and associates of Rouch and Morin. Le joli mai casts its net wider, and permits its subjects to remain within their own words and value systems, challenging them only with an occasional pointed question or remark and instead relying on montage to draw critical comparisons and contrasts that track the wider social, political and racial fault lines of contemporary France through the lives and opinions of individuals."
} 
escolha por esse tipo de câmera é um sinal da preferência pela "urgência" do registro em detrimento de seu resultado final. Contrariamente, L'ambassade opta por esse recurso para filmar em um ambiente fechado, o que pode ser justificado pelo fato de sua leveza favorecer também uma aproximação com as pessoas retratadas, registrando-as de maneira menos invasiva e favorecendo certo conforto frente ao operador de câmera. Dessa forma, o uso do super-8 ia ao encontro de problemas e soluções propostos na época pelos documentaristas, o que reforçava, no caso da ficção aqui analisada, uma ideia de que havia uma preocupação com a verossimilhança.

Outra característica do cinema-direto evocada por L'ambassade é uma suposta ausência de mise-en-scène. Ao final do filme, fica-se sabendo que se trata de um efeito forjado - embora Marker tenha admitido preferir os momentos de improvisação entre seus convidados do que lhes propor um roteiro prévio. Mesmo com essa afirmação, algumas cenas foram claramente encenadas a pedido do realizador, como a que um personagem-advogado dorme no chão ou o personagem-embaixador passa aspirador no apartamento. A precariedade do registro, a montagem e a voz over, porém, manipulam o material bruto, gerando a ideia de que todos os planos foram feitos no "calor" dos acontecimentos.

L'ambassade traz ainda outra característica bastante presente no cinemaverdade: o uso de uma câmera subjetiva. Ou seja, o realizador - que no caso é apresentado como a mesma pessoa que filma - é também um sujeito implicado na ação, não está (como no caso de outros tipos de documentário) anulado por uma pretensa objetividade no registro. Nesse sentido, essa produção assume o aspecto “ciné-ma-véritê" pela completa preponderância do ponto de vista do cineasta, que se iguala aos demais indivíduos retratados, assumindo-se também como um refugiado político - ele se mostra presente, mesmo que seu rosto não seja exibido. Isso é claro, por exemplo, quando uma mulher olha diretamente para a câmera (a personagem Sônia), em uma das cenas finais, demonstrando ter consciência da presença do aparato, o que é bastante raro em ficções.

A voz over é outro recurso que leva o espectador a pensar sobre a condição dúbia do narrador, que é, ao mesmo tempo, sujeito e observador. Por outro lado, assim como no cinema-verdade, ele observa sem interferir nas ações de seus companheiros, ou seja, mostra-se presente, mas não se posiciona diante dos demais. A 
construção desse tipo de relação entre quem olha e quem é objeto do olhar remete a procedimentos comuns desse tipo de cinema.

Essa câmera subjetiva que perpassa todo o filme faz do realizador um personagem, embora a função de gravar o delegue a responsabilidade de permanecer, dentro do possível, distante. Apesar de se revelar um efeito forjado na cena final, esse artifício transforma L'ambassade em um pretenso filme-testemunhal, ou em um objet trouvé, encontrado como um diário audiovisual feito em uma embaixada, como definem os intertítulos que abrem essa ficção. Assim, a frase que a inicia - isso não é um filme, mas anotações do dia a dia - enfatiza um testemunho que pode adquirir status de denúncia ante uma situação de fechamento político, como será desenvolvido ao final deste capítulo.

É necessário ressaltar, mais uma vez, que apesar de todas essas características do cinema-verdade presentes no filme (mesmo que algumas delas apareçam de maneira forjada, mais como efeito do que como prática cinematográfica), é a falta de uma delas que permite a manipulação das demais: o som direto. Ou seja, o que possibilita ao espectador acreditar que acompanha um documentário com características de um ciné-ma-vérité é o fato de que, inserida após a montagem, a banda sonora é composta de uma voz over que induz a leitura do espectador, um recurso bastante contestado pelos realizadores que inauguraram esse gênero documental. O próprio Chris Marker, em Le joli mai, diminui a importância dessa prática, recorrente no restante de sua obra, preferindo dar voz aos seus entrevistados. Isso não ocorre em L'ambassade, em que a única voz é a do realizador-narrador. 


\section{O Chile fora de campo: a derrubada da Unidade Popular}

A proposta de Chris Marker em não ter um roteiro de mise-en-scène preestabelecido concede à voz over - que é também a do personagem-realizador - um peso importante na narrativa. É ela quem descreve as imagens, atribuindo-lhes um sentido que as mesmas não teriam com o uso do som direto ou ausente, corroborando o "efeito Kulechov" almejado pelo diretor. Esse recurso é também o responsável por construir referências que, embora não evoquem o Chile diretamente, guiem a leitura do espectador, induzindo-o a pensar que se trata de um filme sobre esse país. $\mathrm{Na}$ entrevista à autora, em outubro de 2011, Marker ironiza a reação de seu público:

Paradoxalmente, o único filme diretamente ligado à tragédia chilena é aquele em que o Chile não aparece, L'ambassade. Ainda que a ingenuidade de certos espectadores tenha mantido a ambiguidade, do tipo 'Nossa, não sabíamos que Marker estava lá no momento do golpe', ou a mais surpreendente 'nossa, não sabíamos que havia uma Torre Eiffel em Santiago... (MARKER, 2011) ${ }^{316}$.

Esse "efeito", que leva a crer que L’ambassade é um documentário sobre o golpe de Estado do general Augusto Pinochet e suas primeiras consequências, advém de inúmeras referências trazidas pela voz over que - para um espectador que conhecesse os acontecimentos recentes desse país (pensando que o filme foi realizado em 1974, pouco tempo após o trágico 11 de setembro que derrubou Salvador Allende) - estabeleceriam relações diretas com o contexto chileno. Essas relações, no entanto, estão fora de campo. Esse conceito, que nomeia elementos não vistos, que estão além dos limites estabelecidos nos quadros, mas que integram igualmente a produção cinematográfica, é a chave para entender o lugar do Chile em L'ambassade. Nesse sentido, pode-se dizer que ele é uma presença constante, porém, nunca posta diretamente em cena, possibilitando leituras ambíguas sobre o lugar onde os personagens se situam.

Esse procedimento é possível pelo fato do filme se passar em um ambiente fechado e isolado, uma embaixada, que dialoga de modo complexo com o ambiente externo que confina os personagens, refugiados políticos, sem o direito de sair dessa casa. É por meio de alguns poucos mecanismos que esse mundo exterior adentra no

\footnotetext{
${ }^{316}$ Traduzido do original: "Paradoxalement le seul film directement relié à la tragédie chilienne est celui où le Chili n'apparaît pas, L'Ambassade. Encore que l'ingénuité de certains spectateurs ait entretenu l'ambiguïté, du genre 'Tiens, on ne savait pas que Marker était là au moment du coup', ou la plus étonnante 'Tiens, on ne savait pas qu'il y avait une Tour Eiffel à Santiago'..."
} 
cenário de L'ambassade: pela janela, em telefonemas, por um televisor. São nesses momentos que o fora de campo invade esse círculo de giz, afetando-o de maneira bastante efetiva, gerando angústias e conflitos no cotidiano registrado pelo realizador. É nessa "invasão" desse fora de campo que o público se convence de que o confinamento ocorre em um Chile recém-tomado pelos militares, embora esse seja também o mecanismo que revela, somente no último plano, a Torre Eiffel vista da janela, contradizendo as referências espaciais anteriores dadas por Marker.

Cabe, portanto, fazer uma breve descrição da narrativa, tal como é conduzida pela voz over, e destacar algumas cenas em que o Chile aparece, sempre fora de campo. Mapear as "pistas falsas" deixadas por Chris Marker é fundamental para compreender L'ambassade como um filme sobre o golpe de Estado nesse país latinoamericano, mas igualmente para entender, em um segundo momento, por que se trata de uma produção sobre a França. A ambiguidade espacial é uma das marcas do experimentalismo desse filme tanto quanto a ambiguidade de gênero cinematográfico. Esses dois aspectos caminham lado a lado na construção de uma "obra aberta", de múltiplas interpretações possíveis.

A primeira referência clara ao Chile está no próprio enredo, anunciado pela voz over ao princípio de sua participação: trata-se de uma experimentação em super-8 feita com refugiados políticos em uma embaixada. Em 1974, seria impossível não remeter essa premissa à atuação de diversos corpos diplomáticos estrangeiros frente ao golpe de Estado de 11 de setembro de 1973, entre as quais se destacam as da Europa Ocidental e latino-americanas de países que não enfrentavam ditaduras militares nessa época (caso de Argentina e México, além de Venezuela, Panamá e Colômbia, em menor medida) ${ }^{317}$. Em relação às nações europeias, duas embaixadas atuaram ativamente para abrigar e conseguir salvos-condutos de exílio aos apoiadores da Unidade Popular: França e Suécia. De acordo com Fernando Camacho (2006):

A violência com que se realizou o golpe de Estado no Chile fez com que muitos perseguidos políticos, entre os quais se encontravam funcionários do governo da Unidade Popular ou militantes dos distintos partidos políticos que compunham a coalizão, buscassem asilo político em várias representações diplomáticas estrangeiras. Desse modo, só em Santiago, havia mais de cem lugares onde se esconderam os perseguidos políticos, entre os quais se incluíam

\footnotetext{
${ }^{317}$ A embaixada de Cuba também desempenhou um papel extremamente importante, abrigando inúmeros refugiados. Porém, sob ameaça de intervenção militar, foi posteriormente "anexada" pelo embaixador sueco, como será visto mais adiante neste capítulo.
} 
recintos diplomáticos, casas particulares e igrejas, todos conhecidos como "santuários". Dada a magnitude dos acontecimentos, vários organismos internacionais, entre os quais se destacam o Alto Comissionado das Nações Unidas para Refugiados (ACNUR) e o Comitê Intergovernamental para as Migrações Europeias (CIME) colaboraram intensamente com as várias embaixadas para poder tirar do Chile os asilados e radicá-los por todo planeta. (CAMACHO, 2006, p. 22, tradução nossa) ${ }^{318}$

Portanto, pode-se afirmar que a atuação humanitária dos corpos diplomáticos e de outras entidades foi intensa, a ponto de criar uma repercussão internacional em relação à sua atuação humanitária com o objetivo de diminuir os efeitos nefastos de um golpe violento que instaurou, sobretudo entre setembro e dezembro de 1973, uma política sistemática de repressão e extermínio de seus opositores (por meio de prisões, fuzilamentos e pressão para que deixassem o país). De acordo com Nicolas Prognon (2002), na tese La diaspora chilienne en France:

O exílio responde aos objetivos da Junta. Pretendia-se eliminar da cena política todo obstáculo ao projeto do governo, e simultaneamente permitir a expulsão do excedente de mão de obra que o modelo liberal não podia absorver. É difícil quantificar exatamente esse movimento migratório, já que as fontes são discordantes. Um documento oficial do governo militar do mês de junho de 1975 indica que cinco mil salvos-condutos e duzentos vistos de "cortesia" foram concedidos até essa data. Entre outubro de 1973 e outubro de 1975, 777 pessoas foram expulsas e 75 banidas. A Vicaría de la Solidaridad estima em 140 mil o número de refugiados no período de 1973-1975. [...] (PROGNON, 2002, p. 48, tradução nossa) $)^{319}$

Essa enorme dimensão do exílio chileno está no horizonte de L'ambassade.

Entre as iniciativas que permitiram aos partidários da Unidade Popular alcançar essa

\footnotetext{
${ }^{318}$ Traduzido do original: "La violencia con la que se realizó el golpe de Estado en Chile ocasionó que cientos de perseguidos políticos, entre los que se encontraban funcionarios del gobierno de la Unidad Popular o militantes de los distintos partidos políticos que componían dicha coalición, buscaran asilo político en las distintas representaciones diplomáticas extranjeras. De ese modo, tan solo en Santiago hubieron más de 100 lugares donde se escondieron los perseguidos políticos donde se incluían recintos diplomáticos, casas particulares e iglesias, todos los cuales se conocieron como 'santuarios'. Dada la magnitud de los acontecimientos varios organismos internacionales, entre los que resaltaron el Alto Comisionado de las Naciones Unidas para los Refugiados (ACNUR) y el Comité Intergubernamental para las Migraciones Europeas (CIME), colaboraron intensamente con las distintas embajadas para poder sacar de Chile a los asilados y ubicarlos por todo el planeta."

${ }^{319}$ Traduzido do original: "L'exil répond à des objectifs précis de la Junte. Il prétend éliminer de la scène politique tout obstacle au projet du gouvernement, et simultanément il permet l'expulsion de l'excédent de main d'œuvre que le modèle libéral ne peut absorber. Pratiquement, il est difficile de quantifier ce mouvement migratoire, tant les sources sont discordantes. Un document officiel du gouvernement militaire du mois de juin 1975 indique que 5000 sauf-conduits e 200 visas de 'courtoisie' ont été accordés, à cette date. Entre octobre 1973 et octobre 1975, 777 personnes sont expulsées et 75 autres bannies. La Vicaría de la Solidaridad estime à 140000 le nombre de réfugies, pour le période 1973-1975. [...]"
} 
condição de exilados, destacaram-se os casos da embaixada da França e da Suécia, países da Europa Ocidental que se mobilizaram em torno dessa causa. O corpo diplomático francês em Santiago foi, depois do sueco, o que mais recebeu refugiados políticos após o 11 de setembro de 1973. Prognon mapeia a chegada ao país europeu e o retorno ao Chile desse fluxo migratório que perdurou até 1994, quando o acordo de abrigar chilenos em situação de risco foi rompido, já na transição entre os governos democráticos de Patricio Aylwin e Eduardo Frei Ruiz-Tagle. Citando estimativas elaboradas pela Vicaría de la Solidaridad ${ }^{320}$, o autor afirma que cerca de 800 pessoas se refugiaram na embaixada francesa após o golpe de Estado. Muitas delas, certamente chegavam à Europa por auxílio dessa embaixada entre 1973 e 1974, quando Chris Marker realizou a produção analisada nesta tese.

O caso mais emblemático da atuação das embaixadas estrangeiras no pósgolpe foi certamente o da Suécia. Essa observação é importante, pois o personagemembaixador de L'ambassade é claramente inspirado em Gustav Harald Edelstam, diplomata que se projetou internacionalmente por salvar a vida de muitos dos perseguidos pela ditadura, agindo muitas vezes de forma autônoma ao comando superior de seu país. Tendo chegado ao Chile em outubro de 1972, ele estabeleceu excelentes relações com o governo da Unidade Popular, que mais tarde se desdobraram em um grande apoio aos seus partidários. Vale destacar que o interesse dessa nação europeia pelos conflitos chilenos era grande, e pode ser exemplificado pelo fato de Leonardo Henrichsen trabalhar para a televisão sueca na ocasião de seu assassinato.

Além de abrigar refugiados em sua própria embaixada, Edelstam colocou a bandeira sueca na sede diplomática de Cuba, onde se encontravam 147 pessoas sob a ameaça de invasão das tropas militares. Com isso, estendeu sua influência a mais essa embaixada, dormindo muitas vezes no recinto com o objetivo de impedir uma ofensiva da Junta Militar. Ao lado dos chilenos, ele recebeu inúmeros exilados de outros países, sobretudo latino-americanos que se encontravam no Chile. Seu apoio não se restringiu a abrigá-los, mas também a buscá-los pelas ruas ou até no Estádio Nacional. Em um só dia, conforme ressalta Fernando Camacho (2006), retirou desse

\footnotetext{
${ }^{320}$ A Vicaría de la Solidaridad foi criada por setores da Igreja Católica chilena em janeiro de 1976 com o objetivo de substituir o Comité Pro Paz (que reunia cristãos e judeus), extinto no ano anterior por Augusto Pinochet. Atuou dando assistência jurídica e social a perseguidos pela ditadura e foi responsável pelos primeiros informes sobre presos, torturados, desaparecidos e exilados, constituindose como um organismo importante na luta pelos direitos humanos.
} 
campo de concentração e extermínio 54 uruguaios condenados à morte. Camacho destaca ainda uma forte presença do MIR nos corpos diplomáticos da Suécia, já que esse grupo era visto como o mais radical, não encontrando apoio diante de outras nações. Por fim, vale lembrar que Edelstam colaborou para a retirada de materiais fílmicos (como rolos de película de Patricio Guzmán) e gravações de Víctor Jara.

Pela sua atuação no Chile pós-golpe, Edelstam foi expulso do país, em dezembro de 1973. É simbólico que, em sua saída, estivesse acompanhado de 20 refugiados, que seguiram com ele para o exílio. A Suécia tornou-se um dos países que mais recebeu exilados chilenos. As estimativas indicam que seriam 15 mil refugiados e, ainda hoje, é a nação europeia com o maior número de imigrantes vindos do Chile. Edelstam seguiu como um símbolo da solidariedade a essa causa em suas novas missões (tornou-se posteriormente embaixador na Argélia), discursando sobre o assunto nos eventos internacionais dos quais participou. Embora em menor escala, o novo representante diplomático, Carl-Johan Groth, continuou abrigando os perseguidos pela Junta e negociando salvos-condutos até a segunda metade de 1974, quando praticamente não havia mais refugiados nas embaixadas de Santiago.

Os atos "heroicos" do embaixador Edelstam tornaram-se conhecidos na Europa, de forma que um filme como L'ambassade, lançado em 1974, seria visto claramente como uma referência a essa história. Portanto, o próprio enredo induz à leitura de que se trata de um super-8 filmado no país latino-americano. Além disso, Chris Marker introduziu inúmeras outras referências ao Chile nesse curta-metragem, ao menos até o plano final, quando retira essa nação de cena ao mostrar a Torre Eiffel.

Como já foi dito, L’ambassade organiza-se como um diário audiovisual. Dessa maneira, após a apresentação, a voz over indica a cronologia dos acontecimentos: quarta-feira, chega o primeiro grupo de militantes de esquerda, e o narrador reconhece alguns deles de manifestações e encontros (portanto, ele é também um refugiado). Após exibir a entrada dos personagens na casa, a câmera se aproxima do rosto de um jovem que discursa para os outros, cena descrita pelo realizadorpersonagem como exemplo de uma vontade de falar, uma necessidade de contar "o que havia lhes caído sobre a cabeça”. Essa necessidade do testemunho, de compartilhar o trauma, está também subentendida na iniciativa do próprio narrador em registrar o dia a dia na embaixada. O relato, portanto, é uma forma de amparo, mas igualmente de denúncia. 
O embaixador aparece registrado em contraplongée, tendo sua imagem intercalada com close-ups e planos-detalhe das mãos do estudante que conta sua história. Os demais personagens estão em volta, escutando o testemunho, enquanto a voz over informa o que foi dito na ocasião:

Estavam reunidos nos prédios de uma grande escola, bem perto daqui. A ordem era para esperar, enquanto o contra-ataque se organizasse. O contra-ataque não se organizou. Eles se viramm numa armadilha. Os militares começaram a investir contra a escola, metodicamente, prédio por prédio. Eles escutaram as explosões. Sabiam que, em seguida, seria a vez deles. Saíram pelos jardins e se juntaram à embaixada, graças a um estudante prevenido, Marco. Sua tendência natural em prever o pior lhe havia rendido acusações por parte do otimismo revolucionário ${ }^{321}$. Ainda hoje, ele parece se desculpar. (L'ambassade, 1974, tradução nossa) ${ }^{322}$

Nessa passagem, a primeira a referir-se ao tipo de ação violenta dos militares após o golpe, o Chile não aparece citado diretamente. Porém, o relato condiz com a descrição de ocupações e prisões realizadas a comando da Junta em fábricas, escolas, universidades, poblaciones e outros recintos onde a Unidade Popular tinha influência. Um caso que se tornou emblemático, e que foi provavelmente uma referência para Chris Marker constituir esse relato, ocorreu na Universidad Técnica del Estado (Universidade Técnica do Estado) - que mais tarde daria origem à Universidad de Santiago de Chile (Universidade de Santiago do Chile, USACH). Em 11 de setembro de 1973, Víctor Jara foi detido nessa universidade, onde lecionava no Departamento de Comunicação. Levado ao Estádio Nacional, então local de prisões e extermínio, foi torturado por vários dias até seu corpo aparecer em uma favela da capital chilena. A notícia de seu brutal assassinato, com requintes de crueldade - vale lembrar que seus carrascos lhe quebraram as mãos antes de fuzilá-lo - correu o mundo e se tornou um emblema da violência da ditadura de Augusto Pinochet (taxada pela esquerda europeia como "fascista"), contribuindo para sua falta de legitimidade internacional.

\footnotetext{
${ }^{321}$ Nesse trecho, como em muitos outros de L'ambassade, o texto proferido pela voz over recorre à ironia para caracterizar os personagens e as situações. Esse recurso, como já foi analisado em outros momentos desta tese, é uma característica forte no texto de Chris Marker e na maneira como as palavras interrogam, questionam ou confirmam as imagens.

${ }^{322}$ Texto da voz over de L'ambassade, traduzido do original: "Ils s'étaient réunis dans les bâtiments d'une grande école, tout près d'ici. La consigne était de tenir, le temps que la contre-attaque s'organise. La contre-attaque ne s'est pas organisée. Ils se sont trouvés pièges. Les militaires ont commencé d'investir l'école, méthodiquement, bâtiment par bâtiment. Ils ont entendu les rafales. Ils savaient qu'ensuite, ce serait leur tour. Ils ont pu sortir par les jardins et rejoindre l'ambassade grâce à un étudiant prévoyant, Marco. Sa tendance naturelle à envisager le pire lui était reprochée au nom de l'optimisme révolutionnaire. Encore maintenant, il a l'air de s'en excuser."
} 
Assim, a repressão descrita pelo estudante de L'ambassade nos prédios de uma "grande escola" pode ser atrelada aos ataques, tais como o sofrido por Jara, ou seja, como uma referência que contribui para que o espectador remeta-se ao país latinoamericano $^{323}$.

Após descrever os personagens do primeiro grupo que chegou à embaixada (na quarta-feira), o narrador apresenta os militantes que ingressaram na quinta-feira. Novamente as imagens mostram Lou, em seu papel de recepcionista, recebendo personagens que entram em campo, passando a ser registrados em atividades coletivas - comendo, tomando café, conversando etc. Entre os "novatos", um recém-chegado recebe atenção especial: Volodia. A caracterização dos refugiados será um tema do item 4 deste capítulo, mas é necessário adiantar que muitos deles trazem referências explícitas ao Chile, sobretudo no caso dessa remissão ao advogado do Partido Comunista Chileno, Volodia Teitelboim. Senador durante os governos de Eduardo Frei e Salvador Allende, ele se encontrava na Europa em 11 de setembro de 1973, seguindo diretamente para o exílio em Moscou, de onde se tornou uma das principais vozes na articulação da solidariedade às vítimas da ditadura chilena.

A voz over segue descrevendo as cenas, como se lesse um diário. Na sextafeira, há uma divisão de tarefas, e o embaixador dá o exemplo, passando o aspirador no apartamento, ajudado por sua mulher. O tempo é ocupado com jogos de cartas ou apenas conversas. Nesse dia, um episódio trágico, ocorrido fora da embaixada, perturba a ordem interior. A câmera registra crianças na janela, em um dos raros momentos do filme em que o mundo exterior é mostrado. Um corte permite ao espectador ver um plano curto em que um homem corre pela rua. Em seguida, um novo corte, no qual um menino aparece sendo consolado por uma das refugiadas vale destacar que essa sequência é um bom exemplo do "efeito Kulechov" aplicado por Marker. Diante dessas imagens, a voz over completa a narrativa: "Um dos filhos de Isabel, que olhava pela janela, se pôs a chorar, e eu tive tempo de ver apenas um tipo atravessar a rua correndo em direção à porta da embaixada. Ele nunca chegou." (L'ambassade, 1974, tradução nossa). ${ }^{324}$

\footnotetext{
${ }^{323}$ O filme Septembre chilien (1974), de Bruno Muel e Théo Robichet, foi uma referência documental para Chris Marker em L'ambassade. Produzido pela ISKRA, ele incorporava uma sequência em que dois estudantes relatavam a ocupação militar à Universidade Técnica do Estado, bem como trazia tomadas de militares cercando o prédio dessa instituição.

${ }^{324}$ Texto da voz over de L'ambassade, traduzido do original: "Un des enfants d'Isabel, qui regardait par la fenêtre, pousse un cri et $\mathrm{j}$ 'ai juste le temps de voir un type traverser la rue en courant vers la porte de l'Ambassade. Il n'y arrivera jamais."
} 

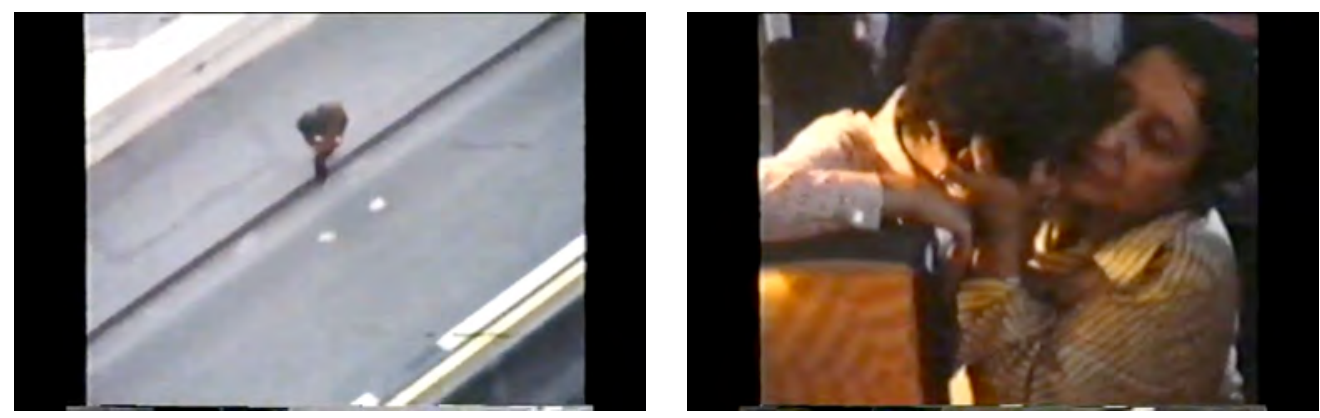

Fotogramas de L'ambassade.

A presença do Chile no "fora de campo" é uma das estratégias de L'ambassade para falar do país sem citá-lo diretamente, como já foi afirmado. Nesse sentido, ele vem à tona sobretudo em momentos como o dessa cena, em que o mundo exterior ao cenário da "embaixada" - ou apartamento de Lou - adentra o seu espaço físico. Nessa passagem, há uma referência a casos ocorridos no pós-11 de setembro de 1973, quando algumas pessoas foram abatidas buscando abrigo nas sedes diplomáticas. Cercados pelos militares, os refúgios dos exilados sofreram ataques a tiros e graves incidentes, como a prisão da uruguaia Mirtha Fernández Pucurull, quando ela teve de sair para se tratar de um câncer de útero (apesar de escoltada pelos embaixadores de Suécia e França), ou ainda o tiro recebido pelo socialista chileno Rolando Calderón, episódios ocorridos em dezembro de 1973 na embaixada sueca.

No filme, o episódio do homem abatido abre caminho para que outro instrumento de passagem traga notícias do exterior: o telefone. Luco é chamado por um companheiro de partido, como informa a voz over, que lhe diz quem era o assassinado. As notícias de fora são as piores. Um novo plano desde a janela permite a visualização de uma cancela, que caracterizaria um cerco ao recinto, ou, nas palavras do narrador, uma grade que se fechou, definindo que não chegariam novos refugiados. O dia seguinte, sábado, é descrito por um isolamento do mundo externo: falta de jornais, comunicados lacônicos na televisão, o telefone monitorado e "uma cidade morta e indecifrável" (exibida em um novo plano curto tomado da janela, dessa vez de um prédio vizinho onde não se vê ninguém).

As referências aos acontecimentos do Chile trazidas por esse mundo exterior tornam-se mais contundentes no domingo, quando um novo telefonema confirma rumores, nas palavras do narrador, de que haviam prisioneiros retidos em um estádio, e que todas as noites ocorriam execuções. Essa passagem é um exemplo contundente da importância da voz over para conceder sentido à narrativa, já que enquanto ela 
transmite as trágicas notícias, diversos planos mostram as atividades dos "refugiados", que tocam violão, cantam, jogam xadrez e brincam com uma tartaruga. Portanto, esse mundo fechado, isolado, onde vive essa esquerda, é circunscrito por um contexto exterior a ele que se apresenta trágico e feroz. Essa espécie de "ilha" onde os militantes se isolam será analisada mais adiante, mas é importante ressaltar que o Estado repressor, a ditadura, aparece no filme também no fora de campo, nesse lugar onde está retratado o país latino-americano.

A referência explícita ao Estádio Nacional chileno e a sua condição de campo de concentração antecede outras citações evidentes dos acontecimentos pós-11 de setembro. Ainda no domingo, os refugiados assistem à televisão, quando os "comunicados anônimos dão lugar às verdadeiras imagens, aos verdadeiros discursos", nas palavras da voz over. Enquanto todos cercam o televisor, sentados no chão e observando atentamente as imagens (que permanecem fora de campo para o espectador de L'ambassade, que só tem acesso aos planos com as reações dos personagens), o narrador resume o discurso do novo governo:

Nós tivemos direito a tudo: explicações, congratulações, adjurações, ameaças. Essa gente não se renova muito. Era necessário extirpar o câncer marxista, o país corria para a ruína, os complôs guiados do exterior, toda essa lira. Essa besteirada é entrecortada de anúncios de medidas, por outro lado, muito precisas. Interdição de todos os partidos políticos, sem exceção. Dissolução de todos os sindicatos, sem exceção. Apelos à delação, com prêmios ao apoio. Declaração de grandes princípios de uma nova Constituição cuja inspiração é evidentemente chauvinista, racista, corporativista. (L'ambassade, 1974 , tradução nossa) ${ }^{325}$

Trata-se de uma referência direta aos primeiros discursos e medidas da Junta Militar que assumiu o poder após a derrubada de Allende. Algumas expressões, inclusive, foram utilizadas tal como proferidas pelos militares, como é o caso de "extirpar o câncer marxista". Pode-se dizer que havia a tentativa da ditadura em caracterizar um estado de caos - ou de ruína - que justificasse a intervenção do exército por meio de uma retórica que está reproduzida na televisão de L'ambassade. Ao mesmo tempo em que traz à cena essa tentativa de monumentalizar o golpe de

\footnotetext{
${ }^{325}$ Texto da voz over de L'ambassade, traduzido do original: "Nous avons eu droit à tout: les explications, les congratulations, les adjurations, les menaces. Ces gens ne se renouvellent pas beaucoup. Il fallait extirper le cancer marxiste, le pays courait à la ruine, des complots téléguidés de l'étranger, toute la lyre. Ce baratin est entrecoupé d'annonces de mesures, en revanche, très précises. Interdiction de tous les partis politiques, sans exception. Dissolution de tous les syndicats, sans exception. Appels à la délation, avec primes à l'appui. Enoncé des grands principes d'une nouvelle Constitution dont l'inspiration est évidemment chauvine, raciste, corporatiste."
} 
Estado como uma ação heroica (que deve ser combatida), o filme cita algumas das restrições que se seguiram ao 11 de setembro, como a proibição dos partidos políticos $^{326}$. Portanto, os espectadores que tinham na memória os recentes informes ditatoriais chilenos certamente os relacionariam aos do filme.

$\mathrm{Na}$ entrevista à pesquisadora, Marker declarou que nessa cena foram, de fato, exibidas as primeiras declarações televisivas da Junta Militar chilena aos seus "convidados": "O único momento em que o verdadeiro Chile se aproxima da ficção é aquele em que eles assistem à televisão. Havia muitos refugiados chilenos entre os meus convidados, eu os passei uma reportagem sobre os primeiros dias da ditadura e nós observamos suas reações em direto.” (MARKER, 2011, tradução nossa) ${ }^{327}$. Nesse sentido, é interessante notar como a câmera foca alguns rostos, detendo-se mais tempo na face de duas mulheres - com traços de origem indígena, remetendo ao país latino-americano -, que trazem um ar de tensão que ainda não havia aparecido na mise-en-scène - nesse caso, uma passagem em que o "efeito Kulechov" não está aplicado.

A declaração militar televisionada inicia um conflito entre os militantes de esquerda, que passam a demonstrar ranhuras internas desse campo político (analisadas no item 4 deste capítulo). Porém, vale ressaltar mais uma evidência explícita ao Chile presente em L'ambassade, que aponta também para o lugar de onde o filme fala: o exílio na França. Ao final, os refugiados se despedem, e pela primeira vez a câmera sai do apartamento e acompanha alguns deles até a porta da rua. Um corte a traz de volta ao apartamento, permitindo que ela grave da janela da "embaixada" uma Kombi que leva alguns deles embora. Ao afastar-se desse plano-detalhe, uma panorâmica permite que o espectador veja o rio Sena, a Torre Eiffel e um avião, ficando claro que os planos são rodados em Paris.

Essa última sequência de L'ambassade revela uma nova referência espacial que contradiz as anteriores. $\mathrm{O}$ espectador acreditava ver imagens rodadas no Chile, mas percebe que as cenas se passam na França. A voz over, no entanto, torna essa quebra menos brusca ao acompanhar a passagem descrita no parágrafo acima introduzindo a questão do exílio: "E depois, os primeiros salvos-condutos chegaram, e algo da antiga amizade realmente ressurgiu. Eles partiram em pequenos grupos, e as

\footnotetext{
${ }^{326}$ Essa proibição foi decretada em outubro de 1973.

${ }^{327}$ Traduzido do original: "Le seul moment où le vrai Chili rattrape la fiction est celui où ils regardent la télévision. Il y avait plusieurs réfugiés chiliens parmi mes invités, je leur ai passé un reportage sur les premiers jours de la dictature, et on voit leurs réactions en direct."
} 
despedidas foram verdadeiras despedidas." (L'ambassade, 1974, tradução nossa) ${ }^{328}$. Nesse sentido, uma das leituras possíveis para a presença da Torre Eiffel em cena é a mudança de lugar dos próprios protagonistas, que, com os salvos-condutos, puderam sair do confinamento, embora isso implicasse em "verdadeiras despedidas" em relação ao seu país de origem.
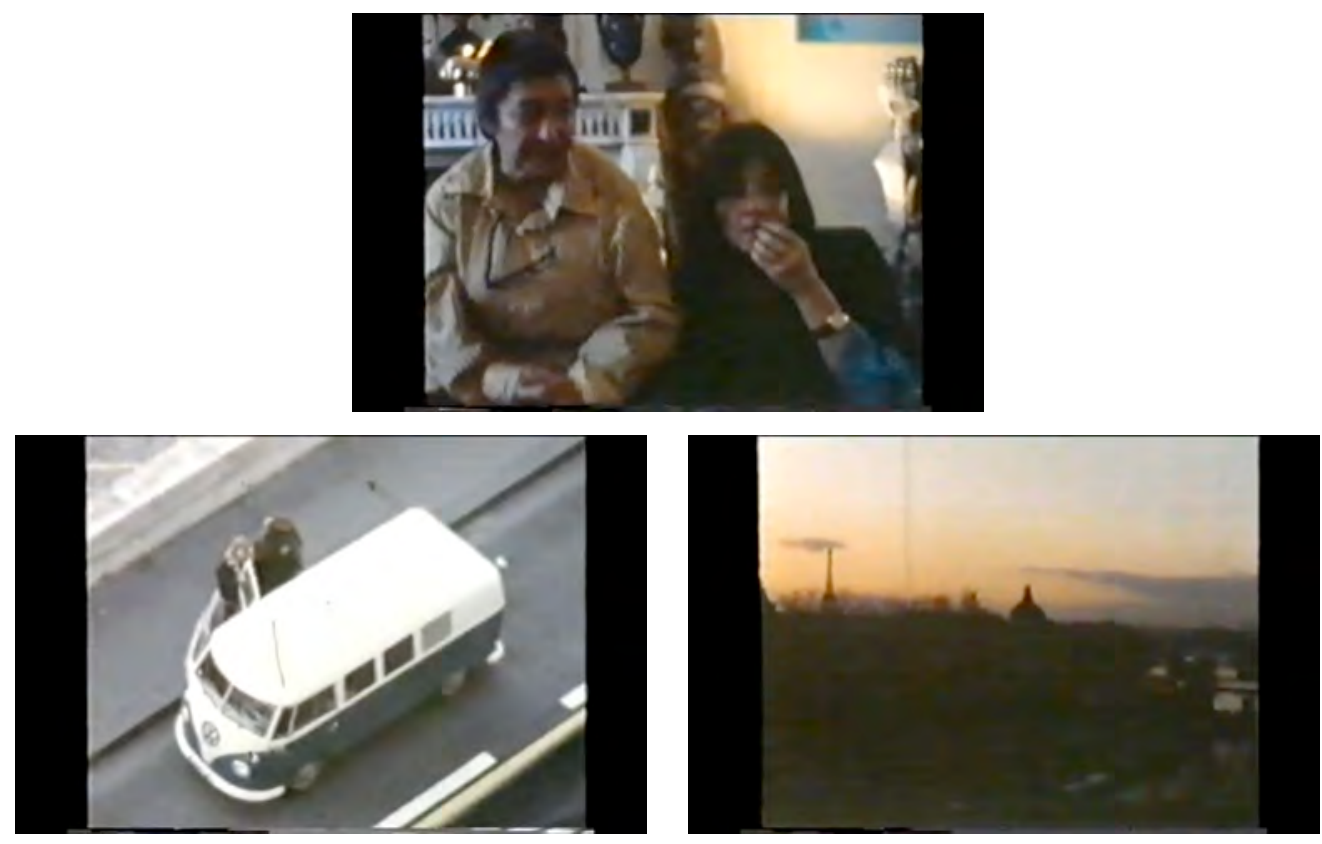

Fotogramas de L'ambassade.

Esse apontamento para o exílio está também no avião que cruza o céu no primeiro plano de L'ambassade, voltando à cena na última tomada. No início do filme, ele contribui como mais uma remissão subentendida ao golpe de Estado no Chile, já que os bombardeios aéreos ao La Moneda produziram imagens impressionantes que se tornaram símbolos da violência empregada no 11 de setembro e no período que se seguiu a essa data. Por outro lado, ao terminar com o mesmo rastro de fumaça formado pela aeronave, introduzido após o Sena e a Torre Eiffel, Marker fecha um ciclo com uma clara referência ao caminho tomado pelos refugiados após os salvos-condutos.

Como foi demonstrado neste subcapítulo, o Chile é uma referência quase onipresente no filme, embora esteja sempre no fora de campo, trazido à mise-en-scène por meio de pistas que induzem à interpretação de que se trata de uma produção sobre esse país. Essas pistas se revelam falsas, ou ao menos questionáveis, quando Marker

\footnotetext{
${ }^{328}$ Texto da voz over de L'ambassade, traduzido do original: "Et puis, les premiers sauf-conduits sont arrivés, et quelque chose de l'ancienne amitié a quand même resurgi. Ils sont partis par petits groupes, et les adieux ont été de vrais adieux."
} 
insere em cena as únicas evidências diretas de lugar: as imagens do rio Senna e da Torre Eiffel. Nesse sentido, esses elementos assumem um status de realidade mais forte do que os relativos à nação latino-americana por se tratarem de evidências espaciais inquestionáveis. É possível afirmar que esse último plano inicia novas possibilidades de leitura, que trazem L'ambassade para o continente europeu e suas questões internas, como será analisado. Nessa nova perspectiva, o avião que se repete nas cenas inicial e final constitui também a hipótese de um tempo em espiral que é revisitado, não mais em Santiago, mas sim em Paris. 


\section{A França em campo: emergência do Programa Comum}

A sequência final de L'ambassade remete a uma passagem de Dimanche à Pékin (1956), já citada no capítulo 1 desta tese. Em ambas, a câmera realiza um traveling desde uma janela e mostra ao espectador a Torre Eiffel. No curta dos anos 1950, Marker acompanhou a cena pela seguinte reflexão proferida pela voz over: "Nada é mais belo que Paris, a não ser um souvenir de Paris. E nada é mais belo que Pequim, a não ser um souvenir de Pequim. E eu, em Paris, me lembro de Pequim e conto os meus tesouros." (Dimanche à Pékin, 1956, tradução nossa). ${ }^{329}$ Nesse trecho, aparecem questões que percorrem sua obra, como a memória e a experiência (retomadas por meio dos objetos trazidos de uma viagem, como os que o realizador expõe em sua sacada parisiense), além de sua condição de "estrangeiro" que transita além das fronteiras nacionais. Repetindo o mesmo movimento de câmera em um cenário similar, a produção de 1974 recupera essa ideia do próprio filme como um souvenir, ou seja, um objeto gerador de um discurso memorialístico produzido $a$ posteriori que pode se apresentar mais icônico do que a própria realidade.

A Torre Eiffel, nesses dois filmes, torna-se um índice de lugar (Paris), mas também uma síntese da França e de suas questões políticas, econômicas, sociais e culturais. É ela também que marca de onde fala o realizador, seu ponto de vista. No caso de Dimanche à Pékin, essa informação é evidenciada na primeira cena, como uma espécie de marco que guia o caminho pelo qual o documentário deverá ser interpretado. Em L'ambassade, esse traveling janela afora só é inserido ao final, descontruindo, como foi abordado, o próprio discurso fílmico anterior.

Essas duas sequências têm em comum a simbologia exercida pela janela como um lugar de passagem entre dois mundos, um interior e outro exterior, um privado e outro público. Elas também levam o espectador a transitar entre países diversos - a China e a França, o Chile e a França. No entanto, novamente estabelecem direções distintas em seus percursos: em Dimanche à Pékin, é o ponto de partida para um documentário francês que se passa no país asiático; em L'ambassade, indica que se trata de uma ficção e transfere o espectador da nação latino-americana à francesa.

\footnotetext{
${ }^{329}$ Texto da voz over de Dimanche à Pékin, traduzido do original: "Rien n'est plus beau que Paris, sinon le souvenir de Paris. Et rien n'est plus beau que Pékin, sinon le souvenir de Pékin. Et moi, à Paris, je me souviens de Pékin et je compte mes trésors."
} 
A presença da Torre Eiffel em L’ambassade pode ser vista de múltiplas maneiras. Uma delas é como uma evidente tentativa de internacionalizar a "experiência chilena", aproximando-a das discussões políticas que se passavam na França nesse mesmo período. Sendo assim, esse filme confirma que, ao abordar o governo da Unidade Popular, Chris Marker tinha em mente sua repercussão nos círculos artísticos e intelectuais franceses - não por acaso, os "atores" são seus próprios amigos que interpretam, muitas vezes, a eles mesmos. As ações ocorridas naquela embaixada, sobretudo as discussões políticas que abalavam a ordem comunitária entre os refugiados, se davam em Paris, entre seus companheiros.

Outra hipótese que será analisada é o fato de o filme trazer à cena um temor alardeado na França após o golpe de Estado no Chile de que, caso a esquerda vencesse as eleições de 1974, o país poderia ter o mesmo destino trágico da nação latino-americana. Esse temor, uma das consequências dessa aproximação entre a Unidade Popular e a união "gauchista" francesa, foi difundido sobretudo pela direita e pela extrema-esquerda como um "alerta" para as "lições" que poderiam ser retiradas da instauração da ditadura chilena por meio de uma violenta tomada do poder. A presença desse discurso em L'ambassade é constatada pelo plano final rodado em Paris, e também pela última frase da voz over, que concede à produção ares de uma "ficção científica" - aos moldes de La jetée - em que a capital francesa sucumbe diante da perda de sua liberdade: "Da janela da embaixada, eu rodei meu último plano: a caminhonete que os levava ao exílio, e essa cidade que nós havíamos conhecido livre." (L'ambassade, 1974, tradução nossa) ${ }^{330}$. Cabe, portanto, situar esse discurso no círculo político francês e verificar suas implicações nesse filme.

Outro exercício necessário para a compreensão da relação entre Chile e França em L'ambassade é identificar o legado atribuído por Chris Marker à experiência chilena nessa produção. Nesse sentido, pretende-se reconhecer a presença de certos debates políticos da época, assim como verificar o posicionamento do diretor diante deles (o que será desenvolvido no item 4 deste capítulo). Essa reflexão relaciona-se diretamente àquela sobre os riscos a que uma união de esquerda estaria submetida, como também ao que a esquerda francesa poderia apreender com a queda da Unidade Popular chilena e incorporar em sua estratégia rumo ao socialismo.

\footnotetext{
${ }^{330}$ Texto da voz over de L'ambassade, traduzido do original: "D'une fenêtre de l'ambassade, j'ai tourné mon dernier plan: la camionnette qui les emmenait en exil, et cette ville que nous avions connue libre."
} 
Diante dessas hipóteses, relacionadas ao plano final de L'ambassade e à leitura que ele acarreta ao restante do filme, uma breve contextualização da política francesa nos anos 1970 e das leituras que a esquerda desse país fizeram sobre a experiência da Unidade Popular chilena são necessárias para compreender a relação entre Chile e França sugerida por essa produção.

\subsection{A Unidade Popular para o Programa Comum da esquerda francesa}

A consolidação de um programa único de governo assinado pelos partidos Comunista, Socialista e pelo Mouvement des radicaux de gauche, em 1972, consolidou uma união desse campo político após quase uma década de frustradas negociações. A candidatura de François Mitterrand para as eleições presidenciais de 1965, único nome da esquerda na ocasião, como opositor do general Charles de Gaulle, apesar da derrota no segundo turno, possibilitou a criação da Fédération de la gauche démocrate et socialiste (FGDS), que englobava a esquerda não comunista (já que o PCF não fazia parte da FGDS). Até o final da década de 1960, no entanto, a esquerda francesa permaneceu fragmentada, tendo três nomes distintos concorrendo no pleito de 1969 (Gaston Defferre pelos socialistas, Jacques Duclos pelos comunistas e Michel Rocard pelo Parti socialiste unifié) - PSU), que consagrou Georges Pompidou presidente.

As derrotas impulsionaram, nos anos 1970, o retorno do diálogo por uma união esquerdista. Em 1969, foi criado o Partido Socialista (a partir da já existente Section française de l'internationale ouvrière - SFIO), do qual Mitterrand se tornou o primeiro secretário. Dois anos depois, outros partidos de esquerda e socialdemocratas se aliaram ao PS, consagrando os esforços por uma aliança que culminou, em 1972, na incorporação do PCF e na confecção do programa comum de governo. Apesar de terem candidatos próprios nas eleições parlamentares no ano seguinte, com a morte de Pompidou e o pleito presidencial antecipado de 1974, Mitterrand concorreu novamente ao cargo como um nome comum dessa aliança. Derrotado, no entanto, só conseguiu se eleger em 1981.

Diante desse quadro político, Olivier Compagnon (2009), em L'EuroAmérique en question, analisa de que maneira a experiência chilena pode ser vista 
como um exemplo de inversão de fluxo na circulação leste/oeste (ou seja, se constituiu como um caso em que as ideias circularam da América à Europa, e não ao contrário), que rompe com a hegemonia europeia de dominação cultural e política entre esses dois continentes. Se a Revolução Cubana havia despertado interesse e admiração nos meios intelectuais franceses, mas parecia muitas vezes um "socialismo tropical exótico" aos olhos dos políticos europeus, o sucesso da Unidade Popular no Chile se diferenciava pela possibilidade real de incorporação de seus métodos:

Assim, uma das lições que podíamos tirar na Europa é que um projeto de transformação política precisa de um sistema de aliança forte, mesmo que a aproximação entre a Unidade Popular e a Democracia Cristã - delineada em outubro de 1970 na ocasião do assassinato do general Schneider - não tenha se confirmado após a instalação do novo governo. (COMPAGNON, 2009, p. 11, tradução nossa) ${ }^{331}$

Esse papel de referência que o Chile representava para a esquerda francesa pode ser comprovado por duas viagens realizadas por membros do Partido Socialista francês para o país, com o objetivo de colher ensinamentos da Unidade Popular. $\mathrm{Na}$ primeira delas, Claude Estier - um dos nomes que trabalhava pelo entendimento com o Partido Comunista - esteve na nação latino-americana, em 1970, para encontrar Salvador Allende e outros líderes da esquerda chilena, debatendo as implicações da escolha pela via democrática e as dificuldades enfrentadas em decorrência dos conflitos com a oposição. Nesse encontro, começaram a se estabelecer bases de solidariedade que se fortaleceriam em uma segunda viagem e que seriam necessárias após o 11 de setembro de 1973, no período do exílio.

Allende teria solicitado a Estier que Mitterrand fosse pessoalmente ao país, o que representaria para seu governo um importante apoio internacional. Assim, uma segunda comitiva socialista francesa - integrada por Estier, Mitterrand e Gaston Defferre - esteve no Chile em novembro de 1971, disposta a observar de perto a Unidade Popular e tirar lições que servissem à consolidação de uma aliança em prol do programa comum das esquerdas na França ${ }^{332}$. A viagem consagraria o nome de

\footnotetext{
${ }^{331}$ Traduzido do original: “Aussi l'une des leçons que l'on en retient en Europe est qu'un projet de transformation politique a besoin d'un système d'alliance fort, même si le rapprochement entre l'Unité populaire et la démocratie chrétienne - esquissée en octobre 1970 à l'occasion de l'assassinat du général Schneider - n'est pas confirmée une fois le nouveau gouvernement installé."

${ }^{332}$ Pierre Vayssière (2005) destaca que a ambiguidade da Unidade Popular chilena, entre a revolução e a reforma, atraiu atores de naturezas diversas para o país latino-americano. Como exemplo, ele cita o encontro de Fidel Castro e François Mitterrand no Chile em novembro de 1971.
} 
Mitterrand como uma referência desses esforços de união, associando sua imagem à do líder da UP, o que muitas vezes lhe rendeu a acunha de "o Allende francês". Sobre esse intercâmbio entre América Latina e Europa, Compagnon coloca que:

Na França, o programa comum da esquerda - cujo projeto é certamente anterior à formação da Unidade Popular - pode igualmente ser visto como uma variação europeia das escolhas táticas dos socialistas chilenos. Após o congresso de Épinay, em junho de 1971, uma delegação compreendendo Mitterrand, Claude Estier e Gaston Defferre foi para o Chile em novembro para observar de perto esse "laboratório onde se efetua uma experiência da qual a esquerda europeia extrairá, talvez algum dia, uma lição". Alguns dias mais tarde, o novo líder do Partido Socialista declarou em Le Monde que "o Chile é o único país do mundo onde a síntese entre reformas de estruturas e respeito das liberdades públicas foi bem-sucedida. Para alcançar esse objetivo, é necessário concluir os acordos eleitorais e, sobretudo, estabelecer uma plataforma comum prévia a um acordo governamental." Já Claude Estier escreveu em Le bulletin socialiste sobre essa viagem: "Se o Chile, em sua história, constantemente se inspirou na França, ele é hoje, para os socialistas franceses, senão um modelo, pelo menos um exemplo". $\mathrm{Na}$ verdade, a experiência chilena alimentou efetivamente as reflexões da esquerda francesa durante toda a década de 1970, e a aliança entre socialistas e comunistas franceses foi finalmente negociada sobre bases táticas comparáveis àquelas da plataforma negociada em Santiago em dezembro de 1969. (COMPAGNON, 2009 , p. 11-2, tradução nossa) ${ }^{333}$

A incorporação dos debates sobre a Unidade Popular chilena para a confecção do programa comum de governo de $1972^{334}$ (assinado pelos partidos Comunista, Socialista e pelos radicais de esquerda) é visível quando se compara esse texto com o formulado pelos dirigentes chilenos da Unidade Popular em 1969, como destacou Compagnon. Entre os diversos pontos semelhantes nos dois documentos, destacam-se

\footnotetext{
${ }^{333}$ Traduzido do original: "En France, le programme commun de la gauche - dont le projet est certes antérieur à la formation de l'Unité populaire - peut également apparaître comme une déclinaison européenne des choix tactiques des socialistes chiliens. Après le congrès d'Épinay de juin 1971, une délégation comprenant Mitterrand, Claude Estier et Gaston Defferre se rend au Chili en novembre pour observer de près ce 'laboratoire où s'effectue une expérience dont la gauche européenne tirera peut-être quelque jour la leçon'. Quelques jours plus tard, le nouveau leader du Parti socialiste déclare dans Le Monde que 'le Chili est le seul pays au monde où la synthèse entre réformes de structures et respect des libertés publiques a été réussie. Pour y parvenir, il faut conclure des accords électoraux, et surtout établir une plate-forme commune préalable à un accord de gouvernement', tandis que Claude Estier écrit dans Le bulletin socialiste à propos de ce voyage: 'si le Chili dans son histoire s'est souvent inspiré de la France, il est aujourd'hui pour les socialistes français sinon un modèle, du moins un exemple.' Dans les faits, l'expérience chilienne alimenta effectivement les réflexions de la gauche française durant toutes les années 1970 et l'alliance entre socialistes et communistes français fut finalement négociée sur des bases tactiques comparables à celles de la plate-forme négociée à Santiago en décembre 1969."

${ }^{334}$ Além da circulação de membros da esquerda francesa que estiveram no Chile e levaram à França suas impressões sobre a Unidade Popular, vale ressaltar que o próprio programa da esquerda chilena foi publicado em grande parte no livro La voie chilienne vers de socialisme, de autoria atribuída a Salvador Allende (1974).
} 
aqueles referentes a uma transferência gradual do poder das mãos do grande capital ao Estado, que previa estratégias de nacionalização e criação de propriedades coletivas (fossem elas nacionais ou de economia mista, como prevê o texto francês). Essa aproximação entre esses programas de governo - o de 1969 e o de 1972 - pode ser verificada nos trechos a seguir sobre essa transferência dos meios de produção:

O processo de transformação de nossa economia se inicia com uma política destinada a constituir uma área estatal dominante, formada pelas empresas que o Estado possui atualmente, mais aquelas que sejam expropriadas. Como primeira medida, se nacionalizarão aquelas riquezas básicas que, como a grande mineração do cobre, do ferro, do salitre e outras, estão em poder dos capitais estrangeiros e dos monopólios internos. (PROGRAMA, 1970, p. 23-24, tradução nossa $)^{335}$

Para quebrar a dominação do grande capital e impor uma nova política econômica e social, rompendo com aquela que se pratica, o governo realizará progressivamente a transferência à coletividade dos meios de produção mais importantes e dos instrumentos financeiros, atualmente nas mãos dos grupos capitalistas dominantes. (JUQUIN, 1977, p. 121, tradução nossa) ${ }^{336}$

A evocação da Unidade Popular na França pode ser vista também em outros documentos. Pierre Vayssière (2005) afirma que a presença do Chile foi constante na imprensa francesa ao longo dos 34 meses do governo Allende (como ocorreu na imprensa televisiva, conforme foi demonstrado no capítulo 3 por meio da análise dos programas especiais da ORTF). $\mathrm{O}$ autor classifica as reportagens em três tendências prioritárias. A primeira delas diz respeito a um discurso que se tornou hegemônico e que encontra voz no jornal Le Monde. Esse periódico apresentava uma certa simpatia pela via democrática ao socialismo, mas, ao longo do mandato da Unidade Popular, assumiu um tom de preocupação e pessimismo diante dos conflitos no país. Nos jornais mais à esquerda, havia um apoio sem reservas à chamada "via chilena", porém, um alerta para os problemas decorrentes das divisões internas nesse campo político que cresceu na medida em que se aproximou o 11 de setembro. Por fim, a

\footnotetext{
${ }^{335}$ Traduzido do original: "El proceso de transformación de nuestra economía se inicia con una política destinada a constituir una área estatal dominante, formada por las empresas que actualmente posee el Estado más las empresas que se expropien. Como primera medida se nacionalizarán aquellas riquezas básicas que, como la gran minería del cobre, hierro, salitre y otras, están en poder de capitales extranjeros y de los monopolios internos."

${ }^{336}$ Traduzido do original: "Pour briser la domination du grand capital et mettre en œuvre une politique économique et sociale nouvelle, rompant avec celle qu'il pratique, le gouvernement réalisera progressivement le transfert à la collectivité des moyens de productions les plus importants et des instruments financiers actuellement entre les mains de groupes capitalistes dominants."
} 
imprensa de centro e de direita ia do ceticismo à crítica, chegando a justificar, ou mesmo comemorar, o golpe de Estado em alguns casos (como em uma reportagem de André Nicolas, em Aspects de la France).

Entre os periódicos de esquerda, constantemente se percebe a tentativa de aproximar a política chilena da francesa. A ênfase na experiência chilena cresceu sobretudo nos primeiros meses de 1973, já que os dois países passariam por eleições legislativas no mês de março. Uma publicação editada pela Ligue communiste, por exemplo, a Document rouge [1973?], indagava sobre o país: Chili: le socialisme sans la révolution?. O texto constatava que, apesar do Chile não ser a França, o balanço sobre a experiência chilena seria inevitável durante a campanha eleitoral no país europeu, dizendo que Mitterrand e Jacques Duclos (líder do Partido Comunista) haviam se apropriado da Unidade Popular como um "modelo", delegando-lhe o papel de "inspiração".

Após o golpe de Estado - além da descrença na UP e da comemoração de sua queda pela imprensa francesa de centro e de direita -, Pierre Vayssière (2005) identifica duas tendências analíticas sobre a experiência chilena que estão presentes também na filmografia de Chris Marker. A primeira delas é um clima de denúncia do complô armado pela direita chilena com apoio dos Estados Unidos para boicotar o governo de Allende. Esse viés se tornou relativamente predominante e foi constante sobretudo no jornal Le Monde, como mostra uma reportagem publicada em 22 de setembro de 1973 (ROCARD, 1973). Trata-se de uma abordagem próxima à proposta pelo documentário La spirale, tema discutido no capítulo anterior. Por outro lado, Vayssière reconhece na imprensa de esquerda a prevalência de teorias que atribuíam aos conflitos internos da Unidade Popular, responsáveis por sua divisão, as causas de sua derrocada. Tal enfoque aparece em L'ambassade, como será desenvolvido no próximo subitem.

A ideia de que as divergências internas colaboraram com o golpe de Estado, sugerida na imprensa de esquerda e em L'ambassade, pode ser relacionada à visão dos próprios líderes da Unidade Popular que, desde o exílio, redigiram balanços sobre a derrota que apontavam para essa conclusão. Em 1976, Joan Garcés, que havia sido o assessor pessoal de Salvador Allende até a sua morte, publicou na França Allende et l'expérience chilienne (GARCÉS, 1976). Além de denunciar o complô que resultou no golpe de Estado, ele dedicava um capítulo aos "erros táticos" e à "derrota estratégica" que deixaram o país vulnerável às forças contrarrevolucionárias. As 
contradições internas da UP, segundo o autor, a haviam "paralisado", assim como a falta de uma direção unitária prejudicou a tomada de decisões fundamentais para a resistência. Em suas palavras:

A origem dessas insuficiências e desses erros táticos se encontra na estratégia, como o desacordo que existia no interior da esquerda entre os que desejavam instaurar a hegemonia social dos trabalhadores, evitando que a burguesia dispusesse de instrumentos que a permitissem recorrer à guerra civil, e aqueles que agiam, conscientemente ou inconscientemente, segundo a estratégia revolucionária, que passa obrigatoriamente pelo enfrentamento armado." (GARCÉS, 1976, p. 231-2, tradução nossa). ${ }^{337}$

Carlos Altamirano - que, publicaria no México ${ }^{338}$ seu clássico balanço autocrítico Dialética de uma derrota (ALTAMIRANO, 1979) - discursou para a juventude socialista francesa em março de 1974, em um encontro em Épinay. Fazendo ressalvas para que suas declarações não prejudicassem a luta na Europa, e sim contribuísse para ela, apelava para que a esquerda não se dividisse, insinuando, como fazia Garcés, que o racha interno teria contribuído para a derrocada da Unidade Popular no Chile. Para o líder socialista chileno, os que trabalhavam para a divisão das forças populares e das forças socialistas trabalhavam também em favor do imperialismo $^{339}$. E concluía:

Em nenhum país onde as forças de esquerda estarão pulverizadas e diversificadas será possível conquistar a vitória. Em todos os países onde as forças revolucionárias e as forças socialistas se dividam, a derrota é possível. É por isso que nós, nós estamos mais preocupados do que qualquer um em elevar o nível da união das forças populares e das forças socialistas no Chile. (ALTAMIRANO, 1974 ?, p. 61-2) 340

Ao apontar as divisões internas da esquerda como uma característica problemática desse campo político, julgando-as responsáveis pelo fortalecimento de

\footnotetext{
${ }^{337}$ Traduzido do original: "L'origine de ces insuffisances et de ces erreurs tactiques se retrouve également au niveau de la stratégie, à savoir dans le désaccord qui existait au sein de la gauche entre ceux qui souhaitaient arriver à instaurer l'hégémonie sociale des travailleurs, en évitant que la bourgeoisie ne dispose des instruments lui permettant de recourir à la guerre civile, et ceux qui agissaient, consciemment ou inconsciemment, selon la stratégie révolutionnaire qui passe obligatoirement par l'affrontement armé."

${ }^{338}$ A primeira edição dessa obra de Altamirano foi publicada no México, em 1977.

${ }^{339}$ Essa fala de Altamirano se aproxima àquela do personagem Tsikos, de L'ambassade, conforme será abordado no próximo subitem.

${ }^{340}$ Traduzido do original: "Dans aucune pays où les forces de gauche seront atomisées et diverses, il n'est possible de remporter la victoire. De tous les pays où les forces révolutionnaire et les forces socialistes se divisent la déroute est possible. C'est pour cela que nous, nous sommes plus préoccupés que quiconque d'élever le niveau de l'unité des forces populaires et des forces socialistes au Chili."
} 
seus inimigos, Chris Marker aproxima-se dessas abordagens que visavam a alertar a esquerda francesa sobre os perigos das divergências, utilizando, para isso, o caso chileno. Em L'ambassade, a solidariedade inicial entre os refugiados é quebrada por eles mesmos, após alguns dias de convivência reclusa. O narrador se declara envergonhado por testemunhar tais desentendimentos, como se a "lição" dada pelo golpe de Estado não tivesse sido apreendida, preferindo deixar de gravar a cena a mostrar a fraqueza das diversas correntes de esquerda:

Fazia apenas uma semana que o golpe de Estado havia ocorrido. Nossa fraternidade não havia durado muito. Inútil reler minhas anotações desse período: elas são sinistras. E também não há muitas imagens para mostrar. Cada um vivia voltado a si mesmo, e a câmera havia se transformado em uma testemunha embaraçosa. (L'ambassade, 1974, tradução nossa) ${ }^{341}$

$\mathrm{Na}$ narrativa, esse trecho sugere que o realizador-personagem fez um corte, suprimindo algumas de suas imagens da edição final com o intuito de evitar a exibição dos conflitos. Além disso, essa fala rompe com os procedimentos anteriores, que indicavam uma cronologia e um conjunto de acontecimentos dia a dia. Sobreposta ao trecho que "encena" a discussão entre os personagens de esquerda (que será analisada adiante), essas frases precedem uma tomada em que a personagem Sonia aparece sozinha em um quarto - em que os ambientes coletivos do cenário (a sala e a cozinha) são deixados de lado para mostrar um momento de introspecção no âmbito privado $^{342}$. A atmosfera coletiva volta à cena apenas na despedida, quando os “militantes" da embaixada se despedem rumo ao exílio ${ }^{343}$.

\footnotetext{
${ }^{341}$ Texto da voz over de L'ambassade, traduzido do original: "Il y avait juste une semaine que le coup d'État avait éclaté. Notre fraternité n'avait pas dure davantage. Inutile de relire mes notes de cette période: elles sont sinistres. Et guère d'images à montre non plus. Chacun vivait replié sur soi, et la caméra était devenue un témoin gênant."

${ }^{342}$ Essa cena corrobora a ideia de que, diante dos conflitos da esquerda, a câmera se torna uma testemunha embaraçosa. Sonia é uma personagem que traz um olho roxo (fruto da tortura, de acordo com o narrador). Após a discussão entre seus colegas, ela aparece em um quarto, sozinha e chorando, olha discretamente para a câmera e pede em um gesto discreto que o aparato seja desligado. Além de quebrar com os ambientes coletivos, a sequência é uma das poucas em que a presença do realizador é evidenciada. Da maneira como é montada, ela reforça uma dupla dimensão presente no filme: a denúncia da opressão por parte da direita e uma certa "vergonha" do próprio campo político devido aos rachas que eclodem, inclusive em momentos em que a tônica deveria ser a solidariedade.

${ }^{343}$ Nessa passagem das despedidas, há outro plano em que um refugiado revela consciência da presença do realizador, olhando diretamente para a câmera. Trata-se de uma personagem não identificada, que encara o aparato por alguns segundos, após ver seus colegas deixarem o prédio da "embaixada". É interessante notar que, nessas sequências finais, Marker insere uma música que passa um tom de nostalgia e quebra com os sons anteriores (restritos ao ruído do super-8, à voz over e ao silêncio de algumas cenas). A expressão da mulher, no contexto em que está inserida, demonstra uma certa incerteza em relação ao futuro.
} 
Portanto, a crítica que Marker faz às divisões dentro da Unidade Popular, bem como o risco de que elas se repetissem no contexto francês, é evidente em L'ambassade. A própria montagem do filme valoriza momentos de convivência entre os personagens, que aparecem - com exceção desse trecho final - em atividades comunitárias. Essa opção dialoga, assim, com uma corrente da esquerda que atribuiu o fracasso da Unidade Popular não apenas ao boicote da direita e dos Estados Unidos, como também às discussões políticas que romperam com a união anterior.

Se a Unidade Popular havia sido um modelo para a gauche francesa, seus erros se tornavam uma espécie de "contramodelo", ou seja, as razões de sua desarticulação deveriam ser vistas como "lições" a serem evitadas. A proximidade entre os projetos políticos das duas esquerdas, que exaltava a experiência chilena na Europa, se transformava em um receio dos riscos que essa proximidade poderia acarretar. O cenário trágico do Chile pós-11 de setembro assombrava uma França que havia passado os últimos três anos encontrando semelhanças entre sua própria história política e a do país latino-americano.

Nesse sentido, a tomada da Torre Eiffel que encerra L'ambassade traz à cena uma discussão bastante frequente entre intelectuais, artistas e políticos franceses após o golpe de Estado chileno: poderia a França passar por uma experiência fascista (como era classificada a ditadura chilena na Europa) e sangrenta como a vivida no Chile? O filme de Marker termina indicando essa possibilidade - pelo menos em termos de ficção científica - ao relacionar os episódios de refúgio político e da partida para o exílio a uma Paris cercada e vigiada. Vale, portanto, repetir o último trecho da voz over: "Da janela da embaixada, eu rodei meu último plano: a caminhonete que os levava ao exílio, e essa cidade que nós havíamos conhecido livre.” (L’ambassade, 1974 , tradução nossa) ${ }^{344}$.

Após o golpe de Estado, o temor de que a França pudesse passar por uma situação semelhante à do Chile se Mitterrand vencesse as eleições foi bastante explorado pela direita e pela extrema-esquerda, que rechaçavam o programa comum dos radicais, comunistas e socialistas. Um artigo do Le Monde dedicado ao golpe de Estado, publicado em 22 de setembro de 1973, intitulado Santiago-sur-Seine, reproduzia alguns trechos divulgados pela imprensa de direita que faziam uso da

\footnotetext{
${ }^{344}$ Texto da voz over de L'ambassade, traduzido do original: "D'une fenêtre de l'ambassade, j'ai tourné mon dernier plan: la camionnette qui les emmenait en exil, et cette ville que nous avions connue libre."
} 
proximidade entre as duas esquerdas para atacar a união francesa. Em Aspects de la France, Pierre Pujo dizia que o ensinamento a ser tirado da experiência chilena era o de que o socialismo, enquanto regime, conduzia um "país relativamente próspero" à "penúria". E seguia seu artigo de forma atemorizante:

Não creiam que as coisas seriam muito diferentes na França. Senhor Mitterrand no poder, encabeçando uma coalizão de esquerda, aplicaria as nacionalizações previstas no programa comum (os comunistas estariam lá, quando necessário, para lembrá-los da ordem), estenderia a influência do Estado sobre um número crescente de atividades, enquanto veríamos os esquerdistas se impor ao governo, instalando aqui e lá os soviéticos. Senhor Mitterrand seria aprisionado em uma engrenagem, como o foi Salvador Allende. (PUJO Apud SANTIAGO, 1974, p. 5)

O uso político do golpe de Estado do general Pinochet não foi mérito da direita, como mostra o caso anterior, mas aparece também em publicações de partidos de esquerda que não compactuavam com o programa comum. O partido Lutte ouvrière divulgou, após a queda da Unidade Popular, um suplemento com perguntas e respostas acarretadas por esse evento. Os questionamentos refletiam dúvidas que circulavam na França nessa época, trazendo possibilidades fatalistas. Um exemplo pode ser visto na questão: "Em caso de vitória da união da esquerda, o exército francês pode desempenhar o mesmo papel que o exército chileno?" (LUTTE, 1974?, p. 12, tradução nossa). Ou ainda: "Mitterrand e [Georges] Marchais nos defenderiam melhor do que Allende?" (LUTTE, 1974?, p. 13, tradução nossa). Ou mais diretamente: "Mitterrand poderia um dia ser fuzilado pela burguesia?" (LUTTE, 1974 ?, p. 40, tradução nossa) ${ }^{346}$. Atribuindo as razões do fracasso ao fato de o exército chileno não estar na mão dos trabalhadores e desses não terem sido armados, o texto critica abertamente a postura do PCF e do PS franceses:

As tomadas de posição dos dirigentes do Partido Comunista francês e do Partido Socialista, logo depois do golpe chileno são perfeitamente claras. Eles não tiraram nenhuma lição desses eventos

\footnotetext{
${ }^{345}$ Traduzido do original: "Ne croyons pas que les choses se passeraient très différemment en France. M. Mitterrand au pouvoir à la tête d'une coalition de gauche appliquerait les nationalisations prévues dans le programme commun (les communistes seraient là, au besoin, pour le rappeler à l'ordre), étendrait l'emprise de l'État sur un nombre croissant d'activité, cependant qu'on verrait les gauchistes tenter de forcer la main au gouvernement et installer ici et là des soviets. M. Mitterrand serait pris dans un engrenage comme le fut Salvador Allende."

${ }^{346}$ Perguntas traduzidas do original: "En cas de victoire le l'union de la gauche, l'armée française pourrait elle jouer le même rôle que l'armée chilienne?". "Mitterrand et Marchais nous défendraient-ils mieux qu'Allende?". "Mitterrand pourrait-il un jour être fusille par la bourgeoisie?".
} 
e, ao contrário, declararam que não pretendem mudar em nada sua politica. (LUTTE, 1974?, p. 13, tradução nossa) ) $^{347}$

O próprio Chris Marker, em depoimento à pesquisadora, reconhecia o temor instaurado nas discussões políticas francesas após o golpe de Estado chileno. Utilizando da ironia que lhe era cara, o realizador respondeu sobre a aproximação entre os dois projetos políticos, negando-lhes semelhança. No entanto, sua própria filmografia confirma o interesse gerado na França pela Unidade Popular, assim como os temores que se instauraram após sua queda. Vale, portanto, analisar suas palavras sobre o prisma de um objeto de memória, elaborado inclusive posteriormente ao mandato de Mitterrand concretizado em 1981 (o que fez do projeto da esquerda no poder um fato histórico real, e não uma possibilidade):

Não havia verdadeiramente comparação alguma a ser feita entre a UP e a união da esquerda na França. As bases políticas e sociológicas eram totalmente diferentes. A única ligação, tênue, era a obsessão que nós depositávamos em Mitterrand de "não terminar como Allende". Mas não havia risco. Sem interesses americanos diretamente em jogo, sem a CIA em emboscada, sem sindicatos de direita, como o dos caminhoneiros no Chile, e, do lado comunista, era mais fácil se livrar de Georges Marchais que de Luis Corvalán. (MARKER, 2011, tradução nossa) $)^{348}$

Em L'ambassade, o risco da tragédia se repetir é evocado, como foi dito, pela mudança do índice de lugar do Chile para a França na sequência final. No entanto, mais do que um risco de repetição, esse fato pode ser visto como uma chance de reviver a experiência anterior, de uma outra maneira. Nesse sentido, existe nessa produção um tempo em espiral, que é revisitado com outras configurações. Essa ideia é uma frequente na obra de Chris Marker, e determinante em filmes como La jetée e Sans soleil (1983), que retomam a ideia de tempo espiralado de Vertigo - como já foi analisado. Sob essa perspectiva, a passagem do cenário de L'ambassade do país latino-americano para o europeu o caracterizaria como a repetição de uma mesma história, porém em outro tempo e lugar - inclusive com o potencial de encontrar um

\footnotetext{
${ }^{347}$ Traduzido do original: "Les prises de position des dirigeants du Parti Communiste Français et du Parti Socialiste, au lendemain du putsh chilien, sont parfaitement claires. Ils n'ont tiré aucune leçon de ces événements, et ont au contraire déclaré qu'ils n'entendaient changer en rien leur politique."

${ }^{348}$ Traduzido do original: "Il n'y a vraiment aucune comparaison à faire entre l'UP et l'Union de la Gauche en France. Les bases politiques et sociologiques étaient vraiment trop différentes. Le seul lien, ténu, serait l'obsession qu'on a prêtée à Mitterrand de "ne pas finir comme Allende". Mais il n'y avait pas de risque. Pas d'intérêts américains directement en jeu, pas de CIA en embuscade, pas de syndicats de droite comme les camionneurs au Chili, et côté communistes il était plus facile de se débarrasser de Georges Marchais que de Luis Corvalán."
} 
novo final. É justamente a ambiguidade causada pela presença insinuante (fora de campo) do contexto chileno, contraposta à certeza da ocorrência dos fatos em Paris, que permite essa leitura.

Uma frase da voz over de L'ambassade resume a relação entre passado e presente, memória e trauma, tal como sugerida pelo filme: "O passado é como o estrangeiro: não é uma questão de distância, é a passagem de uma fronteira" (L'ambassade, 1974, tradução nossa) ${ }^{349}$. Em um tempo espiralado, os acontecimentos podem ser revisitados, mas nunca da mesma maneira: uma vez passada a fronteira, a volta traz o indivíduo transformado pela experiência vivida. Portanto, como numa viagem, as situações passadas deixam uma marca indelével no indivíduo. Criada pelo realizador para esse filme, a sentença se refere também ao papel do "estrangeiro" - do outro - para modificar nossa própria natureza. Ou, aplicando de forma simplificada ao caso específico, o papel do Chile para transformar a realidade francesa.

Nessa perspectiva, emerge novamente a busca por um legado político da experiência chilena, uma estratégia presente também em outras obras de Marker realizadas em contextos de derrota. Após o golpe, restavam os ensinamentos deixados por essa experiência para a própria esquerda chilena e para as esquerdas que acreditavam na via democrática, como a francesa. Se, em La spirale, a lição a ser tirada era a necessidade de se conhecer o inimigo, em L'ambassade existe uma mensagem clara em prol da união e do apaziguamento das divergências nesse campo político. Assim, o filme encena uma realidade vivenciada pelo diretor - e que lhe é indesejada - de desentendimentos internos que dificultam ações vitoriosas por parte da esquerda. É necessário compreender, como será analisado, de que maneira ele representa esse cenário, fazendo do ambiente da embaixada um caso exemplar da sociedade como um todo.

Por fim, vale ressaltar uma dimensão que não deve ser perdida ante a chamada da França à cena em L'ambassade: o exílio chileno no país e a consequente necessidade de se consolidarem redes de solidariedade para receber as vítimas do golpe de Estado, como já foi salientado. A recepção desses exilados aproximaria ainda mais as esquerdas chilena e francesa, delegando uma responsabilidade de cooperação mútua entre essas dois grupos políticos de concepções teóricas e estratégias semelhantes. Nesse caso, a sequência final poderia representar um

\footnotetext{
${ }^{349}$ Texto da voz over de L'ambassade, traduzido do original: "Le passé, c'est comme l'étranger: ce n'est pas une question de distance, c'est le passage d'une frontière.".
} 
intervalo de tempo entre esses dois lugares - Chile e França -, em uma referência clara ao fato de os personagens refugiados na embaixada terem seguido para a Europa (evidenciada pelo avião que cruza o céu de Paris na última tomada). 


\section{A esquerda teatralizada: solidariedade e conflitos}

Conforme já foi dito, L'ambassade foi feito com atores não profissionais (ou "amigos" do realizador), que seguiam um roteiro que não lhes indicava a priori o resultado esperado com suas ações para o desenvolvimento de um enredo. Assim, a montagem e a voz over foram as responsáveis por manipular o material fílmico gravado, dando-lhe um sentido que não estava determinado na mise-en-scène portanto, como ocorria com o "efeito Kulechov", uma mesma interpretação cênica poderia servir a distintos significados, dependendo dos demais planos com os quais estava articulada, bem como do comentário ao qual era submetida.

Este capítulo mostrou que Marker desenvolveu uma espécie de experimento, que mistura práticas e características do documentário e da ficção, resultando em um filme híbrido. Vale acrescentar, todavia, que esse limite tênue entre gêneros passa também por uma não delimitação clara entre ator e personagem. O realizador utilizou simultaneamente distintas configurações na construção de seus "refugiados políticos", o que confunde o espectador e contribui para a elaboração de conclusões dúbias. Há em seu filme, por exemplo, personagens reais (caso de Volodia Teitelboim e de seu filho), que são interpretados por "atores". Porém, o contrário também ocorre: personalidades reais desempenham o papel de refugiados "ficcionais" 350 . Alguns dos "convidados" de Marker para essa experiência interpretam a si mesmos (como a feminista Carole Roussopoulos).

Essa mescla de procedimentos no que diz respeito aos atores e à mise-en-scène colabora para que L'ambassade seja um filme difícil de decifrar, repleto de pistas, algumas das quais não podem ser esclarecidas. No tocante aos personagens, cada um deles traz referências herméticas relativas à esquerda europeia ou latino-americana da época, bem como aos seus debates internos, tornando um desafio gigantesco resolver esses enigmas. No entanto, mesmo sem o conhecimento pleno de cada uma dessas figuras dúbias, a análise dos personagens permite conhecer aspectos fundamentais para a compreensão do filme. O primeiro exercício necessário é entender a maneira como Marker articula realidade e ficção, impossibilitando uma distinção clara entre ator e personagem. Em seguida, cabe verificar como cada um deles representa, no

\footnotetext{
${ }^{350} \mathrm{O}$ personagem militante Théo parece ser interpretado por Théo Robichet, um dos diretores de Septembre chilien, ao lado de Bruno Muel.
} 
âmbito da mise-en-scène, correntes políticas da esquerda - teatralizam esse campo político, expondo algumas de suas divergências. Por fim, deve-se ter em conta que a relação entre esses personagens leva a conclusões sobre a maneira pela qual Marker representa o mundo da esquerda em seu conjunto, inserindo essa representação no âmbito das discussões sobre a Unidade Popular e sobre o programa comum.

A voz over $^{351}$ é a responsável pela apresentação dos personagens, já que esses não trazem outras caracterizações que permitam encaixá-los em um determinado grupo político ou em outro. Embora alguns deles tenham traços indígenas, o que lhes atribuiria uma origem latino-americana, em termos de figurino eles aparentam pertencer a um mesmo grupo socioeconômico: a classe média. Essa impressão é confirmada por uma das falas do narrador - que assume em toda produção um tom irônico, frequente nos comentários markerianos -, que justifica a ausência do operariado entre os refugiados:

Havia professores, estudantes, intelectuais, artistas, profissionais da política. Nenhum operário. As fábricas tinham recebido a mesma ordem que os universitários: resistir o máximo possível. Depois, a retirada. Ocorre que é muito raro que se construam fábricas próximas às embaixadas. (L'ambassade, 1974, tradução nossa) ( $^{352}$

A ironia de Marker nesse comentário atinge uma das fraquezas políticas da esquerda, fruto da preponderância de quadros vindos da burguesia e da relativa ausência do proletariado como autor dos projetos políticos destinados a ele. No caso da Unidade Popular, a falta de consolidação de um poder popular autônomo foi constantemente apontada como uma das razões de sua queda, e era indicada também como um dos pontos fracos do programa comum do PCF, do PS e dos radicais franceses. No debate reforma versus revolução, as críticas à união da esquerda apontavam para a fragilidade em transferir, de fato, o Estado e seus aparatos às classes populares. Apesar de indireta, essa crítica aparece em L'ambassade por meio da voz over. Ela declara que, embora os operários fossem "bem-vindos" na teoria, na prática, havia uma impossibilidade de acolhê-los devido à perpetuação da exclusão e da desigualdade, materializada no plano urbanístico da cidade.

\footnotetext{
${ }^{351}$ É interessante notar, conforme coloca Martin Barnier (2008) em Chris Marker: le son, une band à part, que Marker elege como locutor um estrangeiro, assim como fez em vários de seus filmes, concedendo um sotaque sul-americano ao personagem-realizador.

${ }^{352}$ Texto da voz over de L'ambassade, traduzido do original: "Il y avait là des professeurs, des étudiants, des intellectuels, des artistes, des professionnels de la politique. Pas un ouvrier. Les usines avaient reçu la même consigne que les universités: tenir tant que c'est possible. Après, le repli. Seulement voilà, il est très rare qu'on construise des usines à proximité des ambassades."
} 
O narrador é o primeiro personagem apresentado, já que suas palavras iniciais caracterizam o filme como uma espécie de diário audiovisual de sua autoria. No entanto, ele fornece poucas dicas sobre si mesmo, não se posicionando claramente dentro de uma linha política ou de outra, além de preservar sua imagem dos olhos do espectador (como foi dito, todas as tomadas são subjetivas a ele, tornando seu rosto invisível). Poucas vezes ele fala em primeira pessoa. Uma delas é quando apresenta Mike, um fotógrafo, que exerce a mesma função que ele, "mas profissionalmente". Essa descrição, embora se refira ao colega, serve para marcar sua posição como realizador amador (o que justifica a escolha pelo super-8). Em outro momento, ele evoca um dito popular de seu país - ou de sua região -, dando a impressão que é, portanto, um estrangeiro ${ }^{353}$ : "Na minha terra, os camponeses dizem que a angústia é um urso preto, que é necessário caçar ao custo de risos e gritos, senão ele vem colocar sua pata sobre você, e você não pode mais se mover" (L'ambassade, 1974, tradução nossa) $)^{354}$.

Nessa frase, percebe-se que ele se põe em um lugar diferente dos demais, analisando-os, registrando-os e, muitas vezes, criticando-os por meio de ironias sutis. Assim, embora seja também um refugiado, ele procura o lugar de um observador, que não participa diretamente das ações. Essa distância permite que ele emita comentários que soem como ensinamentos, como esse em que diz que é necessário enfrentar a angústia - reagir frente à derrota - para evitar que ela leve à inércia. Pode-se dizer, portanto, que sua posição é próxima à do próprio Chris Marker, já que o diretor, um homem de esquerda, critica esse campo político em L'ambassade (como o refugiado que, mesmo sendo um deles, pode ver suas fragilidades e seus erros).

Outro personagem que se diferencia dos demais é o próprio embaixador. Inspirado em Harald Edelstam e outros embaixadores que acolheram perseguidos políticos, ele é mostrado como um verdadeiro anfitrião (assim como a embaixatriz e a recepcionista), registrado em contraplongée no primeiro plano em que aparece, o que lhe dá um ar altivo. Ao lado de Volodia, destaca-se dos demais por usar terno e aparentar mais idade. Sobre ele, a voz over tece apenas comentários positivos, embora haja uma ironia em descrever sua conduta impecável diante de uma situação extrema:

\footnotetext{
${ }^{353}$ Vale destacar que, embora apresente um sotaque com traços sul-americanos, a referência a um "urso preto" no dito popular remete a uma origem europeia, asiática ou norte-americana. Desse modo, não há uma indicação clara sobre a nacionalidade do narrador.

${ }^{354}$ Texto da voz over de L'ambassade, traduzido do original: "Chez moi, les paysans disent que l'angoisse est un ours noir, qu'il faut chasser à force de rires et de cris, sinon il revient poser sa patte sur vous, et vous ne pouvez plus bouger."
} 
"O embaixador é perfeito. Ele os acolhe simplesmente, como a convidados ligeiramente adiantados para uma recepção." Ou, ainda, quando ele decide passar o aspirador para dar o exemplo aos demais: "O embaixador dá o exemplo passando ele mesmo o aspirador. É um pouco escoteiro, mas é divertido." (L'ambassade, 1974, tradução nossa) ${ }^{355}$ Apesar desse tom irônico provocado por um certo protocolo que se mantém após a tragédia, o casal é compreensível e solidário com os refugiados, escutando suas narrativas e aconselhando-os.

Nesse corpo diplomático, entre os personagens que não fazem parte do grupo de refugiados, está Lou, a recepcionista da embaixada. Assim como seus patrões, ela é retratada de maneira positiva, como alguém que recebe os militantes de esquerda de maneira acolhedora. Apesar de sua orientação política não ser revelada, ela está entre as pessoas que mais aparecem nas tomadas, participando ativamente, sobretudo dos momentos comunitários (está ao lado das duas sul-americanas, por exemplo, na cena em que a câmera enfoca suas reações ante os informes da Junta Militar, além de ser a responsável pelas refeições). Sua função na narrativa é receber e integrar. O mais interessante, no entanto, é analisar a construção dessa personagem para entender os métodos cênicos adotados por Marker. Vale ressaltar que ela é um dos exemplos em que ator e personagem se misturam, já que ela interpreta o papel de si mesma. $O$ filme foi gravado em sua casa - Lou, a da "vida real", era a companheira do pintor Wilfredo Lam e a amiga do realizador que cedeu o cenário para as gravações. Essa mescla entre realidade e ficção explica por que ela sempre age como alguém que recebe os demais convidados, como se fosse a dona da casa. É provável que Marker tenha lhe tenha atribuído uma função no enredo - assistente do embaixador - posteriormente, na montagem.

Os demais personagens - com exceção das crianças e da tartaruga ${ }^{356}$ - trazem uma indicação de pertencimento a algum grupo político ou social específico, sendo que alguns deles recebem mais destaque por participarem ativamente do grande debate que encena as discordâncias da esquerda. Os estudantes, por exemplo, são os

\footnotetext{
${ }^{355}$ Textos da voz over de L'ambassade, traduzido do original: "L'ambassadeur est parfait. Il les accueille simplement, comme des invités légèrement en avance pour une réception." "L'ambassadeur donne l'exemple en passant lui-même l'aspirateur. C'est un peu boy-scout, mais ça égaie."

${ }^{356}$ Há também a personagem Sônia, que aparece diversas vezes, inclusive no plano-sequência já citado em que ela olha diretamente para a câmera ao final do filme. No entanto, ela não é relacionada a nenhuma corrente política ou grupo social que permita situá-la nas discussões da esquerda. Ela tem um olho roxo, única referência que o narrador faz a ela, dizendo que traz ainda marcas de sua passagem pela polícia.
} 
primeiros refugiados políticos apresentados, ainda na quarta-feira, quando chegam à embaixada. Um deles, não nomeado, é filmado em uma longa sequência, sentado no chão e falando com o embaixador: "Como se mais ainda do que descansar e comer, eles tivessem de saciar a necessidade de contar, de dividir isso que lhes havia caído sobre a cabeça" (L'ambassade, 1974, tradução nossa) ${ }^{357}$. Ele narra o ataque dos militares a uma escola. O outro estudante é chamado de Marco, cujo pessimismo frente ao "otimismo revolucionário" possibilitou que eles fossem até a embaixada. Marker não atribui a eles uma corrente de pensamento específica, mas pode-se dizer que representam um setor importante da esquerda, o movimento estudantil.
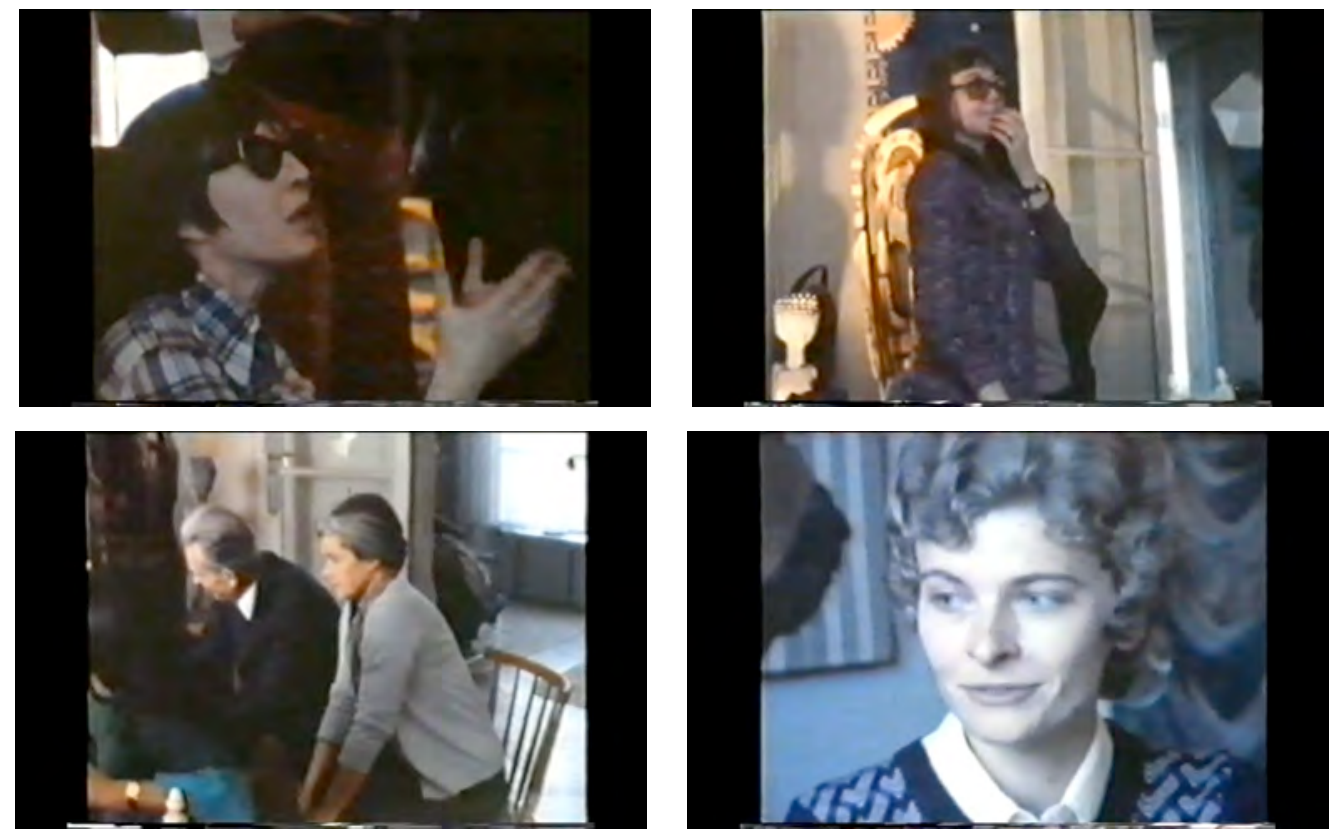

Personagens de L'ambassade: acima, à esquerda, um dos estudantes; acima. à direita, Lou. Em baixo, casal de embaixadores (à esquerda) e Maria (à direita).

Da mesma forma, outros personagens são exemplares de grupos sociais que participavam da Unidade Popular e que estavam refugiados nas embaixadas de Santiago após o 11 de setembro. Um deles é o formado por exilados de outros países (especialmente sul-americanos), vítimas de golpes em suas próprias nações, que haviam buscado abrigo em um governo de esquerda. Muitas pessoas encontravam-se nessa condição e tiveram que seguir para outros exílios com a instauração da ditadura chilena, e a Europa parecia um abrigo mais seguro. Em L'ambassade, essas pessoas

\footnotetext{
${ }^{357}$ Texto da voz over de L'ambassade, traduzido do original: "Comme si plus encore que de se reposer, de manger, ils avaient à assouvir le besoin de raconter, de partager ce qui leur est tombé sur la tête."
} 
são representadas pela figura de Maria ${ }^{358}$, a "mais calma" entre todos - nas palavras da voz over -, já que era a terceira vez, cada uma delas em um país diferente, em que se encontrava nessa situação.

Maria se destaca ainda em uma cena em que procura ler o futuro em uma borra de café, acompanhada de um dos estudantes e do casal de embaixadores. Novamente ela mostra uma postura reconfortante aos demais. A voz over declara que nesse momento, pela primeira vez, a angústia não estava lá. É interessante notar, nessa passagem, como o realizador atribui à continuação da luta (na figura de uma refugiada persistente) a função de uma estratégia para não se deixar abater, já que, como havia declarado, era necessário caçar o "urso" que representa esse sentimento antes que ele os imobilizasse. No entanto, usando um procedimento constante em L'ambassade de ironizar mesmo os momentos apaziguadores, Marker insere, na sequência posterior, o assassinato do homem que tentava entrar na embaixada, como se as previsões para o futuro fossem as piores.

Outro personagem que representa um grupo social é Mike, o fotógrafo, mostrado apenas em um plano rápido em que aparece oculto por sua câmera, registrando os demais. Por meio dele, Marker fala sobre a censura e a intervenção sofrida pela imprensa que apoiava o governo anterior. Ele é apresentado pela voz over que, ao informar sobre a interdição do jornal onde trabalhava e a criação de um novo ministério de informação, afirma que as informações dadas pela Junta não eram verídicas. Assim como o próprio narrador, Mike buscava servir à contrainformação, revelar a realidade, mas enfrentava barreiras intransponíveis para isso: "Então, ele estava bloqueado como os outros, e brincava de nos fotografar. Como não havia laboratório fotográfico na embaixada, essas imagens nossas ficavam em suspenso, como nós." (L’ambassade, 1974, tradução nossa) ${ }^{359}$

A presença de Mike, embora ele só apareça em um plano curto, é importante por abordar a vontade de registrar e denunciar uma situação, e as dificuldades em

\footnotetext{
${ }^{358} \mathrm{O}$ nome dessa personagem, Maria, pode ser uma referência à brasileira Maria Augusta Carneiro, que aparece em On vous parle du Brésil: tortures e na primeira versão de O fundo do ar é vermelho. Após sua ida a Cuba, fruto das negociações para a liberação do embaixador norte-americano, Charles Elbrick, ela esteve exilada no Chile, até o golpe de Estado, quando seguiu para a Suécia. De todo modo, a personagem exemplifica situações como a dela, de pessoas que viviam um novo exílio com o golpe, sobretudo sul-americanos vítimas de outras ditaduras e que, do Chile, chegavam em 1974 à Europa.

${ }^{359}$ Texto da voz over de L'ambassade, traduzido do original: "Donc il est bloqué là comme les autres, et il défoule en nous photographiant. Comme il n'y a pas de labo photo dans l'ambassade, ces images de nous restent en sursis, comme nous."
} 
fazê-lo frente à repressão e à falta de condições materiais. O fotógrafo segue seu trabalho, insiste em documentar, embora pareça um esforço em vão, já que as fotos não sairão de sua máquina (e de sua memória). Essa questão, como será abordado, comprova o peso que Marker atribui aos testemunhos como forma de denunciar a repressão, tendo em vista a impossibilidade de outras provas materiais.

Mike faz também um contraponto com o próprio narrador, um realizador amador. Profissional, ele está impossibilitado de exercer seu trabalho, mas o operador de super-8 pode atuar. Pensando esse paralelo para além do enredo, a presença de Mike justifica o porquê de se produzir um relato fílmico inventado: diante da falta de provas reais, a denúncia encontra viabilidade na produção ficcional. Assim, Marker sabe o que se passou nas embaixadas, por meio do testemunho oral, e por isso produz imagens que não puderam ser produzidas no contexto real. Trata-se de uma espécie de reparação: o amador, na ficção, realiza o que o profissional, no documental, não pôde fazer. Essa ideia será retomada na conclusão deste capítulo.

Como já foi dito, alguns atores fazem o papel de membros reais da Unidade Popular. O caso mais emblemático é o do personagem Volodia, uma clara alusão a Volodia Teitelboim, e seu filho Claudio Bunster ${ }^{360}$. Entre os últimos a chegar, na quinta-feira, a voz over informa que eles estavam cansados após passarem a noite queimando documentos, enquanto a câmera mostra um certo improviso dos outros para arranjar um leito de descanso para os recém-chegados. Em outro momento, o advogado e seu filho jogam xadrez para passar o tempo - assim como os demais refugiados, que buscam atividades para se entreter e vencer o tédio da reclusão forçada. É curioso notar que Marker escolheu a figura desse líder do Partido Comunista chileno para ter um papel de destaque, mesmo que sua inserção em L'ambassade contribua para desarticular sua estratégia de se passar por um documentário, já que o mesmo se encontrava em Moscou no 11 de setembro, onde permaneceu no exílio por quinze anos. Portanto, apenas na ficção ele poderia ter sido refugiado em Santiago.

Cabe perguntar por que Marker elegeu Volodia como um dos poucos personagens existentes na vida real. Uma hipótese é seu papel de destaque no Partido

\footnotetext{
${ }^{360}$ Claudio Bunster, antes Claudio Teitelboim - ele mudou de nome após descobrir que Volodia não era seu pai biológico, em 2005 - é um conceituado físico chileno, que terminou seu doutorado em 1973 e lecionou em importantes universidades norte-americanas. $O$ filho que acompanha o Volodia da ficção L'ambassade é apresentado pela voz over como um químico, mais uma evidência clara de que se trata dos dois chilenos ligados à UP.
} 
Comunista Chileno, pelo qual foi senador de 1965 a 1973 e um dos fundadores do periódico El Siglo. No entanto, é mais provável que essa escolha seja decorrente do alcance internacional de sua figura, sobretudo de sua inserção nos meios políticos franceses. Literato, além de político, usou essa dupla habilidade para encabeçar publicações que tiveram grande repercussão internacional, como a revista Araucaria de Chile, que circulou entre 1978 e 1990, tornando-se um dos ícones da resistência organizada desde o exílio. No caso de sua relação com a França, uma reportagem publicada na ocasião de sua morte, pela $B B C$ mundo, em 2008, indica que sua viagem à Europa na época do golpe tinha a seguinte pretensão:

"O presidente Salvador Allende havia enviado-me para conversar com François Mitterrand, então secretário-geral do Partido Socialista da França, e com outros amigos do Chile para contar-lhes a tensa situação que se vivia no país, quando ocorreu o golpe", nos disse. (TOLEDO, 2008, tradução nossa) ${ }^{361}$

Dessa forma, a presença de Volodia é emblemática em L'ambassade. É provável que o advogado tenha estado na França pouco antes do golpe, alardeando a difícil situação em que se encontrava o governo de Salvador Allende, e que tenha buscado apoio justamente em Mitterrand, que se inspirava na experiência chilena. Por outro lado, ele se tornava um dos ícones da luta que seguia no exílio quando o filme foi divulgado, uma dimensão para qual a produção de Marker também aponta. É notável que, embora membro do Partido Comunista, o personagem-Volodia não participe do conflito entre as diversas correntes políticas que é posto em cena no final. O realizador prefere, assim, inserir um comunista sem vínculo com o mundo real para protagonizar as disputas, preservando o líder da UP.

A personagem Jeanne representa a classe artística. No enredo, após a morte do homem que tentou entrar na embaixada e o isolamento definitivo do prédio, ela relembra o seu país como se recordasse um tempo passado, por meio de canções. $\mathrm{Na}$ maior parte das sequências em que aparece, Jeanne toca um violão, e está ao lado de Isabel, caracterizada apenas como "mãe das crianças". É provável que o nome de sua companheira faça uma referência à figura de Isabel Parra (uma das expoentes da Nueva Canción Chilena, filha de Violeta Parra), que na época de lançamento do filme chegava a Paris após passar pelo exílio em Cuba e Berlim. Assim como essas duas

\footnotetext{
${ }^{361}$ Traduzido do original: “'El presidente Salvador Allende me había enviado a conversar con François Mitterrand, entonces secretario general del Partido Socialista de Francia, y con otros amigos de Chile para contarles la tensa situación que se vivía en el país, cuando ocurrió el golpe', nos dijo."
} 
personagens da ficção, a Isabel da vida real se refugiou em uma embaixada - no caso, a da Venezuela - antes de deixar o Chile.

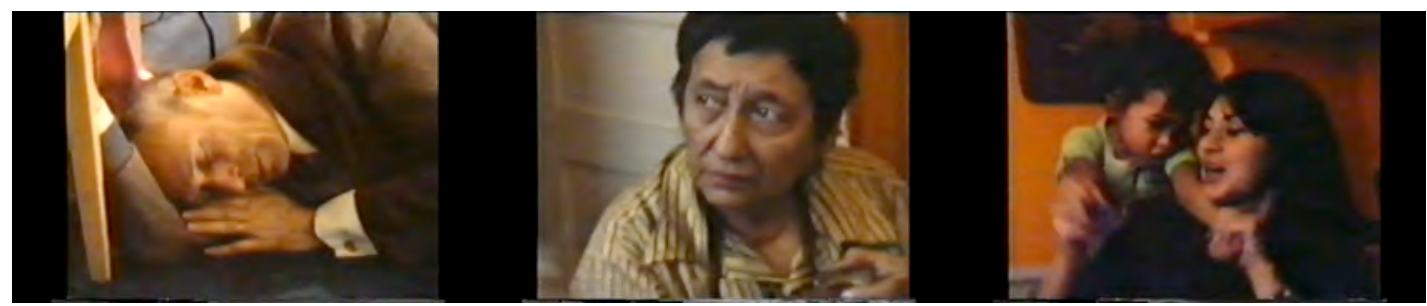

Os personagens Volodia, Isabel e Jeanne, de L'ambassade, respectivamente.

A cena das duas cantando na cozinha seguidas por Jonas, uma das crianças, é uma das poucas sequências alegres do filme. Mas é acompanhada por uma profunda melancolia, expressa nas palavras do narrador. Essa sequência permite a ele concluir que uma fronteira foi ultrapassada. A voz over diz sobre Jeanne:

Jeanne compõe e interpreta canções muito bonitas, frequentemente cantos de luta. Faz apenas uma semana que ela cantava em público, diante de milhares de pessoas que seguiam seu ritmo. Foi somente essa noite que eu pensei que isso acabou, que ela nunca mais cantaria dessa maneira. (L'ambassade, 1974, tradução nossa) ${ }^{362}$

Nesse trecho de L'ambassade, um dos poucos em que a voz over se posiciona em primeira pessoa, as canções de luta recordam ao narrador um tempo cronologicamente próximo, mas superado. A atuação da artista que antes servia para mobilizar, ganha um novo sentido: o de recordar, de manter na memória momentos liquidados. É a mudança de status dessas produções artísticas que trazem uma reflexão melancólica, já que se Jeanne cantava para uma multidão na semana anterior, e agora tem como público alguns poucos exilados. Essa passagem do filme mostra o dilaceramento provocado pelo golpe de Estado, que fez com que uma ação coletiva de grandes dimensões e participação popular fosse reduzida a migalhas. Os refugiados são sobreviventes de uma rica experiência, e resta o legado de serem objetos de sua memória.

Há ainda quatro personagens que merecem destaque, sobretudo por estarem envolvidos na cena que teatraliza os conflitos da esquerda ${ }^{363}$. A primeira dela é

\footnotetext{
${ }^{362}$ Texto da voz over de L'ambassade, traduzido do original: "Jeanne compose et interprète des chansons très belles, souvent des chants de lutte. Il y a une semaine encore, elle les chantait en public, devant un millier de personnes qui suivaient son rythme. C'est seulement ce soir que j'ai pensé que ça aussi, c'était fini, qu'elle ne chanterait plus jamais de cette façon-là."

${ }^{363}$ Vale destacar que há muitos personagens "figurantes", ou seja, que aparecem na embaixada, mas não são identificados pela voz over. Eles têm uma importância na trama sobretudo por participarem das
} 
Carole. Na trama, ela é apresentada entre os primeiros refugiados, caracterizada pela voz over como esposa de Tsikos (que será analisado a seguir). Em sua apresentação, ela é mostrada conversando enfaticamente com um dos estudantes, enquanto a câmera alterna close-ups em seu rosto e suas mãos, valorizando gestos e expressões como de quem necessita expor seus argumentos. O narrador reproduz algumas das informações que ela traria à conversa: o fato de ter dado força a sua irmã, traumatizada pela passagem dos policiais, que, ao chegarem a um imóvel onde só restavam mulheres, sequestraram e estupraram algumas delas, confiscando seus documentos para impedilas de sair. Nessa passagem, Marker aborda a violência sofrida pelas mulheres após o golpe de Estado, não por acaso utilizando para isso a feminista suíça Carole Roussopoulos $^{364}$.

Essa personagem é mais um exemplo das diferentes articulações que o realizador estabelece entre ator e personagem, já que Carole Roussopoulos interpreta ela própria. A feminista e seu marido, Paul Roussopoulos (que, no filme, interpreta Tsikos), compraram em 1969 uma câmera de vídeo portapack da Sony, aconselhados pelo dramaturgo Jean Genet, e criaram um coletivo de vídeo militante intitulado Video out, atuante no início dos anos 1970 em Paris. No entanto, em L'ambassade, ela está no papel de mais uma refugiada política, e sua atuação como realizadora não é informada.

A Carole da ficção é uma das principais debatedoras na discussão da esquerda. Após a exibição do informe da Junta Militar pela televisão ${ }^{365}$, um corte dá início a uma sequência dessa personagem falando enfaticamente a Luco e Tsikos. A câmera segue no mesmo plano-sequência, movimentando-se de modo que se alterne a exibição de sua imagem e da de Théo, que aparenta portar um tom enfático e um riso sarcástico. Em seguida, L’ambassade passa a mostrar Luco, discursando de maneira

ações coletivas, porém, não se destacam por pertencer a algum grupo social ou político. Por essas razões e pelas poucas pistas que Marker dá sobre eles, não aparecem mencionados nesta análise.

${ }^{364}$ Esse discurso da feminista Carole condiz com o de mulheres que estavam no Chile na ocasião do golpe de Estado. Um exemplo está no filme Septembre chilien (1974), de Bruno Muel e Théo Robichet. Os dois realizadores conseguiram registrar imagens feitas no país latino-americano logo após o 11 de setembro e, entre outras denúncias, entrevistaram duas brasileiras que se encontravam exiladas. Ambas relataram casos de violação, a prisão dos maridos no Estádio Nacional e a apreensão de documentos para impedi-las de sair. Dessa forma, é provável que a fala de Carole (tal como lhe é atribuída pela voz over de L'ambassade) tenha sido inspirada nesses registros documentais dessa outra produção da ISKRA.

${ }^{365}$ Pode-se dizer que o informe televisivo da Junta é uma espécie de anticlímax, pois marca uma ruptura entre as ações comunitárias e as brigas internas da esquerda. É ele que rompe com a solidariedade presente nas sequências iniciais, que será retomada de maneira muito mais amena no final, quando os personagens partem para o exílio. 
calorosa e buscando com o olhar a confirmação de suas palavras por parte do silencioso Tsikos. Vale, portanto, identificar a posição política - na ficção - de cada um desses personagens.
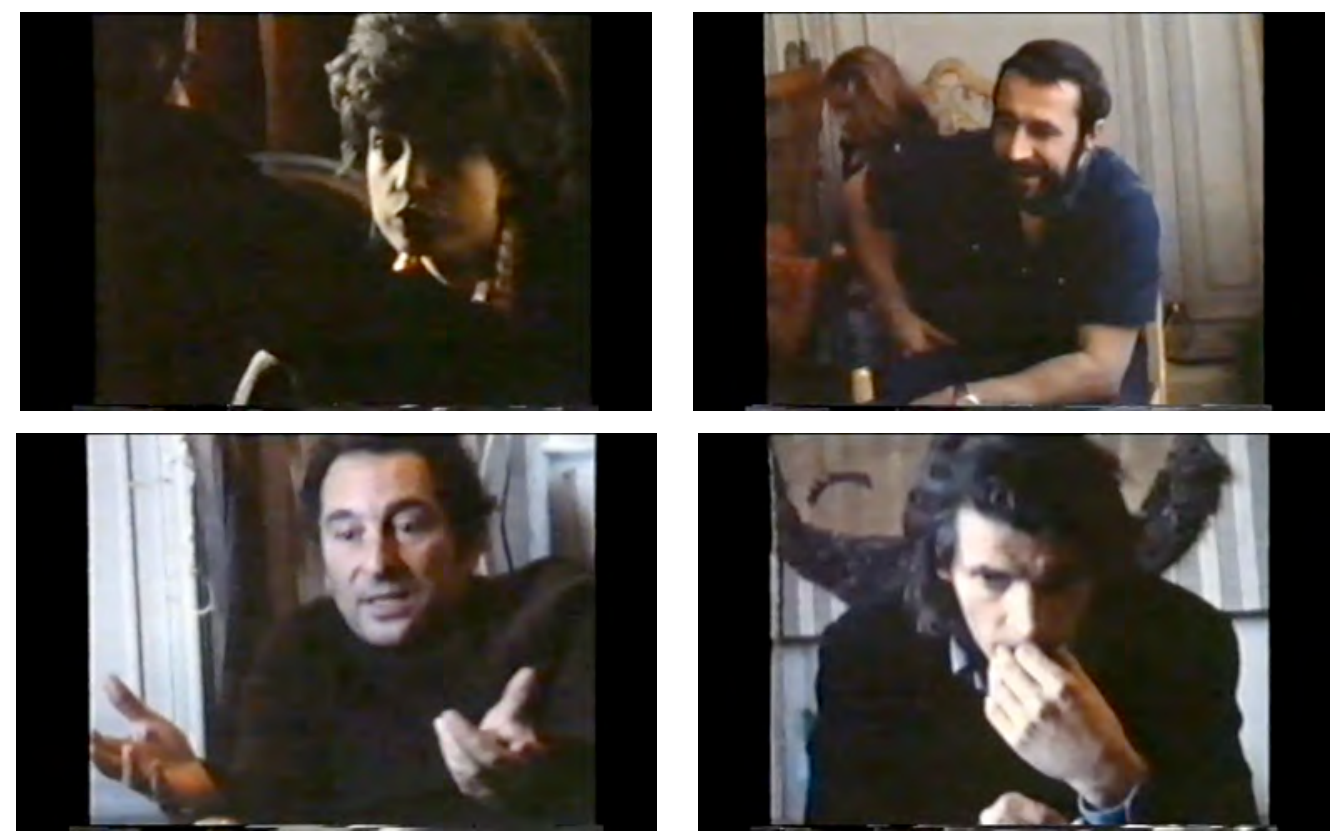

Personagens de L'ambassade. Acima, Carole (à esquerda) e Théo (à direita); em baixo, Luco (à esquerda) e Tsikos (à direita).

Carole é a que inicia o debate, ataca seus companheiros dizendo que deveriam compreender que "as famosas classes médias", as quais o projeto político derrotado pela ditadura almejava "seduzir e manter a qualquer preço", só seriam realmente cooptadas pela ordem reacionária. Nesse comentário inicial, percebe-se que ela se utiliza de um argumento caro aos revolucionários, que criticavam a união de esquerda por buscar aliança com setores da burguesia. A resposta do personagem Théo - que embora só apareça nesse plano é fundamental na discussão - leva a crer que Carole defendia a luta armada. O narrador descreve sua crítica a ela: “[...] Théo lançou que quando se é a tal ponto defensor da luta armada, parecia bom se refugiar em uma embaixada.". E completa, emitindo um juízo de valor a essa declaração: "Era um argumento muito injusto, mas ele não tinha mais argumentos." (L'ambassade, 1974, tradução nossa) $)^{366}$

\footnotetext{
${ }^{366}$ Textos da voz over de L'ambassade, traduzidos do original: “[...] Théo a lancé que quand on étaient à ce point partisan de la lutte armée, on avait bonne mine de se refugier dans une ambassade.". "C'était un argument très injuste, mais il ne s'agissait déjà plus d'arguments".
} 
"Essas eram feridas muito antigas, nunca completamente curadas, que se reabriam em cadeia" (L'ambassade, 1974, tradução nossa) ${ }^{367}$, declara o narrador. Após essa declaração, ele apresenta a opinião do personagem Luco. Ele já havia sido apresentado anteriormente, no momento em que recebia uma chamada telefônica que pedia notícias do homem morto ao tentar entrar no recinto. Nessa ocasião, porém, o espectador era informado apenas que Luco pertencia a um partido. Em suas declarações na discussão com Carole, é possível saber mais sobre esse personagem. Em L'ambassade, ele é mostrado com uma visão política próxima à do Partido Comunista Chileno, que defendia a via legal até as últimas consequências. A voz over define assim suas convicções políticas:

Luco defendia com fúria a política de seu partido, ele citava exemplos de ações desastrosas da extrema-esquerda, opondo-se a elas pela necessidade de uma análise científica baseada na realidade. Esse país era o que era, mesmo se fosse necessário deixar de lado os grandes temas líricos, a única política viável era uma lenta e prudente consolidação das forças populares, apoiada em uma verdadeira maioria. Essa política havia sido sabotada pelos iluminados e impacientes, e atualmente nós víamos o resultado. (L'ambassade, 1974, tradução nossa) ${ }^{368}$

Nessa discussão entre Carole e Luco, aparecem representadas as duas principais correntes políticas presentes no Chile da Unidade Popular. Tomás Moulian (2005), no texto La vía chilena al socialismo, defende que as distintas posições políticas no interior da UP existiam porque havia um objetivo comum - o socialismo -, apenas os meios para atingi-lo eram diversos. Nesse sentido, os debates sobre revolução versus reforma foram se ampliando com a crise econômica e política, fruto do boicote da direita, que colaborou para o acirramento das divergências no interior dessa aliança esquerdista. Um dos temas em que essas divergências apareciam com mais força dizia respeito à busca ou não do apoio da Democracia Cristã (que tinha grande entrada no eleitorado das classes médias). Enquanto a direção do Partido Socialista e do MIR defendiam que as reformas deveriam ser aceleradas e radicalizadas visando a se chegar numa sociedade de fato socialista, o Partido

\footnotetext{
${ }^{367}$ Textos da voz over de L'ambassade, traduzidos do original: "C'étaient de très vieilles plaies, jamais tout-à-faire guéries, qui se rouvraient en chaîne."

${ }^{368}$ Textos da voz over de L'ambassade, traduzidos do original: "Luco défendait avec acharnement la politique de son parti, il citait des exemples d'action hasardeuses de l'extrême-gauche, il leur opposait la nécessité d'une analyse scientifique basée sur les réalités. Ce pays était ce qu'il était, tant pis s'il fallait en rabattre sur les grands thèmes lyriques, la seule politique viable était dans une lente et prudente consolidation des forces populaires, appuyée sur une véritable majorité. Cette politique avait été saboté par des illumines et des impatiens, et maintenant on voyait le résultat."
} 
Comunista e setores do MAPU defendiam a tese da "acumulação de forças", que incluía possíveis acordos com a DC. Entre as máximas "avançar para consolidar" ou "consolidar para avançar", ampliavam-se os rachas internos.

Além da conquista das classes médias, a discussão entre Carole e Luco toca em um dos pontos fracos que dividia a esquerda chilena e que se tornou um tema ainda mais espinhoso após o golpe: a Unidade Popular deveria ter armado seus apoiadores para o caso de um enfrentamento com a direita? A tese do MIR e de uma parte do Partido Socialista defendia que a chegada ao poder pela via democrática deveria ser apenas uma etapa de sua conquista pelo povo, e que uma proteção armada era fundamental, argumento não acolhido pela Partido Comunista e por Salvador Allende (que, apesar de ser do PS, muitas vezes se aproximava mais das posições do PC). Se durante a UP essa discussão dividia a aliança, com a derrocada da experiência chilena pelo golpe militar ganharam força os argumentos dos que atribuíam à derrota uma crença exagerada nos caminhos legais. Essa discussão foi predominante no momento da queda e, para Moulian, escondia uma problemática mais ampla: "Em síntese, o problema da via pacífica versus a via violenta era um problema importante. Mas obscureceu outro mais importante ainda: o tipo de sociedade socialista que se desejava construir, qual deveria ser um socialismo democrático e participativo." (MOULIAN, 2005, p. 56, tradução nossa) ${ }^{369}$.

Embora o narrador indique o conteúdo da discussão entre Carole e Luco, essa cena é um bom exemplo de como Marker manipulou o material fílmico nas etapas de montagem e na inserção do comentário, concedendo-lhe um sentido diverso ao presente no momento da tomada. Ela também exemplifica de que maneira Marker recorreu a atores amadores, seus próprios amigos, propondo-lhes experiências não delimitadas a priori, método que corrobora o efeito documental - numa mise-enscène naturalista - desejado pelo realizador. Ao falar sobre o debate final do filme, no depoimento do diretor à autora, Marker revela uma informação inédita:

Para o grande debate ideológico final, eu havia tido o cuidado de colocar cara a cara um companheiro muito pró-israelense e um selvagem militante pró-palestina. Foi nesse ponto que eles gritaram um com o outro, e a imagem disso se tornou muito crível do enforcamento entre comunistas e esquerdistas. Eu não coloquei em

\footnotetext{
${ }^{369}$ Traduzido do original: "En síntesis, el problema de la vía pacífica versus la vía violenta era un problema importante. Pero oscureció otro más importante aun: el tipo de sociedad socialista que se deseaba construir, el cual debía ser un socialismo democrático y participativo."
} 
cena mais do que alguns momentos da suposta vida dessa embaixada. (MARKER, 2011. tradução nossa) $)^{370}$

O narrador-realizador não toma partido na discussão. No entanto, seus comentários levam o espectador a uma certa simpatia por Tsikos. Entre os primeiros refugiados a chegar, ele é apresentado como um militante anarquista e um ator conhecido. De tão conhecido, não tardou a ser reconhecido na rua e foi salvo de ser torturado por um soldado, que em seguida lhe pôs em liberdade. A voz over, após contar essa história, declara que, enquanto uns viam nela uma prova do apoio da esquerda no exército, outros enxergavam apenas a admiração o ator causava. Ele é introduzido ao espectador como o marido de Carole: de fato, Tsikos é interpretado por Paul Roussopoulos, realizador de esquerda, assim como sua mulher.

Durante a discussão-clímax de L'ambassade, Tsikos tem um papel importante, embora pouco interfira no debate. A câmera o registra em alguns planos alternados aos dos protagonistas da briga, em que quase sempre ele aparece em silêncio (em uma das vezes tem o queixo apoiado nas mãos, com um ar de tédio). Ele é, portanto, um observador passivo, que intervém apenas ao final da discussão, com uma lição que é também a grande tese do filme:

Tsikos havia escutado em silêncio, mas explodiu em sua vez: "Vocês são tão do contra como os mortos que continuam a lutar em seus túmulos. A única lição a tirar é que todas as direções políticas, sem exceção, faliram. Nenhuma, qualquer que seja a análise, nos preparou para o que vivemos nesse momento. Cada vez que alguma coisa quis viver, vocês a esmagaram ou confiscaram. (L'ambassade, 1974, tradução nossa) ${ }^{371}$

É possível afirmar que a visão de Tsikos é a que mais se aproxima da do próprio Marker. Assim, ele optou por fazer um filme sobre a queda da união de esquerda no Chile, apontando as divergências como a principal razão da derrota. Como na fala do personagem anarquista, a lição a tirar é justamente a de que os debates que "esmagam" e "confiscam" o surgimento de novos projetos são os maiores

\footnotetext{
${ }^{370}$ Texto da voz over de L'ambassade, traduzido do original: “ Pour le grand débat idéologique final, j'avais pris soin de mettre côte à côte un camarade très pro-israélien et un farouche militant propalestinien. C'est là-dessus qu'ils s'engueulent, et à l'image ça devient un très crédible accrochage entre communistes et gauchistes. Je n'ai 'mis en scène' que quelques moments de la vie supposée de cette ambassade."

${ }^{371}$ Texto da voz over de L'ambassade, traduzido do original: "Tsikos avait écouté en silence, et plus il a éclaté à son tour: 'Vous êtes aussi cons que des morts qui continuent à se battre dans leur tombe. La seule leçon à tirer, c'est que toutes les direction politiques, sans exception, ont fait faillite. Aucune, quelque soit son analyser, ne nous a préparés à ce que nous vivons en ce moment. Chaque fois que quelque chose a voulu vivre, vous l'avez écrasé ou confisque."
} 
responsáveis por sua própria aniquilação. Portanto, L'ambassade é um filme voltado para os militantes desse campo político (ao contrário de La spirale, que estreou nas salas de cinema buscando um público mais amplo), fazendo um alerta para os perigos dos rachas internos - uma produção destinada aos seus companheiros. Marker clama por uma unidade, e o faz em um contexto em que a esquerda de seu país vivia um árduo processo de negociação e acordo em prol do programa comum ${ }^{372}$.

L'ambassade pode ser visto como uma metáfora do mundo da esquerda. Ele aparece como um universo fechado em si mesmo, invadido pelo ambiente externo em poucos momentos. No entanto, quando isso acontece, é por meio da repressão, colaborando ainda mais para sua clausura. Trata-se de uma comunidade, além de restrita, repleta de divergências políticas. As imagens do filme são exemplares dessa dinâmica. Após o golpe de Estado, há uma vontade de falar, de testemunhar sobre o ocorrido, bem como de escutar os companheiros - uma etapa de solidariedade. Essa etapa é sucedida por atividades comunitárias, como jogos, conversas, refeições e canções. Em seguida, porém, o tédio toma conta das atividades cotidianas, o encarceramento leva ao silêncio (há inúmeros planos em que os personagens interagem pouco entre si e em que o próprio narrador se cala). Por fim, essa aparente tranquilidade leva a uma tensão, que explode na forma de discussões.

Da solidariedade ao conflito, L'ambassade visita esses dois movimentos que caminharam juntos na esquerda após o golpe de Estado do Chile. O próprio filme traz essa dupla dimensão, da denúncia das ações do inimigo (no caso, da situação dos inúmeros refugiados que se exilavam após sofrerem cruéis perseguições pela Junta Militar) e da autocrítica em relação às estratégias internas. Marker retoma, assim, apelos como os de Carlos Altamirano já citado neste capítulo, que clamava por uma esquerda unida e fortalecida. Esse apelo, presente na produção, serve para a organização de um movimento de resistência no exílio chileno, visando a reverter a tragédia da ditadura. No entanto, serve também aos militantes franceses como alerta para o futuro, corroborando um discurso sobre a necessidade de uma revisão do campo da esquerda que abra mão das utopias em prol de sua própria sobrevivência (esse tema será abordado no capítulo 5).

\footnotetext{
${ }^{372}$ Marker optou por se aproximar de um personagem anarquista. Essa escolha é significativa, tendo em vista que essa corrente política não desempenhou um papel relevante no governo da Unidade Popular. Assim, ele se identifica com um discurso de esquerda autônomo, não tomando partido nas diversas discussões sobre a queda da UP feitas no seio da esquerda chilena e francesa.
} 
Essa nova perspectiva das esquerdas deve ser valorizada apesar das múltiplas derrotas, como a sofrida pela Unidade Popular. Para isso, é necessário tirar ensinamentos dos episódios negativos. Essa obstinação pela continuação da luta, que enfrenta a ditadura e sua repressão, é representada em L'ambassade pela personagem Melanie, a tartaruga das crianças. Ela aparece em um plano-sequência em que três refugiadas brincam com ela, e é quem recebe na embaixada os maiores elogios do narrador ${ }^{373}$ : "Essa tartaruga nos fascina. Talvez porque ela seja a única coisa viva nessa sala que escapa do nosso esmagamento. Ela é compacta e obstinada. Ela tem suas ideias de tartaruga, e nenhum policial no mundo vai fazê-las mudar." (L'ambassade, 1974, tradução nossa) ${ }^{374}$.

Os procedimentos usados em L'ambassade foram repetidos por outros realizadores. Em 2011, o cineasta iraniano Jafar Panahi foi condenado a seis anos sem sair de seu país e sem filmar, após tentar fazer um documentário sobre os protestos na ocasião da eleição de Mahmoud Ahmadinejad. Diante de sua pena, realizou This Is Not a Film (2011), que (coincidência ou não) traz como título a primeira frase de L'ambassade. As duas produções têm mais algumas semelhanças: ambas são filmadas em um ambiente interno, e o fazem devido à repressão externa que as enclausura. Essa comparação ajuda a ver a dimensão subversiva proposta por Marker - mesmo que ela se revele posteriormente uma ficção. O relato audiovisual é, em si, um ato político, desafia uma ordem externa que o proíbe e o persegue. Portanto, como no exemplo de Melanie, é fruto de uma obstinação que supera os limites impostos pelo inimigo.

No caso de L'ambassade, essa subversão é encenada. Isso não faz, porém, que o filme perca sua característica de denúncia, mesmo que essa denúncia tenha sido construída ficcionalmente e na forma de um diário ${ }^{375}$. Na falta dos documentos reais

\footnotetext{
${ }^{373}$ Vale ressaltar que Marker recorre constantemente a animais em suas produções, sendo que seu amor pelos gatos se tornou tão conhecido como sua obra. Fez de seu gato, Guillaume-en-Egypte, seu avatar, elegendo-o seu representante nos últimos anos de vida (inclusive no Second Life). O filme $O$ fundo do ar é vermelho recebe, na versão em inglês, o título A grin without a cat (uma referência ao "sorriso" sem gato do país das maravilhas). O termo SLON, que dá nome à produtora que fundou, significa em russo "elefante". À coruja, dedicou o projeto L'Héritage de la Chouette, que consiste em treze episódios televisivos que abordam conceitos filosóficos surgidos na Grécia antiga que permanecem no mundo contemporâneo.

${ }^{374}$ Texto da voz over de L'ambassade, traduzido do original: "Cette tortue nous fascine. Peut-être parce qu'elle est la seule chose vivant, dans cette pièce, qui échappe à notre écrasement. Elle est compacte et obstinée. Elle a ses idées de tortue, et aucun flic au monde ne les lui ferait changer."

${ }^{375}$ Esse impedimento de um registro "real" por força das circunstâncias se relaciona à escolha pelo formato de um diário-fílmico para abordar um episódio histórico de grandes consequências: um golpe
} 
(como mostra a dificuldade enfrentada pelo fotógrafo Mike em imprimir seu trabalho), Marker fabrica seu próprio documento, um documento com base testemunhal. No entanto, ele não é menos verdadeiro do que os documentos e testemunhos "reais".

Paul Ricœur reconhece a importância desse tipo de relato para o uso jurídico, mas questiona sua autenticidade no uso da história:

É na prática cotidiana do testemunho que é mais fácil discernir o núcleo comum ao uso jurídico e ao uso histórico do testemunho. Esse emprego coloca-nos de imediato diante da questão crucial: até que ponto o testemunho é confiável? Essa questão põe diretamente na balança a confiança e a suspeita. (RICEUR, 2007, p. 171)

Documentário ou ficção, é uma questão irrelevante para Chris Marker. L'ambassade é uma denúncia forjada, mas de uma repressão que é real. enclausuramento que define o ambiente privado como o espaço de atuação política. 


\section{Capítulo 5 - O fundo do ar é vermelho $(1977)^{376}$ : "do Chile ao - que, de fato?" 377 apontamentos para uma "via europeia"}

\section{Temas e estratégias do documentário}

Uma passagem sintetiza o apelo à união de $O$ fundo do ar é vermelho. Trata-se de um trecho que se inicia com um grupo de jovens em Paris, cantando $A$ internacional e segurando o livro vermelho de Mao Tsé-Tung. A voz over (nesse trecho proferida por Jorge Semprún) descreve a cena declarando ter a impressão de que, por fim, essa geração (ou a geração de Maio de 68, objeto do filme) pensava ter vivido alguma coisa "de considerável", ou seja, "sua" Revolução de 1917: a Revolução Cultural chinesa. No entanto, o comentário - com uma ironia cara a Chris Marker - ressalta que "essa coisa" seria facilmente vista como “contrarrevolucionária”, se não tivesse a assinatura pessoal de Mao. Um corte

\footnotetext{
${ }^{376}$ Chris Marker realizou diferentes versões para $O$ fundo do ar é vermelho (Le fond de l'air est rouge). A primeira montagem - com quatro horas de duração - foi exibida primeiramente no Festival de Cinema de Paris, em novembro de 1977. Em circuito, estreou em dezembro de 1977, permanecendo em cartaz durante 16 semanas, reunindo cerca de 44250 espectadores. Em 1978, o realizador publicou o comentário e a transcrição das cenas pela Éditions Maspero, com o título de Le fond de l'air est rouge, scènes de la troisième guerre mondiale: 1967-1977 (MARKER, 1978). Cabe dizer que os diálogos e os trechos da voz over transcritos nesta tese foram retirados desse texto. Em 1988, Marker produziu uma versão reduzida, de três horas, para a televisão britânica, que ganhou o nome de A grin without a cat (ou, "um sorriso sem um gato", numa referência ao gato de Alice no país das maravilhas, de Lewis Carroll). Uma nova montagem, em 1993, modificou sobretudo o comentário final, incluindo observações cabíveis após o fim da União Soviética. Em 1997, novas mudanças foram realizadas em ocasião de uma retrospectiva sobre o diretor na Cinemateca Francesa. Para esta pesquisa, foram comparadas a versão original com a atual, com auxílio do roteiro de 1978, de uma cópia em VHS assistida na Bibliothèque de documentation internationale contemporaine (BDIC, Nanterre, França) e da aquisição da versão mais recente em DVD (2008). Entre as principais alterações, estão cortes pontuais ao longo de todo documentário, a inversão da ordem de algumas sequências, além de supressões e revisão do comentário nas sequências finais. Como esta tese se interessa em verificar a apropriação da Unidade Popular chilena no discurso de Marker, privilegiou-se a primeira montagem, realizada pouco tempo após a queda do governo Allende.

${ }^{377}$ Para esta tese, interessa sobretudo analisar de que maneira o Chile aparece em $O$ fundo do ar é vermelho. Sendo assim, as considerações deste capítulo se centram especialmente na segunda parte do documentário, "Les mains coupées" (As mãos cortadas). Essa parte é dividida em duas subpartes - "Du printemps de Prague au programme commun" (Da Primavera de Praga ao Programa Comum) e "Du Chili à - quoi, au fait?" (Do Chile ao - que, de fato?) - que tratam de questões centrais para esta pesquisa: o projeto de união da esquerda francesa e o governo da Unidade Popular chilena. O caso de Cuba também aparece analisado nessa segunda parte, como um contraponto ao modelo chileno, merecendo igualmente uma reflexão. Esse filme é um dos mais comentados pelos pesquisadores markerianos. Sobre uma análise geral dessa produção, consultar a dissertação Chris Marker e as barricadas da memória: comentários em torno de Le fond de l'air est rouge (LEONEL, 2010), o artigo O manual de história idealizado (LANGMANN, 1986) e o livro Chris Marker: memories of the future (LUPTON, 2008).
} 
introduz cenas de uma manifestação da CGT no metrô Charonne (Paris, 1962), onde operários são reprimidos. Um novo corte e o documentário apresenta mais um protesto da CGT, agora em 1967. Nessas sequências, é possível observar duas barreiras humanas: uma de policiais; outra, de manifestantes. Entre as duas, um espaço vazio. E eis que nesse vazio, uma ação começa a se desenvolver. Um homem o ocupa e instiga os demais a avançar. Outro parece apaziguá-lo, levá-lo de volta à retaguarda. Em seguida, o que antes era um vazio transforma-se em um palco de batalha. Não entre a polícia e os esquerdistas, e sim entre os próprios membros do grupo que protesta. Diante dessas imagens, a voz over (dessa vez proferida por François Maspero) conclui:

Havia a barreira de policiais, era uma ordem. O setor de ordem do sindicato era outra ordem. Entre os dois, havia um espaço. A ser ocupado. Um homem que gesticulava nesse espaço para chamar à ação, pela época, só poderia ser um provocador (talvez fosse um, de muitos)... Mas isso anunciava um outro tipo de confronto. Inicialmente, entre nós. No fim da manifestação de outubro de 1967, o problema de desagregação se resolvia a golpes de sapato entre os jovens da CGT e os que chamávamos na época de próchineses, isso não era um banal extravasamento, era algo novo, tinha um novo sentido... E os gritos "unidade", "unidade" que emergiam da multidão, isso também tinha um sentido... ( $O$ fundo do ar é vermelho, 1977 , tradução nossa) ${ }^{378}$
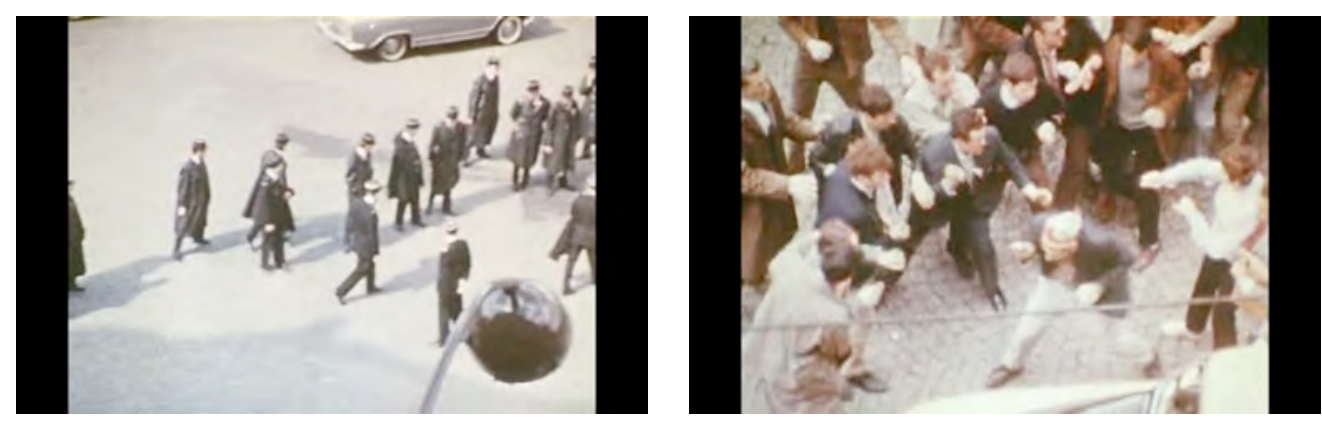

Fotogramas de $O$ fundo do ar é vermelho.

Muitos aspectos marcantes de $O$ fundo do ar é vermelho estão presentes nessas sequências. O primeiro é a junção de diversas batalhas políticas em uma só luta

\footnotetext{
${ }^{378}$ Texto da voz over de $O$ fundo do ar é vermelho, traduzido do original: "Il y avait le barrage de flic, c'était un ordre. Le service d'ordre du syndicat, c'était un autre ordre. Entre le deux, il y avait un espace. À remplir. Un type que gesticulait dans cet espace pour appeler à la action, vu de l'époque, ça ne pouvait qu'un provocateur (c'en était peut-être un, d'ailleurs)... Mais ça annonçait un autre genre d'affrontements. Et d'abord entre nous. Quand à la fin de la manif d'octobre 67, le problème de la dislocation se réglait à coup de tatanes entre les jeunes de la CGT et ceux qu'on appelait à l'époque les prochinois, ça n'était pas un banal débordement, c'était quelques chose de nouveau, ça avait un nouveau sens... Et les cris 'unité', 'unité' qui montaient de la foule, ça aussi ça avait un sens..."
} 
pelo socialismo (jovens franceses se apropriam da Revolução Cultural chinesa), fundamento teórico corroborado por uma montagem associativa. O segundo é uma crítica à geração de Maio de 68, vista como portadora de grandes utopias e poucas realizações concretas. Está presente também uma caracterização da esquerda como um universo fragmentado (assim como já aparecia em L'ambassade), embora o documentário aponte para um chamado pela união que se apresenta como um "novo sentido", como diz a voz over. Por fim, essas cenas materializam uma relação dialética, espiralada, entre revolta e repressão, revolução e contrarrevolução, que já havia sido estabelecida em La spirale. Esses apontamentos serão desenvolvidos ao longo deste capítulo.

Apesar de $O$ fundo do ar é vermelho tratar de inúmeros episódios da história política entre 1967 e 1977 (vale ressaltar que o filme traz como subtítulo "cenas da terceira guerra mundial", integrando esses episódios sob a égide de uma só luta), alguns temas são privilegiados por Chris Marker, acarretando em um documentário com passagens autocríticas (pode-se dizer que o filme faz um balanço sobretudo das derrotas da esquerda nesse período de dez anos) e um chamado à emergência de uma estratégia política $^{379}$. Esses temas principais são identificados nas distintas divisões e subdivisões determinadas pelo realizador. A primeira parte, "Les mains fragiles » (As mãos frágeis), é composta de dois episódios: "Du Viêt-Nam à la mort du Che" ("Do Vietnã à morte de Che") e "Mai 68 et tout ça..." ("Maio de 68 e tudo isso..."). A segunda parte, "Les mains coupées" (As mãos cortadas), também apresenta subdivisões: "Du Printemps de Prague au programme commun" ("Da Primavera de Praga ao programa comum") e "Du Chili à - quoi, au fait?" ("Do Chile ao - que, de fato?"). Interessa particularmente a esta pesquisa a metade final do documentário, porém, é necessário analisar aspectos gerais dessa produção, bem como as estratégias empregadas por Marker, para compreender sua abordagem sobre a união das esquerdas tanto na França como no Chile (abordadas em subitens deste capítulo).

O fundo do ar é vermelho é um documentário montado a partir de arquivos, assim como La spirale. Os dois filmes também se assemelham por utilizar especialmente extratos de documentários militantes e material produzido por

\footnotetext{
${ }^{379}$ Chris Marker dedicou a primeira versão desse documentário ao que chamou de "Nova Esquerda". Cabe ressaltar que nessa primeira montagem estavam presentes referências aos movimentos associados a essa tendência política - como a questão de gênero, por exemplo, debatida na parte final do documentário. Na versão disponível atualmente, essa discussão foi amenizada.
} 
televisões, quase sempre reportagens veiculadas pela $\mathrm{ORTF}^{380}$. No entanto, há uma diferença significativa entre eles. La spirale, apesar de sua assinatura coletiva no processo de produção, traz um comentário em over proferido por um único locutor, que guia a leitura, transformando seus documentos em "provas" de um complô que necessita ser desvelado. Já $O$ fundo do ar é vermelho pretende ser uma reflexão sobre a esquerda feita de dentro de seu próprio campo político. É um filme que propõe uma análise a partir da contribuição de múltiplos agentes e correntes políticas, intenção corroborada pela existência de oito vozes over distintas, proferidas por pessoas do círculo político e de amizade de Chris Marker: Simone Signoret ${ }^{381}$, Jorge Semprún ${ }^{382}$, Davos Hanich $^{383}$, Sandra Scarnati ${ }^{384}$, o próprio Marker, François Maspero ${ }^{385}$, François Périer $^{386}$ e Yves Montand ${ }^{387}$.

A produção de $O$ fundo do ar é vermelho começou em 1973 e foi concomitante à elaboração de vários dos filmes abordados nesta pesquisa, inclusive La spirale e L'ambassade. Nesse sentido, a presença da montadora Valérie Mayoux nos dois documentários de arquivo revela procedimentos parecidos na pesquisa de extratos audiovisuais preexistentes a serem incorporados. Um dossiê publicado na Positif traz um depoimento da montadora sobre como nasceu a ideia de compor uma

\footnotetext{
${ }^{380}$ No arquivo da produtora ISKRA, há um documento que busca identificar plano a plano a origem das imagens de $O$ fundo do ar é vermelho. Embora alguns extratos permaneçam sem identificação, é possível estabelecer essas duas fontes como as mais frequentes: documentários militantes de autores diversos (entre os quais estão muitos trechos do ICAIC) e material da ORTF. Como o objetivo deste capítulo é verificar a maneira como o Chile e o programa das esquerdas é abordado, não será feita a comparação dos sentidos corroborados e modificados resultantes do uso desses extratos pela montagem. No entanto, algumas das produções cinematográficas já citadas por esta tese têm suas imagens reprisadas, possibilitando novas leituras. Nesses casos, serão realizadas comparações pontuais que enriqueçam inclusive a compreensão das diferentes maneiras como esses temas foram abordados na obra de Chris Marker.

${ }^{381}$ A atriz escritora Simone Signoret, como foi salientado no capítulo 1, era casada com Yves Montand e amiga de adolescência de Chris Marker.

${ }^{382}$ Jorge Semprún é um dos entrevistados de On vous parle de Prague: le deuxième procès d'Arthur London (1971). Em $O$ fundo do ar é vermelho, ele aparece exercendo duas funções: como uma das vozes over e como um entrevistado (já que o filme utiliza extratos dessa produção anterior de Marker).

${ }^{383}$ Davos Hanich foi o ator principal de La jetée, em 1962.

${ }^{384}$ Atriz.

${ }^{385} \mathrm{O}$ editor François Maspero foi o protagonista de On vous parle de Paris: Maspero, les mots ont un sens (1970).

${ }^{386} \mathrm{O}$ ator François Périer deu vida à voz over de La première année (a versão francesa do filme de Patricio Guzmán, El primer año) e de La spirale.

${ }^{387}$ Chris Marker dedicou um filme ao amigo Yves Montand: La solitude du chanteur de fond (1974). De modo indireto, esse filme também se relaciona ao golpe do Chile e à solidariedade à Unidade Popular, pois Montand aparece se preparando para um show na França em repúdio à ditadura chilena $\mathrm{e}$ em prol dos exilados que chegavam à Europa. No entanto, optou-se por não abordar diretamente esse documentário nesta tese, já que, embora o país latino-americano esteja no pano de fundo, o contexto político em questão não é discutido diretamente. A produção é muito mais uma homenagem ao atorcantor.
} 
espécie de retrato fragmentado da esquerda do final dos anos 1960 e começo dos 1970 (MAYOUX, 1997). De acordo com ela, numa arrumação do depósito da ISKRA, foram encontradas latas de película, muitas delas jamais montadas, etiquetadas de forma "paranoica" e, muitas vezes, "disfarçadas". Ao revelar a Marker suas descobertas, o diretor teria proposto fazer um "film-collage" que contasse a história desses extratos militantes, alguns deles produzidos por autores não identificados ${ }^{388}$. Vale ressaltar, no entanto, que além desses trechos inéditos, o documentário utiliza material já presente em outras produções do próprio Marker ou de seus companheiros da ISKRA, enviado pelo ICAIC, ou ainda atribuído à televisão francesa ORTF.

Dessa forma, o uso de extratos audiovisuais de natureza diversa na articulação de um novo discurso fílmico, como já havia sido feito em La spirale, faz de O fundo do ar é vermelho um found footage, ou ainda um "filme-montagem", conforme a terminologia empregada por Ursula Langmann (1986) destacada no capítulo 3 desta tese $^{389}$. A autora ressalta que, diante do procedimento de reutilização e junção de materiais de arquivo gravados em diferentes contextos e por distintos autores, é difícil identificar preferências por movimentos de câmera ou enquadramentos, devendo prevalecer na análise considerações sobre o modo como esses extratos são articulados e manipulados na mesa de edição. Nesse sentido, ela afirma que, embora os métodos de montagem variem ao longo do filme, é predominante a tentativa de estabelecer associações entre os planos 390 .

Um bom exemplo de como essa montagem associativa está presente em diversas passagens de $O$ fundo do ar é vermelho é a sequência inicial, que traz uma

\footnotetext{
${ }^{388}$ No documento encontrado na ISKRA com a descrição dos planos e suas origens, inúmeros trechos usados na montagem são atribuídos ao "domínio público" (nesse caso, uma terminologia que classifica a autoria desconhecida). Os créditos finais de $O$ fundo do ar é vermelho são dedicados principalmente a esses autores anônimos, de extratos encontrados sem identificação: "Os verdadeiros autores deste filme, apesar de a maioria não ter sido consultada sobre o uso feito aqui de seus documentos, são os inumeráveis operadores de câmera, captadores de som, testemunhas e militantes cujo trabalho se opõe sem cessar aos poderes que gostariam de nos deixar sem memória." (O fundo do ar é vermelho, 1977, tradução nossa). Traduzido do original: "Les véritables auteurs de ce film, bien que pour la plupart ils n'aient pas été consultés sur l'usage fait ici de leurs documents, sont les innombrables cameramen, preneurs de son, témoins et militants dont le travail s'oppose sans cesse à celui des Pouvoirs, qui nous voudraient sans mémoire.".

${ }^{389}$ Ao contrário de La spirale, O fundo do ar é vermelho não procura estabelecer um conhecimento fechado sobre determinado assunto. Por isso, optou-se pela não utilização do termo "filme-dossiê" para essa produção, mesmo que seja composta por documentos de naturezas e origens distintas.

${ }^{390} \mathrm{Em}$ relação à montagem de $O$ fundo do ar é vermelho, Antonio Weinrichter (2006) ressalta que o filme é o mais vertoviano de Chris Marker. De acordo com o autor, esse documentário parte de um vasto material sobre as lutas políticas dos anos 1960 para compor uma espécie de Kino-nedelia (ou um noticiário cinematográfico semanal), que dá novo sentido a essas imagens, numa articulação de tempo e espaço decorrente de uma montagem fragmentada.
} 
referência ao cineasta Serguei Eisenstein, precursor desse tipo de montagem. As primeiras cenas são extratos de O Encouraçado Potemkin (1925), em que soldados se preparam para abrir fogo, quando um marinheiro com um largo bigode grita, e aparece na tela a palavra "irmãos". Esses trechos audiovisuais correspondem às lembranças de Simone Signoret, que narra em over sua memória sobre a primeira vez em que viu a produção de Eisenstein. As cenas do Potemkin são cortadas por um plano de mãos fazendo um "V", retiradas de uma tomada feita no México, em 1968. Após o intertítulo que anuncia a primeira parte, o documentário passa a mesclar extratos da ficção eisensteiniana com gravações de eventos reais. Os atores da escadaria de Odessa são associados - em planos intercalados - aos manifestantes contemporâneos que sobem uma escada; o choro pelos mortos no enfrentamento com a polícia numa manifestação da CGT no metrô Charonne, em 1962, é intercalado com as lágrimas de uma personagem do filme de 1925; punhos fechados já presentes na ficção russa aparecem em close-ups registrados no enterro do militante francês Pierre Overney, gesto compartilhado também pelos Panteras Negras.
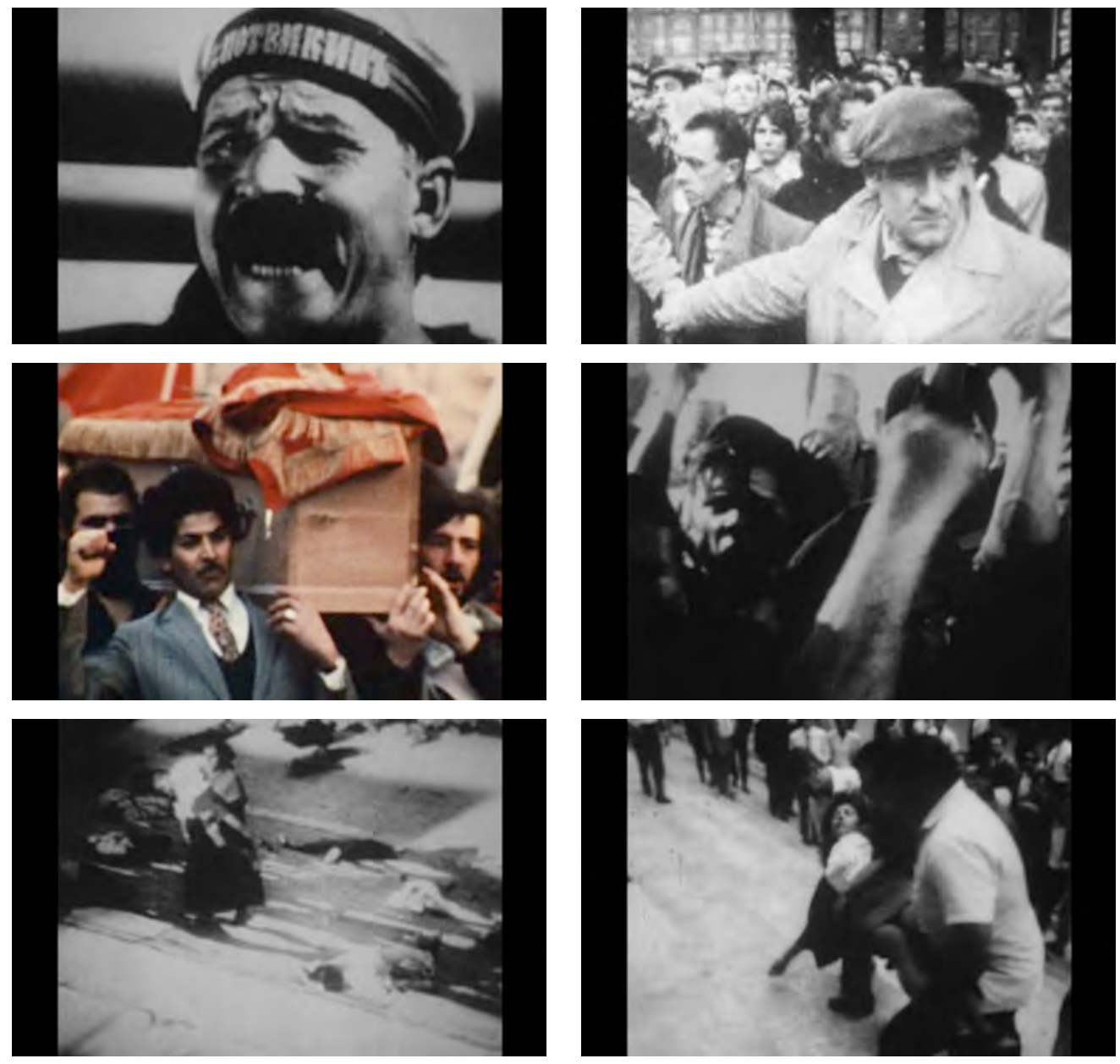

Fotogramas de $O$ fundo do ar é vermelho. 
Nessas primeiras sequências, Marker estabelece dois procedimentos interessantes, que aparecem em outras passagens do filme. Ele inverte a máxima "a vida imita a arte", mostrando como os gestos e a luta encenados em O Encouraçado Potemkin seriam repetidos na história por militantes de diversas partes do mundo. Além dessa ligação entre ficção e realidade, ele associa - por meio do encadeamento de imagens que apresentam semelhanças plásticas - a luta pelo socialismo nos mais distintos países, unindo-as como integrantes de um processo unívoco ${ }^{391}$.

Esse aspecto coletivo da história (como um acúmulo de lutas espraiadas, mas submetidas ao mesmo processo) é corroborado pela montagem, e também pela escolha em utilizar vozes plurais para os comentários que acompanham as imagens. As oito vozes over atuam no documentário com papéis relativamente distintos, conforme identifica Ursula Langmann (1986). Simone Signoret é definida pela autora como uma "narradora participante", misturando reflexões sobre o passado com recordações (como faz nas sequências iniciais de $O$ fundo do ar é vermelho). Assim como François Maspero, ela é representante da intelectualidade francesa. Jorge Semprún e Davos Hanich são caracterizados como portadores de um "relato histórico". Sandra Scarnati, além de narradora, é definida como uma protagonista histórica, quando fala em primeira pessoa sobre Maio de 68. Chris Marker normalmente aparece para comentar as imagens gravadas por ele mesmo para outras produções, reutilizadas nesse filme. François Périer, na classificação de Langmann, mescla reflexões com a descrição das cenas, sendo a voz hegemônica no bloco sobre a Primavera de Praga - vale destacar que ele recorre a um tom irônico parecido ao empregado em La spirale. Por fim, nos textos lidos por Yves Montand, predomina a “ironia mordaz". Apesar de simplificadora, essa descrição permite ver essas presenças como uma espécie de coro, que imprime uma pluralidade à abordagem do realizador:

No filme Le fond de l'air est rouge, as vozes off substituem uma forma tradicional de comentário. É certo que não se trata de depoimentos reais de várias pessoas, porque as pessoas são "atores" que dizem o comentário escrito por Chris Marker, mas esta “distribuição de papéis" confere ao comentário uma dimensão de autenticidade que não teria sido conseguida por uma única voz

\footnotetext{
${ }^{391} \mathrm{O}$ procedimento associativo na montagem aparece também para aproximar ações da direita. $\mathrm{Na}$ parte sobre a Guerra do Vietnã, por exemplo, Marker intercala planos rodados nesse país com aqueles registrados na Escola das Américas. Dessa maneira, expõe como a teoria desenvolvida para a repressão e a tortura tomaram forma na prática. Da mesma maneira, vale lembrar que La spirale também fazia essa relação entre a simulação dos métodos contrarrevolucionários e sua aplicação nas sociedades.
} 
dominando o filme inteiro. Tendo em conta que a duração do filme é de quatro horas, uma única voz teria facilmente produzido um efeito demasiado doutrinário. (LANGMANN, 1986, p. 43)

Nicolau Leonel (2010) descreve as sequências inicias de $O$ fundo do ar é vermelho, o depoimento de Simone Signoret sobre Encouraçado Potemkin, como a passagem de uma memória afetiva e individual para um imaginário social. Essa tentativa de não corroborar um caráter doutrinário por meio de uma espécie de coro relaciona-se, de certo modo, ao esforço em inserir - e superar - essa esfera do indivíduo (da memória afetiva, da militância individual) em função de uma memória coletiva (da atuação conjunta em processos de transformação social, lema da "Nova Esquerda", para a qual o filme aponta). Por isso, as diferentes vozes militantes transformam-se em um discurso único, mas não estanque, pois contempla uma diversidade de experiências e pontos de vista. Além da presença de múltiplos locutores, Chris Marker busca essa diversidade por meio de entrevistas com vários sujeitos, entre os quais se destacam alguns "personagens" desta tese, como Fidel Castro, Salvador Allende e Régis Debray.

Essa escolha por inserir ele próprio e seus próximos como narradores concede ao filme o status de uma autorreflexão sobre o campo político da esquerda - uma tentativa de pensar as derrotas e reconsiderar as vitórias entre 1967 e 1977 . Porém, ela concede a $O$ fundo do ar é vermelho a condição de um olhar geracional, um balanço sobre a geração do realizador e também a que lhe sucedeu, ou seja, a de Maio de $68^{392}$. Esse questionamento aberto da esquerda retomou aquele proposto por Marker em On vous parle de Prague: expor os defeitos da própria prática política seria "dar água ao moinho adversário"? Da mesma forma que a produção anterior, esse filme defende que conhecer os erros cometidos é fundamental para seguir com a luta.

Dessa forma, pode-se afirmar que Chris Marker procura repensar as práticas e as estratégias da esquerda como um todo, bem como suas próprias ações e convicções. Em termos de procedimentos cinematográficos, essa reprise analítica da própria ação política concretiza-se nos comentários que o realizador faz sobre imagens que ele mesmo gravou em momentos passados. A voz over tem, portanto, o papel de interrogar, atualizar esses planos. Uma das frases mais lembradas de $O$ fundo

\footnotetext{
${ }^{392}$ Esse aspecto geracional de $O$ fundo do ar é vermelho foi criticado em uma mesa-redonda realizada por críticos dos Cahiers du cinéma em janeiro de 1978 (TABLE, 1978). Serge Le Péron demonstrou insatisfação com o documentário, declarando que "eles são de uma geração anterior a nossa". Ele criticou um certo tom "paternalista" em relação às "crianças" de Maio de 68.
} 
do ar é vermelho é "Não sabemos nunca o que filmamos" ("On ne sait jamais ce qu'on filme"). Ela é proferida pelo próprio realizador, após a exibição de sequências do congresso do Partido Comunista de Praga, um evento cuja existência foi posteriormente negada pela repressão soviética. Em seguida, Marker passa para uma análise de suas próprias tomadas, especificamente as que registram a atuação de um cavaleiro nos jogos olímpicos, originalmente pertencentes ao documentário Olympia 52. O mesmo homem desempenharia, no futuro, um outro papel:

Eu, seguindo o campeão de hipismo da equipe chilena, acreditava ter filmado um cavaleiro, eu tinha filmado um golpista: o tenente Mendoza, transformado mais tarde no general Mendoza, um dos quatro da junta de Pinochet... Não sabemos nunca o que filmamos. (O fundo do ar é vermelho, 1977, tradução nossa) ${ }^{393}$

Essa prática de reprisar sequências com um comentário em over que modifica seus sentidos originais já estava presente, como foi salientado no capítulo 3, em algumas sequências de La spirale. Em $O$ fundo do ar é vermelho retoma-se essa ideia de que as imagens têm uma história autônoma à vontade de seus autores. Elas fazem parte, assim, de um imaginário coletivo, de uma história que, conforme avança, as submete a novos significados. Portanto, elas devem ser revisitadas, reinterpretadas, bem como as estratégias políticas do passado. Ao contrário do documentário anterior, nessa produção de 1977, Marker reutiliza inclusive extratos fílmicos de sua própria autoria, caracterizando um autoquestionamento sobre suas ações.

Em termos políticos, o trecho que trata das manifestações no Pentágono em 1967 é o que mais exemplifica esse exercício de repensar as próprias convicções por meio da reprise das imagens. Revisitando as sequências que compunham La sixième face du Pentagone (1968), Marker reexibe as cenas em que uma manifestante insiste em voltar ao lugar de onde é tirada por policiais, fazendo-os repetir esse gesto inúmeras vezes. A polícia cerca uma horda de jovens festivos que protestam. Até que, no momento em que estes resolvem avançar rumo a seu alvo, o Pentágono, os policiais saem de cena (com exceção de alguns poucos). O realizador corre com a câmera em punho acompanhando os manifestantes até a porta da sede militar norteamericana, onde poucos soldados com cassetetes colocam fim ao ato, enquanto um

\footnotetext{
${ }^{393}$ Texto da voz over de $O$ fundo do ar é vermelho, traduzido do original: "Moi, en suivant le champion de jumping de l'équipe chilienne, j'avait cru filmé un cavalier, j'avait filmé un putschiste: le lieutenant Mendoza, devenu plus tard le général Mendoza, un des quatre de la junte de Pinochet... On ne sait jamais ce qu'on filme."
} 
aparato policial gigantesco se forma ao fundo para resguardar seu poderio. $\mathrm{Na}$ montagem de 1968, Marker comemorava uma vitória da esquerda, ao mostrar que homens desarmados podiam afrontar o símbolo máximo do imperialismo militar dos Estados Unidos. Porém, em 1977, ele remonta esses planos, desconstruindo-os com o seguinte comentário em over, proferido por sua própria voz:

Relendo essa filmagem, reparamos bem o tipo de truque que os poderes usam para nos enganar. O cordão da tropa era praticamente intransponível pelos manifestantes desarmados. Atrás de nós, os prédios do Pentágono, indicado como alvo de uma "ação direta", pelos panfletos dos organizadores. [...] E tudo se estabilizou lá, nos degraus, depois de uma tentativa de penetração bem simbólica. Os policiais estavam realmente com medo - nós não tínhamos os advertido. Eu filmei isso, e apresentei, numa história para trapacear os trapaceadores, como uma vitória do Movimento. Mas, revendo essas imagens, e as comparando com as receitas de policiais que narram como eles mesmos colocavam fogo nas delegacias de Maio de 68, eu me pergunto se um certo número de vitórias dos anos 60 não foram exatamente dessa mesma ordem. ( $O$ fundo do ar é vermelho, 1977 , tradução nossa) ${ }^{394}$

Esse trecho é um exemplo de como $O$ fundo do ar é vermelho questiona as estratégias políticas dos anos 1960 - inclusive a própria atuação do realizador -, caracterizando suas poucas vitórias como atos simbólicos. Essa simbologia utópica resultou em símbolos esvaziados ao final da década, como as camisetas com o rosto de Che Guevara que passaram a ser usadas por jovens de todo mundo após a sua morte. Nesse sentido, Marker é crítico sobretudo dessa geração de Maio de 68, pondo em dúvida se sua atuação política, rica em termos de emblemas e signos, realmente tinha representado algum tipo de modificação social.

No entanto, cabe ressaltar que $O$ fundo do ar é vermelho insere essa autocrítica diante da impossibilidade de vitória, decorrente também da ação repressora do inimigo. Assim, sua montagem é repleta de sequências em que se alternam planos de ação e reação, revolução e contrarrevolução, numa espiral dialética semelhante

\footnotetext{
${ }^{394}$ Texto da voz over de $O$ fundo do ar é vermelho, traduzido do original: "À relire ce tournage, on repère assez bien le genre de tours que nous jouent les pouvoirs. Le cordon de troupe était pratiquement infranchissable pour des manifestants désarmés. Derrière nous, les bâtiments du Pentagone, désigné comme but d'une 'action directe', par les tracts des organisateurs. [...] Et tout s'est stabilisé là, sur les marches, après une tentative de pénétration plutôt symbolique. Les flics avaient vraiment peur - on n'avait pas dû les prévenir. J'ai filmé ça, et je l'ai présenté, histoire de piper les pipeurs, comme une victoire du Mouvement. Mais en revoyant ces images, en les comparant aux récits des policiers qui racontent comment ils ont mis le feu eux-mêmes dans les commissariats de mai 68, je me demande si un certains nombre de nos victoires des années 60 n'étaient pas exactement du même ordre."
} 
àquela presente em La spirale ${ }^{395}$. Nas imagens do Pentágono, quando os manifestantes avançam, os policiais retrocedem. Essa passagem dialoga diretamente com aquela em que os jovens da CGT ocupam o espaço vazio entre o movimento e a repressão com confrontos internos. De modo complementar, essas duas cenas permitem verificar duas lições: a primeira é a de que é necessário avançar - e em conjunto; a segunda é a de que os objetivos devem ser mais do que simbólicos, devem promover uma real transformação da sociedade.

Essa dialética entre ação e repressão está presente no próprio título das duas partes de $O$ fundo do ar é vermelho: as mãos frágeis e as mãos cortadas. Esses projetos derrocados em 1967 e 1968 mostraram-se insuficientes para fazer frente ao poderio contraofensivo do imperialismo e da direita - e, porque não, da própria face autoritária da esquerda, já que o filme se dedica também à crítica do stalinismo -, tornando-se após essa época utopias descontextualizadas. Nesse sentido, essas "mãos" - tantas vezes focalizadas em punhos erguidos nas manifestações, como reproduzem as imagens militantes - foram "cortadas" ${ }^{396}$, o que exige a necessidade de novas estratégias mais efetivas. Vale dizer que a ideia para esses subtítulos vem de uma frase, ou um slogan, de Maio de 68: "Os operários tomarão das mãos frágeis dos estudantes a bandeira da luta"397.

Essa frase é proferida em $O$ fundo do ar é vermelho por Simone Signoret, quando a escritora define a geração de Maio de 68. Uma sequência de planos

\footnotetext{
${ }^{395}$ Ao contrário de La spirale, a denúncia dessa espiral de ação e reação (revolução e contrarrevolução) não serve apenas para desmascarar a direita, mas também para questionar a própria contraofensiva da esquerda. Em relação a Maio de 68, o filme insinua que a repressão policial foi, em grande parte, responsável pela amplitude que ganhou o movimento, agregando estudantes que não se engajariam se não fosse para responder a essa repressão. Nessa perspectiva, embora haja um desvelamento dos métodos coercivos, há também uma evidenciação da despolitização dos jovens em questão. Uma frase da voz over sintetiza bem esse debate: "Também é um ensinamento dessa época, que a violência dos enfrentamentos não tem nenhuma relação com seus desdobramentos políticos" ( $O$ fundo do ar é vermelho, 1977, tradução nossa). Traduzido do original: "C'est d'ailleurs un enseignement de cette époque, que la violence des affrontements n'a aucun rapport avec leur suites politique."

${ }^{396}$ Nicolau Leonel discorre sobre a origem da expressão "mãos cortadas", que dá origem ao título da segunda parte do documentário: "A segunda parte do filme tem o significativo nome de "mãos cortadas', o mesmo nome de um romance de Blaise Cendrars. É importante em algum momento desenvolver uma interpretação específica deste título. De alguma maneira ele remete a uma citação transversal à peça As mãos sujas de Jean-Paul Sartre. Mas, de alguma maneira, a trajetória que percorremos até agora poderia sugerir que as mãos cortadas foram aquelas que passavam as pedras no Quartier Latin, aquelas que faziam a ponte entre os estudantes e os operários, entre a França e o Vietnã, entre o primeiro e o terceiro mundo. Os revolucionários dentro da revolução, ou aqueles que buscavam revolucionar os revolucionários, se quisermos (para falar com Dutschke)." (LEONEL, 2010, 192). Outra interpretação possível é a de que o subtítulo faz uma alusão à trágica morte de Victor Jara, simbólica do enterro de um tipo de utopia revolucionária sufocada por uma severa repressão.

${ }^{397}$ Traduzido do original: "Les ouvriers prendront des mains fragiles des étudiants le drapeau de la lutte."
} 
gravados em manifestações contra a Guerra do Vietnã (em que uma moça aparece envolvida em uma bandeira com o rosto de Che) e de jovens colando cartazes é intercalada com imagens da África e do próprio Vietnã. Um rosto angelical de uma mulher, por exemplo, antecede o choque de uma criança negra com o rosto deteriorado por uma profunda ferida. A disparidade entre o mundo real - o da guerra e o do terceiro mundo - e o mundo ideal - dos universitários do primeiro mundo - é descrita no comentário de Signoret com uma profunda ironia. Ela ressalta que, em 1967, surgiu uma "raça de adolescentes estranhos", que pareciam ter um conhecimento absoluto de algumas questões, mas nada saber sobre outras:

Suas mãos eram incrivelmente hábeis para colar cartazes, trocar os blocos de calçada, escrever bombasticamente frases curtas e misteriosas que ficavam na memória, todos procurando outras mãos para transmitir uma mensagem que eles tinham consciência de ter recebido sem decifrá-la totalmente. (O fundo do ar é vermelho, 1977, tradução nossa) ${ }^{398}$

Esse final da década de 1960 na França e nos Estados Unidos é retratado como a época de um discurso de esquerda esvaziado (ou um discurso que perdeu seu sentido com as derrotas dos movimentos que deram origem a ele). Essa "ignorância" de certos aspectos por parte da juventude permite, por exemplo, que os manifestantes franceses das barricadas usem a frase sobre "as mãos frágeis estudantis" e seu legado aos "operários" apesar de sua filiação stalinista. No roteiro do documentário, publicado em 1978, Chris Marker revela em uma nota que, após o lançamento do filme, descobriu que o verdadeiro autor da sentença era Stálin. Embora ele não soubesse dessa informação no momento da montagem, ela foi inserida no livro porque reforça uma comparação entre o ano de 1968 na França e em Praga, que já estava presente em $O$ fundo do ar é vermelho.

A passagem entre o bloco dedicado aos eventos estudantis de maio desse ano e as reformas na Tchecoslováquia (que originou a intervenção da URSS) ocorre por meio de sequências em que Jean Villar, organizador do Festival de Teatro de Avignon, é vaiado por estudantes enfurecidos, que o acusam de promover um "festival burguês". Complacente com o isolamento de Villar, a voz over de Signoret conclui sobre o episódio: "Mas, de todo modo, a História não se escrevia em Avignon, no verão de 68. Ela se escrevia em Praga." ( $O$ fundo do ar é vermelho,

\footnotetext{
${ }^{398}$ Texto da voz over de $O$ fundo do ar é vermelho, traduzido do original: "Leurs mains étaient incroyablement habiles à coller des affiches, à échanger des pavés, à écrire à la bombe des phrases courtes et mystérieuses qui restaient dans le mémoires, tout en cherchant d'autre mains à qui transmettre un message qu'ils avaient conscience d'avoir reçu sans le déchiffrer totalement."
} 
1977, tradução nossa) ${ }^{399}$ Essa passagem reforça ainda mais a ideia de que as reivindicações e, sobretudo, os métodos usados por essa jovem esquerda francesa se afastavam muito das reais necessidades de transformação social. Novamente, Marker ressalta o aspecto simbólico (a fúria direcionada ao produtor de um festival de teatro) das reivindicações da juventude.

E como ficam os operários, nessa tarefa de "tomar a bandeira" das frágeis mãos estudantis? No bloco "Maio de 68 e tudo isso...", há indícios de que Marker critica a fragmentação desse movimento em inúmeras correntes políticas. Há longas sequências em que trabalhadores socialistas, comunistas e trotskistas discutem, revelando diferentes perspectivas sobre sua atuação política. O fundo do ar é vermelho também retrata a CGT com bastante ressalva, como demonstra a passagem descrita no início deste capítulo, em que o vazio entre seus manifestantes e a repressão é ocupado com brigas internas. A presença de André Barjonet, que havia rompido recentemente com a central sindical (após ser seu secretário de 1946 a 1968), por discordar dos acordos de Grenelle e de Georges Séguy ${ }^{400}$, seu sucessor, coloca em evidência os desentendimentos internos dessa instituição. Já no bloco "Da Primavera de Praga ao programa comum", Marker insere novos planos de discordância, dessa vez ocorrida na fábrica da Renault entre um militante da Agir en jeunes socialistes (AJS) e um da CGT.

Pode-se dizer, portanto, que $O$ fundo do ar é vermelho clama por uma união da esquerda, para que seja possível encontrar novas estratégias e afastar práticas nocivas desse campo político, como o stalinismo. O documentário mostra que, a partir de 1967, surgiu uma "nova direita", que se apropriou dos métodos da esquerda e repensou suas ações para sufocar seus adversários. É exemplar, nesse sentido, a entrevista com um militar norte-americano do Pentágono que responde ao seu entrevistador sobre as possíveis causas da morte de Che. Demonstrando grande lucidez, ele declara que foi a falta de apoio do Partido Comunista boliviano que isolou a guerrilha, facilitando sua derrocada. Em suas declarações, percebe-se que os Estados Unidos e seus aliados aprenderam com o passado, já que a opção em matar o guerrilheiro argentino - mesmo sabendo dos riscos de que ele poderia se tornar um

\footnotetext{
${ }^{399}$ Texto da voz over de O fundo do ar é vermelho, traduzido do original: "Mais de toute façon, l'Histoire ne s'écrivait pas en Avignon, l'été 68. Elle s'écrivait à Prague."

${ }^{400}$ Os acordos de Grenelle foram pactos assinados em Maio de 68 para apaziguar a crise entre o governo de Georges Pompidou, as centrais sindicais e as organizações patronais.
} 
mártir - visava a evitar um "novo caso Régis Debray", ou seja, uma comoção internacional que desmoralizasse o exército boliviano.

Nicolau Leonel destaca que a ideia de "revolução na revolução" percorre todo o documentário. Essa expressão, originária dos republicanos da Guerra Civil espanhola diante da necessidade de modificar suas estratégias e recuperada por Régis Debray em sua defesa do foquismo em Révolution dans la révolution? (como foi visto no capítulo 1, uma espécie de "coqueluche" na esquerda francesa), volta à tona em $O$ fundo do ar é vermelho ${ }^{401}$. No entanto, diferentemente do livro de Debray, Marker exibe um retrato fracassado da guerrilha e a carência de novas vias para o socialismo. Nesse sentido, a abordagem sobre a América Latina, palco da revolução pelas armas, é ideal para compreender esse fenômeno. As entrevistas com Douglas Bravo ${ }^{402}$ caracterizam um líder isolado, cuja oposição do Partido Comunista contribui para sua derrocada tanto quanto as ações da direita. $\mathrm{O}$ mesmo isolamento pode ser verificado em Che Guevara antes de sua morte, porém, nesse caso, verificado por meio da fala do secretário do PC boliviano, Mario Monje, que confirma sua oposição à atitude guevarista, definindo-a ainda como um problema para os comunistas do país.

Vale destacar que a trajetória do filme, da luta armada à sua transformação em um discurso esvaziado reproduzido pelos jovens dos países desenvolvidos, é paralela a do próprio realizador. Nesse sentido, é necessário entender $O$ fundo do ar é vermelho como um filme crítico e autocrítico de esquerda, sem abrir mão, no entanto, do projeto socialista. Esse exercício é nítido na tentativa de Chris Marker em se inserir entre as "mãos frágeis", presente sobretudo em uma sequência em que ele se interroga: "Por que algumas vezes as imagens começam a tremer?" (O fundo do ar é vermelho, 1977, tradução nossa $)^{403}$. Essa frase é inserida em forma de intertítulos enquanto imagens de ações policiais em diferentes lugares tremem na tela. Em seguida, as vozes over narram em primeira pessoa quando o fato se sucedeu com elas:

Chris Marker - Comigo, isso ocorreu em Maio de 68, no bulevar Saint-Michel.

\footnotetext{
${ }^{401} \mathrm{O}$ livro Révolution dans la révolution? é citado em $O$ fundo do ar é vermelho em um trecho que traz imagens da Bolívia, com um comentário proferido pela voz over do próprio Marker.

${ }^{402}$ Nos créditos finais de $O$ fundo do ar é vermelho aparece a informação de que essas imagens foram retiradas de Douglas Bravo, la guerre de guérilla au Venezuela (1970), de Georges Mathieu Mattéi e Jean-Michel Humeau. No entanto, no documento com a descrição da origem das cenas, encontrado na ISKRA, o trecho é atribuído ao filme Les chemins de la fortune (1964), de Peter Kassovitz, exibido pela ORTF.

${ }^{403}$ Texto da voz over de $O$ fundo do ar é vermelho, traduzido do original: "Pourquoi quelquefois les images se mettent-elles à trembler?"
} 
Davos Hanich - Comigo, em Praga, no verão de 68. Quando eu vi as tomadas, eu vi elas tremendo. Eu havia controlado as mãos, mas a câmera havia captado tudo.

François Maspero - Em Santiago do Chile ${ }^{404}$, a câmera passou sozinha à câmera lenta. Talvez simplesmente por emoção de ver serem utilizados em contrassenso esses caminhões com canhões de água que eu havia visto tantas e tantas vezes sendo utilizados contra os manifestantes de esquerda em outras ocasiões em Berlim, Louvain e nos Estados Unidos. (O fundo do ar é vermelho, 1977, tradução nossa) ${ }^{405}$

Além de mais um exemplo de como essas múltiplas vozes over interrogam as imagens em $O$ fundo do ar é vermelho, o trecho acima situa o próprio Marker entre essas mãos "frágeis" e "cortadas" pelo medo da repressão (materializado pelo pavor do cineasta diante da polícia, o que fez as imagens cambalearem), mas também pelas próprias desilusões dentro de seu campo político - diante do stalinismo e sua herança, que abafou ações transformadoras (como a Revolução Cubana), e com os rachas internos da esquerda ${ }^{406}$.

O fundo do ar é vermelho é um retrato da esquerda entre 1967 e 1977 que se constitui como um found footage fragmentado, cuja montagem integra imagens de diferentes lugares e tempos, agrupando-as por uma reflexão ensaística. No entanto, o filme respeita, na estrutura de suas duas partes, uma espécie de cronologia: a primeira, dedicada ao final dos anos 1960, privilegia como temas a Guerra do Vietnã, a morte de Che, Maio de 1968 e a Primavera de Praga. A segunda foca no início da década seguinte, sobretudo na discussão em torno de um programa comum à esquerda francesa e sobre o governo da Unidade Popular (e sua queda). Outros temas, porém,

\footnotetext{
${ }^{404}$ Maspero refere-se às ações repressivas comandadas pelo governo de Allende. Essa passagem será retomada no item 3 deste capítulo.

${ }^{405}$ Texto da voz over de $O$ fundo do ar é vermelho, traduzido do original:

"Chris Marker - Moi, ça m'est arrivé en Mai 68, boulevard Saint-Michel...

Davos Hanich - Moi, à Prague, l'été 68. Quand je vu les rushes, j'ai vu les tremblement. J'avait maîtrisé mes mains, mais le caméra avait tout capité.

François Maspero - À Santiago du Chili, la caméra s'était mise toute seule au ralenti. Peut-être simplement d'émotion de voir utiliser à contresens ces arroseuses que j'avait vues tant et tant de fois utilisées contre des manifestants de gauche en d'autres occasions à Berlin, à Louvain, aux États-Unis.”.

${ }^{406}$ Sobre a repetição e o tremor das imagens na obra de Chris Marker, é válido destacar a reflexão de Sylvie Rollet, que indica nesses procedimentos uma dupla dimensão de afastamento (temporal) e proximidade (pela presença do realizador no momento da tomada): "A potência da imagem revista sempre já re-vista, registrando a diferença do re-ver em sua origem - está inteiramente nesse tremor que 'melhor do que todo o resto' traz a marca da prova do afastamento, acolhendo a promessa de proximidade". (ROLLET, 2008, p. 43, tradução nossa). Traduzido do original: "La puissance de l'image revue - toujours déjà re-vue, inscrivant la différence du re-voir à son origine - est toute entière dans ce tremblement qui 'mieux que tout le reste' porte la marque de l'éprouve de l'éloignement, tout en accueillant la promesse de proximité."
} 
perpassam o documentário, caso especialmente da Revolução Cubana e da figura de Fidel Castro, que frequentemente vêm à tona nos comentários. Interessa particularmente a esta pesquisa o debate sobre as mudanças na leitura sobre o processo cubano ao longo da obra de Marker, bem como a análise dos casos francês e chileno. Esse enfoque permite verificar mudanças de posicionamento em relação às produções já analisadas nesta tese e a reincorporação de algumas dessas imagens submetidas a um novo ponto de vista (em muitas passagens, reaparecem extratos utilizados nos filmes sobre a América Latina, como Cuba si e On vous parle $d u$ Chili).

Apesar da dimensão autocrítica, $O$ fundo do ar é vermelho mantém a utopia em seu horizonte, dando-lhe novas configurações. Uma canção percorre várias passagens: Le temps des cerises (1866-68), de Jean-Baptiste Clément e Antoine Renard. Considerada uma espécie de hino da Comuna de Paris, a letra fala de um festivo "tempo das cerejas" (uma espécie de "Passárgada"), um tempo pósrevolucionário $^{407}$. A presença dessa canção concede um tom melancólico - em que as utopias fazem parte do passado -, mas também reaviva a esperança revolucionária por meio desse desejo de fundar uma nova sociedade. Dessa forma, o filme não rompe com a perspectiva do socialismo, apenas clama por novas configurações, em que a união se apresenta como um caminho a ser considerado. Esse "estado de espírito", nem eufórico, nem de desespero, está indicado no próprio título, como coloca Langmann:

O título de Le fond de l'air est rouge é uma alusão à expressão francesa, praticamente intraduzível. "Le fond de l'air est frais"..., cujo sentido é qualquer coisa como "há um friozinho no ar", não significando, no entanto, que esteja realmente frio, mas sim que, sob o calor aparente, por exemplo dos dias do começo do Verão, perpassa uma aragem bastante fresca. E, indiretamente, o título já deixa entrever o estado de espírito que está por trás de todo o filme: nem euforia, nem desespero. Apesar do fracasso de todos os movimentos revolucionários apresentados no filme, alguma coisa mudou, embora isso só se note, só se "sinta" à segunda vista, tal como o friozinho que perpassa o calor. (LAGMANN, 1986, p. 31)

O documentário opta, porém, por não indicar novas fórmulas, fazendo com que a multiplicidade de vozes e de imagens evite um discurso doutrinário - como foi

\footnotetext{
${ }^{407}$ Em termos sonoros, além de Le temps des cerises, está presente a canção La musica notturna delle strade di Madrid (c.1780), de Luigi Boccherini (tocada especialmente na parte final do documentário). Marker também utiliza frequentemente o som de sintetizadores, enfatizando ruídos que poderiam estar presentes nas imagens ou potencializando impressões causadas pelas mesmas.
} 
analisado. Assim, de alguma forma, ele pode ser associado ao discurso de Tsikos, o anarquista de L'ambassade, que atribui aos conflitos internos os motivos de sua reclusão, e, ao mesmo tempo, indica que, independente da estratégia, os inimigos sempre tentarão "esmagar" as tentativas para que "algo viva". Essa aproximação com o discurso do personagem anarquista é visível em $O$ fundo do ar é vermelho em uma passagem em que Marker recorre aos gatos, sua grande adoração, para criticar o poder (seja ele qual for, inclusive o stalinista), em uma frase proferida por sua própria voz em over: "Um gato nunca está ao lado do poder" ("Jamais un chat n'est du côté du pouvoir"). Ursula Langmann ressalta o papel dos animais nessa produção:

Em Le fond de l'air est rouge, como na maioria dos filmes de Chris Marker, aparecem gatos e coatis-lavadeiros: os gatos como adversários do poder que não se submetem a nada e a ninguém e representam o ideal de liberdade; os coatis-lavadeiros como "lavadores da Revolução" que querem purificar-se do seu próprio passado. (LAGMANN, 1986, p. 51)

A referência aos gatos está também no título em inglês, A grin without a cat. Muitas interpretações foram feitas a respeito desse "sorriso" sem o "gato". Interpreto essa expressão relacionando-a aos movimentos do final dos anos 1960, em que a utopia (o sorriso) esteve descontextualizada de sua verdadeira essência libertária (o gato). Assim como na história de Carroll, essa essência desaparece, deixando apenas sua aparência - assim como as camisetas de Che após sua morte, repletas de carga simbólica e anacrônicas em termo de possibilidade de ação política. 


\section{A trajetória de Fidel Castro e a revisão da Revolução Cubana}

Entre as inúmeras críticas publicadas na imprensa francesa sobre $O$ fundo do ar é vermelho, na ocasião de seu lançamento, muitas delas destacavam a presença de Fidel Castro em várias passagens do documentário, embora Chris Marker não tenha dedicado uma parte específica ao tema da Revolução Cubana. À medida que Castro se aproxima do discurso soviético, suas falas, ao longo do filme, passam a receber uma evidente visão crítica, que surpreende especialmente pelo fato de o realizador ser também o autor de Cuba si (1961) e La bataille des dix millions (1970), analisados no capítulo 1 desta tese. Embora, como foi visto, houvesse uma espécie de autocrítica na segunda produção em relação à primeira, ela seguia apoiando a Revolução e seus desdobramentos, um posicionamento que foi revisto em 1977.

O jornal Le monde diplomatique, em dezembro de $1977^{408}$, discorria sobre o peso dessa revisão para Marker: "Revisão provavelmente dolorosa para um realizador que, portanto tempo e tão brilhantemente (Cf. Cuba si e La bataille des dix millions) defendeu a generosidade revolucionária das apostas cubanas" (LE FOND, 1977, p. 21, tradução nossa) ${ }^{409}$. Paulo Antonio Paranaguá, na ocasião da exibição de $O$ fundo do ar é vermelho no Festival de Paris, publicou uma crítica em que também ressaltava um visível desconforto do realizador em modificar seu discurso sobre a Revolução Cubana:

O momento em que sentimos que Chris Marker tem mais desconforto em lançar um olhar crítico é sobre a Revolução Cubana, uma vez que ela é provavelmente o que mais lhe tocou. Como não admitir que nós dividimos seu incômodo? Ele escolheu, então, se expressar sobre isso pelos meios próprios do cinema, sem fazer um apelo aos contrapontos fáceis de documentos ou ao comentário. (PARANAGUÁ, 1977, tradução nossa) ${ }^{410}$

Assim como a guerrilha deixa de ser uma estratégia em $O$ fundo do ar é vermelho, a Revolução Cubana é abandonada por Marker como um modelo - de tática revolucionária e de "democracia direta", como aparecia nos seus documentários

\footnotetext{
${ }^{408}$ A matéria é assinada apenas pelas iniciais I.R., não sendo possível a identificação do autor.

${ }^{409}$ Traduzido do original: "Révision probablement douloureuse pour un réalisateur qui a si longtemps et si brillamment (C.f. Cuba si et La bataille des dix millions) soutenu la générosité révolutionnaire des paris cubains."

${ }^{410}$ Traduzido do original: "Là où on sent que Chris Marker a le plus de mal à porter un regard critique, c'est sur la révolution cubaine, puisque c'est elle qui l'a probablement le plus touché. Comment ne pas avouer que nous partageons sa gêne? Il a choisi donc de s'exprimer là-dessus pas les moyens propres du cinéma, sans faire appel aux contrepoints faciles de documents ou au commentaire."
} 
anteriores - para se tornar um exemplo da derrocada das utopias da década de 1960 e da necessidade de se encontrar novos métodos. Nesse sentido, a aparição de diversos discursos de Fidel Castro na montagem, bem como os comentários feitos pelo realizador à sua imagem, é fundamental para compreender o próprio percurso do filme, que reafirma a liberdade em relação ao poder hegemônico como o aspecto principal nos caminhos a serem adotados rumo ao socialismo. É necessário, portanto, analisar as diversas passagens em que o líder cubano aparece.

Ainda no primeiro dos quatro blocos, "Do Vietnã à morte de Che", após mostrar um conflito interno da classe operária na greve de Besançon (França), Marker insere um longo plano de uma entrevista com Fidel Castro registrada em junho de 1967. A ambientação em um cenário de selva vincula sua fala à origem guerrilheira, e seu discurso corrobora a ideia de uma "revolução na revolução", ao romper com os demais partidos comunistas da América Latina. No entanto, essa passagem é apresentada pelo realizador como um exemplo de racha interno na esquerda, assim como os conflitos entre os operários franceses. O líder cubano discursa contra os revolucionários que atrapalham a revolução:

Há aqueles que se intitulam revolucionários e, no entanto, são contra a revolução... Eles tentam desmoralizar os povos. Eles exploram o menor revés para desacreditar a luta contra o imperialismo. Isso quer dizer que, ao invés de inculcar nos povos o senso da luta, o dever, a obrigação sagrada de lutar, eles procuram semear o desencorajamento... Eles apoiam aqueles que se opõem à guerrilha... (O fundo do ar é vermelho, 1977, tradução nossa) ${ }^{411}$

Como exemplo dessa oposição à guerrilha por parte da própria esquerda, Castro cita em seu discurso o caso da Venezuela, que é ilustrado por Marker com imagens da eleição de 1963 no país, bem como da guerrilha de Douglas Bravo isolada na montanha do Falcão. O resultado entre a cisão dessas duas táticas - a via armada e a direção do Partido - foi a vitória de um presidente de direita, Raúl Leoni, o que agravaria ainda mais a divisão da esquerda latino-americana, como informa a voz over. Não por acaso, Marker elege Jorge Semprún, que havia sido expulso do Partido

\footnotetext{
${ }^{411}$ Discurso de Fidel Castro em $O$ fundo do ar é vermelho, traduzido do original: "Il y a ceux qui s'intitulent révolutionnaires et portant sont contre la révolution... Ils tentent de démoraliser les peuples. Ils exploitent le moindre revers subi pour discréditer la lutte contre l'impérialisme. C'est-à-dire qu'au lieu d'inculquer aux peuples le sens de la lutte, le devoir, l'obligation sacrée de lutter, ils tentent de semer le découragement... Ils soutiennent ceux qui s'opposent à la guérilla."
} 
Comunista Espanhol em 1964, como porta-voz de uma fala bastante crítica às duas vertentes:

Mas o problema é: direção do Partido ou direção da selva? E a resposta cubana, essa de Douglas Bravo e mais tarde do Che, essa de Révolution dans la révolution?, é sem dúvida: unidade da direção político-militar, encarnada pelo foco da guerrilha. Em sua variante mais estrita, chamamos isso de foquismo, a teoria do foco. Mas, de todo modo, a questão da direção única está no centro do debate: ela explica um pouco o que se passará na Bolívia... E é lá, na Venezuela, que se consuma a cisão do movimento revolucionário latino-americano, com o risco de fazer da guerrilha um ferro de lança sem lança... (O fundo do ar é vermelho, 1977, tradução nossa $)^{412}$

Essa fala da voz over é crítica tanto com a guerrilha como com o Partido, devido à cisão provocada no movimento revolucionário pela discordância entre essas duas esferas. No entanto, o mais interessante, analisando a postura pró-Cuba que Marker declarava nos anos anteriores, é verificar que o trecho formula uma explicação para o fracasso dessa estratégia, atribuindo-o à separação entre sua teoria foquista e sua prática. Para que a ação guerrilheira funcionasse, era necessário um comando central e unívoco, e foi a falta disso - devido à recusa dos partidos comunistas latino-americanos a endossar esse tipo de ação - que causou o isolamento de Douglas Bravo e de Che Guevara, saturando essa via como uma possibilidade revolucionária para o continente latino-americano.

$\mathrm{Na}$ sequência dessa passagem, Marker insere na montagem outro trecho da entrevista com Fidel Castro na selva, quando ironicamente começa a chover sobre o líder. Dessa vez, ele faz uma autocrítica, dizendo que o problema das guerrilhas latino-americanas era a falta de experiência - assim, nos casos em que elas pudessem contar com nomes experientes, como Che Guevara, certamente seriam vitoriosas. Gravadas no mesmo ano da morte do guerrilheiro argentino, essas palavras soam, em O fundo do ar é vermelho, como uma profecia não realizada. Entre as sequências seguintes, o realizador elege como tema a despedida de Che de Cuba, quando Castro

\footnotetext{
${ }^{412}$ Texto da voz over de $O$ fundo do ar é vermelho, traduzido do original: "Mais le problème c'est: direction du Parti ou direction du maquis? Et la réponse cubaine, celle de Douglas et plus tard du Che, celle de Révolution dans la révolution? est sans équivoque: unité de la direction politico-militaire, incarnée par le foyer de guérilla. Dans sa variante la plus stricte, on appelle ça le foquisme, la théorie du foyer. Mais de toute façon, la question de la direction unique est au centre du débat: elle explique un peu ce qui se passera en Bolivie... Et c'est là, au Venezuela, que s'est consommé le schisme du mouvement révolutionnaire latino-américain, au risque de faire de la guérilla un fer de lance sans lance..."
} 
lê sua carta "espetacular" (como a caracteriza Mario Monje, secretário do PC boliviano, para justificar a impossibilidade de que ele voltasse à ilha após uma saída tão triunfal $)^{413}$. Pode-se dizer que, diante do tema das divisões da esquerda trazido pelo filme, a maneira como essa despedida é tratada a delimita como um marco de ruptura na Revolução Cubana: por um lado, inaugura um caminho solitário e infrutífero por parte da guerrilha, fadada a deixar de ser um projeto para se transformar em uma utopia; por outro, é simbólica de um processo de institucionalização do processo revolucionário, que mais adiante terá graves implicações, como será abordado ${ }^{414}$.

Nessas primeiras aparições de Castro, suas falas são marcadas, sobretudo, por uma crítica aos partidos comunistas latino-americanos. Sua entrevista na selva é intercalada com planos de seus discursos aplaudidos por multidões. Embora essas cenas sirvam para marcar um racha entre a guerrilha e as estratégias dos PCs, não há uma crítica direta ao líder cubano, apenas a evidenciação de rachas internos na esquerda percebida por meio de suas palavras. Essa visão, porém, se modifica em outras passagens de $O$ fundo do ar é vermelho, como será analisado.

Fidel Castro volta à cena no terceiro bloco, "Da Primavera de Praga ao Programa Comum", dessa vez sob um viés muito mais crítico, devido à sua posição sobre a invasão da Tchecoslováquia pela URSS. Uma longa sequência em que a câmera treme bastante - assim como naqueles momentos em que os realizadores revelam sua fragilidade - exibe seu discurso sobre o episódio, gravado em Havana em 23 de agosto de 1968. Marker insere sons de sintetizadores, para enfatizar uma possível interferência na transmissão. Assim como os tremores, essa estratégia passa a ideia de que há algo errado, alguma coisa fora do eixo. A maneira como é tratado

\footnotetext{
${ }^{413}$ Nessa passagem em que Fidel Castro lê em off a carta de Che, Marker insere sequências das ruas de Havana e do guerrilheiro. Entre o material de arquivo usado, está um plano curto de Cuba si em que pessoas caminham segurando uma reprodução do rosto do argentino. Nesse caso, pode-se dizer que as imagens do documentário anterior adquirem um sentido melancólico, como uma espécie de fragmento de memória trazido à tona após a morte de um ente querido. O mesmo sentido é dado pela montagem a cenas de Hasta la victoria siempre (1967), de Santigo Álvarez, que também ilustram a leitura do documento por Castro.

${ }^{414}$ A leitura da carta de Che por Castro se desdobra em planos filmados em uma sala de montagem com jovens realizadores franceses, que assistem às imagens da despedida por uma tela. $\mathrm{O}$ jornalista argelino Paul Seban, que está fora de campo, indaga-os sobre o que procuram na figura de Che: "Um líder?". Um jovem responde que esse papel seria ocupado por Marx, ao que o interlocutor provoca perguntando se o teórico não estaria ultrapassado. Diante da resposta negativa, já que a exploração continuaria a existir, Marker insere um plano curto de um lixão na Venezuela, onde homens e pássaros disputam os restos de comida em decomposição. Trata-se de um exemplo claro de como $O$ fundo do ar é vermelho, apesar da faceta autocrítica, não considera que a luta esteja encerrada. Se os métodos revolucionários devem ser repensados, a necessidade da revolução segue latente.
} 
plasticamente esse plano, com ênfase em sua fragilidade técnica, corrobora a estranheza do realizador frente às palavras do cubano:

Certas coisas que temos de dizer estarão em contradição com o que muita gente aprova. Outras vão estar em contradição com nossos interesses e outras constituirão um risco sério a nosso país. No nosso ponto de vista, a decisão tomada na Tchecoslováquia se explica de um ponto de vista político, não de um ponto de vista legal. Pois, em termos de legalidade, ela francamente não tem nenhuma. O que permitiu um remédio dessa natureza? Um remédio que coloca em dificuldade o movimento revolucionário mundial, que cria um verdadeiro trauma no povo tchecoslovaco, que obriga todo um povo a submeter-se a essa experiência amarga: a ocupação pelo exército de outro país, mesmo que seja socialista...[...] Mas, o essencial, concordemos ou não, é o seguinte: o campo socialista poderia permitir o desenvolvimento de uma situação que conduziria ao distanciamento de um país socialista e sua queda nos braços do imperialismo? No nosso ponto de vista, ele não pode permiti-lo, e o campo socialista tem o direito de impedi-lo de uma maneira ou de outra. (O fundo do ar é vermelho, 1977, tradução nossa) ${ }^{415}$

Apesar das ressalvas feitas pelo líder cubano antes de declarar sua posição, demonstrando-se desconfortável em corroborar a ação soviética, a defesa de Castro da invasão da Tchecoslováquia contrasta com suas mesmas convicções manifestadas no primeiro bloco do filme, quando criticava o Partido e defendia uma guerrilha autônoma. Portanto, pode-se afirmar que, além de realizar uma revisão de suas convicções expostas em Cuba si e La bataille des dix millions, Marker demonstra que a própria Revolução Cubana modificou suas orientações originais, tomando rumos que desagradavam o realizador e que justificariam sua mudança de ponto de vista em O fundo do ar é vermelho.

No último bloco, "Do Chile ao - que, de fato?", o tema Cuba ganha bastante espaço, ao lado do novo projeto latino-americano de socialismo democrático, a Unidade Popular. A guerrilha como um projeto fracassado é caracterizada, sobretudo,

\footnotetext{
${ }^{415}$ Discurso de Fidel Castro em $O$ fundo do ar é vermelho, traduzido do original: "Certains choses que nous allons dire vont être en contradiction avec ce qu'éprouvent beaucoup de gens. D'autres vont être en contradiction avec nos intérêts et autres constitueront un risque sérieux pour notre pays. A notre avis, la décision prise en Tchécoslovaquie s'explique dans un point de vue politique, pas d'un point de vue légal. Car, en fait de légalité, elle n'en a, franchement, aucune! Qu'est ce qui a permis un remède de cette nature? Un remède qui met en difficulté le mouvement révolutionnaire mondial, qui crée un véritable traumatisme chez le peuple tchécoslovaque, qui oblige tout un peuple à subir cette éprouve amère: l'occupation des armées d'autre pays, fussent-ils socialiste... [...] Mais l'essentiel, qu'on accepte ou non, c'est ceci: le champs socialiste pouvait-il permettre le développent d'une situation qui conduisait au détachement d'un pays socialiste et à ça chute dans le bras d'impérialisme? A notre avis, il ne peut pas le permettre et le champ socialiste a le droit de l'empêcher d'une manière ou d'une autre."
} 
por uma fala de Douglas Bravo, filmada na selva em 1970, que define a aplicação do conceito de "foquismo dirigente" - tal como exposta no livro de Régis Debray, Révolution dans la révolution? - como um "grave erro". Essa declaração autocrítica, de um guerrilheiro exilado em sua floresta, é um retrato da própria guerrilha nos anos 1970. Essa ideia aparece igualmente no plano seguinte, de Debray na prisão em Camiri, que indica o destino do autor dessa obra que inspirou movimentos revolucionários desse tipo. Entrevistado por Bernardo Volker em 1970, ele admite que as táticas da década que se inicia seriam muito diferentes das dos anos anteriores, já que a luta revolucionária seguiria de outros modos de acordo com o caminho que cada país encontrasse. A figura de Debray, assim como já havia ocorrido em outras produções markerianas, serve como uma ponte entre a via armada e as novas vias que se abriam, uma vez que o jornalista francês seguiu da Bolívia ao Chile.

É também a voz over de Yves Montand que faz a transição de uma via à outra: "Liberado de sua pena, Régis está no Chile, no coração de um processo democrático que parece a antítese absoluta de Révolution dans la révolution?" (O fundo do ar é vermelho, 1977, tradução nossa) ${ }^{416}$. Enquanto são proferidas essas palavras, a montagem mostra capas de jornais chilenos com a notícia sobre a chegada do jornalista francês ao país, bem como trechos de On vous parle du Chile. Uma declaração de Allende extraída deste último filme é colocada em off, enquanto aparecem imagens de Cuba si, as de uma marcha militar e as dos reis magos barbudos, que desempenham o papel de ilustrar as impressões que o presidente chileno descreve de sua passagem pela ilha. Allende narra seu encontro com Raúl e Fidel Castro, em janeiro de 1959, destacando em sua entrevista com Debray a impressionante inteligência do então presidente cubano.

Essa inteligência, que seria uma virtude, é a deixa para a exposição de um Fidel Castro caricato e ardiloso, iniciada pelo plano seguinte em que ele explica a um editor italiano, Feltrinelli, a receita de uma lasanha. Embora divirta os demais, o comentário de Yves Montand imprime à cena uma ironia tipicamente markeriana: "Fidel tinha a genialidade dos grandes atores, de transformar o acidental em legendário" ( $O$ fundo do ar é vermelho, 1977, tradução nossa $)^{417}$. Travestida de

\footnotetext{
${ }^{416}$ Texto da voz over de $O$ fundo do ar é vermelho, traduzido do original: "A peine libéré, Régis est au Chili, au cœur d'un processus démocratique qui semble être l'antithèse absolue de Révolution dans la révolution?".

${ }^{417}$ Texto da voz over de $O$ fundo do ar é vermelho, traduzido do original: "Fidel avait le génie des grands acteurs, de transformer l'accidentel en légendaire".
} 
elogio, essa frase traz em si uma grande crítica ao líder cubano. Primeiramente, por classificar sua "inteligência", tal como destacada por Allende, como a "genialidade de um grande ator", ou seja, insinua que seu verdadeiro talento era o carisma e sua atuação pública. Além disso, ao comentar a sequência em que ensina uma receita aos seus inventores, a locução em over faz uma análise da própria Revolução Cubana: um "acidente" transformado em "legendário". Essa leitura é radicalmente oposta, como se pode perceber, à realizada em 1961 por Cuba si, uma ode a esse processo.

A fala de Yves Montand sobre Fidel Castro segue desvelando seu gestual, visto como um vício transformado em virtude. O comentário destaca que Castro tinha o gesto de sempre mexer nos microfones, um tique adquirido quando ainda não tinha a experiência de um grande orador. Sua incapacidade para controlá-lo fez com que o transformasse em um ritual, uma marca pessoal. Tais palavras são acompanhadas de inúmeros planos curtos do cubano movendo microfones em suas intervenções públicas, o que define a prática como algo constante. Porém, no último plano da sequência, o aparato não se movimenta, enquanto a câmera focaliza um constrangido Fidel Castro vestido com um chapéu soviético, durante um discurso em Moscou: somente uma vez, alerta Montand, os microfones se recusaram a mover-se.
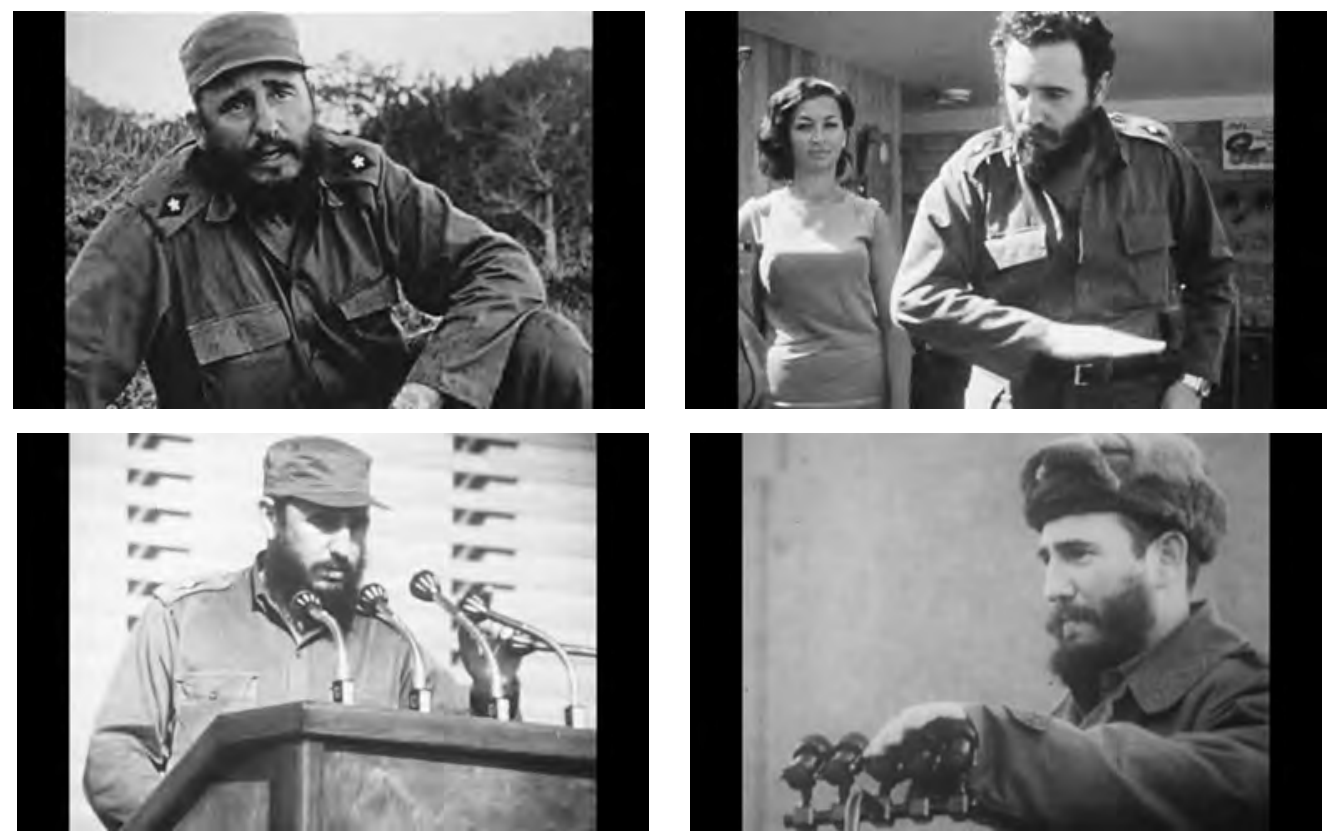

Quatro momentos de Fidel Castro em $O$ fundo do ar é vermelho.

Esse plano e o comentário retomam a grande discordância de Marker com Castro: sua filiação à URSS, chegando ao ponto de defender ações como a intervenção na Tchecoslováquia. É essa aproximação, essa imobilidade causada pela 
submissão da Revolução Cubana aos imperativos soviéticos, que faz com que o realizador reveja sua defesa a Cuba. Na sequência seguinte à dos microfones, é possível vislumbrar de que maneira a crítica a Castro é também uma autocrítica, já que ela passa a ser feita com extratos utilizados em Cuba si. Uma fala do líder que estava presente na produção de 1961 anuncia que a Revolução não é eterna, que ela se institucionalizaria no futuro. $\mathrm{O}$ trecho retoma a ideia de que as imagens têm uma história própria, e trazem em si um potencial que só é descoberto pelo realizador bem depois - como se o mesmo não tivesse compreendido integralmente suas próprias tomadas. Nessa passagem, o próprio ex-guerrilheiro anunciava o fim do processo revolucionário e a instalação de um poder que o desencantaria.

Ursula Langmann (1986) ressalta que Cuba é uma questão central em $O$ fundo do ar é vermelho e descreve Fidel Castro como uma espécie de timbaleiro, que aparece somente quando necessário. A Revolução Cubana é um pano de fundo do documentário, cuja própria trajetória exemplifica o caminho das utopias ao longo dos anos 1960 e 1970 - da revolução à institucionalização. Langmann usa as passagens sobre a ilha como exemplo do procedimento de Marker em interrogar as imagens, inserindo-as em um real contexto histórico:

O melhor exemplo disso, no filme, é sem dúvida a evolução de Cuba, embora seja também o aspecto mais problemático, pois deixa entrever que não só a política de Cuba se alterou como se modificou a atitude emocional do realizador Chris Marker em relação a este país (o que, evidentemente, não pode ser dissociado da própria alteração da situação cubana). (LANGMANN, 1986, p. 32)

A autora usa ainda a palavra "perplexidade" para definir o sentimento do realizador diante dos rumos tomados pela Revolução Cubana que outrora idolatrou. A questão é que, para Marker, a institucionalização de um processo revolucionário traz riscos inerentes ao fato dele se tornar poder. Nesse sentido, vale relacionar a releitura que ele faz de Cuba nesse documentário à defesa de uma liberdade que, para ele, deveria ser inerente à luta revolucionária. O fundo do ar é vermelho realiza uma crítica ao poder - lembrando que os gatos nunca estão próximos dessa esfera -, seja ele o do imperialismo de direita ou o dos resquícios stalinistas na URSS. Sendo assim, a postura de Cuba ao apoiar as ações contra uma Primavera de revisões das velhas estruturas do "socialismo real", ocorrida em Praga, é um fator determinante para seu afastamento desse projeto. 


\section{O programa comum da esquerda francesa em $O$ fundo do ar é vermelho}

Embora a questão do programa comum da esquerda francesa apareça pontualmente em outras passagens do filme, ela é tratada especialmente no bloco " $\mathrm{Da}$ Primavera de Praga ao programa comum" e, de modo secundário, em "Do Chile ao, que, de fato?"418. Esses dois blocos pertencem à segunda parte do documentário, "As mãos cortadas". Como já foi analisado, esse título, de forma simplificada, indica que "as mãos frágeis" das utopias foram reprimidas e amputadas. Portanto, pode-se inferir que o tema da união esquerdista integra as possibilidades possíveis do caminho ao socialismo no início da década de 1970, surgidas após o enfraquecimento das guerrilhas e de outros embates perdidos nos anos 1960.

Georges Marchais era, em 1970, secretário-adjunto do Partido Comunista Francês, passando a ocupar o cargo mais elevado da instituição em 1973. Nesse cargo, seria uma das figuras centrais, ao lado de François Mitterrand, do PS, na busca pelo programa comum da esquerda, o que o fez também um protagonista de $O$ fundo do ar é vermelho. É interessante notar que sua primeira aparição no documentário ocorre justamente após a fala de Fidel Castro apoiando a invasão da Tchecoslováquia, mas ele defende uma posição oposta à do líder cubano. Um plano de Marchais ao lado de outros dois companheiros que ocupam uma mesa de debate na reunião do PCF realizada em Lille, em 1970, reitera resoluções já anunciadas pelo Partido:

O Partido Comunista Francês afirmou-se contra a intervenção, e sua posição não mudou. Ele a renovou na época de nosso XIX Congresso. Eu posso resumir as razões dessa posição em três fases: em janeiro de 1968, quando o Partido Comunista da Tchecoslováquia se pronunciou por mudanças na vida econômica do país, pela aplicação de uma democracia socialista real, sem de modo algum nos metermos nos seus assuntos interiores, consideramos que essa posição era justa, e nós a apoiamos. Como consequência, é evidente que em um país como a Tchecoslováquia, lá também, há pouco mais de um quarto de século..., existem forças que permanecem hostis ao socialismo. Era necessário, então, lutar contra essas forças. ( $O$ fundo do ar é vermelho, 1977, tradução nossa $)^{419}$

\footnotetext{
${ }^{418}$ Este subcapítulo analisará como o tema do programa comum é tratado no bloco "Da Primavera de Praga ao programa comum". Sua presença no último bloco, "Do Chile ao - que, de fato?”, será tratado no próximo subcapítulo, já que a abordagem sobre o assunto está intrinsicamente relacionada à da Unidade Popular.

${ }^{419}$ Discurso de Georges Marchais em $O$ fundo do ar é vermelho, traduzido do original: "Le Parti communiste français s'est affirmé contre la intervention, et sa position n'a pas changé. Il l'a renouvelée
} 
No entanto, embora se posicione contra a invasão da Tchecoslováquia, Marchais termina sua fala declarando que considera o Partido Comunista tchecoslovaco suficientemente forte para resolver sozinho esse "problema". Esta última frase é inserida em off, enquanto o filme exibe tomadas do congresso clandestino realizado pelo PC em Praga, com uma tribuna lotada - imagens que o realizador havia descrito como cenas de um evento inexistente. Esses planos curtos separam as sequências da reunião de Lille das do XIX Congresso, realizado em fevereiro de 1970. Sobre este último encontro do PCF, Marker decide expor trechos de uma discussão entre Étienne Fajon (defendendo a União Soviética) e Roger Garaudy (expulso em 1970 justamente por ter criticado a invasão) ${ }^{420}$, evidenciando que, embora o discurso oficial fosse o de Marchais, não houve um apoio efetivo à Primavera de Praga. Ao contrário, o episódio serviu para gerar discórdias e punições no interior do partido francês.
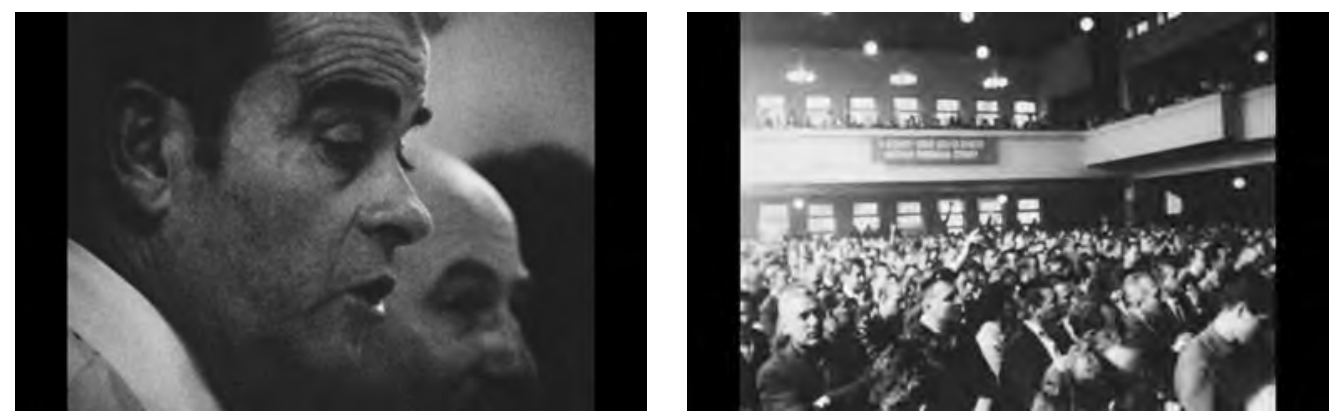

Imagens do congresso do PC de Praga, intercaladas por discurso de Georges Marchais no encontro do PCF em Lille (1970). Fotogramas de O fundo do ar é vermelho.

Essa passagem mostra que, embora Marker considere a guerrilha uma tática amputada, sua esperança nos partidos também é limitada. $\mathrm{O}$ exemplo da repressão à Tchecoslováquia - e o pouco apoio que os comunistas tchecoslovacos receberam por parte dos PCs internacionais - revela que é necessário, na visão do realizador, uma revisão no interior dessas instituições. Percorre o filme a ideia de que a intolerância e a repressão são práticas indesejáveis dentro das esferas partidárias da esquerda, enfatizada sobretudo no bloco sobre a Primavera de Praga e o programa comum.

lors de notre $\mathrm{XIX}^{\mathrm{e}}$ Congrès. Je peux résumer les raisons de cette position en trois phases: en janvier 1968, quand le Parti Communiste de Tchécoslovaquie s'est prononcé pour des changements dans la vie économique du pays, pour l'application d'une démocratie socialiste réelle, sans aucunement nous immiscer dans ses affaires intérieures, nous avons considéré que cette position était juste, et nous l'avons soutenue. Par la suite, il est évident que dans un pays comme la Tchécoslovaquie, que là aussi, il y a à peine un quart de siècle... il y a des forces qui restent hostiles au socialisme. Il fallait donc lutter contre ces forces."

${ }^{420}$ Esta passagem foi cortada na versão atual, que insere o depoimento de Jorge Semprún logo após as cenas do congresso do PC tchecoslovaco. 
Semprún, que além de uma das vozes over aparece no filme em entrevistas (em extratos retirados de On vous parle de Prague), defende, em um trecho inserido na montagem logo após o XIX Congresso do PCF, que o partido que existia durante a Revolução de 1917 permitia o debate entre as facções, e que as disputas internas só seriam reprimidas tempos depois:

Mas o partido que tomou o poder não é o partido cujo modelo foi imposto em seguida pelo mundo inteiro. É um partido que hoje seria excluído do movimento operário comunista, pelas mesmas razões que foram excluídos do partido comunista tcheco os homens e as forças que tentaram reestabelecer esse combate. ( $O$ fundo do ar é vermelho, 1977 , tradução nossa) ${ }^{421}$

As sequências descritas neste subcapítulo, que intercalam o tema da Primavera de Praga às posições do Partido Comunista Francês, trazem um dado importante para pensar o programa comum na visão de Chris Marker. Tal como defende essa fala de Semprún, O fundo do ar é vermelho sugere que é necessário recuperar as origens da Revolução Russa e reformular os PCs pelo mundo, abrindo-os ao debate interno. A união desse campo político, tal como desejada pelo realizador francês, é calcada no diálogo entre as divergências, e não a união imposta por condutas autoritárias. Esse aspecto é fundamental para compreender que as posições políticas de Marker, mesmo quando criticam a própria esquerda e sua fragmentação, apontam para uma conduta unívoca, mas nascida do entendimento - nunca da repressão.

Em $O$ fundo do ar é vermelho, Georges Marchais é um protagonista quase sempre contestado, principalmente por estratégias de montagem. Suas declarações vêm acompanhadas por outras que fazem com que pareçam insuficientes. Um exemplo, ainda no bloco "Da Primavera de Praga ao Programa Comum”, é quando o secretário-adjunto do PCF, em outra tomada da reunião de Lille (1970), critica o stalinismo, classificando o fenômeno como uma "deformação grave do socialismo". O plano seguinte é novamente um trecho de Jorge Semprún, que comenta os riscos inerentes ao uso do termo "stalinismo":

Esse é um termo muito ambíguo, pois, inicialmente, ele sugere que essa evolução esteja ligada a um homem, ou a um grupo de homens, talvez a uma situação social de atraso e de formação de um cerco, e

\footnotetext{
${ }^{421}$ Discurso de Jorge Semprún em $O$ fundo do ar é vermelho, traduzido do original: "Mais le parti qui a pris le pouvoir n'est pas le parti dont le modèle a été imposé ensuite à travers le monde entière. C'est un parti qui aujourd'hui serait exclu du mouvement ouvrière communiste, pour les mêmes raison qu'on exclut dans le parti communiste tchèque des hommes et des forces qui ont essayé de reprendre ce combat."
} 
que, em seguida, uma vez que um certo tipo de dirigente tenha desaparecido da cena histórica e que um certo tipo de cerco e de atraso tenha desaparecido da cena histórica, esses fenômenos não se reproduziriam mais. Mas a experiência mostra que isso não é exatamente verdadeiro [... $]^{422}$ (O fundo do ar é vermelho, 1977, tradução nossa)

Ainda que Marker se mostre favorável ao projeto de união das esquerdas, criticando a fragmentação desse campo político em inúmeros grupos e rachas internos, ele alerta para a necessidade de que essa unificação seja democrática, aberta ao diálogo e incorpore as diferenças. A Primavera de Praga e suas consequências servem como uma espécie de alerta de que o stalinismo não é um fenômeno circunscrito a um período histórico, mas uma maneira de pensar e de agir arraigada no partido. A presença de Jorge Semprún (um homem de esquerda expulso do PC de seu país) em $O$ fundo do ar é vermelho corrobora o desejo do realizador de extirpar certas práticas em prol de uma nova estratégia. Sob esse ponto de vista, apenas uma análise apurada dos processos políticos dos anos anteriores, sejam eles utópicos ou "reais" (no sentido de um "socialismo real" implementado a altos custos), possibilitaria o encontro de novos caminhos. Essa é a chave para se entender esse documentário como um filme autocrítico, mas, ao mesmo tempo, militante ao reafirmar a defesa a uma causa.

O tema do programa comum de governo da esquerda francesa é aprofundado na passagem dedicada à sucessão presidencial após a morte de Georges Pompidou (informada ironicamente pela voz over, que descreve a sequência de seu encontro com a mulher de Mao Tsé-Tung como a de um "futuro morto" com uma "futura viúva”). Outra imagem que marca o início dessa discussão é um plano que registra uma estrada contornada por árvores altas, em que a câmera realiza um traveling dos cumes das árvores até um veículo militar no solo, que se movimenta na direção da câmera enquanto ela "se aproxima" do carro por meio do zoom. O veículo carrega uma caixão coberto por uma bandeira da França. A cena traz um ar sombrio, de incerteza, representando uma nação que vai por trilhas escuras levando seu defunto. Em off, ouve-se a voz de Maurice Grimaud (o responsável do governo pela repressão

\footnotetext{
${ }^{422}$ Discurso de Jorge Semprún em $O$ fundo do ar é vermelho, traduzido do original: "C'est un terme très ambigu, parce que d'abord il laisse supposer que cette évolution est liée à un homme, ou à un groupe d'hommes, peut-être à une situation sociale d'arriération et d'encerclement, et que donc une fois qu'un certain type de dirigeant a disparu de la scène de l'histoire et qu'un certain type d'encerclement et d'arriération a disparu de la scène de l'histoire ces phénomènes-là ne se reproduiront plus. Or l'expérience démontre que ce n'est pas exactement vrais [...]."
} 
ao Maio de 68), que descreve o isolamento que caracterizou os últimos momentos de Charles De Gaulle. Os dois falecimentos - o de Pompidou e o de De Gaulle - são, portanto, relacionados como eventos de um mesmo processo: a disputa pelo poder executivo.

O documentário dedica os minutos seguintes, por meio de extratos de entrevistas e declarações, ao referendo de abril de $1969^{423}$, visto como algo que determinaria ou não a permanência do general De Gaulle no poder. É nesse trecho que François Mitterrand aparece em cena pela primeira vez em $O$ fundo do ar é vermelho, entrevistado por um programa de rádio (intitulado Grand Jury) em 1969. As imagens mostradas por Marker são dos bastidores dessa produção, onde se pode ver as mesas de controle e o próprio político se preparando para o debate. O primeiro debatedor o indaga sobre sua atuação nas campanhas em torno do referendo, tendo em vista que ele seria um "homem de relevo" do regime gaulista. Mais direto, outros integrantes da mesa traduzem que a pergunta trata das campanhas eleitorais, precisamente sobre a possibilidade da articulação de uma aliança de esquerda para concorrer ao pleito. Mitterrand fala de um "modelo francês de socialismo", que integraria ao seu programa a "lei do mercado". Ele termina sua declaração dizendo ser necessário evitar o "caminho dos erros" dos cinquenta anos de experiência socialista e reter "o que há de bom”.

Apesar de se esquivar das perguntas diretas, essa declaração de Mitterrand relaciona as articulações em prol de um programa comum ao referendo. A vitória do "Não" e o frustrado segundo turno entre Pompidou e Alain Poher (anunciado no filme por um extrato de notícia da ORTF), que deixou a esquerda de fora, são prelúdio para o acordo entre o PCF e o PS. Um plano-sequência mostra Jacques Duclos descendo de um carro nas ruas de Paris, entrando por uma porta e cumprimentando companheiros, quando a câmera realiza um movimento que revela tratar-se do Comitê Central do Partido Comunista. Esse plano, que materializa uma espécie de recolhimento de Duclos após sua derrota no pleito presidencial, é acompanhada por uma voz off ${ }^{424}$ que defende que o Partido Comunista, aquele em que os trabalhadores

\footnotetext{
${ }^{423}$ Em 27 de abril de 1969 ocorreu um referendo sobre a criação de regiões e a reforma do Senado. Em meio as agitações populares iniciadas após o maio de 1968 na França, a consulta popular foi vista como uma validação da permanência de Charles De Gaulle no poder, já que ele havia declarado que renunciaria, caso o "não" ganhasse. Com 52,41\% para o "não", o plebiscito terminaria com a renúncia do presidente.

${ }^{424}$ No roteiro do filme, publicado em 1978, essa voz que aparece em off é identificada apenas como "P.".
} 
mais depositam sua confiança, deve procurar alianças com forças mais à direita, como o Partido Socialista e as classes médias.

A montagem segue com cenas de uma conferência de quadros do PCF, e um plano fixa-se novamente na figura de Marchais, que coloca a questão: "Que outro caminho nós temos para irmos em direção às mudanças a não ser o caminho da unidade e da união?" ( $O$ fundo do ar é vermelho, 1977, tradução nossa $)^{425}$. Nas sequências seguintes, o secretário discursa como se respondesse a questões sobre a possibilidade de estabelecer uma aliança com o socialista Guy Mollet, que havia se manifestado contra a existência de um partido comunista na França. Por uma coincidência ou pela manipulação dos extratos fílmicos utilizados, as imagens tremem enquanto Marchais defende a negociação. Nessa passagem, é possível notar como Chris Marker novamente expõe certa desconfiança em relação a esse personagem, já que as câmeras titubeiam adiante da repressão da direita, mas também quando a própria esquerda vacila (vale lembrar que ela havia tremido em Santiago quando a polícia da Unidade Popular usou os mesmo métodos repressivos presentes nos governos conservadores).

Essa certa desconfiança de Marker se justifica por se tratar de um processo que estava sendo consolidado durante a montagem do filme, ou seja, cujo resultado não era factível de se saber na época. O realizador, embora defenda esse diálogo entre as forças de esquerda, demonstra receio diante dos limites aceitáveis para a formação de alianças em prol de uma "união popular" (para usar um termo em voga na época, gritado pelos vendedores de camisetas na Festa da Humanidade do PCF, em 1972, presente em algumas cenas de $O$ fundo do ar é vermelho). Algumas das indagações a esse projeto aparecem em uma passagem em que o próprio Marker, cuja voz permanece em off, entrevista o historiador Jean Elleinstein - especialista da história do comunismo, registrado em um plano próximo, que denota uma aproximação com suas opiniões, considerando que se trata de uma tomada feita pelo realizador ${ }^{426}$. Marker pergunta se essa guinada democrática do Partido, aproximando-se de outros setores para compor uma frente eleitoral, indicaria o fim da ditadura do proletariado. Elleinstein the explica que a resposta seria afirmativa pensando na concepção de

\footnotetext{
${ }^{425}$ Fala de Georges Marchais presente em $O$ fundo do ar é vermelho, traduzida do original: "Quel autre chemin avons-nous pour aller à des changement que le chemin de l'unité et de l'union?'.

${ }^{426}$ De acordo com o roteiro publicado em 1978, essa entrevista, cujo entrevistador é o próprio Marker, foi gravada em 1975. Presume-se, considerando que esses planos não estão em outra produção, que tenham sido registrados especialmente para $O$ fundo do ar é vermelho.
} 
Lênin (na qual esse termo era entendido com configurações ditatoriais para manter o poder), mas não na de Marx (na qual o conceito é usado de modo mais abstrato, como oposição à "ditadura da burguesia"). E o historiador completa, em outro extrato da mesma entrevista, que o problema dos comunistas seria justamente confundir os domínios da "linha política" com as do "debate e da pesquisa marxista".

A conclusão de Elleinstein é endossada em $O$ fundo do ar é vermelho por Marker, na medida em que o filme se propõe a pensar sobre as opções possíveis após o fracasso das utópicas, ao mesmo tempo em que critica as vias autoritárias seguidas especialmente na União Soviética ${ }^{427}$. Dessa forma, apesar do tremor (o da câmera) diante de algumas alianças desagradáveis (e que são vistas assim justamente por se tratarem de visões autoritárias e segregacionistas do campo da esquerda), o documentário endossa a escolha pelo caminho democrático e o fim da "ditadura do proletariado" posta em prática na URSS. A passagem da fala de Marchais e a do historiador francês, próximas na montagem, estabelecem um movimento dialético que vai da desconfiança nos caminhos dos partidos comunistas à reafirmação da causa socialista.

Essa posição condiz com a atuação política do realizador, que, embora engajado nas causas da esquerda e envolvido em práticas cinematográficas militantes, não se filiou formalmente a nenhum partido. Em entrevista à pesquisadora (MARKER, 2011), ele declarou jamais ter militado em organizações ou movimentos sociais específicos. Com a mesma ironia presente em seus filmes, justificou essa conduta independente:

Eu não tenho nem a grande qualidade (a abnegação), nem o grande defeito (o sectarismo). Eu sou biologicamente incapaz de me submeter a uma disciplina, e eu tenho como um bem precioso a faculdade de questionar tudo a todo momento - não é exatamente isso que se espera de um militante. Eu não considerei nunca as ideologias a não ser sob um ângulo hegeliano: roupagem intelectual das estratégias de dominação. E mais um pessimismo histórico absoluto herdado dos anos de guerra (ter vinte anos em 1941 não predispunha ao otimismo). Dito isso, você sabe, assim como eu, que os pessimistas algumas vezes têm boas surpresas, enquanto que os otimistas vão de decepção em decepção. Então, paradoxalmente, é esse pessimismo histórico que me fez correr o mundo à procura de momentos $\mathrm{e}$ lugares em que a espécie humana, contra toda a razão, exprimia sua vontade de "fugir". Isso foi tanto em Israel como em Cuba, o importante

\footnotetext{
${ }^{427}$ Vale lembrar que, nos filmes em que defendia o governo cubano, Cuba si e La bataille des dix millions, Marker visualizava na ilha uma democracia direta, e não um regime autoritário.
} 
para mim era mais o élan vital que as variedades contingentes. (MARKER, 2011, tradução nossa) ${ }^{428}$

Essa autodefinição, apesar de não ser contemporânea a $O$ fundo do ar é vermelho, define bem o espírito do filme e sua oscilação entre um pessimismo latente ante tantas derrotas e a busca por um "élan vital" que reacendesse as esperanças. O programa comum da esquerda francesa, tal como articulado nos anos 1970, foi visto por Marker nessa chave do apoio e da desconfiança. Se, de fato, apresentava-se como uma alternativa possível e, o mais importante, democrática - além de apontar para um respiro dentro do sectarismo esquerdista -, seus articuladores - comunistas e socialistas - mereciam ser vistos com cautela. Dessa forma, o documentário opta pela desconstrução da figura dos líderes e partidos, pela análise múltipla e realista dos processos históricos, pela identificação dos erros cometidos e pela procura por novos caminhos possíveis ao socialismo. Essa postura corrobora o fato de o realizador dedicar essa produção aos "homens e mulheres da Nova Esquerda", aqueles que, como ele mesmo, se mostravam capazes de rever suas posições e encontrar novas vias possíveis.

A Unidade Popular chilena, mais do que essa "Nova Esquerda" europeia, foi vista por Chris Marker como um desses "élans" responsáveis por reavivar o otimismo. Em $O$ fundo do ar é vermelho, em uma abordagem realizada após o desfecho dessa experiência que abalou mesmo os mais pessimistas, esse processo está atrelado à articulação de um programa comum das esquerdas, em um primeiro momento, como modelo estratégico. Porém, se a Primavera de Praga e a resposta repressiva a ela demonstraram a necessidade dos partidos franceses se repensarem, o caso do Chile exigiu, a contragosto, uma nova revisão, abordada no último bloco do documentário.

\footnotetext{
${ }^{428}$ Traduzido do original: “Je n'en ai ni la plus grande qualité (l'abnégation) ni le plus grand défaut (le sectarisme). Je suis biologiquement incapable de me soumettre à une discipline, et je tiens pour un bien précieux la faculté de tout remettre en cause à tout moment - pas exactement ce qu'on attend d'un militant. Je n'ai jamais considéré les idéologies que sous l'angle hégélien : l'habillage intellectuel des stratégies de domination. Plus un pessimisme historique absolu hérité des années de guerre (avoir vingt ans en 1941 ne prédispose pas à l'optimisme). Cela dit, vous savez comme moi que les pessimistes ont quelquefois de bonnes surprises, tandis que les optimistes vont de déception en déception. C'est donc paradoxalement ce pessimisme historique qui m'a fait courir le monde à la recherche des moments et des lieux où l'espèce humaine, contre toute raison, exprimait sa volonté de 's'en tirer'. Cela a été aussi bien Israël que Cuba, l'important pour moi était plus l'élan vital que les variétés contingentes."
} 


\section{A Unidade Popular chilena em O fundo do ar é vermelho}

O tema da Unidade Popular em $O$ fundo do ar é vermelho é tratado com mais destaque nos últimos vinte minutos do documentário, após a passagem já citada que traz inúmeras cenas de Fidel Castro (entre elas, aquela em que ele ensina os italianos a fazerem lasanha) e que aborda a institucionalização da Revolução Cubana. Dessa forma, é o esgotamento de uma fórmula, na visão do realizador, o que demanda novos caminhos, e a experiência chilena apresenta-se como um novo paradigma sucessor ao cubano. É interessante notar que um plano curto de uma declaração do líder do PC venezuelano, Héctor Mujica, é responsável pela transição entre os dois modelos. Esse fato é significativo, pois Mujica representa, dentro do campo da esquerda, as forças antagônicas à guerrilha isolada de Douglas Barros. Portanto, sua fala remete à descrença dos partidos comunistas latino-americanos, ao final dos anos 1960, nas estratégias vitoriosas aplicadas em Cuba: "O exemplo cubano não se repetirá! Marx já dizia... A história não se repete, e, quando se repete, é sobre a forma de tragicomédia." (O fundo do ar é vermelho, 1977, tradução nossa) $)^{429}$

Um dos personagens de L'ambassade volta à cena (agora como ele próprio) em uma entrevista filmada em seu escritório. Volodia Teitelboim, do PC do Chile, explica que, depois da Revolução Cubana, o imperialismo construiu dispositivos antiguerrilha muito difíceis de serem superados. Mais uma vez, O fundo do ar é vermelho recorre ao movimento em espiral, gerado por ação e reação (revolução e contrarrevolução), para explicar a necessidade de mudança nos métodos da esquerda. O domínio de suas estratégias por parte do inimigo levou à necessidade de revisão. Essa teoria é corroborada pela inserção na montagem, entre as sequências de Teitelboim, de uma declaração de M. Wallander (do Pentágono), dizendo que os militares norte-americanos estavam alertas para evitar novamente o "milagre" ocorrido em Cuba. De volta às cenas do advogado chileno, ele defende a emergência de uma nova via: "É por isso que a via chilena, em que é o povo inteiro que prepara a revolução, é muito mais invulnerável ao ataque imperialista e infinitamente mais

\footnotetext{
${ }^{429}$ Discurso de Héctor Mujica em $O$ fundo do ar é vermelho, traduzido do original: "L'exemple cubain ne se répétera! Marx le disait déjà... L'histoire ne se répète pas, et quand elle se répète, c'est sous forme de tragi-comédie".
} 
eficaz que o heroísmo de alguns jovens em uma montanha ou em uma cidade..." $(O$ fundo do ar é vermelho, 1977, tradução nossa) ${ }^{430}$.

Essa declaração, porém na época em que $O$ fundo do ar é vermelho foi montado, tem uma evidente fragilidade. O modelo de implementação do socialismo no Chile mostrou-se tão - ou mais - suscetível ao imperialismo norte-americano do que o da guerrilha. O espectador de 1977 é consciente dessa deficiência. Isso permite que Chris Marker aproxime no documentário o caso chileno do cubano: ambos foram utopias vitoriosas, mas que encontraram dificuldades em sua institucionalização, levando à sua derrocada. Em relação a Cuba, foi a submissão ao imperialismo soviético a responsável pelo fim das utopias, pela deturpação dos preceitos originais dos revolucionários - especialmente de Fidel Castro. No Chile, a situação seria ainda mais grave, com o trágico fim da Unidade Popular por meio de uma ação apoiada pelos Estados Unidos e a morte de seu símbolo máximo.

Essa desesperança, esse fracasso das possibilidades surgidas na América Latina, é o que permite a solidariedade entre essas nações-modelo, simbolizada no filme por um ato em apoio ao Chile com a presença de Beatriz Allende, em Havana, em 1973. Entre os planos de seu discurso, uma panorâmica em plongée mostra a cidade completamente tomada por uma multidão, onde o único rosto nítido é o de Che Guevara, em um enorme cartaz. A filha do presidente morto é focalizada em close-up, quase encoberta pelos famosos microfones de Fidel Castro, lançando um olhar ao vazio e com lágrimas escorrendo dos olhos. Nessa sequência, Marker utiliza diversos recursos comuns a outras passagens do filme. A câmera tremida, junto com sons de sintetizadores, dá à cena uma atmosfera aterrorizante - o tremor característico do temor. ${ }^{431}$ Toda essa atmosfera - seu isolamento ante multidão, sua saída, sob aplausos de Castro, seu desconforto em lançar um tímido sorriso após o pranto discreto incontrolável, o clima de mistério dado pelo ruído eletrônico - faz de suas palavras um consolo estéril:

\footnotetext{
${ }^{430}$ Fala de Volodia Teitelboim em $O$ fundo do ar é vermelho, traduzido do original: "C'est pourquoi la voie chilienne, où c'est le peuple tout entier qui prépare la révolution, est beaucoup plus invulnérable en face de l'attaque impérialiste et infiniment plus efficace que l'héroïsme de quelques jeunes gens sur une montagne ou dans une ville...".

${ }^{431}$ Vale enfatizar a história dessa imagem, após sua tomada (lembrando que, para o realizador, as imagens têm histórias a serem reveladas): Beatriz Allende se suicidou um mês antes do lançamento de $O$ fundo do ar é vermelho. Apesar dessa tomada integrar a primeira versão da montagem de $O$ fundo do ar é vermelho, não se sabe se ela foi inserida antes ou depois da morte da conferencista.
} 
Deste território livre da América, nós podemos responder ao companheiro presidente: seu povo não vacilará! Seu povo não entregará a bandeira da revolução! A luta até a morte contra o fascismo começou e se completará com o Chile livre, soberano, socialista pelo qual você [Allende] deu sua vida. Querido companheiro presidente, venceremos! (O fundo do ar é vermelho, 1977 , tradução nossa $)^{432}$
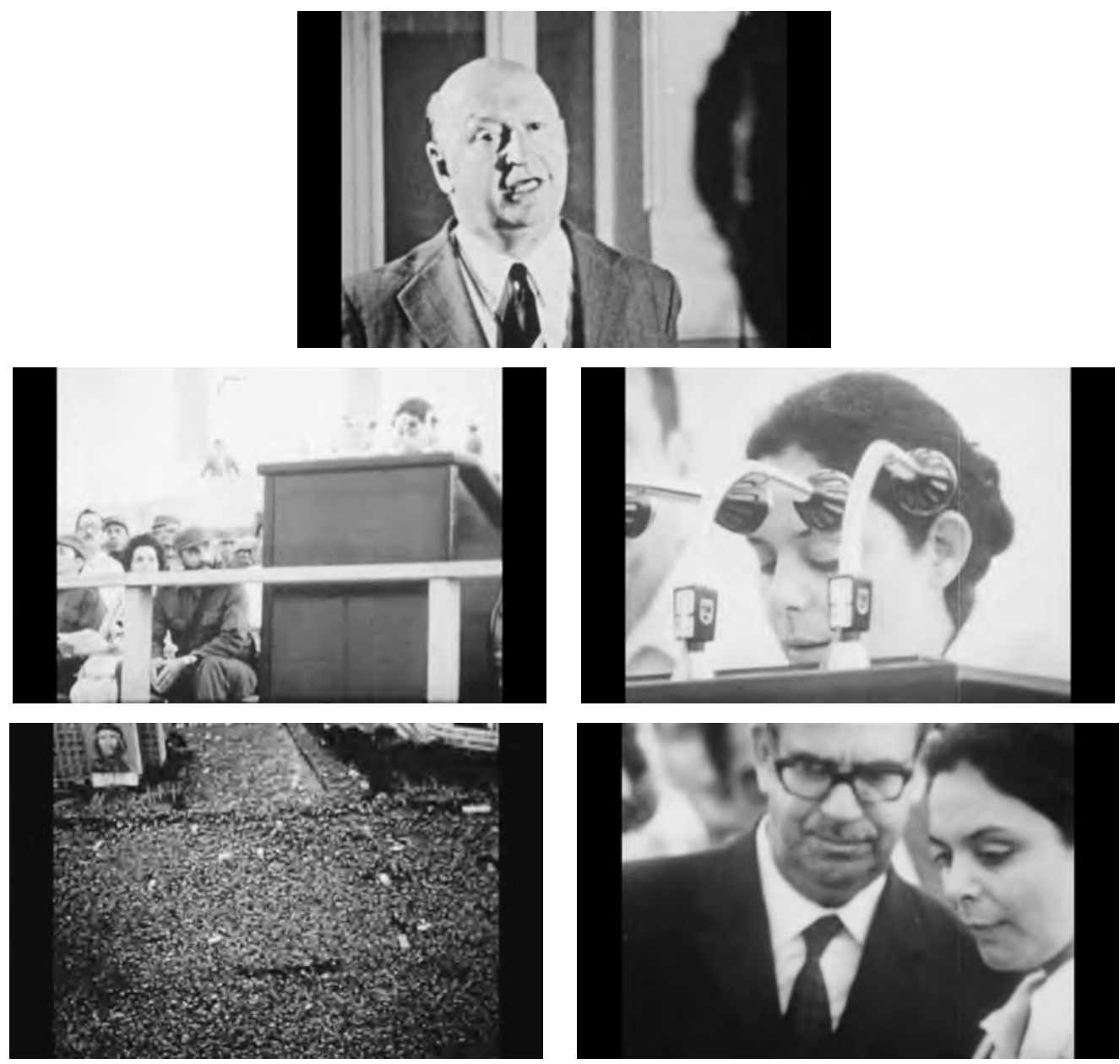

Volodia Teitelboim e Beatriz Allende em $O$ fundo do ar é vermelho.

Essa passagem de $O$ fundo do ar é vermelho imprime uma certa melancolia ao trágico fim do governo de Salvador Allende, o que transforma a reversão da situação no país em uma utopia distante. Se, em La spirale, havia, apesar do cenário trágico, a sugestão de que movimentos de resistência se organizavam em território nacional, nesse documentário, a fala de Beatriz Allende, seguida por seu posterior suicídio demonstra que a possibilidade de um Chile "livre, soberano, socialista" é algo

\footnotetext{
${ }^{432}$ Discurso de Beatriz Allende em $O$ fundo do ar é vermelho, traduzido do original: "Depuis ce territoire libre d'Amérique, nous pouvons répondre au camarade-présidente: ton peuple ne vacillera pas! Il n'amènera pas le drapeau de la révolution! La lutte à mort contre le fascisme a commencé et s'achèvera avec le Chili libre, souverain, socialiste, pour lequel tu as donné ta vie... Cher camaradeprésident, nous vaincrons!”.
} 
improvável naquele momento. Amparada por Fidel Castro, ambos compõem um quadro de desilusões - para o próprio realizador - diante do desfecho de projetos políticos socialistas que enfrentaram, nos anos 1970, uma derrocada.

Nesse sentido, a América Latina, em $O$ fundo do ar é vermelho, passa de continente-modelo para um palco de promessas não consolidadas, "cortadas" pelas hábeis mãos da repressão - seja ela de direita, materializada pelo imperialismo norteamericano, ou de esquerda, simbolizada pela aproximação de Castro com o autoritarismo da União Soviética que "esmagou" a Primavera de Praga. Em relação a Cuba, essa descrença se estende à própria tática de guerrilha, considerada uma fórmula conhecida pelos seus repressores, portanto, deficiente em termos de resultados efetivos. No caso do Chile, porém, a questão se torna ainda mais complexa: como (não) desacreditar na via democrática, a mesma apoiada pela esquerda europeia, para a qual o país havia se tornado referência? Como essa questão é tratada nesse documentário, tendo em vista que ele visa a motivar iniciativas de união entre partidos, tais como as que originaram a Unidade Popular? ${ }^{433}$

Uma das saídas encontradas para esse desafio - não desacreditar na via eleitoral após o fracasso - está novamente em fazer um balanço autocrítico dos limites encontrados internamente, no campo da própria esquerda, e reconhecer os erros. Apesar de fazê-lo de forma mais sutil do que em outras produções, como em L'ambassade, essa revisão da experiência chilena ocorre, sobretudo, em uma passagem em que Salvador Allende discursa em uma fábrica de Santiago, em 1972, para operários de uma empresa estatizada ${ }^{434}$. O presidente saúda a presença dos jornalistas, especialmente dos estrangeiros, já que poderiam testemunhar uma "verdadeira democracia”. A imagem de Allende, registrado quase sempre em closeups acentuados, é intercalada com a da plateia de trabalhadores (predominantemente mostrada em plano-conjunto), que, ao final, aplaude muito seu discurso. Trata-se de

\footnotetext{
${ }^{433}$ Uma das críticas recebidas pelo filme no debate promovido pelos Cahiers du cinéma (TABLE, 1978), na mesa-redonda publicada em janeiro de 1978, dizia respeito à presença da América Latina. Thérèse Giraud considerou $O$ fundo do ar é vermelho "eurocentrista", por abordar o continente apenas em comparação à Europa.

${ }^{434}$ Vale destacar que um trecho dessa sequência estava presente em La spirale, sendo citado no capítulo 3. Porém, nessa produção anterior, as imagens de Salvador Allende discursando nas fábricas serviam para contrapor as falas dos gremialistas, comprovando uma aproximação real entre o poder executivo e os trabalhadores. Em 1977, no entanto, essa cena (mais longa do que o corte feito para a produção anterior) serve a uma autocrítica que verifica no apelo presidencial evidências de que não havia no Chile da Unidade Popular um poder popular consolidado.
} 
uma das sequências mais longas de $O$ fundo do ar é vermelho, e que mostra a fragilidade da Unidade Popular ao implorar por uma maior participação social:

Eu passei aqui dois dias. Eu vi os lados positivos e os lados negativos. Aspecto negativos: não há aqui participação direta dos trabalhadores... Grave erro! É necessário corrigi-lo... Os comitês de produção são baseados no fato de que cada companheiro, onde quer que ele trabalhe, sabe muito bem tanto qual é a sua tarefa quanto a de toda sua seção dentro do Plano, que deve ser discutido, analisado, criticado em reuniões de grupo, depois em assembleiasgerais, no domingo, ou no sábado após o meio-dia... Vocês entenderam bem? Então, é amargo perceber que nas assembleias de estudo do Plano da usina vá apenas uma minoria de camaradas... É uma falta de consciência política! Todo esse processo de mudança para uma sociedade nova repousa sobre o quê? Sobre os trabalhadores! Sobre a produção! Sobre a produtividade! [...] $(O$ fundo do ar é vermelho, 1977, tradução nossa) ${ }^{435}$

Nesse longo discurso de Allende, aqui reproduzido apenas em um trecho, aparece um aspecto autocrítico em relação à Unidade Popular que não estava presente nas outras produções de Chris Marker sobre o tema: a constatação da falta de um poder popular autêntico. A atitude ambígua do presidente na cena - que demonstra proximidade com os operários, mas que cobra uma participação efetiva no planejamento da produção - pode ser vista como a da própria aliança de esquerda, que, apesar de seus esforços, não permitiu a formação de um poder autônomo do povo que pudesse garantir a continuidade desse projeto mesmo contra as ações da oposição. É interessante notar que essa será a tese da terceira parte de A batalha do Chile III - $O$ poder popular (1979), de Patricio Guzmán. Uma hipótese para justificar esse enfoque nas análises sobre a UP feitas no final dos anos 1970 pode ser o fortalecimento da ditadura de Pinochet e as poucas possibilidades de reversão dessa ditadura por um forte movimento popular interno de resistência.

O longo discurso de Allende é ainda intercalado com planos registrados em Santiago durante seu governo, nos quais se vê conflitos entre os cidadãos e repressão policial. Algumas dessas imagens dos caminhões com canhões de água estavam entre

\footnotetext{
${ }^{435}$ Discurso de Salvador Allende em $O$ fundo do ar é vermelho, traduzido do original: "J'ai passé ici deux jours. J'ai vu des côtés positifs et des côtés négatifs. Aspect négatif: il n'y a pas ici participation directe des travailleurs... Grave erreur! Il faut la corriger... Les comités de production ont pour base le fait que chaque camarade, où qu'il travaille, sache aussi bien quelle est sa tâche que celle de toute sa section à l'intérieur du Plan qui doit être discuté, analysé, critiqué en réunions partielles puis en assemblées générales, le dimanche, ou le samedi après-midi... Vous avez bien entendu? Alors, qu'il est amer d'apprendre qu'aux assemblées d'étude du Plan de l'usine ne vient qu'une minorité de camarades... C'est un manque de conscience politique! Tout ce processus de changement vers une société nouvelle repose sur quoi? Sur les travailleurs! Sur la production! Sur la productivité!"
} 
aquelas que tremem (em sua primeira aparição, dizia a voz over com ironia, talvez por emoção de ver mecanismos usados contra a esquerda aplicados à oposição de direita). Nessa passagem, intercaladas com o discurso na fábrica, elas estão em contradição com a fala do presidente, pois são exibidas enquanto ele nega aos trabalhadores a nivelação dos salários, justificando economicamente sua recusa e alegando que, caso eles não se convencessem, teriam direito de protestar. Esse artifício reforça a ideia de afastamento entre o projeto da UP e sua sustentação pelo povo. Não apenas não se constituiu um poder popular autêntico nos meios de produção coletivos, como também enfrentou (com métodos repressivos questionáveis) uma forte oposição nas ruas.
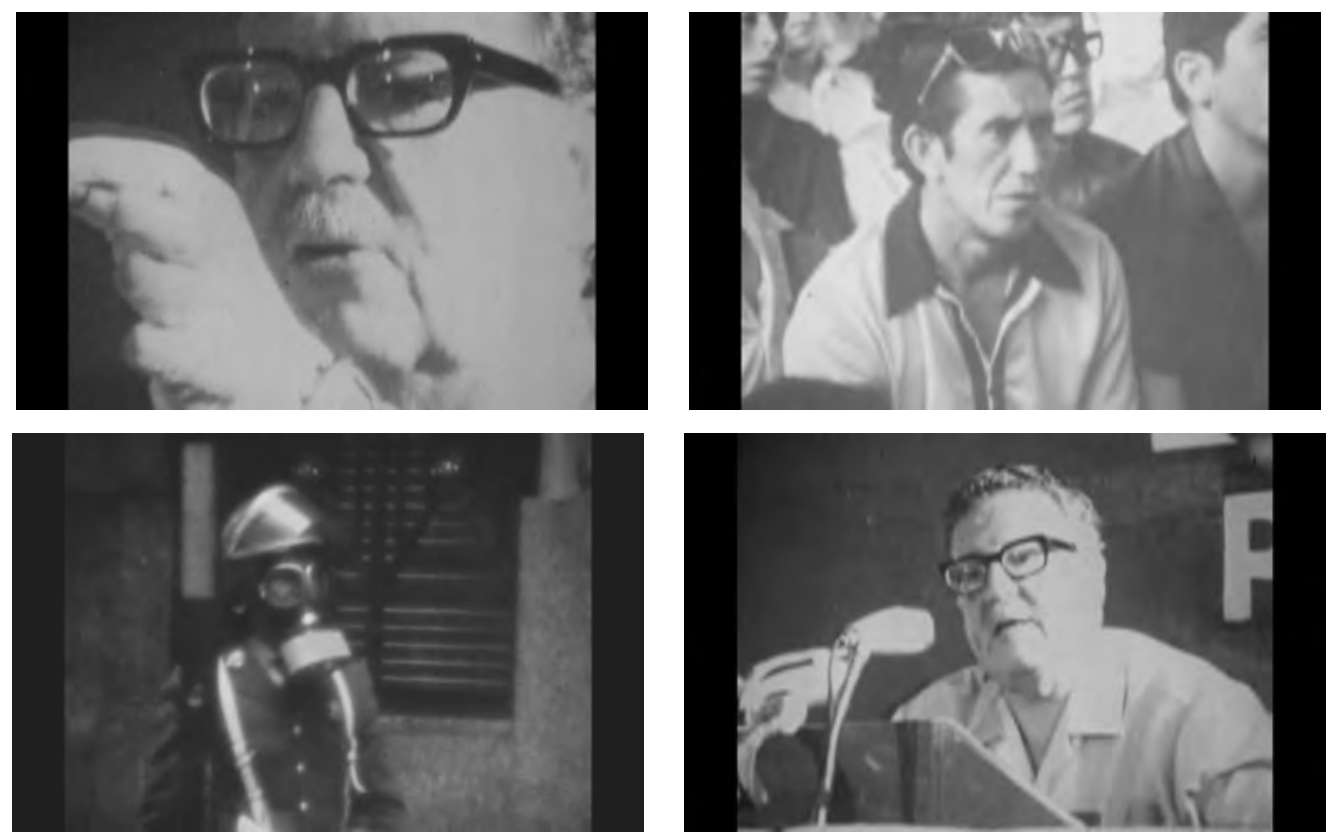

Sequência de Salvador Allende discursando em fábrica em $O$ fundo do ar é vermelho.

As sequências sobre o Chile em $O$ fundo do ar é vermelho foram bastante comentadas pela imprensa, sobretudo por sua relação com a esquerda francesa, que será abordada a seguir. A cena de Allende discursando para os operários esteve presente em algumas das críticas, como na de Noël Herpe, publicada em Libération:

Allende se dirige aos operários de uma fábrica em greve. É um discurso patético, sem a menor demagogia. Ele lhes diz: "Trabalhem, ou nós estamos perdidos". Nós sentimos que os operários adoram. Mas eles realmente querem trabalhar, se tornar responsáveis? Nenhuma imagem da queda de La Moneda. O efeito teria sido muito fácil. Chris Marker deixa de lado. Todos sabemos 
como Allende terminou. E é essa falha o que Chris Marker quer mostrar. (HERPE, 1998, tradução nossa) ${ }^{436}$

Vale ressaltar que essa "ausência" das cenas de La Moneda em chamas, que integravam a produção do ano anterior, $L a$ spirale, concede ao Chile um papel diferente nas duas produções. O fundo do ar é vermelho está longe de ser um documentário de denúncia, embora também se ocupe em mostrar as ações da direita e do imperialismo para destroçar as utopias que buscavam um mundo socialista. No entanto, é esse olhar para si mesmo, para as próprias estratégias, que marca a produção. Nesse sentido, a análise da Unidade Popular serve, sobretudo, como um contraponto à outra reflexão para a qual Marker se volta: a consolidação de uma "via" europeia. É diante desse enfoque que a UP é retomada. Constantemente definida como um modelo por líderes do PCF e do PS francês, caberia, após sua queda, verificar se a comparação entre a experiência chilena e a política na França realmente se aplicava.

Entre a fala de Volodia Teitelboim e a de Salvador Allende, Chris Marker inseriu na montagem outra longa sequência, dessa vez um discurso de Georges Marchais no encontro do PCF em Lille, em 1970. Primeiramente, sua voz aparece em off, acompanhada por tomadas de pessoas nas ruas de Santiago saudando a vitória da Unidade Popular (com o "V" de vitória feito com os dedos). Em seguida, aparece o rosto do secretário em close-up - o que permite verificar sua satisfação em abordar o tema, em um paralelo entre ele e os que celebram o resultado no Chile. Marchais explica a coalizão da UP aos presentes, e depois define a postura do Partido Comunista Francês sobre a posse de Allende:

E, por nossa parte, consideramos que a experiência chilena confirma precisamente a tese do Partido Comunista Francês, a de que a união dos partidos de esquerda, sob um programa claro, sob perspectivas claras, pode permitir a formação de um agrupamento popular suficientemente forte para derrotar a burguesia... [...] Tudo confirma, então, eu repito, a tese dos comunistas: a união dos partidos de esquerda, a união das forças de esquerda é capaz de desencadear em um país, e acredito que será no nosso, a formação de um movimento majoritário capaz de vencer a burguesia... Nós saudamos essa experiência chilena, e eu gostaria de lhes dizer, já

\footnotetext{
${ }^{436}$ Traduzido do original: "Allende s'adresse à des ouvriers d'une usine en grève. C'est un discours pathétique, sans la moindre démagogie. Il leur dit: 'Travaillez, ou nous sommes perdus'. On sent que les ouvriers l'aiment. Mais, ont-ils tellement envie de travailler, de devenir responsables? Pas une image sur la chute de la Moneda. L'effet aurait été trop facile. Chris Marker s'en passe. Nous savons tous comment Allende a fini. Et cet échec ce que Chris Marker voulait montre."
} 
que sabemos bem que essa experiência é tão perigosa para os capitalistas, que há riscos de pressão, senão de intervenção, em particular do imperialismo americano.... eu quero dizer a vocês que, se houver uma intervenção desse tipo no Chile, o Partido Comunista Francês, eu estou certo, com os outros partidos de esquerda, saberá tomar as iniciativas para dar apoio total dos democratas franceses aos nossos companheiros chilenos. ( $O$ fundo do ar é vermelho, 1977, tradução nossa) ${ }^{437}$

Alguns aspectos desse longo discurso devem ser destacados. Em primeiro lugar, ele confirma a apropriação do exemplo chileno pelo PCF e pelos demais partidos esquerdistas como modelo de união em torno de um programa comum de governo. Marchais destaca nessa estratégia sua capacidade de aglutinar forças para vencer a burguesia, tese em voga na esquerda francesa, usando o Chile como "confirmação" de sucesso também da via europeia. Reconhecendo os riscos de dificuldades e até de um possível golpe nessa nação latino-americana, promete apoio caso isso ocorra. Ao inserir em $O$ fundo do ar é vermelho, essa declaração de Marchais, Marker relembra aos comunistas de seu país esse compromisso de solidariedade com os chilenos, firmado antes mesmo da queda da UP.
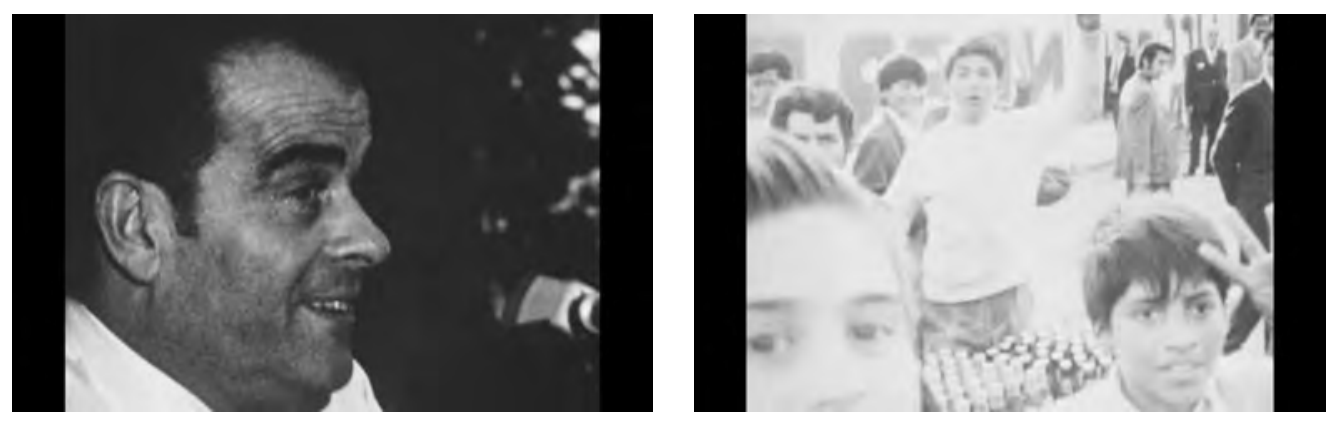

Sequência de Marchais discursando sobre a Unidade Popular em encontro do PCF em Lille (1970) em $O$ fundo do ar é vermelho.

Enfatizando por meio do close-up a euforia de Georges Marchais adiante da vitória da Unidade Popular chilena, Marker desconstrói simultaneamente esse

\footnotetext{
${ }^{437}$ Discurso de Georges Marchais em $O$ fundo do ar é vermelho, traduzido do original: "Et pour notre part, nous considérons que précisément l'expérience chilienne confirme la thèse du Parti communiste français, à savoir que l'union des partis de gauche, sur un programme clair, sur des perspectives claires, peut permettre la formation d'un rassemblement populaire suffisamment fort pour battre la bourgeoise... [...] C'est donc tout à fait la confirmation, je répète, de la thèse des communistes: l'union des partis de gauche, l'union des forces de gauche est capable de déclencher dans un pays, et je considère que ce serait le cas chez nous, de déclencher la formation d'un mouvement majoritaire capable de vaincre la bourgeoisie... Nous saluons cette expérience chilienne, et je tiens d'ailleurs à vous dire, parce que nous sentons bien que cette expérience est tellement dangereuse pour les capitalistes, qu'il y a des risques de pression, sino d'intervention, et en particulier de l'impérialisme américain... je tiens à vous dire que, s'il y avait une intervention dans ce sens au Chili, le Parti communiste français, j'en suis sûr, avec les autres partis de gauche, saura prendre des initiatives pour apporter le soutien total des démocrates français à nos camarades chiliens!".
} 
discurso, tendo em vista que o espectador sabe que esse sucesso da estratégia frentista teve curta durabilidade no país. Em 1977, sabe-se ainda que o apoio das forças de esquerda francesas ao Chile foi insuficiente, já que não impediu a consolidação de uma ditadura militar extremamente repressora. Assim, pode-se dizer que, tal como reexibidas em $O$ fundo do ar é vermelho, essas imagens de 1970 mais desmotivam uma união nos moldes da UP na França do que a incentivam, em decorrência de sua trágica derrocada.

É, porém, um outro depoimento que relativiza essa questão, não mais encontrando semelhanças entre o Chile e a França, mas diferenças. Marker insere novamente um extrato de sua entrevista com Jean Elleinstein gravada em Paris, em 1975. Apesar de deixar sua pergunta fora de campo, a resposta do historiador permite verificar que ela repete o sentido presente no título desse subcapítulo do filme: mas, e o Chile? Vale lembrar que o bloco dedicado à Unidade Popular em $O$ fundo do ar é vermelho traz o sugestivo nome de "Do Chile ao - que, de fato", revelando que a grande dúvida é saber o que poderia se esperar da esquerda depois da derrocada no país latino-americano desse projeto democrático de união. Dessa forma, a declaração de Elleinstein representa uma linha de análise bastante presente na esquerda francesa após a derrocada de seu modelo:

[...] a situação no Chile é radicalmente diferente da situação na França. No Chile, primeiramente, o partido de Allende, o movimento, foi eleito com 36 ou $37 \%$ dos votos; mesmo nas eleições que se seguiram, que precederam o golpe de Estado, tiveram $45 \%$ dos votos com os diferentes partidos que formavam a esquerda unida... e, enfim, a classe operária chilena não era nem tão numerosa, nem tão concentrada. Eu penso que, sob esse ponto de vista, não podemos de forma alguma equiparar a situação do Chile, perdido na América Latina, com a situação da França, que é um grande país industrial cultivado, culturalmente desenvolvido, situado no oeste europeu. (O fundo do ar é vermelho, 1977, tradução nossa) ${ }^{438}$

Esse discurso de Elleinstein, buscando diferenças entre o que antes era semelhante - a Unidade Popular e as tentativas de união na Europa -, foi uma tônica

\footnotetext{
${ }^{438}$ Fala de Jean Elleinstein presente em $O$ fundo do ar é vermelho, traduzida do original: "[...] la situation au Chili est radicalement différent de la situation en France. Au Chili, d'abord, le parti d'Allende, le mouvement a été élu avec 36 ou 37\% des voix; même aux élections qui ont suivi, qui ont précédé le coup d'État, il a eu $45 \%$ des voix avec les différents partis qui constituaient la gauche unie... et enfin la classe ouvrière chilienne n'était ni très nombreuse ni très concentrée. Je pense que, de ce point de vue, on ne peut pas du tout assimiler la situation du Chili, perdu au sud de l'Amérique latine, avec la situation de la France, qui est un grand pays industriel cultivé, développé culturellement, situé dans l'ouest européen...".
} 
comum nas falas dos defensores de uma nova estratégia para a esquerda após o 11 de setembro no Chile, como será abordado no próximo subcapítulo desta tese. No entanto, o realizador não endossa esse afastamento, prefere apenas contrapor as palavras otimistas e inflamadas de Marchais ao balanço pós-1973 eurocêntrico do historiador, mostrando como o modelo da UP foi analisado sob diferentes pontos de vista com o decorrer dos acontecimentos. Apropriado pela esquerda francesa, era deixado de lado com a queda de Allende, acentuando-se, a partir daí, sobretudo uma impossibilidade de comparação pela situação econômica e social tão diversa entre um país do "oeste" europeu e uma nação da América Latina.

Chris Marker, em $O$ fundo do ar é vermelho, prefere expor o problema, o de que rumos a esquerda deve tomar, do que apontar mais uma fórmula ideal, mas frágil e suscetível à repressão, como as anteriores. Nesse sentido, cabe observar que todos os blocos precedentes estabeleciam períodos calcados nas grandes causas esquerdistas: "Do Vietnã à morte de Che", "Maio de 68 e tudo isso..." (ou Maio de 68 e seus desdobramentos) e "Da Primavera de Praga ao programa comum". Somente o bloco dedicado à UP e ao seu fim termina com uma interrogação: "Do Chile ao - que, de fato?".

Essa pergunta pode ser diretamente relacionada à incerteza demonstrada por Marker sobre os rumos que iriam tomar os projetos de união das esquerdas europeias. Como foi analisado no subcapítulo anterior desta tese, apesar de manifestar apoio, o realizador demonstra temor diante do futuro desse programa comum (demonstrado especialmente com críticas ao PC), enfatizando a necessidade de se incorporar o diálogo e as divergências como o alicerce de uma frente única. $O$ fundo do ar é vermelho é um documentário sobre os erros e suas lições, reflexão exercitada sobre inúmeros episódios relacionados ao campo da esquerda no período de dez anos, inclusive a Revolução Cubana e a experiência chilena. Esse posicionamento chegou a ser criticado por Jean Narboni no debate realizado pelos Cahiers du cinéma, que identificava um "lado de velha política" no filme, sem trazer praticamente nada que se "movesse de uma maneira nova atualmente" (TABLE, 1978, p. 47). De certo modo, o crítico está certo: o documentário não propõe soluções, volta-se mais a uma revisão crítica do próprio passado. 


\section{A Unidade Popular chilena para a "via europeia": outras leituras e legado após sua queda}

$O$ fundo do ar é vermelho tem como horizonte o surgimento de novas estratégias no seio da esquerda, especialmente na Europa, e os eventos tratados ao longo do documentário tiveram fundamental importância nessa revisão das estratégias dos anos 1960. A derrocada da guerrilha, as novas relações que os Partidos estabeleceram com a URSS após a invasão da Tchecoslováquia e a vitória da Unidade Popular no Chile foram alguns dos acontecimentos determinantes para que os PCs europeus passassem por uma reformulação teórica e metodológica. Nesse sentido, as questões colocadas por Chris Marker dialogam com outras discussões realizadas no seio da esquerda europeia, que apontavam para a emergência de um eurocomunismo no continente. Apesar desse termo não ser empregado no filme, ele é o pano de fundo para entender a visão do realizador sobre o programa comum do PCF e do PS francês, bem como o papel da Unidade Popular chilena nesse debate.

Ao longo desta tese, foi enfatizada a presença de Régis Debray como um mediador entre a América Latina e a Europa, sobretudo por sua relação com Cuba e, posteriormente, com o Chile. Além de ser próximo a Marker (ele aparece em On vous parle du Chili e em $O$ fundo do ar é vermelho), Debray foi autor de teorias que penetraram com força nas esquerdas desses dois continentes nos anos 1960 e 1970, o que justifica seu destaque nesta pesquisa. Sua trajetória teórica serve também para compreender o próprio processo de revisão desse campo político, que, do apoio à guerrilha e ao foquismo, migrou para a defesa de um socialismo democrático possível pela vitória nas urnas. Se, em 1967, o jornalista despontava com a publicação de Révolution dans la révolution?, na década seguinte ele mesmo reveria suas posições em La critique des armes, lançado em 1974.

O balanço sobre a Unidade Popular chilena e sua queda ocupa um lugar de destaque nessa publicação, na qual Debray revê sua posição anterior, classificando Révolution dans la révolution? como "um livro de um momento", relacionado a um processo revolucionário continental que despontava. O jornalista refere-se à conferência da OLAS (em agosto de 1967), que incentivou a guerrilha, especialmente nos países latino-americanos onde ela já existia, mas que - de acordo com sua autocrítica no prefácio de La critique des armes - falhou por não considerar que os 
diferentes contextos nacionais exigiam métodos de luta distintos. Além de destacar a presença de Salvador Allende nesse encontro, como uma prova de que outras leituras seriam possíveis além do foquismo, ele dedica um capítulo inteiro ao Chile, demonstrando que a experiência chilena está na base de sua crítica às armas.

O golpe de 11 de setembro, de acordo com Debray, havia recolocado a questão se era ou não possível chegar ao socialismo pela via pacífica, e dividia a esquerda entre os defensores do programa comum e aqueles que acreditavam que era necessário armar o proletariado. Como modelo ou antimodelo, o país latinoamericano seguia nos debates esquerdistas internacionais, mesmo com a derrocada da Unidade Popular, levando à reflexão sobre as "lições" a serem tiradas com a queda de Allende. Dedicando-se a esse exercício, La critique des armes defende que o mais importante seria saber como um governo popular que chegou ao poder pelas "vias reformistas" poderia se transformar em "revolucionário" e, no caso de uma contrarrevolução, qual seria o caminho da resistência - indagações pertinentes não apenas ao caso chileno, mas aos demais que adotassem essa estratégia. O que não foi possível no Chile seria factível em condições históricas "incomparavelmente mais favoráveis - na Europa ocidental"? Essa pergunta era pertinente à França, "berço do socialismo utópico e recipiente do científico" (DEBRAY, 1974).

Essas posições de Debray, posteriores ao governo da Unidade Popular e sua queda, propondo uma revisão no conceito da luta armada como meio de chegar ao poder (ressaltando que, para o jornalista, ela poderia ser pertinente como forma de resistir a uma contrarrevolução), são contemporâneas a uma série de novas reflexões realizadas pelos partidos comunistas da Europa Ocidental, especialmente na França, na Itália e na Espanha. Esse recorte, restrito às estratégias desses três partidos, ficou conhecido como eurocomunismo. Enrique Suárez-Iñiguez descreve a origem e a problemática em torno do conceito:

Devo assinalar que a palavra eurocomunismo implica dificuldades e problemas. Não foi aceita oficialmente, pelo menos até novembro de 1975 por [Enrico] Berlinguer em Paris. Antes disso, a imprensa já havia falado de eurocomunismo, mas não se definia propriamente, nem se aceitava o termo como tal, inclusive se usava entre aspas. Acredito que a invenção, como destacaram os próprios secretários-gerais dos PCs europeus, foi feita pelos meios jornalísticos. Até onde pude rastrear, o termo foi primeiramente enunciado por Arrigo Levi, diretor do periódico La Stampa, de Turim. Daí em diante, todos os periódicos italianos, e 
posteriormente os europeus, o utilizaram com alguma frequência. (SUÁREZ-IÑIGUEZ; SEMO, 1977, p. 1-2, tradução nossa) ${ }^{439}$

Suárez-Iñiguez destaca ainda algumas limitações do termo, como o de se referir a somente três partidos - PCF, PCI e PCE -, excluindo outros que apresentariam estratégias semelhantes em regiões distantes (como o PC do Japão), restrição que se justificava pelo fato de o eurocomunismo identificar uma similaridade no desenvolvimento econômico e social de França, Itália e Espanha. Entre os postulados desse termo, o autor ressalta a substituição do conceito de "ditadura do proletariado" pelo de "massas populares", a opção pela via pacífica, a aceitação dos caminhos individuais de cada contexto nacional, entre outros.

Alguns autores preferem o termo "via europeia" a "eurocomunismo" para designar as similitudes teóricas e estratégicas firmadas por Enrico Berlinguer (do PCI), Santiago Carrillo (do PCE) e Georges Marchais ${ }^{440}$. O termo "via europeia" é usado no título de uma coletânea de textos dos três secretários dos Partidos Comunistas, La vía europea al socialismo, publicada em 1977 (BERLINGUER; CARRILLO; MARCHAIS, 1977). Na introdução, Ignazio Delogu ressalta que o conceito faz referência a um nexo entre as diversas "vias nacionais", e que nasceu oficialmente em novembro de 1975 com uma declaração comum entre os comunistas italianos e franceses. Entre as bases similares definidas na ocasião, a declaração estabelecia um esforço em prol de alianças internas, inclusive com os Partidos Socialistas e setores mais ao centro (como as democracias cristãs):

O desenvolvimento de uma cooperação sólida e duradoura entre os comunistas e os socialistas é o fundamento dessa ampla aliança. Pode-se constatar, além disso, que hoje nutridos estratos do mundo católico tomam consciência crescente da contradição que se abre entre a realidade do imperialismo e do capitalismo e suas mais

\footnotetext{
${ }^{439}$ Traduzido do original: "Debo señalar que la palabra eurocomunismo conlleva dificultades y problemas. No fue aceptada oficialmente sino hasta noviembre de 1975 por [Enrico] Berlinguer en París. Antes de esto, la prensa ya había hablado de eurocomunismo, pero no se definía propiamente, ni se aceptaba el término como tal, incluso se lo usaba entre comillas. Creo que la invención, como lo han señalado los propios secretarios generales de los PCs europeos, ha sido realizada por los medios periodísticos. Hasta donde yo he podido rastrear, el término fue primeramente enunciado por Arrigo Levi, director del periódico La Stampa de Turín. De ahí en adelante, todos los periódicos italianos y posteriormente los europeos, lo utilizarán con suma frecuencia.". (SUÁREZ IÑIGUEZ, 1977, p. 1-2)

${ }^{440}$ Vale destacar que o peso dos PCs europeus na formação do conceito de eurocomunismo não foi igual: "Nos anos 1970, o PCI é o principal motivador da tentativa de inventar um comunismo adaptado à especificidade da Europa democrática, o 'eurocomunismo', que o PCF de Georges Marchais só sustenta com a ponta dos lábios" (DREYFUS; GROPPO, 2000, p. 436, tradução nossa). Traduzido do original: "Dans les années 1970, le PCI est le principal animateur de la tentative d'inventer un communisme adapté à la spécificité de l'Europe démocratique, 'l'eurocommunisme', que le PCF de Georges Marchais ne soutien que du bout des lèvres."
} 
fundas aspirações à fraternidade entre os homens, à justiça social, à afirmação de valores morais mais elevados e à plena expansão da personalidade. Esse fato cria possibilidades de ampliar o encontro entre os comunistas, a totalidade do movimento operário e as forças populares de inspiração cristã. Essas podem e devem desempenhar um papel importante na criação de uma nova sociedade. (BERLINGUER; CARRILLO; MARCHAIS, 1977, p. 100, tradução nossa) ${ }^{441}$

Apesar de ter raízes mais antigas, como a ideia de frentismo dos anos 1930, estratégias já presentes da Guerra Civil espanhola e os escritos de Antonio Gramsci (sobretudo no caso da Itália), os ideais de união e a escolha pela via democrática se fortaleceram nos Partidos Comunistas europeus após a Primavera de Praga e a consequente invasão da Tchecoslováquia. O relativo rompimento com a União Soviética possibilitou aos países da Europa Ocidental a busca por um caminho autônomo. No início dos anos 1970, além de procurarem acordos com as forças internas, os PCs promoviam encontros com seus vizinhos, que aproximavam suas discussões teóricas e metodológicas. Como exemplo, podem ser citadas a Declaração firmada pelo PCI e o PCE em julho e a de novembro, assinada pelo PCF e o PCI (referida anteriormente), ambas de 1975. Em junho de 1976, uma conferência internacional em Berlim consagrava esse diálogo entre os comunistas da Europa, com a participação de 29 partidos.

Se a Primavera de Praga e seus desdobramentos contribuíram para a articulação de um eurocomunismo, ou de uma via europeia para o socialismo, o caso do Chile se tornou uma espécie de impasse para os PCs. Isso porque, num primeiro momento, as estratégias para chegar ao poder (por meio de amplas alianças) e a concepção de uma etapa "reformista" como acesso ao socialismo exercidas pela Unidade Popular pareciam confirmar os caminhos trilhados pelo comunismo na Europa Ocidental - como exemplifica o depoimento de Georges Marchais presente em $O$ fundo do ar é vermelho. Porém, com o golpe militar, essa semelhança colocava em dúvida os próprios projetos dessa esquerda europeia.

\footnotetext{
${ }^{441}$ Traduzido do original: "El desarrollo de una cooperación sólida y duradera entre los comunistas y los socialistas constituye el fundamento de esta amplia alianza. Se puede constatar además que hoy nutridos estratos del mundo católico toman consciencia creciente de la contradicción que se abre entre la realidad del imperialismo y del capitalismo y sus más hondas aspiraciones a la fraternidad entre los hombres, a la justicia social, a la afirmación de valores morales más elevados y a la plena expansión de la personalidad. Este hecho crea posibilidades en aumento de un encuentro entre los comunistas, la totalidad del movimiento obrero y las fuerzas populares de inspiración cristiana. Éstas pueden y deben desempeñar un papel importante en la creación de una sociedad nueva."
} 
Pode-se dizer que o 11 de setembro inaugura, na esquerda da Europa, um exercício de encontrar diferenças entre a Unidade Popular chilena e as tentativas de união no continente, combatendo o temor difundido pela direita de que o fascismo poderia se instalar tal como havia feito no Chile (como foi abordado no capítulo 4). François Mitterrand, antigo entusiasta da via chilena, declararia no Le monde que não havia comparação possível entre o socialismo da "penúria" (no país subdesenvolvido) e o da "abundância (LES DÉCLARATIONS, 1973, p. 4, apud LE PARTI, 2008) ${ }^{442}$. Vale lembrar que essa perspectiva é próxima daquela defendida por Jean Elleinstein em $O$ fundo do ar é vermelho, bem como das teses do eurocomunismo que consideravam o desenvolvimento uma variável indispensável para a consolidação de uma "via europeia".

Georges Marchais, após o golpe de Estado no país latino-americano, também passou a elaborar um discurso muito menos pró-Unidade Popular do que aquele exposto na reunião do PCF de Lille, em 1970, e integrado à montagem de $O$ fundo do ar é vermelho. No texto Una vía democrática al socialismo (BERLINGUER; CARRILLO; MARCHAIS, 1977) ${ }^{443}$ ele declara a solidariedade do Partido aos companheiros chilenos, porém, ressalta que a reação violenta conservadora só pode ocorrer onde as "forças políticas são favoráveis". Dessa maneira, o secretário procura caracterizar um contexto nacional chileno distinto do francês, além de identificar falhas na estratégia dos latino-americanos:

No Chile, a Unidade Popular governava de maneira totalmente legal e normal. Não obstante, não se deve esquecer, não dispunha da maioria no país. Diante das intrigas da reação interna e do imperialismo, não havia nada mais importante que a modificação a seu favor da relação de forças em cada campo. Os companheiros chilenos têm dito a esse respeito que, ainda que tenham obtido resultados positivos, também se cometeram graves e prejudiciais erros, que desde cedo não favoreceram a concretização do objetivo. (BERLINGUER; CARRILLO; MARCHAIS, 1977, p. 119-120, tradução nossa) ${ }^{444}$

\footnotetext{
${ }^{442}$ A mesma declaração apareceu em reportagem com Mitterrand feita pela ORTF e citada no capítulo 3 desta tese.

${ }^{443}$ Este texto foi publicado originalmente em L'humanité, em 5 de fevereiro de 1976, e corresponde à segunda parte do discurso de Georges Marchais realizado no XXII Congresso do Partido Comunista Francês.

${ }^{444}$ Traduzido do original: "En Chile la Unidad Popular gobernaba de manera totalmente legal y normal. No obstante, no hay que olvidarlo, no disponía de la mayoría en el país. Frente a las intrigas de la reacción interna y del imperialismo, no había nada tan importante como la modificación a su favor de la relación de fuerzas en cada campo. Los camaradas chilenos han dicho a este respecto que, aunque
} 
Até mesmo nas publicações dedicadas à solidariedade ao Chile na Europa há essa tentativa de estabelecer diferenças entre as duas situações, como uma resposta ao discurso da direita que buscava aproximá-las para abalar o programa comum. Em Chili: l'affrontement de classes, um dossiê organizado pelo Comité de soutien à la lutte révolutionnaire du peuple chilien (1973), aparece a constatação de que o golpe de Estado trouxe uma "desordem" para aqueles que acreditavam, na França, na transição pacífica ao socialismo. Porém, o texto fazia um alerta: "Mas as simplificações e os paralelos sumários são particularmente inaceitáveis. Eles impedem uma real compreensão da realidade francesa e nos privam dos ensinamentos dados pelo povo chileno ao longo desses três últimos anos." (MASSIAH, 1973, p. 3, tradução nossa) ${ }^{445}$.

As discussões sobre o futuro da via pacífica ao socialismo após o $11 \mathrm{de}$ setembro de 1973 ultrapassaram as fronteiras francesas e foram centrais nos debates do eurocomunismo. Nesse sentido, é exemplar um texto publicado por Enrico Berlinguer logo após o golpe militar: Réflexions après les évènements du Chili (BERLINGUER, 1973). Nele, o secretário do PCI caracterizava o episódio como um drama para homens que defendiam a democracia em todos os continentes e afirmava que, como em todos os grandes traumas, o episódio deveria servir para tirar “ensinamentos". Entre as "lições" da queda da Unidade Popular, destacava o cuidado necessário diante do poder do imperialismo; e que a experiência chilena permitiu mostrar que os antidemocráticos seriam as classes dominantes e os partidos que as representavam.

A declaração de Berlinguer, ao contrário das de outros líderes da esquerda europeia, situa-se em um meio termo entre marcar as diferenças entre a Itália e o Chile e reafirmar as semelhanças. Ele descreve uma "via italiana" ao socialismo calcada em uma oposição aos Estados Unidos e à União Soviética, cujo objetivo era a articulação da paz no Mediterrâneo e a consolidação de uma Europa Ocidental autônoma -, que teria em comum com a chilena a escolha pelo caminho democrático $^{446}$. Além disso, o fato de ambas optarem pelo estabelecimento de

se hubieran obtenido resultados positivos, también se cometieron graves y perjudiciales errores, que desde luego no favorecieron la consecución del objetivo."

${ }^{445}$ Traduzido do original: "Mais les simplifications et les parallèles sommaires sont particulièrement inacceptable. Ils interdissent une réelle compréhension de la réalité française et nous privent des enseignent donnés par le peuple chilien tout au long de ces trois dernières années."

${ }^{446}$ Apesar de reconhecer a semelhança com a via chilena, Berlinguer atribui a Antonio Gramsci a origem dessa estratégia. 
alianças amplas permitia que o golpe de Estado gerasse uma reflexão sobre os limites desses acordos na Itália, determinando mais atenção com alguns aliados, como a Democracia Cristã. Mas a principal lição da experiência chilena era a de que a vitória das urnas não era suficiente para garantir a defesa do modelo democrático.

Essas discussões sobre o futuro da "via europeia" - ou do programa comum da esquerda francesa - posteriormente à instauração da ditadura chilena estão no pano de fundo de $O$ fundo do ar é vermelho (como também de outras produções de Chris Marker, como L'ambassade). Embora o realizador não se refira diretamente ao conceito de eurocomunismo, incorpora seus debates, nos quais a persistência na via pacífica apesar da queda da Unidade Popular ocupou um papel fundamental. O filme traz algumas das principais leituras que foram feitas da Unidade Popular após 1973: na cena de Salvador Allende discursando na fábrica, exerce uma autocrítica à esquerda que aponta para a não consolidação de um poder popular autônomo; no extrato da fala de Georges Marchais em Lille, evoca uma responsabilidade, sobretudo do PCF com o Chile, proveniente do uso que se fazia do país como um modelo estratégico para a França; na entrevista de Elleinstein, expõe a tentativa de setores esquerdistas em distanciar-se da realidade latino-americana, visando a combater o uso de uma suposta aproximação entre os contextos dos dois países por parte dos opositores ao programa comum.

Marker opta, porém, em deixar uma pergunta no lugar de uma nova resposta. O que viria depois da queda da Unidade Popular no Chile, para ele, era uma questão em aberto. 


\section{Considerações finais}

O tema da Unidade Popular no Chile foi objeto de inúmeras produções de Chris Marker no início dos anos 1970. Isso se explica, em parte, pelo papel fundamental que a experiência chilena desempenhou no debate político francês da época, que encontrou inúmeros paralelos entre seus próprios caminhos ao socialismo e os que levaram a esquerda ao poder no país latino-americano. Após o golpe de Estado, o estabelecimento de redes de solidariedade também contribuiu para que esse tema continuasse em voga na Europa. Diante desse contexto, a análise desses filmes revela que o realizador elaborou abordagens distintas sobre a UP. Cabe, portanto, retomar algumas delas e verificar possíveis apontamentos sugeridos por elas para o estabelecimento de uma memória sobre esse período da história chilena e de estratégias que servissem ao fortalecimento de uma nova "via" na França.

Antes do golpe, o projeto representado por Salvador Allende era introduzido ao público europeu por meio de suas semelhanças com a história francesa, o que reforçava a ideia de sua viabilidade, sobretudo na França. Nesse sentido, alguns filmes de Marker retomam, por exemplo, a experiência das Frentes Populares, nos anos 1930, como uma evidência de que as duas esquerdas tinham traços em comum, tendo em vista que o Chile foi o único país da América Latina a vivenciar um fenômeno frentista nessa mesma época. Mesmo após o golpe de 11 de setembro, esse discurso foi revisitado como uma forma de "explicar" a Unidade Popular aos espectadores. Pode-se dizer que essa abordagem aparece em La première année, On vous parle du Chili: ce que disait Allende e La spirale.

No início dos anos 1970, a vitória de Allende parecia confirmar que a esquerda francesa, ao buscar uma aliança que envolvesse especialmente os partidos Comunista e Socialista, estava no caminho certo. É exemplar, nesse sentido, a fala de Georges Marchais de 1970, reproduzida por Marker em O fundo do ar é vermelho, declarando que o sucesso da Unidade Popular consagrava também a tese do PCF. Esse ânimo diante dos acontecimentos no Chile ocupava um vazio deixado por algumas decepções de setores da esquerda com alguns acontecimentos internacionais, como a repressão à Primavera de Praga, a aproximação de Cuba com a União 
Soviética e o desmantelamento das guerrilhas (cujo ápice foi a morte de Che Guevara, em 1967).

Em relação à América Latina, a Revolução Cubana havia se tornado uma grande referência para as esquerdas nos anos 1960, como mostram as inúmeras aproximações da intelectualidade e dos artistas franceses com o governo de Fidel Castro, visto pelas esquerdas europeias como um exemplo de democracia direta. Chris Marker foi um dos muitos cineastas da Europa Ocidental que foram ao ICAIC logo após a Revolução, tornando-se uma referência para os cubanos e realizando um filme de propaganda do novo governo: Cuba si. Ao longo de toda década, o cineasta estabeleceu parcerias com o Instituto que o transformaram em um companheiro em terras europeias, atuando em momentos decisivos, como na denúncia das torturas sofridas pelos exilados brasileiros que chegavam nessa época a Cuba - caso de $\mathrm{On}$ vous parle du Brésil: tortures e On vous parle du Brésil: Carlos Marighela.

Marker também foi importante para o ICAIC ao confirmar o apoio à Revolução em uma época em que parte da intelectualidade francesa havia rompido com Fidel Castro, especialmente após o "Caso Padilha". Assim, em La bataille des dix millions, em 1970, o realizador voltava a abordar a ilha, mostrando suas dificuldades e criticando parte da esquerda que abandonava esse projeto revolucionário, como quem busca uma "atriz mais jovem" para substituir uma "fora de moda". No entanto, em 1977, data de O fundo do ar é vermelho, o próprio Marker reveria sua posição sobre Cuba, insatisfeito com a defesa de Castro à invasão da Tchecoslováquia. Nesse filme, identificava de que forma a guerrilha, após inúmeras derrotas sofridas na América Latina, se transformava em um símbolo esvaziado apropriado pela juventude do Primeiro Mundo (especialmente aquela que se consagrava por vitórias mais simbólicas do que reais com o Maio de 68).

Dessa forma, a Unidade Popular, vitoriosa em 1970, aparecia como uma nova referência, com a vantagem de trazer propostas mais cabíveis à realidade europeia do que as sugeridas pela via armada cubana ${ }^{447}$. A experiência chilena, portanto,

\footnotetext{
${ }^{447}$ Apesar de Cuba não ter sido exatamente um "modelo" para parte da esquerda francesa, a Revolução foi celebrada como símbolo de um protagonismo revolucionário que confirmava ideias anticolonialistas em voga, como as de Frantz Fanon (como foi abordado no capítulo 1). No entanto, mesmo que a via insurrecional não fosse uma "alternativa" para a França, embora defendida como uma arma poderosa contra o imperialismo (inclusive o francês) a ser aplicada em outros contextos, alguns aspectos do governo de Fidel Castro podiam inspirar políticas em território europeu. Um exemplo dessa visão é a exaltação de uma "democracia direta", sem intermediários entre o povo e seu representante, presente em Cuba si e em La bataille des dix millions.
} 
amenizava esse "luto" pelo fim do otimismo ante a Revolução Cubana, principalmente porque ia ao encontro de uma estratégia já conhecida e recentemente retomada por parte da esquerda da Europa Ocidental, que era a junção entre socialismo e democracia. Desse modo, a apropriação da UP pelo discurso da esquerda na França foi exemplar de uma espécie de "contrafluxo" na tradicional hegemonia desempenhada pelo continente europeu na circulação de ideias nas redes transatlânticas, delegando ao Chile um papel de protagonista.

Porém, se a aproximação entre a Unidade Popular e o programa comum da esquerda francesa ocupou o debate estratégico desse campo político no início dos anos 1970, sua derrocada, por meio de um golpe militar, em 1973, punha novamente em xeque essa união entre socialistas e comunistas. Assim como havia ocorrido com a Revolução Cubana, mais uma vez a esquerda europeia estava órfã de um projeto político que havia defendido. A direita e a extrema-esquerda, por sua vez, procuraram tirar proveito da exaltação anterior à UP, disseminando o receio de que o golpe se repetisse na França e alardeando para os "perigos" que sugeriam a ditadura chilena. Sob essa perspectiva, Marker montou um filme complexo, L'ambassade, em que o hibridismo de gêneros cinematográficos (ficção e documentário) servia também a uma sugestão dúbia de cenário. O refúgio em uma embaixada para escapar da severa repressão que se instalou no país, bem como a ida para um exílio forçado, poderia se passar em Santiago ou em Paris, em uma chave dupla de leitura.

L'ambassade, porém, tocava em um tema espinhoso: como a própria esquerda, com suas desavenças internas, colaborava para o crescimento da oposição e punha fim a diversas experiências rumo ao socialismo. Essa visão autocrítica, reflexiva sobre o próprio campo político do realizador, ganhou ainda mais força em $O$ fundo do ar é vermelho. Nesse documentário, as inúmeras derrotas sofridas entre 1967 e 1977 eram atribuídas a um movimento dialético entre repressão da direita e do imperialismo e desentendimentos internos, que colaboravam para a derrocada e o fracasso das mais diferentes estratégias, amputando as utopias.

Feitas essas considerações iniciais, vale analisar mais atentamente qual é a visão da Unidade Popular presente nos três filmes aos quais esta tese se dedica com mais profundidade: La spirale, L'ambassade e $O$ fundo do ar é vermelho. Tendo em vista que foram produzidos mais ou menos no mesmo período (apesar de terem datas diferentes de lançamento), ou seja, logo após o golpe de Estado chileno de 1973, vale refletir sobre quais são as "lições" e os "legados" atribuídos por Marker ao governo 
de Salvador Allende. E de que maneira, apesar de abordarem um projeto derrotado, o realizador mantém um discurso engajado nas causas da esquerda, apontando para um possível triunfo do socialismo. Por fim, é necessário verificar qual é (ou quais são) as memórias construídas nessas produções sobre os anos da UP.

La spirale se utiliza de um vasto material de arquivo montado como "provas" das ações da direita chilena e do imperialismo para derrubar Salvador Allende. Nesse sentido, defende a tese de que a burguesia chilena montou uma "frente de massas leninista de direita", que possibilitou ofensivas que resultaram no golpe de Estado. Essa tese considera dois aspectos: o primeiro é o de que os inimigos da Unidade Popular demonstraram um amplo conhecimento dos procedimentos desenvolvidos pela esquerda, subvertendo-os e empregando-os em benefício próprio; o segundo é o de que caberia aos esquerdistas elaborar o mesmo exercício, ou seja, analisar profundamente o modo de agir de seus adversários para prevenir novas derrotas.

Apesar de demonstrar como a direita "ganhou", La spirale dedica bastante espaço à resistência de esquerda durante os anos da Unidade Popular, sobretudo aquela organizada espontaneamente pelos setores populares. Assim, se a "lição" a ser tirada do golpe de Estado era a necessidade de conhecer o inimigo, o "legado" da experiência chilena era um fortalecimento do poder popular. Por meio dele, os realizadores do documentário indicavam acreditar em uma possível reversão da derrota. Existiria, portanto, um aprendizado que não poderia ser sufocado.

Sob esse ponto de vista, o filme confirma teses defendidas pela esquerda francesa nessa época, que apontavam para a estratégia aliancista como um modo de se chegar ao socialismo. Uma delas é a ideia de que a vitória eleitoral, por meio de um programa comum que aglutinasse importantes forças políticas, permitiria que o Estado ocupasse importantes setores da economia e que, gradativamente, incentivasse a formação de cooperativas de produção e instâncias produtivas geridas pelos próprios trabalhadores. Assim, ao sugerir um legado para a Unidade Popular que apontasse para uma herança de autonomia nos organismos populares (que, no Chile, teria o papel de resistir à ditadura), La spirale reafirma as principais estratégias da esquerda chilena que inspiravam os partidos Comunista e Socialista e radicais na França.

Como filme-denúncia, La spirale suprime aspectos importantes que estiveram presentes nos balanços sobre a Unidade Popular após a sua queda. O principal deles é a autocrítica, praticamente inexistente nessa produção (com exceção de alguns momentos em que aparece de forma quase inerente às próprias contradições da UP). 
Algumas considerações colaboram para compreender essa ausência. Montado de forma coletiva, aglutinando forças em prol dessa causa, o documentário foi exibido no circuito dos cinemas de Paris, o que lhe dava um alcance de público significativo, tendo em vista o objetivo de denunciar o "fascismo" que tomou o poder no Chile (para usar um termo empregado na época pela esquerda europeia). Assim, ele tinha pretensões de intervir diretamente no incentivo às redes de solidariedade que se estabeleciam na Europa em função da chegada dos exilados chilenos, difundindo a repressão da qual haviam sido vítimas. Por outro lado, diante dos esforços empreendidos pela esquerda francesa em prol da atualização do programa comum após a derrota de François Mitterrand nas eleições de 1974, é possível que uma visão que questionasse os erros cometidos pela própria esquerda chilena fosse considerada um fator desmobilizador desses esforços de união.

Ao contrário de La spirale, L’ambassade é um filme experimental, tanto em seu formato quanto em seu enredo. Situado no limiar entre ficção e documentário, propôs uma visão igualmente múltipla sobre o processo chileno. Por um lado, também pode ser considerado um filme-denúncia, ao mostrar a situação de refugiados em uma suposta embaixada após o golpe de Estado, bem como sua posterior ida ao exílio europeu. Por outro, há uma forte autocrítica que se desenrola no enredo, que resulta em um retrato do mundo da esquerda como um universo comunitário, mas também fechado e fragmentado.

Marker opta, nesse curta-metragem, por retratar um processo histórico por meio de um diário audiovisual. Filmado em super-8, esse diário é uma alternativa para o fato de os personagens estarem circunscritos a um ambiente interno, a um apartamento (ou embaixada), de onde não podem sair por conta da ditadura que os reprime. Da mesma forma, é essa impossibilidade imposta pela repressão que justifica uma denúncia constituída por meio de um filme de ficção - assim, trata-se de uma denúncia real formulada de modo ficcional. Há, nessa produção, a ideia da câmera como uma testemunha, do realizador como um sujeito que registra a história e intervém nela por meio desse registro.

L'ambassade utiliza estratégias fílmicas complexas, que produzem efeitos e discursos dúbios. Inúmeras referências o caracterizam como um filme sobre o golpe de Estado no Chile, embora esse país permaneça sempre fora de campo. Na última cena, o rio Sena e a Torre Eiffel são mostrados de uma janela, desconstruindo as impressões anteriores e apontando a França como o lugar onde se passam as ações. 
Assim, é nítido o esforço em aproximar os dois países, em relacionar os processos políticos da esquerda francesa e chilena. Essa aproximação permite que a experiência da Unidade Popular resulte em "lições" a serem apreendidas após a sua queda.

Ao contrário de La spirale, essas "lições" deixadas pela queda da UP não se referem ao aprendizado das estratégias do inimigo, e sim a uma reflexão sobre as cisões internas que fragmentam a esquerda e a enfraquecem. Ao longo dos dias, a câmera se torna uma testemunha inconveniente, ao registrar como a solidariedade inicialmente presente na embaixada resultou em discussões entre as diversas correntes políticas nela refugiadas. Portanto, ao contrário do documentário anterior, nessa ficção, há um balanço autocrítico que aponta as divisões internas da Unidade Popular como uma das causas de sua queda e indica que existe o risco dessa prática se repetir em meio aos debates pela união em curso na França.

Esse tom autocrítico sobre a experiência chilena e sobre a própria esquerda francesa se repete em $O$ fundo do ar é vermelho, porém em uma perspectiva que aborda também outras lutas políticas internacionais (agrupadas sob a égide de uma “terceira guerra mundial”). Novamente por meio de um documentário de arquivo, Marker acusa a repressão (da direita e do imperialismo) de "amputar" os punhos revolucionários. No entanto, além das ações dos inimigos, as mãos revolucionárias foram cortadas também pela própria esquerda, que manteve resquícios do stalinismo que sufocam processos revolucionários. Por outro lado, essas mãos que clamam pela revolução são caracterizadas como "frágeis", uma fragilidade que vem da insistência em utopias já derrotadas (como as guerrilhas), que se tornaram símbolos esvaziados de seu conteúdo revolucionário.

Em relação à Unidade Popular, O fundo do ar é vermelho difere radicalmente de La spirale. Nesse sentido, é significativa a reprise de uma sequência em que Salvador Allende discursa para operários em uma fábrica, utilizada em La spirale como a "prova" de sua proximidade com o povo e, no documentário de 1977, como uma evidência da falta de consolidação de um poder popular autônomo no Chile. Não há mais uma perspectiva de reversão da situação por meio de uma mobilização interna fruto de um "legado" da Unidade Popular. Há, nessa produção, um tom nostálgico, que decreta o fim de vários projetos, entre eles a Revolução Cubana e a experiência chilena.

Porém, O fundo do ar é vermelho aponta para uma saída "realista", o surgimento de novas estratégias na Europa. No caso da França, essa nova estratégia é 
endossada pelo realizador, mas com ressalvas que devem ser levadas em conta. Apesar de desejada, a união das esquerdas exige uma revisão dos partidos, sobretudo do PCF, que necessitam se redemocratizar. O filme clama por um entendimento em prol do programa comum, mas recorda que essa união não pode ser calcada pelo autoritarismo que colaborou para o fim das utopias. Assim, é possível afirmar que esse documentário se aproxima do enfoque já presente em L'ambassade. Em ambos, o fim da Unidade Popular serve de "lição" a uma revisão nos projetos esquerdistas europeus.

Vale destacar uma característica comum aos filmes de Marker analisados nesta tese: a busca pelo internacionalismo dos projetos políticos abordados. Se, nas produções sobre Cuba, ela já está presente, com a inserção de reflexões sobre como a Revolução era vista na França e como ela poderia contribuir para o debate político nesse país, nos filmes sobre a Unidade Popular, ela é ainda mais clara. Em La Spirale, por exemplo, há uma organização narrativa que utiliza categorias sociológicas para compreender os conflitos no governo de Salvador Allende. Portanto, esse processo local é submetido a um modelo analítico que se aplicaria igualmente em outras batalhas ideológicas, inclusive nas futuras. Essa tentativa de internacionalizar as discussões sobre a UP é nítida em L'ambassade, no qual as referências ao Chile permanecem "fora de campo", possibilitando que os acontecimentos do enredo sejam válidos a outros contextos (como o francês). Por fim, $O$ fundo do ar é vermelho sugere a ideia de uma "terceira guerra mundial", na qual a experiência chilena foi um episódio central, mas intrinsicamente relacionado a outros.

Apesar de diferenças de enfoque e de estratégias fílmicas, os três filmes se assemelham ao propor uma visão espiralada do tempo histórico, como foi sugerido em alguns momentos desta tese. Em La Spirale, a "espiral" que dá nome ao documentário é aquela da ação e da reação, da revolução e da contrarrevolução. O mesmo enfoque está presente em $O$ fundo do ar é vermelho, em que há um movimento dialético entre os processos de transformação empreendidos pela esquerda e sua amputação pelas ações da direita. Em L'ambassade, o mesmo tempo é retomado, em Santiago e em Paris, como se a história fosse revisitada em uma nova volta dessa espiral. Essa visão espiralada do tempo está presente em outras produções de Marker, inspiradas em Vertigo, de Alfred Hitchcock.

Assim, os filmes aqui analisados propõem uma leitura da História como um tempo espiralado, e não linear. O cinema, por meio da montagem e de outros 
artifícios, seria um suporte compatível à narrativa histórica, permitindo um retorno das imagens e das experiências do passado. Não se trata apenas de uma reprise, mas de um revisitar sob outra óptica, sob um distanciamento possibilitado pelo posicionamento em outra esfera da espiral. Esse é um diferencial importante que faz de Marker um realizador singular no campo do chamado cinema militante. Em sua obra, não há um único caminho que leve à revolução. Tampouco ela é considerada um destino inexorável, embora almejado. A revolução se constrói em cada esfera da espiral, e contribui para isso a reflexão sobre a História, sobre o próprio passado. Portanto, a autocrítica, tão referenciada nesta tese, pode ser conciliada com uma esperança no futuro. Apesar das múltiplas derrotas, há um horizonte de novas voltas na espiral que não se encerra.

A espiral do tempo está também em uma visita ao passado realizada pela memória. O cinema, como suporte dessa memória e de um discurso por ela elaborado, revisita a história. No entanto, se não é possível reviver esse passado, modificá-lo na volta em que se situa, suas imagens recuperadas - também objetos de memória permitem a elaboração de novos discursos sobre ele, constituídos a partir de novos sentidos encontrados nos fotogramas reprisados (por isso, os documentários de arquivo são tão caros a Marker). É sob esse movimento, sob essa vertigem, que a experiência chilena é retomada após 1973.

A Unidade Popular deve ser revisitada, por meio de suas imagens ou de sua encenação. Trata-se de uma rememoração que permite, sobretudo, aprender com essa experiência, verificar as estratégias do inimigo, mas também desvelar os próprios erros. Vale dizer que a espiral, para Marker, é constituída por ações e reações. Assim, entender de que forma essas duas esferas se articularam nos anos de Salvador Allende (por meio de revoluções e contrarrevoluções) permite também atribuir-lhe um legado. E esse legado contribui para os projetos revolucionários internacionais, para que as novas voltas da espiral se afastem e se aproximem das anteriores.

Nessa perspectiva, pode-se responder de que maneira os filmes abordados nesta tese, feitos em contextos de derrota do campo político do realizador, mantêm um status de engajamento e um potencial de ação política revolucionária. Analisar as experiências sufocadas, encontrar as causas de seu esmagamento, podem contribuir, na visão de Chris Marker, com a formulação de novos projetos. Assim, o abandono de um otimismo diante da Revolução Cubana incentiva um interesse por novas vias, como a experiência chilena. O golpe de Estado que põe fim à Unidade Popular, por 
sua vez, exige que se encontrem seus legados e que se aprenda com suas "lições", possibilitando a abertura de novos caminhos.

Dessa forma, a análise dos filmes aqui abordados demonstra diferentes estratégias e temáticas, mas constitui, em seu conjunto, uma trajetória. Essa trajetória parte da celebração das vitórias, da Revolução Cubana e, posteriormente, da Unidade Popular. Conforme essas experiências se transformam, adquirem rumos não desejados, emerge a necessidade de uma revisão. Os filmes adquirem, muitas vezes, um tom melancólico, de autocrítica. No entanto, seguem, em sua espiral, abrindo novas possibilidades. Um novo projeto aponta uma saída: uma "Nova Esquerda", à qual Marker dedica $O$ fundo do ar é vermelho.

Essa "Nova Esquerda" não é tão celebrada, trata-se de uma via possível, desprovida de utopias. Ela marca também uma mudança fundamental na filmografia de Marker nessa época: se, nos anos 1960 e no início dos 1970, a América Latina havia ocupado o papel de um viveiro de experiências revolucionárias para o realizador, em 1977 (ano de O fundo do ar é vermelho), cabe à esquerda da Europa encontrar seus próprios caminhos, uma via que lhe fosse própria. Essa "via europeia" é desprovida de romantismo, é amputada de seus antigos sonhos, órfã de suas antigas referências (especialmente da Revolução Cubana e da Unidade Popular). Ela traz ainda os vícios dos partidos, um peso de antigas filiações stalinistas. Porém, a esquerda europeia, na década de 1970, é uma esquerda que se repensa, que se apresenta como "Nova".

Apesar desta pesquisa se restringir à filmografia de Chris Marker, ela traz um aporte que pode ser desenvolvido em outros recortes da história política e cultural: o legado das experiências revolucionárias latino-americanas nos anos 1960 e 1970 para a consolidação de um "eurocomunismo", ou ainda de uma "via europeia ao socialismo". Nesse sentido, a América Latina ocupa nesse período um papel central nos debates políticos europeus, com suas vitoriosas experiências revolucionárias. No entanto, a derrocada dessas experiências (no caso da Revolução Cubana, materializada nos rumos que o movimento tomou no final dos anos 1960; no caso do Chile, por meio do golpe de Estado) exigiu um questionamento no interior dos partidos e movimentos esquerdistas ao longo da década de 1970. Essa esquerda, que celebrava os aportes do "Novo Mundo", passa a afirmar sua própria identidade, fazendo do desenvolvimento de seu capitalismo um fator que permitia a 
implementação de um socialismo específico a essa realidade (como foi abordado no capítulo 5).

Pode-se dizer, portanto, que a América Latina - a Revolução Cubana e a Unidade Popular - caminham da condição de modelo para a de um contramodelo na filmografia de Chris Marker. O continente que alimentou as utopias nos anos 1960 e no início da década de 1970 passa, após o golpe do Chile, a ser analisado sobre o prisma de uma autocrítica, da necessidade de uma revisão desse campo político. Revisitados pela espiral do tempo, esses processos adquirem um tom melancólico, mas que não leva ao abandono da luta, e sim à sua reformulação. Esse exercício aprofundado pelo realizador permite que sua obra seja caracterizada como um cinema político engajado à esquerda, porém de questionamentos. Um cinema de reflexão. 


\section{Referências bibliográficas}

\section{Documentos citados}

AGGIO, Alberto. Democracia e socialismo no Chile: a experiência chilena. São Paulo: Annablume, 2002.

1999.

Frente popular, radicalismo e revolução passiva. São Paulo: Annablume,

"Uma insólita visita: Fidel Castro no Chile de Allende". História, Franca, v.

22, n. 2, 2003. Disponível em: <http://www.scielo.br/scielo.php?pid=S010190742003000200009\&script=sci_arttext $>$. Acesso em: 25 fev. 2013.

ALBERA, François. «La chute de la dynastie Romavov : de E. Choub à C. Marker». Matériaux pour l'histoire de notre temps, Nanterre, n. 89-90, pp. 20-9, 2008.

ALBORNOZ, César. "La cultura en la Unidad Popular: Porque esta vez no se trata de cambiar un presidente". In: PINTO VALLEJOS, Julio (Coord.). Cuando hicimos historia: la experiencia de la Unidad Popular. Santiago de Chile: LOM, 2005. pp. 147-176.

ALLENDE, Salvador. La voie chilienne vers le socialisme. Paris, Londres, New York : Gordon \& Breach, 1974.

ALTAMIRANO, Carlos. «Discours à la J.S. [Épinay, 9 mars 1974] ». Les cahiers de l'insurgé - Soutien à la résistance populaire chilienne, n. 1, pp. 59-62, [1974?].

. Dialética de uma derrota: 1970/1973. São Paulo: Brasiliense, 1979.

ALTER, Nora M. Chris Marker. Chicago: University of Illinois Press, 2006.

ÁLVAREZ, Santiago (et al). Cine y revolución en Cuba. Barcelona: Fontamara, 1975.

ÁLVAREZ, Santiago. "Discurso: XI Festival Mundial de la Juventud y los Estudiantes”. Cine cubano, La Habana, n. 177-178, p. 35, Jul. / Dic. 2010.

ASTRUC, Alexandre. «Naissance d'une nouvelle avant-garde: la camera stylo ». L'écran français, Paris, n. 144, p. 5, 30 mars 1948.

AUMONT, Jacques; MARIE, Michel. Dicionário teórico e crítico de cinema. Campinas, São Paulo: Papirus, 2003.

BAECQUE, Antoine de. Cinefilia: invenção de um olhar, história de uma cultura, 1944-1968. São Paulo: Cosac Naify, 2010. 
BARNIER, Martin. «Chris Marker: le son, une bande à part». In: HABIB, André ; PACI, Viva (Dir.). Chris Marker et l'imprimerie du regard. Paris : L'Harmattan, 2008. pp. 197-215.

BARRÍA TRONCOSO, Alfredo. El espejo quebrado, memorias del cine de Allende y la Unidad Popular. Santiago de Chile: Uqbar, 2011.

BENAVENTE, David [carta] 11 Ago. 1972, Santiago de Chile [para] MARKER, Chris. Paris. 3f. Versão francesa de El primer año. (Acervo ISKRA, pasta "La première année")

BERLINGUER, Enrico. «Réflexions après les évènements du Chili ». Les communistes italiens - bulletin pour l'Etranger publié par le P.C.I, Roma, n. 5-6, p. 36, sept. / déc. 1973.

BERLINGUER, Enrico; CARRILLO, Santiago; MARCHAIS, Georges. La vía europea al socialismo. Barcelona: Peninsula, 1977.

BERNARDET, Jean Claude. Autor no cinema: a política dos autores - França, Brasil anos 50 e 60. São Paulo: USP; Brasiliense, 1994.

BONITZER, Pascal. «Les silences de la voix ». Cahiers du Cinéma, Paris, n. 256, pp. 22-33, févr./mars 1975.

BORGES, Elisa de Campos. ¡Con la UP ahora somos Gobierno! Experiência dos Cordones Industriales no Chile de Allende. 2011. 224 f. Tese (Doutorado em História) - Instituto de Ciências Humanas e Filosofia, Universidade Federal Fluminense, Niterói, 2011.

BROOKEY, Marcio Paterman. História e utopia: o cinema de Silvio Tendler. Rio de Janeiro: Luminária Academia, 2010.

CAMACHO, Fernando. "Los asilados de las Embajadas de Europa Occidental en Chile tras el golpe militar y sus consecuencias diplomáticas: El caso de Suecia". European Review of Latin American and Caribbean Studies, n. 81, pp. 21-41, Oct. 2006.

CAPRASSE, Edmond F. [carta] 7 Feb. 1973, Nova York [para] GUZMAN, Patricio. Santiago de Chile. 1f. Envio de película para o Chile. (Acervo ISKRA, pasta "La bataille du Chili")

CASTILlO, Carmen; ECHEVERRÍA, Monica. Santiago-Paris, le vol de la mémoire. Paris : Plon, 2002.

CASTRO, Fidel; ALLENDE, Salvador. El diálogo de América. Buenos Aires: Nuestra América, 2003.

CHAMPAGNE, Patrick. Formar a opinião: o novo jogo político. Petrópolis: Vozes, 1996. 
Chris Marker: bricoleur multimedia. Rio de Janeiro, Brasília, São Paulo: CCBB, 2009.

COMPAGNON, Olivier. "L'Euro-Amérique en question : comment penser les échanges culturels entre l'Europe et l'Amérique latine». Nuevo mundo, nuevos mundos, Paris, pp. 1-12, 2009. Disponível em: <http://nuevomundo.revues.org/54783>. Acesso em: 25 fev. 2013.

DA-RIN, Silvio. Espelho partido: tradição e transformação do documentário. São Paulo: Azougue, 2004.

DALMÁS, Carine. Brigadas muralistas e cartazes de propaganda da Experiência Chilena (1970-1973). 2006. 191 f. Dissertação (Mestrado em História Social) Faculdade de Filosofia, Letras e Ciências Humanas, Universidade de São Paulo, São Paulo, 2006.

DEBRAY, Régis. Entretiens avec Allende sur la situation au Chili. Paris : François Maspero, 1971.

. La critique des armes. Paris : Éditions du Seuil, 1974.

. Révolution dans la révolution?. Paris : Maspero, 1969.

DEL VALLE DÁVILA, Ignacio. "Hacia un tercer cine: del manifiesto al palimpsesto". El ojo que piensa, Guardalajara, ano 3, n. 5, Ene./Jun. 2012a. Disponível em: <http://www.elojoquepiensa.net/05/index.php/template/hacia-untercer-cine-del-manifiesto-al-palimpsesto>. Acesso em: 25 fev. 2013.

. Le «Nouveau cinéma latino-américain»: Un projet de développement cinématographique sous-continental. 2012. $754 \mathrm{f}$. Thèse (Doctorat en Cinéma) - École supérieure d'audiovisuel (ESAV), Université Toulouse-II le Mirail, Toulouse, 2012b.

Document rouge - dossier: «CHILI: le socialisme sans la révolution ?» [ligue communiste], n. 21, [1973?].

DOCUMENTOS secretos de la ITT. Santiago de Chile: Editorial Nacional Quimantu, 1972.

DOUIN, Jean-Luc. « La première année ». Telerama, Paris, p. 1, 17 févr. 1973.

DREYER, Sylvain. «Rhétorique de l'engagement critique. Regards de cinéastes et d'écrivains français sur la révolution cubaine (années 1960 et 1970) ». Tracé : Revue de Sciences humaines, n. 11, 2006.

DREYFUS, Michel ; GROPPO, Bruno. «Les Partis communistes français et italien ». In: DREYFUS, Michel ; GROPPO, Bruno (et. al.). Le siècle des communismes. Paris : Éditions de l'Atelier ; Éditions ouvrières, 2000. pp. 423-438.

DUBOIS, Philippe. Théorème 6: Recherches sur Chris Marker. Paris : Presses Sorbonne Nouvelle, 2002. 
ESPAGNE, Michel. Les tranferts culturels franco-allemands. Paris: Presses Universitaires de France, 1999.

FANON, Frantz. Euvres. Paris : La découverte, 2011.

GARCÉS, Joan. Allende et l'expérience chilienne. Paris : Presses de la Fondation Nationale des Sciences Politiques, 1976.

GAUTHIER, Guy. Chris Marker, écrivain multimédia ou Voyage à travers les média. Paris : L'Harmattan, 2001.

2004.

. «Le cinéma et le Front Populaire ». CinémAction, Paris, n. 110, pp. 21-26,

GILMAN, Claudia. Entre la pluma y el fusil: debates y dilemas del escritor revolucionario en América Latina. Buenos Aires: Siglo Veintiuno Editores, 2012.

GOFFMAN, Erving. A representação do Eu na vida cotidiana. Petrópolis: Vozes, 1985.

GRÉLIER, Robert (et. al.). O bestiário crítico de Chris Marker. Lisboa: Livros Horizonte, 1986.

GRUZINSKI, Serge. "O historiador, o macaco e a centaura: a 'história cultural' no novo milênio". Estudos avançados, São Paulo, v. 17, n. 49, set./dez. 2003. Disponível em: $\quad<$ http://www.scielo.br/scielo.php?pid=S010340142003000300020\&script=sci_arttext>. Acesso em: 25 fev. 2013.

GUEVARA, Alfredo. ¿Y si fuera una huella? Epistolario. La Habana: Editorial Nuevo Cine Latinoamericano, 2009.

GUZMÁN, Patricio. Autorização para La respuesta de octubre [documento inédito]. Paris: 5 nov. 1973b. Acervo ISKRA, pasta "La bataille du Chili”.

[carta] 24 jul. 1972a, Santiago de Chile [para] MARKER, Chris. Paris. 1f. El primer año. (Acervo ISKRA, pasta "La première année")

[carta] 15 Ago. 1972b, Santiago de Chile [para] MARKER, Chris. Paris. 2f. El primer año. (Acervo ISKRA, pasta "La première année")

. [carta] 27 jan. 1973a, Santiago de Chile [para] MARKER, Chris. Paris. 1f. Envio de película e material de La première année. (Acervo ISKRA, pasta "La bataille du Chili")

[carta] 16 Dic. 1973c, Madrid [para] ELTON, Federico. Paris. 2f. Versão francesa de La respuesta de octubre. (Acervo ISKRA, pasta "La bataille du Chili")

. [carta] 6 Abr. 1974, La Habana [para] SLON. Paris. 1f. Estimados compañeros de SLON. (Acervo ISKRA, pasta "La première année") 
"Introducción" (15 Abr. 1971). In: GUZMAN, Patricio; SEMPERE, Pedro. Chile: el cine contra el fascismo. Valencia, 1977. pp. 141-2.

. "Lo que debo a Chris Marker". Cine Chile: enciclopedia del cine chileno. Disponível em: <http://cinechile.cl/crit\&estud-220>. Acesso em: 25 fev. 2013.

Texte des auteurs du film, ajouté en postface pour la version française [texto inédito]. 1972c. (Acervo ISKRA, pasta "La première année")

GUZMAN, Patricio; SEMPERE, Pedro. Chile: el cine contra el fascismo. Valencia, 1977.

HERPE, Noël. « Le fond de l'air est rouge ». Libération, Paris, n. 41, 12 mai 1998.

Image, Son, Kinescope et Réalisations Audiovisuelles (ISKRA). Disponível em: <http://www.iskra.fr/>. Acesso em: 25 fev. 2012.

ISKRA. Decupagem de planos e identificação de origem dos extratos de $O$ fundo do ar é vermelho. (Documento inédito localizado no acervo ISKRA, pasta "Le fond de l'air est rouge")

IVENS, Joris. «À Valparaiso ». Cinéma l'Avant Scène, Paris, n’ 76, pp. 50-57, déc. 1967.

“Joris Ivens en Cuba”. Cine cubano, La Habana, n. 3, pp. 19-23, 1960.

JUQUIN, Pierre. Programme commun : l'actualisation à dossiers ouvert. Paris : Edition sociales, 1977.

KOIDE, Emi. Por um outro cinema - jogo da memória em Chris Marker. 2011. Tese (Doutorado em Psicologia Escolar e do Desenvolvimento Humano) - Instituto de Psicologia, Universidade de São Paulo, São Paulo, 2011.

KORNBLUH, Peter. Los EEUU y el derrocamiento de Allende: una historia desclasificada. Santiago de Chile: Ediciones B, 2003.

«LA BATAILlE du Chili, de Patricio Guzmán ». Rouge, Montreuil, p. 1, 5 janv. 1977.

LANGMANN, Ursula, "O manual de história idealizado". In: GRÉLIER, Robert (et. al.). O bestiário crítico de Chris Marker. Lisboa: Livros Horizonte, 1986. pp. 29-61.

Le film français, Paris, n. 1606, 2 févr. 1976.

Le film français, Paris, n. 1641, 3 sept. 1976.

Le film français, Paris, n. 1655, 10 déc. 1976.

Le film français, Paris, n. 1705, 30 déc. 1977. 
Le film français, Paris, n. 1716, 19 mars 1978.

Le film français, Paris, n. 1745, 28 nov. 1978.

«LE FOND de l'air est rouge ». Le monde diplomatique, Paris, p. 21, déc. 1977.

LEANDRO, Anita. "O tremor das imagens: nota sobre o cinema militante.". Devires, Belo Horizonte, v. 7, n. 2, pp. 98-117, jul./dez. 2010.

LEENHARDT, Jacques ; KALFON, Pierre. Les Amériques latines en France. Paris : Découvertes Gallimard: A.F.A.A., 1992.

LEGRIS, Patricia. L'ambivalence du mythe de l'ORTF. Paris : Ed. de la Maison des sciences de l'homme, 2008.

LEONEL, Nicolau Bruno de Almeida. Chris Marker e as barricadas da memória: comentários em torno de 'Le fond de l'air est rouge'. 2010. 223f. Dissertação (Mestrado em Meios e Processos Audiovisuais) - Escola de Comunicações e Artes, Universidade de São Paulo, São Paulo, 2010.

«LES DÉCLARATION des hommes politiques ». Le monde, Paris, p. 4, 14 sept. 1973. Apud «LE PARTI socialiste français face à l'expérience de l'Unité Populaire chilienne ». Institut François Mitterrand, 4 mar. 2008. Disponível em: $<$ http://www.mitterrand.org/Le-parti-socialiste-francais-face.html>. Acesso em: 25 fev. 2013.

LEYDA, Jay. Films beget films. London: George Allen \& Unwin LTD, 1964.

LUPTON, Catherine. Chris Marker: memories of the future. London: Reaktion Books, 2008.

Lutte ouvrières - dossier: "CHILI: un massacre et un avertissement", Paris, n. 12, 1974 ?.

MACHADO Jr, Rubens. "O inchaço do presente: experimentalismo super-8 nos anos 1970”. Filme Cultura, Rio de Janeiro, n. 54, pp. 28-32, maio 2011.

MANET, Eduardo. “Marker, sî”. Cine cubano, La Habana, n. 6, pp. 49-56, 1962.

. "Tres semanas de trabajo junto a Chris Marker". Cine cubano, La Habana, n. 4, pp. 24-33, Dic. 1960/Ene. 1961.

"Manifiesto de los cineastas de la Unidad Popular" (1970). In: MOUESCA, Jacqueline. Plano secuencia de la memoria de Chile: veinticinco años de cine chileno (1960-1985). Madrid, Ediciones del Litoral, 1988. pp. 70-2.

"Manifesto do sequestro do embaixador americano" (Rio, 1969). In: Franklin Disponível em: <http://www.franklinmartins.com.br/estacao_historia_artigo.php?titulo=manifestodo-sequestro-do-embaixador-americano-rio-1969>. Acesso em: 25 fev. 2013. 
NAPOLITANO, Marcos. “A História depois do papel”. IN: PINSKY, Camila (Org.). Fontes históricas. São Paulo: Contexto, 2006.

MARCORELLES, Louis. «L'angoisse nous saisissait devant ce que nous voyions ». Le monde, Paris, p. 26, 27 juin 1975b. . «La violence quotidienne ». Le monde, Paris, p. 1, 21 mai 1975a.

MARDONE, Michel. «Conga no ». Cahiers du Cinéma, Paris, n. 152, pp. 72, févr. 1964.

MARKER, Chris. [carta] 17 janv. 1973, Paris [para] CAPRASSE, Edmond [presumido]. New York. Envio de película para o Chile. (Acervo ISKRA, pasta "La bataille du Chili”)

. Commentaires I. Paris : Éditions du Seuil, 1961.

. Commentaires II. Paris : Éditions du Seuil, 1967.

. [e-mail] 5 nov. 2004, Paris [para] KOIDE, Emi. Paris. Brésil encore.

. [e-mail] 27 out. 2011, Paris [para] AGUIAR, Carolina Amaral de. Paris. Recherche d'une brésilienne.

. "Introducción a la versión francesa". In: GUZMAN, Patricio; SEMPERE, Pedro. Chile: el cine contra el fascismo. Valencia, 1977. pp. 133-4.

1970. . « La bataille des dix millions ». Jeune cinéma, Paris, n. 50, pp. 39-48, Nov.

. Le fond de l'air est rouge: scènes de la troisième guerre mondiale: 19671977. Paris : François Maspero, 1978.

MASSIAH, Gustave (Dir.). CHILI: l'affrontement de classe - 1970-1973. Paris: Comité de soutien à la lutte révolutionnaire du peuple chilien, 1973.

MATTELART, Armand. Frentes culturales y movilización de masas. Barcelona: Anagrama, 1977.

MAYOUX, Valérie. « Témoignages - Dossier Chris Marker ». Positif, Paris, n. 433, pp. 90-5, mars 1997.

MEDVEDKINE, Alexandre. "El tren cinematográfico". In: RAMIÓ, Joaquim Romagueira I; THEVENET, Homero Alsina (Eds.). Textos y manifiestos del cine: estética, escuelas, movimientos, disciplinas, innovaciones. Madrid: Cátedra, 2007.

MORETTIN, Eduardo. "O cinema como fonte histórica na obra de Marc Ferro." IN: CAPELATO, Maria Helena [et al.]. História e Cinema. São Paulo: Alameda, 2007.

MOUESCA, Jacqueline. El documental chileno. Santiago de Chile: LOM, 2005. 
Plano secuencia de la memoria de Chile: veinticinco años de cine chileno (1960-1985). Madrid, Ediciones del Litoral, 1988.

MOULIAN E., Tomás. "La vía chilena al socialismo: Itinerario de la crisis de los discursos estratégicos de la Unidad Popular". In: PINTO VALLEJOS, Julio (Coor.). Cuando hicimos historia: la experiencia de la Unidad Popular. Santiago de Chile: LOM, 2005. pp. 35-56.

MURRAY, Edelman. Pièces et règles du jeu politique. Paris : Seuil, 1991.

NICHOLS, Bill. Introdução ao documentário. Campinas, São Paulo: Papirus, 2005.

NINEY, François. «L'éloignement des voix répare en quelque sorte la trop grande proximité des plans ». In: DUBOIS, Philippe. Théorème 6: Recherches sur Chris Marker. Paris : Presses Sorbonne Nouvelle, 2002.

NORA, Pierre. «Entre mémoire et histoire ». In: (Ed.). Les lieux de mémoire. v.1, p.25-43. Paris : Gallimard, 1997.

ODIN, Roger. «Film documentaire, lecture documentarisante ». IN: ODIN, Roger ; LYANT, Jean-Charles (Ed.). Cinémas et réalités. Saint-Etienne : Université de SaintEtienne, 1984. p. 263-277.

ORTEGA, María Luisa; WEINRICHTER, Antonio. "Introducción: itinerarios y bifurcaciones". In: ORTEGA, María Luisa; WEINRICHTER, Antonio. Mystère Marker: pasajes en la obra de Chris Marker. Madrid: Festival Internacional de Cine Las Palmas de Gran Canaria; T\&B, 2006. pp. 13-54.

PACI, Viva. «On vous parle de... ciné-tracts ». In: HABIB, André ; PACI, Viva (Dir.). Chris Marker et l'imprimerie du regard. Paris : L'Harmattan, 2008. pp. 167177.

PANIZZA MONTANARI, Tiziana. Joris Ivens en Chile: el documental entre la poesia y la critica. Santiago de Chile: Cuarto Propio, 2011.

PARANAGUÁ, Paulo Antonio (Ed.). Cine documental en América Latina. Madrid: Cátedra, 2003.

PARANAGUÁ, Paulo Antonio. «Droit au cour». Rouge, Paris, n. 156?, s/p, oct./nov. 1977.

PERICÁS, Luiz Bernardo. "Che Guevara e o homem novo". In: COGGIOLA, Osvaldo (org.). Revolução cubana: História e problemas atuais. São Paulo: Xamã, 1998.

PRADO, Maria Ligia Coelho. "Repensando a história comparada da América Latina". Revista de História - Universidade de São Paulo, São Paulo, n. 153, p. 11-33, dez. 2005. 
PROGNON, Nicolas. La diaspora chilienne en France : l'exil et le retour: 1973-1994. 2002. Lille: Atelier national de Reproduction des Thèses ; Université de Toulouse-Le Mirail, 2002.

PROGRAMA de la Unidad Popular. Santiago de Chile: Libreria Pla, 1970.

QUEIJA, Berta; GRUZINSKI, Serge (Coord.). Entre dos mundos: fronteras culturales y agentes mediadores. Sevilla: Publicaciones de la escuela de estudios hispanosamericanos de Sevilla, 1997.

RENOV, Michael. Investigando o sujeito: uma introdução. In: MOURÃO, Maria Dora; LABAKI, Amir (Org.). O cinema do real. São Paulo: Cosac Naify, 2005, pp. 234-257.

RICEEUR, Paul. A memoria, a história, o esquecimento. Campinas: Editora da Unicamp, 2007.

ROCARD, Michel. «Madrid, Athènes et Santiago ». Le monde, Paris, p. 6, 22 sept. 1973.

ROLLEMBERG, Denise. O apoio de Cuba à luta armada no Brasil. Rio de Janeiro: MAUAD, 2001.

ROLLET, Sylvie. «Une impression freudienne: rejouer, déjouer la mort». In: HABIB, André ; PACI, Viva (Dir.). Chris Marker et l'imprimerie du regard. Paris : L'Harmattan, 2008. pp. 33-49.

ROSA, Carlos Adriano Jeronimo de. O mutoscópio explica a invenção do pensamento de Santos Dumont. 2008. Tese (Doutorado em Ciências da Comunicação) - Escola de Comunicação e Artes, Universidade de São Paulo, São Paulo, 2008.

RUFFINELLI, Jorge. El cine de Patricio Guzmán: en busca de las imágenes verdaderas. Santiago de Chile: Uqbar, 2008.

SACCHETTA, Vladimir (Org.). Os cartazes dessa História: memória gráfica da resistência à ditadura e da redemocratização (1964-1985). São Paulo: Instituto Vladimir Herzog e Escrituras Editora, 2012.

SADOUL, Georges. "A chacun sa vérité ». Les lettres françaises, Paris, p. 1, 26 sept. 1963.

SÁNCHES-BIOSCA, Vicente. Cine y vanguardias artísticas: conflictos, encuentros, fronteras. Barcelona: Paidós, 2004.

«SANTIAGO-sur-Seine ». Le Monde, Paris, p. 5, 22 sept. 1973.

SARTRE, Jean-Paul. O existencialismo é um humanismo. Petrópolis: Vozes, 2010.

SEMPRÚM, Jorge. Montand: la vie continue. Paris : Denoël ; Clims, 1983. 
SERVOLIN, Inger. [carta] Paris, 1 mars 1973a [para] JORDAN, Sonia. Santiago de Chile. 3f. Recepção La première année. (Acervo ISKRA, pasta "La première année")

. [carta] Paris, 5 avr. 1973b [para] JORDAN, Sonia. Santiago de Chile. 2f. Recepção La première année. (Acervo ISKRA, pasta "La première année")

. [carta] Paris, 1 nov. 1973c [para] Internationale Leipziger Dokumentar und Kurzfilmwoche für Kino und Fernsehen, Berlim. 2f. Recepção La première année. (Acervo ISKRA, pasta "La bataille du Chili")

- [carta] Paris, 11 déc. 1973d [para] BRECHT, Hans. Hamburgo. 2f. Coprodução A batalha do Chile. (Acervo ISKRA, pasta "La bataille du Chili")

. [carta] Paris, 17 déc. 1973e [para] SUNDGREN, Nils Petter, Estocolmo. $2 \mathrm{f}$. Coprodução A batalha do Chile. (Acervo ISKRA, pasta "La bataille du Chili")

"SIMONE de Beauvoir y Sartre hablan de cine". Cine cubano, La Habana, n. 1, p. $25,1960$.

SLON. ESQUEMAS de producción. Paris: s/d. Esquemas de produção de A batalha do Chile. (Documento inédito localizado no acervo ISKRA, pasta "La bataille du Chili")

SLON ; UNIVERSIDAD DE CHILE. Contrato de distribución: La première année. Paris : 6 déc. 1972. (Acervo ISKRA, pasta "La première année")

SUÁREZ-IÑIGUEZ, Enrique ; SEMO, Enrique. América latina y la crisis europea: El eurocomunismo. Ciudad de México: Seminario Permanente sobre Latinoamérica SEPLA, 1977.

«TABLE ronde sur Le fond de l'air est rouge ». Cahiers du Cinéma, Paris, n. 284, pp. 47-50, janv. 1978.

TERRENOIRE, Louis. [carta] 31 juil. 1961 [para] censura francesa. Apud "Symphonie pour un peuple libre (Cuba si, de Chris Marker)". L'Humanité, Paris, p. 1, 14 sept. 1963.

THIRARD, Paul-Louis. « À propos de 'La Spirale' ». Positif, Paris, n. 180, pp. 25-29, 1976.

TODE, Thomas. "Fantasma Marker: inventario antes del filme". In: ORTEGA, María Luisa; WEINRICHTER, Antonio. Mystère Marker: pasajes en la obra de Chris Marker. Madri: Festival Internacional de Cine Las Palmas de Gran Canaria; T\&B, 2006. pp. 55-76.

TOLEDO, Manuel. “Adiós a Volodia Teitelboim”. BBC mundo, 1 Feb. 2008. Disponível em: <http://news.bbc.co.uk/hi/spanish/misc/newsid_7221000/7221394.stm>. Acesso em: 25 fev. 2013. 
TOUBIANA, Serge. «Savoir posthume (La Spirale)». Cahiers du Cinéma, Paris, n.265, p. 56-60, mars/avr. 1976.

TURQUIER, Barbara. «Qu'expérimente le cinéma expérimental ? Sur la notion d'expérimentation dans le cinéma d'avant-garde américain (1950-1970) ». Tracés: Revue de Sciences humaines, n. 9, 2005. Disponível em: <http://traces.revues.org/171>. Acesso em: 25 fev. 2013.

VAYSSIÈRE, Pierre. Le Chili d'Allende et de Pinochet dans la presse française: 1970-2005. Paris : L'Harmattan, 2005.

VÉRAY, Laurent. «L'Histoire peut-elle se faire avec des archives filmiques ?». 1895. Mille huit cent quatre-vingt-quinze, n. 41, pp. 2-10, 2003. Disponível em: <http://1895.revues.org/266>. Acesso em: 25 fev. 2013.

. Loin Du Vietnam. Paris : Edictions Paris Expérimental, 2004.

VERTOV, Dziga. Articles, journaux, projets. Paris : Union générale d'éditions, 1972.

. "Del cine-ojo al Radio ojo". In: RAMIÓ, Joaquim Romagueira I; THEVENET, Homero Alsina (eds.). Textos y manifiestos del cine: estética, escuelas, movimientos, disciplinas, innovaciones. Madrid: Cátedra, 2007.

VILLAÇA, Mariana. Cinema cubano: revolução e política cultural. São Paulo: Alameda, 2010.

$O$ Instituto Cubano del Arte e Industria Cinematográfica (ICAIC) e a política cultural em Cuba (1959-1991). 2010. 433 f. Tese (Doutorado em História Social) Faculdade de Filosofia, Letras e Ciências Humanas, Universidade de São Paulo, São Paulo, 2006.

VILLARROEL, Mónica (et. al.) Imágenes de Chile en el mundo: cadastro del acervo audiovisual chileno en el exterior. Santiago de Chile: Cineteca nacional de Chile, 2008.

VILLARROEL, Mónica; MARDONES, Isabel. Señales contra el olvido: cine chileno recobrado. Santiago: Cuarto Propio, 2012.

WAYNE, Mike. Political film: the dialectics of Third Cinema. London: Pluto Press, 2001.

WEES, William C. Recycled Images: The Art and Politics of Found Footage Films. New York: Anthology Film Archives, 1993.

WEINRICHTER, Antonio. "Montage Marker". In: ORTEGA, María Luisa; WEINRICHTER, Antonio. Mystère Marker: pasajes en la obra de Chris Marker. Madrid: Festival Internacional de Cine Las Palmas de Gran Canaria; T\&B, 2006. pp. 171-184. 
XAVIER, Ismail "Progresso, disciplina fabril e descontração operária: retóricas do documentário brasileiro silencioso". In: ArtCultura, Uberlândia, v. 11, n. 18, p. 9-24, jan.-jun. 2009.

ZAROWSKY, Mariano. "Armand Mattelart: Un itinerario intelectual entre América Latina y Europa". Contracorriente, Raleigh, v. 9, n. 2, pp. 221-247, 2012. 


\section{Referências gerais}

«Appareils idéologiques d'État et luttes de classes: Chili 1970-73 ». IN: Cahiers $d u$ Cinéma, Paris, n. 254-255, p. 5-32, déc./janv., 1974-1975.

BALLÉRINI, Étienne. "L'expérience du cinéma militant de 1968 à 1981: une parenthèse pendant l'entre-deux-mai historique ?». In: CinémAction : le documentaire français, n. 41. Nice : Faculté des Lettres et Sciences Humaines : section d'Histoire, 1974.

BAROT, Emmanuel. Camera politica: dialectique du réalisme dans le cinéma politique et militant. Paris : Vrin, 2008.

BIÉNZOBAS, Pamela; HERNÁNDEZ, Macarena. Testémonos del golpe militar en el cine chileno: el día en que las cámaras dejaron de rodar. Santiago: Universidad de Chile, Facultad de Ciencias Sociales, 1999. (Memoria para obtención de Licenciatura en Comunicación Social).

BITAR, Sergio. Transição, socialismo e democracia: Chile com Allende. Rio de Janeiro: Paz e Terra, 1980.

CARDIEL REYES, Raúl. El eurocomunismo y la ideología de la nueva izquierda. México: UNAM, Centro de estudios sobre la Universidad, Coord. de humanidades, $19 ?$.

Cinéma 70 : spécial politique \& cinéma - les points de vue de treize cinéastes plus ou moins « engages »: Costa-Gavras, Semprun, Heynowski, Scheumann, Allio, Daquin, Espinosa, Ghanassia, Klien, Petri, Rocha, Starub et Ivens, Paris, n. 151, Au Bureau du Journal, 1 janv. 1970.

COMOLLI, Jean-Louis (et. al.). Cinéma et politique: 1956-1970. Paris : Bibliothèque Centre Pompidou, 2001.

CORO, Pablo (et. al.). Teorías del cine documental chileno: 1957-1973. Santiago de Chile: Pontifícia Universidad Católica de Chile, 2007.

CORVALÁN, Luis. El gobierno Salvador Allende. Santiago: LOM, 2003.

. Los comunistas y la democracia. Santiago: LOM, 2008.

Debates críticos en América Latina 2. Santiago de Chile, Arcis, Cuarto Proprio, Revista de Crítica Cultural, 2008.

DESSONS, Gérard (Org.). Cinéma documentaire, cinéma de fiction : frontières et passages. Poitiers : UFR de langue et littératures, 1992.

DORFMAN, Ariel. O longo adeus a Pinochet. São Paulo: Companhia das Letras, 2003. 
DOUGNAC, Paulette (et. al.). El diario de Agustín: cinco estudios de casos sobre $E l$ Mercurio y los derechos humanos (1973-1990). Santiago de Chile: LOM, 2009.

EISENSCHITZ, Bernard (Ed.). Chris Marker: XXXII Mostra Internazionale del Nuovo Cinema. Roma: Pesaro, 1996.

FRODON, Michel. «Et tout ça sous le regard d'un chat». Paris, Cahiers $d u$ Cinéma, n. 596, déc. 2004.

GAUTHIER, Guy ; PILARD, Philippe ; SUCHET, Simone. Le documentaire passe au direct. Montréal : VLB, 2003.

GREZ, Sergio; SALAZAR, Gabriel. Manifiesto de los historiadores chilenos. Santiago de Chile: LOM, 1999.

IVENS, Joris ; DESTANQUE, Robert. Joris Ivens ou la mémoire d'un regard. Paris : Editions BNF, 1982.

LABORDE, Barbara. L'histoire mise en ceuvre dans deux films de compilation de Chris Marker: «Le tombeau d'Alexandre » et «Le fond de l'air est rouge ». Paris : Sorbonne Nouvelle (Paris III), 2005. (Mémorial de master, direction de Sylvie Rollet).

LAMBERT, Arnaud. Also known as Chris Marker. Cherbourg : le Point du jour, 2008.

LE GOFF, Jacques. História e memória. Campinas: Editora da Unicamp, 1996.

LEBEL, Jean-Patrick. Cinéma et idéologie. Paris : Éditions Sociales, 1971.

LÖWY, Michael. O marxismo na América Latina: uma antologia de 1909 aos dias atuais. São Paulo: Editora Fundação Perseu Abramo, 2006.

MARKER, Chris. Le cœur net. Paris : le Club français du livre, 1950.

MARTINEZ-MALER, Odette; VÉRAY, Laurent. Ecritures filmiques du passé. Nanterre : Association des amis de la Bibliothèque de documentation internationale contemporaine, 2008.

Matériaux pour l'histoire de notre temps : Écritures filmiques du passé: archives, témoignages, montages. BDIC: Nanterre, n. 89-90, janv./juin 2008.

MONTUPIL, Fernando (Org.). Exilio, derechos humanos y democracia: el exilio chileno en Europa. Santiago de Chile: Servicios Gráficos Caupolicán, 1993.

SALINAS MUÑOZ, Claudio (Org.). Historia del Cine Experimental en la Universidad de Chile: 1957-1973. Santiago de Chile: Uqbar, 2008.

MURCIA, Calude ; MENEGALDO, Gilles (Eds.). Cinéma documentaire, cinéma de fiction: frontières et passages. Poitiers : La Licorne, 1992. 
NARANJO, Pedro (et. al.). Miguel Enríquez y el proyecto revolucionario en Chile: Discursos y documentos del Movimiento de Izquierda Revolucionaria, MIR. Santiago de Chile: LOM, 2004.

NICHOLS, Bill. Engaging cinema. New York, London: W. W. Norton \& Company, 2010.

PINCEMIN, Marie. Le commentaire chez Chris Marker. Paris : Sorbonne Nouvelle (Paris III), 1995. (Mémorial de master, direction de Gérard Leblanc).

POUVALI, Bamchade. Chris Marker. Paris : Cahiers du Cinéma, 2010.

RIVAS, Patricio. Chile, un largo septiembre. Santiago de Chile: LOM, 2007.

RODRIGUES, Felipe. Critica de la Unidad Popular. Barcelona: Fontamara, 1975.

SARLO, Beatriz. Tempo passado. Cultura da memória e guinada subjetiva. São Paulo, Belo Horizonte: Companhia das Letras; UFMG, 2007.

SIRINELLI, Jean-François. "Os intelectuais". In: RÉMOND, René (Org.). Por uma história política. Rio de Janeiro: FGV, 2003. p. 231-270.

THELEN, David. "Replanteamiento de la historia desde una perspectiva transnacional". In: AZUELA, Alicia; PALACIOS, Guillermo (Org.). La mirada mirada: transculturalidad e imaginarios del México revolucionario: 1910-1945. Ciudad de México: El Colegio de México; Centro de Estudios Históricos; Instituto de Investigaciones Estéticas, 2009. p. 299-309.

VEGA, A. Itinerario del cine documental chileno: 1900-1990. Santiago de Chile: Universidad Alberto Hurtado, 2006.

WERT, William F. van. Chris Marker: The SLON Films. Film Quarterly, v. 2, n. 3, Spring, 1979. Disponível em: 〈http://www.jstor.org/stable/1212205>. Acesso em: 25 fev. 2013.

WIECHMANN, Maria Helena. A construção do conhecimento histórico a partir de fontes cinematográficas: análise dos filmes "Cabra marcado para morrer" - 1981 e "A espiral” - 1975. Dissertação (Mestrado) - Programa de Pós-Graduação em Integração da América Latina (PROLAM), Universidade de São Paulo, São Paulo, 1997. 


\section{Anexos}

\section{A) Chris Marker: filmografia completa ${ }^{448}$}

1952. Les statues meurent aussi. (Realização: Alain Resnais e Chris Marker). 35mm, $\mathrm{P} / \mathrm{B}, 30 \mathrm{~min}$.

1952. Olympia 52. $16 \mathrm{~mm}$ ampliado para $35 \mathrm{~mm}, \mathrm{P} / \mathrm{B}, 82 \mathrm{~min}$.

1955. Noite e neblina. (Realização: Alain Resnais. Assistente de direção: André Heinrich, Chris Marker, Jean-Charles Lauthe). 35mm, P/B, 32 min.

1956. Dimanche à Pékin. 16mm ampliado para 3mm, Cor, $22 \mathrm{~min}$.

1958. Lettre de Sibérie. $16 \mathrm{~mm}$ ampliado para 35mm, Cor, $62 \mathrm{~min}$.

1960. Description d'un combat. 35mm, Cor, $60 \mathrm{~min}$.

1961. Cuba si. Produção: Juan Vilar, Roger Fleytoux, Les films de la Pléiade / Pierre Braunberger. Roteiro: Chris Marker. Montagem: Eva Zora. Imagem: Chris Marker. Música: E.G. Mancini, J. Calzada, C. Puebla. Colaboradores cubanos: Dervis P. Espinosa, Saul Yelin, Eduardo Manet, Selma Díaz, ICAIC. Voz over: Nicolas Yumatov. 16mm ampliado para $35 \mathrm{~mm}, \mathrm{P} / \mathrm{B}, 22 \mathrm{~min}$.

1962. La Jetée. $35 \mathrm{~mm}, \mathrm{P} / \mathrm{B}, 29 \mathrm{~min}$.

1962. Le joli mai. $16 \mathrm{~mm}$ ampliado para $35 \mathrm{~mm}$, P/B, 165 min (versão USA, UK, $123 \mathrm{~min})$.

1963. À Valparaiso. Realização: Joris Ivens. Produção: Argos Films / A. Dauman / PH. Lifchitz. Assistente de montagem: Sergio Bravo / Jean Ravel. Texto: Chris Marker. Música: Gustavo Becerra-Schmidt. Canção: Nous irons à Valparaiso. Voz over: Roger Pigaut. 35mm, P/B e Cor, 34 min.

1964. Les chemins de la fortune. (Realização: Pierre Kassovitz. Colaboração: Chris Marker), 42 min.

1965. Le Mystère Koumiko. 16mm ampliado para 35mm, Cor, 54 min.

1967. La sixième face du Pentagone (Realização Chris Marker e François Reichenbach). 35mm, P/B, Cor, $28 \mathrm{~min}$.

\footnotetext{
${ }^{448}$ Filmografia elaborada a partir dos dados apresentados em LUPTON (2005), ALTER (2006) e ORTEGA; WEINRICHTER (2006). No caso dos filmes analisados nesta tese, foi elaborada uma ficha técnica com as informações disponíveis. Incluiu-se os filmes de Marker como realizador, bem como os que ele colaborou com outras funções.
} 
1967. Loin du Vietnam. (Filme coletivo de Jean-Luc Godard, Joris Ivens, William Klein, Claude Lelouch, Chris Marker, Alain Resnais, Agnès Varda, Michèlle Ray). $16 \mathrm{~mm}$ e $35 \mathrm{~mm}$, P/B, Cor, $130 \mathrm{~min}$.

1968. À bientôt, j'espère. (Realização : Chris Marker e Mario Marret). 16mm, P/B, 43 min.

1969. Nouvelle société $n^{\circ}$ 5. (Grupo Medvedkine Besaçon) 16mm, P/B, 8 min.

1969. Nouvelle société $n^{\circ}$ 6. (Grupo Medvedkine Besaçon) 16mm, P/B, 9 min.

1969. Nouvelle société $n^{\circ}$ 7. (Grupo Medvedkine Besaçon) 16mm, P/B, $11 \mathrm{~min}$.

1969. On vous parle de Flins (Realização: Guy Devart. Imagem e Montagem: Chris Marker). 16mm, P/B, $30 \mathrm{~min}$.

1969. On vous parle de Prague: le deuxième procès d'Artur London. 16mm, P/B, 30 $\min$.

1969. On vous parle de Brésil: tortures. Produção: SLON. Roteiro: Chris Marker. Montagem: Chris Marker. Imagem: Noticiero ICAIC Latinoamericano. 16mm, P/B, $20 \mathrm{~min}$.

1970. La bataille des dix millions. Produção: K.G. Production, SLON, RTB, ICAIC. Roteiro: Chris Marker. Montagem: Valérie Mayoux, Chris Marker. Imagem: Noticiero ICAIC Latinoamericano, Santiago Álvarez. Música: Leo Brouwer. Voz over: Georges Kiejman, Edouard Luntz. 16mm, P/B, 58 min.

1970. Nouvelle société $n^{\circ}$ 8. (Grupo Medvedkine Besaçon) 16mm, P/B, $12 \mathrm{~min}$.

1970. On vous parle de Paris: Maspero, les mots ont un sens. 16mm, P/B, $20 \mathrm{~min}$.

1970. On vous parle du Brésil: Carlos Marighela. Produção: SLON. Roteiro: Chris Marker. 16mm, P/B, 17 min.

1972. La première année. (Realização: Patricio Guzmán. Versão francesa: Chris Marker). Produção: ISKRA, EAC. Roteiro versão francesa: Patricio Guzmán e Chris Marker. Montagem versão francesa: Carlos Piaggio e Chris Marker. Imagem versão francesa: Antonio Ríos e Chris Marker. Voz over e dublagem: Delphine Seyrig, François Perier, Françoise Arnoul e Chris Marker. 16mm ampliado para 35mm, P/B, 91.

1973. On vous parle du Chili: ce que disait Allende. (Realização: Chris Marker, a partir do filme Compañero Presidente de Miguel Littin). Produção: SLON-ISKRA. Roteiro: Chris Marker. Montagem: Chris Marker. 16mm, P/B, 15 min.

1974. L'ambassade. Produção: EFK. Roteiro: Chris Marker. Montagem: Chris Marker. Imagem: Chris Marker. Super 8, Cor, 20 min.

1974. La solitude du chanteur de fond. $16 \mathrm{~mm}$ ampliado para $35 \mathrm{~mm}$, Cor, $60 \mathrm{~min}$. 
1975. A batalha do Chile - A insurreição da burguesia. (Realização: Patricio Guzmán). Produção: Equipe Tercer Año, ISKRA (Chris Marker), ICAIC. Roteiro: Patricio Guzmán (contribuição: Chris Marker, Julio García Espinosa). Montagem: Pedro Chaskel, Patricio Guzmán. Imagem: Jorge Müller Silva. 16mm, P/B, 100 min.

1975. La spirale. (Realização: Chris Marker, Armand Mattelart, Jacqueline Meppiel, Valérie Mayoux). Produção: Les Films Molière, Reggane Films, Seuil Audio-Visuel. Roteiro: Chris Marker. Música: Jean-Claude Eloy, Luc Bérini, Antoine Bonfanti, J. F. Chevalier. Voz over: François Catonné, Med Hondo. 35mm, Cor, 155 min.

1977. O fundo do ar é vermelho. Produção: ISKRA, INA, DOVIDIS. Roteiro: Chris Marker. Montagem: Chris Marker. Música: Le temps des cerises (Jean-Baptiste Clément e Antoine Renard), Luciano Berio. Voz over: Simone Signoret, Jorge Semprún, Davos Hanich, Sandra Scarnati, François Maspero, Laurence Cuvillier, François Perier, Yves Montand. Colaboradores: Valérie Mayoux, Luce Marsant, Pierre Camus, Annie-Claire Mittelburger, Christine Aye, Patrick Sauvion, Jean-Roger Sahunet. $16 \mathrm{~mm}$ ampliado para $35 \mathrm{~mm}, \mathrm{P} / \mathrm{B}$, Cor, $240 \mathrm{~min}$.

1982. Sans soleil. $16 \mathrm{~mm}$ ampliado para $35 \mathrm{~mm}$, Cor, $100 \mathrm{~min}$.

1985. A.K. $35 \mathrm{~mm}$, Cor, $75 \mathrm{~min}$.

1986. Mémoires pour Simone. 35, Cor, $61 \mathrm{~min}$.

1989. L'héritage de la chouette. (TV) 16mm, Cor, $26 \mathrm{~min}$.

1993. Le tombeau d'Alexandre. Super 8 Vídeo, P/B, Cor, 118 min.

1996. Level 5. Betacam SP ampliado para 35mm, Cor, $106 \mathrm{~min}$.

1997. Immemory. Instalação Multimídia Interativa. Centre Georges Pompidou. 


\section{B) Prefácio de La première année}

\section{PREFACE $^{449}$}

La première difficulté d'un film sur le Chili, c'est de faire tenir le Chili dans le film. Il faut aller chercher sur la côte ouest de l'Amérique du Sud ce pays qui commence et finit par des déserts, s'adosse à la Cordillère des Andes, s'étend sur une longueur égale à la distance Maroc-Islande sans jamais dépasses, en largeur, la distance Paris-Strasbourg et rassemble moins d'habitants que le Portugal sur un territoire sept fois plus grand. «Frange de terre géographiquement folle». dit Régis Debray, «mais historiquement raisonnable ».

L'histoire du Chili commence comme celle de tout le continent, par la conquête espagnole. Les Indiens, premiers colonisés du monde moderne, paient du même esclavage le privilège de posséder sur leurs terres des mines d'or. Avec une exception cependant : au Sud, les indiens Mapuches constituent un îlot de résistance inégalé. Ils stoppent les conquérants. Ils défendront leur terre pendant trois siècles.

A l'empire espagnol succède comme ailleurs une indépendance ambiguë, soutenue par d'autres puissances européennes qui convoitent l'héritage. Commence alors la valse des impérialismes : anglais d'abord, allemand ensuite, remplacés enfin par celui qui les remplace en Amérique latine, l'impérialisme des Etats-Unis. Mais à travers ce schéma classique, le Chili dessine des traits originaux. La mainmise étrangère sur les ressources nationales, comme le cuivre et le salpêtre, provoque de plus rapides contre coups : prolétarisation d'une part, réaction nationaliste de l'autre. Une bourgeoisie libérale conquérante, un puissant mouvement ouvrier se développent ensemble, et atteignent un niveau de conscience et d'organisation inconnu ailleurs. On voit ainsi coexister une démocratie formelle teintée de légalisme anglo-saxon, et une montée des luttes populaires sur des positions de classe. Contrairement à un légende, cette double précocité n'empêche ni les chocs, ni les reflux, ni les répressions. Mais au cours d'une histoire aussi violente que celle de ses voisions, le Chili connaîtra de brusques avancées politiques, un Front Populaire en 38, et même, en 32, une république socialiste - qui durera 13 jours. Le parti communiste est fondé en 1922 par Recabarren. Il connaîtra la répression et la clandestinité, et n'en deviendra pas moins

\footnotetext{
${ }^{449}$ Respeitamos a ortografia original, inclusive aquela dos nomes próprios. Os sublinhados pertencem ao texto original.
} 
le parti le plus puissant de l'opposition. En 1933 se constitue un parti socialiste d'un type peu courant : résolument marxiste, résolument étranger à la social-démocratie européenne, mais refusant un certain modèle d'obédience internationale. Parmi ses fondateurs, un médecin devenu député, mais sénateur : Salvador Allende Gossen.

La solidité de la démocratie bourgeoise ne met pas Le Chili à l'abri des vagues qui secouent l'Amérique Latine après la Deuxième Guerre Mondiale - que ce soient le populisme, en Argentine au en Bolivie, ou los luttes révolutionnaires dont Cuba sera le symbole. A la droite traditionnelle et autoritaire incarnée par le président Alessandri succédera le réformisme de la Démocratie Chrétienne dirigée par Eduardo Frei. Mais là comme ailleurs le réformisme ne triomphera pas de sa contradiction fondamentale. Il y a des portes qu'on n'entre' ouvre pas. Une réforme agraire limitée, des nationalisations limitées peuvent se convertir en leur contraire. Chuquicamata, la plus grande mine de cuivre à ciel ouvert du monde, devient ainsi le symbole de la mise à sac du Chili dont la première ressource nationale, le cuivre, rapportera en 6 ans de pseudo-réforme 600 millions de dollars à des compagnies nord-américaines qui investissent, pendant ce temps-là, en Australie.

C'est avec ce bilan que la démocratie chrétienne se présente aux élections présidentielles en 1970. Et pour la première fois, en face de problèmes qui la dépassent, la bourgeoisie va au combat en ordre dispersé. La droite conservatrice se rassemble autour d'Alessandri, partisan d'un retour aux méthodes autoritaires. La démocratie chrétienne, consciente d'une poussée populaire plus exigeante, s'engage plus loin dans le réformisme. La gauche se regroupe dans l'Unité Populaire qui comprend socialistes, communistes, radicaux, sociaux-démocrates ainsi qu'une fraction de gauche détachée de la démocratie chrétienne. A l'extérieur de l'Unité Populaire, mais la soutenant : le MIR, mouvement d'avant-garde, partisan de l'action directe dans la perspective d'une « guerre révolutionnaire prolongée et irrégulière ». Reste à choisir un candidat. Le parti communiste propose le poète Pablo Neruda, le parti socialiste Salvador Allende. En retirant sa candidature, Neruda permet à Allende de faire l'unanimité sur son nom. Tandis que les grosses compagnies nordaméricaines essaient toutes les formes de pression pour «stopper Allende », l'extrême droite commence à s'affoler. C'est la gauche unie qui l'emporte, de très peu. $36 \%$ des voix pour Allende. $35 \%$ pour Alessandri. 28\% pour les démocrates-chrétiens. La majorité absolue n'étant pas atteinte, le Congrès dispose de 50 jours pour ratifier au invalider l'élection. Et le film que vous allez voir commence dans la matinée du 5 
septembre, à quelques heures de la victoire de Salvador Allende, le médecin socialiste qui garde sur son bureau un exemplaire des œuvres du Che Guevara avec cette dédicace : «A Salvador Allende, qui essaie d'obtenir la même chose avec d'antres moyens. Che.» 


\section{C) Esquema de produção e Plano de trabalho de $A$ batalha do Chile}

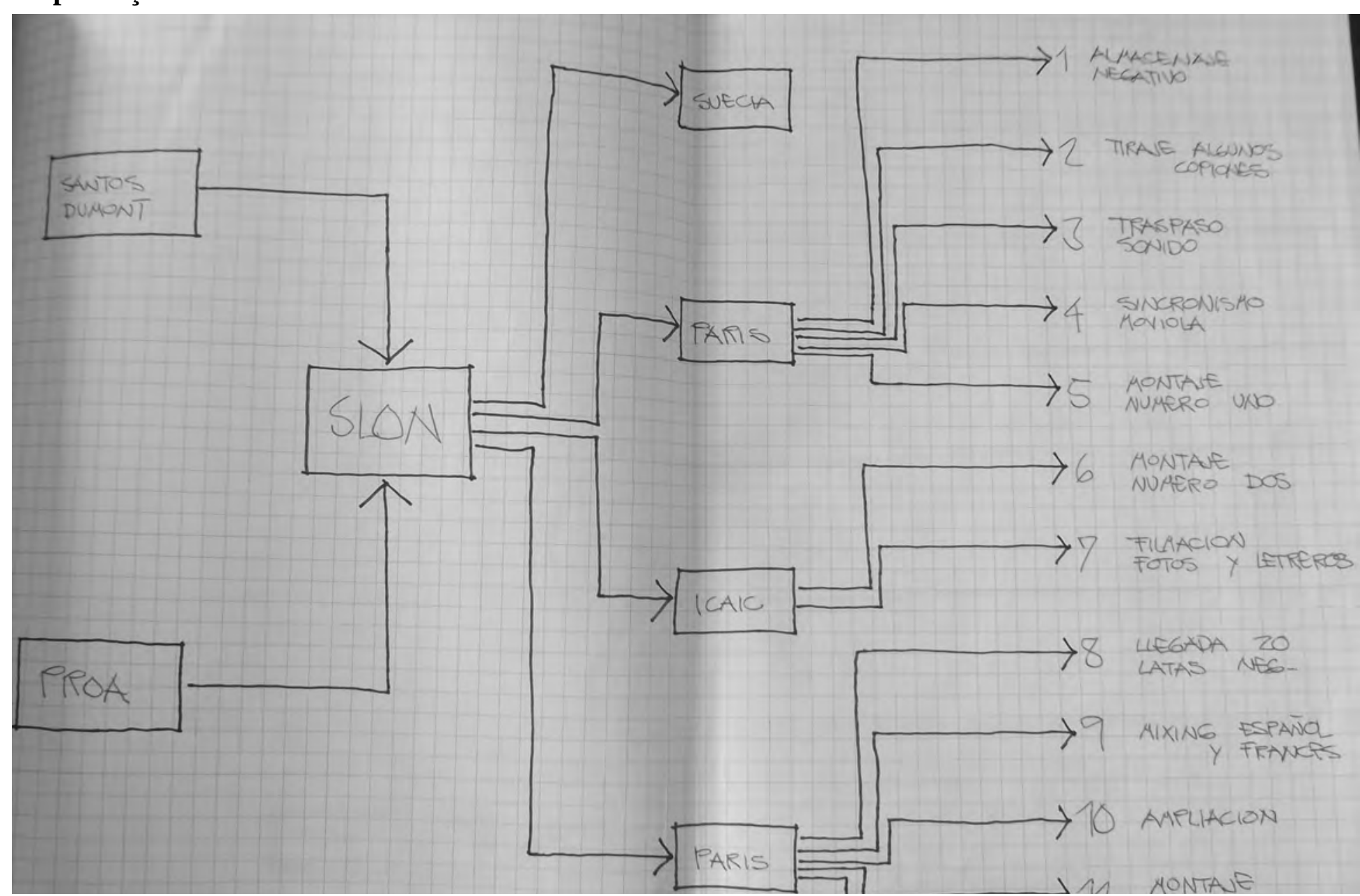




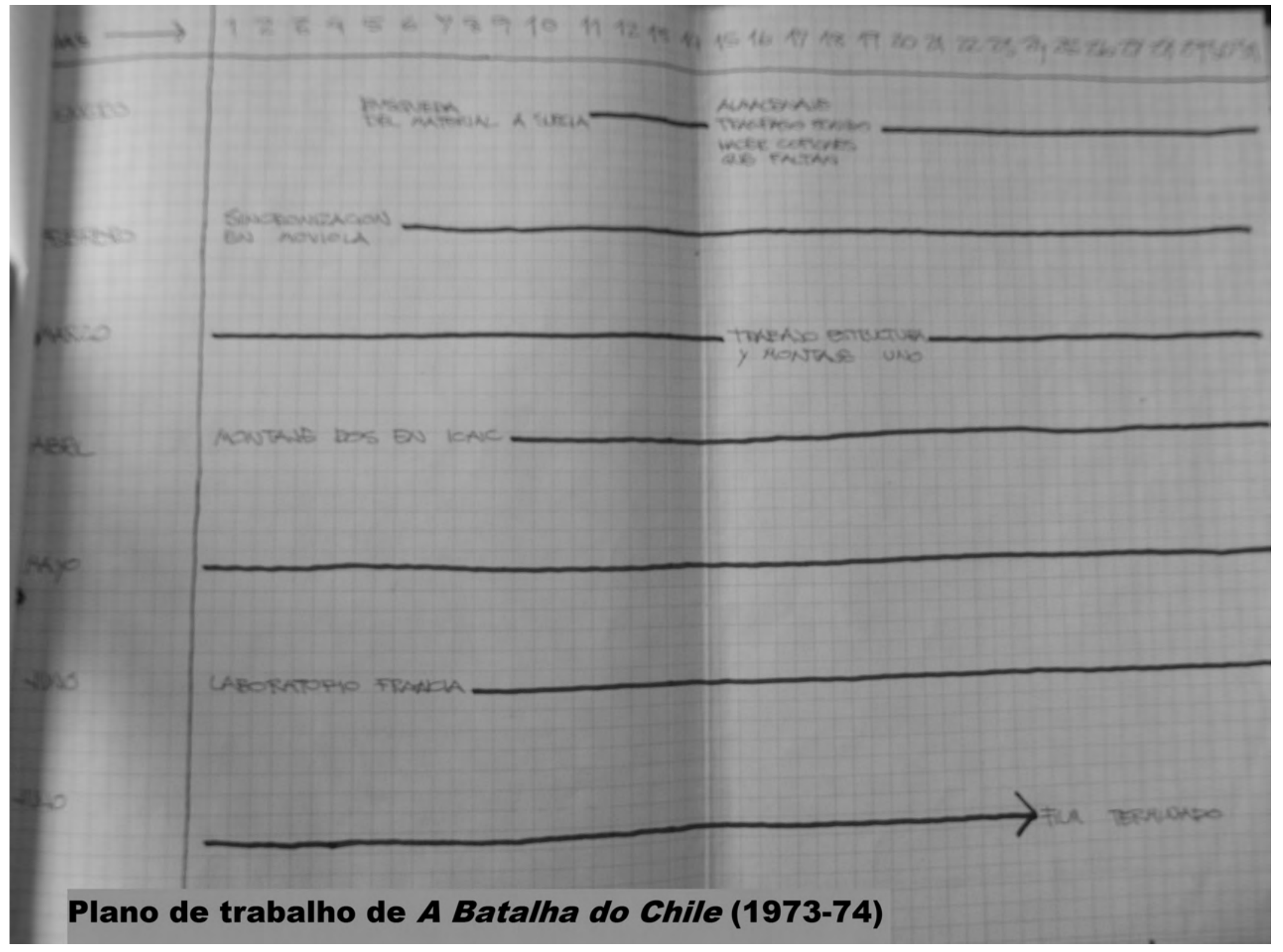


Plano de trabalho de $A$ batalha do Chile (1973-1974) $)^{450}$

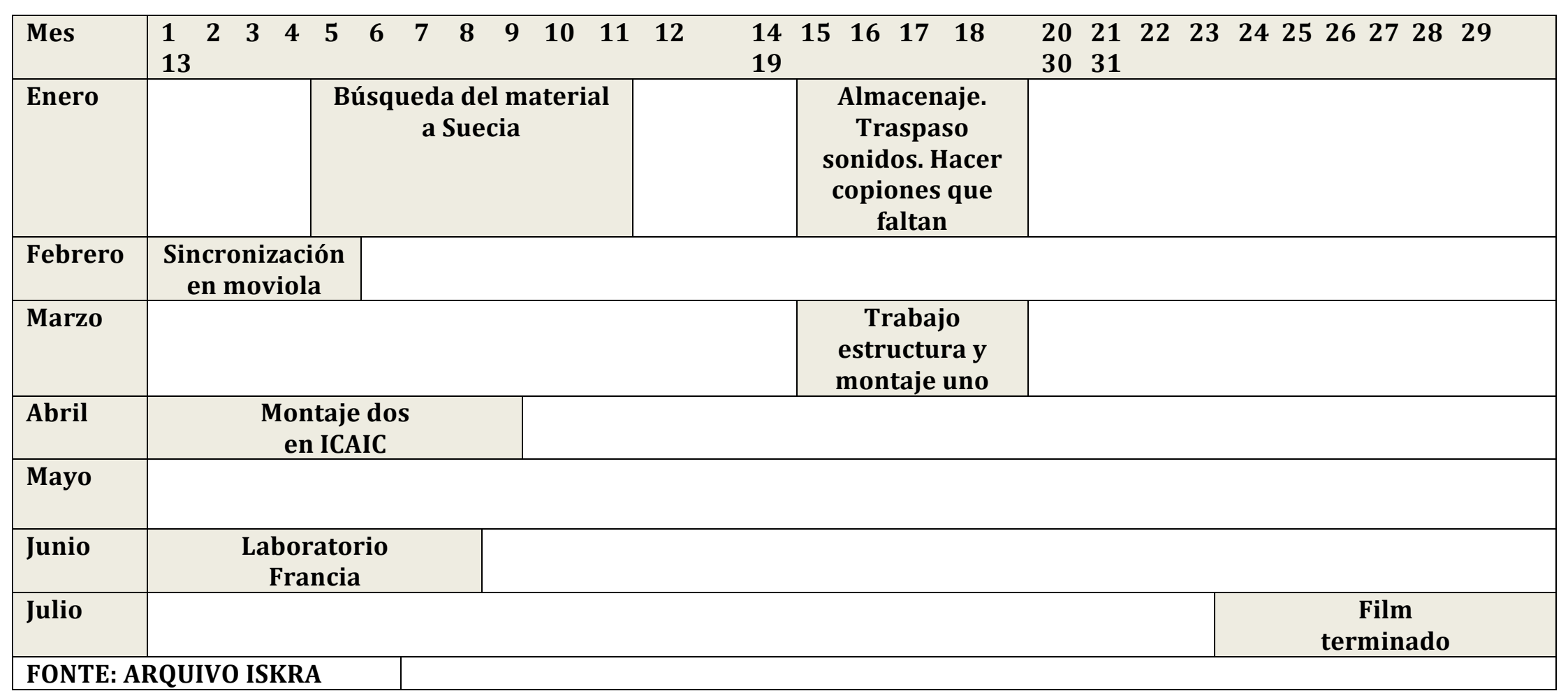

$\overline{450}$ Transcrição do Plano de trabalho da página anterior, que está pouco legível. 


\section{D) Texto da voz over de L'ambassade}

Ceci n'est pas un film. Ce sont des notes prises au jour le jour. En fait de commentaires, d'autres notes, prises quand je ne filmais pas. Quitte à faire une démonstration des possibilités du super-8, j'aurais autant aimé la faire ailleurs que dans cette Ambassade, et avec d'autres personnages que des réfugiés politiques.

Mercredi. Deux jours après le coup d'état. Le premier groupe est arrivé. Des militants de gauche pour la plupart. Je reconnais quelques visages. Vus dans des manifs, dans des meetings. Encore sonnés par la soudaineté de tout ça, par la brutalité de tout ça.

L'Ambassadeur est parfait. Il les accueille simplement, comme des invités légérement en avance pour une réception. L'Ambassadrice les installe dans le petit salon de son appartement privé.

Le moment n'est pas aux questions, mais d'eux-mêmes ils se mettent à parler. Comme si plus encore que de se reposer, de manger, ils avaient à assouvir le besoin de raconter, de partager ce qui leur est tombé sur la tête.

Ils s'étaient réunis dans les bâtiments d'une grande école, tout près d'ici. La consigne était de tenir, le temps que la contre-attaque s'organise. La contre-attaque ne s'est pas organisée. Ils se sont trouves piégés. Les militaires ont commencé d'investir l'école, méthodiquement, bâtiment par bâtiment. Ils ont vu d'autres occupants sortir, les mains sur la tête, jeté; à coups de crosses dais les camions. Ils ont entendu les rafales. Ils savaient qu'ensuite, ce serait leur tour. Ils ont pu sortir par les jardins et rejoindre l'ambassade grâce à un étudiant prévoyant, Marco. Sa tendance naturelle à envisager le pire lui était reprochée au nom de l'optimisme révolutionnaire. Encore maintenant, il a l'air de s'en excuser.

Chaque nouvel arrivant a son histoire. Tsikos, militant anarchiste, est aussi un acteur connu. Si connu qu'il n'a pas été long à se faire repérer dans la rue. C'est un soldat qui l'a sauvé du lynchage, et plus tard l'a remis en liberté. Chacun interprète cet épisode différemment : pour les uns, c'est la preuve que la Gauche avait dans l'armée des alliés, qu'elle n'a pas su utiliser. Pour d'autres, c'est simplement que Tsikos a des admirateurs partout.

Carole, la femme de Tsikos, raconte qu'elle a dû emmener de force sa sœur complètement traumatisée par le passage des policiers. Dans l'immeuble où elle habite, 
Carole, la femme de Tsikos, raconte qu'elle a dû emmener de force sa sœur complètement traumatisée par le passage des policiers. Dans l'immeuble où elle habite, il ne restait presque que des femmes. Sous prétexte de perquisition, les flics les ont séquestrées, en ont violé quelques-unes, et ont prévenu qu'ils reviendraient, après avoir confisqué tous les papiers d'identité pour les empêcher de sortir.

La plus calme, c'est peut-être Maria. Il faut dire que c'est la troisième fois qu'elle se trouve dans cette situation, chaque fois dans un pays différent.

L'Ambassadeur et sa femme, tout au long de la journée, ont écouté les récits, répondu aux questions. Je craignais que ma caméra ne paraisse indiscrète l'indifférence des autres qu'elle n'était que dérisoire.

Jeudi. Un autre groupe est arrivé. Si l'on en croit tes rumeurs, la villégiature à l'ambassade risque d'être longue. Lou, la secrétaire, a pris en mains l'organisation pratique, et d'abord la cuisine. Il faut beaucoup de tact pour faire de la bonne cuisine à des gens dans le malheur. En fait, ce premier vrai repas a été une espèce de cérémonie.

Chez moi, les paysans disent que l'angoisse est un ours noir, qu'il faut chasser à force de rires et de cris, sinon il revient poser sa patte sur vous, et vous ne pouvez plus bouger. Tout le monde à fait de son mieux au cours du repas. Mais je les guettais dans mon viseur et je les ai tous surpris, au moins une fois, qui laissaient l'ours approcher, et s'immobilisaient sous sa patte.

Il y avait là des professeurs, des étudiants, des intellectuels, des artistes, des professionnels de la politique. Pas un ouvrier. Les usines avaient reçu le même consigne que les universités : tenir tant que c'était possible. Après, le repli. Seulement voilà, il est très rare qu'on construise des usines à proximité des ambassades.

Après le repas, Volodia, un des derniers arrivés, s'est endormi d'un seul coup là ou il était, par terre. Volodia est avocat, son fils chimiste. Pour ne rien laisser tomber entre les mains des militaires, il avaient passé toute la nuit à bruler des dossiers.

Vendredi. La collectivité s'invente une vie de naufragés. Article premier : il n'y aura pas de hautes ni de basses besognes. L'Ambassadeur donne l'exemple en passant lui-même l'aspirateur. C'est un peu boy-scout, mais ça égaie.

Nike, le photographe, fait la même chose que moi, mais en professionnel. Son journal est interdit. Toutes les cartes de presse doivent être échangées au nouveau ministère de Information. Donc il est bloqué là comme les autres, et il défoule en nous photographiant. Comme, il n'y a pas de labo photo dans l'ambassade, ces images de nous restent en sursis, comme nous. 
Ils ont tous fini par se trouver une occupation, du jeu de cartes à la conversation. Comme dans toutes les prisons, on s'imagine parler d'Ailleurs en parlant d'Avant.

Faute de nouvelle de l'extérieur, Maria entreprend de lire dans le marc de café, et tout le monde participe. Il est dix heures du matin, et pour la première fois peut-être l'angoisse n'est pas là, parmi nous.

Elle se rattrapera vite. Un des enfants d'Isabel, qui regardait par la fenêtre pousse un cri, et j'ai juste le temps de voir un type traverser la rue en courant vers la porte de l'ambassade. Il n'y arrivera jamais.

Les coups de feu ont terrifié les enfant, et Isabel les console en continuant le jeu, car depuis le début elle leur raconte que c'est un jeu.

Plus tard, nous saurons qui était l'homme abattu. Un camarade de Luco a pris le risque de lui téléphoner pour demander si l'autre était bien arrivé. C'était un jeune militant de leur parti, malade, et qui avait reçu l'ordre de se mettre en sécurité. Trop tard.

Avant de raccrocher, le copain a donné rapidement quelques nouvelles. Elles sont pires que tout ce que l'on imaginait.

Pour le reste, il nous a suffi de regarder à nouveau par la fenêtre. Le quadrillage se resserre, et plus personne maintenant ne nous rejoindra.

Samedi. Toujours pas de journaux, A la télévision, des communiqués pompeux mais laconiques. Des nouvelles filtrent par l'ambassade, par le téléphone qu'on sait surveillé. Toutes contradictoires.

Par les fenêtres nous voyons une ville morte, indéchiffrable.

Ce soir, dans la cuisine, Isabel et Jeanne combattaient le cafard avec des enregistrements des chansons de leur pays. Jonas, le plus petit des enfants d'Isabel, les accompagnait.

Sonia, qui porte encore les traces de son passage à la police, et quelques autres sont entrés pour les écouter. Jeanne compose et interprète des chansons très belles, souvent des chants de lutte. Il y a une semaine encore, elle les chantait en public, devant un millier de personnes qui suivaient son rythme. C'est seulement ce soir que j'ai pensé que ça aussi, c'était fini, qu'elle ne chanterait plus jamais de cette façon-là. Le passé, c'est comme l'étranger : ce n'est pas une question de distance, c'est le passage d'une frontière.

Au dossier du déchiffrage de la ville : dans le grand immeuble de la Sécurité Militaire, que nous apercevons de la terrasse, il y a deux étage toujours allumés. 
Dimanche. Volodia et son fils jouent aux échecs. Jeanne chante en s'accompagnant à la guitare. Les autres lisent ou écoutent.

Cet après-midi, un coup de téléphone nous a confirmé la rumeur qui courait : des milliers de prisonniers politiques ont été enfermés dans un stade, et tous les soirs il y a des exécutions.

Les filles ont été chercher Mélanie, la tortue des enfants. Cette tortue nous fascine. Peut-être parce qu'elle est la seule chose vivante, dans cette pièce, qui échappe à notre écrasement. Elle est compacte et obstinée. Elle a ses idées de tortue, et aucun flic au monde ne les lui ferait changer.

A 8 heures, la télévision s'est réveillée. Les communiqués anonymes ont laissé la place à de vraies images, à de vrais discours. Sans doute le nouveau pouvoir se sent-il assez sûr de ses forces maintenant pour apparaître en pleine lumière. Nous avons eu droit à tout : les explications, les congratulations, les adjurations, les menaces. Ces gens ne se renouvellent pas beaucoup. Il fallait extirper le cancer marxiste, le pays courait à la ruine, des complots téléguidés de l'étranger, toute la lyre. Ce baratin est entrecoupé d'annonces de mesures, en revanche, très précises. Interdiction de tous les partis politiques, sans exception. Dissolution de tous les syndicats, sans exception. Appels à la délation, avec primes à l'appui. Enoncé des grands principes d'une nouvelle Constitution dont l'inspiration est évidemment chauvine, raciste, corporatiste. Ce qui est intéressant, c'est que ce langage n'est pas celui de la bourgeoisie libérale, à peine celui de la Droite classique. C'est plutôt celui des groupuscules fascistes les plus étroits, des journaux les moins lus, ceux dont nous nous moquions parce qu'ils retardaient d'un siècle sur l'histoire. Les militaires, eux, les lisaient. La bourgeoisie a lâché ses chiens sur ses adversaires pour reprendre le pouvoir, mais à présent ce sont les chiens qui tiennent le pouvoir, et ils ne le lâcheront pas.

Et là-dessus, ce qui couvait depuis des jours à éclaté : le grand règlement de comptes politique. Carole a attaqué la première. Ce qu'on venait d'entendra, c'était la réponse de ces fameuses classes moyennes qu'il fallait seduire à tout prix, quand rien ne pouvait les séduire ni les rassurer que l'Ordre le plus réactionnaire... De l'autre bout de la pièce, Théo a lancé que quand on était à ce point partisan de la lutte armée, on avait bonne mine de se réfugier dans une ambassade. C'était un argument très injuste, mais il ne s'agissait déjà plus d'arguments. C'étaient de très viailles plaies, jamais tout-à-fait guéries, qui se rouvraient en chaîne. Luco défendait avec acharnement la politique de con parti, il citait des exemples d'actions hasardeuses de l'extrême-gauche, il leur 
opposait la nécessité d'une analyse scientifique basée sur les réalités. Ce pays était ce qu'il était, tant pis s'il fallait en rabattre sur les grands thèmes lyriques, la seule politique viable était dans une lente et prudente consolidation des forces populaires, appuyée sur une véritable majorité. Cette politique avait été sabotée par des illuminés et des impatients, et maintenant on voyait le résultat. Tsikoz avait écouté en silence, et puis il a éclaté à son tour : vous êtes aussi cons que des morts qui continuent à se battre dans leur tombe. La seule leçon à tirer, c'est que toutes les directions politiques, sans exception, ont fait faillite. Aucune, quelque soit son analyse, ne nous a préparés à ce que nous vivons en ce moment. Chaque fois que quelque chose a voulu vivre, vous l'avez écrasé ou confisqué.

Carole et Luco ont continué de s'agresser. D'autres sont entrés dans la discussion, on a $\mathrm{vu}$ défiler en bon ordre tous les arguments qui n'avaient jamais cessé de s'opposer rituellement pendant toute la durée du gouvernement populaire. Tsikos était redevenu silencieux. Une heure après, ils en étaient aux procès de Moscou et à la trahison congénitale des trotskystes, mais Tsikos se taisait toujours, et jusqu'au moment de son départ, il n'a plus prononcé une seule parole.

Il y avait juste une semaine que le coup d'état avait éclaté. Notre fraternité n'avait pas duré davantage. Inutile de relire mes notes de cette période : elles sont sinistres Et guère d'images à montrer non plus. Chacun vivait replié sur soi, et la caméra était devenue un témoin gênant.

Et puis les premiers sauf-conduits sont arrivés, et quelque chose de l'ancienne amitié à quand même resurgi. Ils sont partis par petits groupes, et les adieux ont été de vrais adieux.

D'une fenêtre de l'ambassade, j'ai tourné mon dernier plan: la camionnette qui les emmenait en exil, et cette ville que nous avions connue libre. 


\section{Index de realizadores, produções e instituições cinematográficas citados}

A batalha do Chile 16, 18, 85, 98, 101, 114, 133-7, 139, 141-147, 149, 157, 214, 222, 225 , 226, 334, 378-380

À bientôt, j'espère 6,57

A confissão 53

A queda da dinastia Romanov 203, 204

À Valparaiso 17, 83-95, 98, 102, 212

A.K. 83

Actas de Marusia 176

Agnès Varda 27-28, 47, 49, 57, 83, 162

Al compás de Cuba 27

Alain Resnais 3-5, 38, 60, 83, 162, 250

Alba de Cuba 26

Alexandre Astruc 5, 164

Alexandre Medvedkine 57, 61, 62, 204

Alfred Hitchcock 249, 353

Alfredo Guevara 25, 27, 31, 48, 49, 58-59, 65, $101,142,151,224-6$

Álvaro Covacevich 108, 111, 174, 183-184, 214, 217, 219-220, 225

Álvaro Ramírez 103, 167, 172

Amuhuelai-mi (Ya no te irás) 105

Anatole Dauman 85

André Bazin 4-5

André Zwoboda 163

Antoine Bonfanti 165

Antonio Campi 105

Apuntes para una geografía 226

Argos Films 85, 116

Armand Gatti 25, 31-32

Armand Mattelart 98-99, 159-161, 165-166

168, 178, 184, 195, 226

Arriba el campesino 27

August Films 135

Before spring 93-94

Bernard Paul 127

Bernardo Menz 138, 227

Brasile tortura 72

Brigada Ramona Parra 103

Bruno Muel 6, 57, 174, 215, 260, 280, 289

Campamento Sol Nasciente 112

Carlos Böker 85

Carlos Flores 105, 107

Carlos Ortiz Tejeda 174, 215

Carmen Castillo 98-100

Carnet de viaje 26, 83, 93

Casa o mierda 174

Casas viejas 112

Catherine Allégret 23

Catherine Belkhodja 248

Central Newsreel and Documentary Film Studio 93
Centro de Cine Experimental de la Universidad de Chile 84-85, 93-94, 102-103, 106, 111-112, 133, 216

Centro de Cultura Popular de Palentes-les

Orchamps 6

Chile Films 100, 106-108, 110-112, 114-115,

133, 135, 166-167, 224-225

Chili impressions 241

Chine 83

Chove sobre Santiago 174, 215

Ciné-Liberté 163

Ciné-tracts 60-61

Cinémathèque française $16,48-49$

Cineteca Nacional de Chile 15, 227

Classe de lutte 57

Claude Lelouch 83, 162

Claudio Sapiaín 106

Comment Yukong déplace les montagnes 83

¿Cómo, por qué e para qué se asesina a un general? 174, 214, 225, 229

Compañero presidente 10, 18, 99, 108-109,

111, 126, 132, 149-154, 157, 174, 184, 214

Contre la raison et par la force 174, 215

Conversation with president Allende 174

Costa-Gavras 50, 53, 98-99

Crônica de um verão 250-251

Cuando despierta el pueblo 174

Cuba si 11-13, 17, 20, 24, 27-28, 30-42, 44-49, 53-54, 56-59, 64, 66, 81, 87, 94, 312, 314, 317-

$321,328,348$

Cuba, pueblo armado 26, 83, 93

David Veras Meiggs 112,

Davos Hanich 300, 303, 311

De América soy hijo... y a ella me debo... 97,

169, 174-175, 214, 225, 227-228

Delphine Seyrig 127

Desaparecido 98

Description d'un combat 31,43

Despegue a las $18.00 \quad 50-52$

Deuda externa 226

Diálogos de exilados 174, 215

Dimanche à Pékin 5, 32, 35, 43, 83, 266

Dominique Landman 23

Dziga Vertov 45, 60-63, 204

Edgar Morin 86, 250-251

Edouard Luntz 127

Eduardo Manet 26, 31, 35, 43-44, 46

Eduardo Paredes 100

El chacal de Nahueltoro 84, 102

El crimen tan comentado 226

El diálogo de América 108, 111, 174, 183-184

214, 217, 225, 238

El pequeño circo 84 
El primer año $10,18,50,98-100,108,112-$ $118,120,124,126-128,131,133-134,136-137$, $146,157,174,185,214,226,300$

El tren de la victoria 85-86, 94, 96

ElectroShow 101, 112

Entre ponerle y no ponerle 107

Escuela de Artes de la Comunicación de la

Universidad Católica (EAC) 104, 112, 129, 133-134

Escuela Santa María de Iquique 1907106

Estado de sítio 98

Esther Shub 203-204

État d'urgence Chili: veille élections

présidentielles 231-232

Étienne Becker 165

Etienne Lalou 37

Faire face 37

Federico Elton 137-138, 140-141, 143, 145, 148

Fernando Bellet 85

Fernando Pino Solanas 93, 102-103, 164

François Armoul 127

François Maspero 63, 99, 298, 300, 303, 311

François Perier 126-127, 165

François Truffaut 5

Gabriela Mistral 112

Georges Rouquier 127

Georges Strouvé 85

Gérard Philipe 25

Gerhard Scheumann 167, 174

Glauber Rocha 38, 103, 164

Grupo Cine Liberación 38, 93, 103

Grupo dos Trinta 27

Grupo Dynadia 162

Grupo Dziga Vertov 45, 60, 162

Grupos Medvedkine 6, 8, 57, 60, 61, 116, 127, 162,163

Guillermo Cahn 105

Gustavo Becerra-Schmidt 86

Hasta la victoria siempre 229, 317

Héctor Ríos 85, 103, 105, 107, 112

Helvio Soto 174, 215

Henri Cartier-Bresson 163

Henri Langlois 27

Hércules 56 68, 72

Ignacio Aliaga 112

Igor Berrère 37

Image, Son, Kinescope et Réalisations

Audiovisuelles (ISKRA) 6, 15-16, 63-64, 66,

114, 116, 128-129, 135-137, 140-144, 149-150,

243, 260, 289, 300-301, 310

Immemory 7, 61

Indonesia Calling 83

Inger Servolin 129-130, 137, 140-141

Institut national d'audiovisuel (INA) 15-16, 241

Instituto Cubano del Arte e Industria

Cinematográfico (ICAIC) 9, 11, 13, 16, 17,

24-29, 31, 35, 40, 42-50, 60, 62-63, 65-66, 69,
71-72, 80, 84, 94, 102, 141-146, 148, 214-215, 218, 223-227, 229, 300-301, 348, 380

Introducción a Chile 174, 224, 226

Jackie Raynal 60

Jacqueline Meppiel 162, 165-167, 195, 215, 226, 387

Jacques B. Brunius 163

Jacques Becker 163

Jacques Prévert 85, 163

Jacques Rivette 250

Jacques Ségui 239-240

Jafar Panahi 295

Janine Kirsch 4

Jean Bertolino 235-239

Jean Genet 289

Jean Lartéguy 50

Jean Ravel 86

Jean Renoir 163-164

Jean Rouch 86, 208, 250-251

Jean-Claude Dauphin 23

Jean-Claude Éloy 165

Jean-Luc Godard 6, 45, 57, 60, 83, 162, 250

Jean-Michel Folon 165-166, 176, 178-180, 183, 192

Jean-Paul Le Chanois 163

Jean-Pierre Castaldi 23

Jean-Pierre Gorin 60

Joaquín Olalla 85

Jonas Mekas 244

Jorge Semprún 23-24, 53, 57, 297, 300, 303, $315,323-325$

Joris Ivens 17, 26-27, 45-46, 83-89, 92-94, 96, 98, 103, 162, 174, 199, 212

José María Berzosa 241

José Pino 138, 145

Julio García Espinosa 103, 146, 226

Kurt Maetzig 26

L'héritage de la Chouette 7, 295

L'ambassade 7-9, 11, 14, 18-20, 22, 33, 45, 53, 66, 78, 132, 148, 158, 195, 200, 242-268, 272-275, 277-278, 280-291, 293-296, 299-300, $313,330,333,346,349,351,353,381$

La bataille des dix millions 6, 11, 14, 17, 24, 27, 41, 44-45, 49-60, 81, 165, 223, 314, 318, 328,348

La expropiación 174, 214

La guerre des momies 174

La hora de los hornos 93, 102

La jetée 7, 86, 101, 200, 248-250, 267, 274, 297, 300

La lámpara azul 26

La merluza 226

La pincoya 226

La première année $6,10,14,18,116-131,137$, $144,146,157,165,300,347,375$

La respuesta de octubre 114-115, 134, 136-

137, 144, 174, 186, 214, 221

La Seine a rencontré Paris 83

La sixième face du Pentagone 305

La solitude du chanteur de fond 300 
La spirale 5-6, 8-9, 11, 13-14, 18-19, 28, 50, $66,78,81,85,96,99,101,103,106,108,116$, $123,126,132,159,161-167,169-178,180-185$, 187-191, 193, 195-203, 205-215, 217, 219-223, 225-230, 232-235, 237-241, 245, 272, 278, 294, 299-301, 303, 305, 307, 332-333, 336, 347, 349-35272, 278, 294, 299-301, 303, 305, 307, 332, 336, 347, 349-353

La tierra prometida 173-174

La vie est à nous 162-163

Lauro Escorel 205

Le Chili: un nouveau Cuba? 198, 230, 232, 234-235, 241

Le joli mai 83, 250-251, 253

Le Mystère Koumiko 83, 208, 245

Le Peuple et ses fusils 83

Le tombeau d'Alexandre 7, 61, 203-204

Leni Riefenstahl 210

Leonardo Céspedes 103

Leonardo Henrichsen 133, 239, 257

Leonardo Martínez 85

Les chemins de la fortune 49, 310

Les évènements au Chili 231

Les statues meurent aussi 5, 38

Lettre de Sibérie 5, 35, 208

Lev Vladimirovitch Kulechov 246-247, 254, 260, 263, 280

Level 5 7, 83, 177, 248

Libertad de prensa 226

Loin du Vietnam 6, 27, 50, 83, 162-164

Luc Perini 165

Luis Araneda 105

Luis Conejo 85

María Casares 25

María Luisa Mallet 105

Mario Gallo 27

Marta Harnecker 145, 226

Maurice Lime 163

Mémoires pour Simone 23

Michael Rubbo 208

Michèle Ray 162

Miguel Ángel Aguilera, presente 167, 172

Miguel Enriquez 174

Miguel Littin 10, 18, 63, 84-85, 99-100, 102, 104, 106, 108-109, 111, 115, 126, 149-155, 157-158, 173-174, 176, 184, 214, 224

Miguel Torres 174, 224, 226

Mijita 107

Mikhail Kalatozov 82, 91

Nanook, o esquimó $\quad 45,87$

Nicolás Guillén Landrián 46, 48

No nos trancarán el paso 105

Noite e neblina 5

Noticiero ICAIC Latinoamericanos 45, 47, 50, 60, 62-63, 72, 226

Nouvelle société 60-61, 64

Nouvelle Vague 26, 42

Nuestro acero 226

Nuevo Cine Latinoamericano 38, 47, 93, 94, 102-103, 164, 224
Nutuayin Mapu (Recuperemos nuestra tierra) 105

O Encouraçado Potemkin 302-304

O fundo do ar é vermelho 6, 8-9, 11-12, 14, 18-19, 22-23, 28, 50, 53, 59, 63, 78, 96, 126, $132,148,150,155,157-158,165,202,209-210$, $228,242,243,285,295,297-340,343-344$, 346-349, 352-353, 355

Octavio Getino 93, 102-103, 164

Office de Radiodiffusion-Télévision Française (ORTF) 37, 50, 96, 187, 197-198, 230-232, 234-235, 237-241, 271, 300-301, 310, 326, 344 Olympia 52 5, 210, 245, 305

On vous parle d'Amérique latine: le message du Che 63

On vous parle de Flins 63

On vous parle de Paris: Maspero, les mots ont un sens 63, 99, 300

On vous parle de Prague: le deuxième procès d'Artur London 52, 53, 63-64, 148, 299, 300, 304, 324

On vous parle du Brésil: Carlos Marighela 7, 13, 17, 20-21, 50, 60, 63-64, 66, 72-81, 157, 348

On vous parle du Brésil: tortures 7, 13, 17, 50, 60, 63-66, 68, 70-73, 80-81, 285, 348

On vous parle du Chili: ce que disait Allende 7, 10, 14, 18, 28, 63-64, 66, 78, 98, 99, 109, 123-124, 132, 149-150, 152-157, 312, 340, 347 Os libertários 205

Oye cabrito 226

Patricio Guzmán 10, 16, 18, 83, 98-101, 108, 111-119, 121, 126-8, 130-131, 133-148, 158, $166,174,185,214,220-222,226-227,258,300$, 334

Patricio Guzmán Campos 85

Pedro Chaskel 72, 84-85, 102-103, 143,145, 146, 174, 214-217, 226-227

Peter Kassovitz 49, 310

Philippe Garrel 60

Philippe Gildas 151

Pierre Desgraupes 231

Pierre Flament 165

Pierre Unik 163

Pintando con el pueblo 103

Pol Cèbe 6

Produtora América (PROA) 135, 141

¿Qué hacer? 174

Rafael Sánchez 112

Raúl Ruiz 139, 174, 214-215

Raymond Depardon 120

Rebeca Yañez 85

Rémo Forlani 4

Rencontre avec le président Hô Chi Minh 83

Révolution dans la légalité 174

Robert Drew 45, 250

Robert Flaherty 45, 87

Robin Hood 35-36

Roger Pigaut 88

Roman Karmen 26 
Ross McElwee 208

Salut les cubains! 27, 47

Samuel Carvajal 105

Sandra Scarnati 300, 303

Sans soleil 7, 83, 277

Santiago Álvarez 35, 45-47, 50-52, 60, 62-64,

72-73, 97, 166, 169, 174-175, 214, 223, 225,

227-229, 317

Santiago, ville violée 174

Sara Gómez 28, 46, 48

Saúl Landau 72, 174

Saúl Yelin 142

Septembre chilien 174, 215, 260, 280, 289

Sergio Bravo 84-86

Sergio Castilla 107

Serguei Eisenstein 302

Service de Lancement des Euvres Nouvelles

(SLON) 6, 18, 27, 50, 60, 63-64 83, 115-116,

128-131, 133, 135-137, 139-145, 147-150, 152, 162, 292, 295

Silvio Da-Rin 72, 250

Silvio Tendler 161, 165-166, 195

Simone Signoret 23, 25-26, 300, 302-304, 307-

308

Situation au Chili 231-232

Six mois d'Unité populaire 187, 230, 235-239, 241

Sociedade Anonyma Fábrica Votorantim 205

Sonia Jordan 129, 130

Soy Cuba 82, 91

Soy Mexico 82

Terre d'Espagne 83

The Four Hundred Million 83

Théo Robichet 260, 280, 289

This Is Not a Film 295

Tómas Gutiérrez Alea 28, 46

UNCTAD III 226

Une histoire de ballon, lycée $n^{\circ} 31$ Pékin 83

Valérie Mayoux 50, 150-151, 161, 165-166, 195, 215, 226, 300-301

Venceremos 103, 174, 214-217, 225

Vertigo (Um corpo que cai) 177, 249, 277, 353

Video out 289

Viêt Nam 83

Vladimir Cech 26

Vote+fusil 174

Walter Heynowski 167, 174, 221

William Guéry 35

William Klein 83, 162

Yves Montand 23, 25, 53, 300, 303, 319, 320 